Ângulos de uma caminhada lenta: exercícios de contenção, reiteração e saturação na obra de Bruce Nauman

Liliane Benetti

São Paulo

2013 


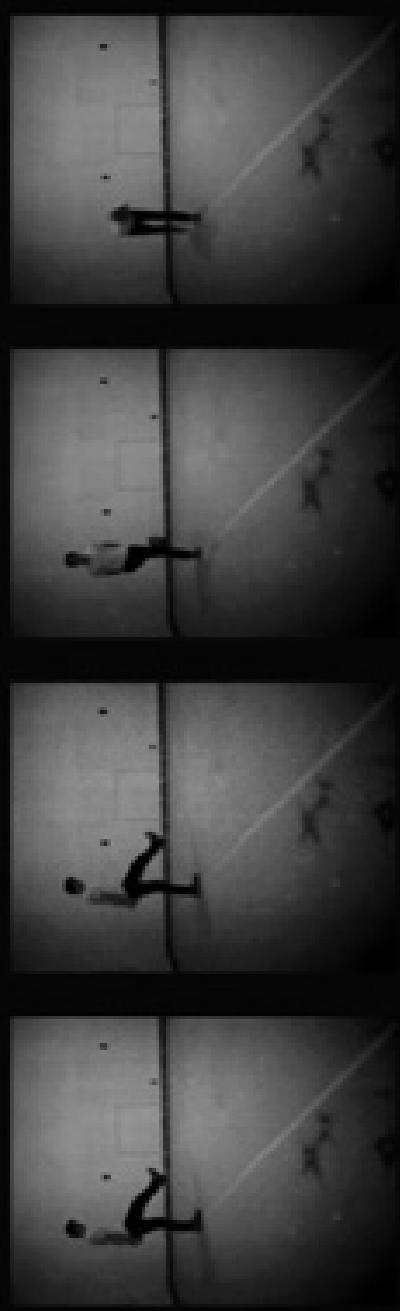

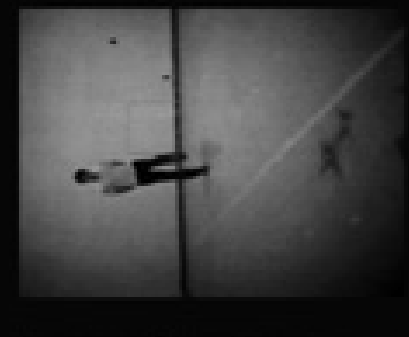
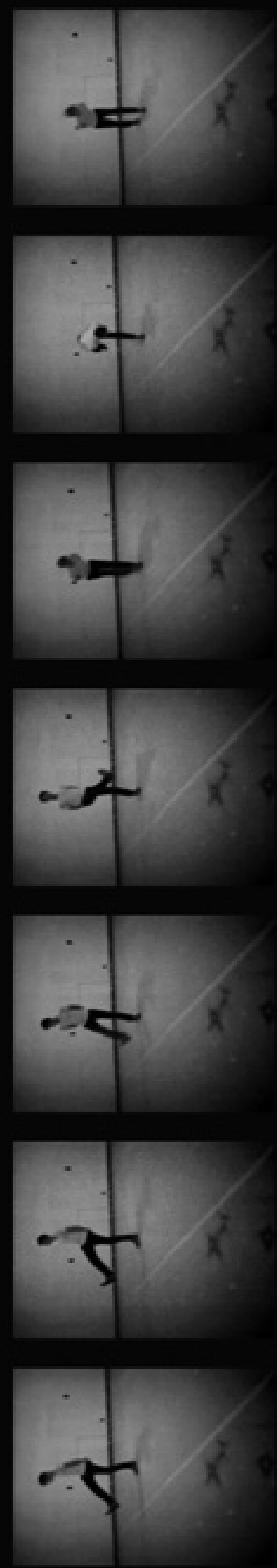
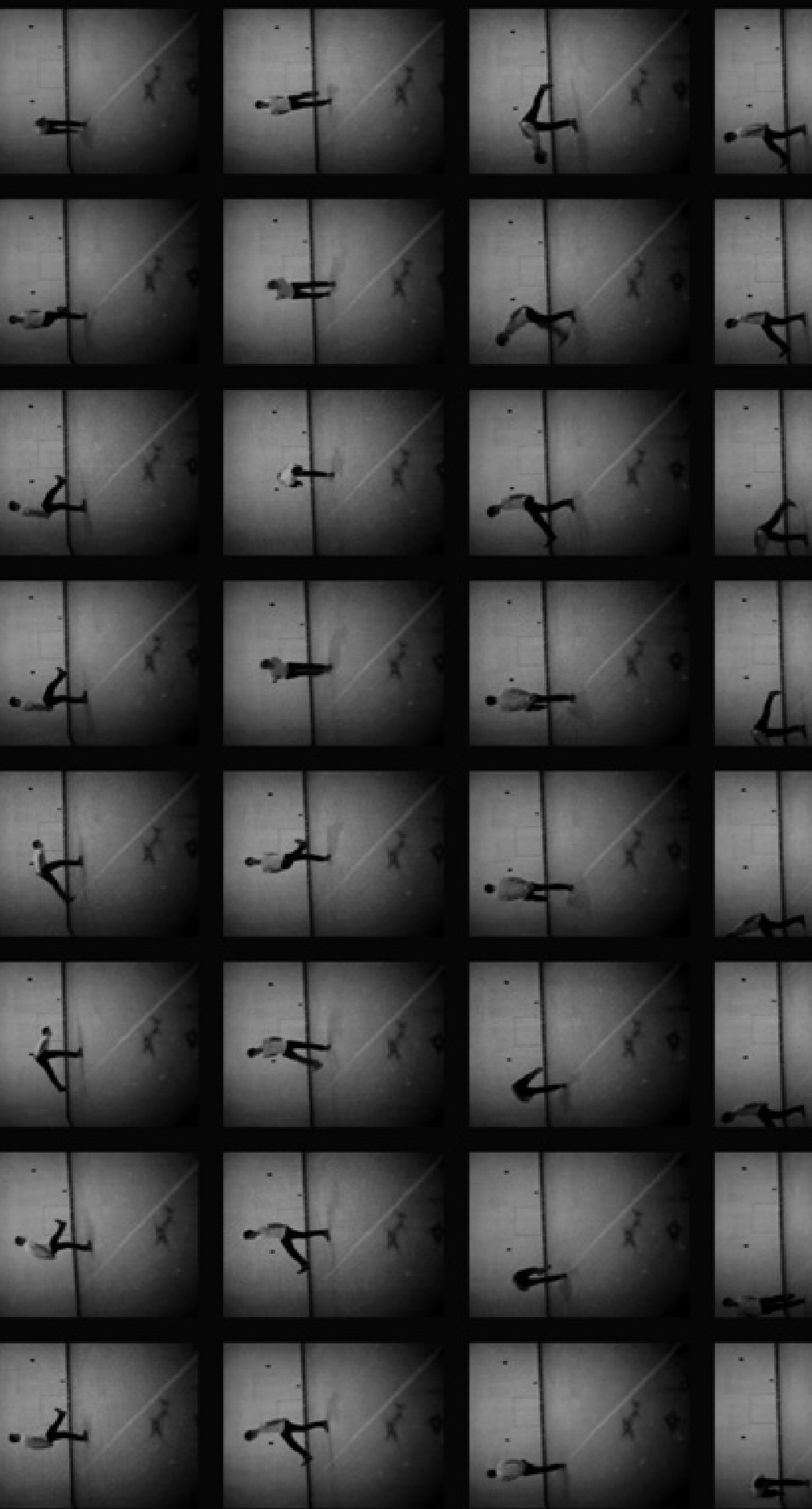
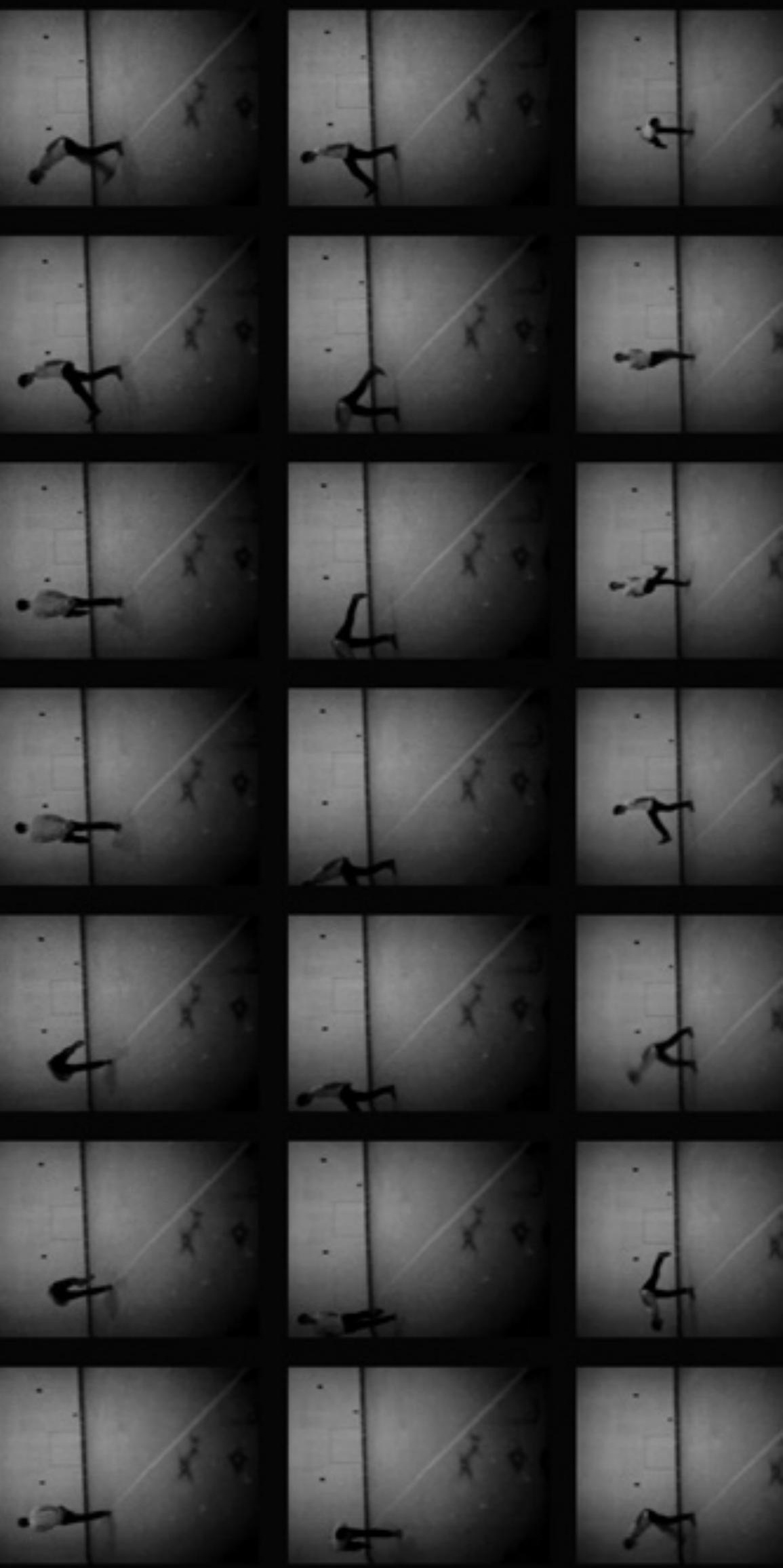


\section{UNIVERSIDADE DE SÃO PAULO}

\section{ESCOLA DE COMUNICAÇÕES E ARTES}

PROGRAMA DE PÓS-GRADUAÇÃO EM ARTES VISUAIS

Ângulos de uma caminhada lenta:

exercícios de contenção, reiteração e saturação

na obra de Bruce Nauman

Liliane Benetti

São Paulo 



\author{
UNIVERSIDADE DE SÃO PAULO
}

ESCOLA DE COMUNICAÇÕES E ARTES

PROGRAMA DE PÓS-GRADUAÇÃO EM ARTES VISUAIS

Ângulos de uma caminhada lenta:

exercícios de contenção, reiteração e saturação

na obra de Bruce Nauman

Liliane Benetti

Tese apresentada ao Programa de Pós-Graduação em Artes Visuais da Escola de Comunicações e Artes da Universidade de São Paulo, como requisito parcial para obtenção de título de Doutor em Artes Visuais.

Orientadora: Profa. Dra. Sônia Salzstein Goldberg

São Paulo 
Catalogação na Publicação

Serviço de Biblioteca e Documentação

Escola de Comunicações e Artes da Universidade de São Paulo

Dados fornecidos pelo(a) autor(a)

Benetti, Liliane

Ângulos de uma caminhada lenta: exercícios de contenção, reiteração e saturação na obra de Bruce Nauman / Liliane Benetti -- São Paulo: L. Benetti, 2013.

496 p . : il. + 1 CD.

Tese (Doutorado) - Programa de Pós-Graduação em Artes Visuais - Escola de Gomunicações e Artes / Universidade de São Paulo.

Orientadora: Profa. Dra. Sônia Salzstein Goldberg.

1. Nauman, Bruce (1941 - ) 2. Arte contemporânea 3. Escultura

4. Vídeos e filmes 5. Instalação 6. Beckett, Samuel (1906 - 1989)

I. Goldberg, Sônia Salzstein II. Ângulos de uma caminhada lenta:

exercícios de contenção, reiteração e saturação na obra de Bruce Nauman

GDD 21. ed. - 700 


\title{
Ângulos de uma caminhada lenta: exercícios de contenção, reiteração e saturação na obra de Bruce Nauman
}

\author{
Liliane Benetti
}

Tese apresentada ao Programa de Pós-Graduação em Artes Visuais da Escola de Comunicações e Artes da Universidade de São Paulo, como requisito parcial para obtenção de título de Doutor em Artes Visuais, sob orientação da Profa. Dra. Sônia Salzstein Goldberg.

Aprovado em:

Banca Examinadora:

$\begin{array}{ll}\text { Prof.Dr. } & \text { Instituição } \\ \text { Julgamento } & \text { Assinatura } \\ \text { Prof.Dr. } & \text { Instituição } \\ \text { Julgamento } & \text { Assinatura } \\ \text { Prof.Dr. } & \text { Instituição } \\ \text { Julgamento } & \text { Assinatura } \\ \text { Prof.Dr. } & \text { Instituição } \\ \text { Julgamento } & \text { Assinatura } \\ \text { Prof.Dr. } & \text { Instituição } \\ \text { Julgamento } & \text { Assinatura }\end{array}$



A pesquisa de Doutorado foi realizada com o apoio da CAPES/

Coordenação de Aperfeiçoamento de Pessoal de Nível Superior, instituição de fomento que também apoiou o estágio de pesquisa no exterior (Programa Institucional de Bolsas de Doutorado Sanduíche no Exterior/PDSE-GAPES). 

Sônia Salzstein, pela interlocução arguta e estimulante, pelo exemplo de dedicação e de generosidade intelectual.

Carlos Fajardo e Lorenzo Mammì, pelas preciosas críticas e sugestões.

Professores, alunos e funcionários do Departamento de Artes Plásticas da ECA-USP, em especial à professora Monica Tavares, ao Bruno Ribeiro e ao Raul Cecilio.

Colegas e amigos do Centro de Pesquisa em Arte Brasileira do Departamento de Artes Plásticas da ECA-USP.

Colegas e amigos do Grupo de Estudos sobre Samuel Beckett do Departamento de

Teoria Literária e Literatura Comparada da FFLCH-USP, em especial ao Fábio de Souza Andrade, pela acolhida.

Jaeho Kang, pelo convite para o estágio de pesquisa em Nova York, junto a The New School.

Funcionários dos arquivos, bibliotecas, museus e galerias visitados durante a estadia no exterior, em especial à Lilian Tone e à Juliet Myers, assistente pessoal de Bruce Nauman.

Robert Storr, pela gentileza da conversa bem-humorada.

Andrea Ferreira e Nilton Bueno, pela ajuda e pelas aventuras inesquecíveis em Nova York.

Joshua Redman, pelos improvisos.

Isabela Rodrigues, Carlos Eduardo Riccioppo, Ana Luiza Dias Batista, Marcos Nobre,

Fabio Flaks, Marco Buti, Lirane Borges, Rebeca Arakaki, Laura Andreato,

Wallace Masuko, Antonio Ewbank, Chico Togni, Vivian Lazzareschi, Alline Nakamura, Marcelo Berg, João Loureiro, Thais Rivitti, Maria Abreu, Karina Boff, Renata Pasqualetto, Raul do Valle, Paulo Prado, Sebastião Nascimento, Ernesto Sang e Leide Costa Cardoso, amigas e amigos queridos, agradeço por tantos momentos de cumplicidade e de amparo cuidadoso.

Luciano Gatti, além da amizade, agradeço pelo apoio entusiasmado e pelos comentários sobre o texto.

Yukie Hori, Vitor Iwasso e Lucas Carpinelli, pela amizade dedicada que se desdobrou em ajuda inestimável e infalível na etapa final desta tese: ao Lucas agradeço especialmente pela ajuda nas dúvidas de traduções e nas transcrições; e à Yukie agradeço especialmente pelas soluções do projeto gráfico.

Bianor da Silva, por tudo, em memória. 

Para Helena e José Antonio Benetti

"There is a crack in everything, that's how the light gets in".

Leonard Gohen 



\section{Resumo}

Ângulos de uma caminhada lenta: exercícios de contenção, reiteração e saturação na obra de Bruce Nauman parte da discussão de um conjunto de trabalhos do artista norte-americano com o intuito de compreender a estrutura, os elementos constitutivos e os procedimentos característicos de sua produção. A obra de Bruce Nauman mantém uma projeção pública há mais de quatro décadas e contempla meios e materiais variados - das primeiras moldagens às recentes instalações sonoras, o artista passa pela performance, vídeo, fotografia, desenho, gravura e intervenção em escala urbana - e mobiliza, a despeito de sua natureza multifacetada, um conjunto recorrente de questões, algumas das quais em franco diálogo com a tradição da escultura. Além de interrogar a persistência de uma espécie de inteligência escultórica na obra, esta tese propõe examinar o modo peculiar com que Nauman lança mão de alguns procedimentos disseminados nas obras de artistas da sua geração, sobretudo o uso da repetição em chave distinta dos processos de seriação em voga na década de 1960. Nos trabalhos de Nauman, os procedimentos de reiteração, redução, contenção e permutação de poucos elementos tendem a promover experiências de saturação e de extenuação, e, nesse sentido, aproximam-se de certos aspectos da obra de Samuel Beckett; duas linguagens artísticas diferentes que, todavia, mantêm pontos de convergência temática e formal.

Palavras-chave: Bruce Nauman; arte contemporânea; escultura; filmes e vídeos; instalação; Samuel Beckett; crítica de arte. 



\begin{abstract}
Angles of a slow walk: exercises in restraint, reiteration and saturation in the work of Bruce Nauman has as its starting point a discussion of a representative array from among the artist's production that seeks to obtain a greater understanding of the structure, constitutive elements and specific procedures found in his work. Nauman's production has sustained its popular prominence for more than four decades, and spanned an impressively wide spectrum of means and materials - from the early castings and moldings to the recent sound installations, through performance, video, photography, drawing, engraving, print and urban scale interventions - which summons, in spite of its multifarious nature, a persistent, recurring set of questions, some of which engage the sculptural tradition in an open and challenging dialogue. In addition to assessing the endurance of this type of sculptural intelligence in the artist's production, the thesis aims at examining the idiosyncratic way in which Nauman employs certain artistic procedures common to the works of artists of his generation, in particular his use of repetition in a fashion quite distinct from the serial processes en vogue in the 1960s; furthermore, the thesis attempts to uncover a number of formal convergences between Nauman's procedures in a significant assortment of pieces, and Samuel Beckett's body of work, with an emphasis on the exhaustive recombination of minimal elements as well as the use of repetition, suppression and restraint as fundamental mechanisms to promote a saturation of experience.
\end{abstract}

Keywords: Bruce Nauman; contemporary art; sculpture; film and video; installation art; Samuel Beckett; art criticism 



\section{Sumário}

$\begin{array}{lll}\text { CaPÍtulo } 1 \text { Corpo/molde/gabarito } & 27\end{array}$

1.1. Formas macias no espaço: a presença ambígua da 38 tradição da escultura

1.2. O espaço negativo debaixo da minha cadeira 48

1.3. Corpo-molde, corpo-gabarito 56

Capítulo 2 Dilatar o tempo e exaurir o espaço 81

2.1. Exercícios de ateliê: a repetição exaustiva como procedimento 82

2.2. Restrição, confinamento, controle: procedimentos de contenção 98

Gapítulo 3 Caminhada Beckett 116

3.1. Palhaços torturados: falhar de novo, falhar melhor 139

CAPÍtulo 4 Contenção, reiteração e saturação: 154 as palavras de Bruce Nauman

4.1. Palavras, peles, pedras: eu esfolado em lugar vagamente desconfortável 201

Capítulo 5 As vozes fundamentais ou um improviso de Coltrane $\quad 227$

$\begin{array}{lr}\text { Considerações finais: verdades parciais... } & 258\end{array}$

$\begin{array}{lr}\text { Referências bibliográficas } & 263\end{array}$

$\begin{array}{ll}\text { Apêndice } & 277\end{array}$

Traduções dos textos de Bruce Nauman $\quad 278$

Entrevista com Robert Storr 466 



\section{Considerações iniciais}

Desde o início, eu tentava ver se poderia fazer uma arte que [... fosse] como ser golpeado no rosto com um taco de beisebol, como ser golpeado na nuca. Você nunca sabe quando vai acontecer, quando menos espera, está nocauteado. Gosto muito da ideia: um tipo de intensidade que não lhe dá qualquer pista se você irá gostar ou não.

Bruce Nauman em entrevista a Joan Simon, em janeiro de $1987^{1}$.

Minha obra é uma questão de sons fundamentais [...] feitos da forma mais plena possível, e não aceito a responsabilidade por mais nada. Se as pessoas têm dor de cabeça com os harmônicos, que tenham. E providenciem sua própria aspirina.

Samuel Beckett em carta a Alan Schneider, em dezembro de $1957^{2}$.

A produção de Bruce Nauman (1941 - ) é extensa e profícua, marcada em igual medida por exigências formais e pela experimentação incessante, abrangendo meios e materiais diversos desde o início, em meados da década de 1960. Esta tese é um dos ângulos possíveis de abordagem e

1. "From the beginning I was trying to see if I could make art that [... is] like getting hit in the face with a baseball bat, like getting hit in the back of the neck. You never see it coming, it just knocks you down. I like the idea very much: the kind of intensity that doesn't give you any trace of whether you're going to like it or not". Cf. KRAYNAK, Janet (Ed.). Please pay attention please: Bruce Nauman's words: writings and interviews. Cambridge, Massachusetts: The MIT Press, 2005, p. 320.

2. "My work is a matter of fundamental sounds [...] made as fully as possible and I accept resposibility for nothing else. If people have headaches among the overtones, let them. And provide their own aspirin". Cf. BECKETT, Samuel. A Samuel Beckett Reader: I can't go on, I'll go on. Nova York: Grove Press, 1976, p. XVI. 
propõe a discussão de um conjunto pontual de trabalhos do artista e da bibliografia correspondente tendo em vista a recorrência de procedimentos de contenção, reiteração e saturação na obra. Tal recorte limita o escopo de questões tratadas e prescinde da apresentação cronológica dos trabalhos.

A perspectiva histórica perpassa o texto e permite articular certos nexos entre a obra de Bruce Nauman e os desafios postos à produção artística a partir dos anos 1960, momento em que rubricas como instalação, land art, intervenção, videoarte e performance passaram a ser empregadas na tentativa de descrever as mudanças em curso. Surgida na crista de movimentos de grande repercussão cultural das décadas de 1960 e 1970, como o minimalismo, a body art, a arte povera e o conceitualismo, a produção de Nauman estabeleceu diálogos com tais correntes sem, todavia, alinhar-se a elas. Ainda que não se possa falar em um "estilo naumaniano" é inegável que a obra, no percurso de mais de quatro décadas, tenha formulado um espectro peculiar de questões em ritmo próprio.

Desde os primeiros anos de sua trajetória, Bruce Nauman dedicase à escultura, ao desenho, à fotografia, ao vídeo, à performance e à instalação - a escultura sendo aí, a um só tempo, o lastro e o solo mais geral de indagações da obra. Partindo da análise de trabalhos inaugurais como as formas macias, as esculturas-corpo e os vídeos e filmes de 16 mm gravados no ateliê do artista, nos dois primeiros capítulos desta tese serão discutidas tanto uma suposta vinculação com a tradição moderna da escultura, manifestada na obra sobretudo pela via negativa, quanto a persistência de uma "inteligência escultórica" ao longo da produção, quer nos procedimentos relacionados à moldagem quer nas questões de escala.

Bruce Nauman entende que a arte demanda um tipo peculiar de atividade investigativa - "para cada regra, busco também o [seu] contrário, para revertê-la" ${ }^{3}$-, de maneira que os postulados categóricos dão lugar às verdades parciais; uma expressão reincidente em desenhos, gravuras e esculturas. Argumenta-se, nesses termos, que o artista submete todos os materiais ao escrutínio rigoroso e os testa de formas variadas, convertendo- 
os indistintamente em matérias-primas. Corpo, fibra de vidro, pedra, argila, pele, palavra, espaço, voz, "grandes temas da condição humana", referências pop ou citações de artistas, filósofos, músicos: tudo é tratado como material bruto [raw]. Em virtude disso, o corpo, a voz e a palavra aparecem nos trabalhos despidos de atributos semânticos, psicológicos ou metafísicos e são manipulados como matérias quaisquer, de modo que não sobram restos de sentido ou de "interioridade" que não possam ser subitamente virados do avesso, conforme esta tese buscará mostrar. Pela mesma razão, as referências a artistas, autores e conceitos são tomadas com liberalidade por Nauman e transformadas em material de certos trabalhos. Samuel Beckett, John Coltrane, John Cage, Marcel Duchamp, Ed Ruscha, Henry Moore, Ludwig Wittgenstein, Willem De Kooning, Dante e Gödel são alguns dos nomes que figuram em citações diretas e indiretas e ajudam a esboçar uma constelação de interesses na qual a obra se inscreve $e^{4}$.

A referência ao romancista e dramaturgo irlandês Samuel Beckett (1906-1989) poderia ser tratada nesta tese como um material entre outros, não fossem as analogias de procedimentos e as convergências temáticas e formais entre as duas produções. Não se trata de empreender um esforço

3. As palavras de Bruce Nauman, no original: "to every rule, I also try to find the opposite, to reverse it". Cf. KRAYNAK, Janet (Ed.). Please pay attention please: Bruce Nauman's words: writings and interviews. Cambridge, Massachusetts: The MIT Press, 2005, p. 313.

4. 0 escritor Samuel Beckett é citado no vídeo Slow Angle Walk, Beckett Walk (1968); a escultura John Coltrane Piece (1968) foi realizada após a morte do saxofonista; o músico John Cage é mencionado na videoinstalação Mapping the Studio/Fat Chance John Cage (2001); a fotografia Self-Portrait as a Fountain (1966-67/1970) faz referência à Fonte de Marcel Duchamp; Burning Small Fires (1968) é um livro de artista de Nauman realizado a partir de Small Fires, trabalho de Ed Ruscha; o escultor britânico Henry Moore é citado em três trabalhos: na escultura Henry Moore Bound to Fail (1967-70), no desenho Seated Storage Capsule for Henry Moore (1966) e na fotografia Light Trap for Henry Moore (1967); em 1966, Nauman pregou uma placa de metal em uma árvore, na qual se lia $A$ Rose Has no Teeth, sentença extraída das Investigações Filosóficas de Ludwig Wittgenstein; já a escultura A Cast of a Space Under My Chair (1965-1968) tem por referência uma frase atribuída a Willem De Kooning, "quando pinta-se uma cadeira, deve-se pintar o espaço entre os tapetes e não a cadeira em si [" when you paint a chair, you should paint the space between the rugs, not the chair itself"]. Nas notas e projetos publicados na revista Artforum, em 1970, Nauman aponta sua proximidade com a matemática ao citar os teoremas de Gödel e, no mesmo texto, faz trocadilhos infames com Dante. Cf. Apêndice. 
inédito de comparação entre ambas as obras, já cotejadas em algumas ocasiões. Guardadas as diferenças geracionais entre Nauman e Beckett e as especificidades de cada área do conhecimento, é possível aproximar as duas poéticas a partir da noção de extenuação e de uma disciplina de contenção no tratamento do corpo.

Tendo em consideração o vídeo Slow Angle Walk, Beckett Walk [Caminhada angular lenta, caminhada Beckett (1968)], do qual se empresta o título desta tese, o terceiro capítulo tratará do uso da repetição e da redução como mecanismos fundamentais para promover experiências de saturação por meio da recombinação extenuante de elementos mínimos. Nauman e Beckett recorrem às circularidades, aos refreamentos e às enumerações ininterruptas para regular as percepções do transcurso do tempo e para provocar experiências de extenuação associadas aos ciclos incessantes. Temas relacionados à crueldade, à frustração, às falhas e ao não-aprendizado são outros pontos comuns. Além disso, o quarto capítulo mostrará analogias entre determinados escritos de Nauman e de Beckett, no que concerne à simplificação e à crueza da linguagem bem como ao emprego de uma precisão descritiva para apontar situações vagas e lugares improváveis. Deve-se esclarecer que não se propõe uma análise dos textos de Beckett segundo os critérios rigorosos da teoria ou da crítica literárias; não apenas a obra é vasta e multifacetada, como também a literatura secundária é abundante, e as discussões desdobram-se em sutilezas que fogem às preocupações e ao escopo desta tese ${ }^{5}$.

Por fim, nos dois últimos capítulos será discutida a importância das palavras, tanto escritas quanto faladas, na produção de Nauman. Tratadas com a mesma desenvoltura e rigor analítico dos demais materiais, as palavras

\footnotetext{
5. Embora tenham sido consultados os originais em inglês e francês, optou-se por citar as traduções em português dos romances e peças de Beckett, frequentemente realizadas por pesquisadores da obra.
} 
reiteram em outra instância as questões levantadas pela obra. A escrita do artista segue uma lógica de secura e contenção comum aos demais trabalhos: amiúde, os textos são engendrados por procedimentos de redução, reiteração, permutação e saturação de termos e sentenças. No Apêndice desta tese, estão reunidos os textos de Nauman e suas respectivas traduções.

Observa-se que, entre 1965 e 1975, a produção textual é intensa e variada, e a escrita é deliberadamente fragmentada e elíptica, produzindo graus variados de desconforto pretendidos em certos trabalhos, segundo será argumentado no quarto capítulo desta tese. Da década de 1980 em diante, os textos passam a ser mais simples e repetitivos, adequando-se à veiculação em meios sonoros. O último capítulo tratará especificamente dos trabalhos com vozes, tomando como exemplo a mostra "Raw Materials", uma instalação sonora realizada na Tate Modern, em Londres, em 2004, cujos registros em áudio encontram-se no CD anexo. Conforme se verá, a voz é o material cujas qualidades expressivas têm sido amplamente exploradas por Nauman em sua busca por experiências de intensidade máxima, tão inesperadas e inescapáveis quanto uma pancada violenta na nuca. 
Gapítulo 1

Corpo/molde/gabarito* 
* Excertos dos três primeiros capítulos desta tese foram publicados no livro Historicidade e Arte Contemporânea, no capítulo intitulado "Bruce Nauman: o corpo como gabarito" [Cf. SALZSTEIN, Sônia \& BANDEIRA, João (Eds.). Historicidade e Arte Contemporânea. São Paulo: USP-CEUMA-ICC, 2012, p. 326-335] e também na revista do Programa de Pós-Graduação em Artes Visuais da ECA-USP, a ARS, em artigo intitulado "Exercícios de contenção, saturação e reiteração: algumas aproximações entre Bruce Nauman e Samuel Beckett" [Cf. ARS, vol. 19, n. 18, São Paulo, 2011, p. 174-193]. 
Das primeiras esculturas realizadas por Bruce Nauman, em meados da década de 1960, Neon Templates of the Left Half of my Body Taken at Ten-Inch Intervals [Gabaritos em neon da metade esquerda do meu corpo tomados em intervalos de dez polegadas], de 1966, é uma das poucas em exibição permanente em um grande acervo público, o Dia Art Foundation, na cidade de Beacon, no estado norte-americano de Nova York ${ }^{1}$. Essa escultura reúne alguns dos atributos mais representativos da produção do artista no período, além de apontar para certos procedimentos que, posteriormente, seriam recorrentes na obra. À princípio, é difícil imaginar que aqueles sete diferentes tubos curvados de neon azul-esverdeado dispostos em uma das paredes, ligados ao pequeno gerador de energia por uma fiação deixada visível, façam alguma referência ao corpo humano. O aparato luminoso emprega um material industrial característico dos anúncios publicitários, nos quais a pulsação intermitente e o uso de cores vivas respondem à exigência da comunicação de slogans. Nos Gabaritos, os primeiros de uma série de trabalhos nos quais Nauman utiliza os neons, a luz preenche tenuamente os contornos sugeridos pelas torções das peças,

1. A Dia Foundation, em Beacon, exibe alguns dos trabalhos mais representativos da trajetória de Bruce Nauman, fato raro para um artista cuja produção se encontra espalhada por diversos acervos públicos e coleções particulares dos Estados Unidos e Europa. Além de Neon Templates of the Left Half of my Body Taken at Ten-Inch Intervals (1966), estão permanentemente em exposição os seguintes trabalhos de Bruce Nauman: Walking in an Exaggerated Manner Around the Perimeter of a Square (1967-1968); Dance or Exercise on the Perimeter of a Square 119671968); Playing a Note on the Violin while I Walk around the Studio (1967-1968) Slow Angle Walk/ Beckett Walk (1968); Stamping in the Studio (1968); Walk with Contrapposto (1968); Wall-Floor Positions (1968); Revolving Upside Down (1969); Corridor Installation (1970); Live Taped Video Corridor (1970); Body Pressure (1974); South America Circle (1981); White
Anger, Red Danger, Yellow Peril, Black Death (1985); Hanged Man (1985); Double Poke in the Eye I/ (1985) e Mapping the Studio I (2001). Além dos trabalhos de Bruce Nauman, o acervo do Dia Beacon conta com trabalhos seminais da arte contemporânea, reunindo obras de Andy Warhol, Robert Smithson, Donald Judd, Walter de Maria, Richard Serra, Sol LeWitt, Dan Flavin, Fred Sandback, Michael Heizer, Robert Ryman, Lawrence Weiner, Robert Irwin, Joseph Beuys, Louise Bourgeios, Gehard Richter, entre outros. Além do Dia Foundation e do acervo de filmes e vídeos do Electronic Arts Intermix, em Nova York, outra coleção que detém um número considerável de trabalhos de Nauman é a de Friedrich Christian Flick, sediada em Berlim, na Hamburger Bahnhof; esses acervos principais, além de coleções públicas, arquivos e galerias que contam com trabalhos de Nauman foram visitados ao longo desta pesquisa de doutoramento. 


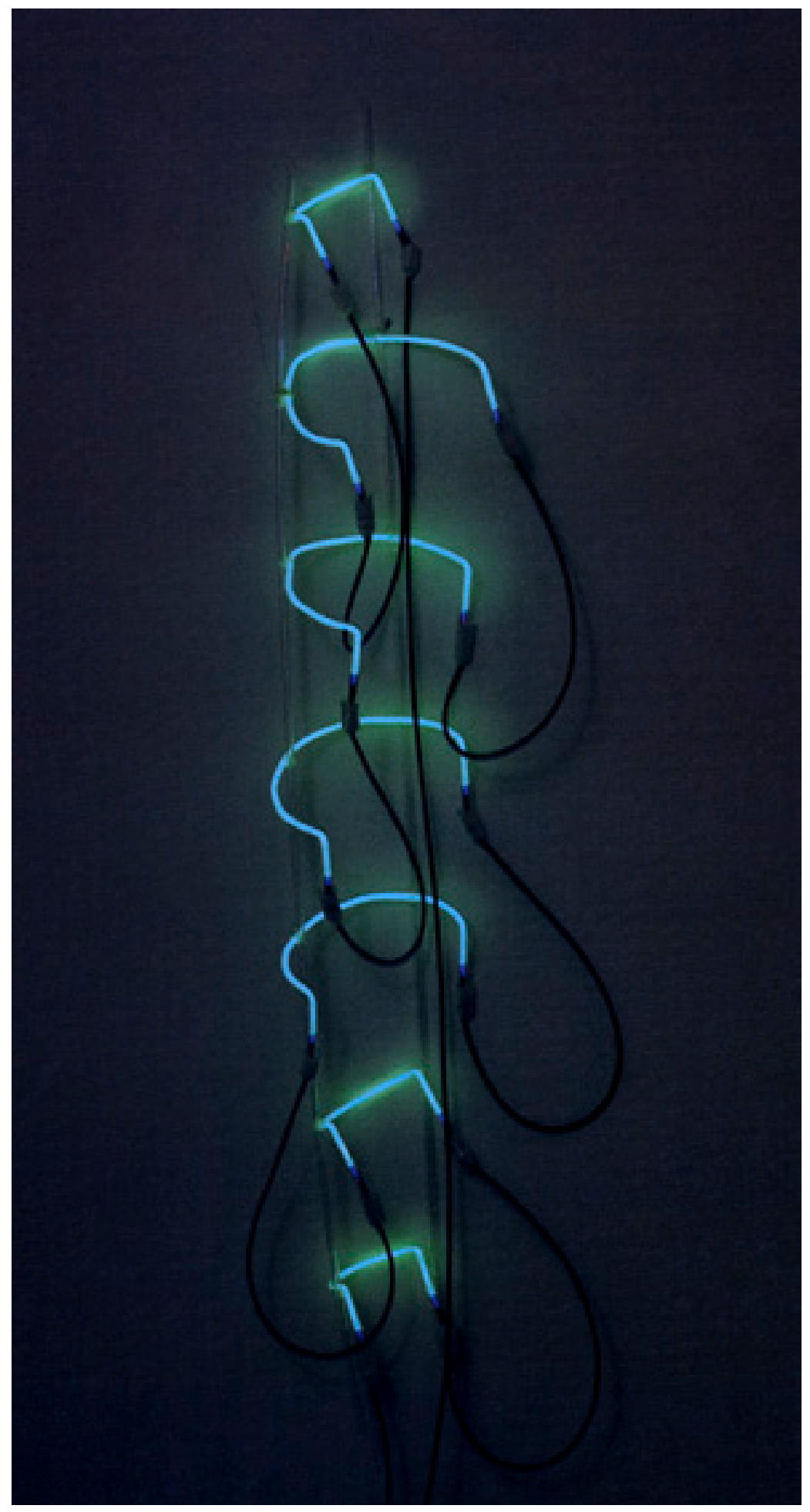

Neon Templates of the Left Half of my Body Taken at Ten-Inch-Intervals, 1966 , tubos de neon, $178 \times 23 \times 15 \mathrm{~cm}$. 
organizadas em intervalos regulares no sentido vertical, totalizando 1 metro e 78 centímetros de altura. Quando se lê o título, as feições diagramáticas daquela estrutura resultante da repetição de sete elementos assemelhados, embora de dimensões diversas, são atenuadas.

Por um lado, a própria ideia de gabarito remete à acurácia, à replicação serial e a uma indiferença ao conteúdo do que é serializado, por outro, o corpo como referente remonta à noção de totalidade e, mais do que isso, à organicidade das partes. Gabaritos são padrões, modelos, moldes, usados na produção e, sobretudo, na multiplicação de algo; são, portanto, mecanismos de repetição por excelência. Já o corpo, mais precisamente o corpo do artista, como informa o título, é afirmado em sua singularidade e individualidade, uma unidade assegurada pela combinação qualitativa de instâncias físicas, psíquicas, fisiológicas e culturais particulares, subjetivas.

O tom descritivo do título, que supostamente define com precisão os materiais e métodos empregados, reforça a estranheza e o absurdo da inversão proposta por Nauman: os gabaritos são singularizados e irreplicáveis ao passo que o corpo é quantificado, dividido em duas metades, uma das quais reduzida à mensuração de partes aleatórias. Ao mesmo tempo, são justamente as palavras que conferem corporeidade ao aparato e garantem-lhe organicidade, sugerindo a junção de pedaços que corresponderiam, inferese, aos cálculos dos contornos do tornozelo, do joelho e da coxa esquerdos e da metade esquerda do quadril, do tórax, do ombro e da cabeça do artista.

Arranjadas na parede e não emancipadas no espaço, posição clássica reservada às esculturas, as sete unidades de medida se tomadas em conjunto podem, decerto, apresentar traços antropomórficos exatamente pela sugestão de que estejam ali recostadas ou apoiadas tal como um corpo cansado, talvez reanimando-se ou aquecendo-se com a luminosidade azulada. Além disso, a altura total da peça reitera que a escala foi decidida em relação ao corpo humano.

Mesmo no desenho realizado posteriormente à escultura, em 1967, uma representação minuciosa da disposição dos sete arcos delgados e dos 
fios aparentes conectados ao gerador, fica evidente que a escultura parece encapsular uma ausência ou, então, guardar a reminiscência de uma presença, o corpo do artista que, de algum modo, interagiu com aquele material, da ação tendo restado o contorno que fora preenchido. De certo modo, o espaço circunscrito pelos limites está vacante; trata-se de um "espaço de vacância", um espaço à espera, um lugar que fora ocupado e que, talvez, volte a sê-lo novamente. Nesta tese, argumenta-se que a noção de "vacância" - um espaço que não se encontra ocupado mas que pode vir a sê-lo - é mais pertinente aos trabalhos de Nauman do que a ideia de vazio. Enquanto a vacância remete à imagem da falta, da carência, da incompletude, o vazio pode remeterse também à imagem do "nada", ao esvaziamento absoluto e irreversível. Pontuar essa sutileza serve para afastar, desde já, quaisquer desdobramentos metafísicos que a ideia de vazio possa carrear, deixando clara a discordância de que interpretações dessa sorte sejam cabíveis à obra do artista.

Untitled (After Neon Templete of the Left Half of My Body Taken at Ten-Inch Intervals), 1967, grafite sobre papel, 45,5 x $61 \mathrm{~cm}$.

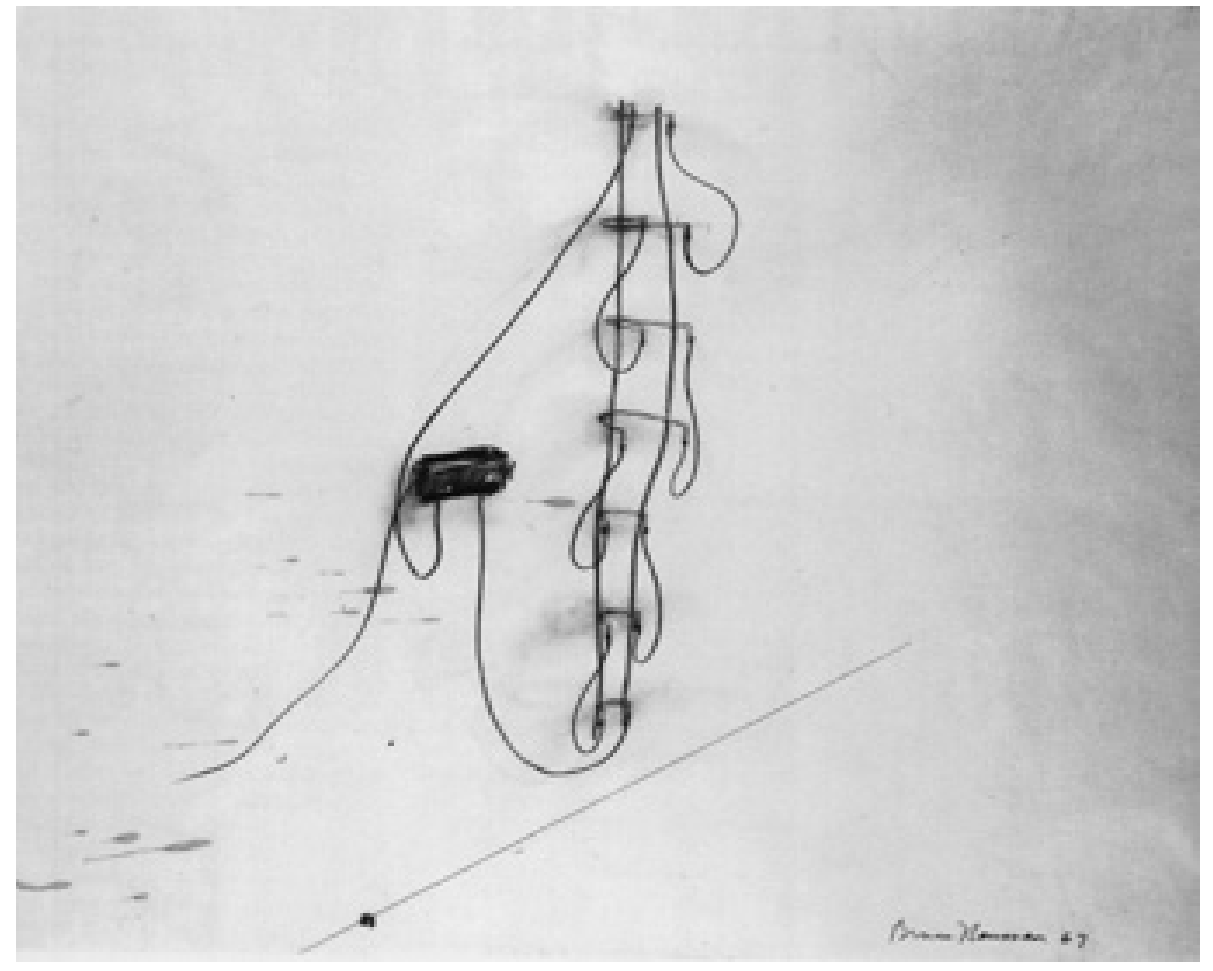


Em entrevista concedida em 1980, quando perguntado se os gabaritos em neon pretendiam desencadear um processo imaginativo que evocaria especificamente a sua presença física, uma vez que eram as medidas do seu corpo que pautavam a realização daquela escultura, Nauman respondeu:

\footnotetext{
Não, acho que essas coisas eram, de fato, bastante impessoais. Acho que usei a mim mesmo como um objeto; talvez impessoal não seja a palavra correta. Acho que a tentativa é ir do particular ao geral. Talvez o mesmo ocorra quando se faz um autorretrato, quando Rembrandt fez seu autorretrato, e muitos outros o fizeram [...] - você está fazendo uma pintura, mas você também está fazendo um exame de si mesmo e fazendo uma generalização para além de si mesmo².
}

Nessa declaração estão pontuadas questões fundamentais para a obra: se o artista toma-se por objeto, o corpo é um material, matéria-prima como outra qualquer e, portanto, passível de ser testada. Não apenas isso, trata-se de uma matéria em estado bruto, sem as marcas caraterísticas da individualidade de Nauman, já que se trata de empreender um exame que possa ir além de si mesmo, ser generalizado. Considerar o corpo um "material bruto" [raw material] é, no caso de Nauman, um jeito de rebaixar ou mesmo contestar uma ideia de "interioridade". É preciso lembrar que o trabalho de Nauman passa ao largo das correntes "expressivas" marcantes em grande parte dos artistas da sua geração, na body art, na arte povera e no chamado pós-minimalismo.

2. Entrevista concedida por Bruce Nauman a Michele de Angelus. No original: "MD - The neon pieces that come out of your body, the templates from your body - so much of your art does come out of your physical presence and size. How do you think the audience can relate to that? Does it involve an imaginative process of evoking the artist and his presence? BN - No, I think those things were really quite impersonal. I think I used myself as an object; maybe impersonal is the wrong word.
I think the attempt is to go from the specific to the general. Maybe it's the same kind of way of making a self-portrait, as Rembrandt made a self-portrait, and a lot of other people [...] - you're making a painting, but you're also making an examination of yourself and also making a generalization beyond yourself". Cf. KRAYNAK, Janet (Ed.). Please pay attention please: Bruce Nauman's words: writings and interviews. Cambridge, Massachusetts: The MIT Press, 2005, p. 249. 
Cumpre esclarecer, a propósito, que os trabalhos de Nauman contaram com um acolhimento precoce nas mais importantes mostras norte-americanas dos anos $1960^{3}$, de modo que a obra manteve um diálogo estreito com os principais movimentos artísticos vigentes à época sem, no entanto, filiar-se a eles.

Veja-se, por exemplo, a noção de repetição, um procedimento recorrente na obra de Nauman, mas que não implica na repetição serial de objetos associada ao minimalismo americano ${ }^{4}$, tampouco na repetição da arte pop, para a qual a própria representação torna-se esquema, padrão ${ }^{5}$. A repetição que caracteriza os primeiros filmes e vídeos, conforme será comentado, não é uma mera seriação que repete invariavelmente o mesmo, não se trata de "jogar o mesmo com o mesmo"6. A despeito da perícia com a qual executa

3. Para que se possa vislumbrar um panorama da época, mencionem-se as mostras coletivas mais importantes de que Nauman participou no início da carreira: "Eccentric Abstraction", na Fischbach Gallery, em Nova York, em 1966 [com Louise Bourgeois, Eva Hesse, Alice Adams, Gary Kuehn, Dan Potts, Keith Sonnier, Frank Lincoln Viner]; "Documenta 4", no Museu Fridericianum, em Kassel, Alemanha, em 1968; "Prospect 68”, na Städtische Kunsthalle, em Düsseldorf, em 1968; "Anti-Form", na John Gibson Gallery, em Nova York, em 1968 [com Eva Hesse, Richard Serra, Keith Sonnier, Richard Tuttle]; “Nine at Castelli”, na Castelli Warehouse, em Nova York, em 1969 [junto com Eva Hesse, Richard Serra, Keith Sonnier, entre outros]; "Live in your Head: When Attitudes Become Form", na Kunsthalle Bern, em Berna, Suíça, em 1969 lexposição que itinerou para o Museu Haus Lange, em Krefeld, Alemanha e para o Institute of Contemporary Arts, em Londres); "Anti-Illusion: Procedures/ Materials", no Whitney Museum of American Art, em Nova York, em 1969 [junto de artistas como Carl André, Eva Hesse, Robert Morris, Richard Serra, Keith Sonnier, Richard Tuttle].

4. Cabe observar que não há consenso quanto ao termo minimalismo e os artistas a ele identificados, como também a seriação não foi um procedimento tão homogêneo em artistas supostamente associados à rubrica, basta pensar na seriação de Carl Andre (1935 -), Dan Flavin (1933-1996) ou mesmo Robert Morris (1931 -) e Donald Judd (1928-1994) e, em um outro extremo, Sol LeWitt (1928-2007) que explorou as possibilidades de variação dentro da repetição serial, exaurindo matematicamente as combinatórias ao limite. Especificamente acerca da seriação na obra de Sol LeWitt, consultar o artigo de Rosalind Krauss [LeWitt in Progress. October Magazine, Cambridge/ Massachusetts, n. 06, 1978, p. 46-60]. A bibliografia acerca do minimalismo é extensa, consultem-se, entre outros: JUDD, Donald. Complete writings/1975-1986. Eindhovem: van Abbemuseum, 1987; MORRIS, Robert. Continuous Project Altered Daily: The Writings of Rober Morris. Cambridge: MIT Press, 1993; MEYER, James. Minimalism: Art and Polemics in the Sixties. New Haven: Yale University Press, 2001; BATTCOCK, Gregory (Org.). Minimal Art: a Critical Anthology. Nova York: E. P. Dutton\&Co, 1968; FOSTER, Hall.The Return of the Real: the Avant-garde at the End of the Century. Cambridge, Massachusetts: The MIT Press, 1999.

5. Do mesmo modo, há na obra de Nauman certos recursos a uma figuração e a materiais típicos da pop sem que isso autorize associá-la ao universo da arte pop.

6. Cf. DIDI-HUBERMAN, Georges. 0 que vemos o que nos olha. São Paulo: Editora 34, 1998, p. 57. 
exercícios corporais intrincados e da extrema concentração exigida, cada recomeço tem acumulado o cansaço do esforço anteriormente realizado e, conforme o padrão se repete, a extenuação física se faz visível ainda que à revelia da contenção corporal do artista. A repetição exaure, mas o artista evita dramatizar a exaustão. A tônica dos filmes e vídeos é comedimento e precisão. A repetição não é ali seriação. Por mais que se possa argumentar que Nauman aplique ao corpo o mesmo tipo de pensamento serial que artistas do minimalismo dispensavam aos objetos, não se pode deixar de notar que a intenção e o resultado são em tudo diversos ${ }^{7}$. A repetição na obra de Nauman é, na verdade, uma reiteração de um padrão, seja uma ação ou as palavras de uma frase, com variações sutis a cada ocorrência, de maneira que nem o sentido original do padrão nem o ritmo da repetição se mantêm iguais, sendo tenuamente alterados, distorcidos ou intensificados ao máximo. Ao fim, as reiterações sucessivas promovem saturação e desgaste. Repete-se não exatamente o mesmo, mas algo parecido com algumas variações capazes de potencializar a experiência. Quando perguntado sobre o emprego da repetição nos trabalhos, Nauman recorre à literatura e não às artes visuais, traçando um paralelo com a repetição presente nos romances do escritor francês Alain Robbe-Grillet (1922-2008), a saber, "chega-se a um ponto no qual ele repetiu o que disse anteriormente, mas o significado é completamente diferente, porque mesmo que ele tenha mudado apenas duas palavras, elas mudaram todo o significado daquilo sobre o que ele está falando".

7. A respeito deste tema, interessante 0 comentário de Nuno Ramos que, em ensaio dedicado à Hélio Oiticica (1937-1980), pontua algumas diferenças entre o carioca e Nauman, sobretudo na lida com o corpo: "ao contrário do trabalho de Oiticica, Nauman trata o eu como um autômato, um rato de Pavlov paralisado por estímulos contraditórios. $\mathrm{Na}$ verdade, grande parte de sua originalidade vem de aplicar a seriação característica do primeiro Minimalismo onde menos se esperava: nos mecanismos da subjetividade. Procura fundir assim a exterioridade absoluta da série à interioridade do corpo e do eu, transpirando por isso uma violência e uma crueldade tanto mais intensas quanto mais naturalizadas" [Cf. RAMOS, Nuno. À espera de um sol interno. In: Idem. Ensaio geral: projetos, roteiros, ensaios, memórias. São Paulo: Globo, 2007].

8. Nauman não especifica a quais romances de Robbe-Grillet se refere. 0 trecho mencionado, no original: "you come to a point where he has repeated what he said earlier, but it means something altogether different, because even though he has changed only two words, they have changed the whole meaning about what he is talking about". Cf. KRAYNAK, Janet (Ed.). Op. cit., p. 181. Alain Robbe-Grillet foi um 

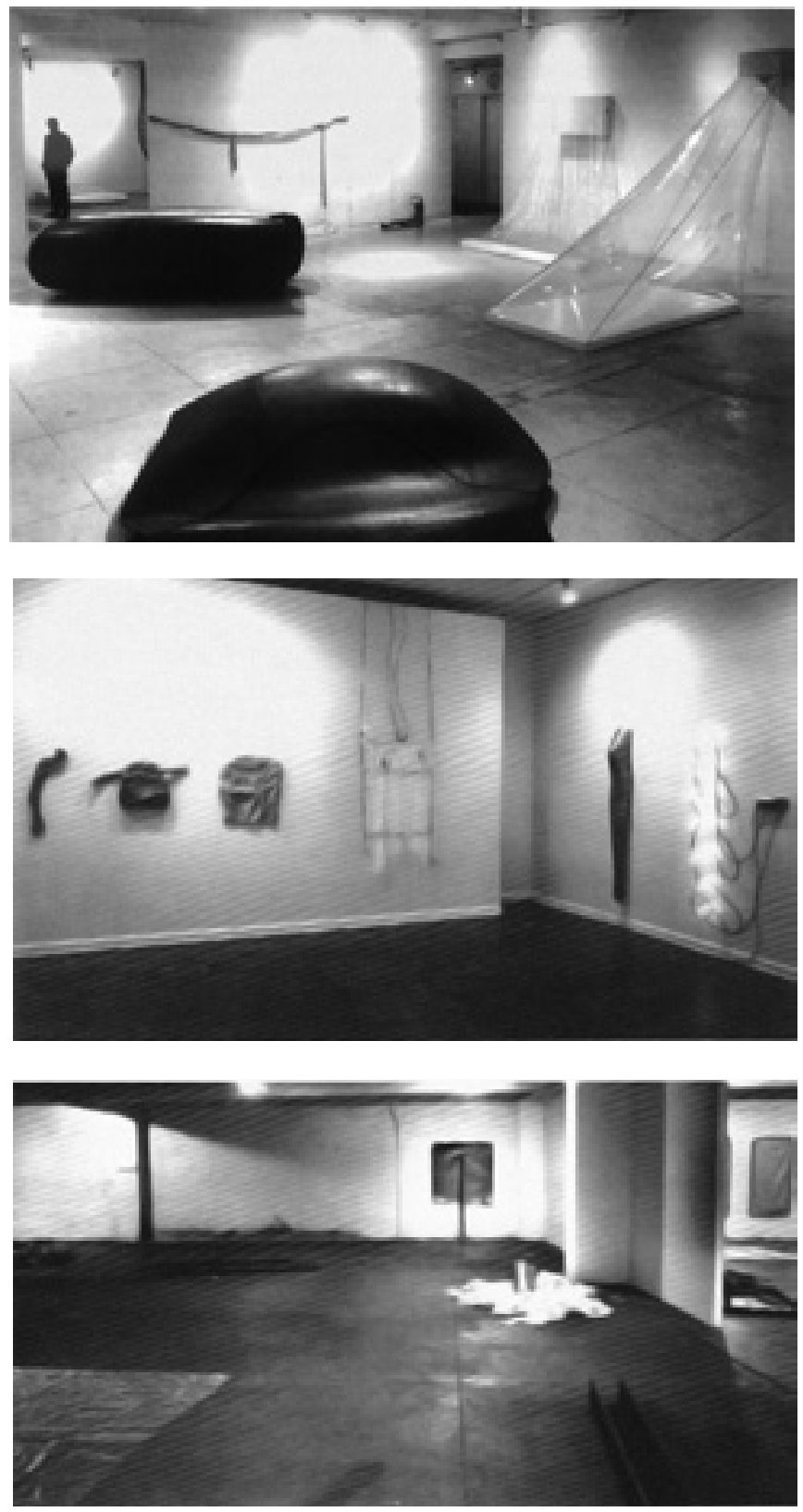

Vista da exposição “Eccentric Abstraction”, Fishbach Gallery, Nova York, 1966.

Vista da exposição “Bruce Nawman”, Leo Castelli Gallery, Nova York, 1968.

Vista da exposição “Nine at Castelli”, Castelli Warehouse, Nova York, 1968. 
Tambémé oportuno esclarecer o fato de que nas antologias dedicadas à arte contemporânea Nauman frequentemente compareça entre os artistas conceituais, especialmente se a arte conceitual é tomada em sua acepção mais ampla9. Os indícios da aparente proximidade da obra de Nauman com essa vertente artística parecem estar espalhados por toda a produção: o uso das palavras, a desconfiança do caráter "objetual” da arte, a ênfase no processo, o emprego de materiais pouco convencionais, a desenvoltura para lidar com diversos meios e a solicitação de uma espécie de engajamento mental do observador. Entretanto, logo se nota que o viés conceitual não prescinde de uma instância física fortemente evocada pelos trabalhos. Além disso, diversamente dos artistas conceituais, para Nauman importa menos uma operação tautológica e mais os limites da dimensão comunicativa da linguagem. Também não se verifica na obra do artista um processo de "desmaterialização", pois nela resta sempre uma presença material enfática, mesmo que para fazer referência ao vacante, conforme se disse.

escritor francês especialmente conhecido pelos ensaios reunidos em Pour un Nouveau Roman (1963) nos quais defendeu a reinvenção da forma romance a cada nova geração, sendo por isso identificado com o movimento do nouveau roman, um conjunto de iniciativas diversas e com diferentes concretizações, nascidas na França, no início da década de 1950, com o intuito de renovar a forma romanesca então vigente, ainda calcada nos preceitos do romance burguês do século XIX. Robbe-Grillet foi também cineasta e escreveu, entre outros, o roteiro de 0 ano passado em Marienbad, filmado em 1963 por Alain Resnais.

9. Pode-se dizer, em termos gerais, que a arte conceitual não corresponde exatamente a um movimento mas a um conjunto de práticas que lançou luz sobre problemas latentes relacionados à natureza da arte, ao papel do artista e às implicações do caráter "objetual” dos trabalhos. Grande parte da bibliografia sobre o tema tende a concordar que arte conceitual, em sentido estrito, corresponderia a certas práticas norte-americanas e europeias ocorridas entre as décadas de 1960 e 1970, no âmbito da crise dos paradigmas tradicionais da visualidade, enquanto que conceitualismo seria um fenômeno espacial e temporalmente mais abrangente, com múltiplos pontos de origem, com presença forte no Brasil e na América Latina. Para um maior desenvolvimento do tema, consulte-se, entre outros: ALBERRO, Alexander; STIMSON, Blake (Ed.). Conceptual Art: a Critical Anthology. Cambridge, Massachusetts: The MIT Press, 2000; BATTOCK, Gregory (Ed.). La Idea como Arte: Documentos sobre el Arte Conceptual. Barcelona: Gustavo Gilli, 1977; HARRISON, Charles. Essays on Art \& Language. Oxford: Blackwell, 1991; LIPPARD, Lucy. Six years: The Dematerialization of the Art Object from 1966 to 1972. Nova York: Studio Vista, 1973; OSBORNE, Peter. Conceptual Art. Londres: Phaidon, 2002; RAMIREZ, Mari Carmen. Tácticas para vivir de sentido: caracter precursor del conceptualismo en America Latina. In: Heterotopías: medio siglo sin-lugar, 1918-1968. Madri: Museo Nacional Centro de Arte Reina Sofía, 2000. 


\subsection{Formas macias no espaço: a presença ambígua da tradição da escultura}

Desde o início de suas atividades artísticas, Nauman mostrou interesse por diversas linguagens: das primeiras moldagens às recentes instalações sonoras, dedicou-se aos vídeos, desenhos, performances, gravuras, fotografias e a algumas intervenções em escala urbana; sua produção mantém, todavia, um lastro na escultura, quer nos procedimentos, quer na escala. As esculturas de Nauman são concebidas tendo em conta múltiplos espaços - espaço circundante, espaço interior, espaço situado entre as superfícies dos corpos e das coisas - e não apenas a partir de um espaço abstratamente inteiriço. Essa espécie de inteligência escultórica que mobiliza uma noção multifacetada do espaço perpassa toda a obra. Em uma das últimas entrevistas concedidas, quando questionado a respeito dos muitos meios que utiliza, Nauman apenas afirmou: "continuo ainda a me considerar um escultor" ${ }^{10}$.

O fato é que Nauman recebeu uma sólida formação nas várias técnicas de escultura durante o período em que esteve na Universidade da Califórnia, em Davis, instituição na qual obteve o título de Mestre em Artes com ênfase em escultura ${ }^{11}$. Antes disso, havia obtido em 1964 o

10. "I always still call myself a sculptor". Entrevista concedida à crítica e curadora Joan Simon por ocasião da abertura de "Raw Materials", grande retrospectiva realizada na Tate Modern, em Londres, em 2004. Essa mostra será abordada no Capítulo 5 desta tese. Cf. SIMON, Joan. Hear here: Interview with Bruce Nauman. Frieze Magazine, n. 86, Londres, out. 2004. Disponível em: http://www.frieze.com/issue/article/hear_ here. Acesso em: 11 fev. 2010.

11. Muitas referências aos primeiros anos da produção de Nauman, sobretudo entre 1965 e 1969, foram consultadas na minuciosa pesquisa de Constance Lewallen, publicada no volume $A$ Rose Has no Teeth: Bruce Nauman in the 1960s [Berkeley: University of California Press, 2007], um estudo feito a partir de entrevistas com colegas e professores de Nauman em Davis, e que também conta com uma cronologia comentada e uma seleção bibliográfica do período inicial. A hipótese defendida pela autora é que temas encontrados ao longo da produção já estariam presentes nos anos iniciais de formação do artista, justamente o período em que Nauman viveu no norte da Califórnia, entre os anos de 1964 e 1969. A pesquisadora aponta os seguintes temas mais recorrentes à época: questionamento do papel do artista e da 
Bacharelado em Artes pela Universidade do Wisconsin, em Madison, no centro-oeste do país, onde frequentou também aulas nos cursos de matemática, música, física e filosofia, áreas do conhecimento que influenciaram decisivamente sua prática artística.

O departamento de artes em Davis era incipiente na década de 1960 e contava com ateliês bem equipados para as técnicas de fundição em metal, de modo que o programa de escultura dava ênfase à moldagem em bronze, ministrada por Tio L. Giambruni (1927-1971), um conservador em meio ao ambiente experimental, lembrado por reavivar "métodos renascentistas" ${ }^{\prime 2}$. Por surpreendente que possa parecer, Nauman fez questão de acompanhar tais aulas e adquiriu ali um notável aprendizado técnico. Posteriormente, Nauman ministrou cursos de escultura no Instituto de Artes de São Francisco (de 1966 a 1968).

Conforme relato do artista, a vontade de experimentação no início de sua trajetória foi instigada pelo próprio ambiente cultural da costa oeste dos Estados Unidos. Na época em que foi estudante, a cena artística da Califórnia era bastante informal e a região estava afastada do crescente mercado de arte centralizado em Nova York. O artista convivia com professoresartistas jovens e engajados, entre eles Wayne Thiebaud (1920 - ),William T. Wiley (1937 - ), Robert Arneson (1930-1992), Roy de Forest (1930-2007)

função da arte; a primazia da ideia e a ênfase conferida ao processo; o ateliê do artista como lugar privilegiado para as experimentações; a relação da escultura com o espaço físico; os jogos de palavras lencorajados por William T. Wiley e Robert Arneson, professores de Davis); a inversão de exterior e interior; a tensão entre exposição e ocultação/mascaramento; e o potencial artístico das atividades comuns [Cf. LEWALLEN, Constance. Op. cit., p. 2].

12. “Dada a ênfase conferida ao bronze e ao monumento, o programa de escultura de Davis dificilmente pareceria moderno: ao contrário, com suas fundições e assistentes de fresagem, é lembrado por seus métodos e 'ar' marcadamente renascentistas. Poderíamos imaginar que um tal contexto fosse inimigo de Nauman, embora o curso de fundição de Giambruni tenha sido um dos que ele fez questão de assistir" ["given its emphasis on bronze and the monument, the Davis program in sculpture hardly seemed modern: on the contrary, with its molten metals and milling assistants, it is remembered for its distinctly Renaissance methods and feel. We might imagine that such a context was inimical to Nauman, yet Giambruni casting course was one that he made sure to be able to take"]. Cf. WAGNER, Anne. Nauman's Body of Sculpture. In: LEWALLEN, Constance. Op. cit., p. 121. 

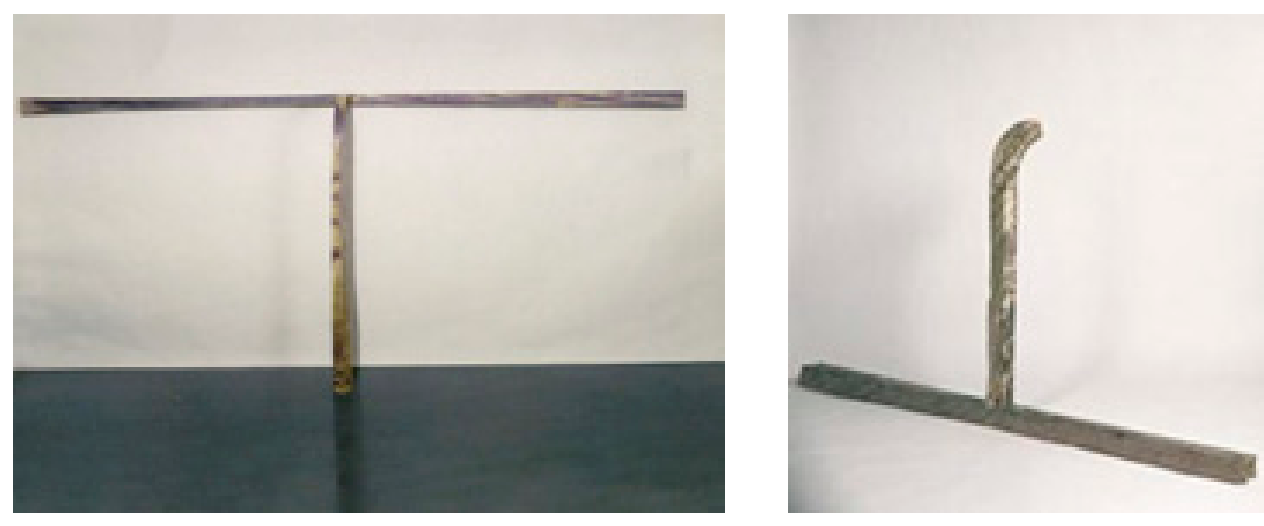

Sem título, 1965-1966, fibra de vidro, $140 \times 233 \times 30 \mathrm{~cm}$.

e Manuel Neri (1930). A maioria desses artistas era ligada ao movimento que se tornou posteriormente conhecido por funk, termo emprestado do jazz, que intitulou uma mostra coletiva no Museu da Universidade de Berkeley, em 1967. O funk pretendia marcar suas diferenças em relação à arte produzida e apresentada nas concorridas exposições que se sucediam em Nova York e preconizava uma arte "quente em vez de fria; comprometida em vez de desengajada; bizarra e não formal; sensual; e, frequentemente, um tanto feia. Ainda que usualmente tridimensional, não é escultórica em sentido tradicional; e é irreverente na atitude. Como um diálogo de uma peça de Ionesco ou de Beckett, a justaposição de coisas inesperadas não parece fazer qualquer sentido aparente"13. Nauman não chegou a ser um

13. No original, o comentário de Peter Selz publicado no catálogo da exposição "Funk", de 1967: "Funk is at the opposite extreme of such manifestations as New York's Primary Structures or the Finish Fetish sculpture which prevails in Southern California. Funk art is hot rather than cool; it is committed rather than disengaged; it is bizarre rather than formal; it is sensuous; and frequently it is quiet ugly. Although usually three-dimensional, it is non-sculptural in any traditional way, and irreverent in attitude. Like the dialogue in a play by lonesco or Beckett, the juxtaposition of unexpected things seems to make no apparent sense" [Cf. SELZ, Peter apud LEWALLEN, Constance. Op. cit., p. 27]. 
artista participante do movimento; todavia foi nesse pano de fundo que sua produção se formou, de modo que foi influenciada pelas ideias e práticas mais gerais da arte funk, conforme se observa na aparência e na formalização de suas primeiras esculturas, no aspecto rústico decorrente da recusa das etapas de acabamento das peças.

Em certos aspectos, o conhecimento das técnicas de escultura recebido nos anos de formação parece perdurar na obra de Nauman, talvez como um contencioso a reclamar um acerto de contas, a partir do qual foi empreendido "um processo de desmantelamento de um sistema inteiro de representação anteriormente impenetrável à exaustão, um sistema estritamente ligado a atributos como solidez, presença, coerência, coisificação e corporeidade", conforme pontua a historiadora e crítica de arte Anne Wagner ${ }^{14}$. Em "Nauman's Body of Sculpture”, ensaio fundamental para a elaboração da hipótese em pauta, Wagner discute as implicações da substituição de um meio "decisivamente conquistado e gradativamente destituído" por práticas que, combinadas de modo variável, extrapolariam suas respectivas especificidades.

Wagner afirma que nos primeiros trabalhos as sedições de Nauman contra a tradição da escultura pareciam tão veementes que conduziram a juízos apressados. Wagner cita como exemplo, entre outros, a recepção desses trabalhos por Lucy Lippard, crítica e curadora norte-americana que organizou em 1966 a exibição "Eccentric Abstraction", uma das mostras mais emblemáticas daquela década ${ }^{15}$. Na ocasião, Lippard escreveu que os trabalhos de Nauman eram modelos do que ela definia como "o estilo nãoescultórico", uma vez que as peças do artista tinham um "aspecto descuidado, envelhecido, superfícies turvas e repelentes, sendo, à primeira vista, totalmente

14. Ibidem, p. 124 [“a process of dismantling an entire system of representation theretofore impervious to exhaustion, a system deeply bound up with solidity, presence, coherence, thingness, and embodiment"].
15. A mostra "Eccentric Abstraction" ocorreu na Fischbach Gallery, em Nova York. Consultese a nota 3 deste Capítulo para uma lista das principais exposições de que Nauman participou nos anos 1960. 

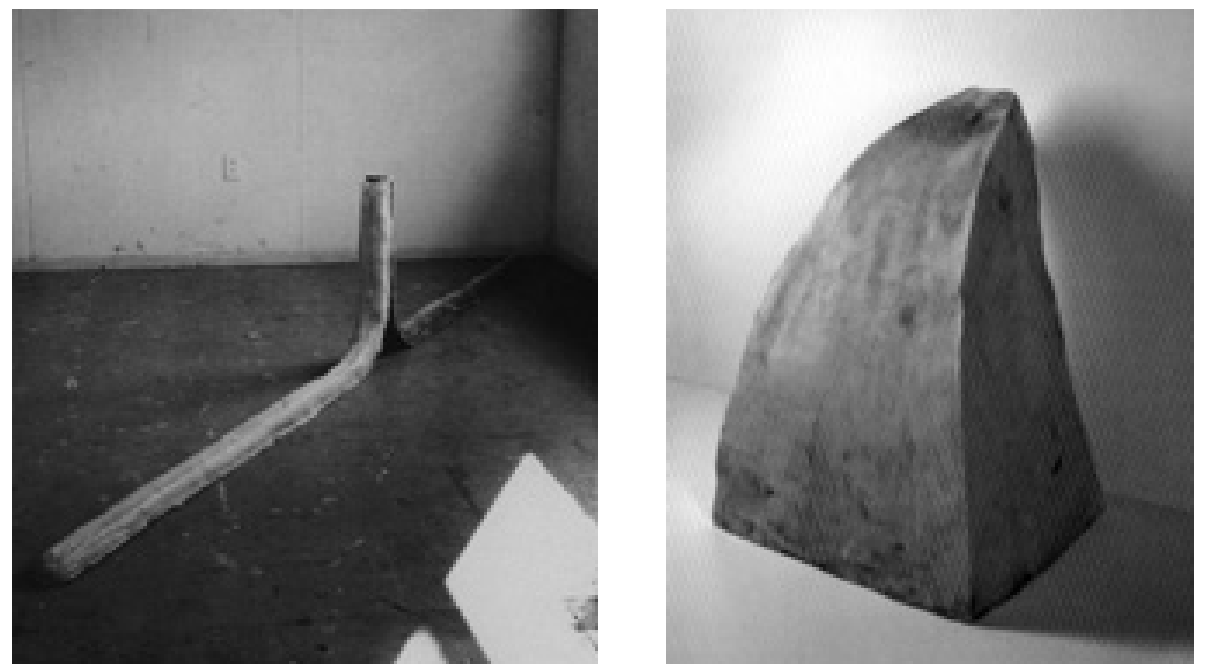

Sem título, 1965-1966, fibra de vidro, $140 \times 233 \times 30 \mathrm{~cm}$.

Sem título, 1965, fibra de vidro e resina de poliéster, $54.6 \times 45.7 \times 29 \mathrm{~cm}$.

Vista da instalação “Bruce Nauman”, Nicholas Wilder Gallery, Los Angeles, 1966.

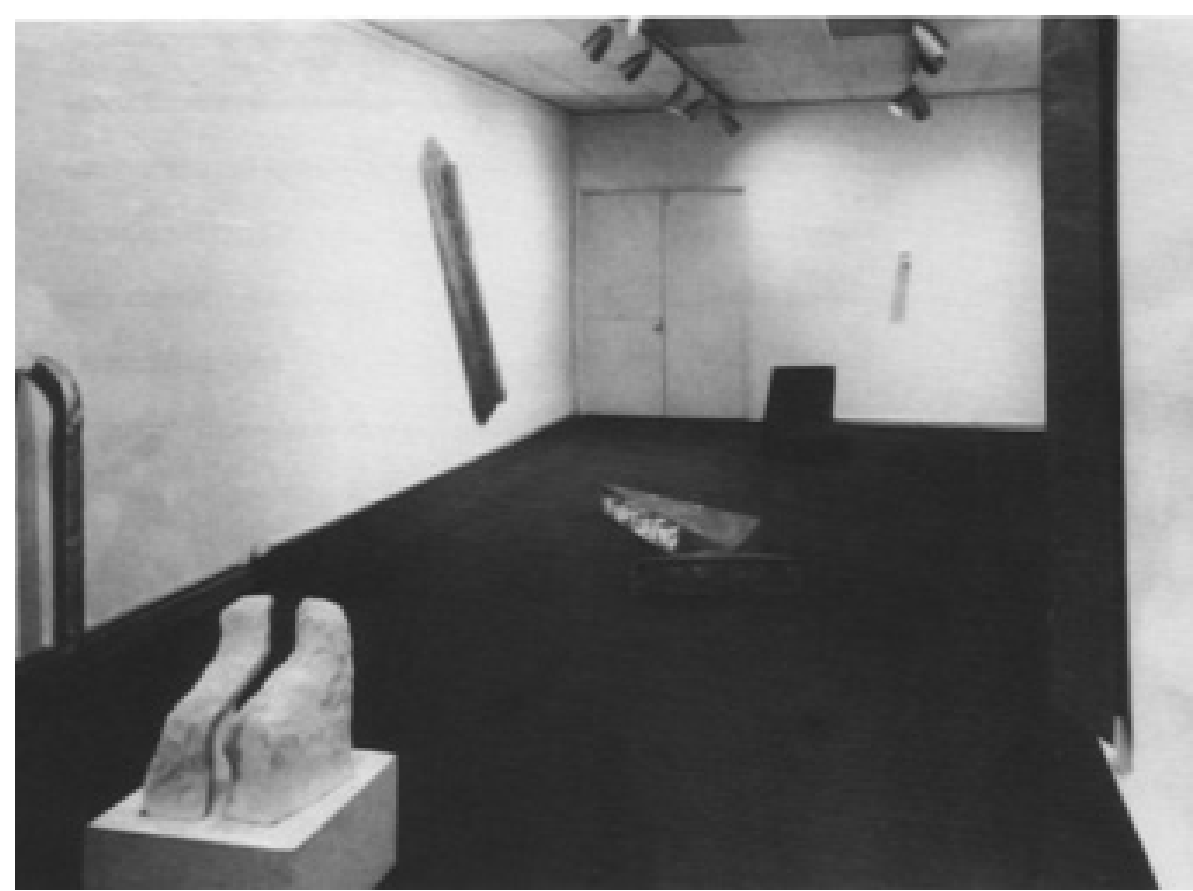



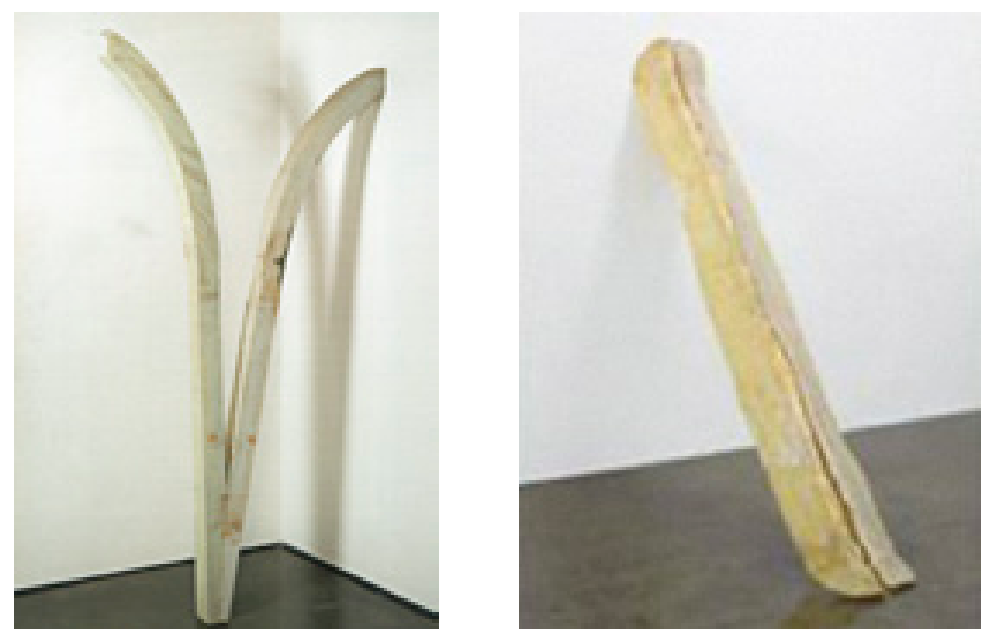

Sem título, 1965, fibra de vidro e poliéster, $210 \times 121 \times 8 \mathrm{~cm}$.

Sem título, 1965, fibra de vidro, $121,9 \times 40,6 \mathrm{~cm}$.

não-escultóricas” ${ }^{16}$. Com isso, ressalta Wagner, Lippard sugeria a imagem um tanto caricatural da escultura como algo atemporal e feito para ser olhado, presumindo superfícies adequadamente rematadas, distantes decerto da aparente fragilidade de formalização das peças de Nauman. Wagner defende que tais trabalhos eram, antes de tudo, "corpóreos", aludindo à presença vital e ostentando a manualidade da feitura, ou seja, trazendo em seu cerne, ainda que a contrapelo, atributos da escultura mais tradicional, tais como corporeidade e materialidade ${ }^{17}$.

Ao lidar francamente com a tradição da escultura, Nauman acabou por alargar a própria noção de material. Além dos tradicionalmente associados à escultura (como bronze, argila, cera ou gesso) e dos característicos do mundo da técnica, plenamente incorporados desde, pelo menos, as primeiras experiências da pop (neon, resina, fibra de vidro, piche, alumínio, entre outros),

16. “Nauman's pieces are carelessly surfaced, somewhat aged, blurred and repellent, wholly non-sculptural and deceptively inconsequential at first sight". Cf. LIPPARD, Lucy R. apud WAGNER, Anne. Op. cit. p. 122. Conferir também LIPPARD, Lucy. Six years: The Dematerialization of the Art Object from 1966 to 1972. Nova York: Studio Vista, 1973.

17. Cf. WAGNER, Anne. Op. cit., p. 122- 125 e 142. 

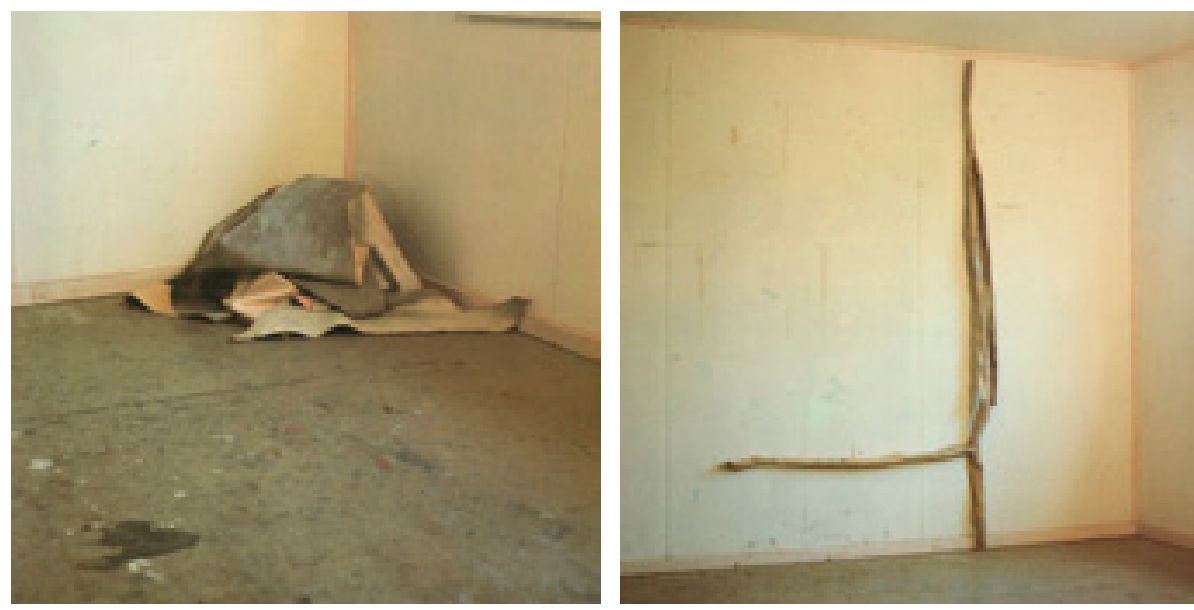

os experimentos escultóricos do artista desdobraram-se de tal modo que passaram a abarcar elementos associados a outras áreas (como a literatura, o teatro, o cinema e a dança): os textos escritos e falados, o corpo, os ruídos e o tempo passam a figurar entre os materiais passíveis de manipulação por Nauman e abrem espaço a meios tais como o vídeo, a performance e a instalação, práticas inovadoras na época. Diante disso, pode-se dizer que nos trabalhos de Nauman a própria forma é pensada como material na medida em que os modelos formais tradicionais se tornam elementos entre outros à disposição do artista, isto é, tornam-se matéria bruta (raw material).

Com efeito, nas experiências iniciais o repertório tradicional da escultura foi tomado por Nauman de modo ambíguo, como se "por trás de cada aparente falha houvesse um duplo antitético, uma antiga prática escultórica superada friamente" ${ }^{18}$. Desde os primeiros conjuntos de trabalhos - as soft shapes [formas macias] e as body-sculptures [esculturas-corpo], tal como o próprio artista informalmente passou a chamar duas séries de peças "sem título" realizadas entre 1965 e 1966 -, a escultura seria concebida a partir de uma combinação de

18. Cf. Ibidem, p. 122 ["behind each of Nauman's apparent failings stands a shadow antithesis, a bygone practice of sculpture that the artist has coolly trumped"]. 
múltiplos espaços. Ao contrário da centralidade esperada da peça escultórica no espaço, as formas de Nauman eram dispostas em configurações plurais em meio a um conjunto também plural de espaços: apoiavam-se contra a parede, reclinavam-se nos cantos, repousavam no chão e pendiam do teto, conjugando aos dados fornecidos pelos espaços que ocupavam, ou melhor, definiam e recompunham, os resultados das ações exercidas contra a matéria (suster, curvar, reclinar, amarrar, pendurar, medir etc.).

Nessas primeiras peças macias, Nauman utilizava materiais de estruturação mais penosa, como a borracha, o papelão, o tecido, e lhes conferia formas que prescindiam de uma ordenação axial, já que as paredes ou o chão serviam-lhes de apoio. Basta pensar nas esculturas em borracha realizadas entre 1965 e 1966: uma delas compreendendo cinco peças moldadas em látex a partir de uma mesma forma, pintadas em cores diferentes e displicentemente empilhadas no chão; outra, um amontoado de pedaços de tecido e de borracha ajeitados em um canto de parede; e, por fim, uma forma esguia de cerca de 2,5 metros constituída por tiras de borracha penduradas na parede por apenas um dos filetes.

Sem título, 1965-1966, látex e juta, $35 \times 125 \times 17 \mathrm{~cm}$.

Sem título, 1965-1966, látex e fita adesiva, $24.3 \times 127 \times 8.9 \mathrm{~cm}$.

Estudo para escultura em borracha, 1966 , grafite sobre papel,

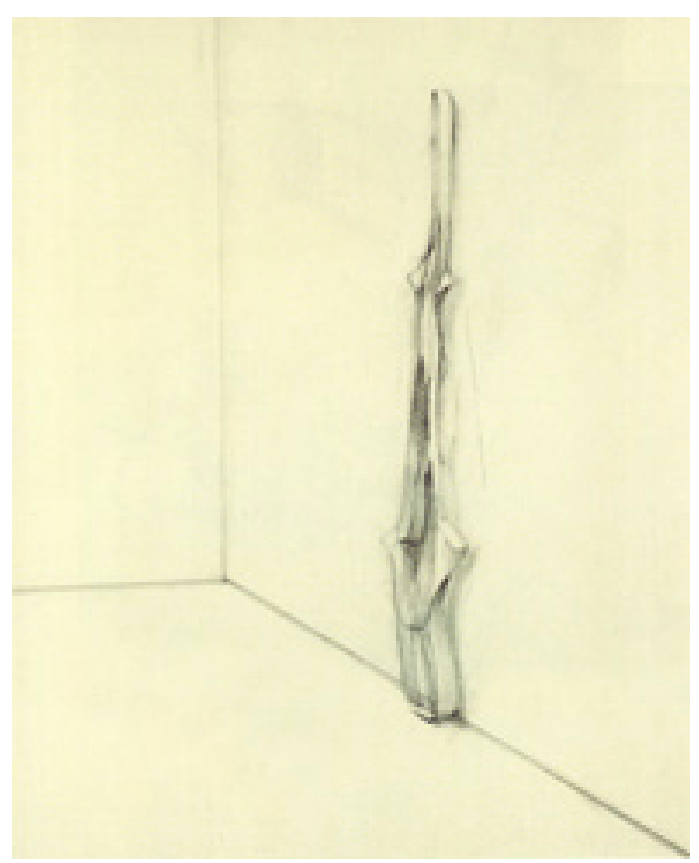




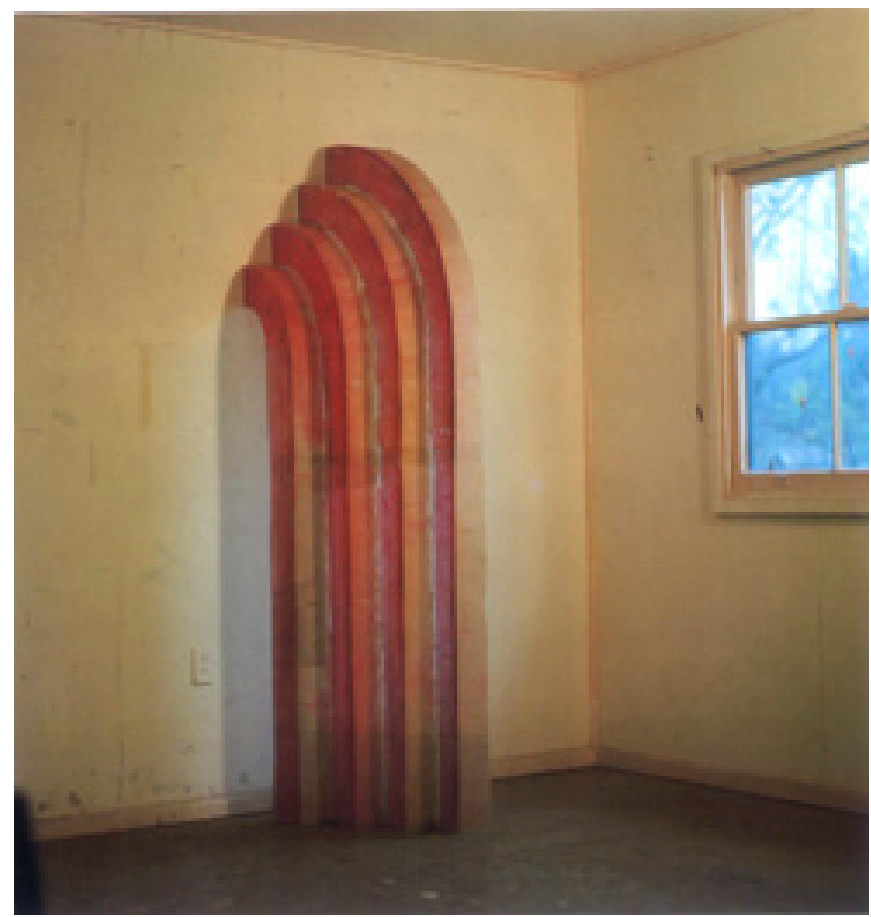

Sem título, 1965, fibra de vidro, $200 \times 53 \times 68 \mathrm{~cm}$.

Depois disso, o artista passou a empregar também resina poliéster associada àfibra de vidro na realização de moldes, posteriormente desmontados, reajeitados e expostos ao inverso, construindo uma forma oca a partir da permutação inusitada entre a superfície interna mais lisa e a externa, rugosa.

Por vezes, eram misturadas cores à fibra de vidro como o verde, o rosa e o amarelo, de modo que a peça usualmente translúcida adquiria um tom colorido pálido, conforme se vê na escultura vermelha (1965) de quatro partes arqueadas de tamanhos diferentes e justapostas em ordem crescente. Ou em dois outros trabalhos alongados e muito finos, um deles com duas partes, uma vermelha e outra púrpura (1965); o outro alaranjado, trazendo um tubo de neon no interior, também de 1965. No geral, as formas eram delgadas e guardavam algumas características antropomorfas, tornadas mais evidentes pela ordenação que assumiam no espaço.

Comentando os trabalhos com moldes e a inversão das superfícies, Nauman declarou em 1970: 

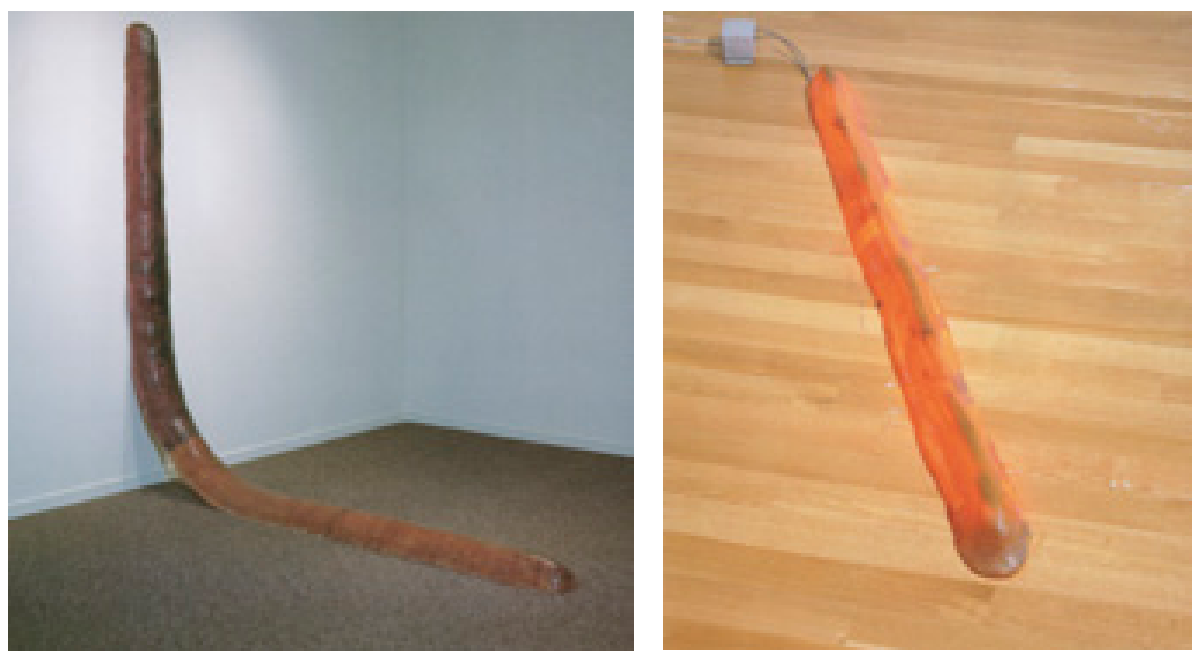

Sem título, 1965, fibra de vidro, 210,8 × 210,8 x 20,3 cm.

Sem título, 1965, fibra de vidro, poliéster e tubo de neon, $10 \times 15 \times 200 \mathrm{~cm}$.

[os primeiros trabalhos] envolveram coisas simples como fazer um molde, tomar as duas metades, juntá-las para fazer uma forma oca e virar esse oco do avesso. Tentei criar uma confusão entre o interior e o exterior de uma peça. Um lado é liso e por isso se parece com a parte externa, e o outro é áspero em razão da maneira como a fibra de vidro é moldada, mas pode-se vê-lo também ${ }^{19}$.

A inversão entre interior e exterior e a contiguidade das superfícies são questões que perpassam toda a obra, sendo que nas primeiras esculturas já se nota que as superfícies dos diversos materiais têm o mesmo estatuto. Também fica patente que a "fisicalidade" dos trabalhos se constitui nas e pelas superfícies, não se pretendendo resguardar o interior de um objeto, um "dentro", uma "essência” que não possa ser virada ao avesso e exposta.

19. No original: "They involved simple things like making a mold, taking the two halves and putting them together to make a hollow shape and turning it inside out. I tried to create a confusion between the inside and outside of a piece. One side is smooth so that it looks like the outside, and the other is rough because that's the way the fiberglass is cast, but you can see it as well". (Cf. KRAYNAK, Janet (Ed.). Op. cit., p. 117). 


\subsection{O espaço negativo debaixo da minha cadeira}

Nos primeiros trabalhos se constata a importância de como os objetos se mostravam mais ou menos resistentes ao espaço, discriminando limites e apoios. Para Nauman, interessavam tais demarcações, mas fundamentalmente na busca por modos de excedê-las. Por essa razão, dedicou-se às esculturas moldadas que tornavam visíveis os limites e as junções entre as estruturas. As distâncias entre as superfícies das coisas eram evidenciadas por moldes negativos do espaço.

Em A Cast of the Space Under My Chair [Um molde do espaço sob minha cadeira (1965-1968)] foi trazido à luz o espaço invisível situado entre o chão e o assento de uma cadeira, um "oco" preenchido por cimento. Segundo Nauman, a inspiração para a ideia teria sido uma frase de William De Kooning, "quando se pinta uma cadeira, deve-se pintar o espaço entre os tapetes e não a cadeira em si” ${ }^{20}$. A propósito, De Kooning é um dos artistas a que Nauman se refere com admiração, "ele é um belo desenhista e um artista poderoso - e também alguém que estava lutando. Artistas daquela geração, e mesmo depois dela, tiveram que lutar com Picasso. O problema deles era basicamente como ir além de Picasso. De Kooning, finalmente, encontrou um caminho, e por isso confio nele em sua escolha de como proceder" ${ }^{21}$.

Assim como fez com o espaço negativo debaixo de uma cadeira, Nauman moldou com resina e fibra de vidro o espaço contíguo a duas

20. No original, o comentário de Nauman: "Casting the space under a chair was the sculptural version of De Kooning's statement: when you paint a chair, you should paint the space between the rugs, not the chair itself'. I was thinking like that: about leftovers and negative spaces". Cf. KRAYNAK, Janet (Ed.). Op. cit., p. 254.
21. "He's a beautiful draftsman and a powerful artist - and also somebody who was struggling. Artists from that generation, and even after that, had to struggle with Picasso. Their problem was basically how to get beyond Picasso. De Kooning finally found a way, and so I trust him in his choice of how to proceed". Cf. BRUGGEN, Coosje von. Bruce Nauman. Nova York: Rizzoli International Publications, 1988, p. 8. 
caixas deixadas no chão, escultura intitulada Platform Made Up of the Space Between Two Rectilinear Boxes on the Floor [Plataforma feita do espaço entre duas caixas retilíneas no chão (1966)] e também os vãos debaixo de uma prateleira em Shelf Sinking into the Wall with Copper-Painted Plaster Casts of the Spaces Underneath [Prateleira afundando na parede com moldes de gesso pintados em cobre dos espaços subjacentes (1966)]. Neste último trabalho, foram expostas não apenas as duas peças em gesso colorido resultantes da moldagem do espaço debaixo da prateleira, mas também a prateleira-matriz, que, em razão do ângulo em que foi fixada na parede, simulava um "afundamento" na superfície do espaço expositivo.

De certa maneira, esses trabalhos atribuíam forma às escoras que permitiam estabelecer a escala e o peso dos materiais e, com eles, o artista confirmaria seu interesse pelos limites, pelas divisórias ou junções que revelam as contiguidades entre as superfícies:

A Cast of the Space Under my Chair, 1965-1968, concreto, 44,5 x 39 × 37cm. Plataform Made Up of the Space between Two Rectilinear Boxes on the Floor, 1966, fibra de vidro e poliéster, $18 \times 211$ × $105 \mathrm{~cm}$.
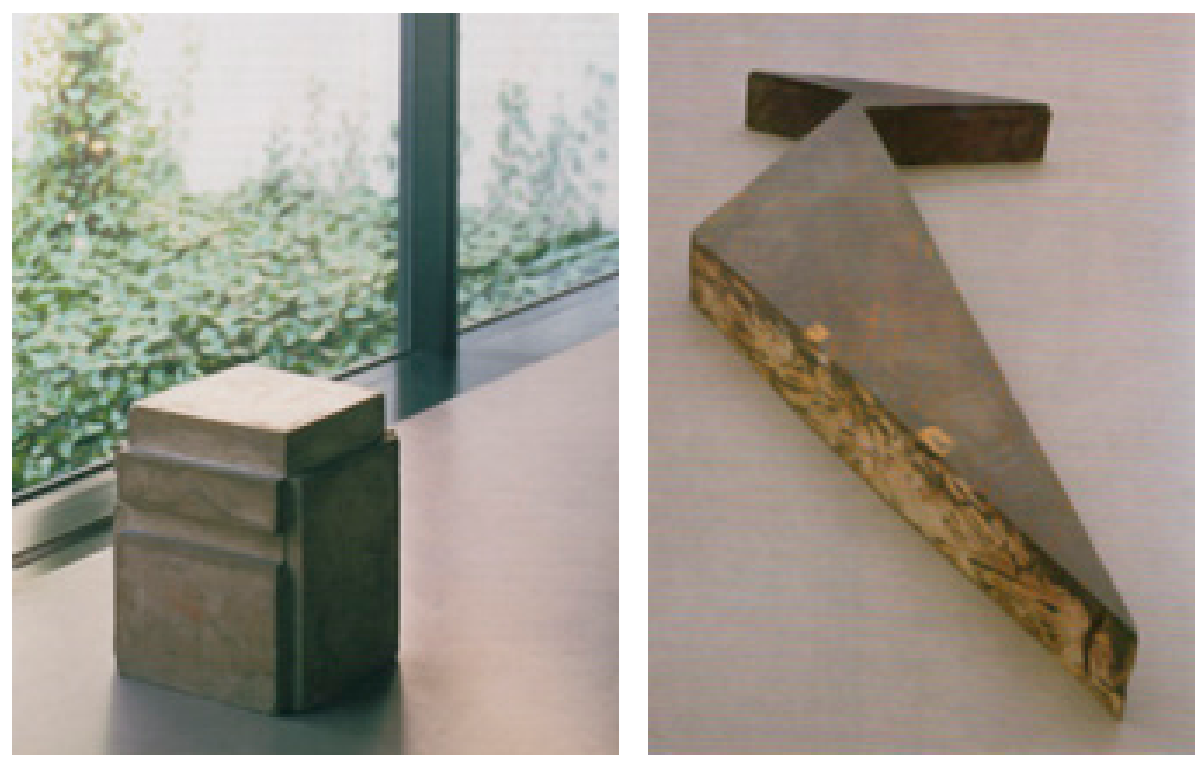
Espaço negativo para mim é pensar na parte debaixo e detrás das coisas. Na moldagem, sempre gostei das linhas de partição e das junções - coisas que ajudam a localizar a estrutura de um objeto, mas geralmente são removidas na finalização da escultura. Essas coisas ajudam a determinar a escala do trabalho e o peso do material. Tanto o que está dentro quanto o que está fora determina nossas respostas físicas, fisiológicas e psicológicas - como olhamos para um objeto ${ }^{22}$.

As esculturas resultantes das moldagens dos espaços intersticiais foram os primeiros trabalhos a receber os "títulos funcionais" 23 que passaram a caracterizar a produção no fim da década de 1960. Em um ensaio que trata das noções de entropia presentes nas artes visuais dos anos 1960 e 1970, Rosalind Krauss e Yve-Alain Bois comentam brevemente as moldagens dos espaços negativos de Nauman, procedimento que "não abre a forma fechada do objeto fabricado para liberar seus componentes materiais das amarras de sua construção" mas solidifica o próprio espaço circundante $^{24}$, propondo a equivalência de cheios e vazios. Uma operação que, segundo os autores, termina por "solidificar" as possibilidades de sentido; restrição que é, em última instância, entrópica. Ainda que enfatize os aspectos que corroboram os argumentos dos autores em torno das

22. No original: "negative space for me is thinking about the underside and the backside of things. In casting, I always like the parting lines and the seams - things that help to locate the structure of an object, but in the finished sculpture usually get removed. These things help to determine the scale of the work and the weight of the material. Both what's inside and what's outside determine our physical, physiological and psychological responses - how we look at an object". Cf. KRAYNAK, Janet (Ed.). Op. cit., p. 324.

23. A respeito disso, Nauman afirmou: "ela [Prateleira afundando na parede...] foi uma das primeiras peças com um título complicado, uma espécie de título funcional; eu gosto bastante da peça, tomei um molde e fiz moldagens em gesso do espaço debaixo da prateleira. Suponho que o título elaborado permita mostrar o molde com as peças resultantes sem apresentar o trabalho como tal" ["it [Shelf Sinking into the Wall...] was one of my first pieces with a complicated title, a sort of functional title; I like the piece quite a bit, I took a mold and made plaster casts of the spaces underneath the shelf. I suppose the elaborate title enables you to show a mold with its casts without presenting the work as such"). Cf. KRAYNAK, Janet (Ed.). Op. cit., p. 127.

24. "It does not open the closed form of the fabricated object to release its material componentes from the corset of their construction [...] rather, it takes the path of implosion or congealing, and the thing to which it submits this stranglehold of immobility is not matter, but what vehiculates and subtends it: space itself". Cf. KRAUSS, Rosalind \& BOIS, YveAlain. A user's guide to entropy. October Magazine, Cambridge/ Massachusetts, n. 78, 1996, p. 72. 


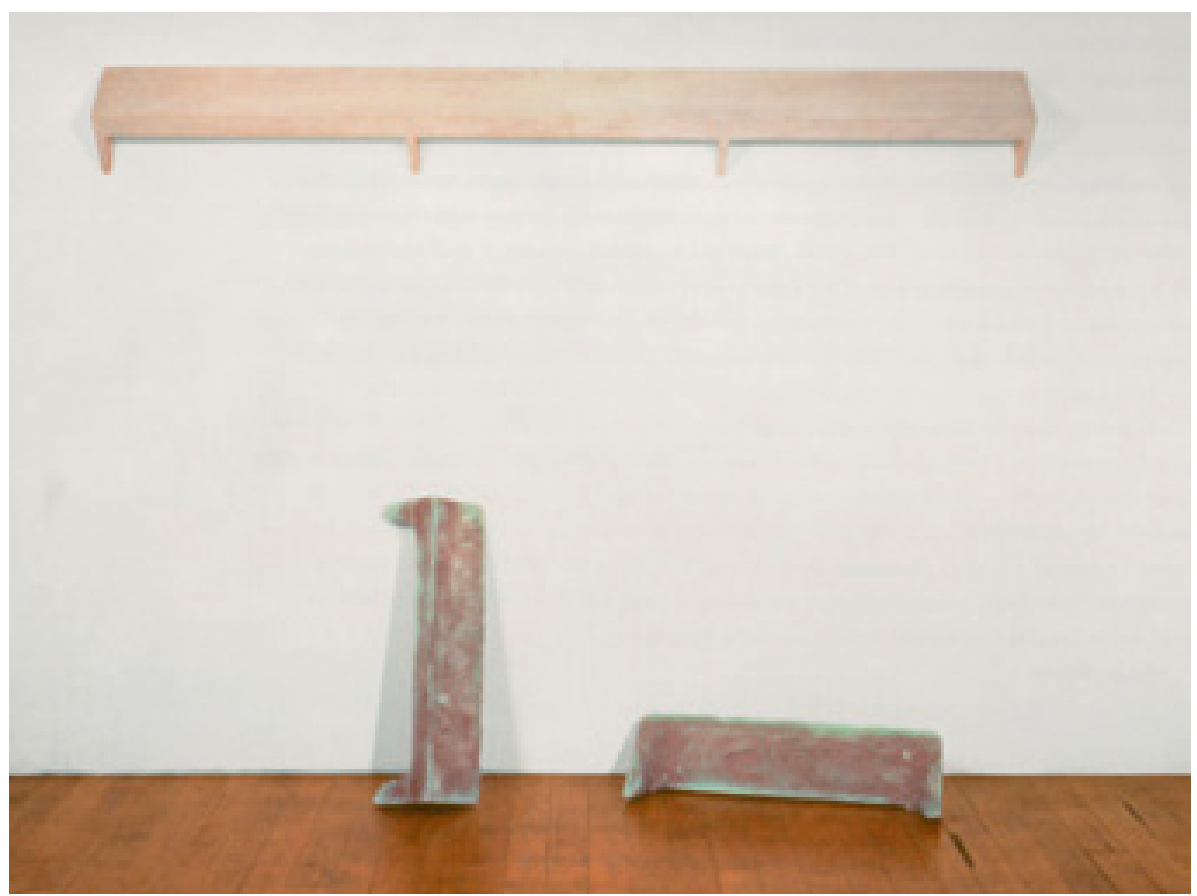

Shelf Sinking into the Wall with Copper-Painted Plaster Casts of the Spaces Undernearth, 1966, madeira e gesso pintado, $177,8 \times 213,4 \times 15,2 \mathrm{~cm}$.

questões da entropia, que não interessam imediatamente a este estudo, a análise merece ser citada na íntegra:

A ambiguidade que envolve esses resíduos dos moldes de espaço intersticial de Nauman, isto é, o sentido de que são "objetais", mas também de que sem o título a eles associados como um rótulo absurdo não se tem ideia do que de fato são, sequer da categoria genérica de objetos à qual devam pertencer, parece particularmente adequada. É como se a solidificação dos espaços intersticiais nessa condição rigidamente entrópica também os privasse de todos os meios de ser "como" o que quer que seja. Se o constante caráter utilitário dos objetos minimalistas - eles são "como" caixas, bancos, pórticos etc. - ou o viés mais fortemente evocativo das obras processuais continuaram a operar com a condição de forma, a saber, havendo uma identidade, que ela tenha sentido, então o fato de que ela solidifica também as possibilidades de sentido será, como os moldes de Nauman nos forçam a perceber, a entropia em caráter último. O que é o mesmo que dizer que tal concepção de 
entropia, como uma força que suga todos os intervalos entre os pontos do espaço, não somente concebe o "movimento browniano" da agitação molecular como tendo sido refreado até o ponto de inércia, mas também imagina a erradicação daquelas distâncias que regulam a teia de oposições ou diferenças indispensáveis à produção de sentido ${ }^{25}$.

Não apenas nas moldagens da década de 1960, mas em toda a obra de Nauman é comum que a presença remeta ao ausente - ou vacante -, os fragmentos às partes faltantes, o cheio ao vazio, o fora ao dentro. Já se mencionou que não é casual o apreço pela moldagem, técnica que o artista utilizará em momentos variados de sua carreira. Entretanto, é pouco ortodoxo o uso que faz da técnica. De modo geral, a moldagem demanda a confecção de um modelo prévio em argila a partir do qual se faz uma fôrma de gesso a ser preenchida por um material líquido que deve ser resfriado e desenformado. Frequentemente a peça em argila e o molde são descartados depois de concluída a série. Tradicionalmente empregado para a seriação das peças, em Nauman é o próprio molde que se converte em um objeto singular, uma vez que seu conteúdo é eliminado e a fôrma é exposta no lugar da peça pronta e de suas possíveis seriações. Ou seja, toma-se metonimicamente o continente pelo conteúdo. Nauman opera, portanto, uma inversão essencial da técnica ao converter o mecanismo de repetição em objeto único, anulando a natureza replicante do molde.

25. "The ambiguity that grips these residues of Nauman's cast of interstitial space, that is, the sense they are object-like, but that without the title attached to them like an absurd label, one has no idea of what they are, even of what general species of object they might belong to, seems particularly fitting. It is as though the congealing of space into this rigidly entropic condition also strips it of any means of being 'like' anything. If the constant utilitarian character of Minimalism objects - they are 'like' boxes, benches, portals etc. - or the more evocative turn of process works, continued to operate along the condition of form, which is that, having an identity, it be meaningful, it is the ultimate character of entropy, Nauman's casts force us to realize, that it congeal the possibilities of meaning as well. Which is to say that this conception of entropy as a force that sucks out all the intervals between point of space, not only understands the 'Brownian movement' of molecular agitation as slowed to a stop, but also imagines the eradication of those distances that regulate the grid of oppositions or differences necessary to the production of meaning". Cf. KRAUSS, Rosalind \& BOIS, YveAlain. Loc. cit. 

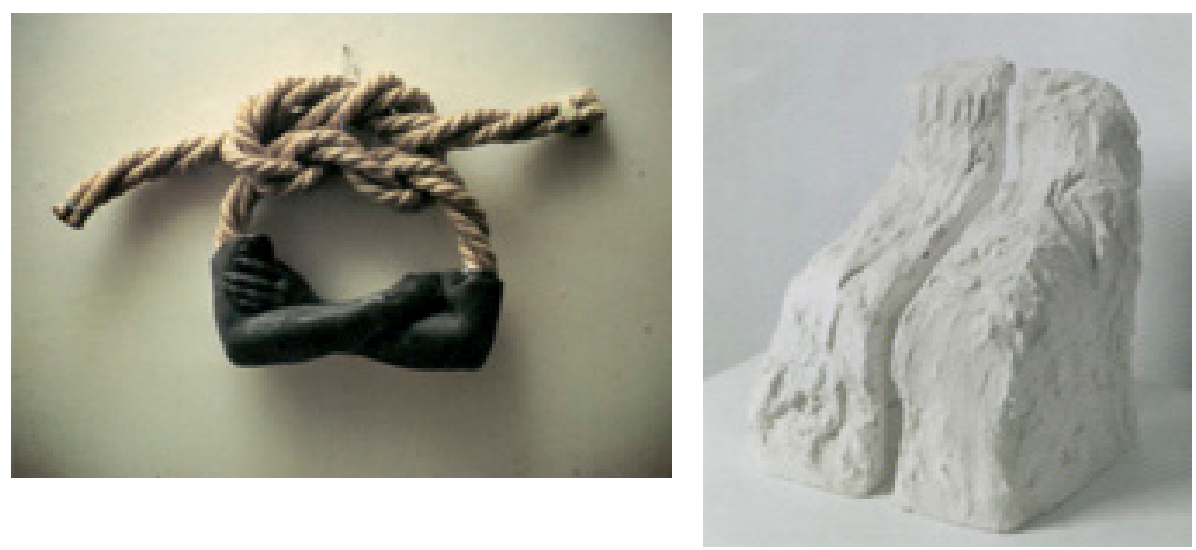

Sem título, 1967, cera de abelha, gesso e corda, $43 \times 66 \times 11 \mathrm{~cm}$. Mold for a Modernized Slant Step, 1966, gesso, $44 \times 36 \times 30 \mathrm{~cm}$.

É igualmente significativo que a moldagem, prática que requer perícia, evoque ademais uma dose de manualidade, como a manter um lastro físico da ação sobre a matéria. Mas, como se não bastasse a presença material - uma fisicalidade inerente à escultura, também era preciso insuflá-la de duração e evidenciar a incompletude.

Assim, em substituição aos materiais anódinos da produção industrial, para os quais a seriação seria essencial, Nauman preferia materiais que buscavam reproduzir na superfície uma aparência expressiva, porosa, enervada, como se carregassem calor epidérmico, ressaltando uma espécie de artificialidade duplicada. Há um trabalho sem título, de 1967, que ilustra bem esse aspecto: um pedaço de corda enrolado em nó se prende a um molde de um par de braços cruzados, de maneira que o elemento faltante é evocado por um substituto que simula de modo falho a parte "carnal" alheada, ou seja, a corda disposta como está sugere ossos, músculos, artérias, tendões, ligados à detalhada carcaça moldada em gesso e revestida em cera $^{26}$.

26. Cf. LEWALLEN, Constance. Op. cit., p. 48. 
A tudo isso se soma uma propositada negligência do acabamento das peças, uma aspereza visível que ostenta cruamente o processo de feitura e, ao revelar os materiais, denuncia também uma desconfiança em relação à perenidade e à elegância presumidas de um produto final. Esse é o caso, por exemplo, de Mold for a Modernized Slant Step [Molde para um degrau inclinado modernizado (1966)], duas metades em gesso do molde feito a partir de um móvel pouco convencional, um misto de escada e banquinho que, no entanto, não tinha nenhuma serventia em virtude de estranha inclinação do suposto degrau. $\mathrm{O}$ molde resultou ainda mais estranho e rústico do que o próprio objeto que lhe deu origem.

Ao contrário do que aparentam, as esculturas foram rematadas com a máxima precisão, exatamente no momento em que passaram a comunicar eficazmente a ideia pretendida, nem antes disso, nem depois: "quando está suficientemente terminado para que eu apreenda, quando a questão está clara, então não é mais necessário nenhum acabamento. Precisa ser bem feito o suficiente para comunicar" ${ }^{27}$. Portanto, aquilo que se entende por acabamento das peças seria, nas esculturas de Nauman, um pós-acabamento, um adornamento supérfluo que comprometeria a execução precisa da ideia.

27. 0 trecho completo, no original, "when it's finished far enough so that I apprehend, so that the point is clear [...] then it doesn't need any more finish work. It needs to be made well enough to communicate. I very seldom can work with anyone else, because when it gets that point where I can say, "Now I know what's going on, you can finish it", it doesn't need any more finishing". Cf. KRAYNAK, Janet. Op. cit., p. 208. 


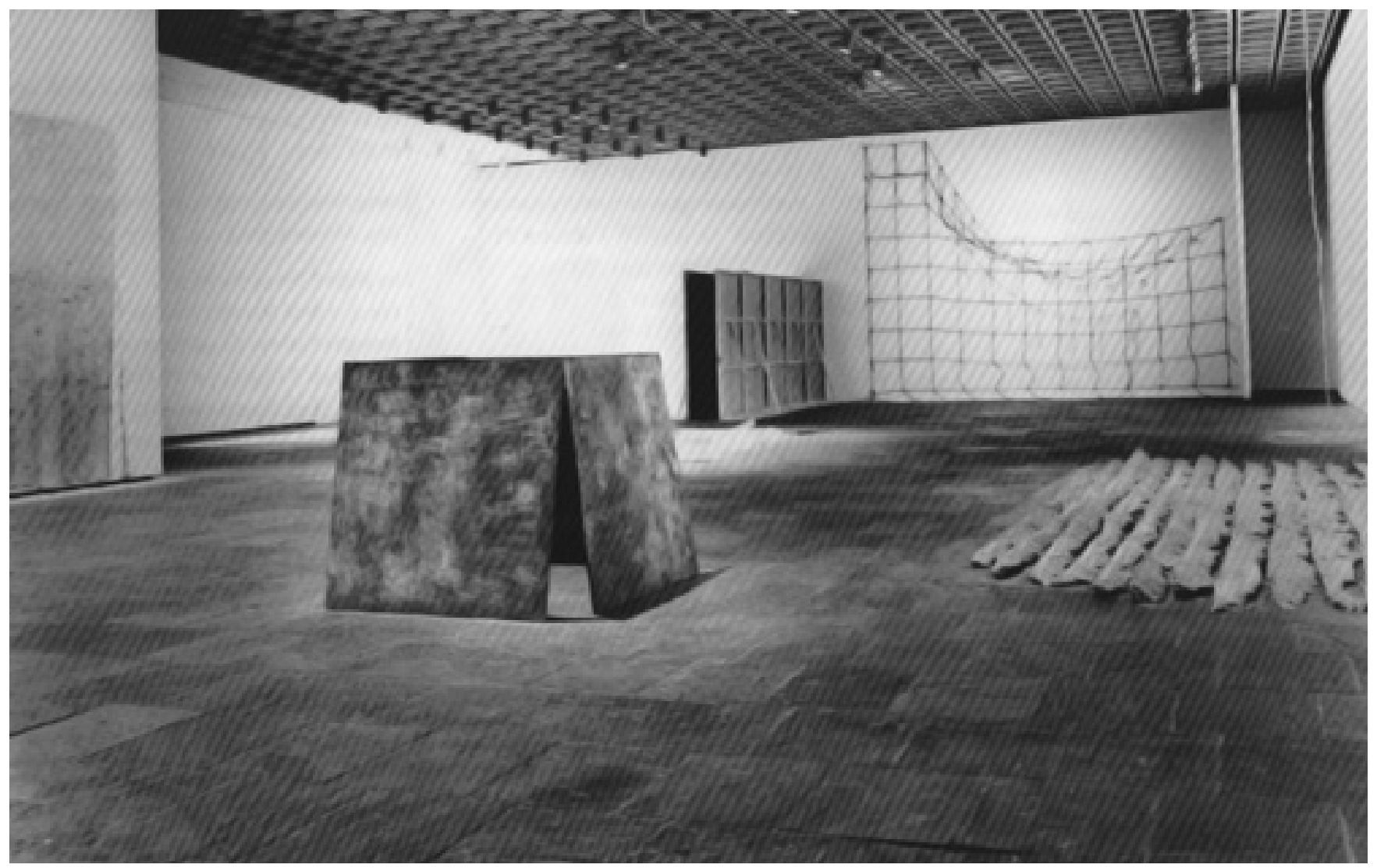

Vista da exposição "Anti-Illusion: Procedure/Materials",

Whitney Museum of American Art, Nova York, 1969. 


\subsection{Corpo-molde, corpo-gabarito}
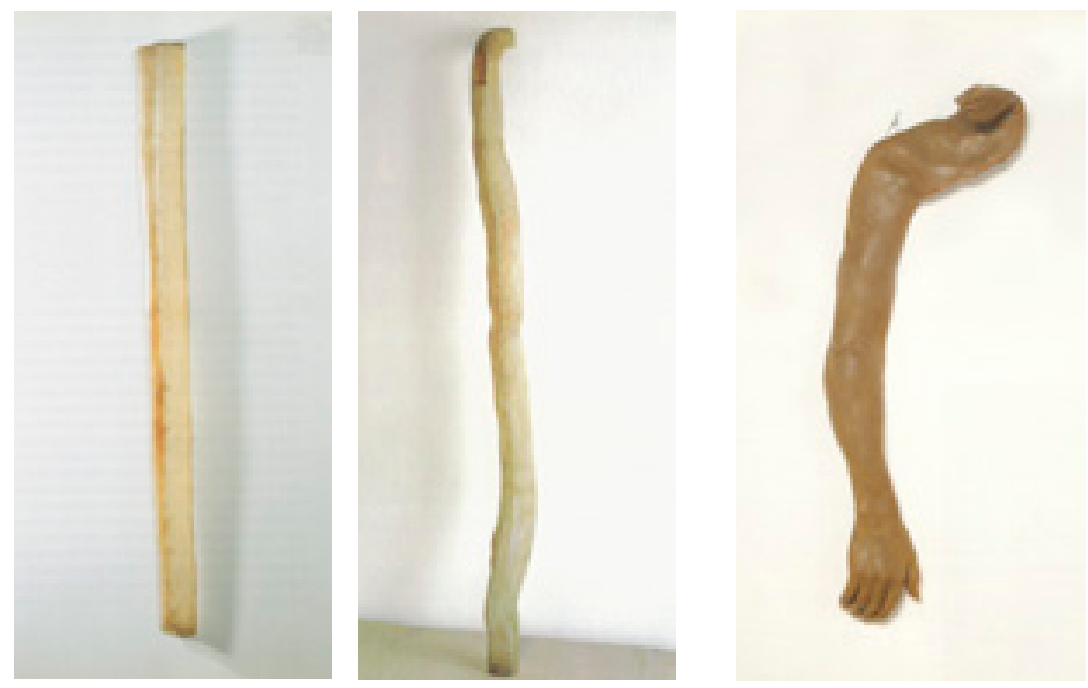

A operação de preservar o continente para evocar uma ausência serviu de base para as moldagens que se remetiam às mensurações de fragmentos do corpo humano, como o já comentado Neon Templates of the Left Half of My Body Taken at Ten-Inch Intervals ou Six Inches of My Knee Extended to Six Feet [Seis polegadas do meu joelho estendidas por seis pés (1967)]. A depender do material de que eram feitas, as esculturas que tomavam o corpo por molde retinham nas superfícies a rusticidade do processo de fabricação, como as marcas de joelhos deixadas em Wax Impressions of the Knees of Five Famous Artists [Impressões em cera dos joelhos de cinco artistas famosos (1966)], reportando-se a frações de corpos ausentes, que antes teriam interagido de algum modo com o material - suposição confirmada, neste caso, por indícios de joelhos impressos em uma placa presumidamente de cera, conforme o título sugere. Registra-se no material um espaço vacante, como se da mediação entre a ação do artista e a fisicalidade das peças sobrassem inscrições residuais de uma performance sobre a matéria ${ }^{28}$.

28. MORGAN, Robert. Bruce Nauman: An Introductory Survey. In: Bruce Nauman. Baltimore: The Johns Hopkins University Press, 2002, p. 2. 


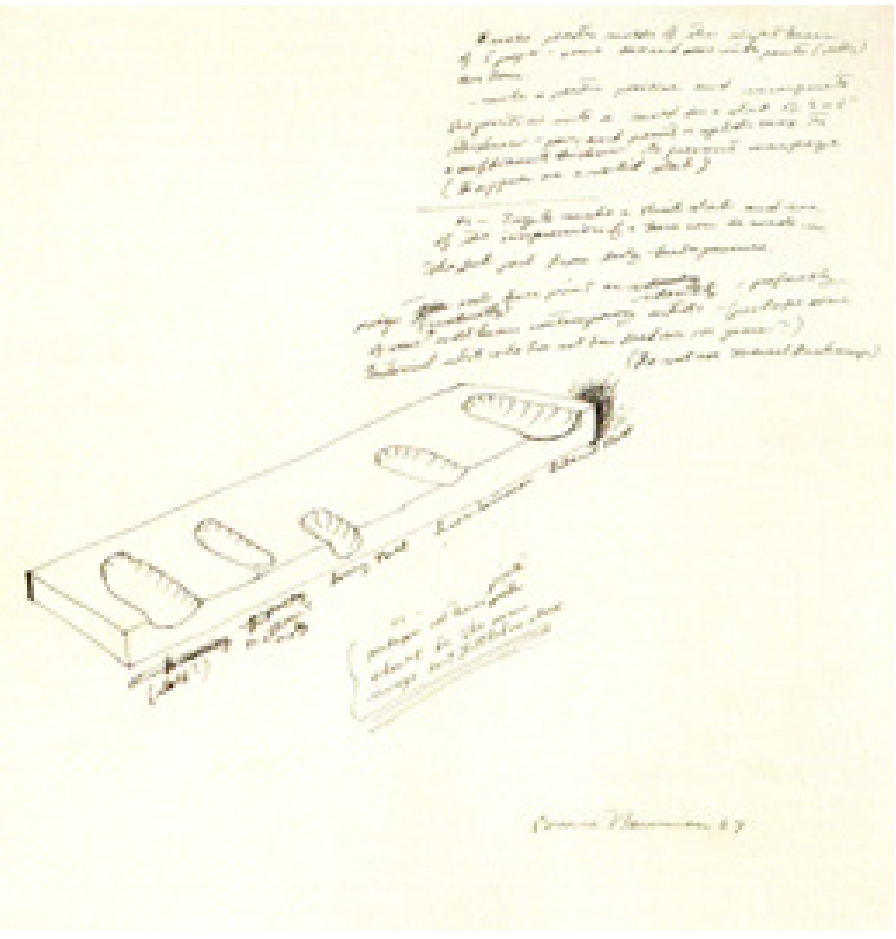

Untitled/Study after Wax Impressions of the Kness of Five Artists, 1966, nanquim sobre papel, $55 \times 45 \mathrm{~cm}$.

Six Inches of My Knee Extended to Six Feet, 1967,

fibra de vidro, $174 \times 14.6 \times 9.84 \mathrm{~cm}$.

Sem título, 1965, fibra de vidro e resina poliéster

$171 \times 16 \times 8 \mathrm{~cm}$

From Hand to Mouth, 1967,

cera sobre tecido, $71 \times 25.7 \times 10.16 \mathrm{~cm}$

Wax Impressions of the Knees of Five Famous Artists, 1966, fibra de vidro e poliéster, 37 × 208 × $5 \mathrm{~cm}$. 
O título descritivo, Impressões em cera dos joelhos de cinco artistas famosos, serve, todavia, para falsear os dados da peça: a placa é de fibra de vidro e não de cera, e os "joelhos dos artistas famosos" correspondem, na verdade, ao joelho direito de Nauman repetido cinco vezes. Outra informação relevante é que a escultura foi sucedida por um estudo detalhado, um esboço que prescreve supostas instruções de feitura para a peça já realizada, Untitled/Study after "Wax Impressions of the Right Knees of Five Famous Artists [Sem titulo/Estudo a partir de "Impressões em cera dos joelhos direitos de cinco artistas famosos (1967)]. No desenho, leem-se os seguintes comentários: "fazer moldes de gesso dos joelhos direitos de cinco pessoas; atribuir a cada joelho uma identidade - de preferência algum artista contemporâneo (moderadamente) conhecido (talvez algum artista histórico que não esteja morto há mais de 100 anos) ”, mas inclui a ressalva: "não use Marcel Duchamp". Em seguida, sugere alternativas: "William T. Wiley, Larry Bell, Lucas Samaras, Leland Bell ou talvez todas as 'impressões de joelho' devam ser a mesma imagem, mas intitulada como acima"29.

Essas anotações confirmam que, em meados da década de 1960, Nauman conhecia a obra de Marcel Duchamp (1887-1968), mas também revelam a sua ressalva; uma ressalva que se manifesta recorrentemente quanto à comparação de sua obra com a de Duchamp. Em todas as ocasiões em que foi questionado sobre a importância da produção de Duchamp para trabalhos tais como os moldes ou aqueles que implicam trocadilhos e jogos de palavras, Nauman afirmou que, à época, não tinha acesso direto aos trabalhos de Duchamp e o pouco que sabia era por meio de um legado duchampiano perceptível nos trabalhos de Jasper Johns (1930 - ). Em 1972, ressaltou que "Japer Johns e talvez Jim Dine [1935 - ] e outras poucas pessoas usaram Duchamp, eacho queo que aconteceu foi queaquelainformação simplesmente

29. "Make plaster molds of the right knees of five people... assign each knee an identity - preferably some (moderately) well known contemporary artists (perhaps some historical artist who has not been dead over 100 years? - Do not use Marcel
Duchamp - William T. Wiley/ Larry Bell/ Lucas Samaras/Leland Bell or perhaps all 'knee prints' should be the same image but titled as above". Cf. LEWALLEN, Constance. Op. cit., p. 53 e 151. 
estava no ar" e concluiu "na área da baía em torno de San Francisco, onde morei por uns anos, há realmente um grande sentimento nostálgico em relação ao Dada, mas não tanto por Duchamp"30.

Nauman afirmou ainda preferir as operações de Man Ray (1890-1976), mais próximas das suas porque mais simples e diretas, do que as de Duchamp. Quer-se crer que com essas declarações Nauman não incorresse em uma espécie de denegação da influência recebida, mas sim que percebesse, desde muito cedo, que as implicações dos deslocamentos que Duchamp propunha na linguagem artística eram muito mais sutis do que se comentava nas décadas de 1960 e 1970, e, ao mesmo tempo, incontornáveis.

Deve-se mencionar que os autores consultados frequentemente comparam From Hand to Mouth [Da mão à boca (1967)] - um molde em cera do fragmento anatômico que vai da boca aos dedos de uma mão, passando pelo braço e antebraço, trabalho em que Nauman "literaliza escultoricamente" um trocadilho com uma expressão proverbial da língua inglesa, "hand-tomouth", que se refere a uma existência precária - com With my Tongue in my Cheek [Com minha lingua na minha bochecha (1959)], trabalho um pouco mais antigo do que o de Nauman e no qual Duchamp havia procedido de maneira parecida, literalizando visualmente a expressão "tongue in cheek", que indica uma ironia jocosa, sarcástica, quase maliciosa, e que, por aproximação, corresponderia talvez à "velhacaria” da língua portuguesa ${ }^{31}$.

30. “Japer Johns and maybe Jim Dine and a few other people used Duchamp, and I think what happened was that information was just sort of in the air [...]. In the Bay Area around San Francisco, where I lived for a couple of years, there is a really big nostalgic feeling about Dada, but not so much Duchamp". Cf. KRAYNAK, Janet (Ed.). Op. cit., p. 157. Consultemse também as entrevistas concedidas em 1970 , 1980 e 1988 reunidas no mesmo volume (p. 126127; 229; 232-233; 248-249; 321).

31. A maioria dos estudiosos de Nauman aproxima esses dois trabalhos, podendo-se consultar, entre outros: BASUALDO, Carlos. Bruce Nauman: Topological Gardens. In: NAUMAN, Bruce. Topological Gardens. Filadélfia: Philadelphia Museum of Art, 2009, p. 15-44; STORR, Robert. Please Pay Attention, Please. In: LEWALLEN, Constance. Op. cit., p. 147-170; KRAYNAK, Janet. Bruce Nauman's Words. In: . Op. cit., p. 1-46; BRUGGEN, Coosje von.

Op. cit.; LEWALLEN, Constance. Op. cit.; além de muitos dos artigos publicados na coletânea organizada por Robert Morgan (MORGAN, Robert C. (Ed.). Bruce Nauman. Op. cit.). 


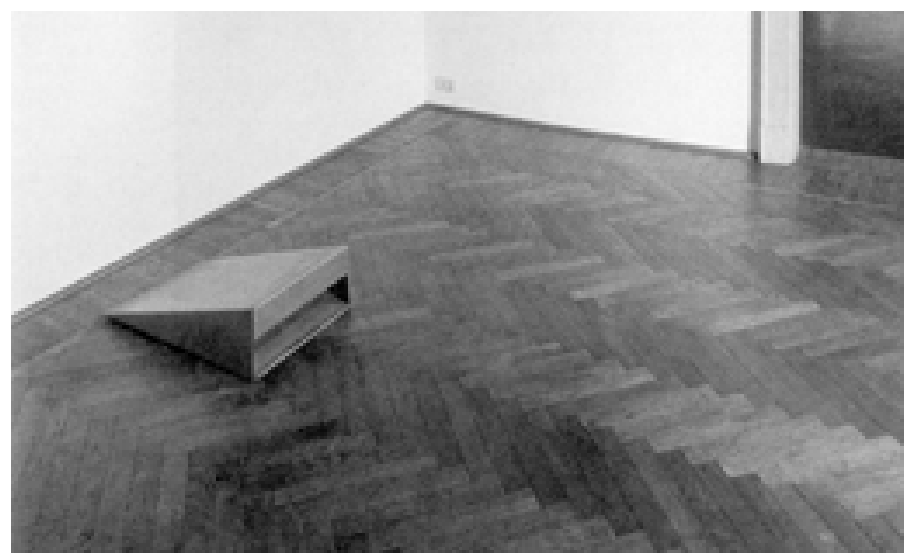

Device to Stand In, 1966, aço, $21 \times 43 \times 68 \mathrm{~cm}$.

Além dos trocadilhos, os autores não comentam outros assuntos pertinentes às duas obras como, por exemplo, o papel da sexualidade e as noções de "atraso", duas questões que se desdobram de modo completamente diverso em cada uma delas. De modo geral, na obra de Nauman, sexualidade e violência são pares indissociáveis e recebem uma abordagem direta e em tudo distante da complexidade do maquinário erótico deslizante da "noiva posta a nu por seus solteiros mesmo", em $O$ grande vidro (1915-1923). Também a ideia de transcurso do tempo em "atraso" é diferente e muito mais complexa em Duchamp do que em Nauman. O próprio cerne de O grande vidro é o "atraso em vidro", um refreamento infinitamente prolongado mas que pode implicar um desfecho, ao menos conceitualmente: o momento em que o material "vidro" fluiria e faria deslizar a "máquina celibatária" desenhada em sua superfície, uma vez que "qualquer vidro é apenas um líquido de fluxo lento do ponto de vista físico" 32 . Já em Nauman, a ideia de atraso é mencionada em um texto de $1969^{33}$ como uma experiência de percepção da duração a ser forjada por uma tecnologia não disponível na época. Poucos anos depois, o artista "resolveu" a questão por meio de circuitos de câmeras de vídeo que captavam imagens em tempo real e as transmitiam com um ligeiro atraso. Esse dispositivo é usado em muitos dos trabalhos com corredores, que não estão entre os objetos desta tese. Aqui, interessam os modos como Nauman 


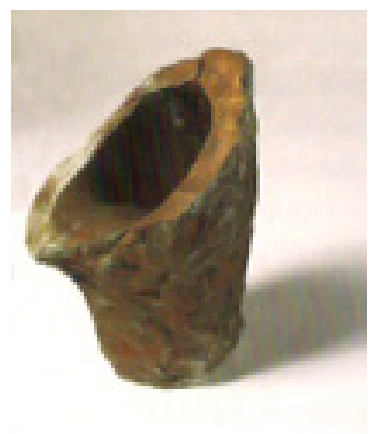

Device for Left Armpit, 1967, gesso pintado, $35,6 \times 17,7 \times 25,4 \mathrm{~cm}$.

Storage Capsule for the Right Rear Quarter of my Body, 1966, ferro galvanizado, $183 \times 15 \times 23 \mathrm{~cm}$.

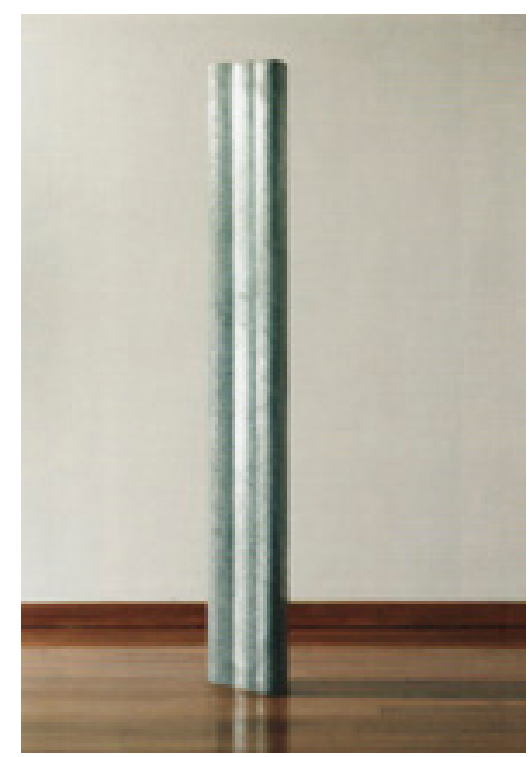

manipula o transcurso do tempo através de mecanismos de repetição, forjando uma duração circular, sem culminação ou desfecho. Tampouco o aprofundamento das relações com a obra de Duchamp está no escopo da tese, de maneira que se encerra a digressão neste ponto.

De todo modo, é significativo que em lugar do "joelho" de Duchamp, ele preferisse o de William T. Wiley, artista que, já se mencionou, havia sido seu professor em Davis e juntamente com Robert Arneson ensinara Nauman a usar o "dumb eye" [olho burro]. A ideia era olhar para as coisas ou apreender as palavras sem ter consciência da multiplicidade

32. Segundo os físicos Kostya Trachenko e Vadim Brazhkin, que pesquisam as propriedades do vidro, "tem-se observado que o vidro em antigas igrejas medievais é mais espesso na parte inferior, e foi proposto que isto ocorre porque o vidro flui ao longo do tempo. Essa explicação pode não ser correta do ponto de vista quantitativo, porque alguns séculos não é tempo suficiente para o vidro fluir. Na verdade, nós mostramos em nosso trabalho que pode demorar mais tempo do que a idade do Universo para alguns corpos fluir. No entanto, a ideia qualitativa está correta: qualquer vidro é apenas um líquido de fluxo lento do ponto de vista físico". Esse comentário sobre as propriedades do vidro foi apontado por Wallace V. Masuko, na dissertação de mestrado intitulada Henri Robert Marcel Duchamp: ERre. [Escola de Comunicações e Artes da Universidade de São Paulo, São Paulo, 2012].

33. Consulte-se no Apêndice desta tese o texto na íntegra e a tradução. Trata-se do texto "sem título", de 1969, que se inicia do seguinte modo: "a person enters and lives in a room for a long time - a period of years or a lifetime" [uma pessoa entra e vive em um recinto por um longo período - por anos ou por toda uma vida]. 
de conteúdos semânticos subjacentes, tomar uma palavra, por exemplo, em toda sua literalidade superficial. Dumb eye corresponderia, portanto, a um olhar destreinado, não sofisticado, e que permitiria perceber as coisas nelas mesmas. A partir disso é que Nauman fez jogos de palavras e os chamados "one liners", isto é, a construção de uma sentença que carrega em si algo de comicidade tendo por base um trocadilho ou uma justaposição incongruente com sentenças anteriores. A crítica de arte e curadora Emma Dexter comenta:

\footnotetext{
No início de sua carreira sob a influência de seu professor William T. Wiley, Nauman desenvolveu a noção de "ver com um olho burro". Ele quer dizer com isso desaprender todas as noções aceitas do que a arte é ou pode ser, desenvolvendo uma forma de inocência avessa a qualquer ideia de procedimento correto, e explorar o uso da linguagem, do corpo e comportamento como material. Como resultado, Nauman desafiou obstinadamente as convenções artísticas da sua época: "para cada regra, tento também encontrar o oposto, para revertê-la"34.
}

Concomitantemente às moldagens da década de 1960, Nauman elaborou alguns dispositivos para registrar o "espaço vacante" dos corpos ou de suas partes, tal como Device for a Left Armpit [Dispositivo para uma axila esquerda (1967)] ou Device to Stand In [Dispositivo para pôr-se de pé (1965-1966)], este último uma escultura muito particular que remonta a uma espécie de armadilha de aparência geométrica a ser colocada em posição central no espaço expositivo, como se estivesse ali gravemente postada à espera de uma presença humana a ser capturada por sua fenda ${ }^{35}$.

34. "Early in his career under the influence of his teacher William T. Wiley, Nauman developed the notion of 'seeing with a dumb eye'. By this he meant unlearning all accepted notions of what art is or can be, developing a form of innocence that overturns any idea of correct procedure, and exploring the use of language, the body and behavior as material. As a result, Nauman doggedly challenged the artistic conventions of his day: 'to every rule, I also try to find the opposite, to reverse it'". Cf. DEXTER, Emma. Raw Materials. In: NAUMAN, Bruce. Raw Materials. Londres: Tate Publishing, 2004, p.18. 35. Cf. WAGNER, Anne. Op. cit., p. 125. 


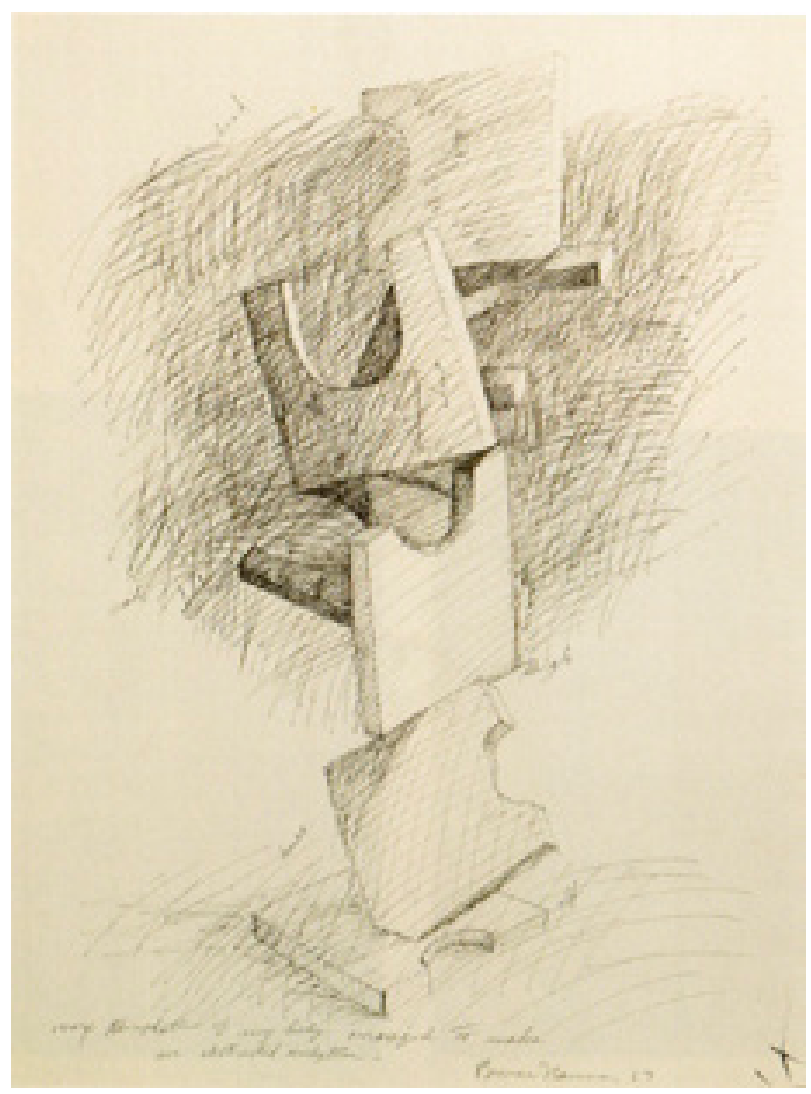

Head/Shoulder/Chest/Waist/Thigh/Knee/Calf/Wax Templates of my Body Arranged to Make an Abstracted Sculpture, 1967, nanquim sobre papel, $63 \times 48 \mathrm{~cm}$.

Em muitos casos, a referência ausente passa a ser o corpo do artista, cujas medidas são vertidas em padrões orientadores da execução das esculturas, tais quais gabaritos, procedimentos reiterados nos títulos descritivos dos trabalhos. Para Storage Capsule for the Right Rear Quarter of My Body [Cápsula de armazenamento para a porção posterior direita do meu corpo (1966)], por exemplo, Nauman dimensionou a parte de trás de seu corpo e triplicou a curva resultante, estabelecendo um padrão para o desenho de um compartimento quase geométrico, feito de ferro galvanizado, a ser disposto na vertical, alcançando cerca de 180 centímetros, mesma altura do artista. Como resultado dessa mensuração, uma escultura que reitera suas características antropomórficas por mimetizar um porte austero e fazer uma alusão tumular, como decerto deveriam ser cápsulas para conservar partes do corpo. 

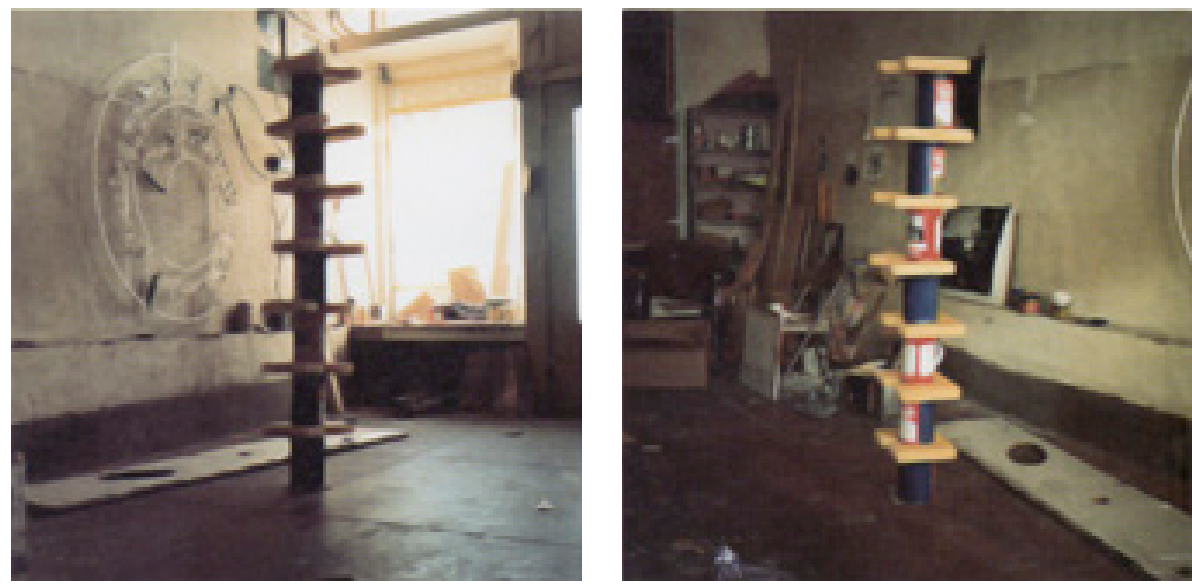

Vista de Wax Templates of the Left Half of my Body Separated by Cans of Grease, 1967.

Em outro trabalho, de que só restou um desenho, Wax Templates of My Body Arranged to Make an Abstract Sculpture [Gabaritos em cera do meu corpo arranjados para fazer uma escultura abstrata (1967)], sete peças semelhantes em cera, cada qual referida e nomeada em relação a uma parte do corpo do artista, cabeça, ombros, torso, quadril, coxa, joelho e panturrilha, são ajeitadas displicentemente numa pilha que evoca uma coluna vertebral. Em uma variação desse trabalho, foram também executados gabaritos em vidro, material em tudo distante da lembrança da textura e do calor superficial emanado do corpo humano, tornando, portanto, ainda mais abstrato o enunciado formulado no título.

Nesses últimos exemplos, fica óbvio como em trabalhos aparentemente tão singelos Nauman confronta o repertório tradicional da escultura. Nessa série de mensurações o artista faz uma mordaz provocação ao tomar o corpo humano como se fosse um gabarito, como se estivesse operando em conformidade com as disjunções próprias da realidade tecnológica, cuja complexidade abstrata se substitui ao antigo mundo industrial. E, assim, produz um incômodo desajuste ao descrever como se fossem meros produtos construções maciças tão inusitadas como a de uma cápsula para armazenar fragmentos de corpo, algo pelo 


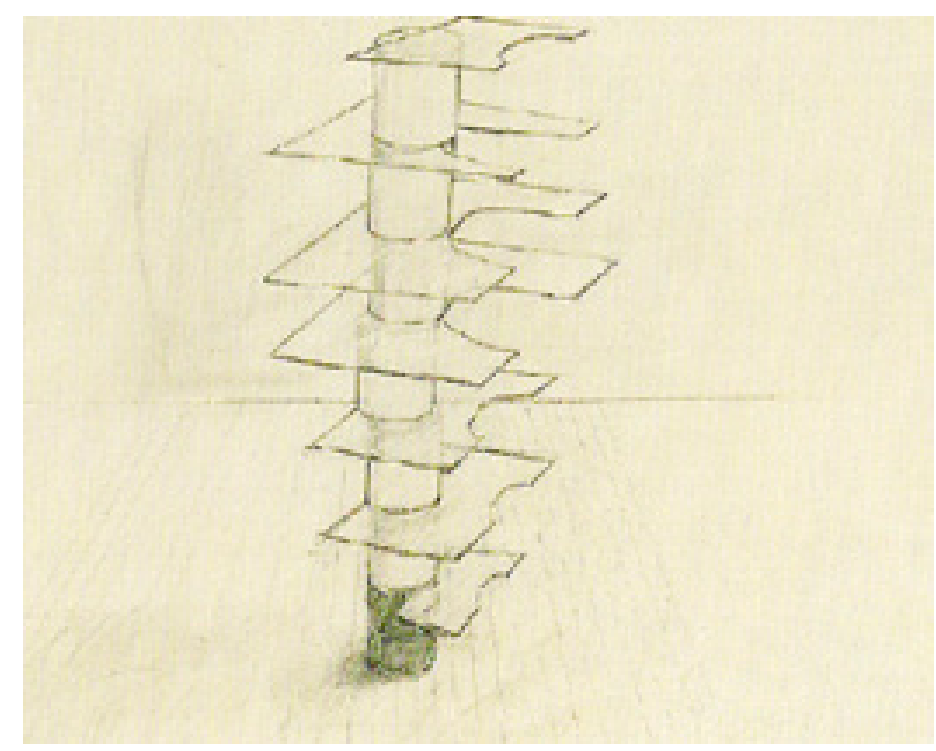

Desenho de Templates of the Left Half of my Body (10" Intervals) Separeted by Cans of Grease, 1966, lápis sobre papel, 41 x $50 \mathrm{~cm}$.

menos tão absurdo quanto propor o caminho inverso, tal como ocorre em Wax Templates of the Left Half of My Body Separated by Cans of Grease [Gabaritos em cera da metade esquerda do meu corpo separados por potes de graxa (1967)], uma forma empilhada na qual se alternam fatias de cera e vasilhas de graxa, obedecendo a proporções gerais do corpo humano ${ }^{36}$.

A forma peculiar de comparecimento do corpo na produção de Nauman, que já se manifestava em seus primeiros trabalhos tridimensionais, destaca-se também em uma série de filmes e vídeos captados no ateliê do artista no fim da década de 1960 e início da década de 1970. Ambos os conjuntos de trabalhos mostram-se, ademais, nitidamente interconectados. A hipótese de que há implicações recíprocas entre eles pode ser fundamentada a partir da análise do álbum Pictures of Sculpture in a Room [Imagens de escultura em um recinto], um livreto que reúne fotografias de esculturas realizadas no decorrer de dois anos (1965-1966), 
precisamente a série "sem título" apelidada de formas macias, devidamente dispostas no espaço, apoiadas e penduradas nas paredes. No álbum, as imagens explicitam uma aguda consciência das alterações que a percepção da forma sofre em virtude de diferentes arranjos assumidos no espaço ${ }^{37}$.

Em 1965, exatamente na mesma época em que realizava as formas macias e o referido livreto com os fotogramas, Nauman relatou ter feito uma performance de cerca de meia hora. Permanecia em pé de costas para uma parede por cerca de um minuto. Depois, inclinava-se para se afastar da parede. Em seguida, dobrava a cintura. Então, posicionava-se de cócoras. Sentava-se. E, finalmente, deitava-se. Somavam-se sete posições diferentes em relação à parede e ao chão. Em seguida, ele repetia toda a sequência começando a série já desencostado da parede; repetia então a série de frente para a parede; depois, voltado para a esquerda; e, por fim, voltado para a direita ${ }^{38}$. Essa performance pode ser considerada um esboço, um estudo, para o vídeo Wall-Floor Positions [Posições Parede-Chão (1968), 60 min.].

Percebe-se que o corpo do artista é manipulado tal qual a matéria escultórica da referida série de imagens feitas a partir das esculturas macias. No vídeo, Wall-Floor Positions, Nauman formaliza uma espécie de catálogo filmado de movimentos possíveis, assumindo cuidadosamente cerca de 28 posições distintas, com exceção da vertical, arranjadas entre o chão e as paredes de seu ateliê, inclinando-se, apertando-se, amparandose, esgueirando-se, contorcendo-se, revirando-se etc. Um programa que

37. Além dos depoimentos de Bruce Nauman, há um conjunto fundamental de ensaios que serviram para elucidar esta questão, a saber: a) WAGNER, Anne. Op. cit.; b) BRUGGEN, Coosje van. Op. cit.; c) MORGAN, Robert C. Op. cit.; d) BENEZRA, Neal. Surveying Nauman. In: MORGAN, Robert. Op. cit., p. 116-145; e) KRAYNAK, Janet (Ed.). Op. cit.

38. A descrição da performance por Nauman, no original: "I did a piece at Davis which involved standing with my back to the wall for about fortyfive seconds or a minute, leaning out from the wall, then bending at the waist, squatting, sitting and finally lying down. There were seven different positions in relation to the wall and floor. Then I did the whole sequence again standing away from the wall, facing the wall, then facing left and facing right. There were twenty-eight positions and the whole presentation lasted for about half an hour". Cf. KRAYNAK, Janet. Op. cit., p. 122. 

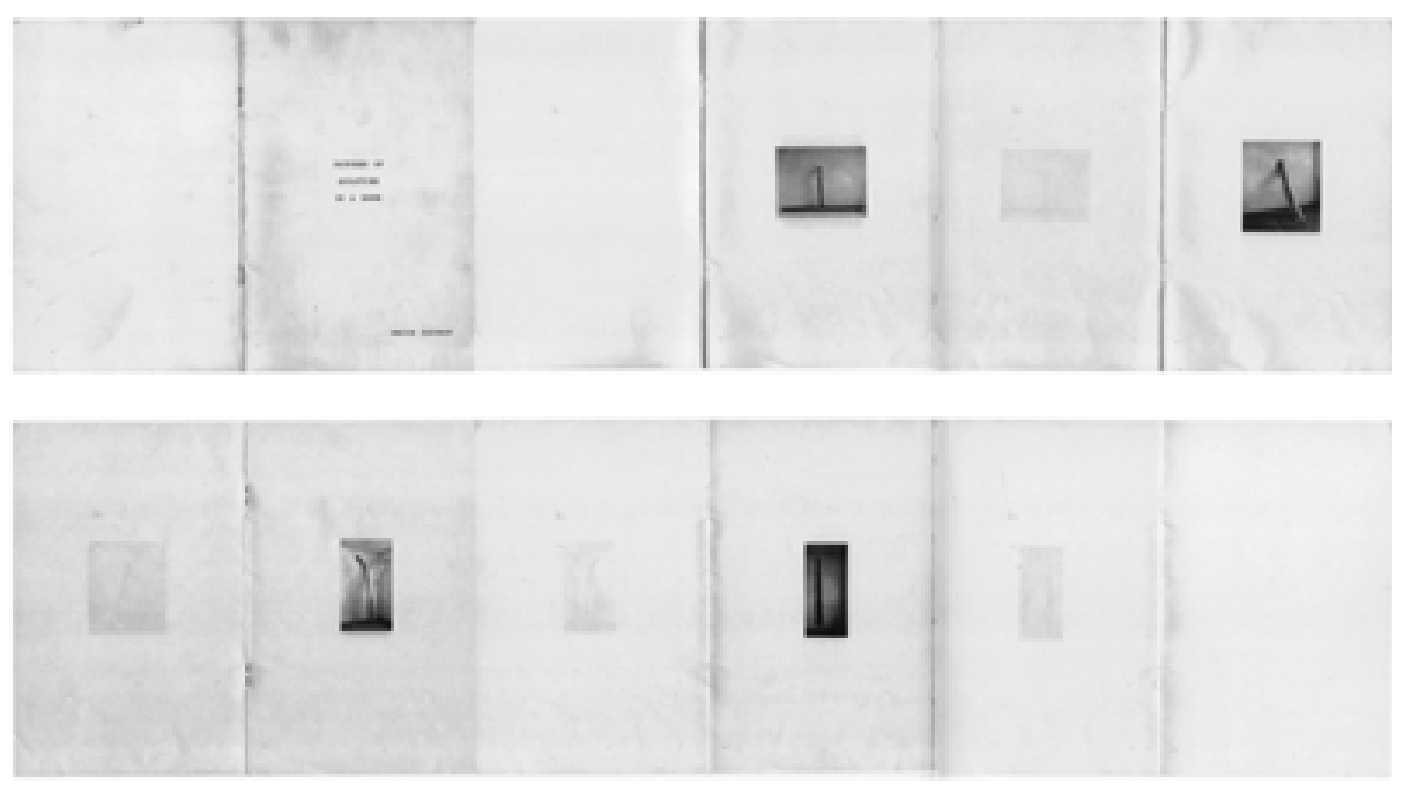

Pictures of Sculpture in a Room, 1965-66, livro de artista, 8 páginas, 21 x $13 \mathrm{~cm}$.

tenta levar ao extremo a tensão corporal, invocando para tanto uma perícia que exige de cada fibra muscular uma tenacidade e uma concentração voltadas à descoberta e à sustentação de novas posturas que recusem a simetria, desconsiderando assim um atributo essencial do corpo humano.

$\mathrm{Na}$ mesma época da performance-estudo para Wall-Floor Positions e das formas macias em fibra de vidro, borracha, papelão, cera e outros materiais, Nauman realizou performances em que examinava o posicionamento de seu corpo em uma progressão de ações realizadas em relação a um tubo de lâmpada fluorescente aceso (posteriormente refeita para a câmera, em Manipulating a Fluorescent Tube [Manipulando um tubo fluorescente (1969), 60 min.]) e diante de dois vergalhões unidos, em Manipulating the T Bar [Manipulando a barra em T (1965), 10 min.], ações nas quais forjava contiguidades entre materiais de natureza e densidades distintas, propondo equivalências entre seu corpo e a luz ou o ferro, ou seja, entre matérias orgânicas e inorgânicas, entre superfícies aquecidas e frias. Corpo, lâmpada, vergalhão eram tomados como matérias brutas (raw 

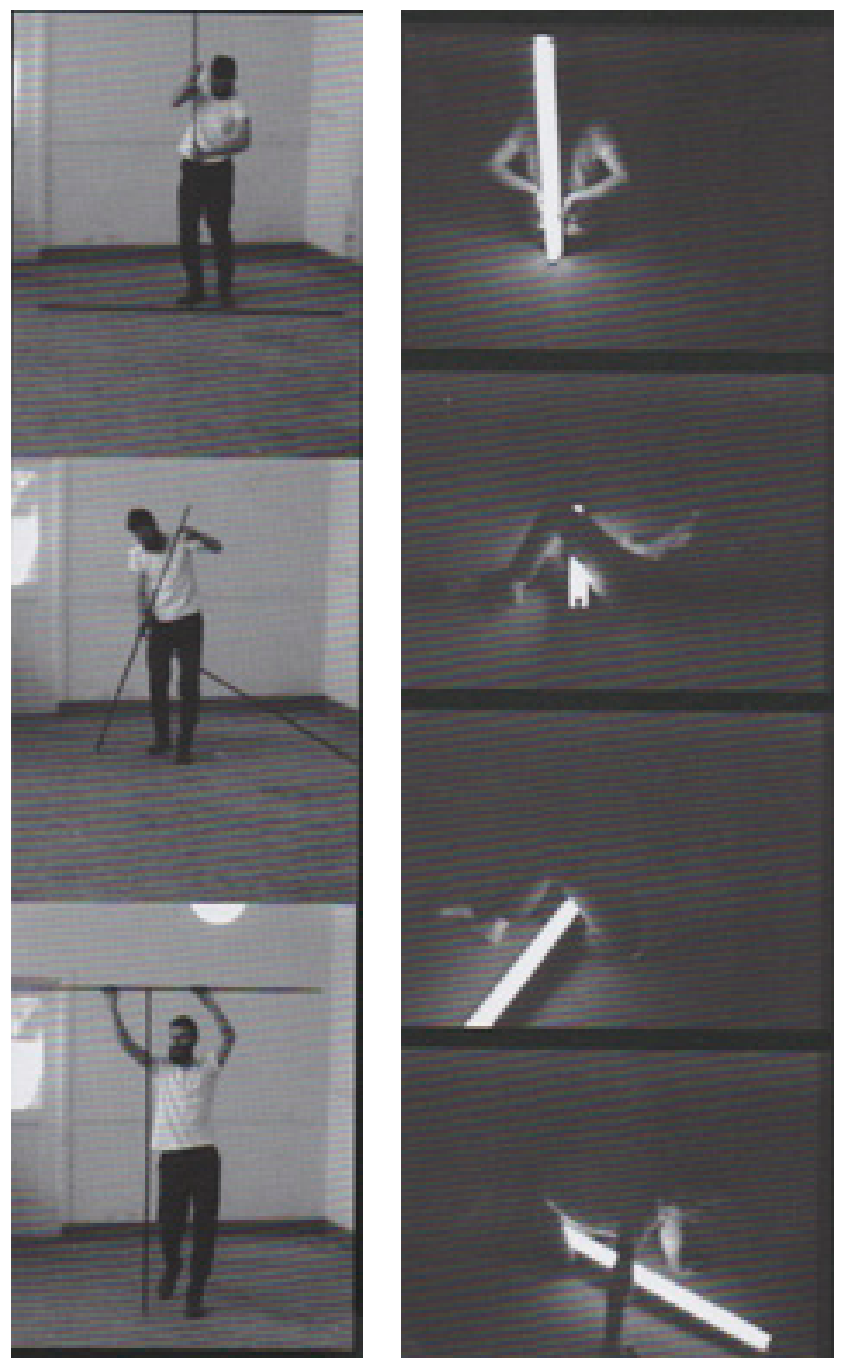

materials). É curioso que muitas posturas realizadas com a lâmpada contra o corpo façam alusão à sexualidade, como se o contato de superfícies tão díspares pudesse tornar-se um "exercício muito erótico", emprestando as palavras de Nauman em Body Pressure [Pressão corporal], texto para performance escrito em 197439. Acerca das ações com a barra de ferro, Nauman afirmou: "lembro-me vagamente de fazer listas de coisas que se poderia fazer com uma barra reta: curvá-la, dobrá-la, torcê-la; e penso que foi assim que a performance finalmente surgiu, já que se tratava apenas de uma progressão de ações, de pé, encostado etc., que realizei" ${ }^{40}$. Certamente 


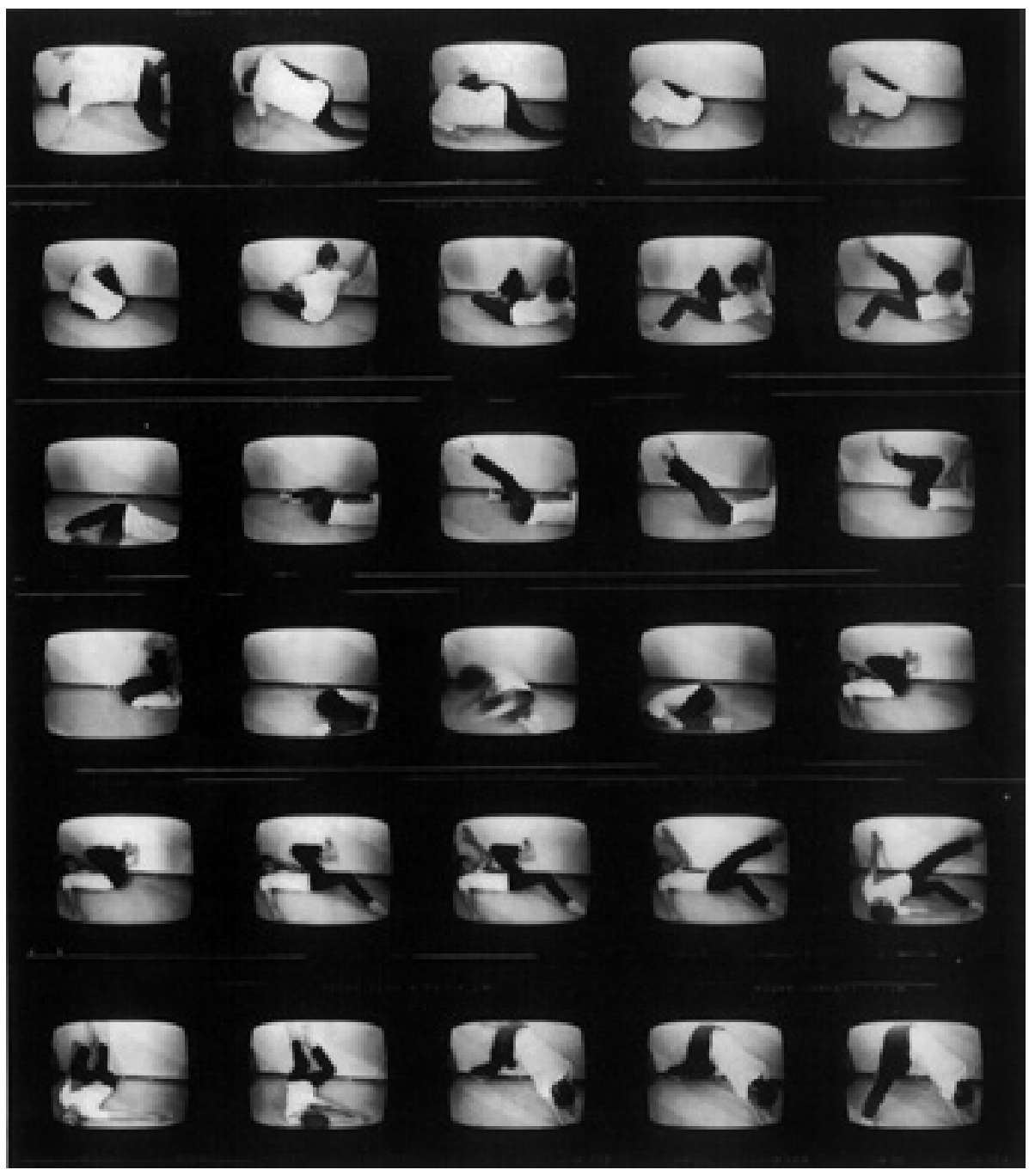

Wall-Floor Positions, 1968, vídeo, 60 min.

Manipulating the TBar, 1965, filme $16 \mathrm{~mm}, 3 \mathrm{~min} .27 \mathrm{seg}$.

Manipulating a Fluorescent Tube, 1969, vídeo, 62 min.

39. 0 texto e a tradução encontram-se no Apêndice desta tese.

40. "I vaguely remember making lists of things you could do to a straight bar: bend it, fold it, twist it; and I think that's how the performance piece finally came about; because it was just progressions of actions, standing, leaning etc., which I carried out". Cf. KRAYNAK, Op. cit., p. 123-124. 

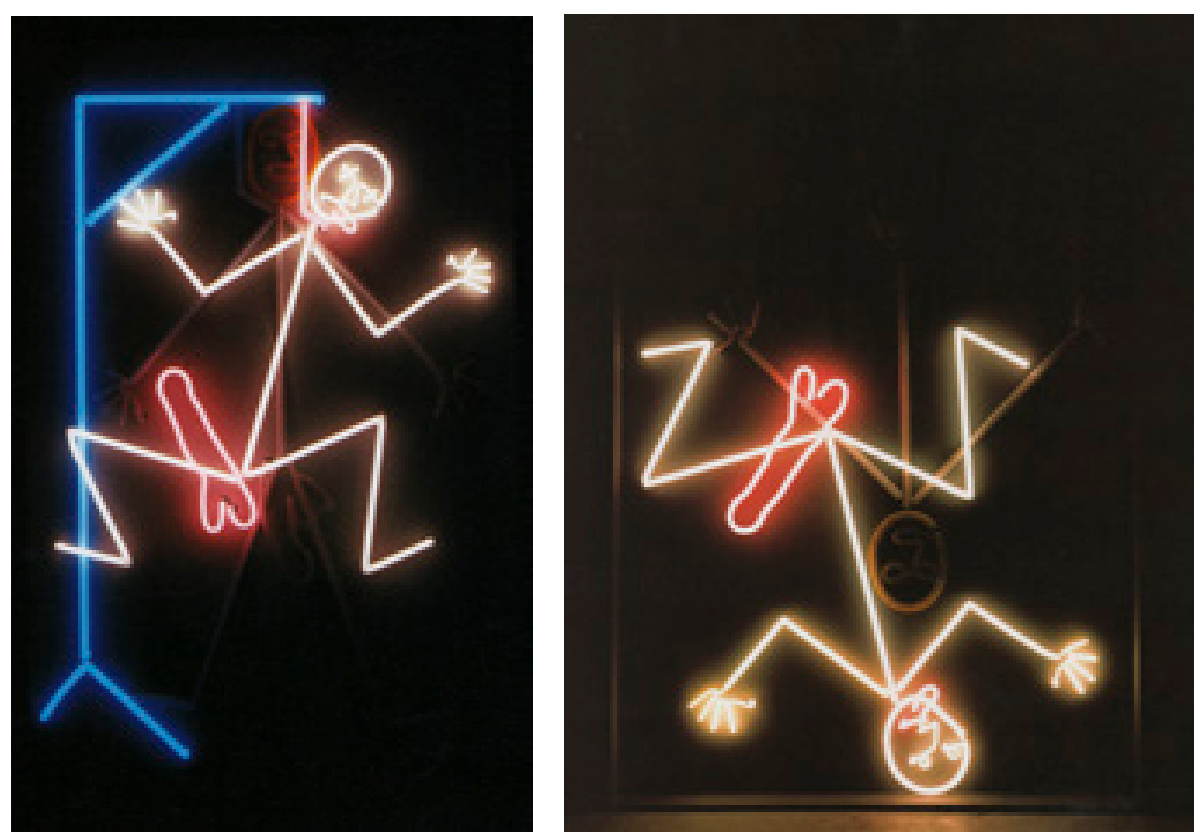

Hanged Man, 1985, tubo de neon e tubo de vidro montado em moldura de madeira, 220x140cm. Diver, 1988, tubo de neon, $230 \times 140 \times 35 \mathrm{~cm}$.

um indício de que ele lançava mão de seu corpo como se fosse uma matéria escultórica entre outras, a ser testada em relação ao espaço: "eu usava meu corpo como um pedaço de matéria e manipulava-o" ${ }^{4}$.

A noção de "expressividade corporal" não se aplica satisfatoriamente aos trabalhos de Nauman. Se o corpo é expressivo, ele só o é pela e na experiência física do esgotamento, conforme se argumentará adiante, e não pela suposta veiculação de estados emocionais. De resto, o corpo em Nauman é coisa, matéria bruta, e, se é expressivo, o é como qualquer material pode ser expressivo. Aliás, a representação do corpo na obra aparece em registros distantes da ideia de expressividade habitualmente associada ao corpo humano, em materiais trazidos de um repertório pop, 


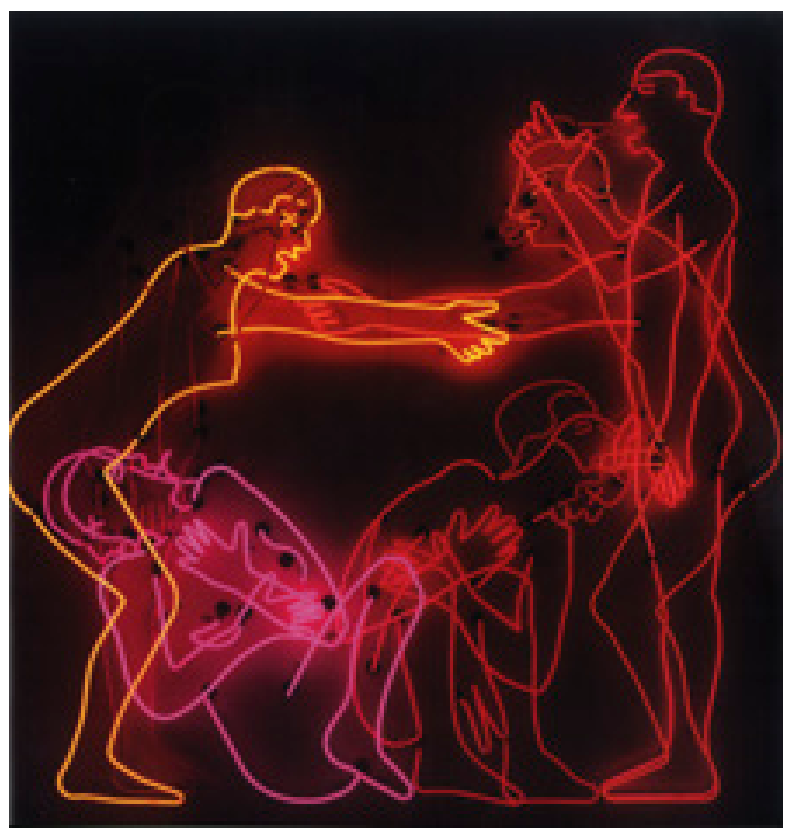

Sex and Death by Murder and Suicide, 1985, tubos de neon, $198 \times 198 \times 30 \mathrm{~cm}$.

pouco nobres e adequados a um humor cáustico e um tanto grotesco. É o que ocorre, por exemplo, em uma série de neons de 1984 e 1985: figuras esquemáticas em desenhos resumidos, sem detalhes, à maneira de desenhos infantis. Nesses neons, Nauman traz para o nível literal a tensão primordial entre as pulsões eróticas e a pulsão de morte, sexo e violência indissociáveis e realimentados reciprocamente, numa circularidade infinita, ritmada na pulsação frenética das luzes neon. Tal como uma placa chamativa do comércio, um anúncio em material sedutor para os olhos, colorido e brilhante. Ao mesmo tempo banal e grotesca, uma brincadeira boba de criança ganha uma representação jocosa e cruel em Hanged Man [Homem enforcado (1985)]. A proposta da brincadeira é enforcar o que comete o erro de não adivinhar certo o que outro está pensando. Nauman aproveita para elaborar um ciclo: crueldade-erotismo-fisiologia-crueldadeerotismo. Na série de neons fica evidente a precisão das escolhas formais e de material para atender à literalização dos sentidos operada por Nauman, um procedimento semelhante ao que utilizara nos primeiros trabalhos, 


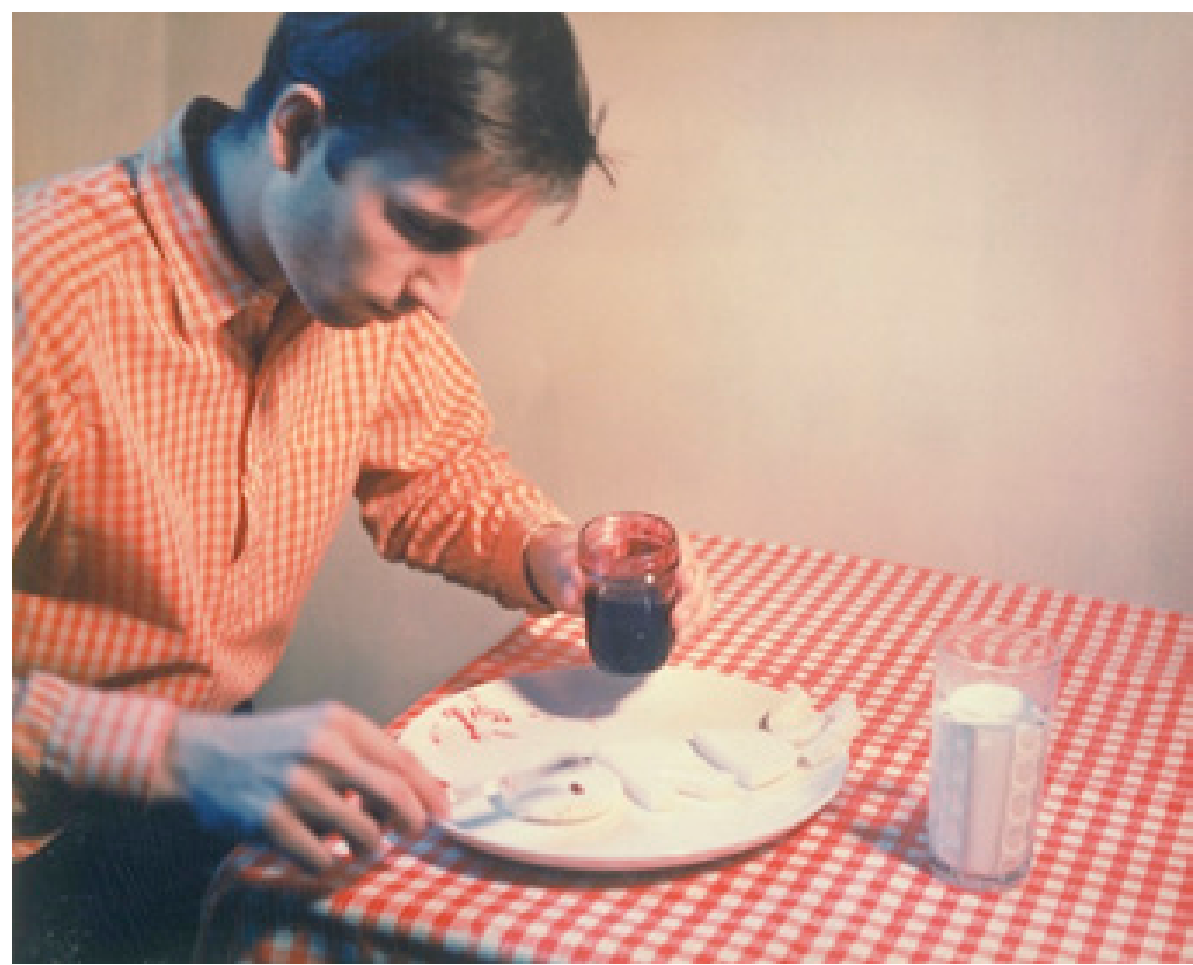

Eating my Words, 1966-67/1970, fotografia, $50 \times 60 \mathrm{~cm}$.

sobretudo na série em que fotografava uma ação desvendando o sentido literal de algumas expressões idiomáticas, como em Eating my Words [Engolindo as minhas palavras, 1966-67/1970].

Para encerrar este capítulo que trata das esculturas de Nauman, é importante ressaltar que a técnica moldagem, muito usada nos primeiros trabalhos, só reaparecerá na obra no fim da década de 1980, em peças prioritariamente realizadas em cera, bronze e alumínio, e apresentadas não mais como esculturas isoladas mas como elementos de instalações complexas. Nesses trabalhos mais recentes, já não são expostas as fôrmas mas as peças resultantes do processo de moldagem, todas com superfícies toscas, rastros da feitura e junções aparentes. 


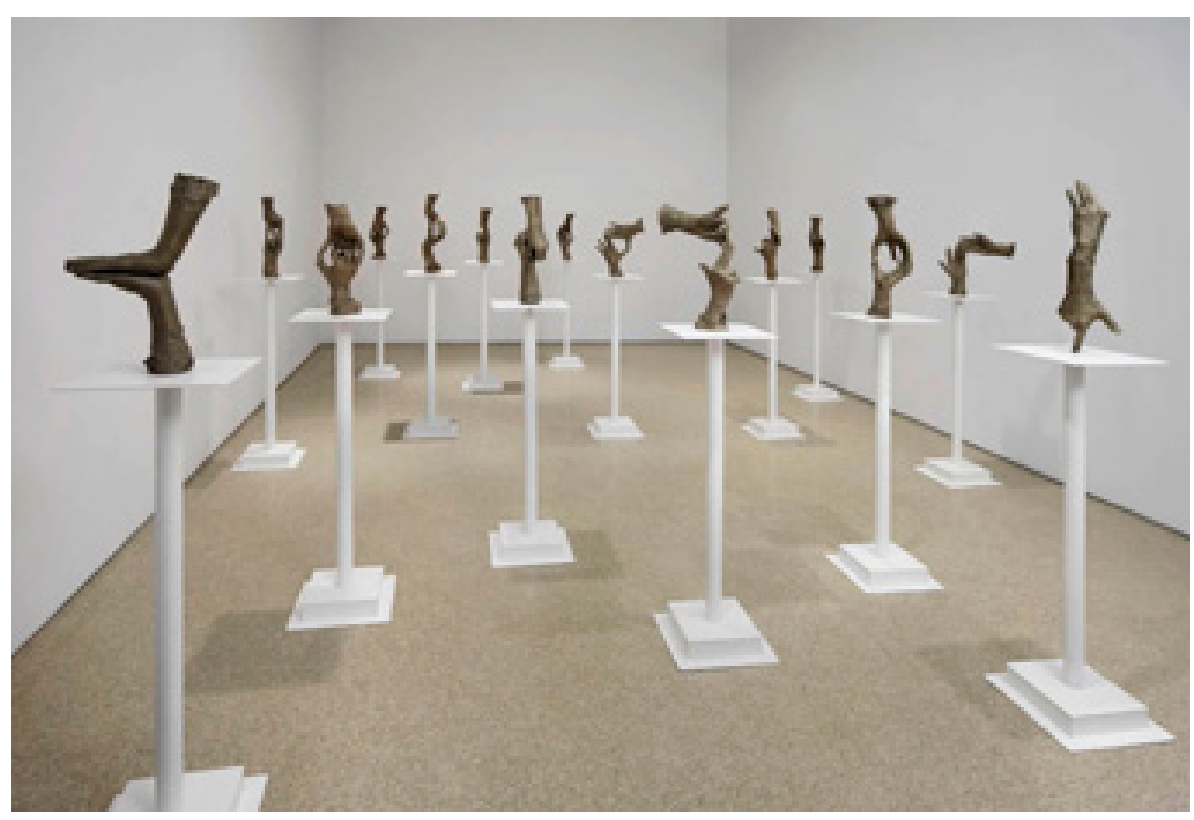

Fifteen Pairs of Hands, 1996, bronze e metal pintado, dimensões variáveis.

As séries de mãos e de cabeças, ora em cera, ora em metal, configuram múltiplos arranjos. A instalação Fifteen Pairs of Hands [Quinze pares de mãos (1996)], por exemplo, comporta pares de mãos moldadas em bronze que sugerem gestos congelados e aludem à linguagem de sinais. Cada unidade corresponde a um par espelhado de mãos moldadas a partir de uma mesma matriz; as quinze matrizes derivam de quinze diferentes gesticulações das mãos de Nauman. Em um trabalho do mesmo ano, Hand Circle [Círculo Manual], uma escultura em bronze suspensa por fios de arame presos ao teto, um par de mãos em forma de um gesto obsceno se repete cinco vezes de modo a fechar um círculo. 

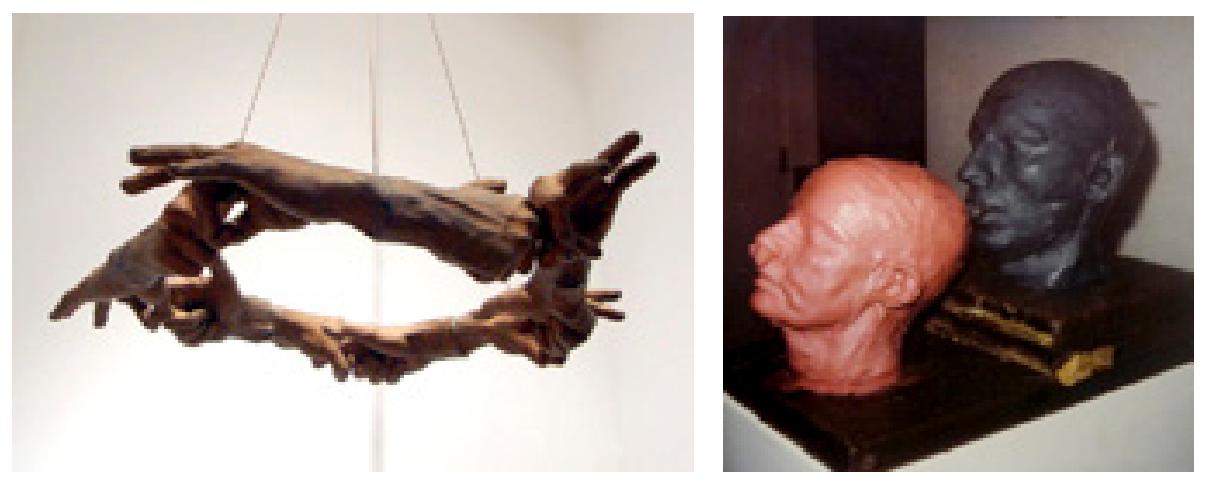

Untitled (Hand Circle), 1996, bronze, dimensões variáveis.

Two Heads, 1991, cera, dimensões variáveis.

Já os moldes de cabeças comparecem em um número ainda maior de trabalhos do que os moldes de mãos. Geralmente em cera ou bronze, são cópias de três diferentes cabeças rearranjadas de múltiplas maneiras. Algumas vêm em pares, combinadas tanto em posição normal quanto invertida (Andrew Head/Andrew Head Reversed, Nose to Nose [Cabeça do Andrew/cabeça do Andrew invertida, nariz com nariz - 1990]); outras são acopladas em mecanismos que vertem água, mimetizando o formato de "fonte" ou "chafariz" (Three Heads Fountain/Juliet, Andrew, Rinde [Fonte de três cabeças/Juliet, Andrew, Rinde - 2005]); ou empilhadas no chão, no canto das paredes (Five Pink Heads in the Corner [Cinco cabeças rosa no canto (1992)]; e outras distribuem-se de modo mais bizarro, pendendo do teto, como que enforcadas (Hanging Head for Leo [Cabeça pendurada para Leo - 1990] ou Four Pairs of Heads [Quatro pares de cabeças - 1991]).

Conforme se sabe, as replicações e o acoplamento de peças moldadas a partir de uma única matriz são procedimentos recorrentes na escultura desde, pelo menos, Auguste Rodin (1840-1917) - artista que de um mesmo modelo de argila reproduzia séries de fragmentos de corpos e os justapunha em diversas configurações ${ }^{42}$. Além das séries de cabeças e mãos, as replicações e acoplamentos são empregados na obra de Nauman em trabalhos feitos a partir de modelos taxidérmicos de animais silvestres, como raposas, lobos e cervos. 

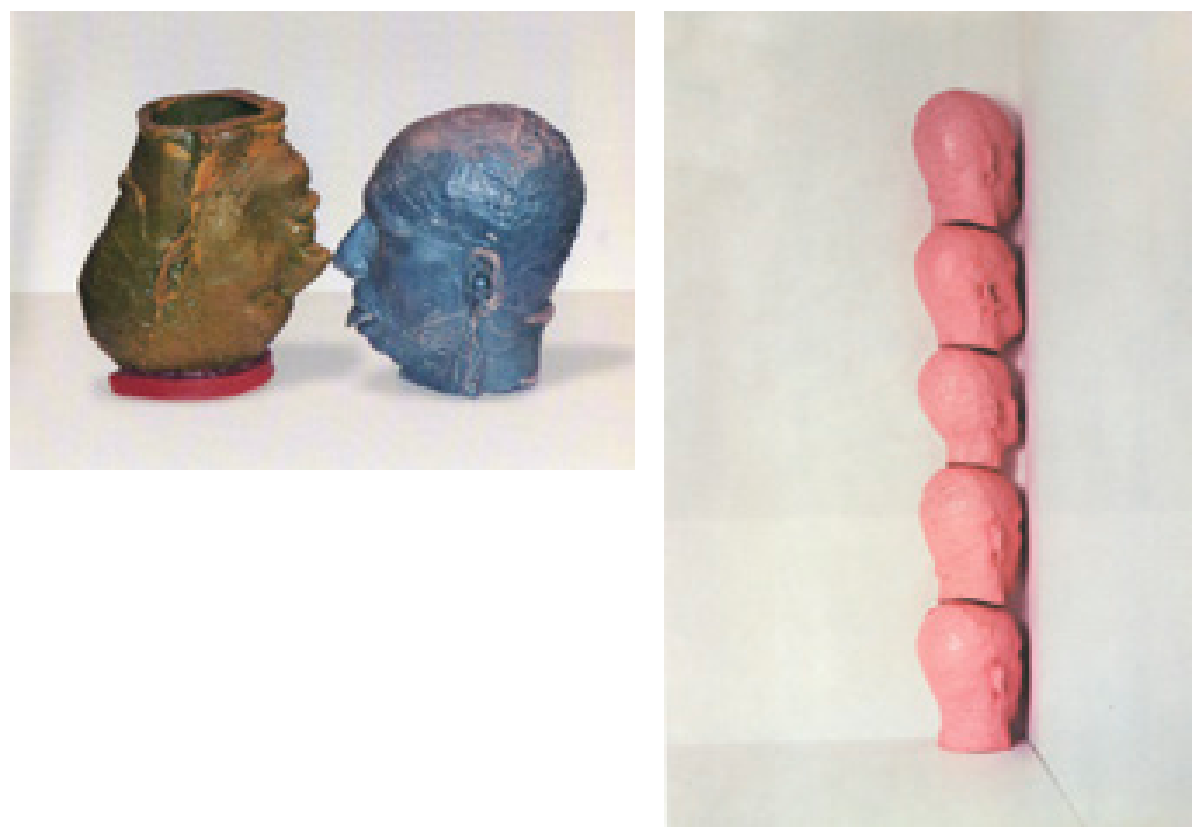

Andrew Head/Andrew Head Reversed/Nose to Nose, 1990, cera, dimensões variáveis. Five Pink Heads in the Corner, 1992, resina epóxi, fibra de vidro e tecido, $127 \times 21,5 \times 19 \mathrm{~cm}$.

Não à toa o interesse do artista pela taxidermia, uma técnica que remonta às superfícies e à evisceração das peles. O processo, grosso modo, consiste na estripação do animal e na reorganização da carcaça a partir das superfícies. Para tanto, o oco surgido do descarte das vísceras é preenchido com um molde pré-fabricado de espuma de poliuretano que ajuda a estruturar o couro do animal. Nas suas moldagens, Nauman utiliza como matriz justamente os modelos de poliuretano, e a partir deles faz as próprias carcaças de alumínio e de cera. 


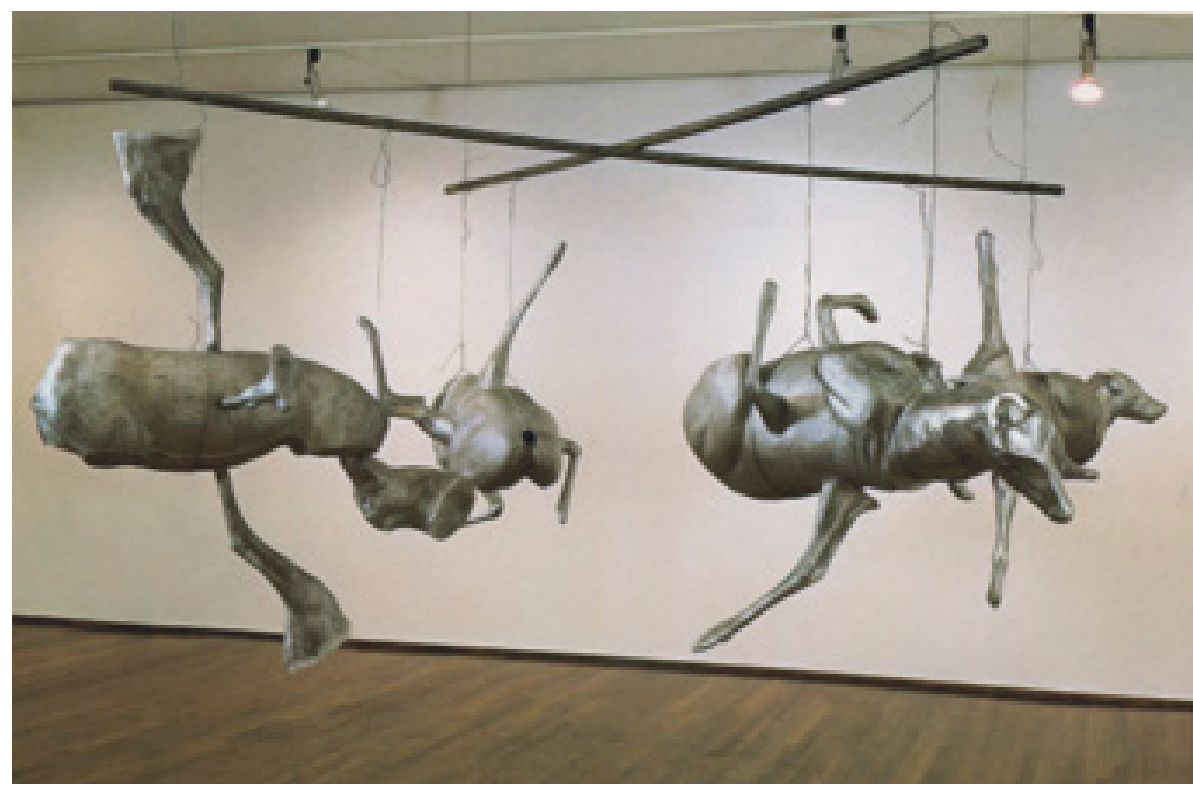

Four Large Part Animals, 1989, alumínio, tubos de ferro, 142 × 376 × $368 \mathrm{~cm}$.

As carcaças feitas por Nauman resultam, na verdade, de arranjos "antinaturais" de fragmentos anatômicos: as pernas de um animal são fixadas ao tronco em sentido contrário, pelas patas, ou sua cabeça é invertida ou deslocada para a parte posterior, como se vê em Four Large Part Animals [Quatro grandes animais partidos (1989)], entre outros. Em Two Wolves, Two Deer [Dois lobos, dois cervos (1989)], as peças são feitas em cera e as junções entre as partes são tão mal ajambradas que a espuma interna chega a rasgar as superfícies, tornando-as mais repulsivas. Algumas carcaças são penduradas por arames, às vezes suspensas em instalações circulares, como ocorre com os animais de alumínio presos a uma estrutura giratória em Carousel [Carrossel (1988)]. Outra versão desse carrossel, Hanging Carousel/George Skins a Fox [Carrossel suspenso/George despela uma raposa (1988)], traz, além de quatro carcaças suspensas em círculo, uma pequena televisão dependurada no centro que transmite o passo a passo da remoção da pele de uma raposa, um ritual cruel metodicamente narrado pelo caçador George Stumpff, um vizinho do artista. 

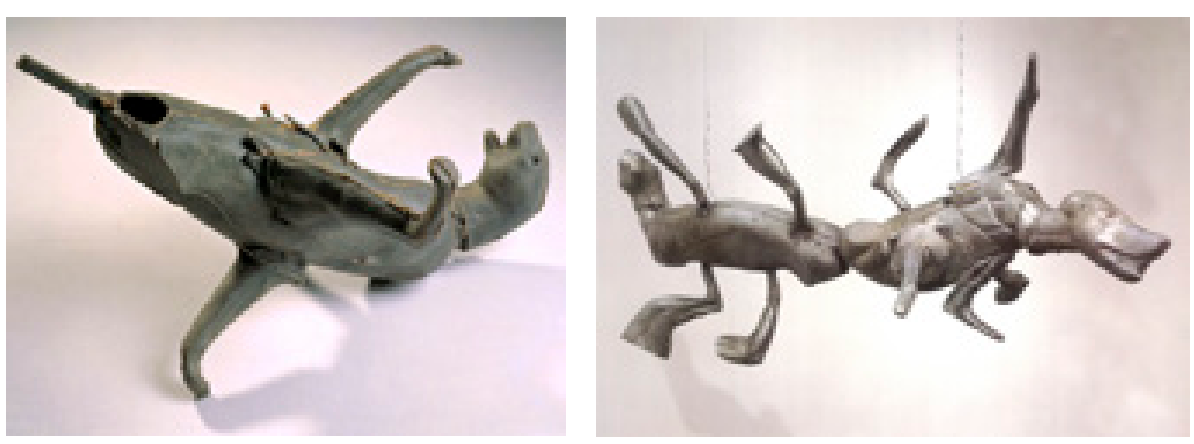

Blue Cat, 1989, cera, $71,4 \times 52,1 \times 59,9 \mathrm{~cm}$.

Large Butt to Butt, 1989, alumínio, arame, 132,1 × 248,9 × 121,9cm.

Nauman compõe híbridos, espécies de quimeras. São inquestionavelmente trabalhos que aludem à violência, à crueldade, à morte. Além das desfigurações, alguns moldes são acoplados simulando a empalação concomitante de dois animais, como em Butt to Butt [Bunda com bunda (1989)]. A empalação é também assunto do desenho Spinning Cat with Stick Up its Ass [Gato giratório com uma vara enfiada no rabo (1989)] e da escultura de um gato anatomicamente deformado, feita em cera a partir do mencionado esboço, Blue Cat [Gato azul/triste (1989) $]^{43}$.

Esse conjunto de trabalhos com moldagens de animais taxidérmicos causa repugnância na medida em que reitera várias instâncias de violência, e não apenas no nível simbólico conforme o ritual de despelar a raposa comprova. Causar respostas emocionais é, com efeito, um dos objetivos da obra de Nauman a partir da década de 1980, uma busca por intensidade máxima capaz de nocautear inesperadamente, nas palavras já citadas do artista.

43. Para outras análises das moldagens de carcaças de animais, consultem-se os seguintes ensaios: YAU, John. Thirteen Ways to Skin a Nauman. In: NAUMAN, Bruce. Selected Works. Nova York: Zwirner \& Wirth,
2001; STORR, Robert. Partial Truths. In: NAUMAN, Bruce. Bruce Nauman: Neons, Sculptures, Drawings. Nova York: Van De Weghe Fine Art, 2002; BENEZRA, Neal. Op. cit., p. 116-145. 
Carousel,1988, caneta sobre papel, $21 \times 29,7 \mathrm{~cm}$.

Hanging Carousel (George

Skins a Fox), 1988, espuma de TV, $\emptyset 426,7 \mathrm{~cm}$.
Estudo para Hanging de poliuretano, aço, monitor
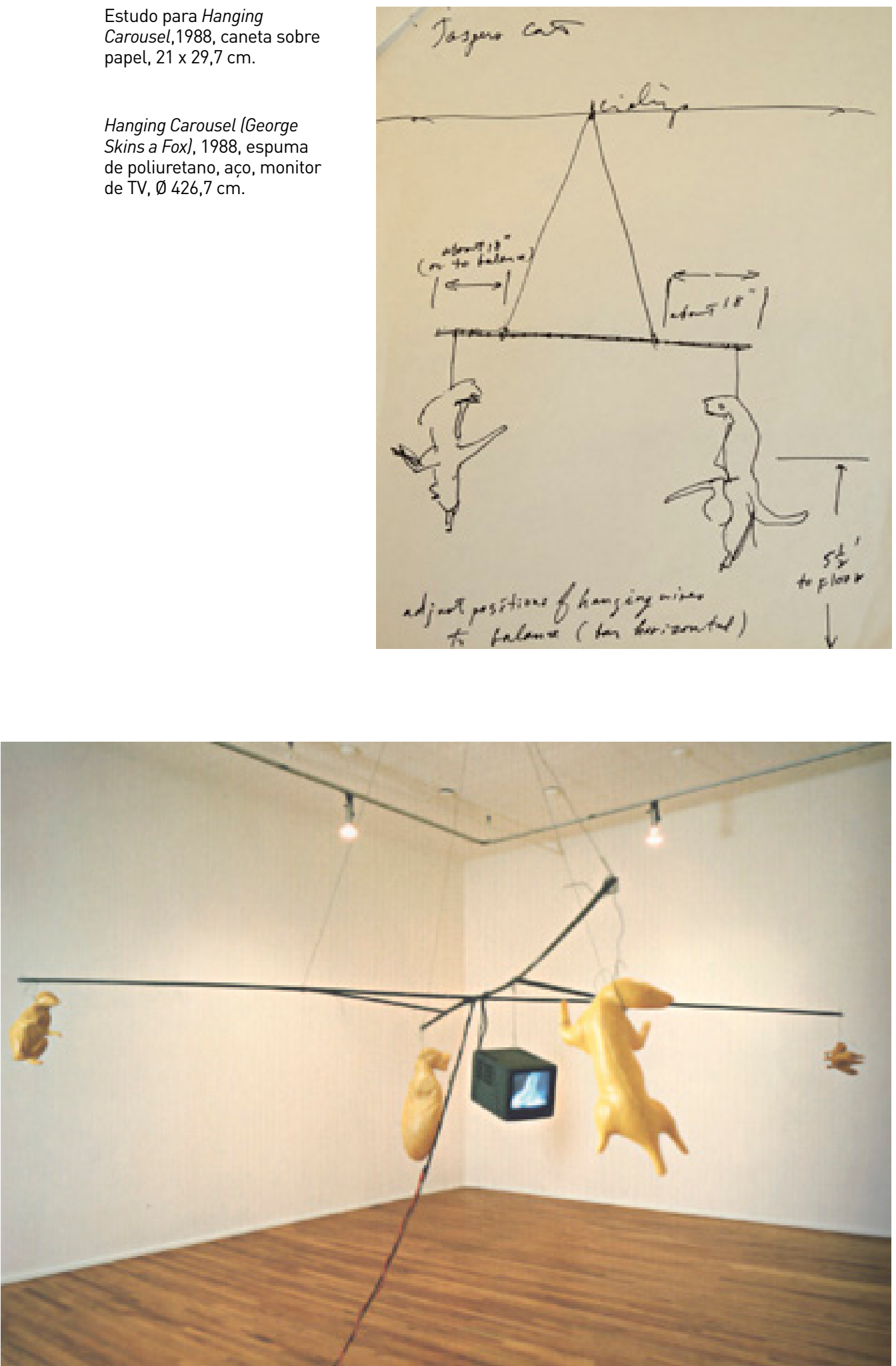


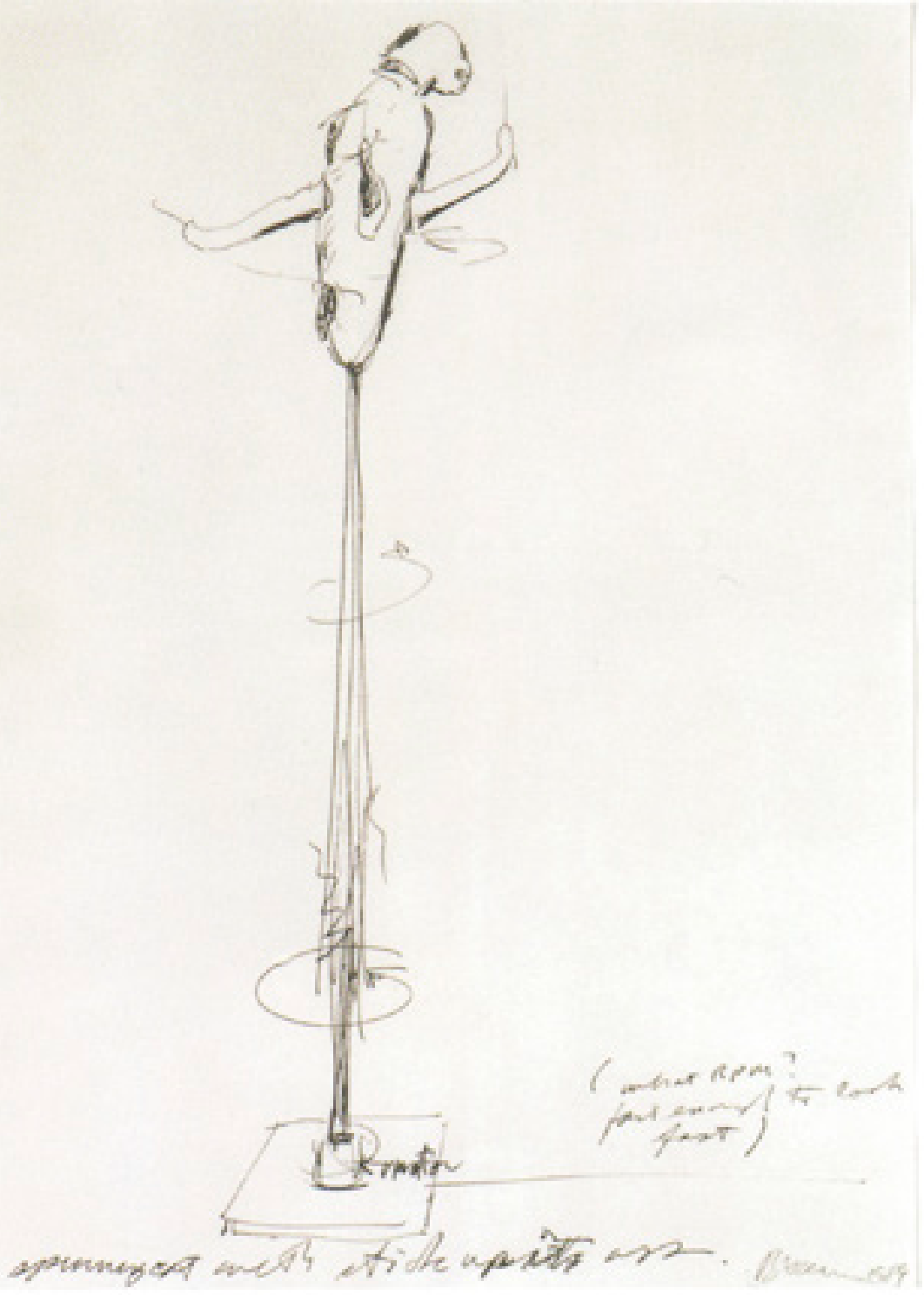


Gapítulo 2

Dilatar o tempo e exaurir o espaço 


\subsection{Exercícios de ateliê: a repetição exaustiva como procedimento}

No fim da década de 1960, Bruce Nauman filmou-se no ateliê cumprindo à exaustão séries preordenadas de movimentos com nenhuma outra finalidade aparente que não a de testar as possíveis variações assumidas por seu corpo naquele espaço delimitado, como se estivesse a inventariar posturas estáticas e modos de se mover enquanto executava atividades tão banais como andar, bater os pés no chão ou arremessar bolas de borracha contra as paredes. Tais filmes $16 \mathrm{~mm}$ ou vídeos mostravam repetições de padrões predeterminados de exercícios ora assemelhados a passos de dança ora a tarefas desempenhadas no dia a dia ${ }^{1}$.

A equivalência entre exercício e dança é a proposta do filme Dance or Exercise on the Perimeter of a Square [Dança ou exercício sobre o perímetro de um quadrado (1967-1968), 10 min.]. Uma câmera fixa à esquerda da cena mostra o artista de costas para o centro de um quadrado previamente desenhado com fita adesiva branca no chão do ateliê, com as

1. Os filmes mencionados nesta tese e outros que não foram expressamente citados foram assistidos na íntegra pela pesquisadora na sede do arquivo Electronic Arts Intermix, em Nova York, durante o estágio de pesquisa no exterior, amparado pelo Programa Institucional de Doutorado Sanduíche no Exterior da CAPES (CAPES/PDSE), realizado entre os meses de março e agosto de 2012. Segue a relação dos filmes e vídeos assistidos: Thighing/Blue [1967, 4:36 min, $16 \mathrm{~mm}$ ]; Art Make-Up, No. 1, White [1967, $10 \mathrm{~min}, 16 \mathrm{~mm}$ ]; Art Make-Up, No. 2, Pink [1967-68, $10 \mathrm{~min}, 16 \mathrm{~mm}] ;$ Art Make-Up, No. 3, Green [1967-68, $10 \mathrm{~min}, 16 \mathrm{~mm}$ ]; Art Make-Up, No. 4, Black [1967-68, 10 min, 16 mm]; Bouncing Two Balls Between the Floor and Ceiling with Changing Rhythms [1967-68, $10 \mathrm{~min}, 16 \mathrm{~mm}$ ]; Dance or Exercise on the Perimeter of a Square/ Square Dance [1967-68, 8:24 min, $16 \mathrm{~mm}$ ]; Playing A Note on the Violin While I Walk Around the Studio [1967-68, $10 \mathrm{~min}, 16 \mathrm{~mm}$ ] Violin Film
\# 1 / Playing The Violin As Fast As I Can [1967-68 10:54 min, $16 \mathrm{~mm}$ ]; Walking in an Exaggerated Manner Around the Perimeter of a Square [196768, $10 \mathrm{~min}, 16 \mathrm{~mm}]$; Bouncing in the Corner No. 1 [1968, $60 \mathrm{~min}]$; Flesh to White to Black to Flesh [1968, $51 \mathrm{~min}]$; Pinch neck [1968, 2 min, 16 mm]; Slow Angle Walk / Beckett Walk [1968, $60 \mathrm{~min}$ ]; Stamping in the Studio [1968, $62 \mathrm{~min}$ ]; Walk with Contrapposto [1968, $60 \mathrm{~min}] ;$ WallFloor Positions [1968, 60 min]; Black Balls [1969, $8 \mathrm{~min}, 16 \mathrm{~mm}$ ]; Bouncing Balls [1969,9 min, 16 $\mathrm{mm}$ ]; Bouncing in the Corner, No. 2: Upside Down [1969, $60 \mathrm{~min}$ ]; Gauze [1969, $8 \mathrm{~min}, 16 \mathrm{~mm}]$; Lip Sync [1969, $57 \mathrm{~min}] ;$ Manipulating a Fluorescent Tube [1969, 62 min]; Pacing Upside Down [1969, $56 \mathrm{~min}$ ]; Pulling Mouth [1969, $8 \mathrm{~min}, 16 \mathrm{~mm}$; Revolving Upside Down [1969, $61 \mathrm{~min}$ ] Violin Tuned D.E.A.D. [1969, $60 \mathrm{~min}]$; Elke Allowing the Floor to Rise Up Her, Face Up [1973, 39 min]; Tony Sinking into the Floor, Face Up, and Face Down [1973, $60 \mathrm{~min}]$. 

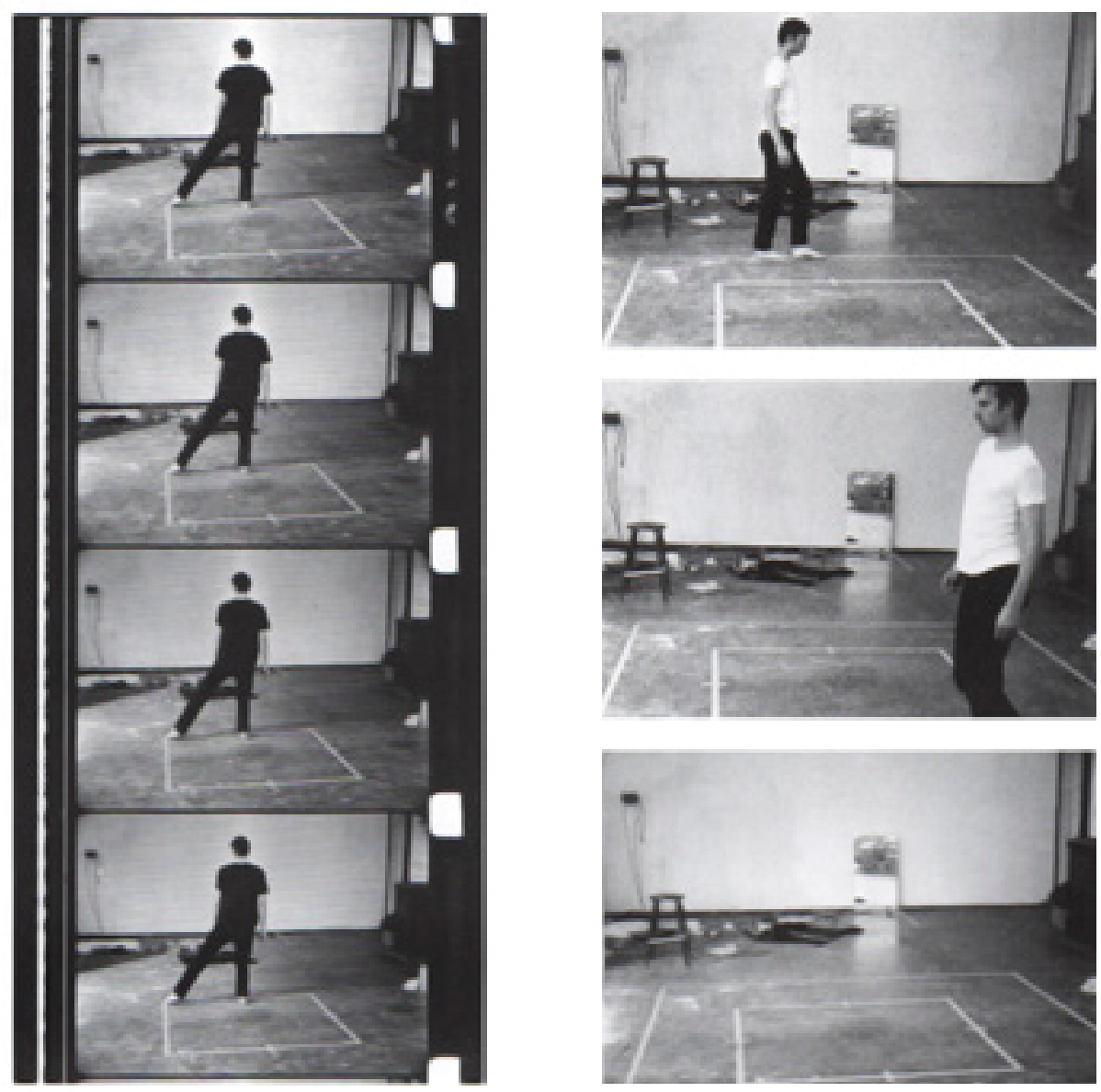

Dance or Exercise on the Perimeter of a Square, 1967-68, filme $16 \mathrm{~mm}, 10 \mathrm{~min}$. Walking in an Exaggerated Manner around the Perimeter of a Square, 1967-68, filme 16 mm, $10 \mathrm{~min}$.

metades dos lados assinaladas. De uma das arestas, Nauman parte para a realização ininterrupta de um mesmo passo de dança ao longo de todo o perímetro do quadrado, regulando o ritmo de seu corpo pelas batidas de um metrônomo. A cadência é mantida pelos dez minutos correspondentes à duração do filme $16 \mathrm{~mm}$ utilizado pelo artista.

Já em Walking in an Exaggerated Manner around the Perimeter of a Square [Caminhando de maneira exagerada pelo perimetro de um quadrado (1967-1968), 10 min.], a cadência rigorosa da caminhada é forjada em silêncio absoluto, no posicionamento de um pé à frente do outro e na transferência 
do peso do corpo entre o movimentar das pernas, num gesto que exagera propositalmente as torções do quadrileo balançar correspondente dos ombros - movimento retomado no vídeo Walk With Contrapposto [Caminhada com contraposto (1968), $60 \mathrm{~min}$.], comentado adiante. Obedecendo rigorosamente o padrão determinado, Nauman caminha em vaivém ao longo do perímetro de um quadrado maior riscado com fita, concêntrico àquele quadrado da dança. Ao fundo, há ainda um terceiro quadrado com um espelho recostado em um dos lados, junto à parede, no qual aparece uma imagem rebatida toda vez que Nauman passa em frente a ele. Mas a câmera disposta no canto inferior esquerdo não abarca as dimensões totais do quadrado maior e, sendo assim, o corpo sai parcial ou completamente do enquadramento, para reaparecer em seguida, caminhando sem perder o compasso.

Convém notar que esses riscos no chão do ateliê servem tanto para direcionar e formalizar os exercícios quanto para reiterar o caráter calculado que a repetição exaustiva do movimento parece conferir aos gestos, quase na tentativa de esvaziar suas potencialidades expressivas por meio de um rigor que conduz à desnaturação. A demarcação de limites também enfatiza o estranhamento provocado pela ausência de Nauman em certos quadros, momentos em que a câmera, em virtude de sua posição fixa, deixa de captá-lo. Tem-se a sensação de que o artista arma rotas de fuga para os sucessivos confinamentos impostos ao seu corpo: o espaço do ateliê, as fronteiras dos quadrados riscados no chão e os limites do enquadramento da própria câmera.

Depurando um movimento simples em frações mínimas ou realçando gestos e poses particulares, Nauman consegue uma espécie de dilação do tempo implicado em cada tarefa, executada por ele com mais delonga do que o habitual. A reiteração contínua de uma mesma matriz não chega a atribuir às ações um aspecto mecanizado, ao contrário disso, a volição tenaz e o esforço de um sujeito concernido física e psiquicamente no seu desempenho corporal transparecem e imprimem às cenas algo de uma natureza expressiva peculiar, ainda que à revelia das intenções do artista. 
Quer seja pelos 10 minutos de duração dos filmes $16 \mathrm{~mm}$, quer seja por 60 minutos ininterruptos das captações em vídeo, Nauman cumpre impassivelmente as rotinas pré-estabelecidas e quase não se notam falhas no padrão executado tamanha a destreza corporal que demonstra ter. A extenuação é uma consequência da reiteração incessante do padrão pois cada recomeço retém o cansaço e a tensão da série anterior. Alguns exercícios são particularmente exigentes, demandando intensa concentração, mas o artista evita acentuar ou dramatizar a exaustão que provocam, e procura seguir o método com precisão. Portanto, a expressividade não é um programa desses trabalhos e, se surge ali, é a reboque, como uma intrusão que se dá às expensas de toda disciplina de contenção gestual, na experiência mesma de sua dificuldade.

Dito de outro modo, o que ocorre é que "o movimento é expressivo indiferentemente da intenção de expressividade" ${ }^{2}$, palavras do coreógrafo e bailarino norte-americano Merce Cunningham (19192009), uma referência declarada. As experiências corporais levadas a cabo em certos filmes e vídeos da série são, segundo Nauman, "exercícios de equilíbrio [...] pensei neles como problemas de dança sem ser um bailarino" 3 e "os primeiros filmes de Warhol e o que conhecia e via da dança de Merce Cunningham foram importantes. Porque a sua dança é construída de atividades comuns" ${ }^{4}$. Há, portanto, um flerte com a dança tal como a concebia Cunningham, uma "nova dança" também buscada por companhias como o Judson Dance Theater, sediado em Nova York e ativo entre 1962 e 1964, que contou com Trisha Brown (1936 - ), Yvonne

2. Cf. CUNNINGHAM, Merce. Changes: Notes on Choreography. Nova York: Something Else Press, 1968.

3. "[...] the films and some of the pieces that I did after that for videotapes were specifically about doing exercises in balance. I thought of them as dance problems without being a dancer [...]". Cf. KRAYNAK, Janet (Ed.). Please Pay Attention
Please: Bruce Nauman's Words: Writings and Interviews. Cambridge, Massachusetts: The MIT Press, 2005, p. 142.

4. "[..] what I might say is that those early Warhol films and what l'd know and see of Merce Cunningham's dance were important considerations. Because his dance is built up of normal activities". Cf. Ibidem, p. 248. 
Reiner (1934 - ) e Meredith Monk (1942 - ), entre seus integrantes. Em um breve comentário acerca da relação entre a dança e a escultura na década de 1960, Rosalind Krauss aponta que:

[...] a meta comum dos bailarinos ligados ao Judson Theater era "o estabelecimento de uma economia radicalmente nova do movimento. O que exigia uma crítica sistemática da retórica, das convenções, das hierarquias estéticas impostas pelas formas de dança tradicionais ou clássicas. Tal retórica foi, na verdade, invertida, destruída, no que passou a ser conhecida como a 'dança da linguagem comum' e do 'desempenho de tarefas"'. As tarefas que constituíam a trama da dança - como mover colchões, carregar tijolos ou obedecer às regras de um jogo - atendem a uma dupla estratégia: substituir o ilusionismo pelo tempo real e despsicologizar o seu executante ${ }^{5}$.

De todos os artistas ligados a essas inovações, Nauman também cita como referência a norte-americana Meredith Monk, cantora, compositora, artista performática e coreógrafa, especialmente conhecida pelas inovações vocais. Comentando a consciência corporal adquirida com certo treinamento ao longo dos anos, Nauman constatou:

A primeira vez que eu realmente conversei com alguém sobre consciência corporal foi no verão de 1968. Meredith Monk estava em São Francisco. Ela tinha ouvido falar ou visto alguns de meus trabalhos e os reconheceu. Uma consciência de si mesmo [an awareness of yourself] vem de uma certa quantidade de atividades e você não a alcança apenas pensando em você. Você faz exercícios, tem certo tipo de consciência que não tem se apenas lê livros. Assim, os filmes e alguns trabalhos que fiz depois para vídeo tratavam especificamente de fazer exercícios em equilíbrio. Eu pensei neles como problemas de dança sem ser um bailarino, interessado em

5. Cf. KRAUSS, Rosalind. Balés mecânicos: luz, movimento e teatro. In: Caminhos da escultura moderna. São Paulo: Martins Fontes, 1998, p. 282. 
tipos de tensão que emergem quando você tenta se equilibrar mas não consegue. Ou fazer algo por um longo tempo e ficar cansado ${ }^{6}$.

Não apenas a tensão provocada por exercícios de equilíbrio, mas também aquela que advém da execução de tarefas simples porém inabituais interessavam a Nauman. Em dois outros vídeos, a perscrutação do espaço é concomitante à tentativa de fazer soar um violino, tão rapidamente quanto possível. Uma atividade aparentemente simples, mas que para os inexperientes no instrumento, como Nauman à época, converte-se num exercício físico tortuoso $^{7}$. Ao fim, o barulho inicial encontra na repetição persistente uma estrutura rítmica capaz de converter os sons desagradáveis em uma espécie peculiar de peça musical, tanto em Playing a Note on the Violin while I Walk around the Studio [Tocando uma nota no violino enquanto ando pelo ateliê (19671968), 10 min.] quanto no vídeo posterior, Violin Tuned D.E.A.D. [Violino afinado D.E.A.D (1969), 60 min.], cujo título alude à palavra formada pelas notas d (re) e (mi) a (la) d (re) que, em português, corresponde a "morto", "inerte", "apático", "silencioso". Neste último trabalho, Nauman faz uma inversão no posicionamento da filmadora e, na imagem captada, o artista aparece na lateral, talvez como se estivesse flutuando.

6. "The first time I really talked to anybody about body awareness was in summer of 1968. Meredith Monk was in San Francisco. She had thought about or seen some of my work and recognized it. An awareness of yourself comes from a certain amount of activity and you can't get it from just thinking about yourself. You do exercise, you have certain kinds of awareness that you don't have if you read books. So the films and some of the pieces that I did after that for videotapes were specifically about doing exercises in balance. I thought of them as dance problems without being a dancer, being interested in kinds of tension that arise when you try to balance and you can't. Or do something for a long time and get tired. Cf. KRAYNAK, Janet (Ed.). Op. cit., p. 142.

7. Comentado seus primeiros filmes, Nauman lembrou-se de que "no filme do violino \{Playing a Note on the Violin while I Walk around the Studio [Tocando uma nota no violino enquanto ando pelo ateliê (1967-1968)]\}, eu toquei o violino por mais tempo que pude. Eu não sei tocar violino, então foi difícil tocar todas as quatro cordas o mais rápido e por mais tempo que eu conseguisse. Eu tinha dez minutos de filme e consegui fazê-lo por cerca de sete minutos antes de ficar cansado e parar para descansar um pouco, para terminar depois". No original: in the violin film [Playing a Note on the Violin while I Walk around the Studio (1967-1968)], I played the violin as long as I could. I don't know how to play the violin, so it was hard, playing on all four strings as fast as I could for as long as I could. I had ten minutes of film and ran about seven minutes of it before I got tired and had to stop and rest a little bit and then finish it". Cf. KRAYNAK, Janet. Op. cit., p. 142. 


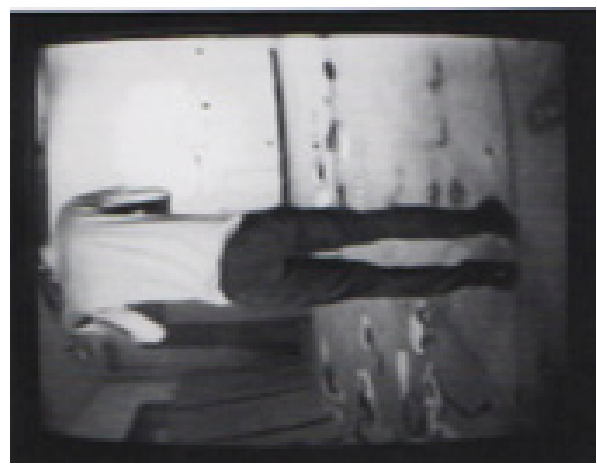

Violin Tuned D.E.A.D., 1969, vídeo, 60 min.

Playing a Note on the Violin while I Walk around the Studio, 1967-1968, filme $16 \mathrm{~mm}, 10 \mathrm{~min}$.

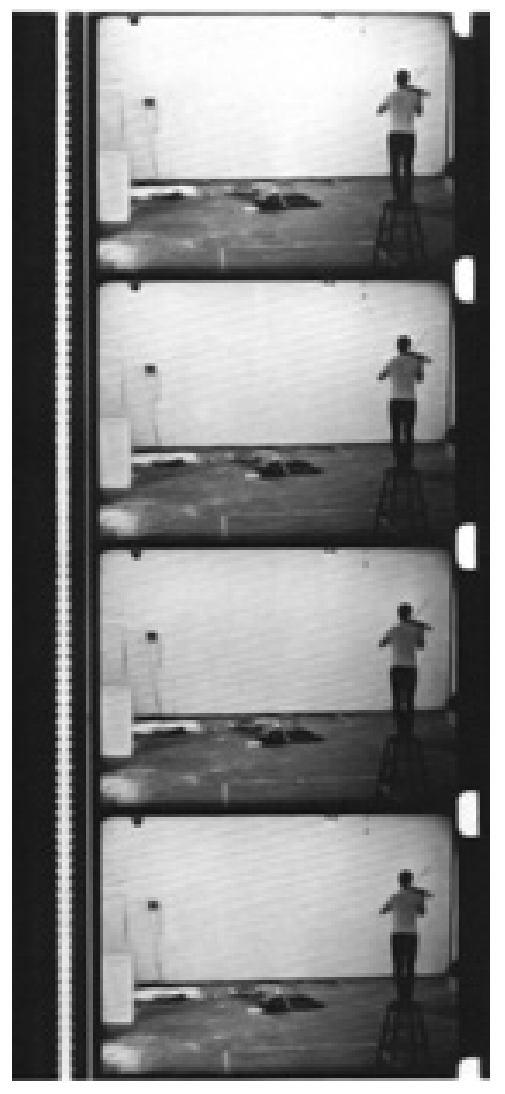

Em Revolving Upside Down [Revirando de ponta-cabeça (1969), 60 min.], Nauman faz o mesmo truque com a câmera, de modo que o ângulo da filmagem o põe de ponta-cabeça e no centro do quadro, como a sugerir uma atração antigravitacional sobre o volume pendente. No vídeo, o artista gira lentamente o corpo num círculo completo, apoiando-se em um pé só enquanto mantém a perna contrária erguida à frente do corpo. Aos poucos, desempenhando as cuidadosas piruetas, o corpo perde a centralidade e vai se aproximando da superfície da tela, desaparecendo pouco a pouco do plano, para depois ressurgir, imperturbável e ainda no cumprimento do extenuante exercício de equilíbrio, tarefa realizada por 60 minutos. 

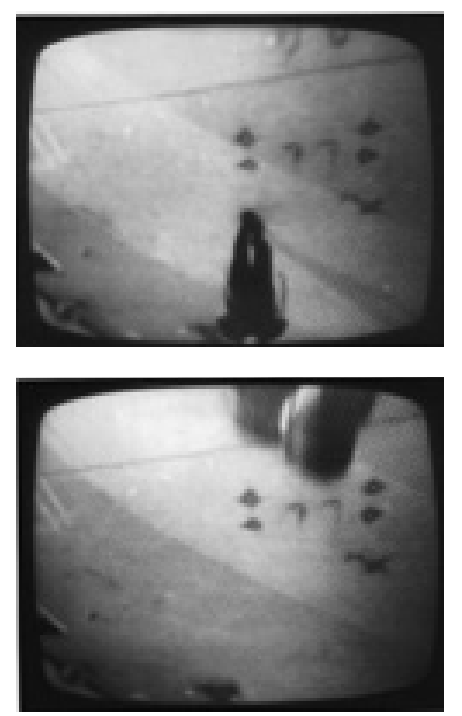

Stamping in the Studio, 1968, vídeo, $62 \mathrm{~min}$. Revolving Upside Down, 1969, vídeo, 60 min.
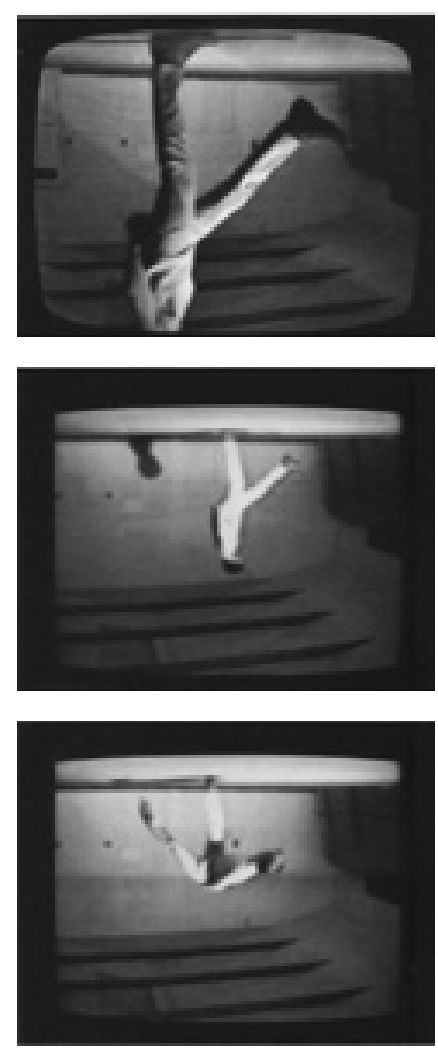

Em Stamping in the Studio [Carimbando no atelie (1968), 62 min.], a imagem também está invertida mas o que chama mais atenção é a energia cumulada em cada passada forte e a sustentação do ritmo, assim como ocorre em Bouncing in the Corner, $\mathrm{n}^{\circ} 1$ [Quicando no canto (1968), 60 min.], um exercício muito exaustivo e incômodo não apenas pela dor física que parece provocar mas pela própria estultice de se lançar numa empreitada como aquela: arremessar o corpo reiteradamente contra um dos cantos do ateliê. Em 1969, por ocasião da mostra "Anti-Illusion: Procedures/Materials", no Whitney Museum of American Art, em Nova York, Nauman apresentou um desdobramento desse exercício diante de 


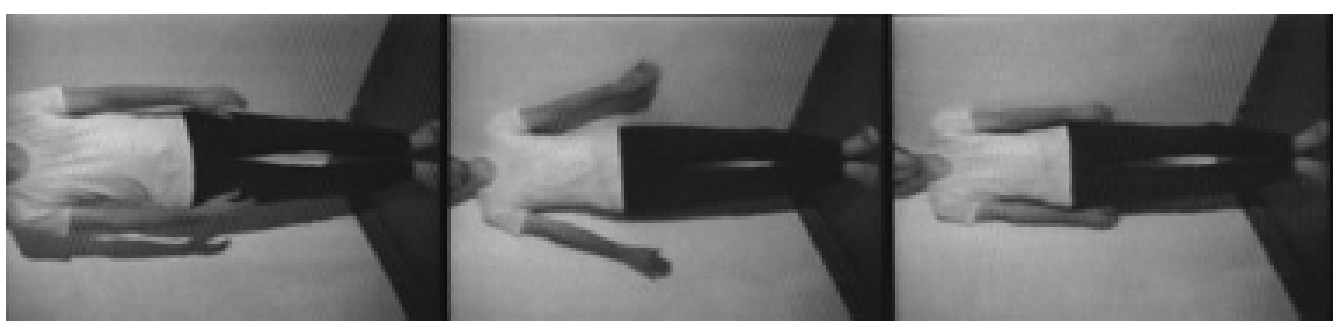

uma plateia, por uma hora, juntamente com sua esposa à época, Judy, além de Meredith Monk. Cada um deles se posicionou em um canto diferente do museu, de modo que não podiam se ver, apenas ouvir os sons produzidos pelo impacto de seus corpos violentamente atirados contra as quinas das paredes. Além dessa, Nauman realizou apenas três outras performances "ao vivo": as já comentadas Wall-Floor Positions [Posições parede-chão (1965)] e Manipulating a Fluorescent Tube [Manipulando um tubo fluorescente (1965) ], além de uma ação apresentada em 1970, no "Santa Barbara Arts Festival”, junto com Meredith Monk e Richard Serra ${ }^{8}$.

Em Bouncing Two Balls between the Floor and the Ceiling with Changing Rhythms [Quicando duas bolas entre o chão e o teto em ritmos variáveis (1967-1968), 10 min.] uma brincadeira infantil típica converte-se numa tarefa hercúlea. Ao lançar as duas bolas contra o solo, Nauman o faz com tanto vigor que elas quicam de modo imprevisível: primeiro mantémse o compasso, mas depois ele perde o controle de seu próprio jogo e uma mesma bola bate, por exemplo, duas vezes no chão antes de ser apanhada, desregulando o ritmo. Assim, o que começa com o cumprimento estrito de normas, termina como um evento que aceita o próprio acaso, um “imprevisto calculado” proposto pelo próprio exercício.

8. Cf. VAN ASSCHE, Christine apud LEWALLEN, Constance. (Org.). A Rose Has No Teeth: Bruce Nauman in the 1960s. Berkeley: University of California Press, 2007, p. 111.
9. No original, "there was nothing in the studio because I didn't have much money for materials, so I was forced to examine myself, and what I was doing there". Cf. KRAYNAK, Janet (Ed.). Op. cit., p. 119. 
Bouncing in the Corner, n. 1, 1968, vídeo, 60 min.

Bouncing Two Balls between the Floor and the Ceiling with Changing Rhythms, 1967-1968, filme $16 \mathrm{~mm}, 10 \mathrm{~min}$.
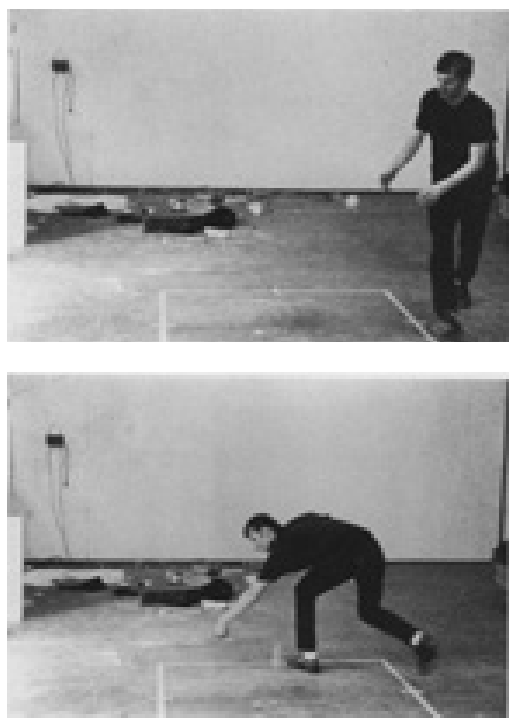

Nesses primeiros filmes e vídeos tão primordial quanto o corpo de Nauman era seu ateliê, espaço que frequentava diariamente. Mantendo uma atitude investigativa diante da arte, o ateliê do artista assumiu um papel fundante na obra: "não havia nada no ateliê porque eu não tinha muito dinheiro para os materiais, então fui forçado a examinar a mim mesmo e o que eu estava fazendo ali”, , relatou em 1970. Livre das limitações dos materiais convencionais, seu meio foi "desmaterializado" e se tornou processo e prática. Aliás, o corpo do artista no ateliê é a composição mais fiel de seu autorretrato, seja nas imagens mencionados, seja em trabalhos como Failing to Levitate in the Studio [Fracassando em levitar no ateliê], fotografia com dupla exposição, de $1966^{10}$.

\begin{abstract}
10. Analisando a foto, Jeff Wall, no ensaio "Sinais de indiferença: aspectos da fotografia na arte conceitual ou como arte conceitual", aponta que ela promove um desdobramento do que caracterizou como "fotografia de reportagem", revelando a problemática da imagem encenada (da pose) nas performances para a câmera, cujo tema principal era o jogo egocêntrico e auto-reflexivo que ocorria no ateliê do artista que trabalhava fora dos limites dos meios tradicionais. Desse modo,
\end{abstract}

tais fotografias documentariam gestos artísticos concebidos previamente, ações ou acontecimentos de ateliê, que haviam deixado de ser completamente regidos por normas para serem reinventados como teatro, fábrica, sala de leitura, lugar de encontro, galeria, museu. [Cf. WALL, Jeff. Señales de indiferencia: aspectos de la fotografia en el arte conceptual o como arte conceptual. In: PICAZO, Glória \& RIBALTA, Jorge (Eds.). Indiferencia y singularidad. Barcelona: Ed. Gustavo Gilli, 2003]. 
De modo geral, constata-se que esses primeiros filmes e vídeos estabelecem relações entre a intensidade de cada ação ou de cada inação prolongada e a fadiga surgida da persistência ou da circularidade de uma postura ou de uma atuação, isto é, uma relação tensa entre duração e repetição. Os trabalhos postulam experiências complexas de apreensão do tempo e graus diferentes de percepção de seu decurso, assim como permitem ao artista demonstrar como o espaço pode ser mobilizado tanto para indicar e medir como para simbolizar um tempo não homogêneo.

Reservatórios de um tempo distendido, a duração parece interminável, mas as ações têm um desenrolar preciso. No mais das vezes, são elaboradas para propulsar ritmos incessantes que, embora sujeitos às variações de cadência, não são levados a termo, revogando-se assim uma lógica narrativa que implicaria em culminação e conclusão; não há síntese, portanto. De fato, Nauman parece concordar que qualquer duração representa uma composição no tempo, uma compilação de instantes que, no caso desses trabalhos, corresponderia diretamente à extenuação física provocada pelas repetições e, sobretudo, ao esgotamento das possibilidades de uma ideia - de quantas maneiras, por exemplo, seria possível tocar uma

Failing to Levitate in the Studio, 1966, fotografia com dupla exposição, $51 \times 61 \mathrm{~cm}$.

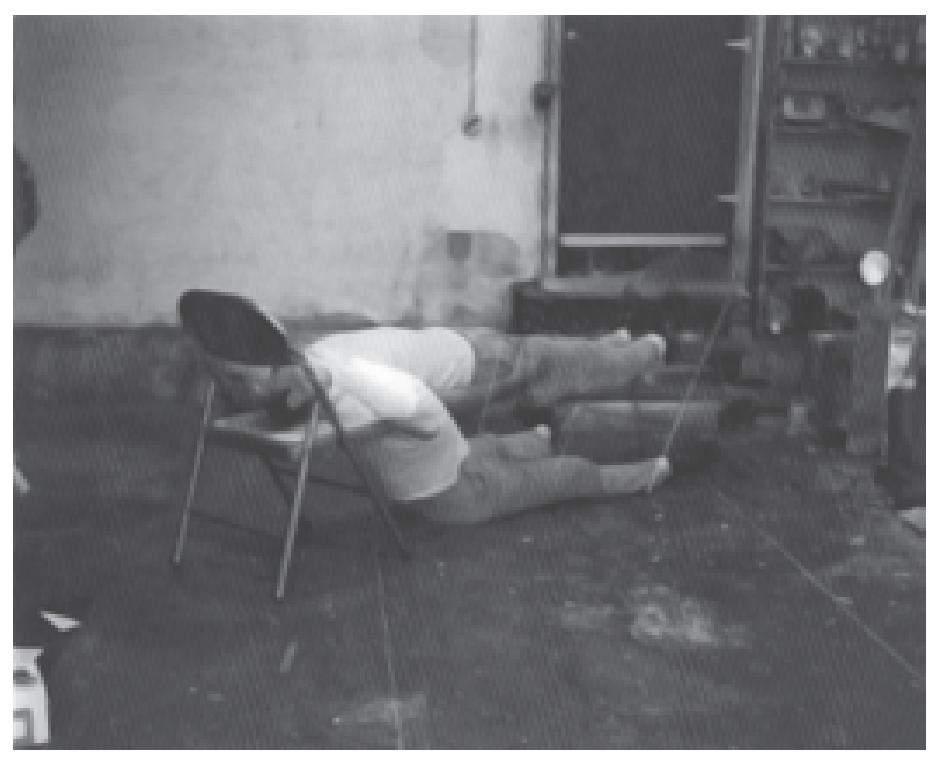



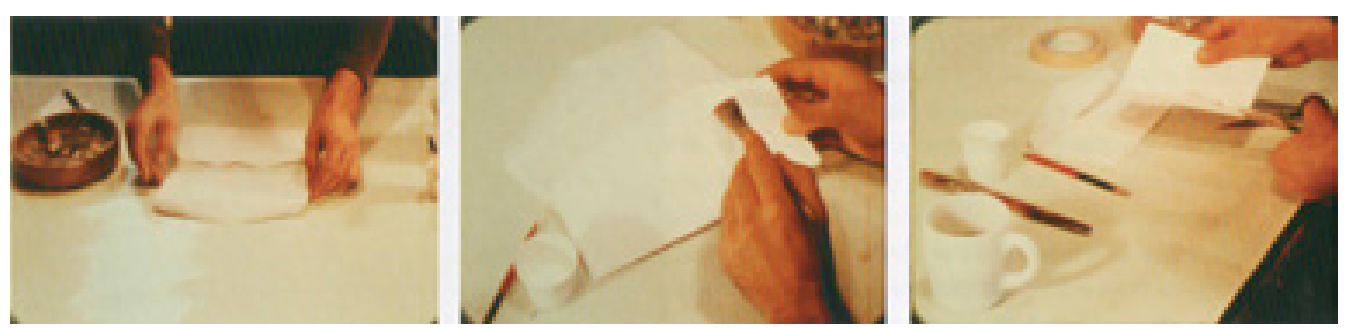

Legal Size, 1966, filme $16 \mathrm{~mm}, 3 \mathrm{~min} .47 \mathrm{seg}$.

nota musical em um instrumento num dado espaço ou caminhar e dançar ao longo de um perímetro ou bater alternadamente duas bolas entre o chão e o teto? ${ }^{21}$. Obviamente o que está em jogo aqui é um procedimento por absurdo, já que não se esgota o inesgotável, as possibilidades de uma ideia.

Deve-se considerar também que Nauman estava testando as possibilidades técnicas de equipamentos que, à época, implicavam tecnologias novas. Nos primeiros vídeos, possivelmente inspirados em Sleep [Sono (1963)], de Andy Warhol - uma tomada de 8 horas de duração, na qual se registra um homem dormindo - a duração correspondia justamente à que demandava a atividade exercida diante da câmera, como o tempo gasto para confeccionar um envelope de papel e fita adesiva em Legal Size [Tamanho lícito, 1966, 3 min. 47 seg.]. Os filmes posteriores envolveram poucas interferências, basicamente o que se alterava era o posicionamento da câmera. Todas as atividades mencionadas, por mais fatigantes que fossem, eram executadas continuamente pelo tempo de duração de cada filmagem, sem looping.

11. CF. MORGAN, Robert. Bruce Nauman: An Introductory Survey. In: (Ed.). Bruce Nauman. Baltimore: The Johns Hopkins University Press, 2002, p. 12. 

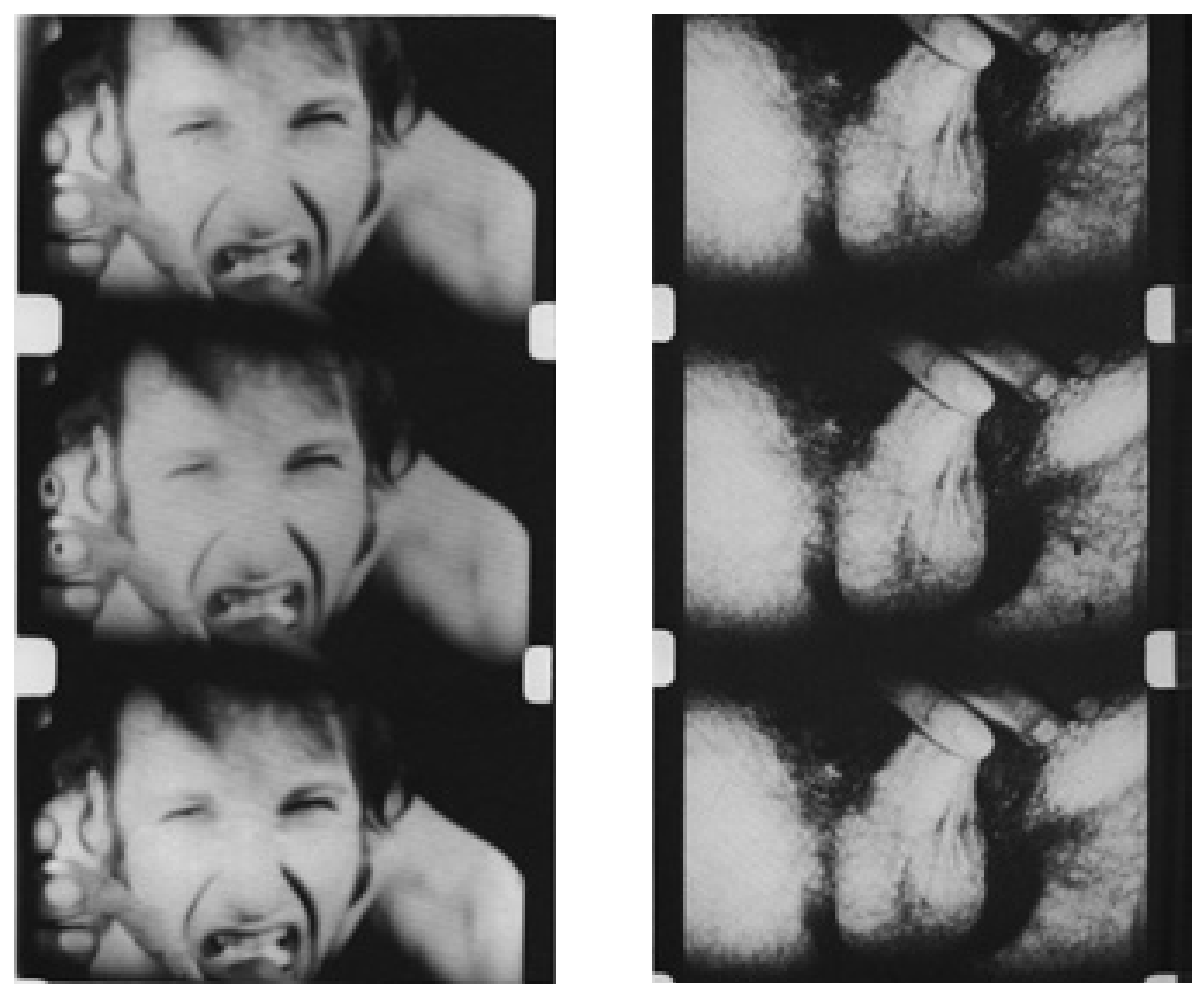

Gauze, 1969, filme $16 \mathrm{~mm}, 8 \mathrm{~min}$

Bouncing Balls, 1969, filme $16 \mathrm{~mm}, 9 \mathrm{~min}$.

Em 1969, Nauman realizou uma série de quatro filmes em preto e branco, silenciosos, com enquadramento em superclose e com o uso da câmera lenta. Desse modo, pouco se nota a movimentação dos quadros que mostram o artista colocando uma grande quantidade de gaze na boca em Gauze [Gaze, 8 min.] ou estirando as bochechas com os dedos em Pulling Mouth [Puxando a boca, $8 \mathrm{~min}$.], assim como demora um pouco para se atinar que em Black Balls [Bolas pretas, 8 min.] e Bouncing Balls [Batendo bolas, 9 min.] são focalizados os testículos do artista, ou recobertos com tinta preta ou lentamente chacoalhados. Nada mais pessoal do que isso e, no entanto, nada mais indiferente. Afinal, o corpo é aqui apenas uma matéria bruta passível de manipulação: a cavidade da boca é preenchida por tecido até que as bochechas se deformem ou a pele do pescoço é puxada num demorado beliscão. Nauman espreme, torce, estica, balança e pinta porções de sua pele, como se estivesse verificando a plasticidade de um material qualquer. 

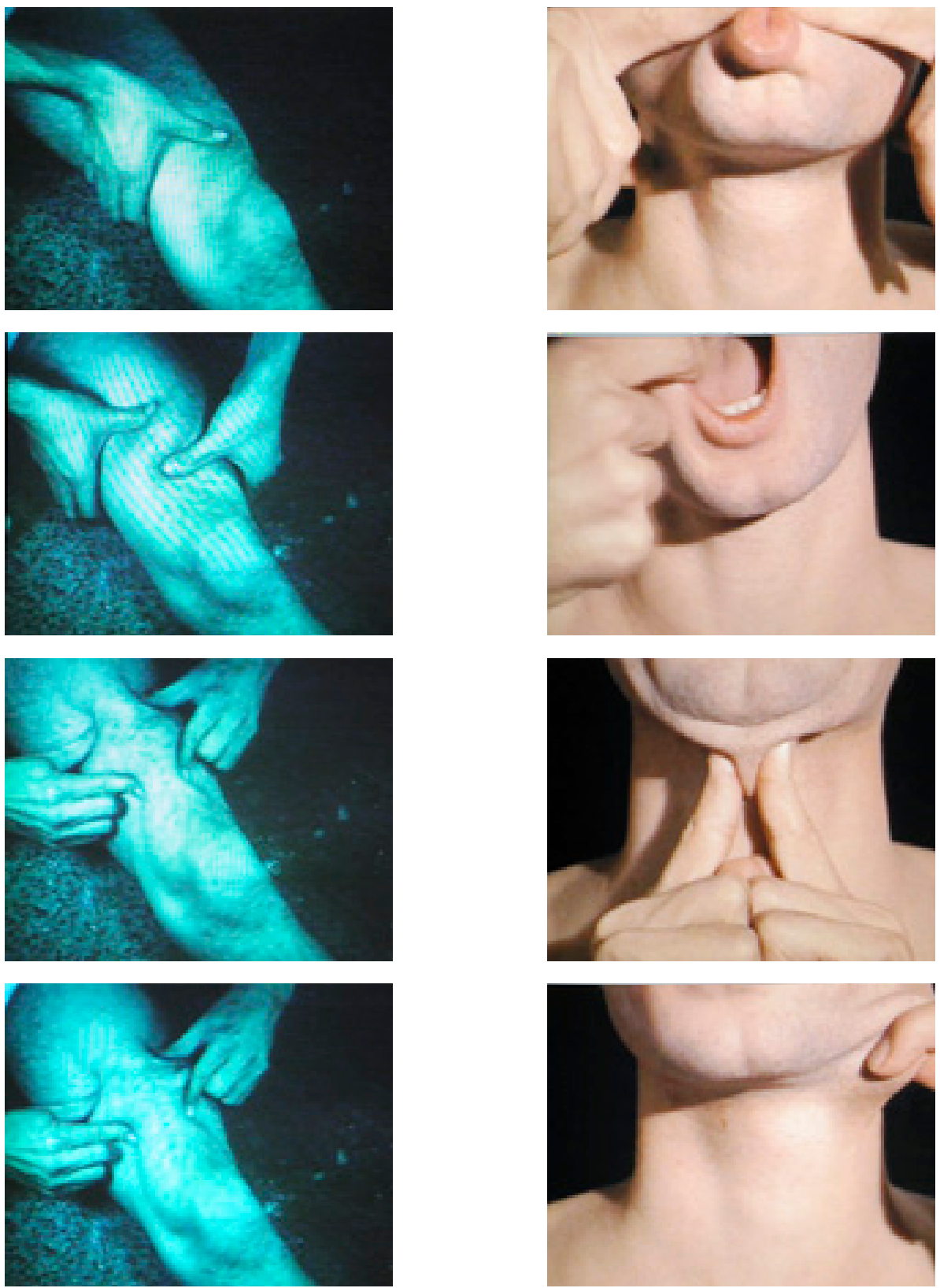

Thighing, 1967, filme $16 \mathrm{~mm}, 8 \mathrm{~min}$ Pulling Mouth, 1969, filme 16 mm, 8 min. 


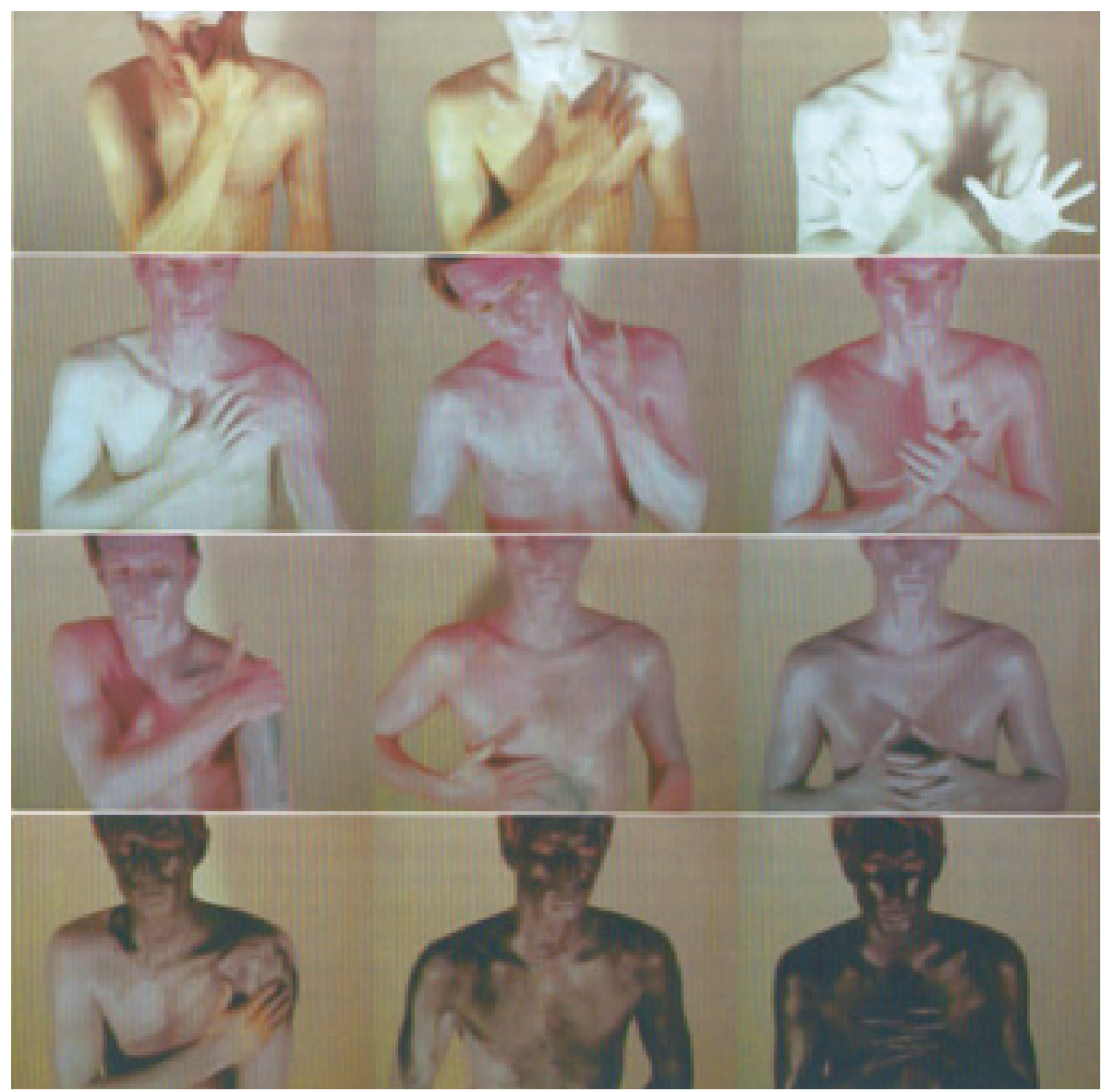

Art Make-Up, 1967, filme 16 mm em quatro partes [n 1, White; $n^{\circ} 2$, Pink; $n^{\circ} 3$, Green; $n^{\circ}$ 4, Black], 10 min cada.

Já se mencionou que Nauman procedia, a um só tempo, um exame de si mesmo e uma generalização além de si, estabelecendo um ponto de transição entre interioridade e exterioridade. E, para tanto, a contenção era o procedimento adotado, e os gestos calculadamente drenados de aspectos comportamentais ou de qualquer possibilidade de catarse. Nesse sentido, a observação de Jean-Charles Masséra:

Entre fins de 1960 e início de 1970, os trabalhos de Nauman pareciam marcados por uma das últimas utopias modernas: a construção de um sujeito liberto das determinações psicológicas, sociais e históricas. Concebendo um sujeito fora "do som e da fúria", no espaço abstrato do ateliê ou do cubo branco; exibindo um corpo neutro, transhistórico. 
O espaço simbólico e a dimensão histórica da experiência estavam refreados. Desde 1980, as instalações de Nauman têm incorporado a dimensão histórica da experiência, particularmente através da insistência em certos processos de instrumentalização do corpo e da negação do sujeito ${ }^{12}$.

Uma preocupação que perpassa a obra é a quantidade de informação a ser mostrada ou velada em cada trabalho: "quanta informação pode ser subtraída de uma situação de modo que ela ainda seja efetiva"13. Nauman não apenas emprega o corpo como matéria-prima mas, por vezes, cobre-se com tinta, mascarando-se literal ou metaforicamente, como se pretendesse um apagamento ou ocultação do "eu" sob as camadas de maquiagem: "maquiagem não é necessariamente anônima mas é distorcida de alguma forma, é algo escondido por trás. É não dar o bastante, não expor o bastante. A tensão na obra é frequentemente sobre isso" ${ }^{14}$. Veja-se, por exemplo, Art Make-up [Maquiagem/composição de arte (1967)], uma sequência de quatro filmes nos quais o artista pinta a face, o torso, os braços e as mãos sobrepondo camadas de tinta colorida branca, rosa, verde e preta, respectivamente em $n$. 1, White $\left[n^{\circ} 1\right.$, Branco, 10 min.]; $n^{\circ}$ 2, Pink [n॰2, Rosa, 10 min.]; $n^{\circ} 3$, Green [n॰3, Verde, 10 min.]; $n^{\circ} 4$, Black [ $n^{\circ} 4$, Preto, 10 min.]. Ao final, Nauman está como que apagado pelas tintas, sem as evidências de um corpo expressivo.

12. "In the late 1960s and early 1970s, Bruce Nauman's works seemed to be marked by one of the last modern utopias: that of constructing a subject cut free from all psychological, social, and historical determinisms. Conceiving a subject outside the 'sound and fury', in the abstract space of the studio or the white cube; exhibiting a neutral, transhistorical body. The symbolic space and the historical dimension of experience were repressed. Since the early 1980s, Nauman's installations have incorporated a historical dimension of experience, particularly through their insistence on certain process of the body's instrumentalization and the subject's negation". Cf. MASSÉRA, Jean-Charles.
Dance with the Law. In: MORGAN, Robert C. (Ed.). Op. cit., p. 174.

13. "I got interested in how much information you could take away from a situation and still have it be effective". Cf. AUPING, Michael. Metacommunicator. In: NAUMAN, Bruce. Raw Materials. Londres: Tate Publishing, 2004, p. 11. 14. "Make-Up is not necessarily anonymous but it's distorted in some way, it's something hide behind. it's not quite giving, not quite exposing. The tension in the work is often about that". Cf. BRUGGEN, Coosje van. Bruce Nauman. Nova York: Rizzoli International Publications, 1988, p. 196. 


\subsection{Restrição, confinamento, controle: procedimentos de contenção}

1. Vamos falar sobre controle.

2. Nós estávamos falando sobre controle.

3. Nós estamos falando sobre controle.

Bruce Nauman, Cones Cojones, $1974^{15}$.

A partir das análises desses primeiros filmes e vídeos de Nauman, depreende-se que o corpo ali comparece de modo peculiar: nem um corpo totalmente livre tampouco domesticado pelas exigências de funcionalidade. Trata-se de um corpo que se lança em atividades insólitas e que nelas e com elas perde tempo. Mas também se trata de um repertório de atividades que exige um desempenho preciso, uma extrema concentração e considerável motricidade e treinamento: o corpo está sempre tensionado, pronto para disparar o próximo movimento, que se encadeia numa série usualmente extensa e desgastante pelo esforço de repetição requerido, como se estivesse preso em um momento distendido e perpetuado para o qual não há desenlace.

Nessa safra de filmes e vídeos, há um em especial, Walk with Contrapposto [Caminhada com contraposto (1968), 60 min.], em que Nauman enfatiza uma questão recorrente nas primeiras esculturas, a equivalência e a comutação das superfícies, sejam elas interiores ou exteriores, sejam as peles ou os revestimentos de materiais inertes. A Caminhada com contraposto também antecipa um conjunto de procedimentos que eventualmente se desdobrariam em outro trabalho fundante, Performance Corridor [Corredor performance (1969)], o primeiro dos muitos corredores ${ }^{16}$.

15. "1. Let's talk about control. 2. We were talking about control. 3. We are talking about control". 0 texto na íntegra e a tradução encontram-se no Apêndice desta tese.

16. Os demais corredores empregam câmeras de vídeo em circuito e não serão analisados nesta tese pois as questões que desdobram fogem do escopo das hipóteses formuladas; para citar alguns deles: Live Taped Video Corridor [Corredor de vídeo filmado ao vivo (1970)], Going Around the Corner Piece [Peça da virada da esquina (1970)], Video Surveillance Piece: Public Room, Private Room [Peça de monitoramento por vídeo: sala pública, sala privada (1969-1970)]. 
Walk with Contrapposto, 1968, vídeo, 60 min

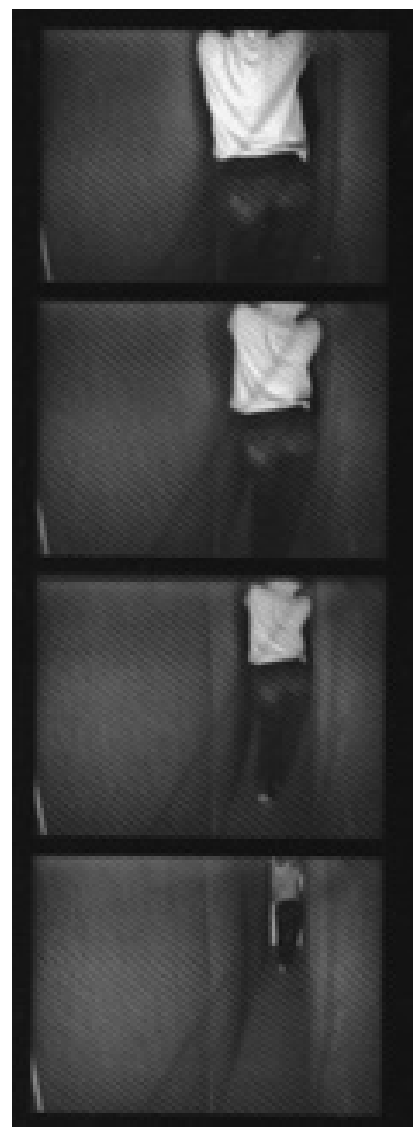

Um corpo flagrado de costas por uma câmera colocada no alto se distancia lentamente da superfície da tela. Mãos cruzadas atrás da cabeça, uma torção vigorosa dos quadris desloca o peso para uma das pernas e os ombros para o lado oposto, a outra perna é levemente flexionada e então se lança na próxima passada, e assim alternadamente. A imagem da cabeça aparece cortada um pouco acima do pescoço. Aos poucos, os ombros roçam as laterais, os movimentos se tornam mais penosos, a musculatura se retesa e o equilíbrio é mantido com considerável dificuldade. No limiar entre ação e repouso, um caminhar arrastado. Nesse escoramento do corpo, percebese que o espaço percorrido se estreita em direção ao fundo. Conforme o tempo passa, mais se reconhecem nos gestos de forte carga expressiva as posturas distorcidas da escultura clássica e renascentista, o contraposto do título, um recurso cuja função é a de simular uma movimentação na superfície estática do material, como para lhe insuflar vida. 
Nesse vídeo, o ateliê, que antes parecia francamente se abrir para a câmera, ganha uma nova configuração. $\mathrm{O}$ corpo de Nauman não mais vasculha a amplidão do espaço, mas uma fenda construída ali dentro e cujas grandezas correspondem às medidas de seu corpo, esgueirando-se entre paredes que se afastam, deixando livres cerca de 50 centímetros, numa largura ajustada a seus ombros e quadris. Nauman cria um dispositivo de restrição e de compressão para o corpo ao erguer-lhe barreiras. Ao dificultar o desempenho, as paredes são incorporadas à coreografia, e o roçar dos quadris nas superfícies realça as torções. Num certo sentido, o artista dá corpo ao perímetro do quadrado outrora riscado no chão, sobre o qual caminhava de maneira exagerada ${ }^{17}$.

Em meio à experiência reguladora que se dá entre o corpo e as paredes, o corpo é constrangido a atinar com os limites ao mesmo tempo em que os demarca e confronta. Encerrado em um espaço forjado para si, o corpo comporta-se de modo ambíguo, tal como se encontrasse abrigo e repouso contra as superfícies que o envolvem tanto quanto o refreiam e obstruem; superfícies que se definem na negação mesma do movimento.

No deslizar moroso contra as laterais, o corpo de Nauman parece investido de uma potência erótica ativada no contato das superfícies, tal como se vê no vídeo em que uma lâmpada fluorescente é manipulada contra o corpo o artista. Não se trata de forjar um substitutivo sexual, mas de uma espécie de "erotismo de contato" entre dois materiais convertidos em pura externalidade. A ideia é reforçada em Body Pressure [Pressão corporal (1974)], um texto prescritivo para uma performance mental que se encerra com a seguinte observação: "isto pode tornar-se um exercício muito erótico" ${ }^{18}$.

17. Faz-se referência aqui a Walking in an Exaggerated Manner Around the Perimeter of a Square [Caminhando de maneira exagerada pelo perímetro de um quadrado (1967-1968)], filme já abordado.
18. "This may become a very erotic exercise". Para o texto e a tradução, consulte-se o Apêndice. 
O conjunto de instruções prevê modos de pressionar com veemência o corpo contra uma parede: "pressione tanto da superfície frontal de seu corpo (palmas para a frente ou para trás, bochecha esquerda ou direita) contra a parede quanto for possível; pressione com muita força e se concentre". Mas também exige um esforço mental do executante que deve exercitar a imaginação a partir dos seguintes comandos: "forme uma imagem de si mesmo (suponha que você tivesse acabado de dar um passo a frente) no outro lado da parede empurrando contra a parede as costas com muita força; pressione com muita força e se concentre na imagem pressionando arduamente". Deve-se então remover mentalmente a parede, "comece a ignorar ou bloquear a espessura da parede (remova a parede)". Por fim, são convocadas as instâncias físicas da experiência: "concentre-se na tensão nos músculos, na dor onde os ossos se encontram, deformações da carne que ocorrem sob pressão; considere os pelos do corpo, suores,

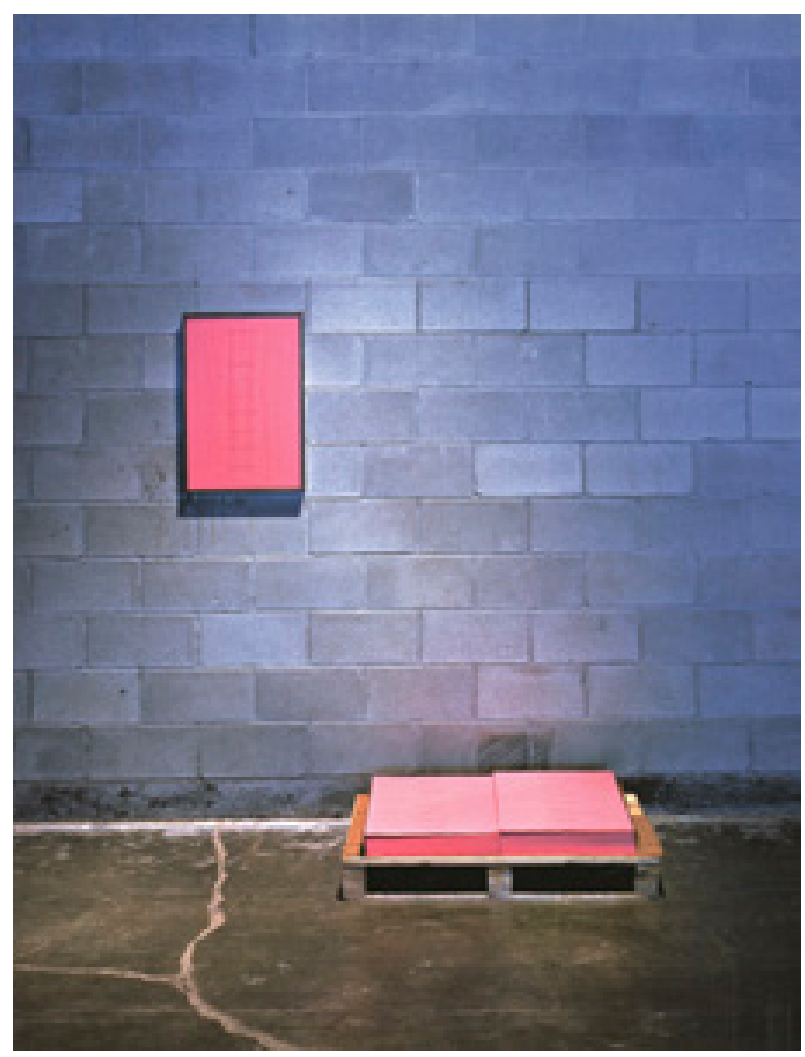


odores (cheiros) ${ }^{19}$. O texto termina com a advertência sobre o potencial erótico do exercício. Verifica-se que mesmo em uma performance mental que deveria ser, por definição, "incorpórea", há a preservação do orgânico na utilização de um vocabulário que ressalta aspectos fisiológicos. De todo modo, a construção do erotismo tal como se dá no texto é bastante peculiar na obra, pois, em geral, as referências à sexualidade vêm associadas à violência, conforme já se adiantou.

Além de Body Pressure, Nauman elaborou outras regras para "performances mentais", como Instructions for a Mental Exercise [Instruções para um exercício mental (1974)], texto que prevê exercícios de concentração e de utilização da visão periférica como métodos para afundar no chão ou para permitir que o chão se eleve em torno do corpo ${ }^{20}$.

As performances mentais se assemelham a diretivas para ações e, embora funcionem mais propriamente como proposições a serem imaginadas, não pretendem experiências de descompressão, conforme se poderia supor à primeira vista. Em vez disso, demandam exercícios disciplinadores, restritivos e que, por isso, soam tal qual testes de contenção e de autodomínio, confirmando a importância que Nauman atribuiu à ideia de controle e, sobretudo, de autocontrole. Veja-se, por exemplo, dois trechos de Notes and Projects [Notas e projetos (1970)], um conjunto de pequenos textos nos quais, entre outas coisas, são prescritos métodos para transformar o corpo em cilindro ou em esfera, como se de cada fibra muscular fosse exigida muita concentração para se alcançar um objeto geométrico o mais perfeito possível:

19. "Press as much of the front surface of your body (palms in or out, left or right cheek) against the wall as possible. Press very hard and concentrate [...] Form an image of yourself (suppose you had just stepped forward) on the opposite side of the wall pressing back against the wall very hard [...] begin to ignore or block the thickness of the wall Iremove the wall] [.. Concentrate on tension in the muscles, pain where bones meet, fleshy deformations that occur under pressure; consider body hair, perspiration, odors (smells)". Cf. Apêndice.

20. Essas instruções bem como os demais escritos de Nauman para exercícios mentais estão reunidos no Apêndice da tese. 
(A) Corpo como um cilindro

Deite-se junto à junção da parede com o chão de um recinto, com o rosto para o canto e as mãos ao lado. Concentre-se no endireitamento e na expansão do corpo ao longo de uma linha que passa pelo centro do corpo paralelamente ao canto do recinto em que você se encontra. Ao mesmo tempo tente trazer o corpo em direção ao entorno dessa linha. Em seguida tente empurrar essa linha em direção ao canto do recinto.

(B) Corpo como uma esfera

Enrole seu corpo no canto de um recinto. Imagine um ponto no centro de seu corpo enrolado e concentre-se em tracionar seu corpo em torno desse ponto. Em seguida tente pressionar esse ponto para baixo no canto do recinto. Deve-se esclarecer que não se intenciona que essas sejam posições estáticas a serem mantidas por uma hora por dia, mas atividades ou processos mentais e físicos a serem realizados. No início, o performer pode precisar repetir o exercício várias vezes a fim de preencher a hora, mas ao fim de cerca de dez dias, ele deverá ser capaz de estender a execução a uma hora inteira. O número de dias necessários para uma performance ininterrupta de uma hora depende, naturalmente, da receptividade e da preparação do performer ${ }^{21}$.

Nesses dois exemplos, a intensidade do esforço mental exigido combina-se à prática e à habilidade corporal do performer, preferencialmente um bailarino, no intuito de aproximar-se o mais possível da perfeição. Há sempre um grau de extenuação física e psíquica implicadas nos exercícios de Nauman, um esgotamento que não deve ser enfatizado e dramatizado, mas contido. O artista declarou que confiava mais em si mesmo na realização das performances do que em terceiros, e quando as instruções eram dadas a outros, deveriam ser as mais explícitas e exatas possíveis, "tornar a situação suficientemente específica, de modo que o performer/dançarino não pudesse interpretar muito a sua posição"22.

21. Consultar o original, em inglês, no Apêndice, onde consta a versão integral de Notes and Projects, publicada em 1970, na revista Artforum [vol. 9, n 4, dez. 1970, p. 44-45].
22. What I try to do is to make the situation sufficiently specific, so that the dancer can't interpret his position too much". Eis uma declaração de Nauman acerca das 
Justamente isso é o que ocorre quando dois atores profissionais são chamados a realizar as Instruções para um exercício mental, segundo se observa nos vídeos Tony Sinking into the Floor, Face Up and Face Down [Tony afundando no chão, de frente e de bruços (1973), 60 min.] e Elke Allowing the Floor to Rise Up over Her, Face Up [Elke permitindo que o chão se eleve ao redor dela, de frente (1973), 39 min.]. Em um estúdio profissional e com as cenas captadas em cores por duas câmeras, Tony tentou afundar no chão e Elke buscou permitir que o chão emergisse ao redor de seu corpo. Nauman, que acompanhou os exercícios sem aparecer nas filmagens, havia conversado separadamente com os dois atores e garantiu que as performances foram realizadas com o máximo empenho. No entanto, nem Tony nem Elke conseguiram executar as instruções mentais ininterruptamente: eles se mexeram, tossiram, tremeram e sentaramse. Em uma das pausas, Tony alegou: "fiz muito rapidamente e me assustei". Em outro momento, segundo o relato de Nauman, "ele ficou com medo de mover as mãos porque pensou que poderia perder moléculas" ${ }^{23}$. Elke, ao que parece, teve reações psicológicas ainda mais violentas, tanto que seu vídeo dura só 39 minutos. Acerca das performances, Nauman comentou "foi uma experiência incrivelmente emocional e intensa para todos nós, duvido que essa intensidade possa ser transmitida por meio do filme" ${ }^{24}$. De fato, os filmes dão a impressão de que Tony e, especialmente, Elke enfatizam demasiadamente as suas sensações, cumulando-as com um tipo de expressividade dramática que não se vê nos demais vídeos. Seja como for, Nauman acolheu o resultado e, posteriormente, salientou os efeitos emocionais provocados pelos exercícios. Esses são os únicos filmes da safra inicial não realizados pelo artista. A partir

performances, "eu sempre prefiro fazê-las eu mesmo, embora tenha dado instruções para outros de tempos em tempos. É um pouco mais difícil do que fazê-las eu mesmo; preciso dar instruções realmente explícitas, porque confio em mim como performer mais do que nos outros" ["I always prefer to do them myself, although l've given instructions to someone else from time do time. It's a bit more difficult that doing it myself; I have to make the instructions really explicit, because I trust myself as a performer more than I do others."]. Cf. KRAYNAK, Janet (Ed.). Op. cit., p. 115.

23. "I did it too fast and I scared myself" / "he was afraid of moving his hands because he thought he might lose molecules". Cf. Ibidem, p. 191.

24. "[..] it was an incredibly emotional and intense experience for all of us; I doubt if that intensity comes across on the tape". Cf. KRAYNAK, Janet (Ed.). Loc. cit. 

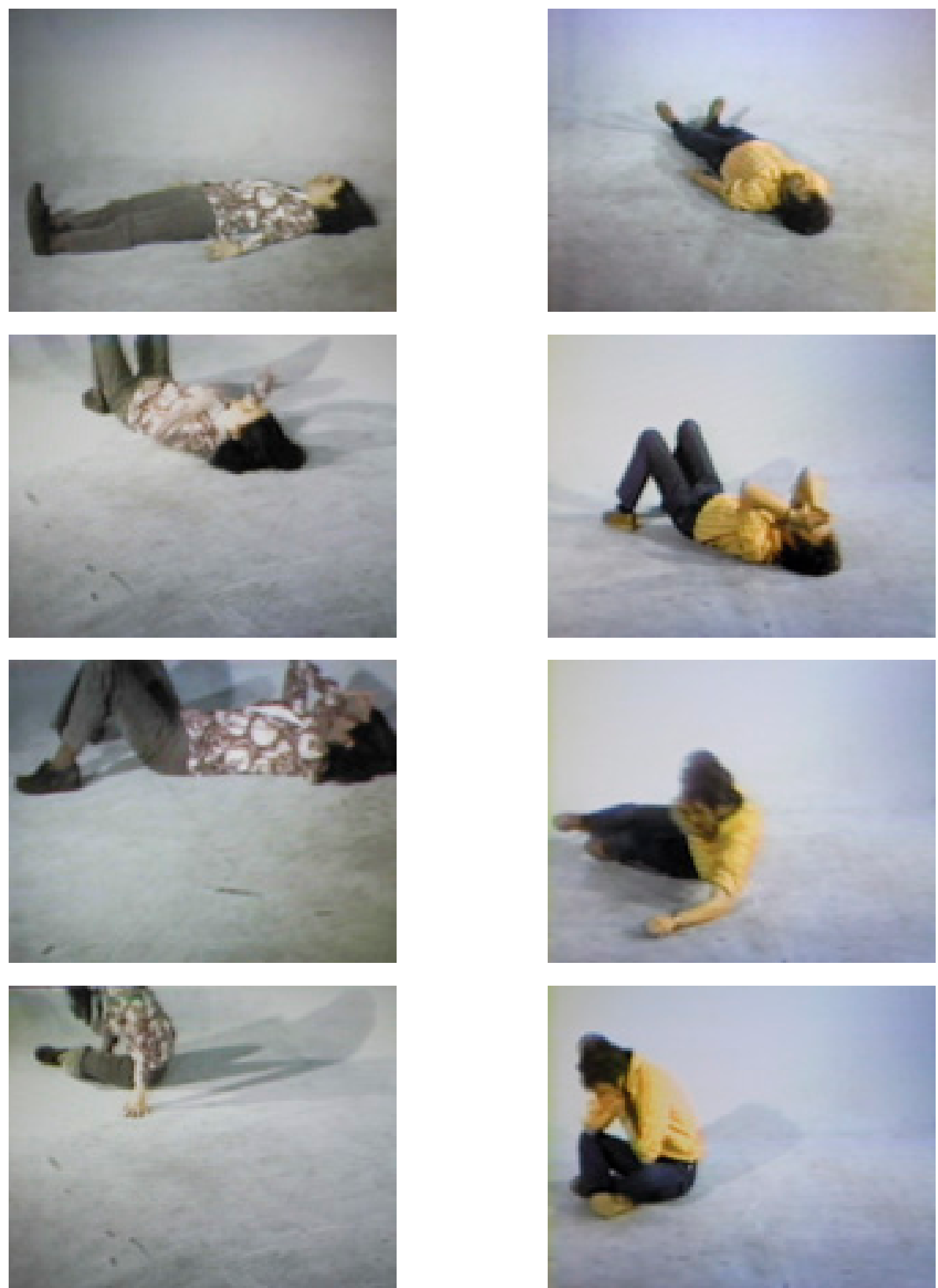

Elke Allowing the Floor to Rise Up over Her, Face Up, 1973, vídeo, 39 min. Tony Sinking into the Floor, Face Up and Face Down, 1973, vídeo, 60 min. 


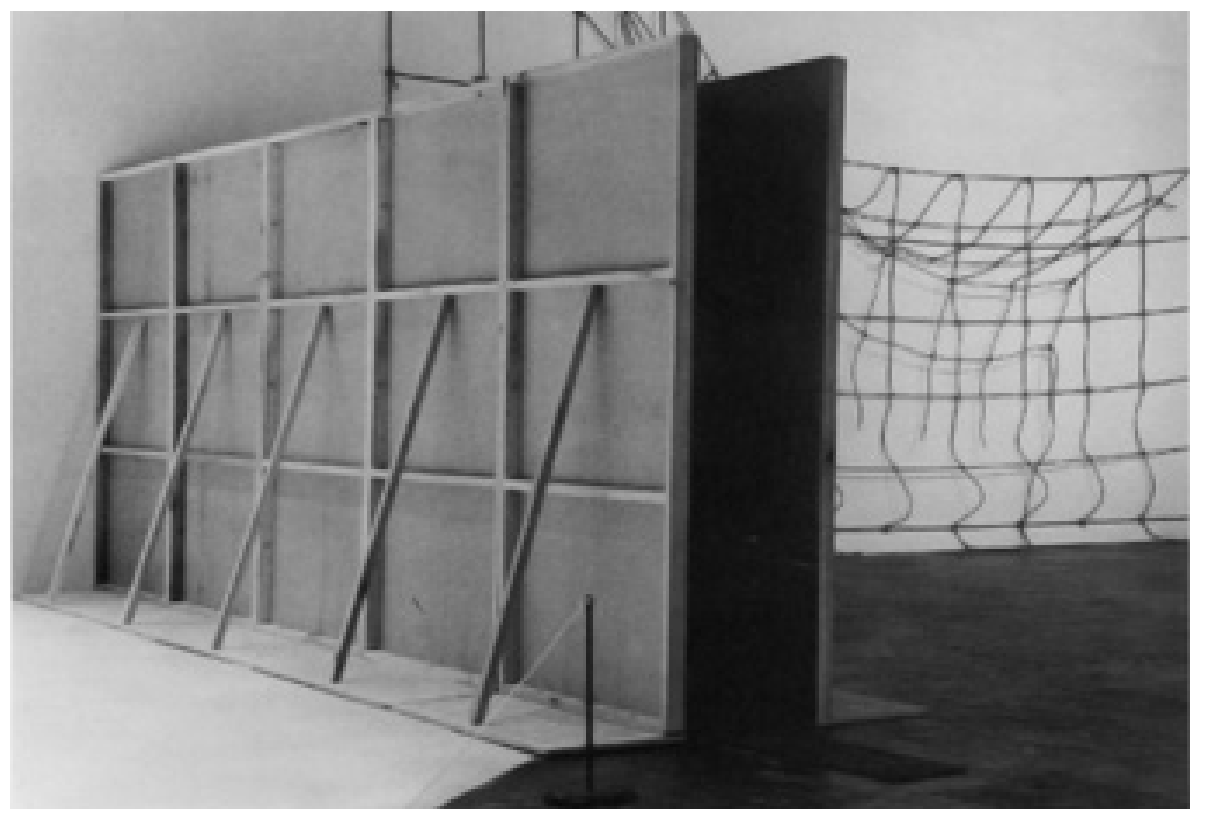

Performance Corridor, 1969, madeira e gesso, $244 \times 610 \times 51 \mathrm{~cm}$.

da década de 1980, ocorre o inverso disso: os atores aparecem nos trabalhos com mais frequência do que ele próprio.

Quanto ao vídeo Walk with Contrapposto, em 1969, a estrutura que formalizava o corredor - placas de gesso sustentadas por madeira - foi transferida para um museu, por ocasião da mostra "Anti-Illusion: Procedures/Materials", ocorrida no Whitney Museum of American Art. Fora do ateliê, o corredor passou a se chamar Performance Corridor [Corredor performance], como a demandar a participação de quem o observava. Não uma participação de qualquer natureza, mas uma performance cujas regras eram inferidas pelas dimensões da peça: uma abertura com os mesmos 50 centímetros correspondentes ao porte do artista. Um convite dirigido não ao público genericamente considerado, mas a um único indivíduo por vez. Nauman queria converter o corpo do outro em matéria a ser testada, tanto quanto, em condições análogas, isso ocorreu com o seu próprio corpo. 
Sobre o fato do Performance Corridor não vir expressamente acompanhado de instruções, Nauman afirmou que "não queria escrevê-las ou ter uma seta, por isso foi deixado em aberto. Esta peça é importante porque me deu a ideia de que poderia fazer uma peça participativa sem que os participantes fossem capazes de alterar o trabalho" 25 .

Nos trabalhos de Nauman, as propostas de participação são sempre dirigidas ou controladas: "eu desconfio da participação do público; por isso tento fazer os trabalhos o mais limitados possíveis" ${ }^{26}$, declarou em 1970. Temendo que os trabalhos fossem "palco" para que as pessoas fizessem suas próprias performances, Nauman criava mecanismos para regular a participação. Em 1988, voltou a afirmar acerca do Performance Corridor e dos trabalhos que solicitavam interação: "o problema foi encontrar um modo de restringir a situação para que as performances acabassem por ser aquelas que eu tinha em mente. De certa maneira, tratavam de controle" 27 . Nauman ou bem emprega seu próprio corpo ou então se torna "um diretor ou coreógrafo" por trás das cenas ${ }^{28}$.

Não apenas corredores, mas também formas "restritivas" internalizadas como os túneis são recorrentes no repertório de Bruce Nauman a partir da década de 1980: Smoke Rings, Models for Underground Tunnels [Anéis de fumaça, modelos para túneis subterrâneos (1979-1980)] e Three Dead End Adjacent Tunnels, Not Connected [Três túneis sem saída, adjacentes, não conectados (1981)] são dois desses trabalhos, ambos pensados para dimensões arquitetônicas, mas que permaneceram como maquetes ou modelos de túneis sem entrada ou saída. Esses modelos contam, geralmente, com versões em mais de um material, alguns em gesso, fibra de vidro e até em ferro.

25. "I didn't want to write it down, or have an arrow, so it was left open. This piece is important because it gave me the idea that you could make a participation piece without the participants being able to alter your work". Cf. Ibidem, p. 114.

26. "I mistrust audience participation; that's why I try to make these works as limiting as possible". Cf. Ibidem, p. 113.
27. "[..] the first corridor pieces were about having someone else do the performance. But the problem for me was to find a way to restrict the situation so that the performance turned out to be the one I had in mind. In a way, it was about control". Cf. Ibidem, p. 327.

28. Cf. CROSS, Susan. Bruce Nauman: Theaters of Experience. Nova York: D.A.P., 2003, p. 16. 

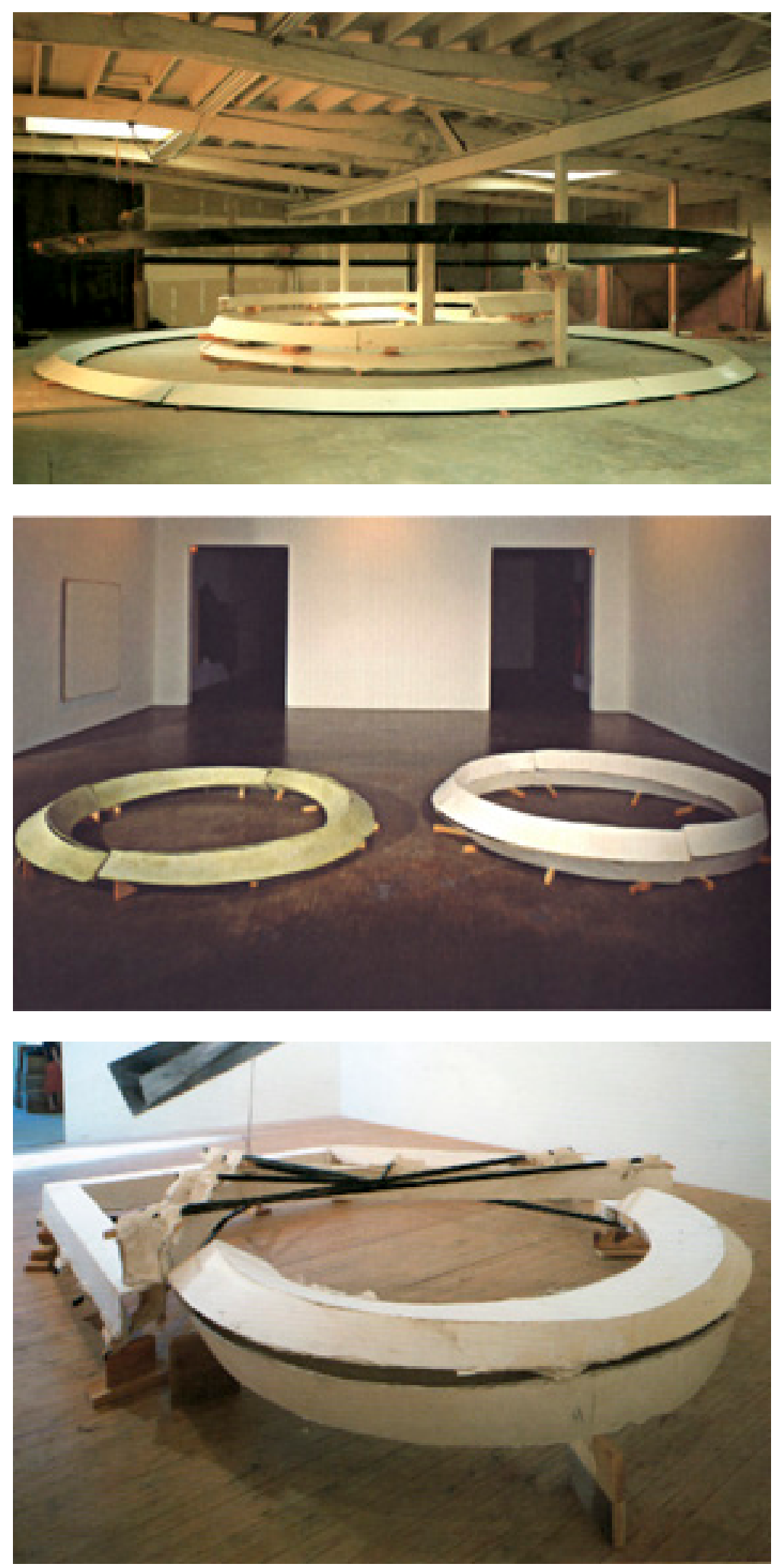
Model for Trench and Four Buried Passages, 1977, gesso e fibra de vidro, $\varnothing 165, \varnothing 487, \varnothing 915 \mathrm{~cm}$.

Smoke Rings, Models for Underground Tunnels, 1979-1980, gesso e madeira, $\varnothing 340 \mathrm{~cm}$.

Model for Tunnels: Half Square, Half Triangle, and Half Circle with Double False Perspective, 1981, gesso, aço, madeira e arame, $90 \times 475 \times 447 \mathrm{~cm}$.

Three Dead End Adjacent Tunnels, Not Connected, 1979, gesso e madeira, $63 \times 286 \times 247 \mathrm{~cm}$.

Three Dead End Adjacent Tunnels, Not Connected, 1981, aço, $63 \times 286 \times 247 \mathrm{~cm}$
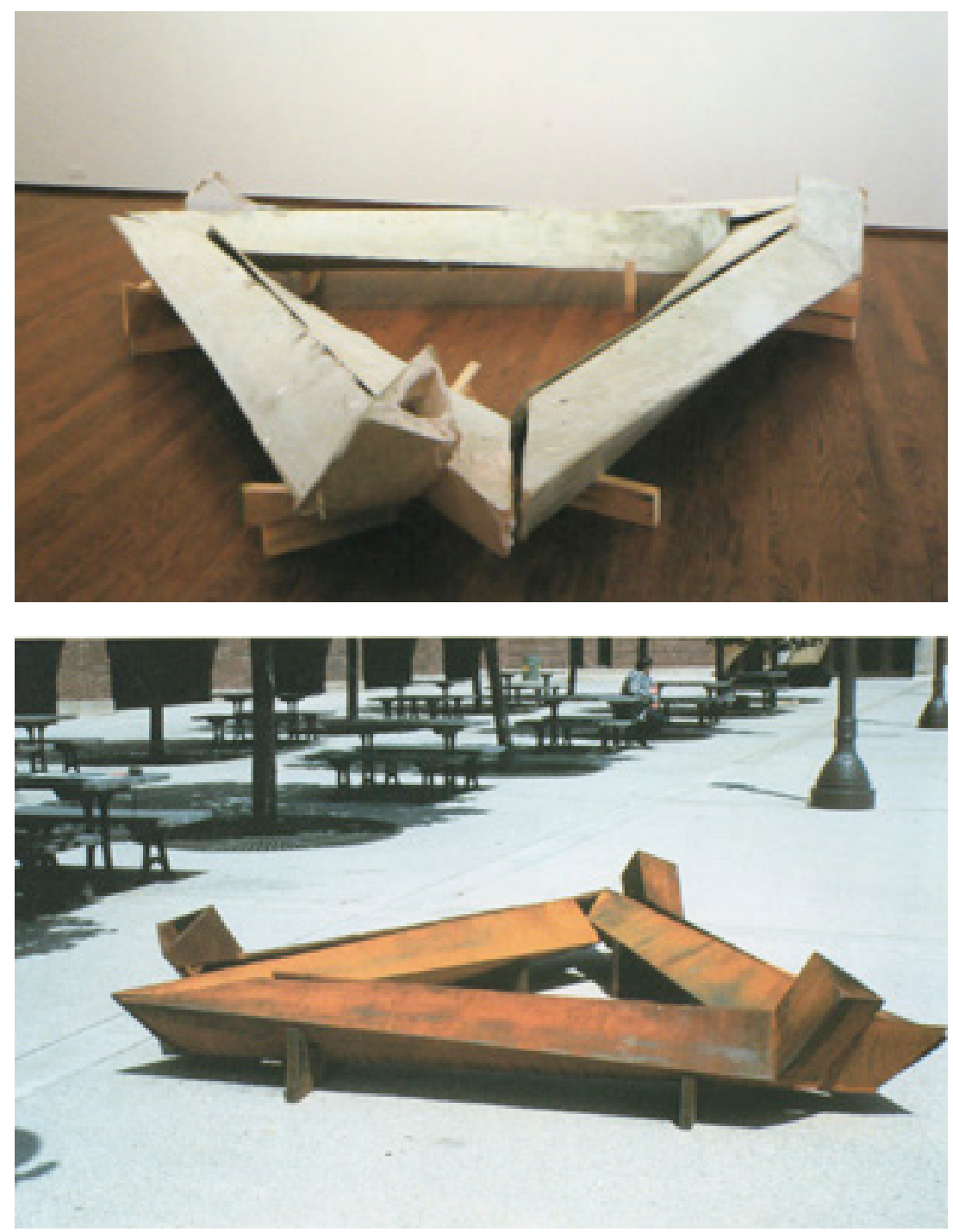
Trata-se de maquetes enormes que, por vezes, ocupam o espaço expositivo todo. Cada um dos modelos de túneis circulares da série Smoke Rings tem 3 metros e quarenta centímetros de diâmetro e comporta-se antes como escultura do que como maquete. Há outros modelos para intervenções subterrâneas ainda maiores, como Model for Trench and Four Buried Passages [Modelo para trincheira e quatro passagens enterradas (1977)], um conjunto de círculos concêntricos, fechados, com diâmetros que variam de 1,65 a 9,15 metros. A informação de que se trata de maquetes é dada pelo título ou pela descrição que indica a escala de 1:40. Nauman propõe, portanto, algumas inversões: a maquete assemelha-se a uma escultura na escala do corpo, entretanto deve-se imaginá-la quarenta vezes maior. Ao mesmo tempo em que foram pensadas como intervenções em escala urbana, não adicionariam elementos novos à paisagem uma vez que são maquetes de túneis ou bunkers, ou seja, construções subterrâneas. A respeito disso, Nauman afirmou:

Uma das coisas de que gostei sobre esta série de trabalhos é que os modelos existem sem qualquer vestígio daquela informação ou função no recinto que os estabelece como objetos escultóricos, com os quais se pode lidar muito diretamente. Mas quando se adiciona a informação de que ele é realmente um modelo para um grande trabalho ao ar livre, chega-se ao ponto de fornecer e retirar informações concomitantemente ${ }^{29}$.

O artista também declarou que esses túneis encerrados em si mesmos, sem escapatória, foram inspirados por um livro tardio de Samuel Beckett. Ao ler The Lost Ones [O despovoador/Le Dépeupleur, publicado em 1970, primeiro em francês, depois em inglês] percebeu "uma conexão poderosa com muitos trabalhos que fiz antes e que me encorajaram na

29. "One of the things that I liked about this series of works is that the models exist without any of that information and function in the room as object sculpture which can be dealt with very directly. But when you add on the information that it is really a model for a huge outdoor work, you get to the point of giving out information and taking it away at the same time". Cf. KRAYNAK, Janet (Ed.). Op. cit., p. 186. 
direção dos túneis e do tipo de comentário oblíquo que eles fazem sobre a sociedade" ${ }^{30}$. Nauman apontou que The Lost Ones "descreve um grande número de pessoas num espaço estranho, descrito com muita clareza e acurácia, onde elas estão presas. Uma luz amarelo-esverdeada, um espaço circular, apenas a escuridão e a luz esverdeada [sic] acima, e o andar em torno do círculo" ${ }^{31}$. Com efeito, a série de túneis se aparenta notavelmente com o ambiente confinado minuciosamente descrito por Beckett na obra. De fato, ambos propõem espaços de constrição aos quais os corpos, sem muitas alternativas, terminam por adaptar-se $\mathrm{s}^{32}$.

Odespovoadoréumpequenotextoemprosa,umdosúltimosescritos por Beckett, agrupado entre as chamadas "narrativas do encerramento" ${ }^{33}$, nas quais os corpos, ou os pedaços dos corpos, são representados parcialmente imóveis, truncados em recintos apertadíssimos, ocupados conforme normas estritas, instituídas para o controle minucioso do gestual dos personagens, geralmente em estado terminal.

No texto de Beckett, o narrador é movido pelo rigor e esforça-se em um escrutínio o mais objetivo possível dos fatos observados ${ }^{34}$. Duzentas

30. "...] when I read this, a very powerful connection to a lot of the work I had done before encouraged me in the direction of the tunnels and the kind of oblique comment they make on society". Cf. KRAYNAK, Janet (Ed.). Op. cit., p. 299.

31. "There is a Beckett book called The Lost Ones which describes a large number of people in a strange, very accurately and clearly described space, but they're stuck in it. A greenish yellow light, circular space with no top to it, just black and then greenish light and walking around and around in a circle". Cf. KRAYNAK, Janet (Ed.). Loc. cit.

32. Acerca disso, Steven Connor, comparando as produções de Nauman e Beckett, afirma que em ambas as obras a claustrofobia praticamente se converte em "claustrofilia" ["die Arbeiten vermitteln eher klaustrophile denn klaustrophobe Züge"]. Cf. CONNOR, Steven. Auf schwankendem Boden. In: GLASMEIER, Michael \& HOFFMANN,
Christine (Org.). Samuel Beckett/ Bruce Nauman. Viena: Kunsthalle, 2000, p. 84.

33. Este termo, cunhado pelos estudiosos da obra de Samuel Beckett, é empregado por Fábio de Souza Andrade no prefácio da edição brasileira de 0 despovoador (Cf. BECKETT, Samuel. 0 despovoador. Mal visto mal dito. Tradução de Eloísa Araújo Ribeiro. São Paulo: Martins Fontes, 2008, p. XXIII.

34. Nas palavras que o prefácio de Fábio de Souza Andrade toma emprestado de Gilles Deleuze: “O despovoador descreve as condições em que, presas em um cilindro, duzentas criaturas de uma humanidade quase irreconhecível, transfigurada pelo confinamento a um espaço revestido de borracha escura, submetem-se a estranhas regras de comportamento, esgotando, combinatória típica de Beckett, as possibilidades de existir e se relacionar". Cf. Ibidem, p. XXIII. 
criaturas compartilham um cilindro emborrachado, banhado por uma perene luz amarela, apresentando, conforme descreve o narrador, cerca de 50 metros de circunferência e 16 metros de altura, com temperatura variando entre 25 e 5 graus: "trata-se de um recinto onde corpos vão buscando cada um o seu despovoador. Amplo o bastante para permitir buscar em vão. Estreito o bastante para que qualquer fuga seja vã”35:

\begin{abstract}
Interior de um cilindro tendo cinquenta metros de circunferência e dezesseis de altura em nome da harmonia ou seja mais ou menos mil e duzentos metros quadrados de superfície total sendo oitocentos de parede. Sem contar os nichos e os túneis. Onipresença de uma fraca claridade amarela sacudida por um vaivém vertiginoso entre extremos que se tocam. Temperatura agitada por um tremor análogo porém de trinta a quarenta vezes mais lento que a faz cair rapidamente de um máximo da ordem de vinte e cinco graus a um mínimo na ordem de cinco daí uma variação regular de cinco graus por segundo. De quando em quando parada das duas vibrações tributárias sem dúvida do mesmo motor e retomada de ambos ao cabo de uma acalmia de duração variável podendo atingir uma dezena de segundos. Suspensão correspondente de qualquer movimento nos corpos em movimento e rigidez aumentada dos imóveis. Únicos objetos umas quinze escadas simples sendo várias de rodízios erguidas contra a parede em intervalos regulares. Na metade superior da parede sobre toda a sua circunferência dispostos em quincunce em nome da harmonia uns vinte nichos dos quais vários ligados entre si por túneis ${ }^{36}$.
\end{abstract}

Uma abordagem mais detalhada deste texto de Beckett será feita no capítulo que tratará do uso das palavras na obra de Nauman. Por ora,

35. Cf. Ibidem, p. 5. Nesta tese serão citados excertos da referida tradução brasileira, possivelmente vertida a partir do francês. Em inglês, todavia, a ideia de "despovoador" é um pouco diversa: "abode where lost bodies roam each searching for its lost one" ["local onde vagam corpos perdidos, cada qual buscando por seu perdido"]. Cf. BECKETT, Samuel. The Selected Works of Samuel Beckett [Vol. IV Poems Short Fiction Criticism]. Nova York: Grove Press, 2010, p. 381.

36. Cf. BECKETT, Samuel. Op. cit. [0 despovoador. Mal visto mal dito], p. 10. 
deve-se mencionar que a escala do cilindro emborrachado não se adequa confortavelmente ao corpo humano ou, pelo menos, as criaturas "algo" humanas que ali vivem não dispõem de espaço suficiente para mover-se sem que precisem roçar suas peles que, em função da incidência ininterrupta da luz amarela, tornam-se ressequidas e amareladas; "apergaminhamse”. Quando as superfícies entram em contato provocam sensações de aspereza, "os corpos se roçam com um ruído de folhas secas. As próprias mucosas sofrem com isso. Um beijo produz um som indescritível. Aqueles que ainda insistem em copular, não conseguem" ${ }^{37}$.

Todos dentro do cilindro seguem regras estritas. Em certos trechos, porém, irrompem pequenas advertências que quebram a estrutura e o ritmo descritivos, deixando pairar uma hesitação e, com ela, a tênue sugestão de que aquele estado de coisas poderá ser alterado caso algumas "noções e suas consequências" não sejam mantidas. Decerto que tudo se mantém inalterado. Mas disso nunca se pode ter garantias. Entre a repetição contínua e o colapso final, abre-se uma ínfima possibilidade de evasão, como se por ali bordejasse um "fantasma da revogabilidade", nas palavras de Fábio de Souza Andrade ${ }^{38}$. A expressão é também pertinente a muitos trabalhos de Nauman, conforme se comentará, uma vez que frequentemente elabora mecanismos repetitivos nos quais instila variações mínimas, que simulam - mas não cumprem - a promessa de ruptura dos esquemas dos ciclos de repetição.

37. Cf. Ibidem, p. 6.

38. Cf. Ibidem, p. XXV. Mais adiante, Fábio de Souza Andrade também afirma: "da mesma forma que a voz narrativa agrega, sorrateira contrabandista, elementos de desconfiança e perturbação à sua pretensa objetividade la começar das declaradas dimensões do espaço, comportando cifras de áreas incompatíveis em seções diversas do texto, passando pelas locuções adverbiais que sinalizam hesitação, como 'se tal noção for mantida'), ela introduz no espaço fechado um vetor histórico, um momento remoto, de origem, quando todos os corpos buscavam, irriquietos, uma possibilidade de evasão e um termo final entrópico, quando todos se imobilizarão, vencidos e desistentes". 


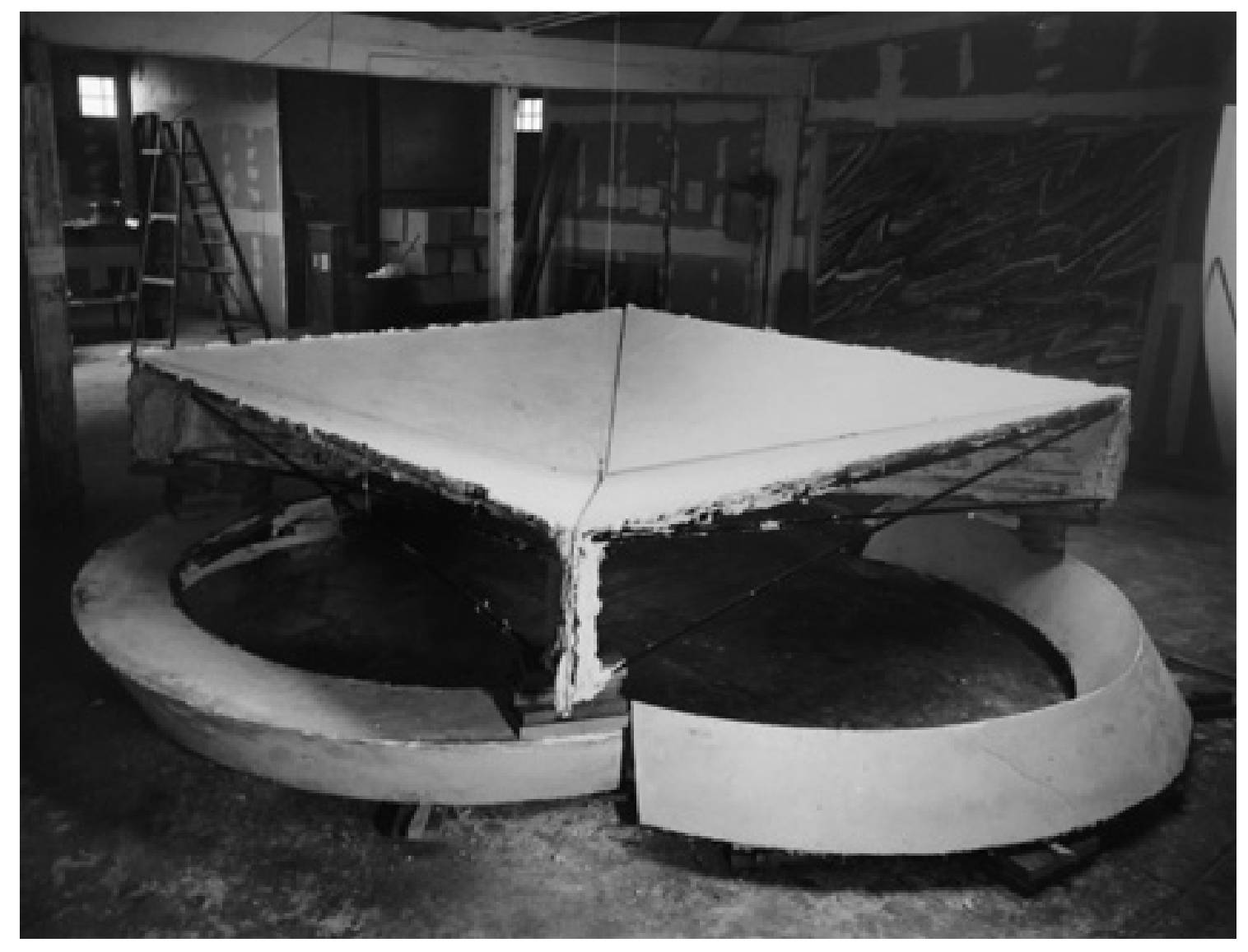

Studio Piece, 1978-79, gesso, aço, madeira e arame, $112 \times 427 \times 427 \mathrm{~cm}$. 
Gapítulo 3

Caminhada Beckett 
Aproveitei essa temporada para fazer um estoque de pedras de chupar. Eram seixos, mas eu, eu chamo isso de pedras. Sim, dessa vez, fiz uma reserva importante. Eu as distribuí com equidade entre os meus quatro bolsos e as chupava uma de cada vez. Isso me colocava um problema que primeiro resolvi da seguinte forma. Tinha digamos dezesseis pedras, donde quatro em cada um dos meus quatro bolsos, que eram os dois bolsos das minhas calças e os dois bolsos do meu casaco. Pegando uma pedra do bolso direito do meu casaco, e metendo-a na boca, eu a substituía no bolso direito do meu casaco por uma pedra do bolso direito das minhas calças, que substituía por uma pedra do bolso esquerdo das minhas calças, que substituía por uma pedra do bolso esquerdo do meu casaco, que substituía pela pedra que estava na minha boca, logo que tivesse terminado de chupá-la. Assim havia sempre quatro pedras em cada um dos quatro bolsos, mas nunca exatamente as mesmas pedras. E quando a vontade de chupar me tomava outra vez, puxava de novo do bolso direito do meu casaco, com a certeza de não tirar de lá a mesma pedra da última vez. E, ao chupá-la, rearrumava as outras pedras, como acabo de explicar. E assim por diante. Mas esta solução só me satisfazia pela metade. Pois não me escapava que podiam ser, por meio de um acaso extraordinário, sempre as mesmas quatro pedras que circulavam. E, neste caso, longe de chupar as dezesseis pedras, uma de cada vez, chupava na verdade apenas quatro, sempre as mesmas, uma de cada vez. Mas eu as misturava bem nos meus bolsos, antes de fazer a sucção, e ao fazê-la, antes de proceder às transferências, na esperança de generalizar a circulação das pedras, de bolso em bolso. Mas isso era apenas um paliativo com o qual não podia se contentar por muito tempo um homem como eu. Comecei então a procurar outra coisa. [...] Bom. Agora posso começar a chupar. Olhem bem para mim. Pego uma pedra do bolso direito do casaco, chupo-a, não a chupo mais, coloco-a no bolso esquerdo do meu casaco, o vazio (de pedras). Pego uma segunda pedra do bolso direito do casaco, chupo-a, coloco-a no bolso esquerdo do casaco. E assim por diante, até que o bolso direito do casaco esteja vazio e que as seis pedras que acabo de chupar, uma após a outra, estejam todas no bolso esquerdo do casaco. Parando então, e me concentrando, pois tratase de não fazer nenhuma besteira, transfiro para o bolso direito do casaco, onde não há mais pedras, as cinco pedras do bolso direito das calças, que substituo pelas cinco pedras do bolso esquerdo das calças, que substituo pelas seis pedras do bolsos esquerdo do casaco. Eis então que não há de novo mais pedras no bolso esquerdo do meu casaco, enquanto o bolso direito do meu casaco está de novo guarnecido, e da maneira certa, quer dizer, com pedras diferentes daquelas que acabo de chupar e que me ponho a chupar outra vez, uma após a outra, e a transferir gradativamente para o bolso esquerdo do meu casaco, tendo a certeza, tanto quanto se pode ter certeza com essa ordem de ideias, de que não chupo as mesmas pedras que ainda há pouco, mas outras [...]. Eaqui estou eu pronto para recomeçar. Devo continuar? Não, pois está claro que ao fim da próxima série de chupadas e transferências, a situação inicial se restabelecerá [...]. As minhas dezesseis pedras foram chupadas pela primeira vez numa sucessão impecável, sem que uma única tenha sido chupada duas vezes, sem que uma única tenha ficado sem chupar [...]. 
Slow Angle Walk (Beckett Walk), 1968, vídeo, 60 min.

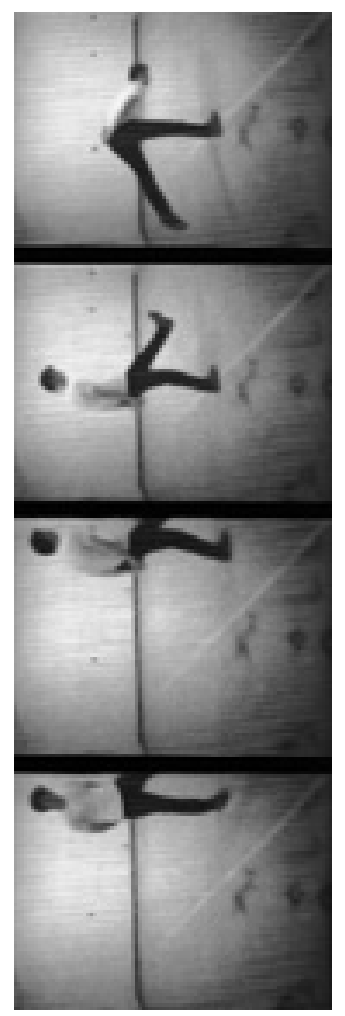

Dentre os filmes e vídeos captados no ateliê de Bruce Nauman, há um único que, diferentemente dos demais, traz em seu título não uma descrição objetiva da ação praticada pelo artista, mas uma espécie de pista qualificada para a sua própria decifração: Slow Angle Walk (Beckett Walk) [Caminhada angular lenta (Caminhada Beckett), 1968, 60 min.]. Tratase de um trabalho em que a câmera de vídeo está disposta de tal modo que, na cena registrada, o protagonista parece caminhar não sobre o piso, mas pela parede. Desempenhando um esforço descomunal, Nauman "anda" vagarosamente por essa parede de maneira bizarra, examinando as minúcias daquela superfície enquanto tenta, a muito custo, manter o equilíbrio numa sequência de passos complicados tanto na execução física quanto nos cálculos mentais que os definem e sustentam. 
Primeiro, lança uma das pernas esticada e a paralisa no ar, torce seu tronco em uma meia volta antes de calcar no chão o pé que acabara de erguer; inicia então o próximo passo lançando a outra perna esticada para paralisá-la no ar, torcendo depois o tronco antes de cravá-la e recomeçar a rotina, mantida por intermináveis sessenta minutos. Sem dúvida, um exercício intrincado que requer perícia e concentração, pois ao mesmo tempo em que alarga a trajetória expandido-a para as bordas, Nauman aplica uma tensão extrema às passadas para se conservar no eixo, exigindo que todo o corpo reverbere a pressão dos pés contra o solo. Seguindo pormenorizadamente esse padrão autoimposto de gestos, Nauman avança em ritmo refreado, sem culminação ou desfecho.

Surge, nessa toada, um contrassenso: o caminhante se movimenta muito para efetivamente deslocar-se pouco. Tal disparate confirma-se nos traçados de Beckett Walk Diagram II [Diagrama Caminhada Beckett II (1968-1969)], um estudo desenhado a lápis que detalha graficamente as passadas normatizando uma sucessão de segmentos a serem percorridos e a maneira exata de fazê-lo. Há uma inscrição no canto superior esquerdo do desenho em que se lê: "perna direita balança e pisa/perna esquerda gira em torno do eixo e/passo/primeiro/oscile para direita 3 vezes/depois para esquerda 3 vezes/repita”2 Observa-se no esboço que as convenções espaciais são revolvidas para que o menor esforço da linearidade seja abolido. De um ponto ao outro não se segue uma reta, ao revés, percorrese o espaço em angulações sucessivas que terminam por formalizar um complicado circuito em lugar de uma simples linha.

A propósito disso, na imagem do vídeo, vê-se uma linha branca atravessando o ateliê de fora a fora, uma marcação que parece estar ali para servir de contraste e enfatizar o absurdo da rotina cumprida impassivelmente pelo artista. Nauman golpeia o ar, verga o tronco, repisa 


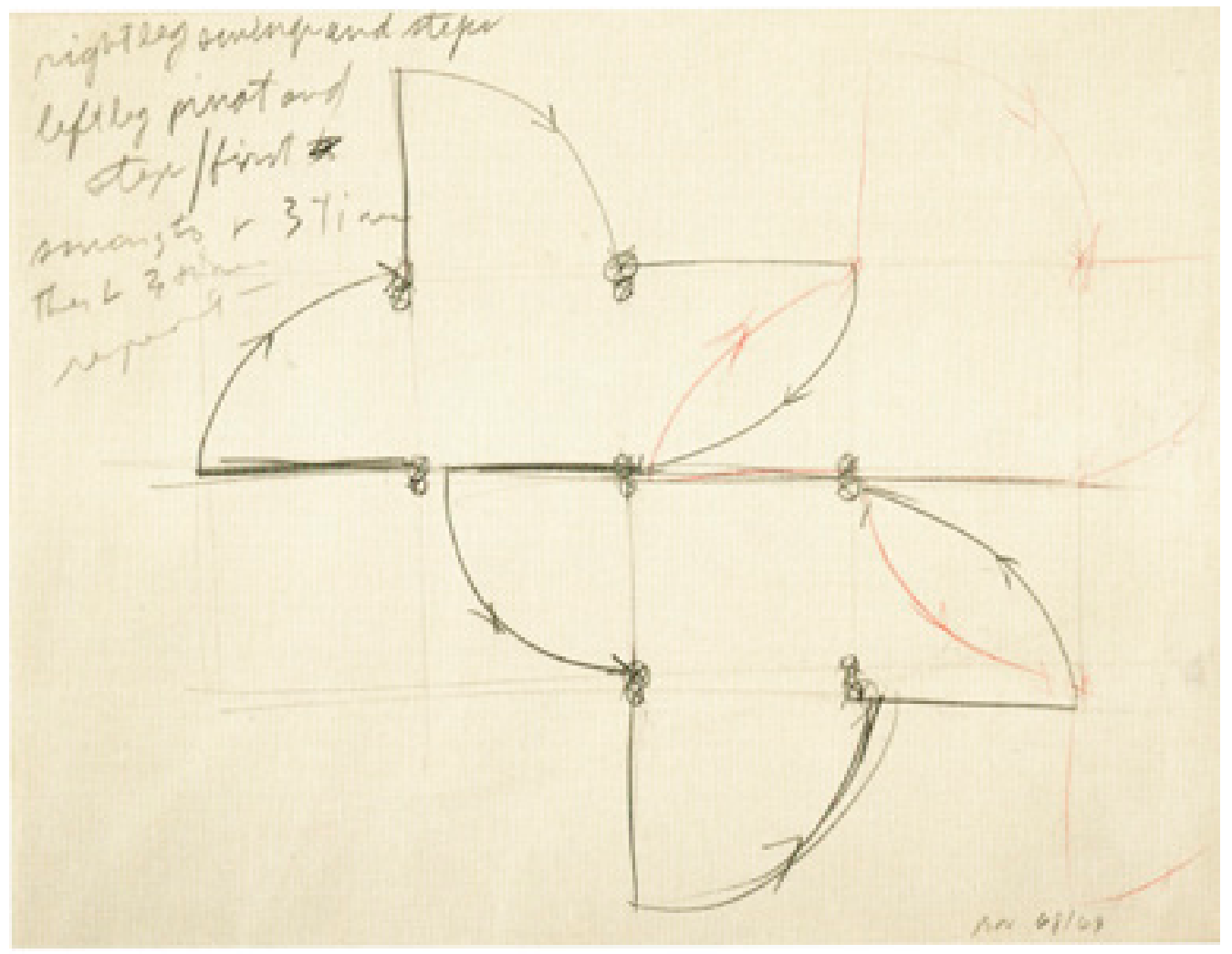

Beckett Walk Diagram II, 1968-69,

grafite e lápis de cor sobre papel, 21 × $27 \mathrm{~cm}$.

Film with Sound: 1. Stamping, 2. Beckett Walk? 1968-69, grafite e lápis de cor sobre papel, $28 \times 21,6 \mathrm{~cm}$
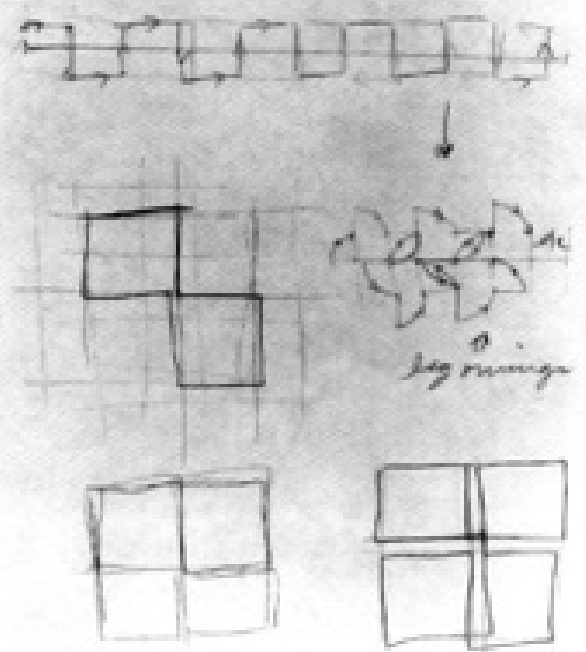

wor 
o solo com veemência, equilibrando-se no chão que parece se desfazer para continuamente se refazer sob seus pés, de sorte que tudo se passa como se aquele lugar só fosse trazido à existência em virtude da ação do artista no espaço. E assim, a duras penas, o conjunto de gestos conquista certa plasticidade pela resiliência da disciplina corporal que exige que os músculos se tonifiquem e se estirem na propulsão incessante de um mesmo movimento, e também pela resiliência de toda a energia psíquica que se adivinha necessária para alimentar a cadência extenuante.

O título anuncia tratar-se, afinal, de uma caminhada Beckett. Numa entrevista concedida em 1972, dez anos antes da citada declaração sobre $O$ despovoador, Nauman confirmou que o vídeo da caminhada faz alusão a passagens descritivas dos livros de Samuel Beckett, escritor de quem já era leitor assíduo desde 1966. Ao mesmo tempo, ressaltou que seu interesse principal era o de fazer vídeos contínuos, sem início ou fim e que sustentassem a tensão da espera por algum acontecimento ${ }^{3}$. Referiu-se ainda à pertinácia com que Molloy, personagem do livro homônimo de Beckett publicado em 1951, transfere meticulosamente pelos bolsos de seu casaco suas dezesseis pedrinhas de chupar, num ritual detalhado no decorrer de algumas páginas ${ }^{4}$. Quando o complicado sistema de mover pedrinhas chupadas de bolso em bolso atinge o fim do ciclo, Molloy vê-se impelido a recomeçar. Trata-se de um programa rigorosamente pautado por um método estrito, sem qualquer finalidade que não a do cumprimento do imperativo de prossegui-lo na ordem determinada pelo personagem.

3. "My problem was to make tapes that go on and on, with no beginning or end. I wanted the tension of waiting for something to happen, and then you should get drawn into the rhythm of the thing". Cf. SCHAFFNER, Ingrid. Bruce Nauman through Samuel Beckett. In: MORGAN, Robert C. (Ed.). Bruce Nauman. Baltimore: The Johns Hopkins University Press, 2002, p. 167.
4. "There's a passage in Beckett's Molloy about transferring stones from one place to another, the pockets of an overcoat, without them getting mixed up. It's elaborate without any point". Cf. SCHAFFNER, Ingrid. Loc. cit. 
O procedimento da repetição pautado por um método obstinadamente cumprido pelos personagens é reincidente na obra de Beckett. Há um termo da teoria musical possivelmente adequado para descrever essa operação: "ostinato", uma figura melódica ou rítmica repetida persistentemente ao longo de toda uma composição, com variações mínimas. Repetir obstinadamente um tema à exaustão é, antes de mais nada, forjar para o transcurso do tempo uma cadência muito particular, o que, no caso de alguns personagens de Beckett, implica regular o metrônomo para medir um tempo que parece escoar a esmo, mas que, no entanto, é o estritamente necessário para a execução correta do método.

Assistindo à caminhada de Nauman um leitor de Beckett poderia se lembrar do andar extravagante de Watt, personagem do romance homônimo publicado em 1953, considerado, no rol das narrativas circulares do escritor, a obra máxima das seriações e combinatórias ${ }^{5}$. Sem dobrar seus joelhos, Watt segue em linha reta exaurindo todo o espaço: depois de uma inclinação inaugural, uma pequena queda adiante, Watt vai em direção ao leste, girando o tronco em direção ao norte e jogando a perna direita em direção ao sul e, em seguida, o tronco em direção ao sul e a perna esquerda ao norte, e assim sucessivamente:

5. Em Watt, os personagens principais, Watt e Mr. Knott, conduzem seus pensamentos e ações segundo lógicas precisas de combinação e recombinação de alguns poucos elementos. Vejam-se, por exemplo, alguns excertos: "mas era no seu quarto, embora por vezes intentasse sair dele pelo armário suspenso, que $\mathrm{Mr}$. Knott parecia menos estranho, e aparecia mais favorecido. Era aí que se tinha de pé. Que ficava sentado. Que ficava ajoelhado. Que ficava deitado. Era aí que andava de cá para lá, da porta para a janela, da janela para a porta; da janela para a porta, da porta para a janela; da lareira para a cama, da cama para a lareira; da cama para a lareira, da lareira para a cama; da porta para lareira, da lareira para a porta; da lareira para a porta, da porta para lareira; [...]". E assim sucessivamente. Mais adiante: "este quarto estava mobiliado com mobília sólida e de bom gosto. Essa mobília sólida e de bom gosto era sujeita por Mr. Knott a frequentes mudanças de posição, tanto absolutas como relativas. Assim, não era raro encontrar, no domingo, a cômoda de pé junto à lareira, e o toucador de pés para cima junto à cama, e a cadeira do penico de borco junto à porta, e o lavatório de costas junto à janela, e na segundafeira, a cômoda de costas junto à cama, e o toucador de borco junto à porta, e a cadeira do penico de costas junto à janela, e o lavatório de pé junto à lareira; e, na terça-feira, a cômoda de borco junto à lareira, e o toucador de costas junto à janela, e a cadeira do penico de pé junto à lareira, e o lavatório de pés para cima junto à cama [...]". Uma movimentação que se prolonga por semanas, cuidadosamente descrita nas páginas de Watt. Cf. BECKETT, Samuel. Watt. Lisboa: Assírio \& Alvim, 2005, p. 235-239. 
A forma como Watt andava quando se dirigia para leste, por exemplo, consistia em virar o busto o máximo possível para norte, lançando simultaneamente a perna direita o máximo possível para sul e, depois, virar o busto o máximo possível para sul, lançando simultaneamente a perna esquerda o máximo possível para norte, e, depois, de novo, virar o busto o máximo possível para norte, lançando a perna direita o máximo possível para sul e, depois, virar o busto o máximo possível para sul. Lançando a perna esquerda o máximo possível para norte, e por aí fora, sucessivamente, repetidamente, até chegar ao destino e poder sentar-se. Assim, apoiando-se primeiro numa perna, e, depois, na outra, seguia em frente, impetuoso tardígrado, em linha reta. Nessas ocasiões, os joelhos não se dobravam. Podiam dobrar, mas não dobravam. Não havia joelhos que dobrassem melhor do que os de Watt quando lhes dava para aí, os joelhos dele não tinham qualquer defeito, contra o que parecia. Mas, ao andar na rua, por motivo obscuro, não dobravam ${ }^{6}$.

Presa de seus hábitos, Watt converte uma ação simples num colossal mecanismo de drenagem e desperdício de tempo. Em um pequeno ensaio consagrado a Beckett, O esgotado, Gilles Deleuze comenta que o caminhar do personagem recobre todos os pontos cardeais, todas as direções possíveis, sendo, portanto, não apenas exaustivo mas esgotante, no sentido de que se dedica a esgotar todo o espaço:

Vê-se que essa maneira de andar é exaustiva, pois ela envolve todos os pontos cardeais, o quarto ponto sendo, evidentemente, a direção de onde se vem sem se afastar. Trata-se de cobrir todas as direções possíveis, indo, entretanto, em linha reta. Igualdade entre a reta e o plano, entre o plano e o volume. Essa consideração do espaço dá um novo sentido e um novo objeto ao esgotamento: esgotar todas as potencialidades de um espaço qualquer ${ }^{7}$. 
Ao nomear seu filme, Nauman não apenas demonstrou uma admirável percepção da lógica coreográfica de organização do movimento e do transcurso do tempo na obra de Beckett, como forjou um rastro a partir do qual podem-se divisar pontos de imbricação ou afinidades temáticas e formais entre a sua produção e a do escritor irlandês, a despeito da relativa especificidade dos domínios da literatura e das artes plásticas e da distância geracional entre eles. Já se esclareceu que não se trata de um esforço inédito de comparação entre as duas obras, cotejadas, por exemplo, na exposição intitulada "Samuel Beckett, Bruce Nauman", ocorrida em 2000, em Viena ${ }^{8}$.

Nesta pesquisa, na busca por pontos novos de articulação entre as produções, deparou-se com dois desenhos diagramáticos na mesma página de uma publicação alemã̃: o já mencionado Beckett Walk Diagram II (19681969) de Nauman e um pormenorizado estudo preparatório para Quad I + II (1981) de Beckett ${ }^{10}$. Logo se percebe que, nos dois casos, trata-se de rubricas, de diretivas minuciosas para ações. Ações que, conforme as legendas informam, implicam percorrer o espaço, esquadrinhá-lo conforme normas estritas: uma alternância de movimentos centrípetos e centrífugos no desenho de Nauman, e movimentos mais periféricos no de Beckett, ambos propondo

8. A mostra foi realizada entre 4 de fevereiro e 30 de abril de 2000 [Cf. GLASMEIER, Michael \& HOFFMANN, Christine (Org.). Samuel Beckett, Bruce Nauman. Viena: Kunsthalle, 2000]. Outro indício de que essa aproximação pode ser profícua encontra-se no catálogo referente à mostra especial dedicada à Beckett em comemoração dos trinta anos do Centre Pompidou, Paris [ALPHANT, Marianne \& LÉGER, Nathalie (Orgs.). Object Beckett. Paris: Centre Pompidou/ Imec Éditeur, 2007]. Há alguns artigos inteiros e, mais comumente, pequenos trechos em artigos mais amplos dedicados à comparação entre as obras de Bruce Nauman e de Samuel Beckett, parte deles reunidos na mencionada publicação que acompanhou a exposição “Samuel Beckett, Bruce Nauman”.
9. Trata-se de um livro que aproxima a obra de Beckett, especialmente a fase tardia, com os experimentos dos chamados "novos meios", como a videoarte e a videoperformance. Cf. LEMKE, Inga. Fernsehtheater: Videoperformance. Samuel Beckett und die Videokunst. In: Peter Seibert (Ed). Samuel Beckett und die Medien. Neue Perspektiven auf einen Medienkünstler des 20 Jahrhunderts. Bielefeld: Transkript, 2008.

10. Segundo se falará adiante, não há como, numa primeira visada, não associar o projeto de Beckett para Quad com Square Depression, um trabalho em escala ambiental executado por Bruce Nauman, em 2007, na cidade de Münster, Alemanha. 


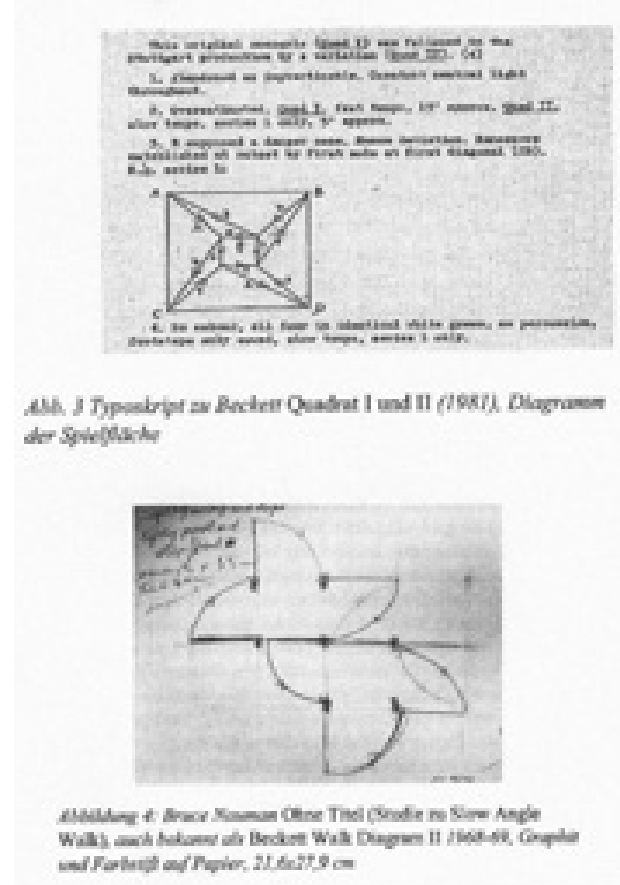

trajetos angulosos em vez de lineares. Os cálculos e as combinatórias são tão precisos como os de uma partitura e os traçados apurados chegam a sugerir uma métrica ${ }^{11}$, um controle extremado que evita o improviso.

Tanto Beckett quanto Nauman tentam evitar os imprevistos, primando pelo cálculo quer do êxito quer do fracasso das probabilidades. Entretanto, Nauman confessa aceitar que, em momentos inevitáveis, um acaso consentido ingresse nos trabalhos, conforme ocorre em vídeos como Bouncing Two Balls between the Floor and the Ceiling with Changing Rhythms [Quicando duas bolas entre o chão e o teto em ritmos variáveis (1967-1968)], sobre o qual se comentou. Há uma videoinstalação de 2001, Mapping the Studio I/ Fat Chance John Cage [Mapeando o ateliê I/Sem chances John Cage] que tematiza a ideia de acaso: o infravermelho de uma

11. Esclarece-se que, em música, métrica refere-se ao conjunto de metros - "organização das pulsações" em padrões constantes de acentuação - usadas numa composição por um compositor ou dentro de um estilo. 
câmera de vídeo captou, em sete posições diversas, tudo o que acontecia durante várias noites no ateliê de Nauman, em Galisteo, no estado norteamericano do Novo México. O local estava infestado por camundongos e são eles e um gato os personagens dos vídeos. Ao longe, ouvem-se uivos e outros ruídos incidentais. Nauman anotou minuciosamente todas as ações filmadas e editou algumas versões do trabalho. A mais conhecida fica permanentemente em exposição no Dia Art Foundation, em Beacon, e conta com sete grandes projeções simultâneas. Os comentários de Nauman sobre o trabalho estão reunidos em A Thousand Words [Mil palavras], texto que pode ser consultado no Apêndice desta tese.

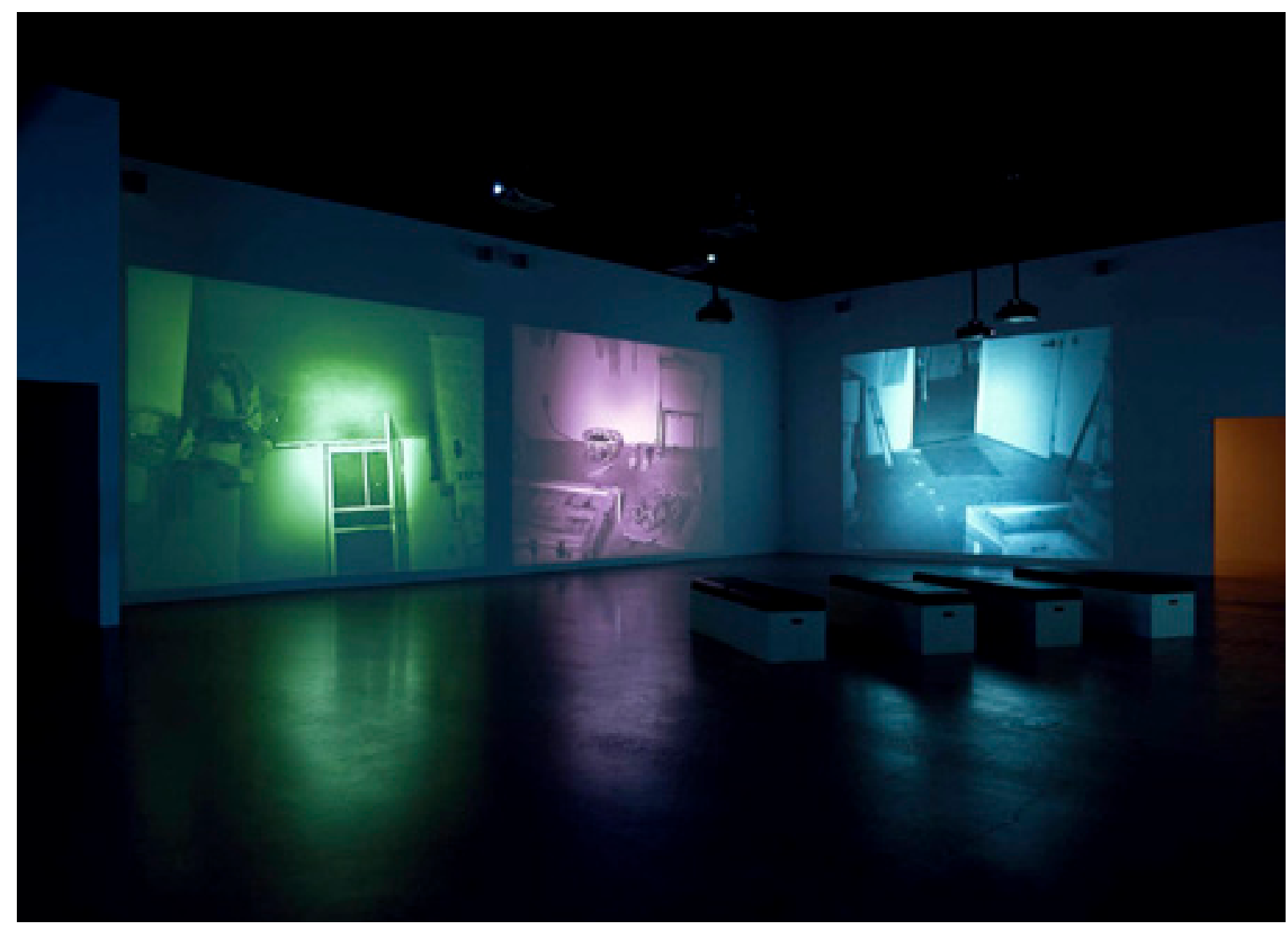


Beckett, por sua vez, revela-se mais inflexível em relação aos imprevistos e improvisos: é muito conhecida a sua obsessão pela reescrita dos textos e pelas rubricas acuradas, que destrincham não apenas o gestual do ator, a entonação da voz, as pausas, a movimentação no palco, mas também cada minúcia cenográfica. Só a título de exemplo, em uma das encenações de Fim de partida (primeira versão publicada em francês, em 1957) dirigida por ele próprio, Beckett dividiu a peça em dezesseis seções, para efeito dos ensaios, partes que demonstram com clareza a lógica musical que orientou a construção do texto, conforme aponta Fábio de Souza Andrade em seu estudo sobre o escritor ${ }^{12}$.

Conforme se supõe pelos procedimentos de que lançam mão, operações lógicas, estruturas matemáticas e exatidão musical interessam tanto a Nauman quanto a Beckett. Já se mencionou em capítulo precedente que Nauman estudou matemática e música durante o período passado na Universidade doWisconsin, Madison. Justifica-se seu interesse e habilidade na formalização de estruturas que remontam às combinatórias enumerativas e mesmo a profusão das figuras geométricas em seus trabalhos - o quadrado, o círculo e o triângulo são renitentes ao longo de toda produção. É notável que, em alguma medida, suas atividades artísticas impliquem formular "problemas sem solução": "estava interessado na lógica e na estrutura da matemática e, especialmente, em como virar essa lógica do avesso. Era fascinado por problemas matemáticos, particularmente um chamado "quadratura do círculo"”13. Trata-se de um problema clássico proposto por antigos geômetras gregos e dado como insolúvel pelo matemático Ferdinand Lindemann, em 1882. Grosso modo, o problema referia-se à possibilidade de se construir com régua e compasso um quadrado cuja área fosse

12. Cf. ANDRADE, Fábio de Souza. Samuel Beckett: o silêncio possivel. São Paulo: Ateliê Editorial, 2001, p. 80.
13. "I was interested in the logic and structure of math and especially how you could turn that logic inside out. I was fascinated by mathematical problems, particulary the one called "squaring the circle". Cf. KRAYNAK, Janet (Ed.). Op. cit., p. 323. 
rigorosamente igual à área de um dado círculo. Nauman comentou que o matemático só chegou à conclusão da impossibilidade definitiva de solução porque se posicionou fora do problema e não dentro dele ${ }^{14}$; a observação a partir de um ponto de vista externo é uma prática que Nauman afirma seguir em relação aos seus trabalhos ${ }^{15}$.

Voltando aos diagramas. Beckett concebeu Quad, também designada Quadrat, em 1981, para a veiculação na televisão ${ }^{16}$, uma peça julgada atípica mesmo quando comparada com outras obras incomuns do autor, que a considerava, aliás, uma "impossível aberração televisiva" 17.

Trata-se de uma peça para quatro atores, quatro instrumentos de percussão, quatro caminhos para se cruzar diagonalmente o cenário quadrangular ${ }^{18}$. Os atores são nomeados por números e estão cobertos por vestes coloridas que lhes vedam os corpos e as cabeças, impedindo, portanto, quaisquer recursos de expressão facial ou gestual. O personagem

14. Em termos gerais, Lindemann provou a transcendência de $п$ e, a partir disto, inferiu a impossibilidade de solucionar-se o problema da quadratura do círculo.

15. "His approach was to step outside the problem. Rather than struggling inside the problem, by stepping outside of it, he showed that it was not possible to do it at all". Cf. KRAYNAK, Janet (Ed.). Op. cit., p. 323.

16. Quad ou Quadrat foi filmada para a emissora de televisão alemã Sueddeutscher Rundfunk. Em 1997, a peça televisiva foi apresentada na “Documenta X”, em Kasel, na Alemanha. Comparando as produções de Bruce Nauman com as de Samuel Beckett, Kathryn Chiong adverte que na televisão as informações e as narrativas são fragmentadas ao passo que as interrupções são dramatizadas no intuito de incitar a expectativa da audiência, sendo que “essas descontinuidades velam o fato de que a televisão é precisamente o lugar do nãoevento, uma máquina do tempo disfarçada que opera sobre o tempo clássico". Em certo sentido, portanto, Beckett em Quad acentua tais características ao expor o seu não-evento prolongando-se sem as pausas habituais [Cf. CHIONG, Kathryn. Nauman's Beckett Walk. October 86, Cambridge/Massachusetts, 1998, p. 68-69].

17. BECKETT, Samuel apud HERREN, Graley. Samuel Beckett's Plays on Film and Television. Nova York: Palgrave Macmillian, 2007, p. 123. Para uma análise mais aprofundada de Quad 1+Il e de sua relação com demais trabalhos da última fase da produção de Samuel Beckett, consultar além dessa obra de Graley Herren e do mencionado ensaio de Gilles Deleuze, o livro de Erik Tonning, Samuel Beckett's Abstract Drama: Works for Stage and Screen/1962-1985 [Berna: Peter Lang, 2007, p. 240- 243; 270-273]. 18. “A piece for four players, light and percussion", segundo a descrição de Beckett. A rubrica de Quad detalha a coreografia e traz os diagramas demonstrativos dos movimentos. Cf. BECKETT, Samuel. Quad. In: . The Selected Works of Samuel Beckett [Vol. III Dramatic Works]. Nova York: Grove Press, 2010, p. 475-478. 
Samuel Beckett, Quad I, 1981 curta-metragem para televisão, 15 min.
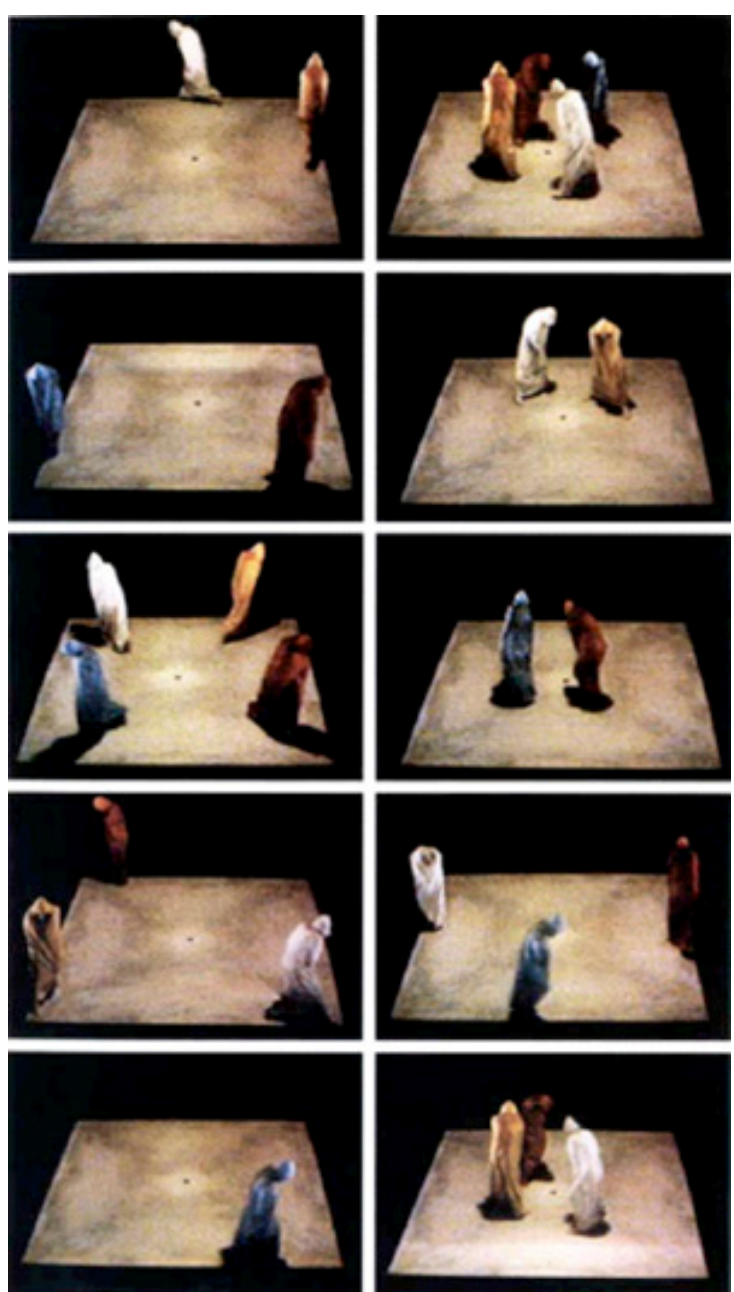

The players $(1,2,3,4)$ pace the given area, each following his particular course. Area: square, Length of side: 6 paces.
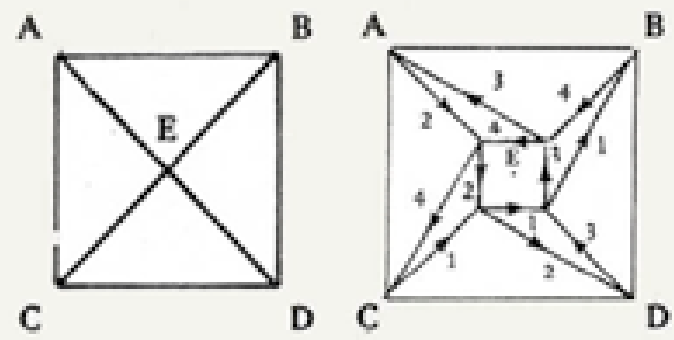

Course 1: AC, CB, BA, AD, DB, BC, CD, DA Course 2: BA, AD, DB, BC, CD, DA, AC, CB Course 3: CD, DA, AC, CB, BA, AD, DB, BC Course 4: DB, BC, CD, DA, AC, CB, BA, AD 
1 está vestido de branco; o 2, de amarelo; o 3, de azul; e o 4, de vermelho. Cada número caminha na batida de um instrumento de percussão (tambor, gongo, triângulo e blocos sonoros, respectivamente), em ritmo acelerado, atravessando em bissetriz vigorosamente o quadrado, cuidando para evitar o centro, tido como a "zona de perigo" [danger zone], segundo informa o estudo preparado por Beckett.

Quad tem início com a movimentação dos personagens branco e amarelo no quadrado iluminado. De súbito, o amarelo sai para a área enegrecida, enquanto o branco passa a realizar uma sequência preordenada de passos. Assim, cada cor entra em cena alternadamente por um dos cantos, vira à esquerda em cada canto subsequente, e cumpre o percurso prescrito sempre se esquivando da área central, até sair por uma das quinas e entrar na próxima, reiniciando a série. Verifica-se que cada série constrói progressivamente uma tensão cujo auge é pontuado pelas quatro percussões que acompanham os quatro personagens no palco, mas, ao mesmo tempo, o clímax é desmontado pela própria consecução da rotina. Passados cerca de quinze minutos, a imagem é abruptamente interrompida quando os quatro personagens estão na metade da quarta série, distanciando-se do centro.

Tudo se passa sem palavras, sem conflitos e, surpreendentemente, sem colisões. Note-se que os personagens irrompem o espaço limitado com certa velocidade e em momentos distintos, o que não afasta a hipótese de colisão. Beckett, porém, calculou não apenas as permutações entre os caminhos corretos, mas também previu possíveis erros, eliminados da caracterização final, rodada em $1981^{19}$. De fato, a coreografia é tão precisa e os atores tão ágeis que se resguardam dos encontrões com tanta eficácia quanto se esquivam da área de risco, o centro do quadrado. Aqui é pertinente falar em "coreografia”, segundo afirma Deleuze: 
Quad está próximo de um balé. As concordâncias gerais da obra de Beckett com o balé moderno são numerosas: o abandono do privilégio da estatura vertical; a aglutinação dos corpos para se manterem em pé; a substituição das extensões qualificadas por um espaço qualquer; a substituição de toda história ou narração por um "gestus" como lógica das posturas e posições; a busca de um minimalismo; a apropriação, pela dança, da caminhada e de seus acidentes; a conquista de dissonâncias gestuais... É normal que Beckett exija dos caminhantes de Quad "alguma experiência de dança”. Não apenas as caminhadas o exigem, mas também o hiato, a pontuação, a dissonância. Também está próximo de uma obra musical ${ }^{20}$.

Os números cumprem com meticulosidade as diretivas do esboço diagramático de Beckett. Os caminhantes são "parte de uma harmonia pré-estabelecida, perfeitamente coordenada mas sem interação real, num movimento perpétuo em torno de um centro indefinível" ${ }^{21}$. Em sua leitura de Quad, Deleuze observa que o centro é a potencialidade máxima daquele quadrado, pois ali reside a única possibilidade de ação, de que algo se realize de fato, ou seja, de que os corpos se esbarrem no curso das séries; hipótese que ao ser vedada termina por despotencializar todo o espaço, esgotá-lo:

A potencialidade do quadrado é a possibilidade de que os quatro corpos em movimento que o povoam se encontrem, a dois, a três ou a quatro, segundo a ordem do curso da série. O centro é o lugar em que eles podem se encontrar; e seu encontro, sua colisão, não é um acontecimento entre outros, mas a única possibilidade de acontecimento, isto é, a potencialidade do espaço correspondente. Esgotar o espaço é exaurir sua possibilidade, tornando todo encontro impossível. Desde então, a solução do problema está nesse leve recuo em relação ao centro, nesse esgueiramento, nesse desvio,

20. Cf. DELEUZE, Gilles. Op. cit., p. 90-91.

21. Cf. TONNING, Erik. Op. cit., p. 241 [“The pacers are clearly part of a pre-established harmony, perfectly coordinated without actually interacting, in perpetual motion around an undefinable centre. They are versions of each other, but can never provide company or comfort for one another"]. 
nesse hiato, nessa pontuação, nessa síncope, nessa rápida esquiva ou pequeno salto, que prevê o encontro e o conjura. A repetição não retira nada do caráter decisivo, absoluto, desse gesto. Os corpos evitam-se respectivamente, mas evitam o centro absolutamente. Eles se esgueiram em relação ao centro para evitar um ao outro, mas cada um se esgueira, em solo, para evitar o centro. $O$ que é despotencializado é o espaço ${ }^{22}$.

Concernido com um implacável processo de concentração e de redução que, em última instância, visava a uma unidade mínima inquebrantável, mas ainda assim com alguma capacidade de comunicar, Samuel Beckett aparou os excessos do desenho original, e decidiu por uma importante modificação: acrescentou uma segunda parte, pensada como se acontecesse "dez mil anos depois" ${ }^{23}$. Pois bem, após quinze minutos de cores e de movimentos vigorosos (Quad I), a tela enegrece para então retornar a rotina, agora degradada. Nessa continuação (Quad II), removemse as cores vibrantes pela substituição das vestes coloridas por outras de um branco homogêneo. Os instrumentos se calam e o que se ouve são os sons das passadas arrastadas num ritmo moroso. Os caminhantes descoloridos esmaecem os passos na medida de uma presumível exaustão, e cada número cumpre somente uma série, de modo que a duração é reduzida a cinco minutos. Em Quad II, Beckett se entrega, portanto, a uma caminhada à la Beckett. O caminhar lento em ângulo de Nauman é, em certo sentido, muito mais beckettiano do que os frenéticos números ambulantes de Quad I.

A "loucura televisiva" ["crazy TV piece"] conjuga procedimentos suficientemente demonstrativos dos métodos de Beckett: "forja-se uma rotina, repete-se o padrão enfaticamente (pré-ação), decompõese e rearranja-se o esquema (re-ação), e o que fica faltando é uma ação propriamente considerada" ${ }^{24}$.

22. Cf. DELEUZE, Gilles. Op. cit., p. 89-90

23. Cf. BECKETT apud HERREN, Graley. Op. cit., p. 125.
24. "He establishes a routine and repeats it for emphasis (four times) in the 'pre-action' section, then decomposes and rearranges the default routine in 


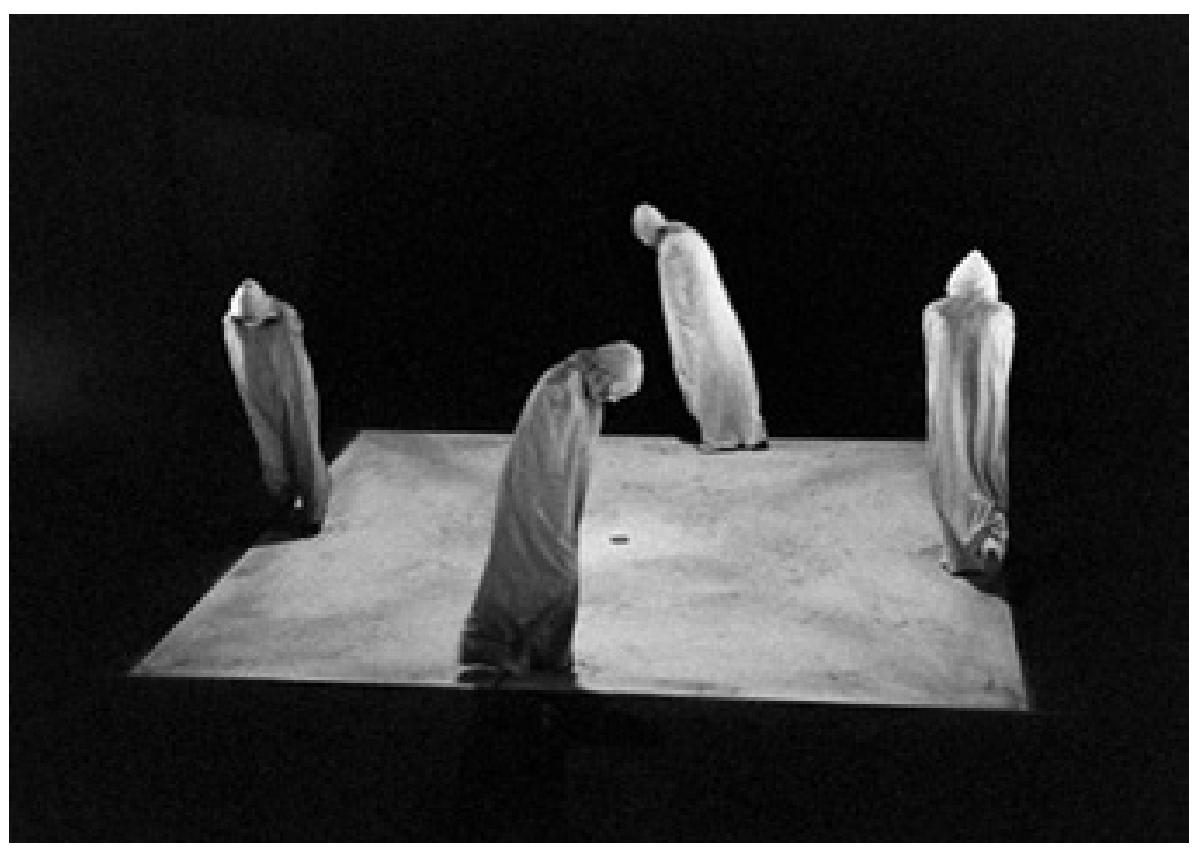

Samuel Beckett, Quad II, 1981, curta-metragem para televisão, 5 min.

Cabe dizer que a interpretação deleuziana de Quad é bastante particular e estabelece que a ideia de esgotamento é o fim último da obra de Beckett, um esgotamento que só se dá por meio do esgotamento fisiológico. Esgotamento e não cansaço enfatiza Deleuze, pois o esgotado é muito mais do que o cansado: "o cansado não pode mais realizar, mas o esgotado não pode mais possibilitar" ${ }^{25}$. Esse "esgotamento que não pode mais possibilitar" não é, todavia, adequado à obra de Nauman - e é provável que também seja alvo de questionamentos por muitos estudiosos de Beckett. A ideia de exaustão ou de extenuação física e psíquica, mas sem a irreversibilidade do esgotamento proposto por Deleuze, é mais

the 're-action' section. What remains conspicuously missing from Quadrat I+II is the middle section, the action', the crucible of conflict where the previous teleplays developed their formal and narrative tensions". Cf. HERREN, Graley. Op. cit., p. 125.

25. “O cansado não dispõe mais de qualquer possibilidade (subjetiva) - não pode, portanto, realizar a mínima possibilidade (objetiva). Mas esta permanece, porque nunca se realiza todo o possível; ele é até mesmo criado à medida que é realizado. 0 cansado apenas esgotou a realização, enquanto o esgotado esgota todo o possível" Cf. DELEUZE, Gilles. Op.cit., p. 67. 
pertinente aos trabalhos de Nauman, sobretudo àqueles que promovem experiências de saturação por meio de recombinações de elementos, como é o caso das instalações sonoras baseadas em textos repetidos sem cessar.

Uma outra proposta de uma quebra da percepção do plano contínuo do quadrado através de uma distinção pontual entre o centro e as bordas da figura geométrica é Square Depression, intervenção urbana concebida por Nauman em 1977 e executada em 2007, no campus da Universidade de Ciências Naturais de Münster, cidade alemã que acolhe a exposição decenal de esculturas públicas "Skulptur Projekte Münster”. É significativo que na produção extensa e profícua do artista raros sejam os momentos em que um trabalho é exposto a céu aberto, uma esquiva que decerto revela a feição assumida pelas obras ao longo dos anos. Não que muitas delas não exijam áreas amplas, apenas não costumam ser grandes o bastante para solicitar as escalas de proporções geográficas típicas das intervenções na paisagem. Square Depression, portanto, figura entre as exceções.

Conforme o nome sugere, Square Depression ${ }^{26}$ é uma espécie de praça pública em sentido negativo, um declive cimentado das bordas em direção ao centro. Ao percorrê-lo a pé, alcança-se o ponto mais baixo que conduz o corpo à cavidade central, a uma altura a partir da qual a visão do arredor é parcialmente interditada - eventualmente interditada por completo, dependendo da postura assumida pelo observador ou de sua altura quando em pé. No nível dos olhos veem-se apenas os limites entre a construção de concreto e a faixa tênue do gramado que a cinge e, mais ao longe, copas de árvores e cimos dos edifícios mais altos, cujas bases, caules ou suportes parecem faltantes.

De certo modo, pode-se dizer que Nauman cavou no solo uma espécie de mirante ao avesso que, ao forjar uma distância tanto em 


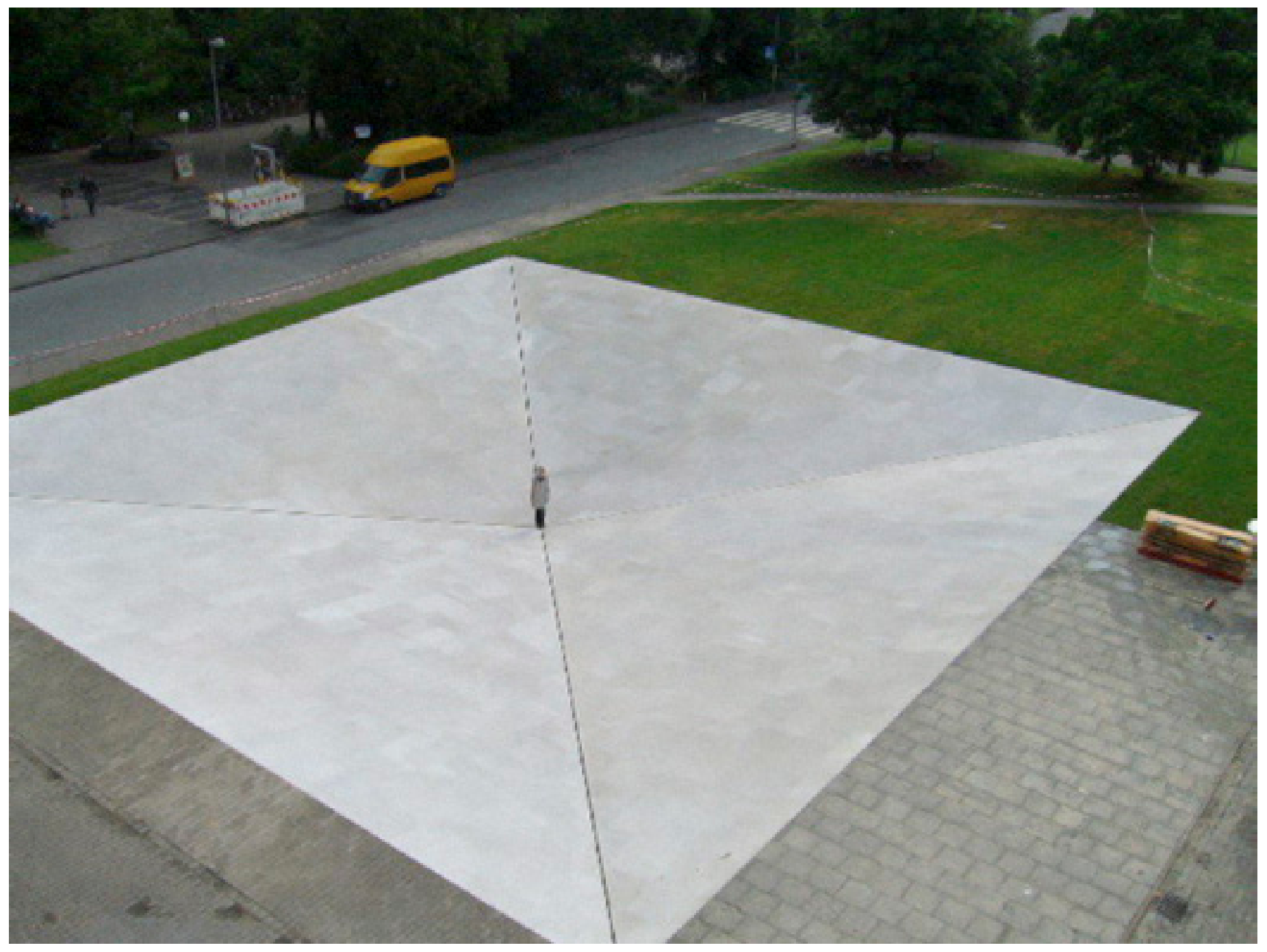

Square Depression, 2007, concreto, 25 × 25 × 2,3 m. 
extensão quanto em profundidade entre o corpo e a paisagem, quebra a percepção de continuidade e recompõe o espaço (e o próprio olhar) a partir dos fragmentos. À escala da cidade o trabalho ambiental responde de modo crítico restituindo uma escala do corpo e da visão que, todavia, não mais é capaz de abranger a totalidade.

A despeito dos $25 \mathrm{~m}^{2}$ de superfície, a escala é calibrada em relação ao corpo: como se o espaço pudesse se encolher para se ajustar ao corpo - invariavelmente atraído pelo declive em direção a um ponto central que, de dimensões exíguas, a cada vez somente pode ser ocupado por um único observador - para que em seguida torne a se expandir em direção às bordas, não sem o concurso do modesto esforço de ascender por uma das quatro faces da pirâmide negativa. Numa improbabilidade geométrica, cortar caminho poupando esforço e tempo implica percorrer o perímetro, e não atravessar pelo centro do quadrado. Invocando uma praticidade tática no deslocamento, o caminho mais curto é contornar o obstáculo (seja ele uma depressão ou uma elevação) e não o vencer, descartando tanto o ônus de perda de visibilidade implicado pela incursão em uma depressão quanto o privilégio de uma perspectiva mais ampla oferecido pelo cume de uma elevação. Um convite, portanto, ao dispêndio disfuncional de tempo e energia.

Tem-se a impressão de que, para negar a adição de um acontecimento impositivo à paisagem, enterrou-se nela um imenso molde cujo conteúdo foi despejado, um volume colossal forçado à subsunção no entorno ou ao desaparecimento, sensação reforçada pelo sentido de neutralidade ou ausência associado à cor branca do material utilizado. Mas a aparente incoerência ganha novo sentido se considerarmos os trinta anos que separam a concepção do projeto de Square Depression de sua execução. Basta lembrar que entre as décadas de 1960 e 1970, Nauman dedicou-se às moldagens, delas preferindo os próprios moldes às peças resultantes, e, nessa mesma época, trouxe à luz os espaços negativos entre os objetos, os limites e as junções das superfícies, conforme se analisou há pouco. 


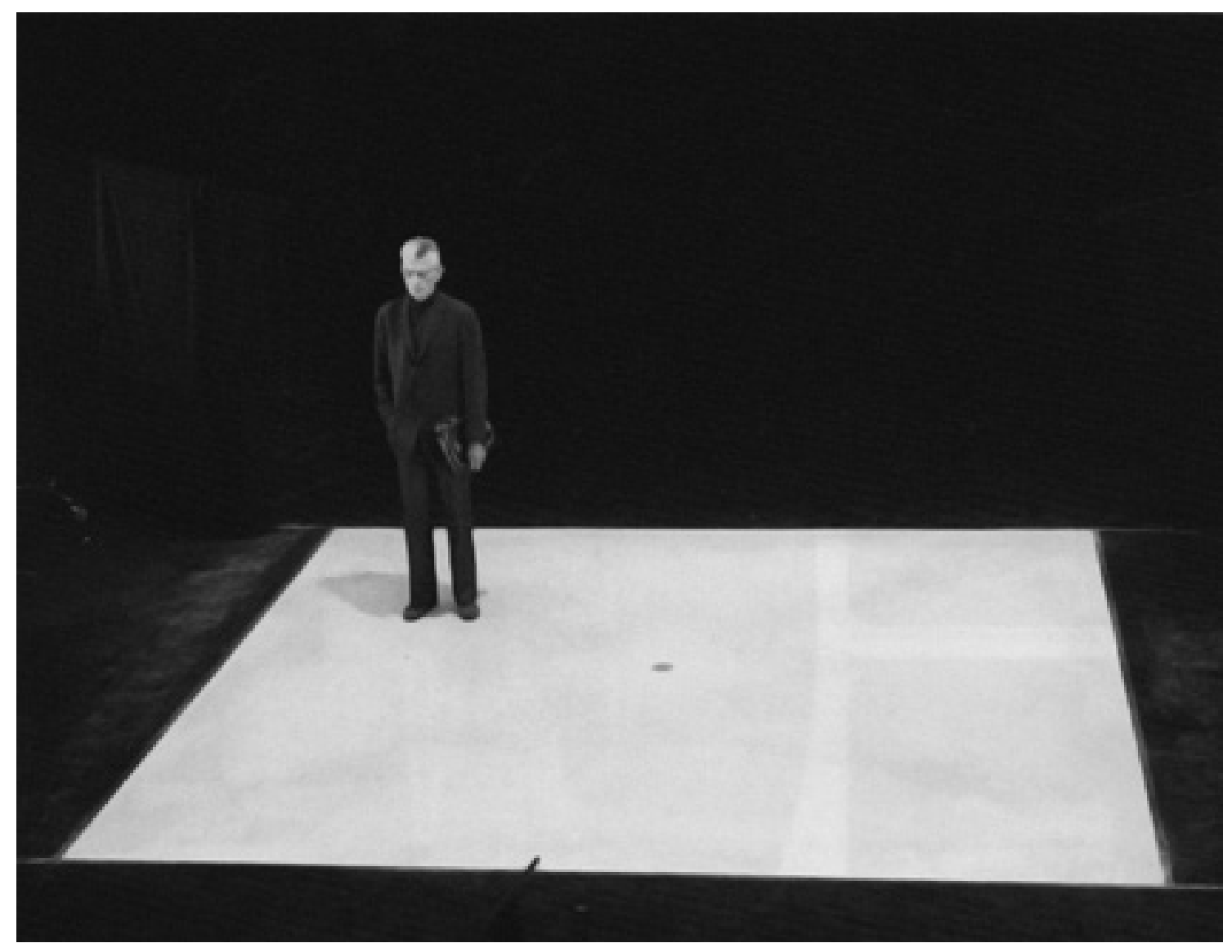

Fotografia de Samuel Beckett no cenário de Quad. 
Essa proposta de uma quebra da percepção do plano contínuo do quadrado através de uma distinção pontual entre o centro e as bordas da figura geométrica traz à mente Quad I + II.

Em face dos trabalhos mencionados até aqui, constata-se que para Nauman assim como para Beckett o tempo (time) guarda estreita relação com a regulação do tempo (timing $)^{27}$, e sua manipulação é uma das vias mais úteis para se alcançar a extenuação física e psíquica. A ideia é compreensível ainda que o jogo de palavras funcione apenas no inglês - time, timing - e foi formulada pelo escritor Paul Auster em uma pequena resenha de 1975 dedicada ao romance Mercier e Camier, de Beckett (escrito em francês em 1946 e traduzido por Beckett para o inglês em 1974). Nesse ensaio, Auster traz a seguinte imagem:

\footnotetext{
Um tantoestranhamente, a prosa de Merciere Camier progride num ritmo de caminhada e, depois de algum tempo, começa-se a ter a impressão distinta de que algures, enterrado profundamente nas palavras, um metrônomo silencioso está marcando o ritmo das perambulações de Mercier e Camier. As pausas, os hiatos, as súbitas mudanças de conversa e a descrição não quebram esse ritmo; pelo contrário, têm lugar sob sua influência, de modo que seu efeito não é ruptura, mas de contraponto e preenchimento. Uma quietude misteriosa parece rodear cada sentença do livro, uma espécie de gravidade ou de calma, de modo que entre cada sentença o leitor sente a passagem do tempo, os passos que continuam a se mover, mesmo quando nada é dito ${ }^{28}$.
}

Nauman e Beckett recorrem continuamente às circularidades e aos refreamentos para regular o tempo, tanto que as pausas - quando existem - não surtem o efeito de ruptura e de desfecho, mas de "contraponto e preenchimento" desencadeante do ciclo subsequente. Para ambos, importa a continuidade do padrão e não o fim da série. 


\title{
3.1. Palhaços torturados: falhar de novo, falhar melhor ${ }^{29}$
}

\author{
O verdadeiro caminho passa sobre uma corda que não está estendida \\ no espaço, mas quase ao rés do solo. Parece destinada a fazer tropeçar \\ e não a ser percorrida. \\ Franz Kafka ${ }^{30}$
}

Além dos filmes e vídeos iniciais, a construção de uma temporalidade circular por meio de mecanismos de repetição ininterrupta é o procedimento que pauta os trabalhos em que Nauman utiliza atores representando palhaços, figuras que surgem na obra em meados da década de 1980. Eis mais uma proximidade com a obra de Beckett, autor cuja galeria de personagens reúne tipos algo clochards, algo clowns.

Veja-se, por exemplo, Film [Filme (1965)], o único roteiro de filme escrito por Beckett, em 1963, e dirigido no ano seguinte por Alan Schneider (1917-1984). O personagem enigmático "O” é ninguém menos que Buster Keaton (1895-1966). Rodado em preto e branco, "o filme é totalmente silencioso exceto por um 'sssh!' na primeira parte” ${ }^{11}$. Uma pálpebra preenche a tela e se abre. Um homem, visto de trás, esgueira-se apressadamente por uma rua, e se presume pelas roupas (casaco, calças largas, uma valise, um lenço sob o chapéu puído que parece vedar parcialmente suas feições) e pelo gestual que se trate de um velho. Ele colide com estranhos que se espantam ao olhá-lo, horrorizados. Entra em um prédio e mede a própria pulsação. Uma senhora que descia as escadas cai morta depois de fitá-lo. Ele entra

29. “Tente. Fracasse. Não importa. Tente de novo. Fracasse de novo. Fracasse melhor" ["Ever tried. Ever failed. No matter. Try again. Fail again. Fail better"], frase extraída de Worstward Ho, publicado em 1983. Cf. BECKETT, Samuel. Worstward Ho. In: ___ The Selected Works of Samuel Beckett [Vol. IV Poems - Short Fiction -
Criticism]. Nova York: Grove Press, 2010, p. 471. 30. Cf. KAFKA, Franz. Antologia de páginas intimas. Tradução de Alfredo Margarido. Lisboa: Guimarães Editores, 2002, p. 143.

31. "The film is entirely silent except for the "sssh!" in part one". Cf. BECKETT, Samuel. Film. In: Ibidem, p. 367. 
em um apartamento, fecha as trancas da porta e volta a medir a pulsação. O recinto está quase vazio, exceto por um cachorro, um gato, uma gaiola com um papagaio, um aquário com um peixe, uma cama, uma cadeira de balanço, um espelho, uma reprodução em papel de uma imagem religiosa com olhos arregalados. Ele veda a claridade vinda da janela e também o espelho. Depois, retira lentamente todos os olhos que parecem recair sobre ele: o gato e cachorro são postos para fora em uma cena burlesca, o papel com a imagem é rasgado, a gaiola e o aquário são cobertos. Sentado na cadeira de balanço, ele examina cuidadosamente fotos de família retiradas de um envelope. A câmera, até então mantida à certa distância, gira e o capta de frente: Buster Keaton aparece usando um tapa-olho e, à semelhança dos estranhos que encontrou no trajeto, faz uma expressão de espanto e cobre o rosto com as mãos. O filme se encerra com o mesmo olho focalizado na abertura. No roteiro, Beckett cita a máxima do filósofo irlandês George Berkeley (1685-1753), Esse est percipi ("ser é ser percebido") e aponta que o protagonista cinde-se em dois: "O" (object/objeto) e "E" (eye/olho). A despeito da supressão da percepção alheia - os estranhos encontrados pelo caminho, os animais e a imagem referida ao elemento divino -, resta a "O" a inevitabilidade da auto-percepção. Beckett ressalta: "clima do filme cômico e irreal. 'O' deve convidar ao riso por sua maneira de se mover" ${ }^{32}$. Para tanto, o papel é entregue a Keaton, grande ator norte-americano de comédias mudas e, possivelmente, o melhor dos clowns.
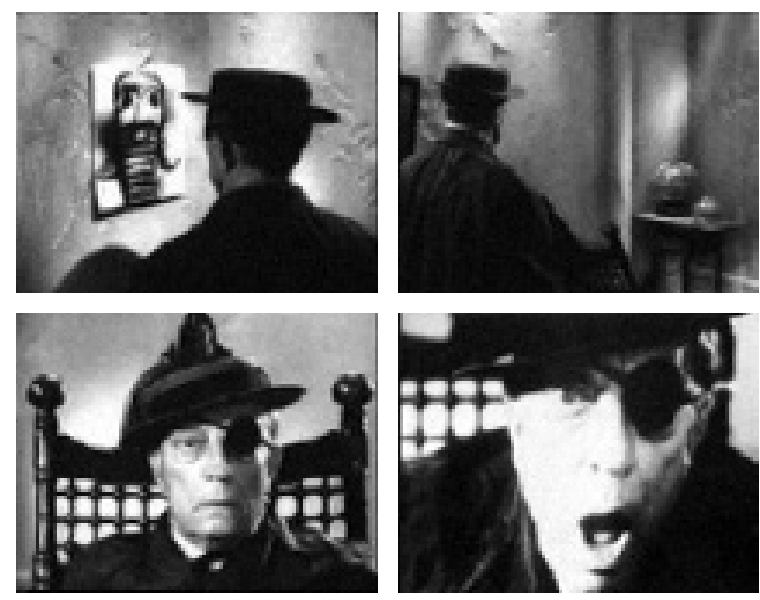

Samuel Beckett, Film, filme, 1965, $24 \mathrm{~min}$. 
Veja-se também a descrição de Krapp, personagem de A última gravação de Krapp, de 1959, que inicia a peça descascando e comendo duas bananas com um gestual desengonçado e expressão pensativa, "calças pretas desbotadas, estreitas e muito curtas para ele. Colete preto desbotado e sem mangas, quatro bolsos espaçosos. Relógio de corrente de prata pesado. Camisa branca encardida e aberta no pescoço, sem colarinho. Surpreendente par de botas brancas sujas, tamanho dez pelo menos, muito estreitas e pontiagudas. Rosto branco. Nariz roxo. Cabelos grisalhos desarrumados. Barba por fazer. Muito míope. Problemas de audição. Voz esganiçada. Entonação distinta. Andar penoso" ${ }^{33}$. Amiúde os personagens recebem caracterização parecida, maltrapilhos, sapatos grandes surrados, chapéuscoco: Vladimir e Estragon (de Esperando Godot, de 1952); Hamm e Glov (de Fim de Partida, de 1957) e Mercier e Camier, entre outros. Algumas dessas duplas inseparáveis aludem aos pares complementares de palhaços de circo, o dominador e o submisso, o espertalhão que humilha e escarnece do tolo.

Assim como os personagens de Beckett, os palhaços de Nauman trazem à tona temas como a frustração, o fracasso, a crueldade, o ridículo e a incapacidade de aprendizado. O procedimento crucial é o da repetição infindável e a perversão maior é a simulação do desenlace ou da interrupção dos ciclos: o "fantasma da revogabilidade", tal como citado para comentar as ocorrências dentro do cilindro de $O$ despovoador. Diante do elenco do circo, lugar por excelência da crueldade, Nauman e Beckett escolhem as figuras sub-humanas ou sobre-humanas, os personagens feitos para fracassar diante da plateia, para suportar as humilhações, as quedas, os

32. "Climate of film comic and unreal. 'O' should invite laughter throughout by his way of moving". Cf. BECKETT, Samuel. Loc. cit.

33. "Rusty black narrow trousers too short for him. Rusty black sleeveless waistcoat, four capacious pockets. Heavy silver watch and chain. Grimy white shirt open at neck, no collar. Surprising pair of dirty white boots, size ten at least, very narrow and pointed. White face. Purple nose. Disordered grey hair. Unshaven. Very near-sighted. Hard of hearing. Cracked voice. Distinctive intonation. Laborious walk". Cf. BECKETT, Samuel. Krapp's Last Tape. In:__. The Selected Works of Samuel Beckett [Vol. III Dramatic Works]. Nova York: Grove Press, 2010, p. 217. 


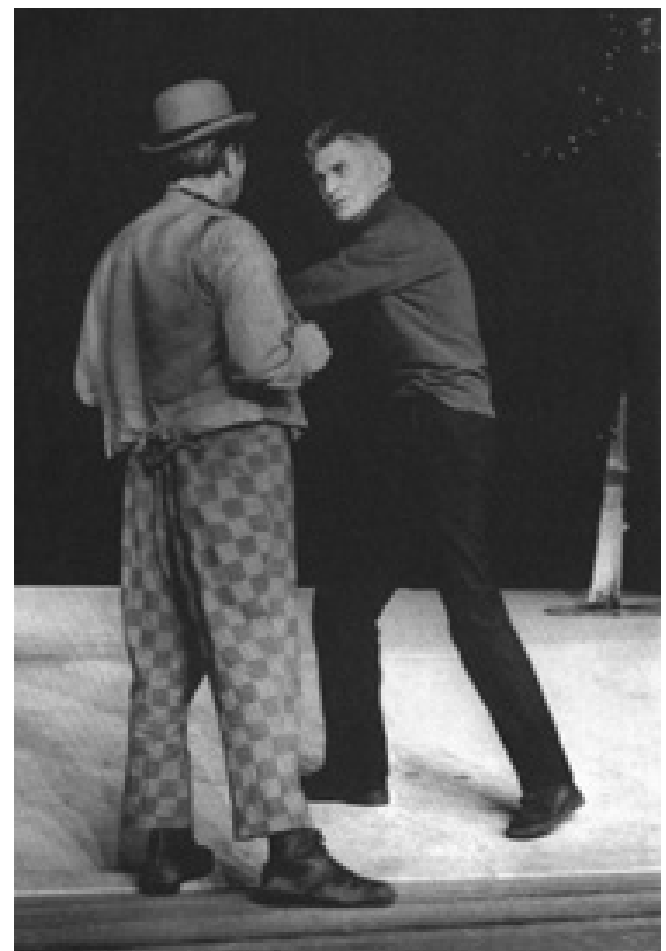

Samuel Beckett e Karl Raddatz ensaiando Esperando Godot, Berlim, 1975.

golpes, as repetições das piadas e dos gracejos e, sobretudo, a tensão da espera pela próxima provação ${ }^{34}$.

Os palhaços de Nauman não são os da tradição da Commedia dell'Arte, iniciada no século XV, na Itália. Em nada se parecem com os arlequins e saltimbancos de Picasso (1881-1973), por exemplo, figuras astutas e repletas de vitalidade, trapaceiros que burlam a norma com métodos espirituosos, inteligentes, que podem tudo e que por isso têm capacidade de transformar e pôr as coisas em movimento; uma metáfora

34. Conforme o comentário do prefácio da edição brasileira de Fim de Partida, "Hugh Kenner, um de seus primeiros e melhores críticos [da obra de Beckett], vale-se da imagem de dois caminhos estéticos opostos para explicá-la: há a família dos acrobatas, empenhados em fazer mais e melhor que seus antecessores, colocar a corda bamba, sem rede, cada vez mais alta; mas há também a linhagem dos clowns, que trazem a corda bamba junto ao chão e se ocupam de exibir os limites humanos, projetando luz sobre a falha e o fracasso". Cf. ANDRADE, Fábio de Souza. Matando o tempo: o impasse e a espera. In: BECKETT, Samuel. Fim de partida. Tradução de Fábio de Souza Andrade. São Paulo: Cosac\&Naify, 2002, p. 10. 
fartamente analisada por Yve-Alain Bois em "Picasso the Trickster" 35 . Os palhaços de Nauman são grotescos, sejam eles cruéis ou humilhados.

Na mencionada série de trabalhos em neon, de 1985, que trata de violência e sexualidade, certos desenhos esquemáticos lembram palhaços, sobretudo pelo formato dos olhos e das bocas e pelos narizes redondos. Em Mean Clown Welcome [Boas-vindas do palhaço maldoso (1985)], a referência é explícita. A representação da brincadeira de retirar inesperadamente a mão estendida para um cumprimento, truque clássico do humor pastelão, ganha o adendo dos órgão sexuais dos palhaços, desenhados com destaque, pulsando ora eretos ora flácidos, sem parar.

Na série Clown Torture [Tortura do palhaço (1987)], Nauman atormenta palhaços variados, deixando-os envergonhados das próprias aflições, submetidos que estão a travessuras que se repetem, se repetem, se repetem...

Fiquei interessado na ideia do palhaço antes de tudo porque há uma máscara, e se torna uma ideia abstrata de uma pessoa. [...] e porque os palhaços são abstratos em certo sentido, tornam-se muito desconcertantes. [...] Além disso, quando se pensa em palhaços de vaudeville ou palhaços de circo, há muita crueldade e maldade. Não se sairia impune daquilo sem maquiagem. As pessoas não aguentariam, é muito maldoso. Mas, no circo, fica tudo bem e ainda é engraçado ${ }^{36}$.

Os vídeos de palhaços surgem na obra de Nauman, portanto, como um desdobramento dos vídeos em que maquiava o próprio corpo,

35. Cf. BOIS, Yve-Alain. Picasso the Trickster. In: Picasso Harlequin: 1917-1937. Milão: Skira, 2009. Já para uma aprofundamento do tema dos palhaços nas obras de Nauman e Beckett, consulte-se SCHAFFNER, Ingrid. Bruce Nauman through Samuel Beckett. In: MORGAN, Robert C. (Ed.). Bruce Nauman. Baltimore: The Johns Hopkins University Press, 2002, p. 163-173.
36. "I got interested in the idea of the clown first of all because there is a mask, and it becomes an abstract idea of a person. [...] and because clowns are abstract in some sense, they become very disconcerting. [...] Also, when you think about vaudeville clowns or circus clowns, there is a lot of cruelty and meanness. You couldn't get away with that without makeup. People wouldn't put up with, it's too mean. But in circus it's okay, it's still funny". Cf. KRAYNAK, Janet (Ed.). Op. cit., p. 335. 


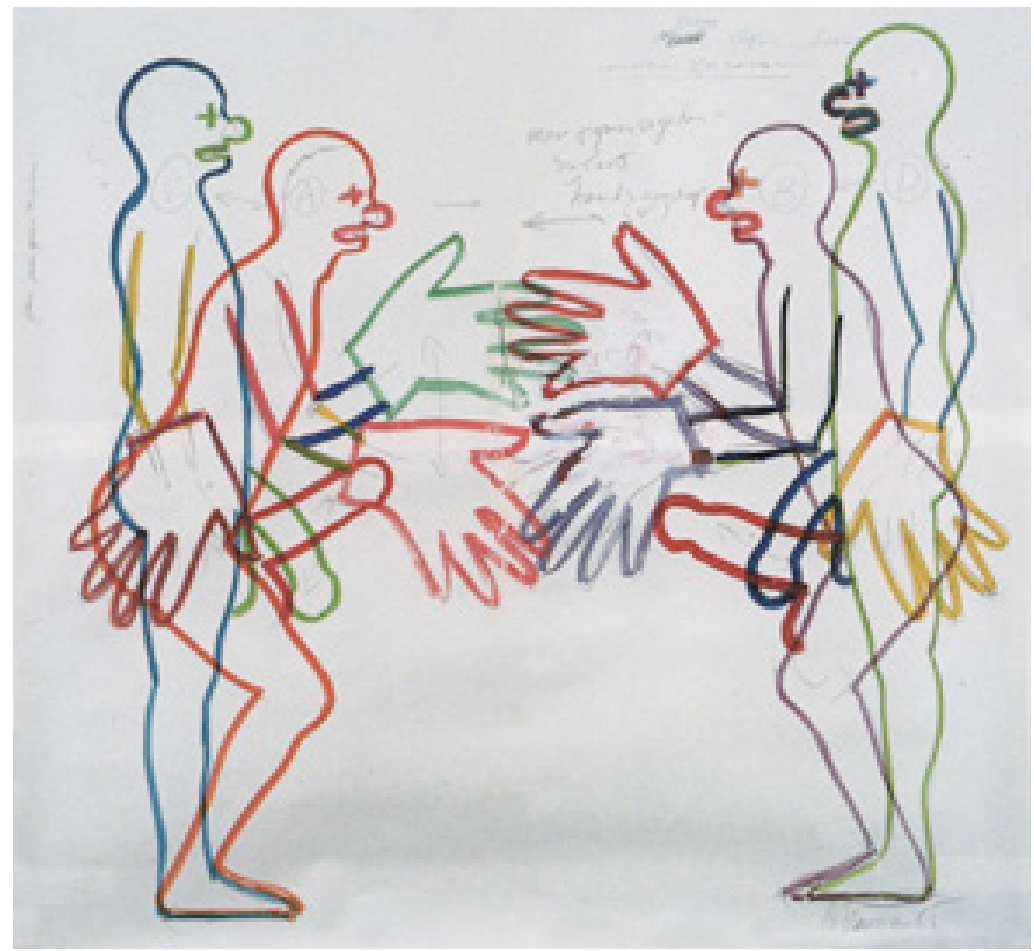

Estudo para Mean Clown Welcome, 1985, grafite e aquarela sobre papel, $183 \times 209,5 \mathrm{~cm}$

escondendo-se ou apagando os traços expressivos individualizantes (como na citada série Art Make-Up de 1967 ou Flesh to White to Black to Flesh [Carne para branco para preto para carne], de 1968). A máscara do palhaço - sua maquiagem - torna-o apto a comportar-se de modo mesquinho ou a perpetrar ações cruéis; torna-o igualmente apto a sofrer indefinidamente. E os palhaços de Nauman costumam sofrer. Os maus-tratos recaem sobre palhaços caracterizados com figurinos e maquiagens diferentes: "no vídeo do palhaço, há quatro diferentes trajes: o palhaço tolo [representado por] Emmett Kelly; um antigo palhaço barroco francês; um de cabelos vermelhos, roupas de bolinhas e sapatos enormes; e um bobo da corte" ${ }^{37}$.

37. "In the clown videotape, there are four different clown costumes: one of them is the Emmett Kelly dumb clown; one is the old French Baroque clown; one is a sort of traditional polka-dot, red-haired, oversize-shoed clown; and one is a jester". Cf. KRAYNAK, Janet (Ed.). Op. cit., p. 335; 337. 
Clown Torture: I'm sorry, 1987, vídeo.

Clown Torture: No, No, No,

1987, vídeo.

Clown Torture: Clown Taking a

Shit, 1987, vídeo.
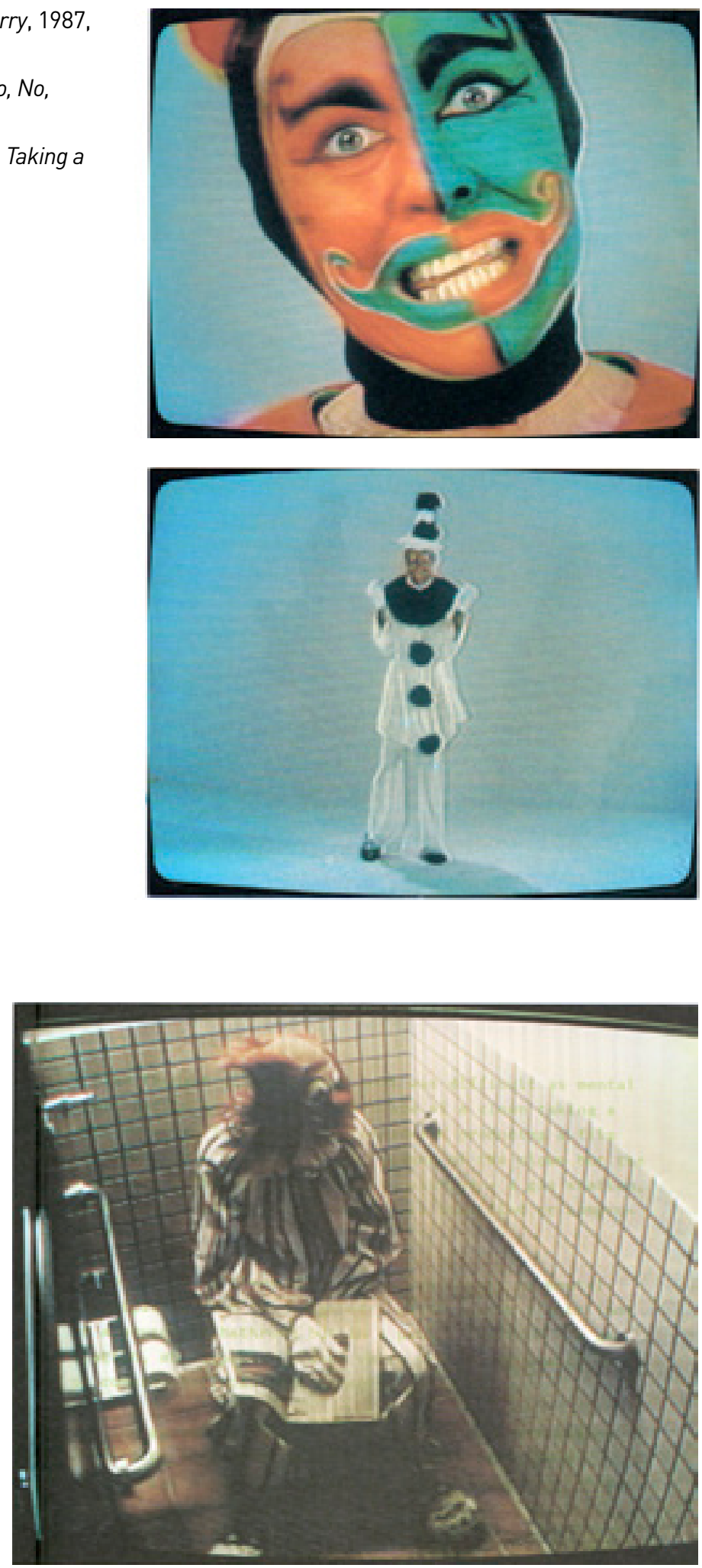

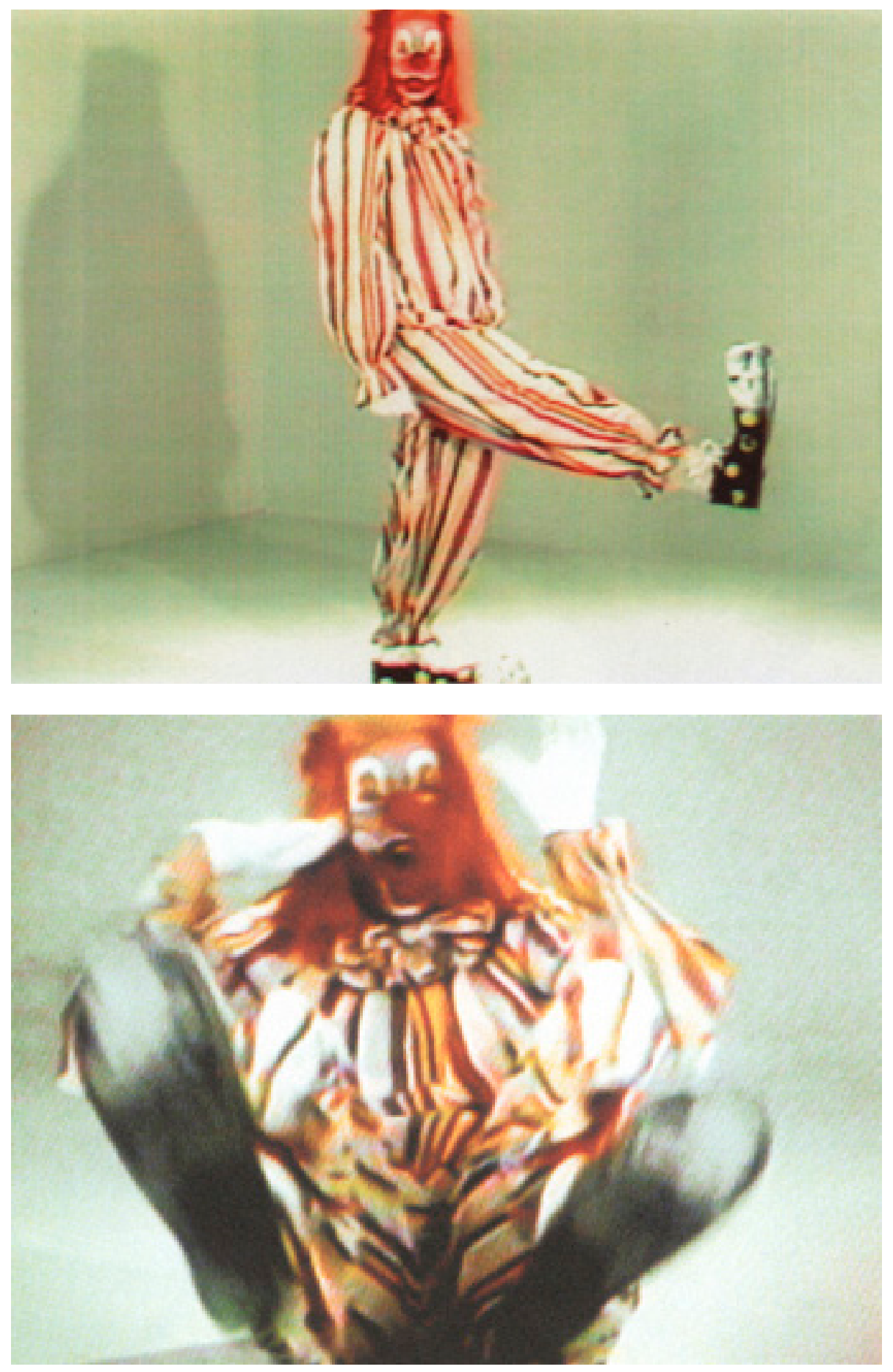

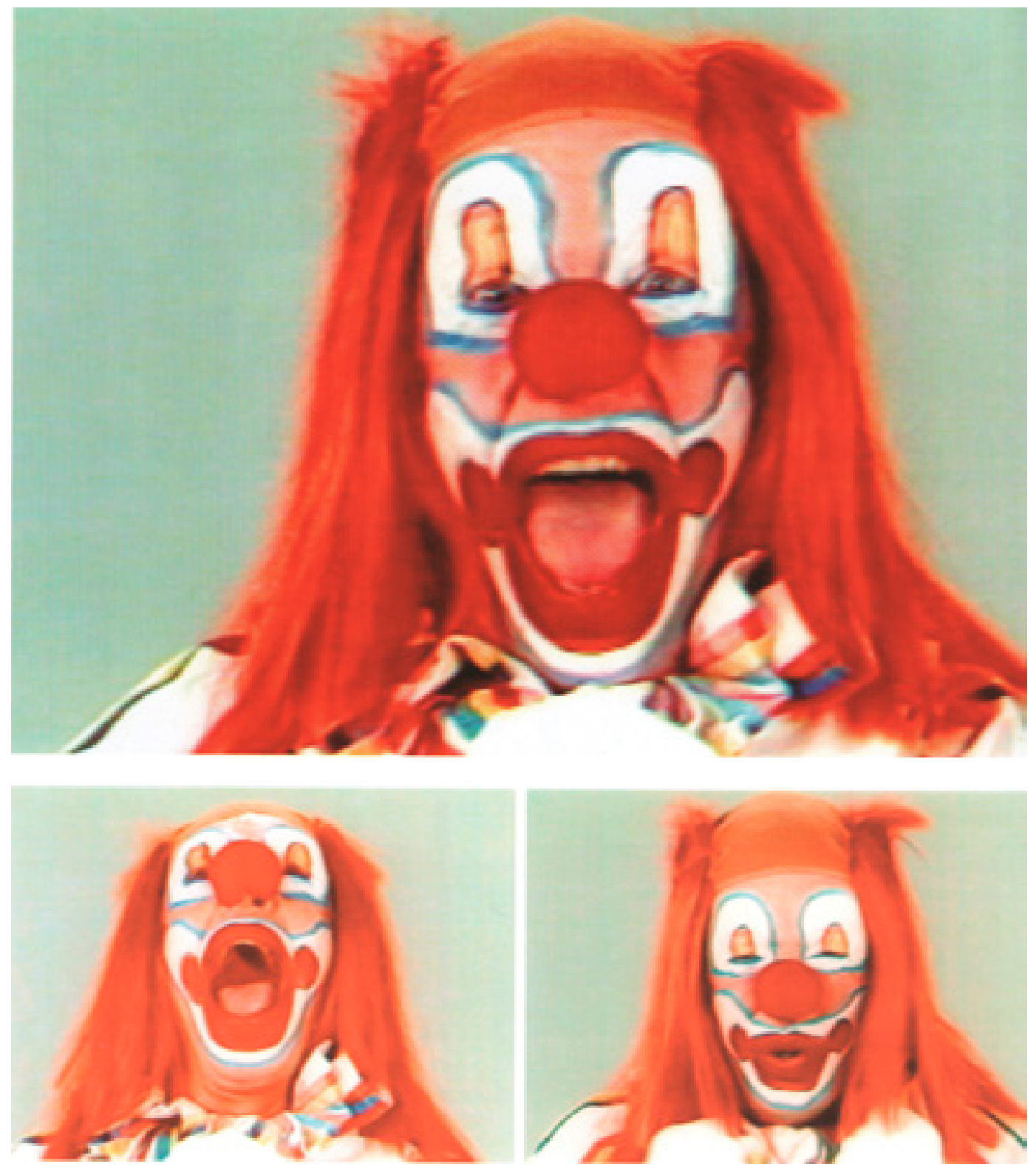

Clown Torture: Pete and Repeat/Dark and Stormy Night/No, No, No, 1987, videoinstalação. 
Clown Torture é um trabalho que tem configurações diferentes, sendo frequentemente apresentado em uma instalação composta por projeções de diversos vídeos, todos de 1987. Em um deles, por exemplo, um palhaço de peruca vermelha e maquiagem à la Bozo, debate-se e grita, de olhos arregalados, "não, não, não..." [No, No, No, No]. Em outra versão, o palhaço está trajado como um pierrô e pula freneticamente enquanto grita "não". Há outro, fantasiado como um bobo da corte, que repete com vigor "I am sorry" [desculpe-me]. Em Clown with Goldfish Bowl [Palhaço com aquário de peixe dourado], um palhaço trôpego tenta equilibrar um aquário em um cabo de vassoura. Em Clown with Water Bucket [Palhaço com balde de água], um palhaço é atingido por baldes de água toda vez que abre uma porta. Nos dois últimos casos, os palhaços são incapazes de aprender com a falha, restando-lhes o mero impulso de repetição do comportamento: o palhaço continua a abrir a porta, mesmo sabendo - ou melhor, como se não soubesse - da inevitável humilhação que o espera. Já em Clown Taking a Shit [Palhaço cagando] a humilhação é mais surpreendente: o vídeo traz o palhaço de peruca vermelha, está sentado no vaso sanitário; lendo uma revista, enquanto é filmado por uma câmera de vigilância, uma exposição ambígua de sua intimidade, uma vez que o anonimato é garantido por seu traje.

Há ainda vídeos com as clássicas piadas circulares, repetidas ininterruptamente em função de suas próprias estruturas, e que lembram a cantoria de Vladimir para Estragon na abertura do segundo ato da interminável espera por Godot: "um cão foi à cozinha/roubar pão e chouriço/o chefe e um colherão/deram-lhe fim e sumiço/Outros cães tudo assistindo/o companheiro enterraram/sob uma cruz que dizia/aos demais que ali passavam/um cão foi à cozinha/roubar pão e chouriço..."38.

38. Vladimir e Estragon são personagens da célebre peça teatral de Beckett, Esperando Godot, escrita em 1948, publicada em 1952 e estreada em Paris, em 1953, sob a direção de
Roger Blin. Cf. BECKETT, Samuel. Esperando Godot. Tradução de Fábio de Souza Andrade. São Paulo: Cosac\&Naify, 2005, p. 109-110. 

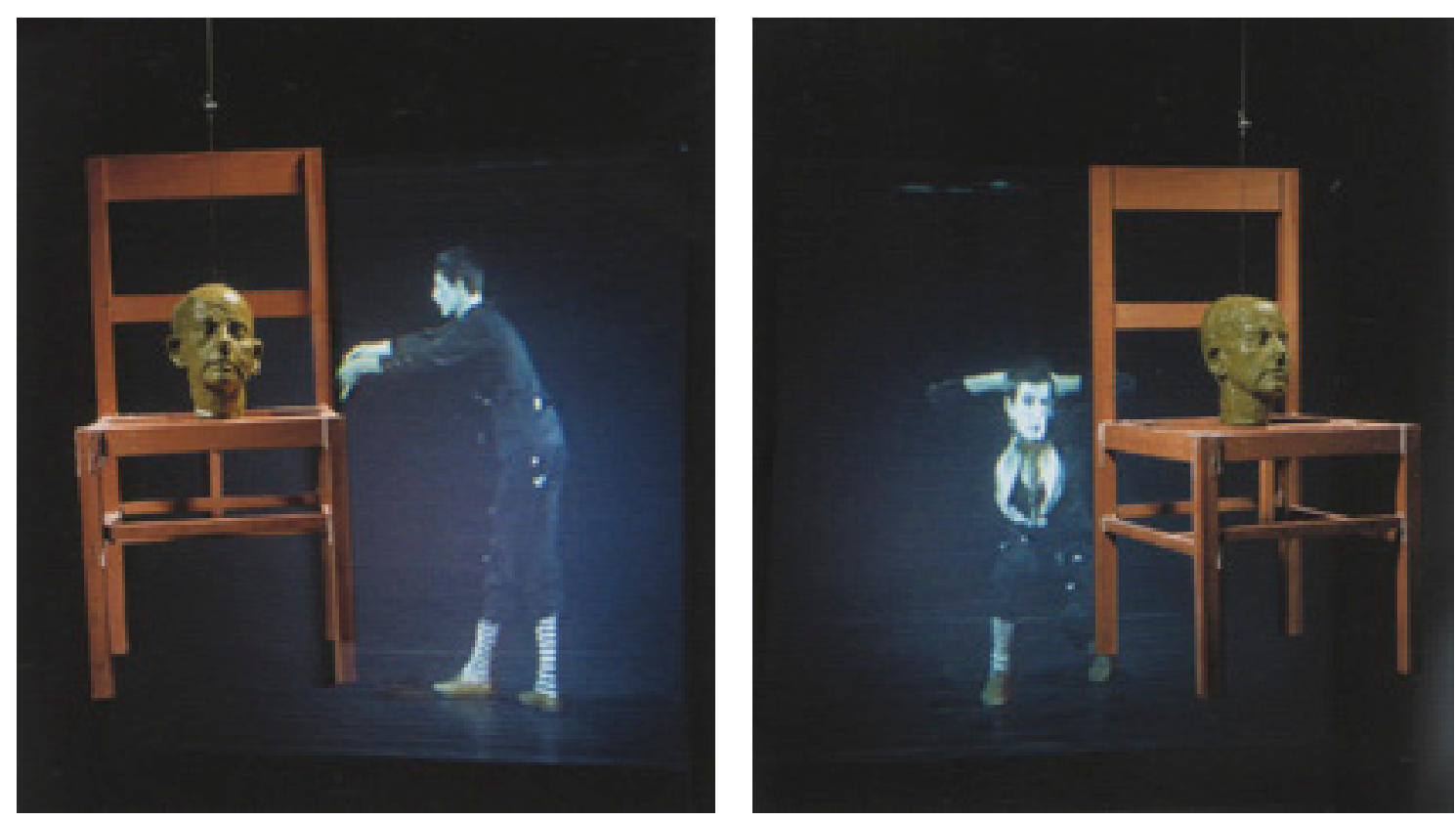

Shit In Your Hat - Head On A Chair, 1990, cera, madeira, projeção de vídeo, dimensões variáveis.

Em Pete and Repeat [Pita e Repita], o palhaço conta a piada tentando se equilibrar em um pé só, como se estivesse sentado e de pernas cruzadas, "Pita e Repita estavam sentados numa cerca. Pita caiu. Quem ficou? Repita. Pita e Repita estavam sentados numa cerca. Pita caiu. Quem ficou? Repita..."39. Em algumas montagens, há também Dark and Stormy Night with Laughter [Noite escura e tempestuosa com gargalhada] em que, à semelhança de Pete and Repete, um palhaço repete a piada em um monitor e, em outro, disposto à frente, um palhaço gargalha ("era uma noite escura e tempestuosa. Três homens estavam sentados em volta de uma fogueira. Um dos homens disse, "Conte-nos uma história, Jack”. E Jack disse, 'Era uma noite escura e tempestuosa. Três homens estavam sentados em volta de uma fogueira.... $)^{40}$. A cada repetição o palhaço vai ficando mais frustrado

39. "Pete and Repeat were sitting on a fence. Pete fell off. Who was left? Repeat. Pete and Repeat were sitting on a fence. Pete fell off. Who was left? Repeat...".
40. "It was a dark and stormy night. Three men were sitting around a campfire. One of the men said, 'Tell us a story, Jack'. And Jack said, 'It was a dark and stormy night. Three men were sitting around a 
pela obrigação de recomeçar. E, numa tentativa de afastar a repetição, ele muda as entonações, simula sotaques variados, rosna como um cão, mas nunca consegue romper o ciclo.

Por fim, não se pode deixar de mencionar um outro trabalho que emprega um clown e é estruturado por combinatórias extenuantes de poucos elementos, no qual a contenção dá a tônica e o torna um dos mais cortantes da lavra de Nauman, Shit In Your Hat - Head On A Chair [Cague em seu chapéu - Cabeça numa cadeira (1990)]. A instalação compreende uma projeção de vídeo de uma atriz, mais propriamente uma mímica e, à frente, uma cabeça moldada em cera que repousa em uma cadeira que pende do teto. Uma voz vigorosa vinda de fora da cena ordena uma sequência de instruções executadas pela mímica. Permutamse quatro verbos put, drop, show, shit [pôr, largar, mostrar, cagar] e seis substantivos hat, table, head, hand, lap, face [chapéu, mesa, cabeça, mão, colo, rosto]. Elabora-se uma estrutura matemática fechada de termos comutáveis em equações: "ponha o seu chapéu sobre a mesa. Ponha sua cabeça em seu chapéu. Ponha sua mão em sua cabeça com sua cabeça em seu chapéu. Ponha o seu chapéu no seu colo. Ponha sua mão em seu chapéu, seu chapéu no seu colo. Largue o seu chapéu... ${ }^{41}$. De repente, o que parecia um procedimento calculadamente anódino converte-se em um mecanismo extremado de violência. A série de comandos simples se revela um exercício de poder que envolve manipulação, humilhação e sadismo: "cague no seu chapéu. Mostre-me o seu chapéu. Ponha o seu chapéu em sua cabeça. Ponha a cabeça sobre a mesa..." ${ }^{42}$.

campfire. One of the man said, 'Tell us a story, Jack'. And Jack said, It was a dark and stormy night. Three men were sitting around a campfire....".

41. "Put your hat on the table. Put your head on your hat. Put your hand on your head with your head on your hat. Put your hat in your lap. Put your hand on your hat, your hat in your lap. Drop your hat...".

42. Shit in your hat. Show me your hat. Put your hat on your head. Put your head on the table...". 
A respeito disso, é interessante um comentário do crítico e curador Robert Storr sobre um conjunto de trabalhos de Nauman que lida com temas semelhantes aos abordados por meio dos palhaços:

[...] os palhaços atormentados, mais do que isso, as formas de animais esfolados em Carousel [Carrossel] (1988) e trabalhos relacionados também personificam o reflexo da crueldade humana. A estridente videoinstalação Learned Helplessness in Rats/Rock and Roll Drummer [Desamparo aprendido em ratos/Baterista de rock and roll], (1988) baseia-se na noção de que as nossas reivindicações de superioridade são, na melhor da hipóteses, muito tênues. Uma gravura intitulada Learned Helplessness from the Rats [Desamparo aprendido com os ratos] sugere, ao contrário disso, que a psicologia comportamental, com a qual se contava para aperfeiçoar a natureza, pode facilmente voltar-se contra nós. A inabilidade repetida para aprender com os erros é uma questão constante para Nauman, nenhum projeto de melhoria ou punição do fracasso muda as chances contra o erro. A dor é uma má professora ${ }^{43}$.

43. "[...] the tormented clowns, moreover, the flayed animal forms in Carousel (1988) and related works also personify humanity's reflex cruelty. The raucous video installation Learned Helplessness in Rats/Rock and Roll Drummer (1988), is predicated on the notion that our claims of superiority are tenuous at best. A print [...] entitled Learned Helplessness from the Rats suggests instead that behaviorial psychology, counted upon to improve on nature, may easily be turned against us. The repeated inability to learn from mistakes is a constant issue for Nauman; no design for betterment or punishment for failure changes the odds against error. Pain is a poor teacher". Cf. STORR, Robert. Flashing the Light in the Shadow of Doubt. In: MORGAN, Robert C. (Ed.). Bruce Nauman. Baltimore: The Johns Hopkins University Press, 2002, p. 160. 


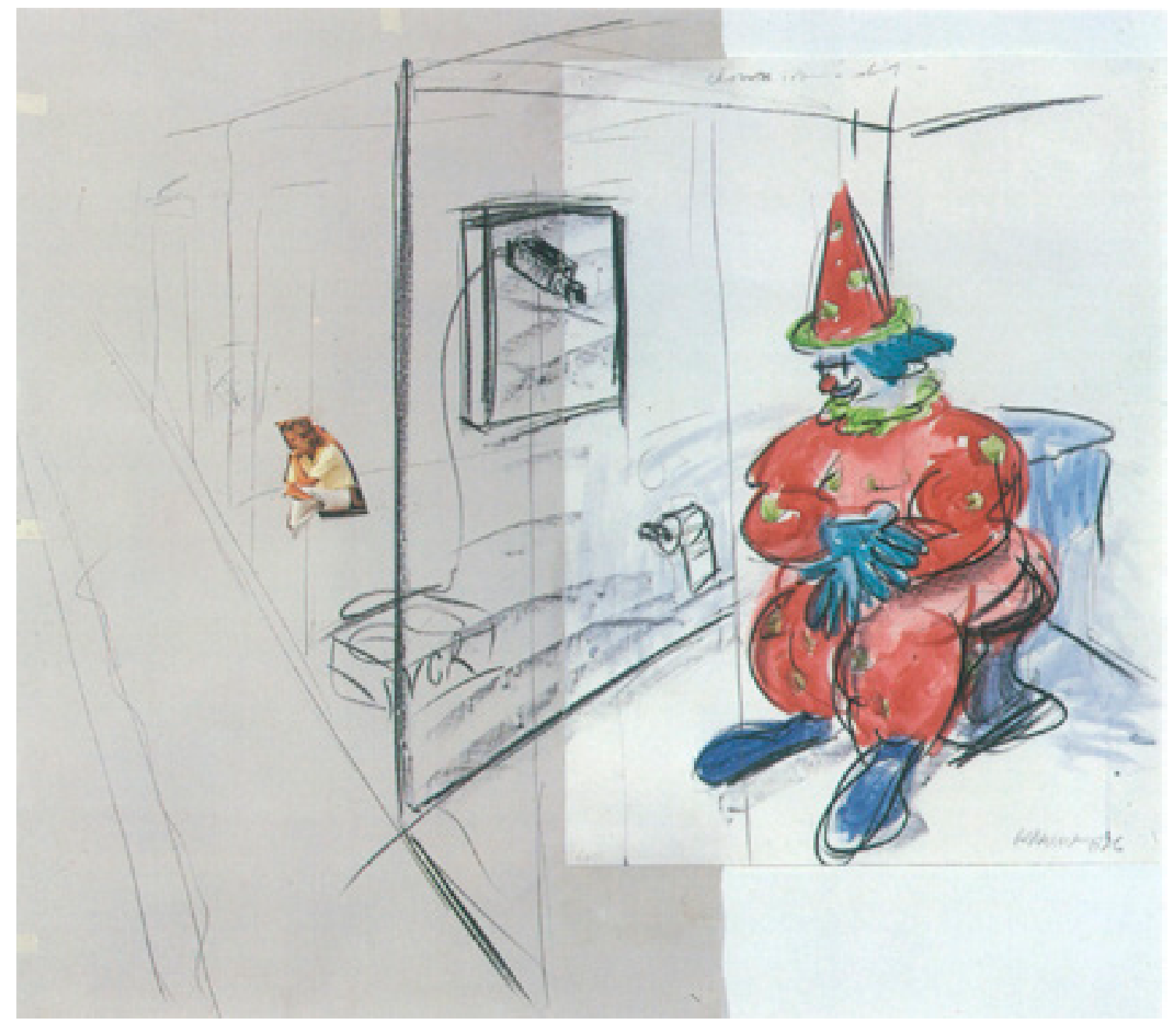

Clown with Video Surveillance, 1986, aquarela, grafite e colagem sobre papel, $108,5 \times 96 \mathrm{~cm}$. 


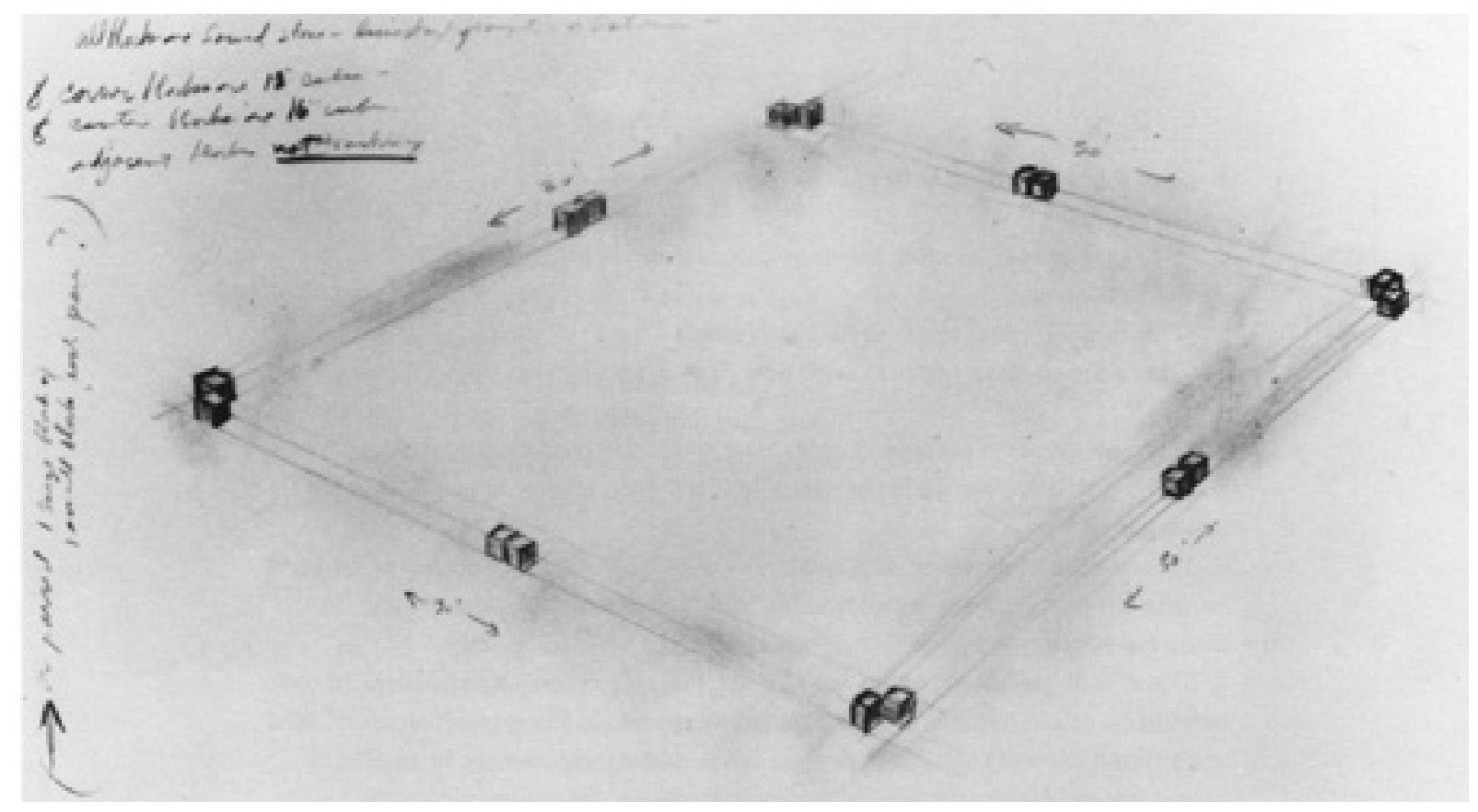

Sem título (Study for The Consummate Mask of Rock), 1975, grafite sobre papel, 75,6 x 101,6 cm. 
Contenção, reiteração e saturação: as palavras de Bruce Nauman 
O poema e as pedras têm o mesmo peso. Eu trabalhei primeiro no poema e, depois, na ideia da pedra. Em algum ponto, eles passaram a significar a mesma coisa para mim. Havia uma analogia.

Bruce Nauman sobre The Consummate Mask of Rock ${ }^{1}$.

A analogia entre poema e pedra, uma aproximação nada incomum na literatura, soa certeira nessa declaração de Bruce Nauman acerca de The Consummate Mask of Rock [A máscara consumada de pedra] e é também sugestiva do papel atribuído às palavras (textos escritos ou falados) na obra do artista. Em 1975, Nauman organizou meticulosamente dezesseis cubos de arenito de dois tamanhos diferentes no chão de uma galeria, distribuindo-os em oito pares iguais, um bloco de cada par sutilmente maior do que o outro². Críticas da época mencionam que, tal como estavam dispostos, cada um na diagonal de seu par, todos ajustados em ângulos idênticos, os blocos induziam uma ligeira distorção perspectiva: "o chão não mais parecia ser plano e, quando alguém se movia ao redor, o espaço parecia torcido. O espaço calmo e clássico da Galeria Albright-Knox contrastava com a presença rigorosa, escultural das pedras, sua textura áspera e cortes afiados" ${ }^{3}$. Esse contraste

1. "The poem and the stones carry equal weight. I worked on the poem first, than the idea of the stone. At some point they came to mean the same thing to me. There was an analogy". Cf. KRAYNAK, Janet (Ed.). Please Pay Attention Please: Bruce Nauman's Words: Writings and Interviews. Cambridge, Massachusetts: The MIT Press, 2005, p. 33.

2. Os oito cubos maiores tinham $38 \mathrm{~cm}$ cada e os oito menores, $35,5 \mathrm{~cm}$. A mostra ocorreu na Galeria Albright-Knox, na cidade de Buffalo, no estado de Nova York. O primeiro título aventado foi The Mask to Cover the Need for Human Companionship [A máscara para cobrir a necessidade de companhia humana], mas Nauman decidiu-se por The Consummate Mask of Rock assim que terminou a escrita do texto que acompanhou o arranjo de pedras.
The Consummate Mask of Rock foi a primeira instalação de uma série realizada em 1975 na qual blocos de pedra (arenito e/ou granito) eram dispostos em configurações diversas no espaço expositivo. Diamond Mind; Enforced Perspective: Allegory and Symbolism; e Forced Perspectives or False Perspectives são as outras instalações dessa série.

3. Depoimento de Coosje van BRUGGEN. No original: "the floor no longer appeared to be flat; when one moved around the space it looked twisted. The calm, classical space of the AlbrightKnox Art Gallery contrasted with the rigorous, sculptural presence of the stones and with their rough texture and sharp gashes". Cf. BRUGGEN, Coosje van. Bruce Nauman. Nova York: Rizzoli International Publications, 1988, p. 195. 
reforçava as percepções incongruentes do espaço e também a importância do ajuste das escalas para o artista: pequenas em relação ao corpo humano, as pedras decerto pareciam mais austeras e reduzidas na galeria espaçosa em que estavam. Verificando-se os desenhos preparatórios e os registros fotográficos originais da mostra ${ }^{4}$, infere-se que tal discrepância pudesse causar a impressão de que os blocos tivessem peso e densidade maiores do que de fato tinham, provocando a sensação descrita no depoimento, a de um ligeiro enviesamento do chão, como se o peso presumido das pedras pudesse afundar levemente aquela superfície. Por sua vez, o texto que acompanhava a instalação construía por si mesmo outras tantas linhas de torção capazes de reiterar, num outro nível, a perturbação percebida no espaço físico 5 .

A prosa poética de The Consummate Mask of Rock é vertiginosa porque mistura inesperadamente termos utilizados em uma brincadeira infantil com referências à violência, à sexualidade e às situações de desamparo. A brincadeira ou jogo em questão é o rock, paper and scissors - "pedra, papel e tesoura" também chamado de "joquempô". No jogo, os participantes devem, em momento determinado e a um só tempo, exibir uma de suas mãos, anteriormente oculta, de forma a representar um dentre os três itens simbólicos do jogo: a pedra é o punho fechado; a tesoura, dois dedos esticados; e o papel, a mão aberta. Os jogadores comparam os símbolos para determinar o vencedor, sendo que a pedra vence a tesoura, amassando-a ou quebrando-a; a tesoura vence o papel, cortando-o; e o papel vence a pedra embrulhando-a. Ressaltase que os jogos, quando citados na obra de Nauman, envolvem algum tipo de ação corporal e doses de violência, explícita ou simbólica: o próprio joquempô, um jogo literalmente manual, carrega um conteúdo violento implícito.

4. Os registros fotográficos originais desta instalação bem como de outros trabalhos de Bruce Nauman constam na documentação reunida pelo galerista de longa data do artista, Leo Castelli, e que atualmente se encontra no Arquivo de Arte Americana do Instituto Smithsonian, em Washington (D.C),
Estados Unidos. 0 material foi consultado pessoalmente pela pesquisadora entre os dias 28 de maio e 01 de junho de 2012, durante o estágio de pesquisa no exterior.

5. The Consummate Mask of Rock e os demais textos mencionados neste capítulo encontram-se compilados e traduzidos no Apêndice desta tese. 


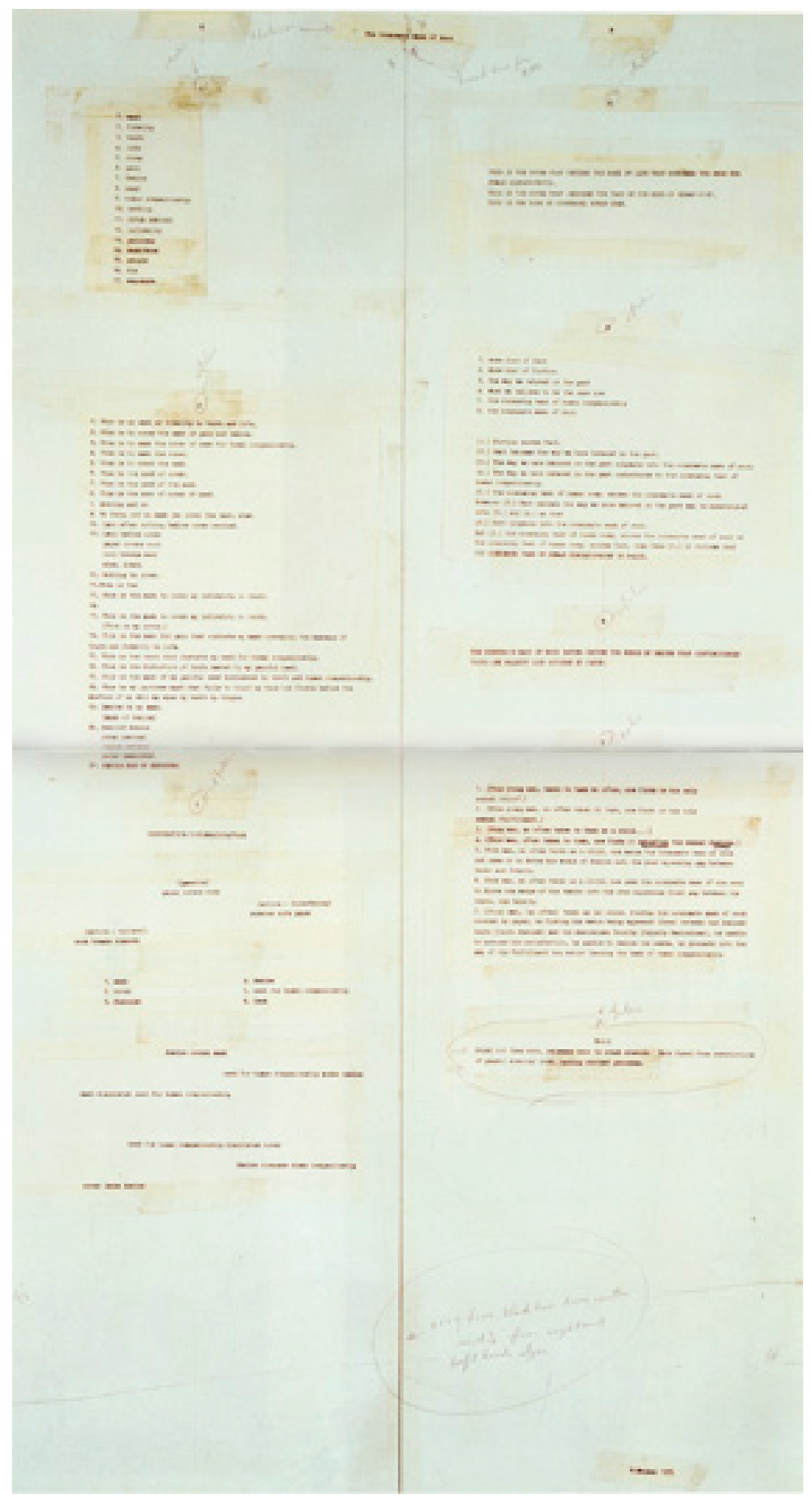

The Consummate Mask of Rock, 1975, texto datilografado, grafite, papel e fita adesiva, $100,3 \times 49,5 \mathrm{~cm}$. 
O texto conta com sete partes numeradas e simula, a princípio, obedecer a uma lógica rigorosa de exposição de ações e de seus efeitos causais. Na abertura, são listados itens diversos: "1. máscara; 2. fidelidade; 3. verdade; 4. vida; 5. cobertura; 6. dor; 7. desejo; 8. necessidade; 9. companhia humana; 10. nada; 11. cobertura revogada; 12. infidelidade; 13. indolor; 14. almíscar; 15. pessoas; 16. morra; 17. exposição" ${ }^{\circ}$. As seis outras seções resultam de combinações variadas entre as 17 proposições e termos inseridos a cada passagem, de modo que as asserções ganham complexidade conforme o texto avança. A composição implica uma estruturação cumulativa em aparente sequenciamento lógico. Embora reduzido, o elenco de palavras tem conteúdo emocional inequívoco e arranja-se de modo que seus significados são expandidos e tensionados numa reverberação desorientadora: "isto é para mascarar a cobertura da necessidade de companhia humana” (seção 2, item 3); "esta é a máscara para cobrir minha infidelidade à verdade/esta é a minha cobertura" (seção 2, item 13); "esta é a máscara da minha necessidade dolorosa torturada pela verdade e pela companhia humana" (seção 2, item 17); "esta é minha máscara indolor que fracassa em tocar minha face mas flutua diante da superfície da minha pele meus olhos meus dentes minha língua” (seção 2, item 18) .

Nessa toada, "o sistema lógico gradualmente desmorona e

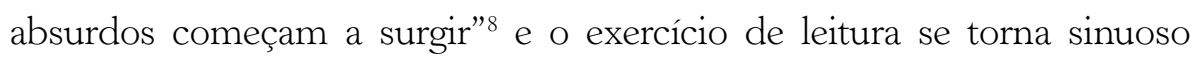
e presumidamente tão desconcertante quanto a "torção do espaço" vivenciada pelos visitantes da mostra. Os termos repetem-se e combinamse de modo surpreendente e, de rompante, emerge o conteúdo violento implícito no jogo somado a referências à sexualidade, como ocorre no início

6. "1. mask; 2. fidelity; 3. truth; 4. life; 5. cover; 6. pain; 7. desire; 8. need; 9. human companionship; 10. nothing; 11. cover revoked; 12. infidelity; 13. painless; 14. musk/skum; 15. people; 16. die; 17. exposure". Cf. Apêndice.

7. "This is to mask the cover of need for human companionship"/"This is the mask to cover my infidelity to truth/this is my cover"/"This is the mask of my painful need distressed by truth and human companionship"/"This is my painless mask that fails to touch my face but floats before the surface of my skin my eyes my teeth my tongue". Cf. Apêndice.

8. Cf. BRUGGEN, Coosje van. Op. cit., p. 195. 
da seção 3: "passivo" associa-se a "papel cobre pedra"; "ativo-ameaçador" liga-se a "tesoura corta papel"; e "ativo-violento" com "pedra quebra tesoura". Reiteram-se diversas vezes os termos desejo, necessidade, falta, carência, fidelidade, companhia humana. Assim como em outros escritos de Nauman, as camadas de significados são tecidas com a intromissão de palavras que sugerem que uma espécie de processo inconsciente (reprimido) está emergindo. A sétima seção do texto é um exemplo disso, trazendo excertos como: "este jovem homem, tão frequentemente repreendido, agora se dá conta de que esse é seu único alívio sexual” ou "este homem, tão frequentemente repreendido quando criança... (item 3 ) .

Nauman considera The Consummate Mask of Rock uma "pedra angular de sua prática”, uma obra na qual "os elementos espaciais e linguísticos são intercambiáveis, ligados por uma qualidade elíptica e dela inextricáveis" ${ }^{10}$. Os textos elaborados por Nauman especificamente para acompanhar certos trabalhos, como é o caso de The Consummate Mask of Rock e de outras instalações da década de 1970, jamais explicam esses trabalhos. Fornecem, em vez disso, informações de natureza diferente e se relacionam de viés com os demais elementos constitutivos das obras, isto é, mantêm pontos de contato, mas não se prestam a "explicálas". Escritos ou falados, os textos são frequentemente engendrados por procedimentos de repetição, permutação e saturação de termos e sentenças, tendo por consequência ora a ampliação ora a exaustão dos sentidos. O propósito é o de realçar a relação disjuntiva, elíptica e fragmentária que os textos mantêm com os elementos "físicos" dos trabalhos, de modo que os textos costumam "embaralhar" ou "embaçar" a compreensão das obras.

9. "This young man, taken to task so often, now finds it his only sexual relief/ This man, so often taken to task as a child...". Cf. Apêndice.
10. "Nauman regards this work as a cornerstone of his practice, in which the spatial and the linguistic elements are interchangeable, bound by and inextricable if elliptical quality". Cf. BORTHWICK, Ben. In: NAUMAN, Bruce. Raw materials. Londres: Tate Press, 2004, p. 138. 
A escrita de The Consummate Mask of Rock é densa e opaca como as pedras dispostas na galeria. O texto provê informações de outra natureza, mas "o poema e as pedras têm o mesmo peso", e, análogos, palavras e pedras cumprem funções semelhantes, desabituam a experiência de percepção do espaço e causam incômodos em graus variados. Nauman forja, desse modo, uma correlação entre o espaço físico e o "espaço mental e psíquico", e transtorna ambos. Afinal, conforme se argumenta nesta tese, Nauman propõe trabalhos que buscam perturbar ou mesmo inviabilizar a relação contemplativa do observador com a obra, ou no comentário bem-humorado de Robert Storr, "ao contrário de se acomodar na reconfortante 'poltrona' da pintura de Matisse, tomar assento na arte de Nauman é correr o risco de cair de cabeça” ${ }^{11}$.

Se, na literatura, comparar poemas às pedras é geralmente um modo de ressaltar a concisão compositiva, a austeridade e precisão com que o autor desbasta o texto e lapida detidamente a forma final ${ }^{12}$, no caso da obra de Nauman a comparação reforça, além disso, a ideia de que as palavras, assim como as pedras, são igualmente tratadas como materiais, equivalendo-se na condição de matéria-prima a ser testada com a mesma disciplina e rigor analítico como Nauman costuma tratar todos os materiais de que lança mão. Desdobrando a analogia, palavra é análoga à pedra e análoga ao corpo. Todos têm o mesmo estatuto, são materiais brutos (raw materials) e não há precedência de um material sobre o outro.

11. A referência do comentário é o conhecido escrito de Henri Matisse, "sonho com uma arte de equilíbrio, de pureza, de tranquilidade, sem temas preocupantes e inquietantes, uma arte que seja para qualquer trabalhador cerebral, quer o homem de negócios, quer o homem cultivado, por exemplo, um lenitivo, um calmante mental, algo como uma boa poltrona onde ele possa relaxar do cansaço físico" [MATISSE, Henri. Escritos e reflexões sobre arte. São Paulo: Cosac Naify, 2007, p.
47]. Cf. STORR, Robert Apud SIMON, Joan. Breaking the Silence. In: MORGAN, Robert C. (Ed.). Bruce Nauman. Baltimore: The Johns Hopkins University Press, 2002, p. 281. A frase de Robert Storr, no original, a saber: "unlike settling into the reassuring 'armchair' of Matisse's painting, to take one's seat in Nauman's art is to risk falling on one's head".

12. Na literatura brasileira, Carlos Drummond de Andrade (1902-1987) e João Cabral de Melo Neto (1920-1999) são bons exemplos. 


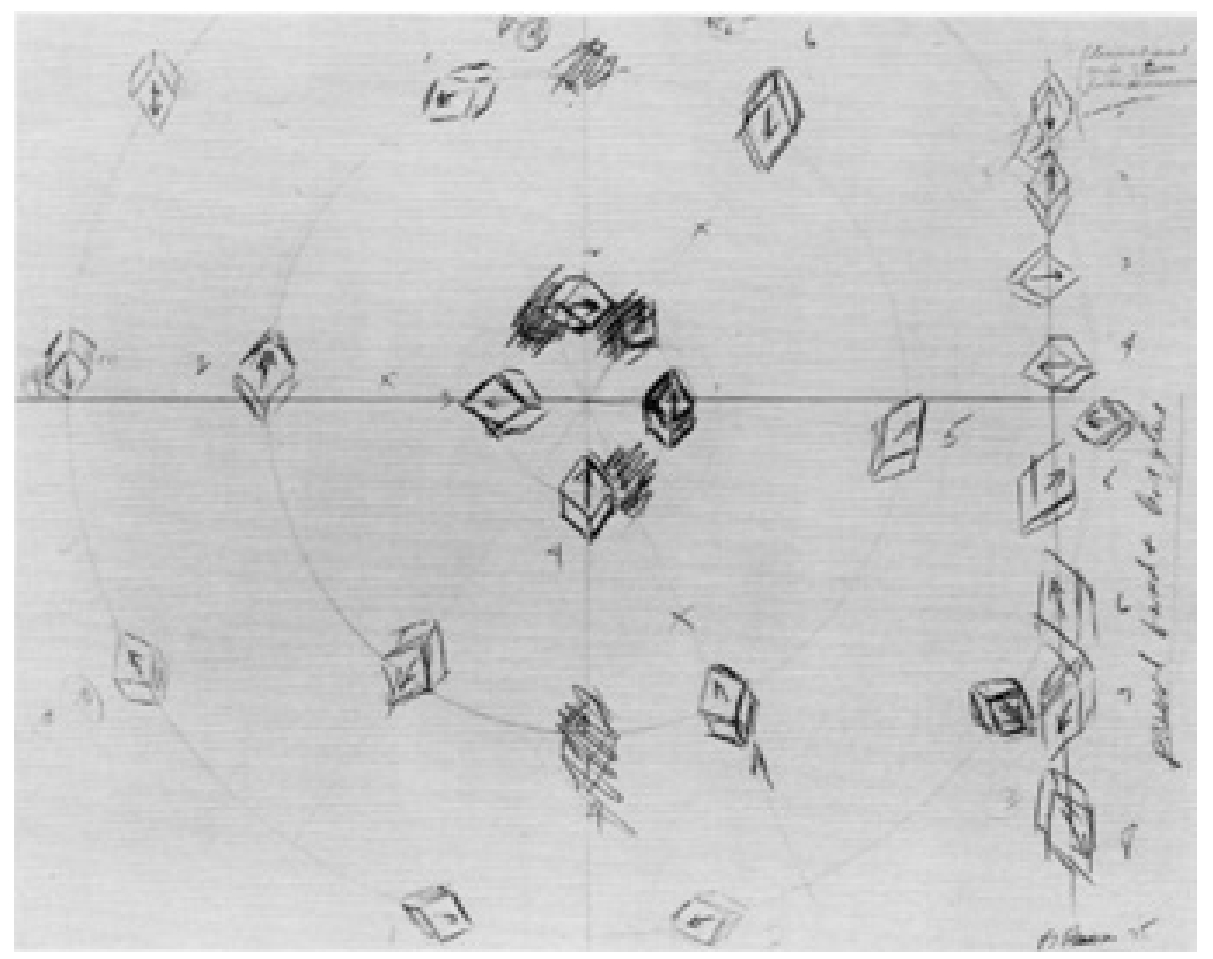

Sem título (Study for Diamond Mind), 1975, grafite sobre papel, 76,2 x 101,6 cm.

Sem título (Study for Forced Perspectives), 1975, grafite e colagem sobre papel, 74 x 162,2 cm.

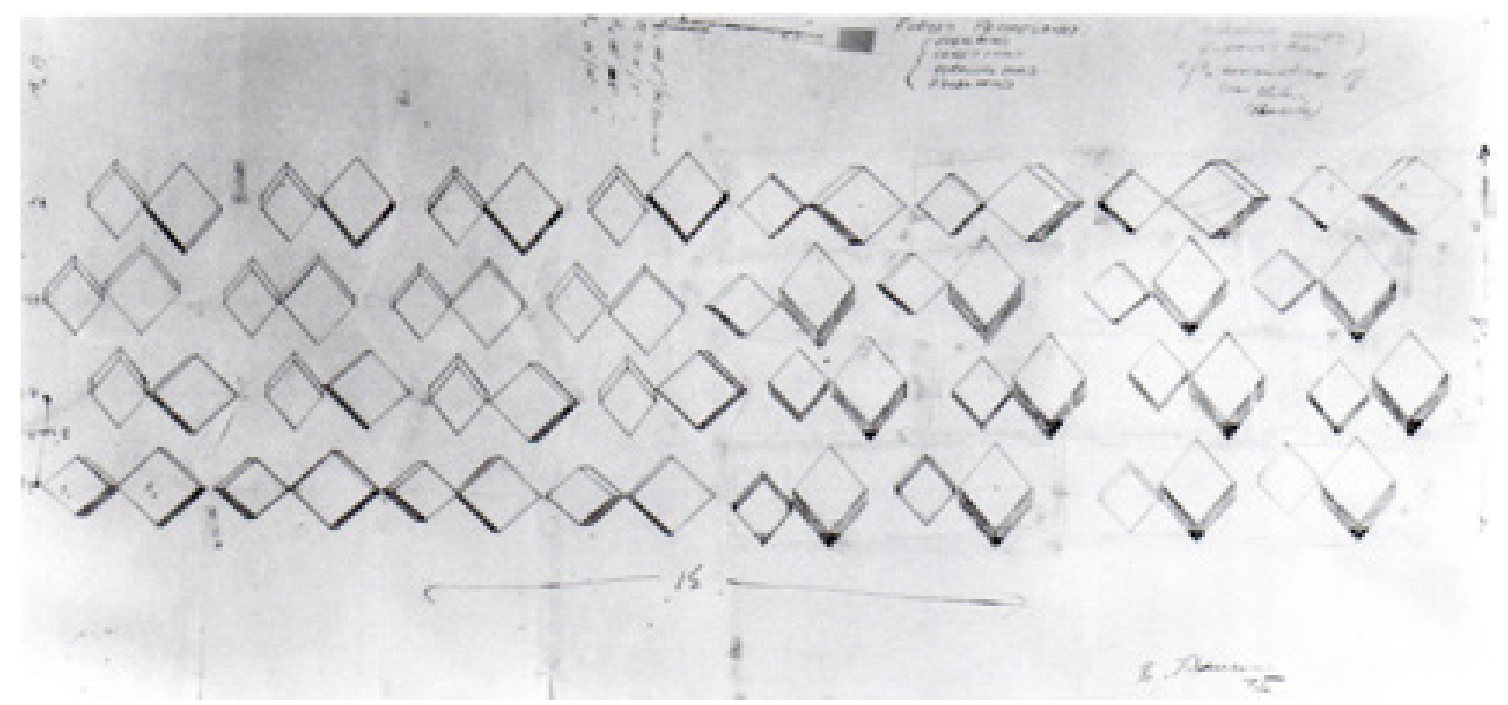




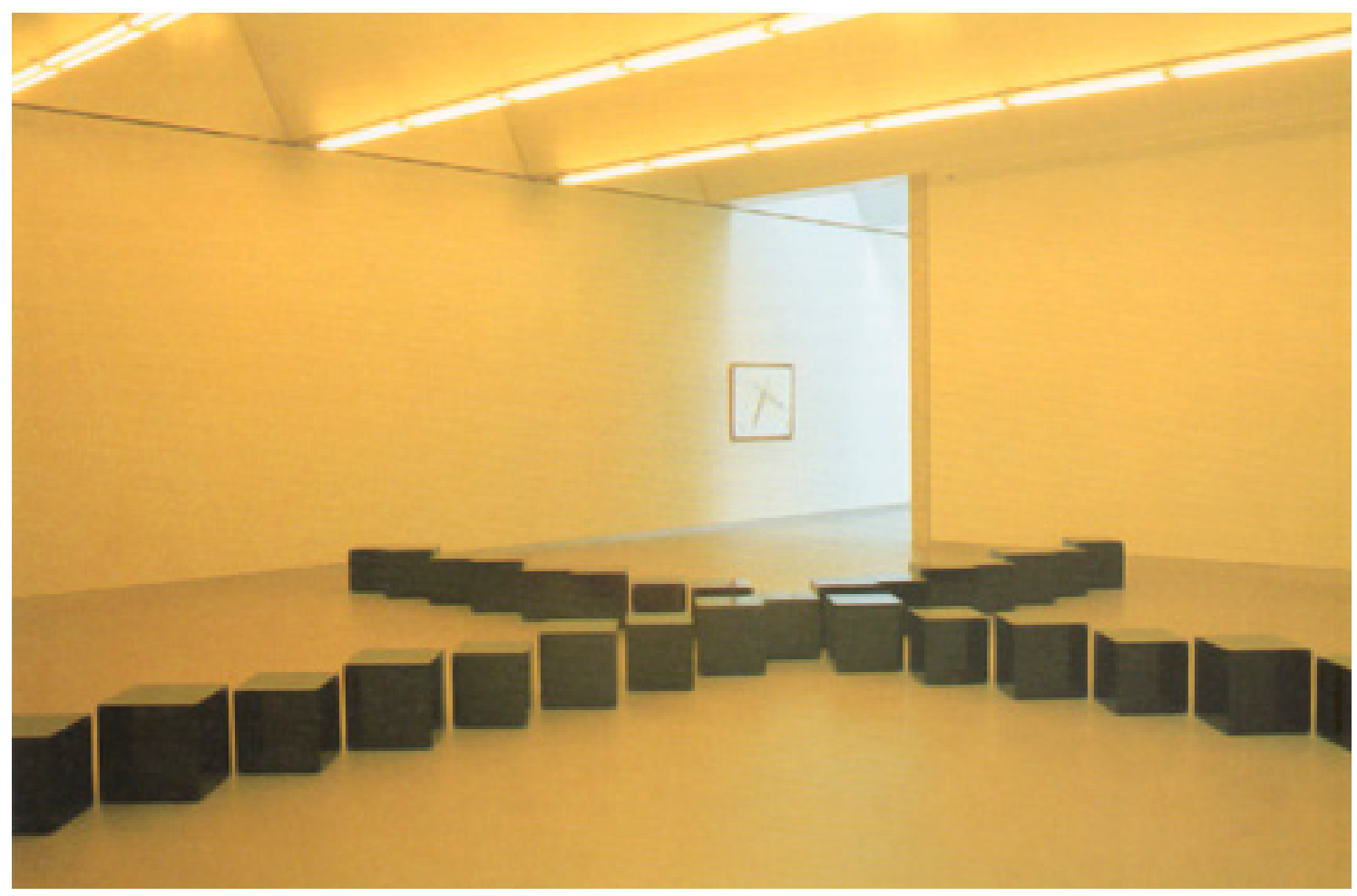

Black Marble with Yellow Light, 1971, blocos de madeira esmaltados e tubos fluorescentes, dimensões variáveis. 
O uso das palavras, escritas ou faladas, é reincidente e profuso nas cerca de cinco décadas de trajetória pública da obra. A produção textual de Nauman desdobra-se para além da escrita de artista e tende a passar ao largo de notas biográficas, ensaios críticos e filosóficos ou comentários sobre processos de trabalho. Dados pessoais, detalhes sobre seus métodos e motivações só são eventualmente fornecidos nas raras entrevistas concedidas ao longo dos anos. Nauman preserva seu silêncio e reclusão, reduzindo ao mínimo a dose de autoexposição no circuito profissionalizado ou mundano das artes, um cálculo que frustra ao mesmo tempo que intriga a audiência ${ }^{13}$. Conforme se comentou, é uma questão crucial para sua obra sopesar a quantidade de informação fornecida e a maneira correta de fazê-lo, buscando um ponto de tensão entre o que se mostra e o que é velado. Observando uma mesma disciplina de contenção nos trabalhos e em seus pronunciamentos públicos: people die of exposure [pessoas morrem de exposição], escreve Nauman no item 21, seção 2, de The Consummate Mask of Rock ${ }^{14}$.

Palavras são ritmadas nervosamente em neons de colorido pop, gravadas em chapas de metal, inscritas em pedras de aspecto tumular; são pronunciadas aos berros ou balbucios por cabeças-falantes, recitadas em cantilenas tediosas ou marteladas agressivamente por repetição; podem ser impostadas por um cantor de ópera ou então vocalizadas como um exercício amador; são emitidas como comandos estritos a que se deve obedecer ou servem às cenas simuladas de vaudeville, aos contos jocosos e piadas sem graça;

13. Cf. AUPING, Michael. Metacommunicator. In: NAUMAN, Bruce. Raw Materials. Londres: Tate Publishing, 2004, p. 8.

14. Numa entrevista concedida em 1975, ano em que escreveu este poema em prosa, Nauman declarou: "algumas das peças têm relação com a retirada de um pouco de informação para que se possa ir longe, mas não tão longe. Tenta-se criar um tipo de situação de tensão. Eu penso que isso tem relação com o meu medo pessoal de me expor [...] realmente queremos expor a informação, mas, por outro lado, temos medo de deixar que as pessoas invadam" I"some of the pieces have to do with taking away a little of information so that somebody can only go so far, and then can't go any farther. It attempts to set up a kind of tension situation. I think it has to do with a personal fear of exposing myself [...] we really want to expose the information, but, on the other hand, we are afraid to let people in"). Cf. KRAYNAK, Janet (Ed.). Op. cit., p. 182. 
vão das tolices aos palavrões, da neutralidade quase científica às obscenidades mais chulas. As palavras de Nauman descrevem, cumprimentam, agradecem, ordenam, humilham, constatam, falseiam, praguejam, suplicam, agridem. Aparecem em desenhos, gravuras, esculturas, filmes e vídeos, gravações de áudio ou projeções no espaço. A produção textual do artista abrange também anotações em desenhos, indicação de técnicas de montagem, descrição precisa de materiais e procedimentos (ou "falseamento" de materiais e procedimentos, como na escultura dos "cinco joelhos dos artistas famosos" já mencionada), algumas instruções para filmagens e rubricas para atores. Há propostas de trabalhos inexequíveis, instruções para exercícios físicos que exigem habilidade incomum ou treinamento espartano e diretivas para performances mentais. Sem mencionar os títulos escolhidos com diligência, que somam informações cruciais aos trabalhos de Nauman.

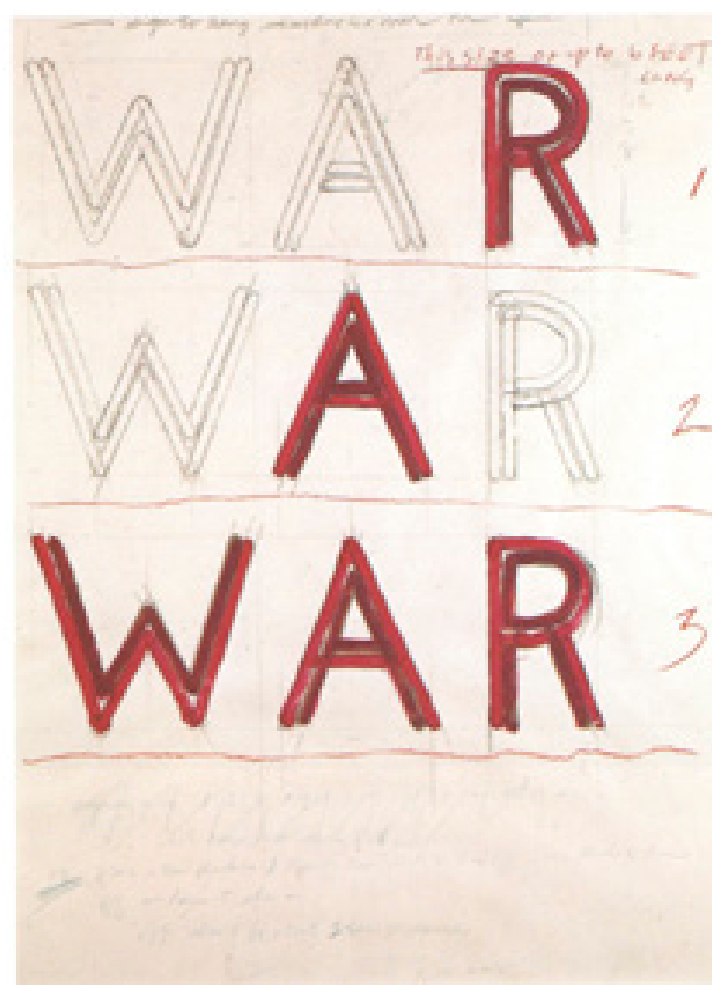


Diante disso, constata-se que o modo como ele trata as palavras escritas ou faladas - os textos para serem lidos ou ouvidos pela audiência está em perfeita consonância com os demais movimentos da obra: com a mesma desenvoltura e rigor analítico como lida com os demais materiais, Nauman testa minuciosamente as palavras em suas muitas funções, no espaço do papel e no espaço físico, no limite de desnaturá-las ou exaurilas. De modo semelhante ao que procede com todas as matérias-primas que elege, o artista, vez ou outra, desfaz e refaz um texto originalmente elaborado para uma situação determinada e o reedita num contexto diverso, ponderando as especificidades da nova circunstância.

O viés explicativo, estritamente funcional da linguagem, é o que menos importa para o artista ${ }^{15}$. Interessa-lhe, ao inverso disso, o ponto em que a linguagem é tensionada no limite de sua eficácia, quando falha ou se torna pouco eficiente, quando deixa de ser um mero instrumento para garantir a efetividade da comunicação, quando perde a clareza e ganha ambiguidade, "o ponto onde a linguagem deixa de funcionar como uma ferramenta útil para a comunicação é o mesmo limite onde poesia e arte ocorrem" ${ }^{16}$. Nauman argumenta que diante da falha, do erro, da dificuldade de compreensão imediata, "você se vê forçado a estar ciente dos sons e das partes poéticas das palavras". Além do que, "se você lidar somente com o que é conhecido, haverá redundância, por outro lado, se você lidar somente com o desconhecido, não poderá comunicar de jeito algum. Haverá sempre uma combinação entre as duas coisas e o modo como uma toca na outra é o que torna a comunicação interessante" ${ }^{17}$.

15. Nauman afirma que "o lugar onde a linguagem comunica melhor e mais facilmente é também o lugar onde ela é menos interessante e emocionalmente envolvente" ["the place where it communicates best and most easily is also the place where language is the least interesting and emotionally involving"]. Cf. KRAYNAK, Janet (Ed.). Op. cit., p. 354.

16. "I think the point where language starts to break down as a useful tool for communication is the same edge where poetry or art occurs". Cf. KRAYNAK, Janet (Ed.). Loc. cit. 

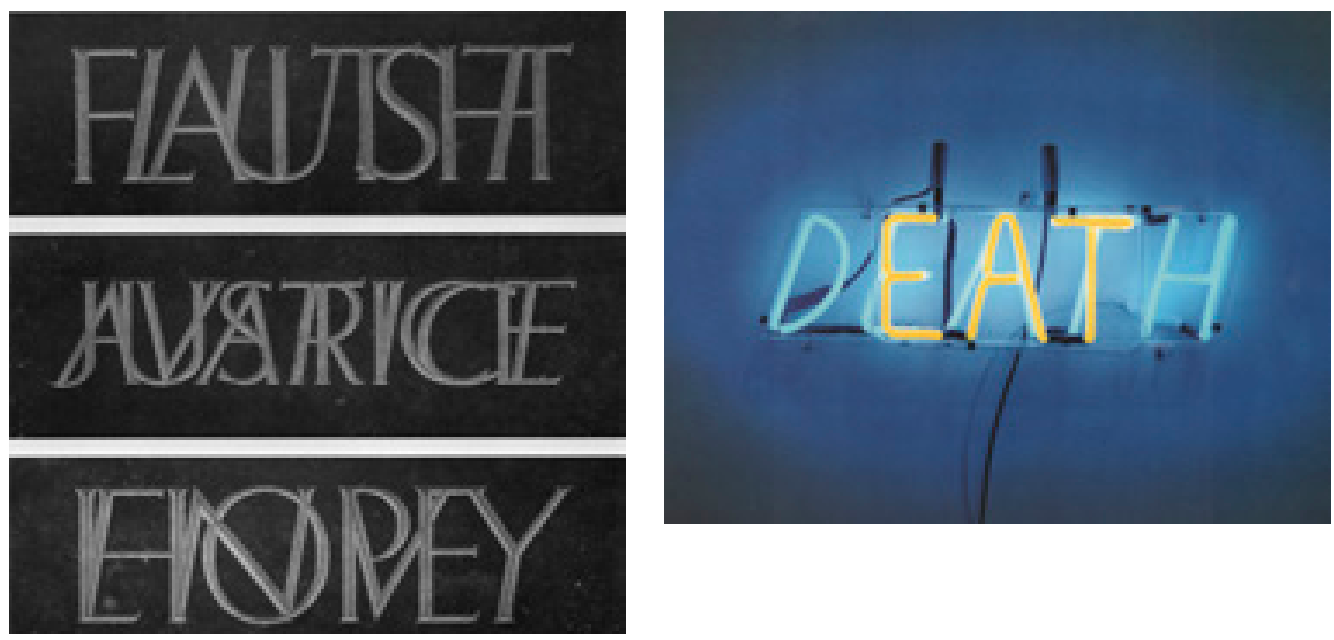

Seven Virtues and Seven Vices, 1984, granito, 60,3 x $120 \mathrm{~cm}$.

Eat/Death, 1972, tubos de neon, $19 \times 64 \times 5 \mathrm{~cm}$.

Nauman pretende alcançar um "chiaroscuro da linguagem"18, embaçando, ou melhor, "borrando" propositalmente a nitidez dos sentidos exigida dos processos comunicativos competentes, mas não da arte. Para atingir a opacidade pretendida, ele desencaixa as palavras dos contextos habituais de uso, realça entonações inadequadas ao significado ou à utilização cotidiana de um termo ou então infiltra nos discursos elementos ardilosos de disrupção, injetando metodicamente doses precisas de gracejos, sarcasmo ou crueldade que corroem qualquer hábito cristalizado.

17. "[...] you are forced to be aware of the sounds and the poetic parts of words. If you deal only with what is known, you'll have redundancy; on the other hand, if you deal only with the unknown, you cannot communicate at all. There is always some combination of the two, and it is how they touch each other that makes communication interesting". Cf. KRAYNAK, Janet (Ed.). Loc. cit.

18. Expressão tomada de empréstimo de Robert Storr que assevera que no chiaroscuro "reside a beleza da obra [de Bruce Nauman], embora, assim como no chiaroscuro dos pintores do Barroco, os conteúdos parcialmente escondidos e parcialmente revelados muitas vezes sejam alarmantes". Cf. STORR, Robert. Beyond Words. In: SIMON, Joan (Ed). Bruce Nauman: Exhibition Catalogue and Catalogue Raisonné. Minneapolis: Walker Center Art, 1994, p. 53. Trecho completo, no original: “[...] Nauman's technique of rendering ideas depends on a kind of linguistic 'chiaroscuro' - that is, an artful alternation of clarity and obscurity. Therein lies his work's beauty, though like the chiaroscuro painters of the Baroque, his partially hidden and partially revealed content is often alarming". 
Nauman propõe jogos linguísticos simples como a inversão das palavras nas frases ou das frases no discurso; o uso de palavras de duplo sentido entrecortando textos aparentemente sisudos com conteúdo sexual e escatológico; a interpretação literal de expressões idiomáticas com o auxílio do repertório visual, sobretudo com o uso da fotografia; e a elaboração de aliterações, trocadilhos, palíndromos e anagramas. Mesmo a função sintática dos termos empregados é frequentemente ambígua, às vezes sendo difícil decidir mesmo quanto ao tempo verbal de algumas frases. O desafio é manter, a um só tempo, coesão e ambiguidade. Para tanto, Nauman toma as palavras com a mesma avidez com que inspeciona qualquer material, como se fosse possível virá-las do avesso como moldes de fibra de vidro, ou torcê-las como um pedaço de feltro, ou apagá-las com maquiagem de tinta colorida, ou curvá-las como a uma barra de ferro, ou atirá-las numa quina de parede como fez com seu corpo. Com a mesma pertinácia e minúcia com as quais examina os parcos recursos à mão num ateliê quase vazio, Nauman detecta e extrai a capacidade potencial de desconforto ou incivilidade que subjaz no uso trivial de frases-feitas ou de certos vícios de linguagem banalizados no dia a dia. O resultado, por vezes, tem qualidade literária inegável e carga emocional desconcertante.

A linguagem é tão crua que chega a ser crassa, rude. As frases costumam ser curtas e estruturadas na forma direta. Não há volteios retóricos, vocabulário sofisticado ou loquacidade fora de lugar. Sujeito, verbo, complemento. Ou só verbo e conectivo. Ou apenas uma sentença ou uma palavra sozinhas e repetidas à exaustão. Ou uma mistura pouco discernível de fonemas, quase uma cacofonia. Assim como Beckett, Nauman consegue o máximo efeito com o mínimo recurso, comunica extraindo muito de quase nada.

Se a comparação com Beckett volta a ser adequada e incontornável neste ponto da argumentação, torna-se também necessário ressaltar que a simplificação e o empobrecimento da linguagem foi um projeto que mobilizou a obra de Beckett em toda a sua extensão, um norte perseguido 


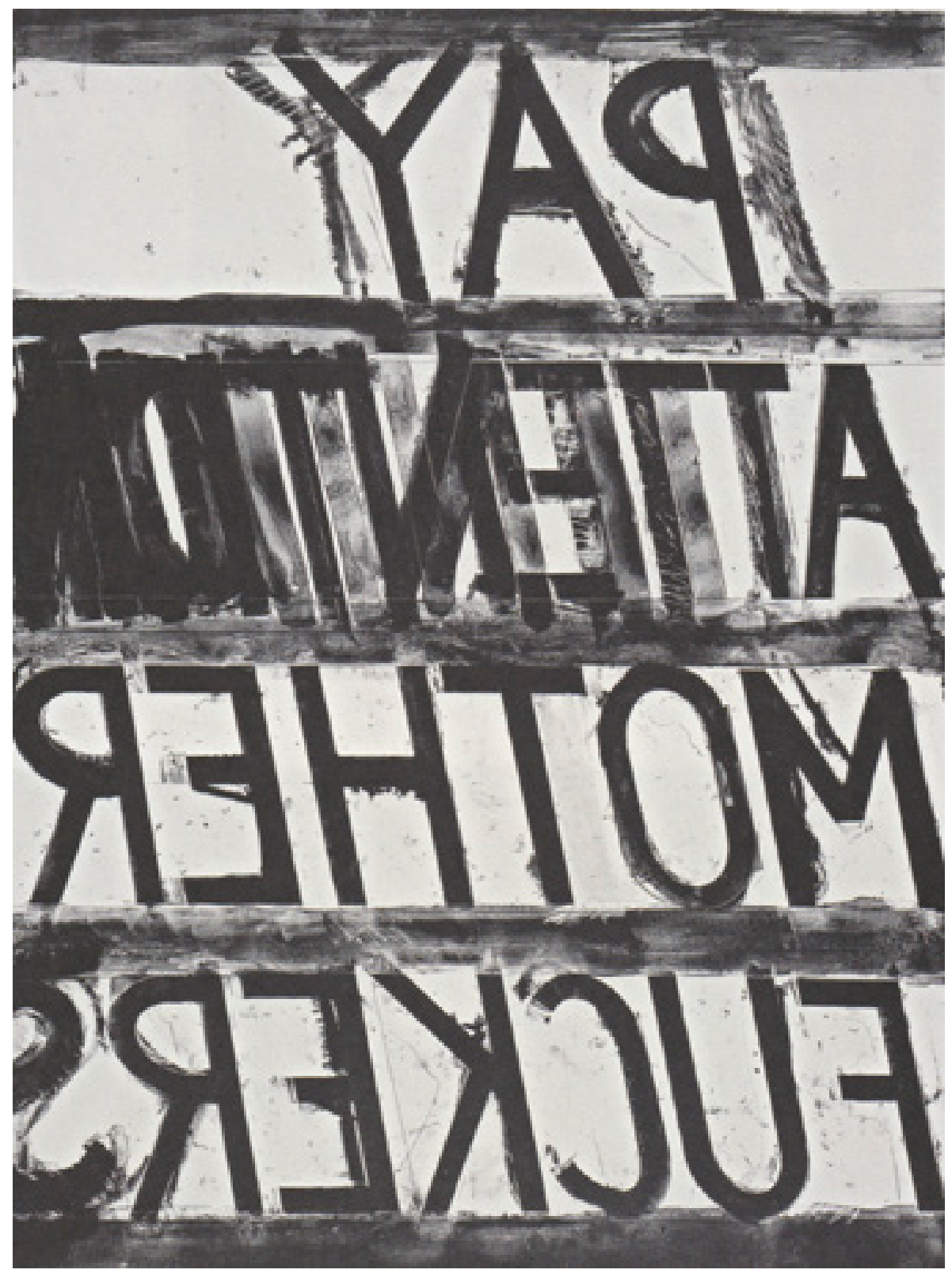

Pay Attention, 1973, litografia, 97 x $72 \mathrm{~cm}$. 
obstinadamente e que exigiu disciplinados ataques contra a própria eloquência, a primeira das estocadas contra a fluência no inglês e que resultou no seu propalado bilinguismo voluntário. Os passos dados por Beckett rumo à "literatura da despalavra"19 e as reverberações que esses passos produziram no interior da obra, em seu processo de composição, e, por outro lado, as consequências inescapáveis que suas ideias imprimiram na literatura e na dramaturgia atuais são assuntos detidamente tratados por muitos estudiosos da obra do escritor, uma discussão profícua e com farta fortuna crítica, mas que foge ao escopo desta tese ${ }^{20}$. A obra de Beckett, assim como Watt, personagem com o qual o Nauman do filme de 1968 vagamente se assemelha, também realizou sua própria caminhada lenta em ângulo, "rumo ao pior". A esta tese cabe somente um flagrante do arremesso de uma perna lançada ao sul ou um giro de tronco para o norte.

De todo modo, é oportuna a menção da conhecida carta que, em 1937, Beckett envia a Axel Kaun, nela relatando a decisão de abandonar a escrita num "inglês oficial" e constatando que "a linguagem é mais eficientemente empregada quando mal empregada", assertiva que não deixa de ser um indício precoce do vetor que passará a orientar a produção, o "falhar melhor" 21 , uma expressão síntese que faz do insólito par, fracasso e persistência, consortes inseparáveis. Eis um trecho da "Carta Alemã":

Está se tornando mais e mais difícil, até sem sentido, para mim, escrever num inglês oficial. E, mais e mais, minha própria língua me parece como um véu que precisa ser rasgado para chegar às coisas (ou ao Nada) por trás dele. Gramática e Estilo. Para mim, eles parecem

19. Expressão cunhada por Beckett em carta escrita para Axel Kaun, em 1937, a chamada “Carta Alemã”. Cf. ANDRADE, Fábio de Souza. Samuel Beckett: o silêncio possível. São Paulo: Ateliê Editorial, 2001, p. 170.

20. Entre os estudiosos beckettianos brasileiros, destacam-se Fábio de Souza Andrade, Luiz Fernando Ramos, Celia Barrettini,
Gabriela Borges, Ana Helena Souza, Cláudia Vasconcellos, entre outros (Cf. referências bibliográficas desta tese). Cite-se também o prefácio de João Adolfo Hansen para a tradução brasileira de 0 Inominável.

21. Cf. Nota 29 do Capítulo 3. [“Ever tried. Ever failed. No matter. Try again. Fail again. Fail better"]. 
ter se tornado tão irrelevantes quanto o traje de banho vitoriano ou a imperturbabilidade do verdadeiro cavalheiro. Uma máscara. Tomara que chegue o tempo, graças a Deus que em certas rodas já chegou, em que a linguagem é mais eficientemente empregada quando mal empregada. Como não podemos eliminar a linguagem de uma vez por todas, devemos pelo menos não deixar por fazer nada que possa contribuir para sua desgraça. Cavar nela um buraco atrás do outro, até que aquilo que está à espreita por trás - seja isto alguma coisa ou nada - comece a atravessar; não consigo imaginar um objetivo mais elevado para um escritor hoje $\mathrm{e}^{22}$.

Beckett "cava os buracos" escrevendo contra a linguagem ou, segundo afirma na mesma carta, esforça-se para encontrar um método pelo qual se possa "representar esta atitude de ironia para com as palavras, através das palavras” ${ }^{23}$. Dizer para desdizer o dito, dizer menos, dizer mal. Com ironia cáustica dissolve a loquacidade, comprime ou elimina os elementos da linguagem até o mínimo possível: descasca das palavras o sentido, rarefaz o discurso, atrapalha a enunciação, destrói a sintaxe, estraçalha os fluxos de consciência dos personagens, depaupera o vocabulário, e, quando chega ao que julga mínimo tira dele possibilidades infinitesimais, repete, fadiga, exaure.

Dificílimo simplificar, chegar ao mínimo com alguma capacidade de comunicar algo, de comunicar "o nada a ser expresso" ["nothing to express"]. Pelo menos desde os romances da trilogia do pós-guerra-Molloy (publicado em 1951), Malone Morre (1951) e O Inominável (1953)²4, os personagens de Beckett estão às voltas com o "não querer dizer, não saber

22. Trecho extraído da tradução de Fábio de Souza Andrade. Cf. ANDRADE, Fábio de Souza. Op. cit., p. 169.

23. Cf. Ibidem, p. 170.

24. Embora primeiramente publicados nas datas mencionadas - Molloy e Malone Morre em 1951 e O Inominável em 1953 - consta que os três romances teriam sido escritos respectivamente em 1947, 1947-1948 e 19491950 [Cf. BECKETT, Samuel. The Selected Works of Samuel Beckett. Vol. II Novels. Nova York: Grove Press, 2010, p. 522]. Para uma análise cuidadosa dos romances da trilogia consultar o supracitado livro de Fábio de Souza Andrade, Samuel Beckett: o silêncio possível. 
o que se quer dizer, não poder dizer o que se acredita que se quer dizer, e sempre dizer ou quase, isto é que é importante não perder de vista no calor da redação", nas palavras de $\mathrm{Molloy}^{25}$, uma variação do célebre dito do autor sobre o "dilema feroz da expressão", proferido em 1949, justamente em conversas com Georges Duthuit a pretexto das pinturas de Tal Coat, Andre Masson, Bram Van Velde: "não há nada a expressar, nada a partir do que expressar, nenhuma possibilidade de expressar, nenhum desejo de expressar, aliado à obrigação de expressar" ${ }^{26}$.

Concomitantemente a esse esburacar da linguagem, o corpo sofre, na obra de Beckett, processos incessantes de contenção e redução: é paralisado, aleijado, violentado, retido, desmembrado, ressequido, perfurado, até que se assemelhe a um não-corpo: sobram das cabeças falantes ou apenas uma boca, às vezes também ouvidos e os outros buracos. Sobram vozes, emitidas no espaço ou confinadas no crânio. Se ainda lhes restam os corpos, falhos que sejam, os personagens neles padecem extenuação física e mental: enfrentam tarefas excruciantes sem finalidade aparente, atêm-se a infindáveis rotinas preparatórias, postergam à irresolução aflições prementes, sujeitamse a experiências claustrofóbicas e a humilhações grotescas. Alguns deles vivem em agonia sem remate, compelidos unicamente a saciar seus ritmos metabólicos, reduzidos à mera fisiologia ${ }^{27}$. Se é que se pode chamar de fisiológicas as necessidades de um organismo assistemático. Corpos falhos que emitem linguagem falha. Ou melhor dizendo, secretam palavras.

25. Conforme já citamos no capítulo precedente, Molloy é personagem do livro homônimo. Cf. BECKETT, Samuel. Molloy. Tradução de Ana Helena Souza. São Paulo: Globo, 2007, p. 49.

26. Conforme comenta Fábio de Souza Andrade acerca da tradução de Três Diálogos com Georges Duthuit, perde-se com a dupla negativa necessária no português o sentido positivo da formulação no inglês, já que "nothing to express" pode significar tanto que não há nada a expressar como também que há justamente este nada a ser expresso. No original, "there is nothing to express, nothing with which to express, nothing from which to express, no power to express, no desire to express, together with the obligation to express". Cf. ANDRADE, Fábio de Souza. Op. cit., p. 175.

27. Para um desenvolvimento mais consequente da questão do corpo em 0 Inominável, além do prefácio de João Adolfo Hansen para a tradução brasileira [Cf. HANSEN, João Adolfo. Eu nos faltará sempre. In: BECKETT, Samuel. 
A propósito das falhas e deformações impostas à linguagem e ao corpo na obra de Beckett, o prefácio de João Adolfo Hansen para a tradução brasileira de $O$ inominável alerta-nos que se trata de "deformações imanentes”, que não pressupõem originais, não se remetem a modelos, a essências ou a esquemas tradicionais de representação:

O corpo que a voz de O Inominável figura como sendo o seu não tem essa unidade suposta. Faltam-lhe órgãos. Dessubjetivado, é cômico - e não porque faça rir. [...] É cômico porque deformado, sem que a deformação possa ser entendida como derivação, desvio ou distorção de uma unidade prévia qualquer de significação ou sentido. $\mathrm{Na}$ figuração clássica e na representação realista, que Beckett destrói, a deformação é sempre diferença definida e capturada como semelhança degradada de um modelo unitário - o Ideal, o Essencial, o Um, o Uno, o Belo, o Bom, o Justo, o Natural, o Racional, o Científico, o No-Lugar, o Nacional, o Formado, o Formatado etc. Como outros grandes artistas modernos - Picasso, Giacometti, Dubuffet, Bacon são os que aparecem imediatamente - Beckett produz deformação imanente, sem modelo: o corpo que a voz inventa se repete deformado em si, sem nariz, sem orelhas, sem pálpebras, sem sexo, encharcado em lágrimas involuntárias que choram sem parar por nada e por ninguém ${ }^{28}$.

Se o corpo habitado pela voz em $O$ inominável desconsidera os padrões de representação "clássico-romântico-realista-naturalista-organicista" ${ }^{29}$, também à voz não se pode atribuir significações e sentidos unívocos, ela diz em solilóquio séries de aporias, afirmações e negações simultâneas, situando-se aquém de uma identificação com um eu que

0 inominável. Tradução de Ana Helena Souza. São Paulo: Globo, 2009], consultar o capítulo intitulado "O Inominável ou a Vida no Limbo", do já citado livro de Fábio de Souza Andrade, especialmente as páginas 152 e 153 . 0 posfácio de Ana Helena Souza para a tradução que realizou de Como é (publicado em francês em
1961 e em inglês em 1964) também aborda sucintamente a questão (Cf. Como é: Limites e desenvolvimentos da prosa de ficção. In: BECKETT, Samuel. Como é. Tradução de Ana Helena Souza. São Paulo: 2003, p. 167-178).

28. Cf. HANSEN, João Adolfo. Op. cit., p. 10.

29. Cf. Idem, p. 12. 
possa lhe conferir subjetividade inequívoca: a voz "ocupa sempre a mesma posição pelo meio, no meio, entre significação e sentido" ${ }^{30}$.

Por um lado, o processo de depauperamento da linguagem em O Inominável e nas obras posteriores de Beckett teve por pano de fundo incontornável as abjeções perpetradas nas duas grandes guerras e a consequente experiência de destituição espiritual a ser elaborada - "um mundo mesquinho e mutilado" ${ }^{11}$ eivado por relações humanas igualmente miseráveis; por outro lado, o autor também tinha no horizonte a própria crise histórica da forma dramática e das convenções narrativas, já em curso desde, pelo menos, o final do século XIX, de modo que se há um diagnóstico de época subjacente aos lances irredutíveis de Beckett contra a linguagem, esse diagnóstico passa necessariamente pelas fraturas observadas no próprio material artístico, pelo exame cuidadoso do estado em que se encontrava a ficção e a arte em geral. Diante disso, justificam-se, por exemplo, as objeções de Theodor Adorno (1903-1969) contra a recepção da obra de Beckett pelas correntes tributárias do existencialismo francês, que interpretavam o absurdo de suas peças teatrais - o termo "teatro do absurdo" foi cunhado à época - imediatamente como um non-sense ilustrativo da ausência de sentido da condição humana no pósguerra. Nem a obra é non-sense, nem pretende restaurar um sentido metafísico decaído: "as peças de Beckett são absurdas não pela falta de sentido, pois então seriam simplesmente irrelevantes, mas porque põem o sentido à prova, desdobrando sua história” ${ }^{2}$. Antes de mais nada, Beckett teria elaborado a

30. Cf. Idem, p. 21.

31. Expressão tomada de empréstimo da seguinte interpretação de Fábio de Souza Andrade acerca da leitura que Adorno faz de Beckett: "aos olhos de Adorno, trata-se, ao mesmo tempo, de um reflexo, reprodução do mundo mesquinho e mutilado em um nível segundo, imaginário, e sua reelaboração na forma conferida ao (in) significante, denunciando a privação de sentido do sujeito e da realidade. As particularidades da sintaxe e do estilo Beckttiano se resumem a este paradoxo: num mundo privado de sentido imanente, a partir de um sujeito esvaziado da capacidade de reflexão, é preciso elaborar formas significativas, ao mesmo tempo denúncia e cópia deste estado de coisas". Cf. ANDRADE, Fábio de Souza. Op. cit. p. 31.

32. Trecho traduzido a partir da versão para o inglês da Teoria Estética de Adorno: "Beckett's plays are absurd not because of the absence of any meaning, for then they would be simply irrelevant, but because they put meaning on trial, they unfold its history". Cf. ADORNO, Theodor W.. Aesthetic Theory. Londres, Nova York: Continuum, 1997, p. 153. 
experiência da dissolução do sentido internamente à forma literária, no próprio cerne das categorias do drama e do romance, expondo a inadequação, o descompasso ou mesmo a obsolescência das formas literárias tradicionais.

Em suas obras do pós-guerra, Beckett faz uso das formas artísticas tradicionais como quem manipula um objeto antiquado. É assim que Adorno caracteriza o recurso aos elementos constituintes do drama em uma peça como Fim de partida (1957). Com o colapso de muitos dos pressupostos que haviam moldado o drama da era burguesa, tais como a noção de liberdade individual e uma concepção progressista do tempo histórico, o gênero não tem mais condições para apresentar, entre outros, aquela curva dramática que, pela intensificação de um conflito intersubjetivo, estilizado no diálogo entre as personagens, encaminha a ação para um desfecho ${ }^{33}$. Os elementos, porém, que constituíam esse gênero dramático em sua história, não desaparecem da peça. Eles continuam por ali, mas privados de sua função original. Aos olhos de Adorno, um dos muitos méritos de Fim de partida reside no fato de Beckett não ter ignorado tal problema formal, mas, ao contrário, tê-lo alçado à posição de conteúdo mesmo do drama. Nesse sentido, a impossibilidade de arrematar a peça com um desfecho concludente, que conferiria sentido retrospectivo à ação transcorrida, transforma-se em um tema trabalhado pela peça em múltiplas variações. Da mesma maneira, pressupostos metafísicos do drama, como a ideia de um sentido unificador ou então o vínculo entre interioridade psicológica e expressividade corporal, perpassam a peça como vestígios de uma época ultrapassada pelo curso recente da história. A estratégia adotada por Beckett, diz o crítico, teria sido empreender uma paródia do drama. Paródia, para Adorno, define-se como "a utilização de formas na época de sua impossibilidade" ${ }^{34}$, estratégia que confere à obra beckettiana, portanto, uma alta consciência a respeito da historicidade de seu material. 
Ora, a crise da forma literária enfrentada por Beckett é uma das facetas da crise histórica da representação que marcou toda a arte moderna. $\mathrm{Na}$ modernidade, a arte assumira a condição de sua bastardia e se deixara contaminar com os materiais prosaicos da cultura, tornando problemática a dedução de um absoluto, de uma essência. Especificamente nas artes visuais, Picasso talvez seja um exemplo notável desse enfrentamento: o artista fez da própria história da arte seu material primeiro e reduziu o repertório da tradição à condição de imagem, tirou-lhe a espessura histórica, e, frequentemente, citou e reorganizou as formas tradicionais em desabusado tom paródico. Além do que, o flerte de Picasso com o imaginário da cultura de massa, com os materiais cotidianos, infiltrouse por toda a obra, alcançando aquelas nas quais se lançou contra a representação convencional do corpo na pintura. Picasso, segundo argumenta Leo Steinberg, experimentou incansavelmente formas novas de figurar o corpo humano partindo não apenas dos corpos reais dos modelos-vivos, mas sobretudo dos corpos já representados na própria história da pintura (Velázquez, Poussin, Delacroix, Ingres, Courbet, Manet, Cézanne, Matisse, só para citar alguns) e, mais do que isso, da imagem lugar-comum do corpo feminino na cultura de massas, "apossando-se do poder expressivo e estrutural do clichê", tomando a figura feminina como fórmula pronta para abastecer o repositório da imaginação e, obviamente, da fantasia erótica ${ }^{35}$. Picasso apropriava-se das imagens banais e testava os limites da representação do corpo: torcendo, comprimindo, deformando,

fugindo do objeto específico desta tese. Para compreender as implicações da leitura que Adorno fez de Fim de partida recomenda-se o ensaio de Luciano Ferreira Gatti, "Adorno e Beckett: as aporias da autonomia do drama" [manuscrito enviado para publicação na revista Kriterion (2013)].

35. A bibliografia sobre a obra de Picasso é das mais extensas e, nela, os ensaios do crítico norte-americano Leo Steinberg (1920-2011) merecem lugar de destaque; para mencionar alguns: "Picasso: observando o sono" (1968); “Os crânios de Picasso" (1971); “0 bordel filosófico" (1972); “As mulheres Argelinas e Picasso em aberto", publicado em Outros critérios (1972/2008); “O fim de partida de Picasso" (escrito em 1988 e publicado em 1995). 0 comentário de Steinberg mencionado no texto foi extraído do ensaio dedicado às mulheres de Argel ICf. STEINBERG, Leo. Outros critérios: confronto com a arte do século XX. São Paulo: Cosac Naify, 2008, p. 163-288). 
desmembrando-o em partes para depois rejuntá-las com capricho de modo que pudessem, em alguma medida, funcionar como um corpo, um corpo transtornado mas ainda assim um corpo. A "deformação imanente do corpo" na obra de Picasso, diferentemente do que se disse da obra de Beckett, não implica a perda da unicidade orgânica, por mais que resulte em organismos improváveis. Basta lembrar da recorrência de representações simultâneas de frente e dorso das figuras, com a qual Picasso fazia coabitar órgãos e partes anatômicas antípodas numa mesma superfície sem a perda da sensação de integridade corporal. De fato, o artista propôs formas inovadoras de figurar o corpo na pintura e fez apostas cada vez mais altas desde, pelo menos, Les Desmoiselles d' Avignon (1907), com suas as cinco figuras monumentalizadas, altivas, brutais de tão sólidas, compactadas, quase caricaturas de tão resumidas.

A menção a Picasso soa extemporânea em relação a Nauman, todavia quando perguntado se, na história da arte, algum artista em particular teria lhe ensinado algo, Nauman surpreendentemente respondeu: "Picasso tanto quanto qualquer outro" ${ }^{36}$. O assunto, entretanto, não foi desenvolvido e nem retomado em outra ocasião, de maneira que não é possível precisar as implicações da declaração de Nauman. Cogita-se que ele não teria deixado de notar os modos complexos do comparecimento do corpo na obra de Picasso, a crueza das formas, a equivalência entre os materiais prosaicos e tradicionais, o interesse por manifestações do grotesco na cultura de massas, entre outros aspectos da obra do espanhol que possam dizer respeito à sua própria produção ${ }^{37}$.

36. Transcreve-se o trecho correspondente da entrevista concedida a Michele de Angelous, em 1980, “MD: Is there anybody - any historical artist's work that's important to you, or whom you admire, or have learned things from? BN: Well, certainly Picasso. I think Picasso as much as anybody. Cf. KRAYNAK, Janet (Ed.). Op. cit., p. 274.
37. Um exercício de aproximação pontual entre as obras de Nauman e Picasso foi feito pela doutoranda no âmbito do Seminário Internacional Picasso Outros Critérios, ocorrido em novembro de 2012, na conferência intitulada "O corpo e o grotesco nas obras de Picasso e Bruce Nauman". 

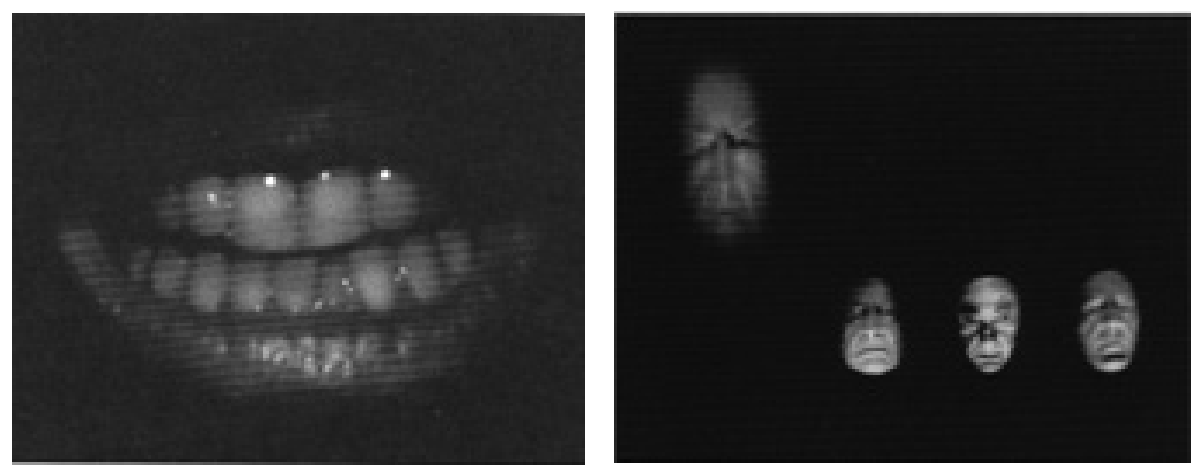

Samuel Beckett, Not I, 1989.

Samuel Beckett, What Where, 1978.

É importante retomar, neste ponto, a aproximação com a obra de Beckett, uma vez que muitos dos textos de Nauman, notadamente os posteriores à década de 1980, constroem-se por circularidade ou reiteração de poucos termos simples, estruturados em combinatórias, por vezes sutilmente nuançadas, cuja repetição exaustiva pretende conduzir experiências de saturação dos sentidos, desgaste físico e extenuação mental. Se, nos vídeos já comentados das décadas de 1960 e 1970, os procedimentos de repetição, contenção e saturação formalizavam-se mais nitidamente nos movimentos padronizados do corpo do artista inspecionando as possíveis informações dadas pelo espaço restrito de seu ateliê, nas últimas décadas, são os trabalhos com textos proferidos por vozes em fluxo os que mais têm evidenciado tais procedimentos.

Já se comentou a proximidade entre Nauman e Beckett quanto aos textos circulares e claustrofóbicos recitados grotescamente pelos palhaços nos vídeos de Clown Torture [Tortura do palhaço (1987)]. Além dos trabalhos com palhaços, as cabeças falantes que entoam ininterruptamente e em ritmos diversos palavras ou fonemas, tais como lip sync; brrrrr; mmmmmm; ok ok ok; feed me/ eat me/ anthropology/help me/hurt me/ sociology; think think think; work, work, work ${ }^{38}$, talvez possam evocar ao conhecedor da obra de Beckett não apenas a logorreia da voz que domina a narrativa de $O$ inominável, mas também as cabeças falantes de Play (1946) e a boca solitária do monólogo Not I (1973), duas peças tardias. 

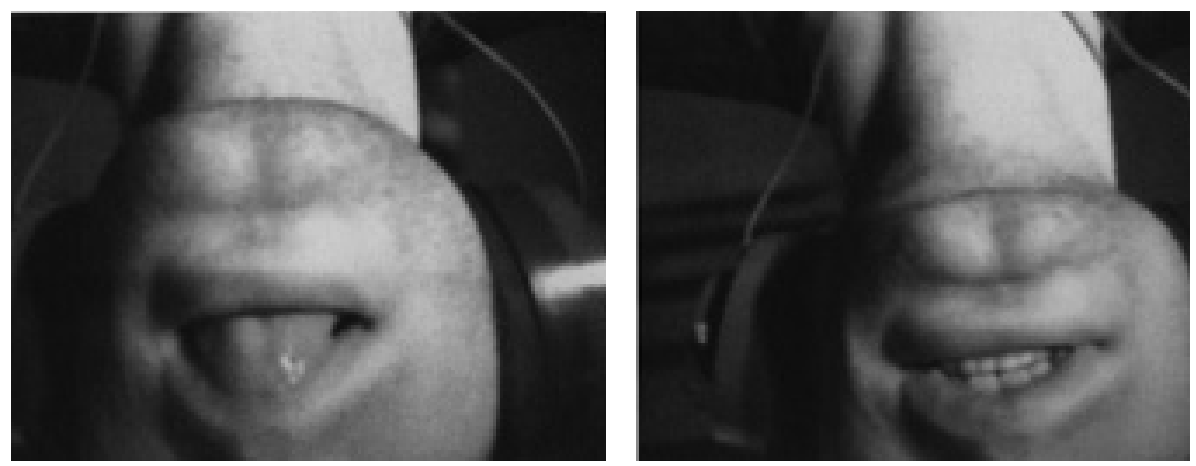

Lip Sync, 1969, vídeo, 60 min.

Textos como 100 Live and Die [100 Viva e Morra (1983-1985)], Good Boy Bad Boy [Bom menino mau menino (1985-1987)] e World Peace [Paz mundial (1996)], comentados a seguir, também implicam mecanismos que constroem saturação por reiteração e temporalidade sem desfecho: embora relativamente simples, estruturadas pela permutação de um número estrito de palavras, as variadas inflexões de voz com as quais os textos são pronunciados, em repetição infindável, vão da morosidade das ladainhas balbuciadas aos berros de agressividade incontida, provocando um espectro também variado de reações, do tédio à exasperação. Podem, assim, referir-se vagamente a Beckett.

Já nos textos iniciais de Nauman, escritos entre 1966 e 1975, os mecanismos de saturação da experiência dão lugar a operações mais sutis, de maneira que as repetições de palavras, termos ou sentenças são construídas em contextos ligeiramente diversos uns dos outros e tendem, antes, a tornar ora mais complexos ora mais confusos os sentidos das palavras do que propriamente a desgastá-los, conforme se verá. Nesses primeiros textos são recorrentes as frases descritivas em tom neutro, aludindo às

38. Essas frases são ditas nos seguintes trabalhos de Nauman: Lip Sync [Sincronia labial (1969)], BRRR (1990), MMMM (1990), OK OK OK
(1990), Anthro/Socio [Antro/Socio (1991)], Think Think Think [Pense pense pense (1993)], Work Work [Trabalhe trabalhe (1994)]. 
proposições da lógica ou aos enunciados de problemas matemáticos, que, pouco a pouco, vão se deixando permear por expressões destoantes, produzindo incongruências pontuais ou disparates significativos.

Um dado curioso e eventualmente elucidativo é que, exatamente nesta época, Nauman relata conhecer The Lost Ones [O despovoador], de Beckett. O fato foi constatado durante a pesquisa nos arquivos do galerista Leo Castelli, onde se encontrou carta de Nauman para Castelli, datada de 9 de novembro de 1973, que permanece inédita, na qual o artista detalha as instruções de montagem de Floating Room [Recinto Flutuante (1972)] e, ao final, indaga se Castelli já havia lido o livro de Beckett ${ }^{39}$. Nauman só falou publicamente do livro em 1982, na entrevista mencionada no Capítulo 2, período em que realizava maquetes de escala arquitetônica de túneis sem saída, trabalhos que foram imediatamente associados a The Lost Ones, conforme se comentou. Além da correlação com os projetos de túneis da década de 1980, é provável que The Lost Ones tenha impressionado Nauman em virtude da neutralidade e da acurácia descritiva que caracterizam a escrita, uma narrativa bastante peculiar na produção de Beckett. Pode-se presumir da carta enviada a Castelli que Nauman tenha lido o livro na época em que costumava escrever textos para acompanhar os trabalhos, como Floating Room, instalação mencionada na carta, além de Left or Standing, Standing or Left Standing [Deixado ou Em pé, Em pé ou Deixado em pé (1971)]; Double Doors, Projection and Displacement [Portas duplas, projeção e deslocamento (1973)]; Flayed Earth/ Flayed Self [Terra esfolada/Eu esfolado (1973)]; Cones Cojones [Cones colhões (1974)]; The Consummate Mask of Rock [A máscara consumada de pedra (1975)]; e False Silence [Silêncio falso (1975)]. Talvez haja, nesses textos específicos, algo da "acurácia descritiva" forjada pela linguagem crua e matemática usada por Beckett para apresentar ao leitor o cilindro emborrachado, onde vagam quatro tipos específicos de criaturas em danação. Parece plausível a existência 


\section{Mov. $9 / 73$}

\section{Dear Loo -}

Here is a bunch of plash and notes for the $\mathrm{y}$ with wirror piece.

In for the harring roes ( Mootine Room) 1 don't think stretehing s aheet of blakk eloth over the tep is atisfactory thouch I can't think of a very satisfactery alterrative vithoul seeine the site. It might be best to leave it

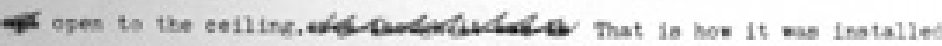
of Irvine shere we hat to work with very high eellingen and though it elaneved the elaractor of the plede it seened to me to be ox. The lijht fixtures sheuld

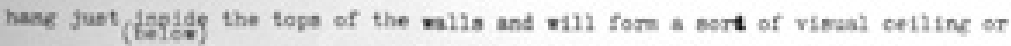
barrier.

The door sheuld be located at the center of sne wall as should meabure about

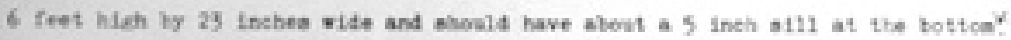
the door wheuld be flush on the insild fad wave a small lateh.

I hepe this all works ent a vell etouch.
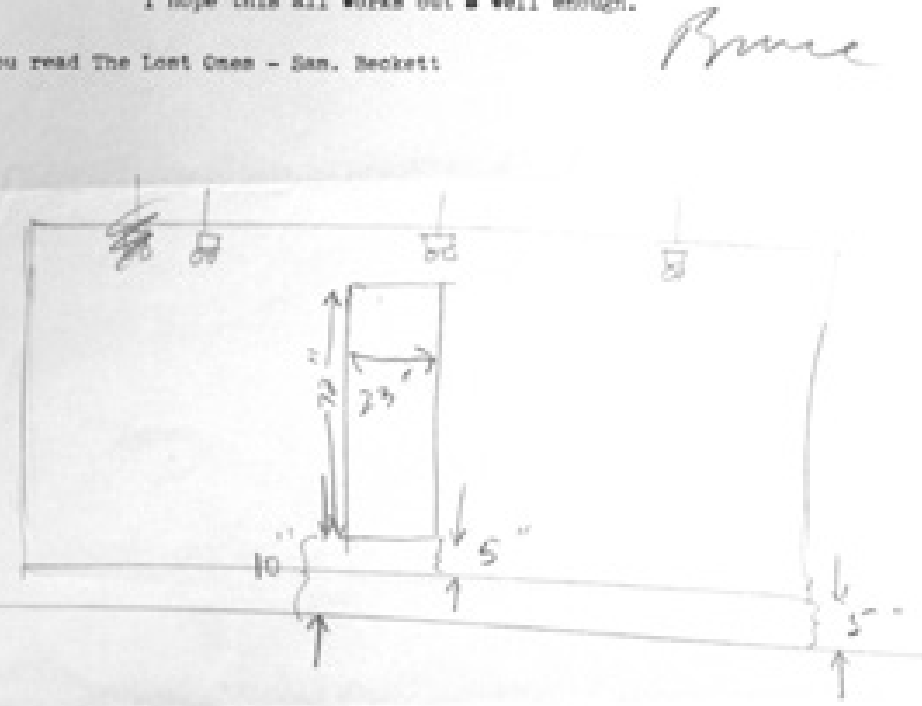
de afinidades entre as duas escritas, dado que ambas pretendem precisão extrema para, todavia, apontar para situações de indeterminação, vagueza ou então para naturalizar a improbabilidade e o absurdo de certos espaços ou ações descritas. Não se encontrou na bibliografia coligida nenhum estudo que coteje as duas obras a partir de um esforço interpretativo voltado aos textos escritos entre 1966 e 1975; acredita-se, portanto, que se trata de uma abordagem inédita. Tal hipótese será retomada adiante ${ }^{40}$.

Já foi mencionado, no capítulo dedicado à análise da Caminhada Beckett, que Nauman declara-se um leitor de Beckett desde 1966, fazendo especial referência ao livro Molloy e ao personagem de mesmo nome obcecado por rituais metodicamente elaborados para atividades simples e sem muito sentido, como a transferência em ordem rigorosa de suas pedrinhas de chupar pelos bolsos do casaco. Watt, conforme se disse, talvez tenha inspirado a engenhosa coreografia desenhada e diligentemente executada por Nauman no filme de 1968. Em nenhum momento, no entanto, sugeriu-se que Nauman tenha ilustrado as palavras de Beckett. Aliás, seria incorreto afirmar que haja aí uma relação clara de "influência", sobretudo se influência pressupuser um polo passivo que apenas se deixasse imprimir por ideias e informações que lhe fossem externas. Muitos fatores decerto se combinam para que um artista deixese realmente influenciar por outro. Defende-se, portanto, que observar atentamente e tentar compreender a obra de Beckett ajuda a compreender a obra de Nauman que, por sua vez, ajuda a compreender a obra de Beckett.

40. Ressalte-se novamente que a aproximação entre as produções de Nauman e Beckett não é infrequente e chegou a resultar numa exposição ocorrida na Áustria, em 2000. Nauman, geralmente avesso às comparações, parece aceitar de bom grado que comparem seus trabalhos aos de Beckett, não tendo manifestado qualquer discordância quanto à realização da mostra. 


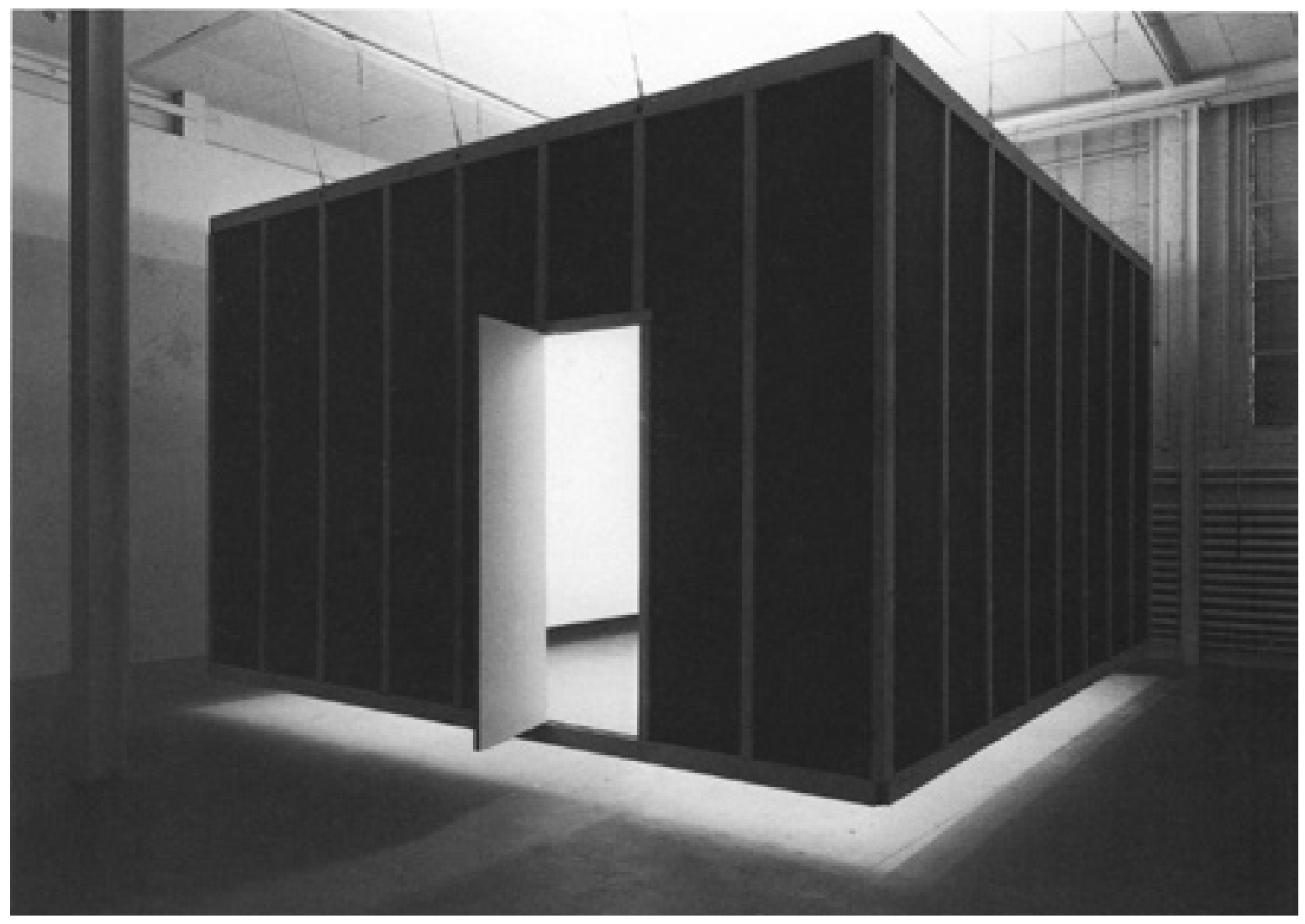

Floating Room: Lit from Inside, 1972, compensado e lâmpadas fluorescentes, $305 \times 488 \times 488 \mathrm{~cm}$. 
O "dilema feroz da expressão" formulado por Beckett ou, mais precisamente, a pergunta pela possibilidade de expressão tal como enunciada pelos artistas modernos é, em alguma medida, intrínseca à obra de Nauman, formulando-se como um movimento interno da própria produção. Seus trabalhos, desde o início, põem em dúvida as noções usuais de expressão na história da arte apontando para os limites e, mais do que isso, para a própria irrelevância da vontade expressiva de sujeitos singularmente considerados, e para a gritante banalidade que vem de par com manifestações declaradas da "expressão da subjetividade". Aqueles trabalhos nos quais Nauman utiliza o próprio corpo, por exemplo, não pleiteiam um estatuto autobiográfico ${ }^{41}$. Em algumas ocasiões, aliás, o corpo do artista como se "apaga" por debaixo de camadas espessas de tinta ${ }^{42}$ ou seus movimentos acentuadamente gestuais são despersonalizados e convertidos em módulos de repetição, como na caminhada exagerada pelo perímetro do quadrado ou na Caminhada Beckett, dois segmentos de ação de gestualidade inequívoca mas cujos trejeitos expressivos são desnaturados pela padronização e pela reiteração excruciante das séries. Se alguma expressão ainda resta, ela é residual e não programada, surge às expensas da exaustão física e psíquica acarretadas pelas repetições ou então na dificuldade e nas raríssimas falhas de execução continuada do padrão estabelecido.

Temas como o "autoapagamento" do artista, a padronização gestual ou a redução da expressividade mediante a supressão de informações, "quanta informação pode ser subtraída de uma situação de modo que ela ainda seja efetiva" ${ }^{43}$, perpassam a obra e comparecem já nos primeiros textos de Nauman, como no referido The Consummate Mask of Rock, que

41. Nas décadas de 1960 e 1970, muitos artistas, assim como Nauman, "testaram" o corpo. Parte deles priorizou o registro autobiográfico, enquanto outros levaram a cabo gestos de violenta insurgência contra o corpo, executando proposições por vezes de um radicalismo de viés abjeto ou escatológico. Pode-se referir, por exemplo, aos muitos matizes daquilo que se convencionou chamar de body art ou mesmo a artistas como Vito Acconci, Marina Abramovic, Chris Burden, Paul McCarthy, só pra lembrar de alguns.

42. Como em Art Make-Up [Arte-maquiagem (1967-68)], Flesh to White to Black to Flesh [Carne para branco para preto para carne (1968)] ou Black Balls [Bolas pretas (1969)], vídeos já abordados em capítulos precedentes. 
traz a ideia de mascaramento no próprio título e em diversos outros termos empregados, Codification [Codificação (1966)], Withdrawal as an Art Form [Privação como forma de arte (1970)] e Appendix [Apêndice (1972)].

Codification é uma listagem sumária de "codificáveis": "1. aparência pessoal e pele; 2. gestos; 3. ações comuns tais como aquelas relacionadas ao comer e ao beber; 4 . vestígios de atividades tais como pegadas e objetos materiais; 5. sons simples, palavras faladas ou escritas" ${ }^{44}$. Trata-se de itens não hierarquizados, plenamente comutáveis entre si, de modo que aparência pessoal, pele, gestos, ações simples e palavras são todos equivalentemente passíveis daquilo que se designou por "codificação", talvez no sentido de operação que converte uma linguagem em outra, talvez no sentido de uma mera reunião de dados, um mapeamento preliminar de interesses ou de materiais sob a investigação do artista em seu ateliê, à época, quase vazio. Os tópicos listados em Codification têm sido revisitados ao longo dos anos, assumindo formalizações as mais variadas. Basta pensar que a vedação por tinta das características expressivas da pele do rosto ou do corpo, nos primeiros filmes, retorna, duas décadas depois, nas maquiagens dos palhaços e nas suas clássicas fantasias. Pode-se também mencionar os registros de ações simples, como as passadas enérgicas contra o chão do ateliê ou os lançamentos de bolinhas de borracha ${ }^{45}$, que tornam a aparecer em vídeos como Washing Hands (Normal/Abnormal) [Lavando as mãos, normal/anormal (1996)] ou mais recentemente em Setting a Good Corner (Allegory \& Metaphor) [Estabelecendo um bom canto/alegoria e metáfora (2000)]. Este último registra Nauman empenhando-se na construção de um canto para esticar uma cerca e instalar uma porteira na sua fazenda: o tempo de duração é o mesmo da ação filmada, ocorrendo captação contínua

43. Cf. AUPING, Michael. Metacommunicator. In: NAUMAN, Bruce. Raw Materials. Londres: Tate Publishing, 2004, p. 11 [Nota 13, Capítulo 2].

44. "1. Personal appearance and skin; 2. Gestures; 3. Ordinary actions such as those concerned with eating and drinking; 4. Traces of activity such as footprints and material objects; 5 . Simple sounds - spoken and written words". Cf. Apêndice.

45. Respectivamente Stamping in the Studio [Carimbando no ateliê (1968)] e Bouncing Two Balls between the Floor and the Ceiling with Changing Rhythms [Quicando duas bolas entre o chão e a teto em ritmos variáveis (1967-68), vídeos já analisados. 

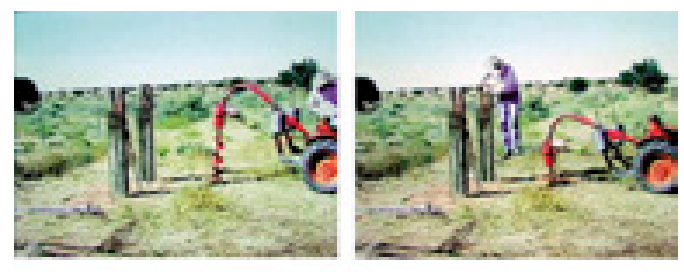

Setting a Good Corner (Allegory and
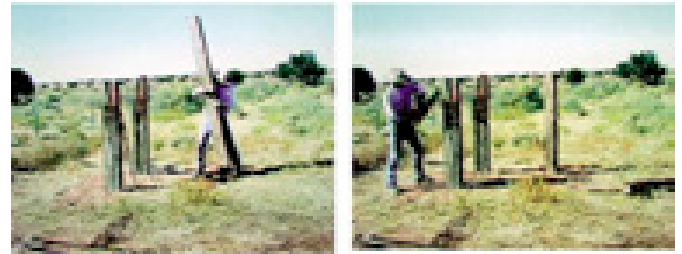

Metaphor), 1999, vídeo, 60 min.
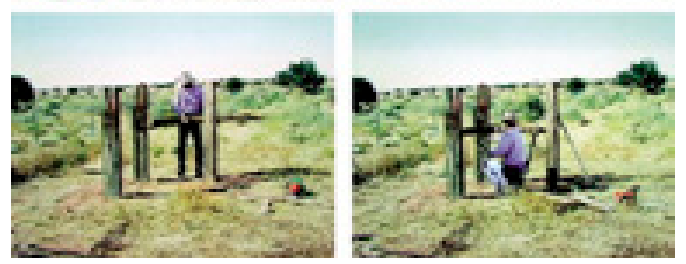

do passo a passo; a câmera permanece fixa; os sons são incidentais, como o barulho do vento, latidos ao longe e o próprio ronco da motosserra. Nauman parece completamente absorto de tão concentrado que está numa ação que é tão trivial para um fazendeiro quanto eram triviais as ações filmadas no ateliê, e a vastidão daquele espaço, acentuada pela paisagem desértica do Novo México, estado americano onde se situa o rancho, compara-se inevitavelmente ao vazio desolado do primeiro estúdio do artista. Quase quarenta anos separam esses registros que, todavia, mantêm nítidas linhas de continuidade.

Já em Withdrawal as an Art Form ou Appendix, Nauman servese da neutralidade descritiva para fazer notações dispersas relativas às possibilidades de manipulação sensorial por procedimentos de amplificação ou de privação dos sentidos ou das informações, aventando, inclusive, hipóteses de "sobrecarga sensorial" [sensory overload], fadiga física ou fisiológica e colapso. Esses escritos conferem ao corpo um estatuto próximo ao de um sistema de estímulos-respostas à disposição de experimentos conduzidos por manipulação de dados, com vistas à observação de resultados e à coleta de informações. Propõem, entre outas coisas, o exame das respostas físicas e fisiológicas a situações muito simplificadas capazes de gerar fenômenos experimentáveis. Há entre os 
dados fragmentários uma prescrição bastante condizente com os testes físicos e mentais a que Nauman se submetia naquele período: "manipulação ou observação 'de si mesmo' em situações extremas ou controladas" ${ }^{4}$. O próprio uso de termos anódinos, aparentemente científicos ${ }^{47}$, reforça a imagem de um corpo exposto a estímulos por meio de experimentos controlados no laboratório; imagem avivada pela lembrança do papel central atribuído às noções de contenção, controle e autovigilância na obra.

A intensidade máxima almejada por Nauman em sua obra é, na metáfora que costuma empregar, tal qual uma "pancada inesperada na nuca": simples, direta, certeira, enfática, truculenta. Dentre todas as matérias-primas que utiliza, a voz humana quando isolada do corpo que a produz tem se sobressaído como o material mais "plástico" de seu repertório. É da minuciosa calibragem entre entonação da vOz e o texto enunciado que o artista tem alcançado a intensidade pretendida. Mas, para isso, não basta que as inflexões das vozes oscilem da calmaria tediosa aos rompantes violentos, há que haver desajustes precisos entre o sentido da palavra e o modo com que ela é falada para que os termos destoem do uso habitual. Somado a isso, é impreterível afinar o ritmo em conformidade com a reação pretendida, pois a palavra, o fonema ou a frase deve encontrar a sua sonoridade adequada. Às vezes, uma batida forte a cada tantas batidas, às vezes uma pancada forte após outra após outra. Para tanto, a estrutura da língua inglesa tal qual usada cotidianamente pelos norte-americanos parece se amoldar com perfeição; uma sonoridade em que, em alguma medida, está implícito o imediatismo da dicção pop dos slogans e dos signos banalizados da cultura norte-americana. Conforme afirma Robert

46. Manipulation or observation of self in extreme or controlled situations". Cf. Apêndice.

47. Como, por exemplo, no seguinte trecho de Withdrawal as an Art Form: "negação ou invocação da Gestalt de mecanismo de defesa fisiológica (voluntária ou involuntária). Exame de resposta física e fisiológica a situações simples ou até sobresimplificadas que podem produzir fenômenos claramente experenciáveis (fenômenos e experiência são o mesmo ou indiferenciáveis]" ["Denial or confusion of a Gestalt invocation of physiological defense mechanism (voluntary or involuntary). Examination of physical and physiological response to simple or even over-simplified situations which can yield clearly experienceable phenomena (phenomena and experience are the same or undifferentiable)"]. Cf. Apêndice. 
Storr, "Nauman tem um ouvido afiado para o inglês americano simples, e não importa como quão ambíguo é o significado, o ritmo e o sotaque de sua escrita são bem definidos. Mesmo na página pode-se ouvi-lo. Esta acuidade auditiva permite a orquestração densa de tons de voz"48.

Não apenas a sonoridade do inglês americano se adequa à simplicidade e franqueza exigida dos textos de Nauman, mas também a própria qualidade factual da língua, a "facticidade" ou "efetividade" que lhe é característica ("matter-of-factness of plain English"49). Nos textos, assim como nas demais instâncias da obra, são tomadas decisões formais que objetivam "fazer as coisas parecerem menos importantes" do que são, pois o desafio maior a que se propõem é o de apresentar ideias do modo mais simples possível ${ }^{50}$. Alguns críticos concordam que um dos aspectos mais provocativos da obra é abordar de modo conciso e despretensioso os "grandes temas", tais como vida, morte, sexo, violência, intimidade, e, ademais disso, adequá-los à facticidade do inglês, reduzindo-os à uma dimensão constatável ${ }^{51}$. Nauman parece empenhado em detectar e expor o aspecto mais corriqueiro de tais temas, que talvez existam com mais evidência em uma dimensão mais rebaixada, talvez próxima das experiências de crueldade, frustração, fracasso e incapacidade de aprendizado que os palhaços torturados trazem à tona. $\mathrm{O}$ certo é que tornar as coisas mais simples e menos importantes é o postulado que serve como a chave interpretativa mais viável para os trabalhos nos quais Nauman discute, segundo suas próprias palavras, a "condição humana":

48. "Nauman has a keen ear for plain american english, and no matter how ambiguous his meaning, the pace and accents of his writing are sharply defined. Even on page you hear him. This aural acuity allows for dense orchestration of verbal tones of voice". Cf. STORR, Robert. Op. cit., p. 53.

49. Observação feita pela crítica de arte Joan Simon, que acompanha de perto a produção de Nauman, sendo responsável, entre outras publicações, pela edição do catalogue raisonné do artista [SIMON, Joan (Ed). Bruce Nauman:
Exhibition Catalogue and Catalogue Raisonné. Minneapolis: Walker Center Art, 1994].

50. Eis os dois trechos das declarações de Nauman, no original, respectivamente, "it has to do with trying to make the thing look less important" $\mathrm{e}$ "I think the hardest thing to do is to present an idea in the most straightforward way". Cf. KRAYNAK, Janet (Ed.). Op. cit., p. 319.

51. Joan Simon e Robert Storr entre eles. Cf. STORR, Robert. Op. cit., p. 65, nota 10. 

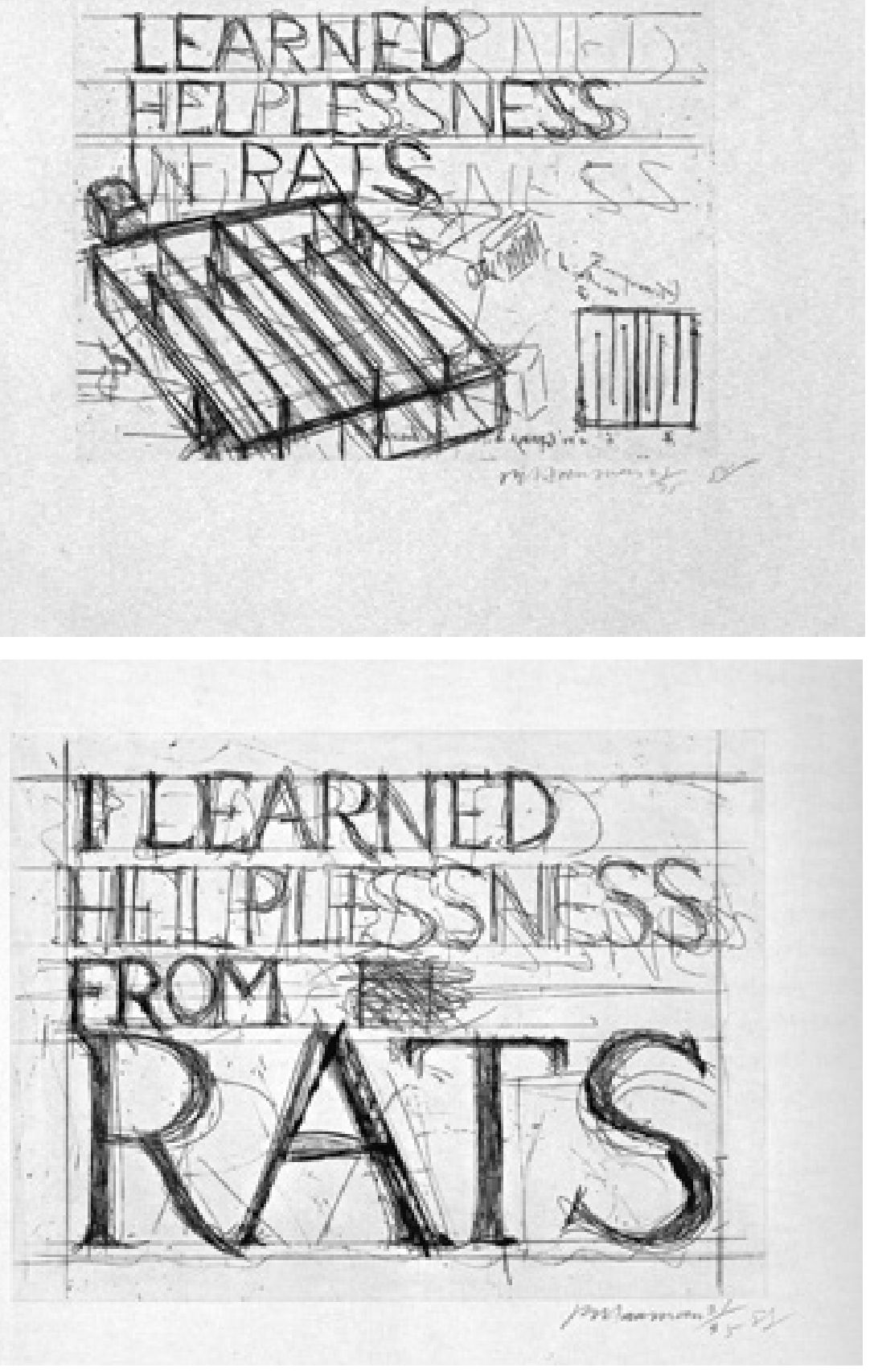

Learned Helplessness in Rats, 1988, gravura, 39,4 × 45,7 cm I Learned Helplessness from Rats, 1988, gravura, $39,4 \times 45,7 \mathrm{~cm}$. 
Eu sei que há artistas que funcionam em relação à beleza [...] são movidos por coisas bonitas e veem aí o seu papel: dar ou fazer coisas bonitas para outras pessoas. Eu não trabalho dessa forma. [...] O sol, flores, paisagens, este tipo de coisa não me move a fazer coisa alguma. Eu só quero deixá-las em paz. Meu trabalho tem sido a respeito de ficar frustrado com a condição humana. E sobre como as pessoas podem ser cruéis umas com as outras. Não é que ache que possa mudar isso, trata-se apenas da parte frustrante da história humana ${ }^{52}$.

À primeira vista, a declaração soa demasiadamente ingênua, mas Nauman não é exatamente um tipo angelical, muito embora uma farsa aos moldes de um personagem idiot savant ou mesmo um papel de bobo da corte lhe caia bem ${ }^{53}$. Não se pode esquecer que é dele a frase "I learned helplessness from the rats", "eu aprendi o desamparo com os ratos", título de uma instalação e sentença que aparece em desenhos e gravuras. A frase faz o teor cáustico dos trabalhos de Nauman vir à tona. Risos malévolos de palhaços cruéis como resposta a gritos de pavor, ruídos infernalmente agudos do atrito de moldes giratórios de carcaças de animais deformados contra o chão, uma briga de casal que termina em morte, um desenho de um gato empalado, joguinhos infantis contagiados de violência e de sexo violento, rituais de dominação com pitadas de escatologia ${ }^{54}$. O catálogo

52. "I know that there are artists who function in relation to beauty [...] They are moved by beautiful things and they see that as their role: to provide or make beautiful things for other people. I don't work that way. [...] Sunsets, flowers, landscapes; these kinds of things don't move me to do anything. I just want to leave them alone. My work comes out being frustrated about the human condition. And about how people can be cruel to each other. It's not that I think I can change that, but it's just such a frustrating part of human history". Cf. KRAYNAK, Janet (Ed.). Op. cit., p. 332-333.

53. Emprega-se aqui a expressão em sentido coloquial para uma referência breve ao "tolo sábio", uma figura que recebe dispensação especial para dizer verdades indecorosas e inoportunas sem punição de qualquer espécie, tal como o papel desempenhado pelo bobo da corte tradicional, um bufão que, sob o pretexto de divertir o rei, gozava do consentimento para dirigir-lhe críticas severas.

54. Os trabalhos a que se faz referência são: os vídeos da instalação Clown Torture [Tortura do Palhaço (1987)]; a escultura Carousel [Carrossel (1988)]; Violent Incident [Incidente violento (1986)], cujo roteiro integral pode ser consultado no Apêndice da tese; Spinning Cat with Stick Up its Ass [Gato girando com uma vara no rabo (1989)]; séries de neons que se referem ao jogo da forca como Hanged Man [Homem enforcado (1985)] ou ainda um texto como The Consummate Mask of Rock [A máscara consumada de pedra (1975)]; Shit In Your Hat - Head On A Chair [Cague em seu chapéu - Cabeça numa cadeira (1990)]. 
da parte frustrante da história humana é, de fato, um catatau. Assim, o dito aparentemente ingênuo é, antes de qualquer outra coisa, uma espécie de baliza ética do artista. Nauman diz que "realmente desconfia de arte que é apenas sobre arte" ${ }^{55}$. Sua obra, portanto, procura conjugar as duas coisas: é também "sobre arte" uma vez que é na formalização artística do material que ele lida com os "grandes temas". Assim como Beckett que, conforme se mencionou, teve de forjar uma forma artística adequada para o seu material, um jeito correto de expressar o nada. O fato é que o partido de ambas as obras é tornar as coisas mais simples e menos importantes. A propósito, ao que parece, além de empatia pela "estrutura do pensamento" de Beckett, sua "profunda compreensão da inevitabilidade das frustrações" interessa particularmente a Nauman ${ }^{56}$.

Da mesma maneira que parte da crítica pretendeu relacionar sem mediações a obra do irlandês ao vazio metafísico e ao absurdo remanescentes dos horrores das guerras, há na bibliografia dedicada a Nauman interpretações da obra com jargões que se referem vagamente à filosofia existencialista ou mesmo aqueles críticos que parecem tomar como inequívoca a frase de um dos primeiros e mais conhecidos trabalhos de Nauman, o neon colorido em forma de espiral em que se lê "o verdadeiro artista ajuda o mundo revelando verdades místicas" [The True Artist Helps the Word by Revealing Mystic Truths (1967) $]^{57}$. O mais curioso é que o

55. Grifo nosso. "I really mistrust art that's just about art". Cf. KRAYNAK, Janet (Ed.). Op. cit., p. 249.

56. Estas afirmações foram feitas por Robert Storr em entrevista concedida à doutoranda, quando se comentava da proximidade entre as duas obras. Conferir a transcrição da entrevista no Apêndice da tese.

57. A discussão encontra-se dispersa pela bibliografia e mais comumente em críticas de jornal feitas por ocasião de aberturas de mostras. Há, todavia, um debate mais explícito que pode ser citado aqui como indicação de leitura: as críticas de Kathryn Hixson no ensaio "Nauman: Good and Bad" [publicado na coletânea organizada por Robert Morgan; Cf. MORGAN, Robert. Bruce Nauman. Baltimore: The Johns Hopkins University Press, 2002] dirigidas contra o ensaio de Kathy Halbreich, "Social Life", publicado no catalogue raisonné de Nauman [Cf. SIMON, Joan (Ed). Bruce Nauman: Exhibition Catalogue and Catalogue Raisonné. Minneapolis: Walker Center Art, 1994]. Cada autora interpreta de modo diametralmente oposto os aspectos mais mórbidos dos trabalhos de Nauman, precisamente o tema do medo da morte que comparece em alguns deles. Kathryn Hixson objeta veementemente à leitura em certa medida "metafísica" 


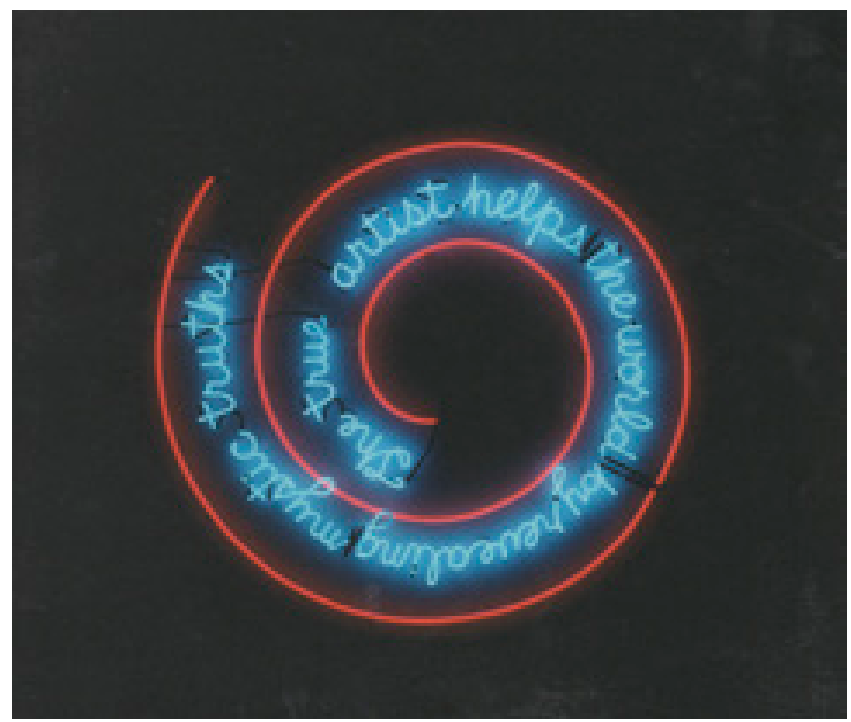

The True Artist Helps the Word by Revealing Mystic Truths, 1967, tubos de neon, $149,9 \times 139,7 \times 5,1 \mathrm{~cm}$.

interesse deste trabalho é precisamente a incongruência entre o conteúdo da frase e sua formalização em luz neon: suas letras manuscritas em azul vivo envolvidas por uma espiral vermelha anunciam uma frase que não se caracteriza pelo imediatismo dos slogans publicitários, para os quais a vivacidade do neon é adequada. Trata-se, na verdade, do primeiro trabalho em que Nauman escreve em neon, procedimento que posteriormente reaparece inúmeras vezes na obra ${ }^{58}$. A espiral reluzente foi originalmente instalada junto à janela do ateliê do artista na época. Nauman afirma que partiu de um antigo letreiro de anúncio de cerveja que lá estava para elaborar

feita por Kathy Halbreich. Pode-se também mencionar o ensaio de abertura de um catálogo de Nauman, escrito por Eugen Blume, que aborda a obra priorizando o tema da condição humana retomando as questões da filosofia existencialista [Cf. BLUME, Eugen. Bruce Nauman: Live or Die - or: The Measuring of Being. In: NAUMAN, Bruce. Live or Die. Colônia: DuMont Buchverlag, 2010].
58. Antes disso, ele já havia usado o material na escultura intitulada Neon Templates of the Left Half of My Body Taken at Ten-Inch Intervals [Gabaritos em neon do lado esquerdo do meu corpo tomados em intervalos de dez polegadas (1966)], analisada no Capítulo 1. No mesmo ano da espiral, Nauman realizou uma outra peça na qual escreveu seu sobrenome, todavia de modo ilegível: My Last Name Exaggerated Fourteen Times Vertically [Meu sobrenome exagerado quatorze vezes verticalmente (1967)]. 
seu próprio "anúncio", uma assertiva que, por sua própria natureza, não é passível de verificação quanto ao seu teor de verdade ou falsidade. Nas ocasiões em foi publicamente questionado sobre o propósito da frase, ele deu respostas evasivas que, naturalmente, reforçam a ambiguidade pretendida no trabalho. No ano em que executou a peça, foi perguntado se acreditava naquilo que escrevera, respondendo "não sei, acho que devemos deixar isto em aberto". Em 1982, afirmou: "foi uma espécie de teste, como quando você diz algo em voz alta para ver se acredita [...] por um lado, é uma ideia totalmente tola mas, por outro lado, eu acreditava; ao mesmo tempo, é e não é verdade, depende de como se interpreta e o quanto você se leva a sério”. Em 1987, vinte anos após a execução da peça, confrontado uma vez mais com o mesmo questionamento, respondeu: "sempre senti que acreditava naquilo em algum sentido, mas provavelmente não no sentido que pensei inicialmente. É uma daquelas coisas que você diz para descobrir o que pensa a respeito, testando a si mesmo" ${ }^{59}$.

Além disso, é provável que uma peculiar declaração de Nauman, proferida em 1979, tenha corroborado os equívocos, "diz-se que a arte é uma questão de vida e morte; isto pode ser melodramático, mas é também verdadeiro" ${ }^{60}$. Conforme se argumentará na análise de 100 Live and Die [100 Viva e Morra (1985)], Nauman desnatura o tema com procedimentos idênticos aos que aplica às demais instâncias da obra; neste trabalho, por exemplo, ele enumera e comuta verbos que corresponderiam, em suas palavras, a uma "lista dos atributos humanos e ações", conferindo valores

59. As respostas de Nauman, no original: "I don't know; I think we should leave that open" [Cf. KRAYNAK, Janet (Ed.). Op. cit., p. 109]; “/t was a kind of test like when you say something out loud to see if you believe it [...] it was on the one hand a totally silly idea and yet, on the other hand, I believed it. It's true and it's not true at the same time; it depends on how you interprete it and how seriously you take yourself" [Cf. RICHARDSON, Brenda. Bruce Nauman: Neons.
Baltimore: The Baltimore Museum of Art, 1982, p. 20]; e "I've always felt that I believed it in some sense, but maybe not in the sense I thought about it initially. It's one of those things you say to find out what you think about it, testing yourself" [Cf. MORGAN, Robert (Ed.). Op. cit., p. 269].

60. "It is said that art is a matter of life and death; this may be melodramatic but is also true". Cf. KRAYNAK, Janet (Ed.). Op. cit., p. 188. 


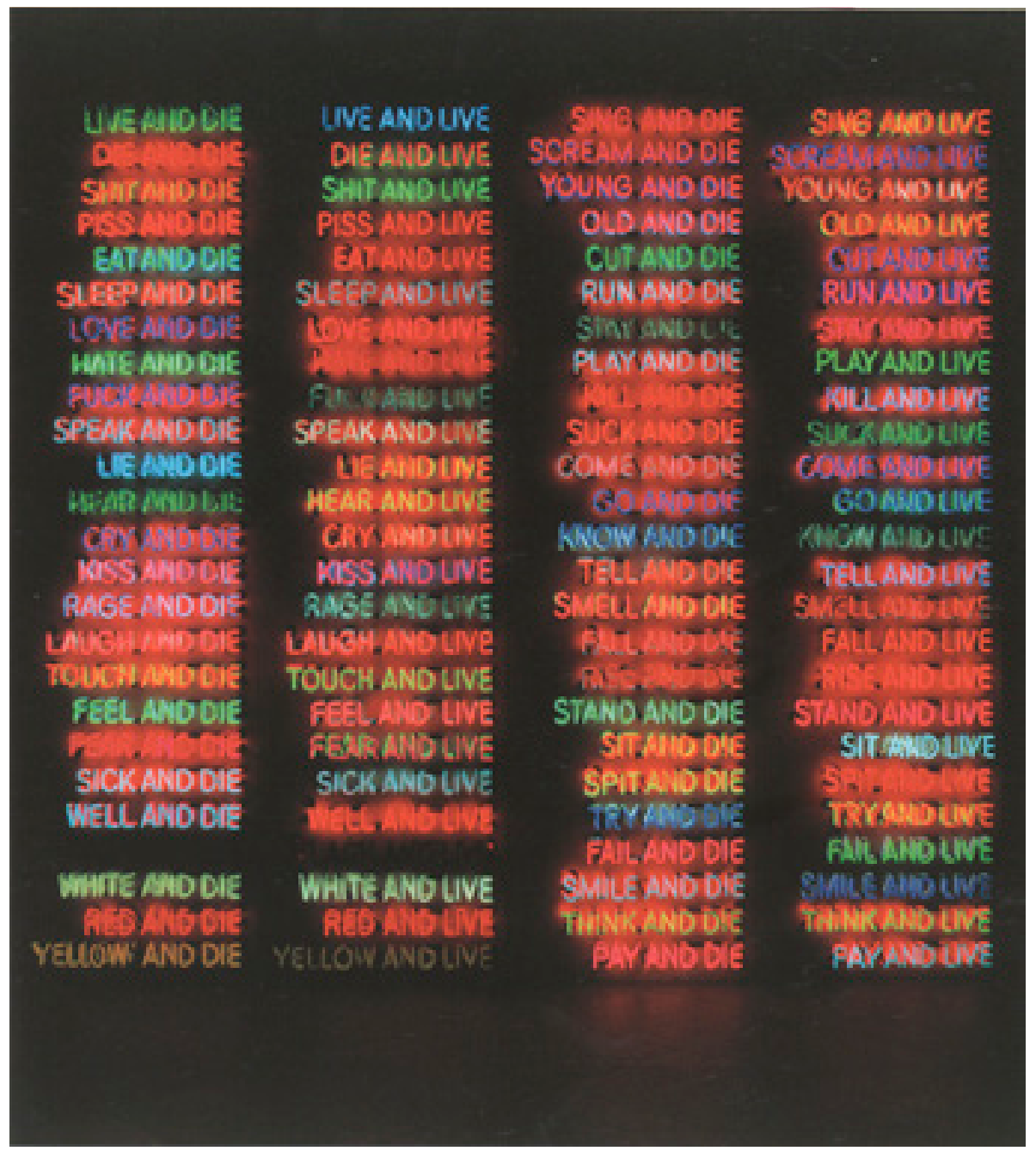

100 Live and Die, 1984, tubos de neon, $300 \times 336 \times 53 \mathrm{~cm}$. 

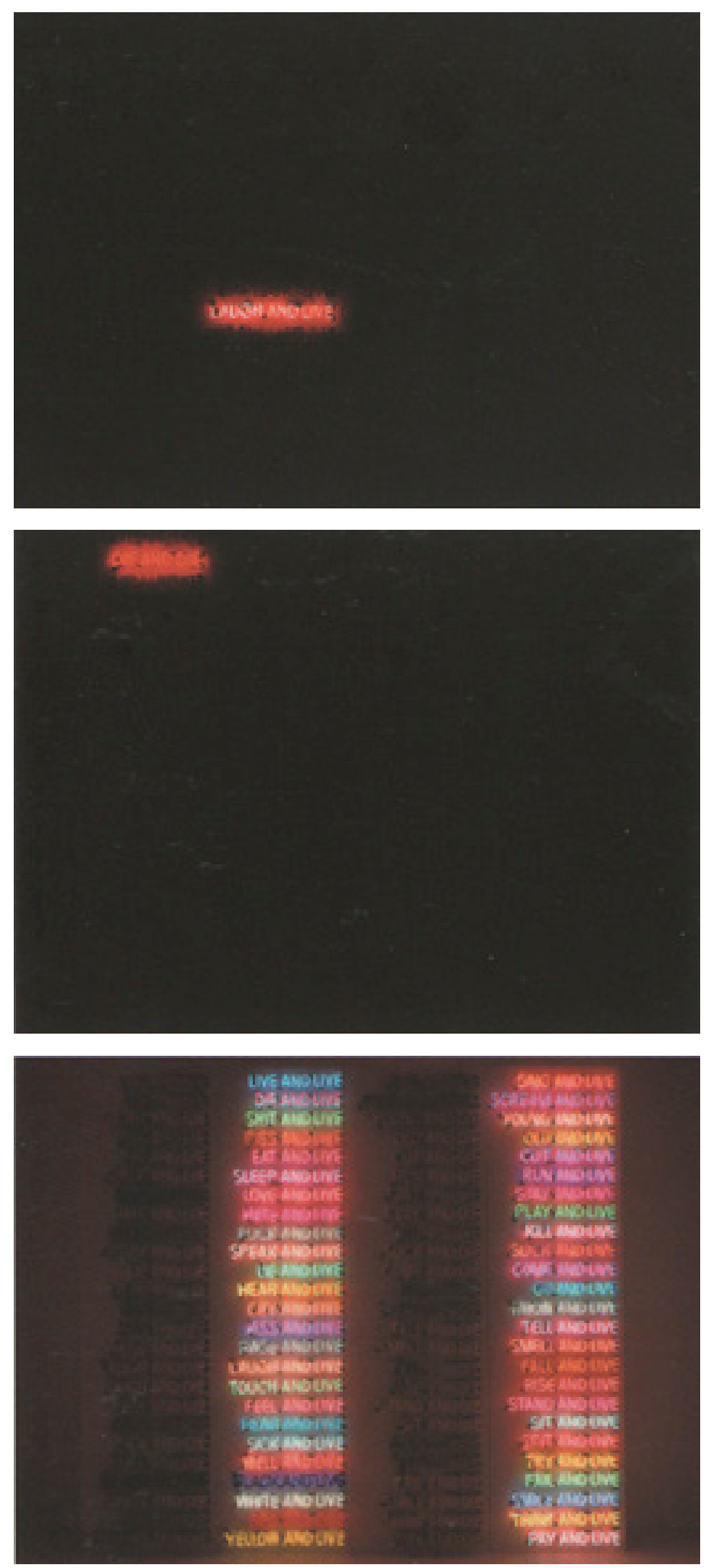
iguais a verbos que se relacionam a sentimentos ou a experiências subjetivas e aos que correspondem às funções fisiológicas do organismo. A absoluta ausência de hierarquia entre os itens parece reduzir a condição humana a uma mera constatação de eventos passíveis de ocorrência num determinado período de tempo. Trata-se de uma lista de verbos repetidos e comutáveis e a repetição do mesmo conectivo, além da intrusão sorrateira de oito adjetivos. Argumenta-se nesta tese que se a condição humana é questão de vida e morte na obra de Nauman, ela só o é no sentido mais cru possível (raw, palavra que tanto reincide nos trabalhos) e sua expressão mais adequada é, possivelmente, a do corpo reduzido à mera fisiologia, o que aliás também ocorre paulatinamente nos textos de Beckett.

Nesse sentido, é oportuno citar uma passagem de uma crítica ostensivamente contrária às interpretações mitificadoras da obra, sobretudo aquelas que tentam interpretar de modo metafísico o tema do medo em Nauman, mais especificamente o medo da morte. A autora, Kathryn Hixson, no ensaio "Nauman: Good and Bad", expõe seus argumentos e toma por referência trabalhos que causam riso nervoso e outras reações de desagrado e desconforto, como a série dos palhaços torturados, sobretudo o vídeo do palhaço sendo filmado no banheiro [Clown Taking a Shit (1987)] ou a instalação na qual um clown obedece a comandos sádicos [Shit in Your Hat - Head on a Chair (1990)], dois da safra que combina crueldade com escatologia; o comentário se vale mais precisamente da imagem do palhaço no banheiro para apontar que ali são tematizados os conflitos mais primários da socialização, justamente os que reportam o adestramento recebido para tornar socialmente aceitáveis as premências de ordem fisiológica: "na raiz da emoção básica [provocada pelos trabalhos de Nauman] está o medo de perder o controle do corpo e da consciência, de perder o controle das regras sociais que o intelecto sabe como seguir e terminar por borrar as calças" ${ }^{\prime 1}$. Ao fim e ao cabo, o medo que se incute na obra não se expressa com grandiosidade, mas do modo mais rasteiro e, de certa maneira, mais desafetado possível. O comentário indelicado é, todavia, um eficaz contra-argumento à busca de um sentido transcendental para o medo da perda de controle do corpo abordado em muitos trabalhos. 
Nauman, conforme se comentava, pretende a um só tempo relevar a importância das coisas e comunicar-se de modo certeiro, intuito que se formaliza nas sentenças concisas, palavras simples e diretas, por vezes monossilábicas, ou ainda na repetição de um só fonema em alguns trabalhos sonoros. Tais procedimentos de simplificação, redução e contenção fazem parte da própria operação dos trabalhos do artista. A secura dos textos e, ocasionalmente sua rudeza, aludem, em alguma medida, à rusticidade das primeiras esculturas, àqueles moldes revirados do avesso e mal ajambrados num canto de parede, suturas deixadas visíveis, superfícies acutiladas e ásperas, como que inacabadas. Ao contrário do que aparentam, as peças foram rematadas com a máxima precisão, exatamente no momento em que alcançaram a ideia pretendida, "precisa ser bem feito o suficiente para comunicar" ${ }^{62}$. Trata-se, em realidade, de acurácia que se deixa passar por desleixo. Aquilo que se entende por acabamento seria, nas peças de Nauman, quase uma afetação. A exigência de uma precisão máxima demove procedimentos de adição nas esculturas e ênfases retóricas nos textos.

Tal equivalência pode ser atestada no processo de escrita de Nauman, em absoluta consonância com o método de feitura de todos os outros trabalhos; citando uma entrevista de 1988: "o que eu tendo a fazer é ver algo, então refazê-lo e refazê-lo e refazê-lo, tentar todas as formas possíveis de refazer aquilo. Se eu for suficientemente persistente, eu volto para onde eu comecei. Eu acho que foi Jasper Johns que disse: 'às vezes é preciso dizer o óbvio”'63. Para a mostra "Raw Materials", comentada adiante, foram reunidos textos

61. Consultar a nota 57 deste capítulo para um contexto da discussão em pauta. A citação, no original, "At the root of this basic emotion is the fear of losing control of body and consciousness, of losing control of the social rules that the intellect knows how to follow, and again shitting in your pants". Cf. HIXSON, Kathryn. Nauman: Good and Bad. In MORGAN, Robert. Bruce Nauman. Baltimore: The Johns Hopkins University Press, 2002, p. 114.
62. O trecho todo no original foi citado na nota 27 do Capítulo 1.

63. "What I tend to do is see something, then re-make it and re-make it and remake it and try every possible way of re-making it.If I am persitent enough, I get back to where I started. I think it was Jasper Johns who said, 'sometimes it's necessary to state the obvious". Cf. KRAYNAK, Janet (Ed.). Op. cit., p. 319. 
produzidos ao longo da trajetória do artista e, nessa ocasião, ele falou a respeito de seu método de escrita: "a maioria dos textos, tanto os longos quanto os muito breves, é resultado de muita edição. Muita escrita condensada. Penso neles como poesia mais do que como literatura". Também deixou claro que o processo da escrita é semelhante ao processo de toda a obra: "trata-se, quase sempre, do resultado obtido após ter tentado de tudo, este é o modo como trabalho. Tenho alguma ideia, envolvo-me em todas as maneiras de executála, depois tento resgatá-la, torná-la mais simples, mais direta. E, às vezes, o resultado é muito próximo daquilo do que parti e, às vezes, não é” ${ }^{64}$.

Antes de passar aos comentários pontuais de alguns dos primeiros textos de Nauman, cabe esclarecer que há autores que abordam o uso da linguagem na obra concentrando-se nas aproximações com a filosofia da linguagem desenvolvida a partir do pensamento de Ludwig Wittgenstein (1889-1951). Janet Kraynak, por exemplo, desdobra o assunto para as teorias da linguagem de Ferdinand de Saussure (1857-1913), Mikhail Bakhtin (18951975) e J. L. Austin (1911-1960), enfatizando aspectos da teoria dos atos de fala e as noções de linguagem performativa ${ }^{65}$; já Jean-Christophe Ammann e Robert Storr comparam brevemente trabalhos de Nauman a trechos das Investigações Filosóficas de Wittgenstein (obra publicada postumamente, em 1953 ${ }^{66}$. Decerto a formulação de jogos de palavras, prática que Nauman faz questão de associar aos ensinamentos de William T. Wiley em torno da

64. 0 trecho completo, no original: "most of the texts, the long ones, as well as the little short ones, are the result of a lot of editing. A lot of writing that gets more and more condensed. I thought of it as more poetic than literature. [...] On writing the texts, of course, there's a lot of editing. Almost always, the result of trying everything, but that's the way I work. I have some sort of idea about something, get involved in all other ways you could do it, and than try to get it back - get it down to the simplest, most straightforward estimation. And sometimes that's really close to what I started with, and sometimes, it is not". Cf. SIMON, Joan. Hear Here: Interview with Bruce Nauman. Frieze
Magazine n. 86, Londres, out. 2004. Disponível em: http://www.frieze.com/issue/article/hear here. Acesso em: 11 fev. 2010.

65. Cf. KRAYNAK, Janet. Bruce Nauman's Words. In: Op. cit., p. 1-45.

66. Cf. AMMANN, Jean-Christophe. Wittgenstein and Nauman: Notes on the Works of Bruce Nauman. In: Bruce Nauman. Londres/Basel: Whitechapel/Kunsthalle, 1986, p. 21-29; STORR, Robert. Op. cit. [Beyond Words]; STORR, Robert. Please Pay Attention, Please. In: LEWALLEN, Constance M. (Org.). A Rose Has No Teeth: Bruce Nauman in the 1960s. Berkeley: University of California Press, 2007, p. 146-167. 
A Rose Has no Teeth, 1966, chumbo, $20 \times 20,5 \times 7,5 \mathrm{~cm}$.

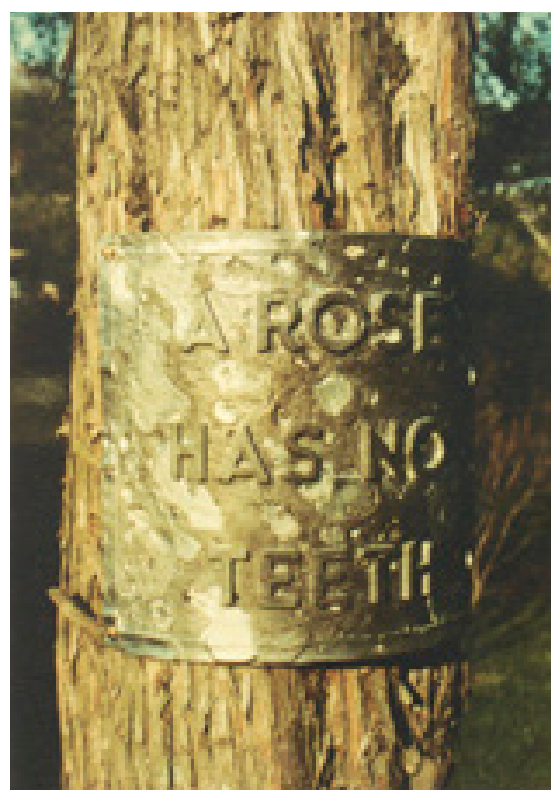

noção de dumb eye já comentada ${ }^{67}$, relaciona-se às leituras de Wittgenstein difundidas entre os artistas na década de 1960.

Esses autores focalizam o trabalho que Nauman realizou em 1966, A Rose Has No Teeth [A rosa não tem dentes]. A frase, extraída das Investigações Filosóficas, foi gravada em uma placa de chumbo e afixada em uma árvore. Em Wittgenstein, a frase exemplifica sentenças que são perfeitas em sua estrutura gramatical, mas que não possuem referencial concreto, empírico, no mundo. A respeito desse trabalho, Nauman declarou: "quando cogitei no que colocar nessa placa pensei nessas palavras, porque elas têm tanto a ver com a natureza quanto qualquer outra coisa que eu pudesse pensar" ${ }^{\prime \prime 8}$. Argumenta-se aqui que as palavras de Wittgenstein nesse trabalho são

67. Nas palavras de Wiley, "olhar para as coisas de um modo inocente e inculto para que se possa vê-las como elas são em vez de como são nomeadas" ["looking at things innocently and unlearnedly so you can see them for what they are instead of what they are named for"]. Cf. BRUGGEN, Coosje van. Op. cit., p. 107.
68. "When I thought of what to put on this plaque I thought of these words, because they have as much to do with nature as anything I could think of" [Cf. Kraynak, Janet (Ed.). Op. cit., p. 107]. 
tomadas antes por matéria-bruta (raw material) e, assim, em lugar de aprofundadas deveriam ser desdobradas em superfície.

Veja-se que, em 1970, quando questionado se seus trabalhos relacionavam-se aos moldes de Duchamp, Nauman afirmou que tinham mais relaçãocomas Investigações Filosóficas. Quando perguntado sobreo que mais lhe havia interessado na obra de Wittgenstein, respondeu: "somente o modo como Wittgenstein procede ao pensar sobre as coisas, sua consciência a respeito de como pensar sobre as coisas. Não acho que se possa apontar qualquer trabalho específico que seja resultado da leitura de Wittgenstein, mas há relação com um tipo de processo de como proceder ao pensar sobre as coisas” ${ }^{\prime 9}$. Em 1980, discutindo os trabalhos com jogos de linguagem, sobretudo aqueles nos quais expressões idiomáticas são "literalizadas visualmente" por meio de fotografias - série chamada Eleven Color Photographs [Onze fotografias coloridas (196667/1970)], nas quais ele fotografa-se "comendo as próprias palavras" ou com "pés de barro" etc. -, Nauman volta a ressaltar: "estava lendo as Investigações Filosóficas deWittgenstein, que acho que não oferecem nada exceto uma forma de questionar as coisas. Pode-se ter um argumento e persegui-lo até descobrir se faz sentido ou não, mas foi útil para mim de qualquer forma descobrir se [o argumento] ia a algum lugar ou se estava errado"70. Em outra ocasião, afirmou: "Wittgenstein perseguia uma ideia até ou poder afirmar que funcionava, ou que a vida não funciona daquele jeito e ter-se-ia que recomeçar. Ele não jogava fora o argumento falho, mas o incluía em seu livro"71.

69. Os trechos correspondentes às respostas, no original: "[...] it had more to do with Wittgenstein's Philosophical Investigations which I was reading at that time"/"Just the way Wittgenstein proceeds in thinking about things, his awareness of how to think about things. I don't think you can point to any specific piece that's the result of reading Wittgenstein, but it has to do with some sort of process of how to go about thinking about things". Cf. Kraynak, Janet (Ed.). Op. cit., p. 127.

70. “/ was reading Wittgenstein's Philosophical Investigations, which I think doesn't provide you with anything except a way of question [sic] things. You can have an argument and follow it until you find out that it makes sense or doesn't make sense, but it was still useful to me to find out that it did go to [sic] anywhere or it was wrong". Cf. Ibidem, p. 231.

71. "Wittgenstein would follow an idea until he could say either that it worked or that life doesn't work this way and we have to start over. He would not throw away the failed argument, but would include it in his book". Cf. BRUGGEN, Coosje von. Op. cit., p. 9. 
A estrutura do pensamento é, portanto, aquilo que Nauman credita como influência de Wittgenstein e o fato de que, para o filósofo, o processo de examinar as proposições a fundo é tão ou mais importante do que alcançar resultados válidos ${ }^{72}$. Em uma declaração mais recente, o artista foi ainda mais enfático quanto a esse aspecto: "gostava da clareza de seu processo e do fato de que ele desenvolvia um argumento até o ponto do absurdo lógico - o ponto onde a lógica e a linguagem entram em colapso"73.

\subsection{Palavras, peles, pedras: eu esfolado em lugar vagamente desconfortável}

Entre 1966 e 1975, a produção textual de Nauman foi intensa e diversificada, conforme as traduções anexas podem comprovar. Além das notas de projetos, das diretivas para performances e das propostas para exercícios mentais - algumas destas instruções devidamente comentadas em capítulo precedente - Nauman aventurou-se numa prosa poética de acento autoral em textos que acompanhavam suas primeiras instalações, como The Consummate Mask of Rock citado há pouco. Tais escritos, mencionou-se, operavam como análogos dos demais elementos dos trabalhos, somando informações distintas e enviesadas ao espaço expositivo, forjando, desta maneira, instâncias outras de apreensão sensível dos ambientes concebidos por Nauman. Em vez de acelerarem a imersão nos espaços, os textos tendiam a ser óbices para o suposto imediatismo da experiência física a que pudessem convocar; a experiência pretendida por tais trabalhos era precisamente a de um lugar intermediário, a um só tempo física e linguisticamente engendrado.

72. Note-se que todas as observações são feitas em relação às Investigações Filosóficas e nem sequer menciona-se o Tratado Lógico Filosófico (1922), obra precedente na qual a argumentação de Wittgenstein é completamente diversa.
73. "I liked the clarity of his process and the fact that he developed an argument to the point of logical absurdity - the point where the logic and the language breakdown". Cf. AUPING, Michael. Op. cit. [Metacommunicator], p. 9. 
Mais do que a saturação por reiteração exaustiva de poucos elementos, característica da produção textual a partir da década de 1980, conforme se verá no capítulo subsequente que tratará dos textos falados, os escritos relacionados às instalações dos anos 1970 saturam antes pela simultaneidade de sensações incitadas por oscilações abruptas de escala - ora referida às moléculas do corpo ora às grandezas astronômicas - e pela justaposição de temporalidades destoantes - que transitam da volatilidade dos pensamentos ao vagar geológico, da propulsão vascular aos ritmos submarinos. Desse modo, textos e ambientes procediam como informações enviesadas umas em relação às outras, nem corroborantes nem contraditórias, tal como as "linhas de enviesamento ou distorção" descritas por Nauman em Appendix [Apêndice, 1972], a saber: "linhas enviesadas nunca se encontram e não são paralelas no espaço, mas podem estar muito próximas ou muito distantes" ${ }^{74}$.

Tais trabalhos, nomeados por Nauman de instalações, ativavam o espaço expositivo alterando padrões perceptivos: blocos de pedra calculadamente distribuídos podiam causar ligeiras distorções da perspectiva, e essas poderiam resultar também de intervenções mais ostensivas na arquitetura, como o erguimento de paredes e a construção de recintos incongruentes, ou mesmo as interferências sutis feitas com fita adesiva no chão, tais como os quadrados desenhados no ateliê que aparecem nos filmes iniciais. Nas palavras do artista, "muitas das primeiras instalações tratam da construção de um espaço que poderia não parecer, à primeira vista, algo assim tão fora do comum, mas então você percebe que o espaço não é exatamente aquilo que você esperava. As paredes, a iluminação, ou algo está acontecendo e você não tem certeza de como categorizá-lo"75. Seja como for,

74. Skew lines never meet and are not parallel in space - but they can be very close together or very far apart". Consulte-se o Apêndice para o texto completo e a tradução.

75. “'A lot of the early installations are about making a space that might at first appear not to be anything that much out of the ordinary, and then you realize that the space isn't exactly what you expected. The walls or the light or something is happening and you're not quite sure how to categorize it". Cf. NAUMAN, Bruce. Drawings for Installations. Nova York: Sperone Westwater, 2008, p. 5. 
Diagrama/estudo para Get Out Of My Mind, Get Out Of This Room.

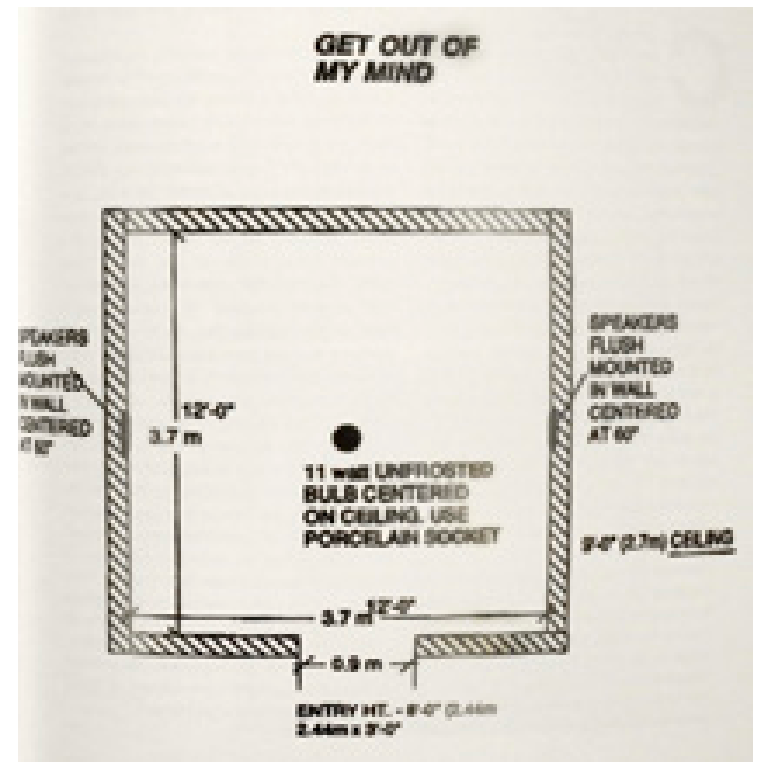

a escala dessas instalações é sempre dada em relação ao corpo humano e, mais do que isso, há trabalhos nos quais arquitetura é tratada como metáfora do corpo, porquanto o recinto onde são montados "simula" um espaço mental. Antes delas, apenas a sala vazia com dois alto-falantes embutidos nas paredes pelos quais se emitia a frase título Get Out Of My Mind, Get Out Of This Room [Saia da minha mente, saia desta sala (1968)] havia incitado a analogia entre o espaço expositivo e o espaço mental: Nauman intencionava provocar reverberações cerebrais simulando uma alucinose auditiva por meio da reiteração incessante da "frase comando" em entonações variadas, dos sussurros apavorantes aos gritos de ameaça. Este é, aliás, o trabalho precursor das grandes instalações sonoras em lugares vazios que o artista realizou recentemente, como a mostra "Raw Materials", em 2004, e o trabalho Giorni/ Days [Dias], montado pela primeira vez na Bienal de Veneza em 2009.

Nas instalações de meados dos anos 1970, textos e ambientes juntos geravam o desconforto desafiador pretendido por Nauman ao propugnar por "uma arte que leva você ao limite, e o obriga a uma maior consciência de si mesmo e da situação. Muitas vezes, sem que você saiba o que está enfrentando e/ou vivenciando. Tudo o que se sabe é que se 
está sendo empurrado para um lugar com o qual não se está acostumado e que há alguma forma de ansiedade envolvida nisso"76. Esses trabalhos propunham experiências físicas e intelectivas que instigavam percepções do espaço desvencilhadas de condicionantes que tomassem o corpo como entidade estável e axiomaticamente coordenada ${ }^{77}$. Poucas dessas instalações dos anos 1970 foram posteriormente remontadas ${ }^{78}$, mas os depoimentos confirmam que os ambientes concebidos por Nauman eram, em certo sentido, desorientadores, sendo a sensação agravada pelos textos lacunares que, em vez de de esclarecer ou facilitar a experiência física proposta, estimulavam vagamente a ansiedade já difusa nos espaços. Acerca disso, vale exemplificar com um comentário sobre o texto Left or Standing, Standing or Left Standing [Deixado ou Em pé, Em pé ou Deixado em pé (1971)] concebido para Installation with Yellow Lights [Instalação com luzes amarelas (1971)]: "este texto é típico da escrita de Nauman: preciso mas enigmático, intencional, refletido e, em última análise, obtuso. O clima é de mal-estar social combinado com a noção de que a violência reprimida é inerente à linguagem e à interação social"79.

76. "[...] an art that puts you on an edge; it forces you into a heightened awareness of yourself and the situation. Often without you knowing what it is that you're confronting and/or experiencing. All you know is that you're being pushed into a place that you're not used to and that there's an anxiety involved in that" [Cf. BRUGGEN, Coosje van. Op. cit., p. 194]. Também interessa a Nauman a ideia de resistência, ou melhor, o enfrentamento da resistência, a saber (no original): "what interested me was the idea that you go to your resistances, to whatever physical or social situation in you life or your work causes you problems. in other words, you don't try to avoid the resistance. you go straight to it, try to analyze the parts that make you uncomfortable. you can get at those things physically and then certain mental blocks will be released, or you can get at them mentally, using language, and then certain physical blocks will be released - or at least you will react physically to certain disruptions in the mental pattern. I've always thought that was an interesting approach, even if you think about it in terms of sculpture". Cf. AUPING, Michael. Op. cit. [Metacommunicator], p. 12.

77. Cabe notar que, nessa época, Nauman mostrava interesse por descobertas realizadas em outros campos do conhecimento; percebemse em seus escritos referências vagas à Gestalt, à fenomenologia e aos experimentos da psicologia comportamental. Como ocorre com as demais referências de que lança mão, Nauman também se aproxima dessas áreas com liberalidade e apresenta despretensiosamente os seus próprios experimentos, conforme atestam textos como Appendix e Withdrawal as an Art Form. Cf. Apêndice.

78. A série de corredores realizada na mesma década, ao contrário, vem sendo exibida com frequência, mas, segundo já se esclareceu, não será objeto desta tese. 


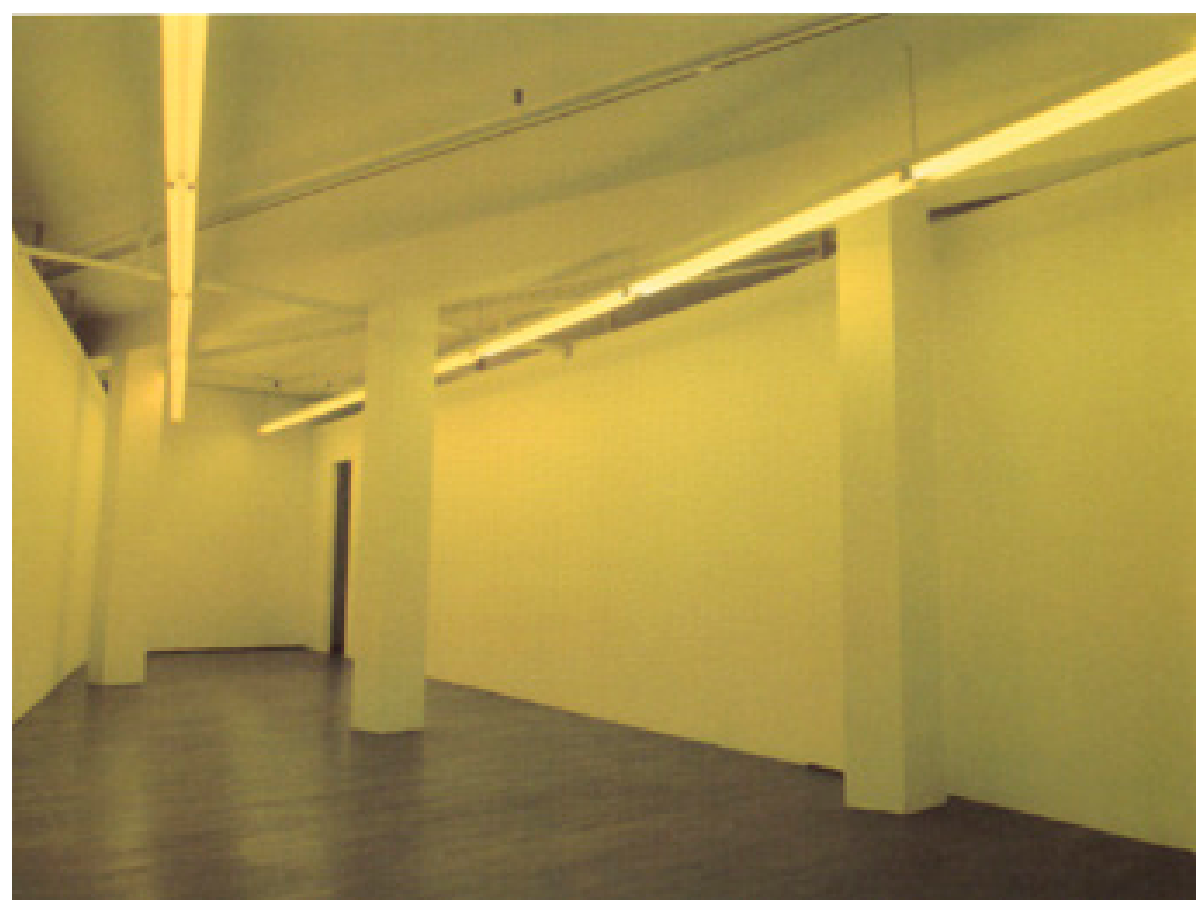

Installation with Yellow Lights, 1971, compensado e lâmpadas fluorescentes, dimensões variáveis.

Justamente assim é a escrita de Nauman nos textos que serão brevemente analisados: rigorosa mas enigmática ou lacunar, e tal como ocorre em The Lost Ones de Beckett, demonstrando um cuidado obsessivo com a exatidão para, entretanto, designar lugares e situações improváveis ou impossíveis. Além disso, a linguagem austera e acurada simula precisão matemática ao passo que flerta com os coloquialismos dos discursos de divulgação científica, sem mencionar as infiltrações de duplos-sentidos, por vezes inesperadamente grosseiros. Os textos são, portanto, capazes de criar graus variados de desconforto e estranhamento por si mesmos, independentemente dos espaços para os quais foram primeiramente elaborados, tanto que alguns foram reeditados em circunstâncias diversas

79. Comentário de Emma Dexter: "this text is typical of Nauman's writing: precise yet enigmatic, deliberate, thoughtful and ultimately obtuse. The mood is one of social unease combined with the notion of the suppressed violence inherent in language and social interaction" [Cf. DEXTER, Emma. Raw Materials. In: NAUMAN, Bruce. Raw Materials. Londres: Tate Publishing, 2004, p. 20]. 
das originais ou tiveram trechos vertidos em outros meios, como desenhos, gravuras, vídeos ou áudios, como ocorreu, para persistir no exemplo, com The Consummate Mask of Rock, cuja introdução integrou a grande instalação sonora montada na Tate Modern, em 2004.

A propósito da menção de Left or Standing, Standing or Left Standing, cumpre dizer que se trata do primeiro dos textos escritos para as instalações de Nauman, neste caso um recinto trapezoidal excessivamente iluminado por lâmpadas fluorescentes amarelas, construído no interior da galeria de Leo Castelli, em Nova York, em 1971. Consta que o ambiente de Installation with Yellow Lights precedeu e inspirou o texto, uma vez que ao caminhar pelo lugar recém-montado, que contava tão somente com duas paredes paralelas e, além do mais, havia sido instalado em meio aos pilares preexistentes no espaço, Nauman detectou que a angulosidade da estrutura e a intensidade da iluminação geravam sensações físicas desconcertantes, e o esforço de compensação visual do amarelo fluorescente provocava a emissão de flashes arroxeados que terminavam por fatigar os olhos:

\footnotetext{
No trabalho para Leo, construí um recinto dentro da galeria para que se pudesse ir de um ambiente a outro. Você partia da iluminação normal da galeria e depois ia para o espaço com o amarelo fluorescente. [...] Não era realmente dramático, apenas uma daquelas situações em que não é possível acostumar-se com a luz diferente. Ela incomodava e tornava difícil ficar no recinto. Se você olhasse para a parte de cima das paredes, a luz fria e a luz amarela se misturavam e produziam um roxo estranho ${ }^{80}$.
}

80. "In the piece for Leo, I built a room inside the gallery so that you go from one atmosphere to another. You'd start out in normal gallery lighting, and then go into this space with flourescent yellow [...] It wasn't really dramatic, just one of those situations where you couldn't quite get used to the different light. It nagged at you and made it difficult to be in that room. If you looked up at the tops of the walls, the cool light and the yellow light would mix and create a weired purple". Cf. NAUMAN, Bruce. Op. cit. [Drawings for Installations], p. 26 e 28. 
Nauman declarou que "talvez o espaço fosse insuficiente" e decidiu elaborar um texto que "de certa maneira é um poema autônomo que, ao lado do espaço, não o descreve. A escrita trata da linguagem e inclui um tipo de ansiedade que o espaço parecia gerar" ${ }^{\text {"1 }}$. Na instalação original, Left or Standing, Standing or Left Standing foi impresso no convite da mostra e no formato de pôster destacável a ser deixado à disposição dos visitantes na entrada da galeria. Numa remontagem posterior, em 1999, no Museu de Arte Moderna de Fort Worth, Texas, os dois trechos foram transpostos para dois monitores de televisão, posicionados na entrada do recinto.

O texto curto parece projetar-se um pouco além ou, talvez, um pouco aquém dos fenômenos perceptivos estimulados pelo ambiente, evocando um estado de vacilante indefinição que conduz a sucessivas releituras, estas, imagina-se, em lugar de favorecer refreavam a experiência do espaço. A composição em duas partes e a repetição de certos termos em ambas, sugerem, num primeiro momento, uma relação especular ou uma complementaridade mutuamente esclarecedora, hipóteses afastadas tão logo se constata que os trechos mantêm-se encerrados neles mesmos, não se podendo derivar de um deles quaisquer consequências para o outro: são, a um só tempo, irredutíveis e lacunares, pois a precisão da linguagem retém a vagueza e a indefinição pretendida no conteúdo. Notável na construção poética é a cópula de termos tão marcadamente contrastantes quanto "precisão", "exatidão" e "acuidade" em face de "vacância", "lugar vagamente desconfortável" e "período não muito longo mas indeterminável" ${ }^{\prime 2}$. Notável também que tais termos se remetam a assuntos recorrentes na obra, como é justamente o caso da ideia de "vacância", um espaço à espera, um lugar que fora ocupado e talvez esteja em busca de um novo preenchimento, noções essas condizentes com a produção escultórica de

81. “[...] perhaps the space was insufficient [...] in a way it's a poem that's stands by itself, next to the space, without describing it. The writing is about language; it includes a kind of anxiety that the space seemed to generate". Cf. BRUGGEN,
Coosje van. Op. cit., p. 193.

82. "Precision/accuracy/acuity/vacancy/vaguely/ uncomfortable place/not a long but undeterminable period". 0 texto e a tradução encontram-se no Apêndice. 
Nauman, especialmente com os trabalhos que se referem às mensurações do corpo do artista ou a série de moldes vazios, apresentados ao avesso.

As superfícies, outra questão constante, aparecem no texto na alusão à pele machucada, "pequenos cortes nas pontas dos meus dedos ou sobre as costas das minhas mãos" ${ }^{\prime 3}$. Aliás, nesse e nos demais escritos que acompanham as instalações, as superfícies - quer sejam as dos objetos, da arquitetura ou a própria pele do corpo - bem como os modos físicos ou metafóricos de as cobrir, tensionar, camuflar, expor, esgarçar ou ferir são assuntos reincidentes, sendo que, assim como ocorre nas demais instâncias da obra, também nos textos as superfícies do materiais se equivalem e não há um interior que não possa ser, de chofre, revirado e exposto.

Embora não soubesse qual imagem poderia representar adequadamente as sensações instadas pelo amarelo intenso no interior de uma arquitetura pouco congruente, Nauman, em seu texto, buscou reforçar, ainda que de modo enviesado, a impressão de que aquele era o lugar errado para se estar ${ }^{84}$. Os comentários de época tendem a confirmar que texto e ambiente funcionavam de modo análogo, cada qual despertando níveis próprios de tensão e estranhamento, tocando-se de viés, sem que se esclarecessem mutuamente. A historiadora Coosje van Bruggen escreveu que "o texto correlaciona estados de espírito e atividades que evocam medos específicos, enquanto a ansiedade evocada pelo recinto permanece completamente indefinida e abstrata" ${ }^{85}$. O curador Michael Auping, que convidou Nauman a remontar a instalação em 1999, confirmou que o texto antecipava, em certa medida, o desconforto e a ansiedade sutis criadas espacialmente, e que texto e espaço mesclavam razão e consciência com

83. "[...] small cuts on the tips of my fingers or across the backs of my hands". Cf. Apêndice.

84. Nas palavras do artista, "I couldn't imagine what particular image could represent the space. There wasn't any part that summed it up. There wasn't an image that could give you that underlying sense that you were maybe in the wrong place".
Cf. AUPING, Michael. Op. cit., p. 13.

85. No original, "the text correlates states of mind and activities that evoke specific fears, while the anxiety evoked by the room stays completely undefined and abstract". Cf. BRUGGEN, Coosje von. Op. cit., p. 193. 
desconexão e afeç̧ões inconscientes ${ }^{86}$, ressaltando que "Left or Standing acessa aquele ponto pivotante, levemente ansioso, entre o físico e o mental que não faz sentido, mas não é um absurdo. Nem é surreal; 'sub-real' talvez fosse uma descrição mais precisa - uma experiência que ocorre abaixo dos canais normais de comunicação" 87 . De fato, não é surreal pois os trabalhos de Nauman não se relacionam ao "transe" ou à "transfiguração" pressupostos na tradição surrealista.

Nem surreal, nem absurdo, mas vagamente ansioso e desconfortável. Talvez essa seja uma maneira de referir-se ao texto em que são relatadas as ocorrências no interior do cilindro emborrachado, de cinquenta metros de circunferência e dezesseis metros de altura, onde Beckett encapsulou duzentas "criaturas" que vivem em abstemia, sujeitas às privações de diversos níveis. A escala do ambiente é inadequada para um convívio caso se pressuponha que tais "criaturas" possam ser "algo" humanas. O narrador contabiliza: "um corpo por metro quadrado ou seja um total de duzentos corpos número redondo" 88 . As condições excruciantes como a intensa e perene iluminação amarelada que resseca as peles e provoca cegueira e o espaço "milimetricamente" apertado em que vivem em constante atrito, mas, acima de tudo, a linguagem descritiva e neutra empregada por Beckett são dados que dão ao leitor a sensação de que ele observa experiências de laboratório. Aqui, voltam à baila os já mencionados Withdrawal as an Art Form (1970) e Appendix (1972), e outro escrito de Nauman, False Silence [Silêncio falso (1975/2000)].

86. Palavras de Michael Auping, citadas na integra: "the text and the space touch each other through strangely discursive analogies in which reasoning and consciousness blur with disconnectedness and unconscious feeling. Seeing the text on a monitor before walking into the space is particularly effective because the language provides an internal dissonance that antecipates the low levels of anxieties and subtle discomfort evoked in the space [...] Left or Standing taps that slightly anxious pivot point between the physical and the mental that does not make sense but is not nonsense. Nor is it surreal; sub-real would be a more accurate description - an experience that takes place below normal channels of communication". Cf. AUPING, Michael. Op. cit., p. 13.

87. Nas palavras de Michael Auping, conforme nota acima.

88. Cf. BECKETT, Samuel. O despovoador. Mal visto mal dito. Tradução de Eloísa Araújo Ribeiro. São Paulo: Martins Fontes, 2008, p. 8. 
Em 1975, Nauman gravou False Silence na íntegra e construiu, dentro de uma das salas de uma galeria de Los Angeles, um corredor estreito e intensamente iluminado por luzes fluorescentes brancas, no interior do qual dispôs dois alto-falantes que transmitiam a gravação. Depois disso, trechos variados desse texto, ou por ele inspirados, passaram a figurar em outros trabalhos, tanto em desenhos e gravuras, como No Sweat [Nenhum suor (1975)] ou Help Me Hurt Me [Ajude-me Fira-me (1975)] ou Silver Grotto/ Yellow Grotto [Gruta prateada/ Gruta amarela (1975)] - que trazem excertos do escrito como "eu não transpiro; eu pisco meus olhos para marcar o tempo; você não pode me ajudar; eu posso sugá-lo até a última gota" ${ }^{\$ 9}$-, como também em novas instalações sonoras como Anthro/Socio [Antro/Sócio (1992)], na qual são repetidas de modos diversos expressões como "help me hurt me", que também pode ser traduzida por "ajude-me a me ferir".

Já se comentou que, na década de 1980, Nauman associa as grandes maquetes de túneis e corredores sem saída à leitura, entre outros, de $O$ despovoador. Conforme foi sugerido nesta tese, segundo a carta enviada a Castelli em 1973, é provável que ele tivesse lido o livro à época. Cogitase aqui uma aproximação inédita entre alguns dos textos de Nauman da década de 1970 e este pequeno livro de Beckett, publicado em inglês no mesmo período. Conjectura-se que não somente temas como confinamento e contenção do corpo estejam em pauta em ambas as produções no mesmo momento, mas também um certo sentido de extenuação provocada por condições externas, como a luz intensa que perpassa o livro de Beckett e é empregada nas primeiras instalações de Nauman. Também as formas de apreensão do transcurso do tempo são enfatizadas por ambos. O narrador de Beckett aponta a agitação frenética de parte dos habitantes do cilindro e também o ritmo relentado, amortecido, de outros, um tipo

89. "I don't sweat; I blink my eyes to keep the time; you can't help me; I can suck you dry". Consultem-se o texto e a tradução no Apêndice. 


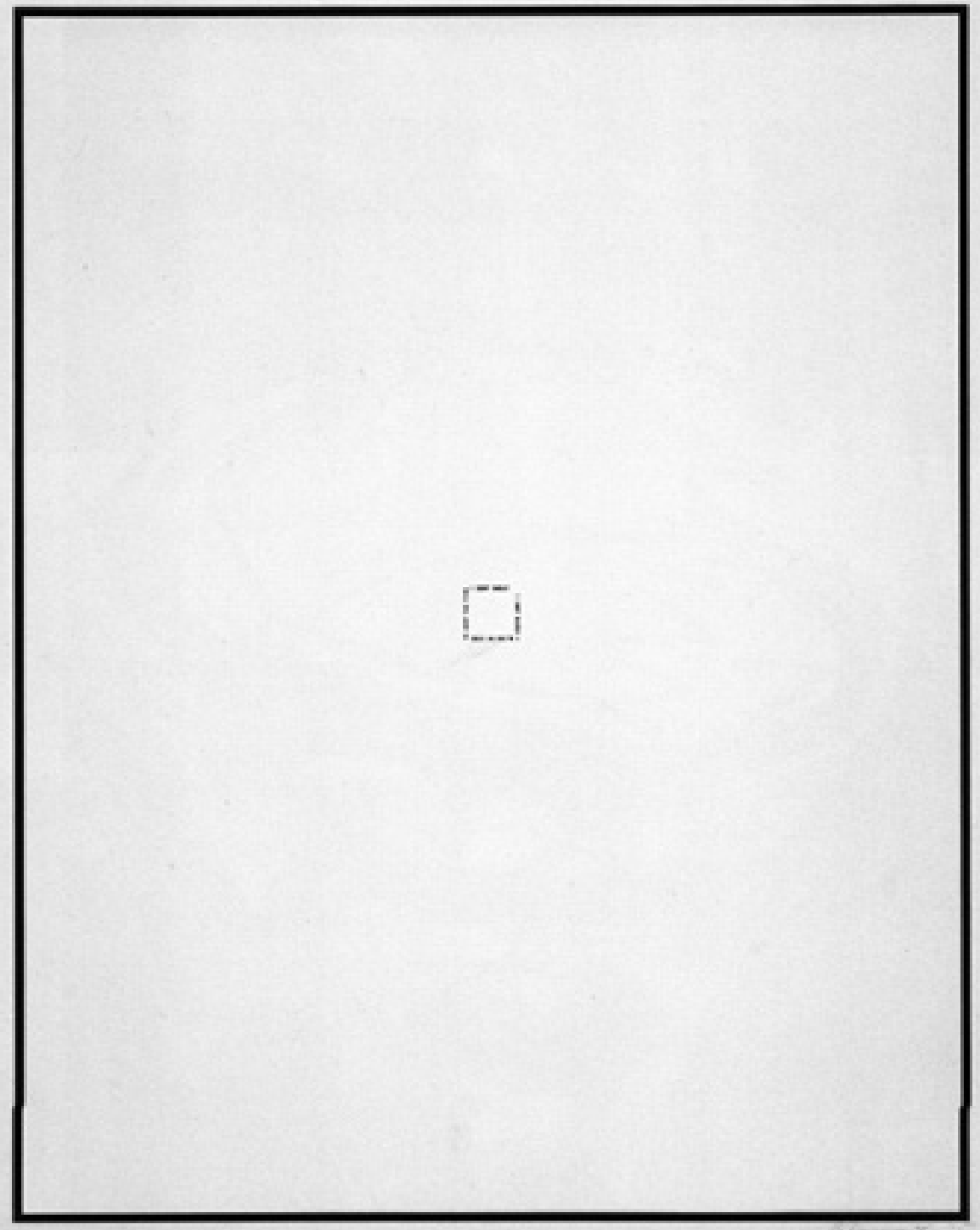


de vagar que promove uma percepção em voltagem rebaixada. Já False Silence é encerrado com "eu pisco os meus olhos para marcar o tempo". No texto, Nauman descreve uma situação "algo" humana, porém os processos corporais, sejam eles físicos, psíquicos e, principalmente, fisiológicos estão transtornados: um corpo que suga ou drena absolutamente tudo que dele se aproxima, sorve "até a última gota". Tudo é consumido, nada excretado, "um observador, um consumidor, um usuário apenas" Uma acumulação máxima, sem descompressão: "nenhuma expressão, nenhuma comunicação de qualquer tipo" ${ }^{91}$. Detritos gerados por processos fisiológicos incompletos "eu inalo", "não exalo", "eu não transpiro", "eu não tenho odor", "sem urina/eu não defeco" ou por processos intelectivos e emocionais falhos, "eu coleciono, eu não consigo processar" ou "eu não tenho controle sobre os tipos e as qualidades dos pensamentos" ou "sem resposta emocional às situações" ${ }^{2}$. Ao final, um algo a que ou a quem - não se discerne com precisão apesar das palavras precisas empregadas na descrição - não se pode nem ferir nem ajudar ["you can't hurt me; you can't help me"]. Voltam aqui também os temas do desamparo e da incapacidade de aprendizado, que aparecem em trabalhos com palhaços, nos carrosséis de animais mutilados e nos trabalhos que mencionam os ratos e as experiências de laboratório, como as gravuras nas quais se lê "I learned helplessness from the rats".

Em $O$ despovoador, o ambiente e as regras de convivência são descritos com frieza e minúcia. As criaturas, ou melhor, os "corpos" são tipificados. Entretanto, o narrador não menciona se há oxigênio ou sistemas de ventilação no recinto; não menciona se as criaturas respiram. Não há indicação de outras necessidades fisiológicas além da satisfação sexual,

90. "I can suck you dry" e "an observer, a consumer only, a user only". Cf. Apêndice.

91. "No expression, no communication of any kind". Cf. Apêndice.
92. "I don't sweat/l have no odor/l inhale don't exhale/no urine/l don't defecate: no excretions of any kind"; "I collect, I can't process"; "I have no control over the kinds and qualities of thoughts"; "no emotional response to situations". Cf. Apêndice. 
eventual e bastante rebaixada. Não se alimentam, não excretam, não se comunicam verbalmente ao que parece. São qualificadas por uma condição existencial pautada pela falta (buscadores, ex-buscadores, desistentes), características atribuídas segundo a movimentação dentro do cilindro:

Vistos de um certo ângulo esses corpos são de quatro tipos. Em primeiro lugar aqueles que circulam sem parar. Em segundo aqueles que às vezes param. Em terceiro aqueles que a menos que sejam expulsos nunca deixam o lugar que conquistaram e expulsos se jogam sobre o primeiro livre para ali se imobilizar de novo. Não é exatamente assim. Pois se nestes últimos ou sedentários a vontade de escalar morreu ela não deixa de estar sujeita a estranhas ressurreições. O fulano deixa então seu posto e parte em busca de uma escada livre ou se junta à fila de espera menos longa ou mais próxima. Na verdade é dificil para um buscador renunciar à escada. São paradoxalmente esses sedentários que mais perturbam com seus atos de violência a calma do cilindro. Em quarto aqueles que não buscam ou nãobuscadores sentados em sua maioria contra a parede na atitude que arranca de Dante um de seus raros pálidos sorrisos. Por nãobuscadores e apesar do abismo ao qual isso conduz é impossível finalmente entender outra coisa além de ex-buscadores ${ }^{93}$.

Os "fulanos" buscam presumivelmente a saída. A hipótese de evasão nem se confirma nem é abandonada, pairando constantemente a incerteza quanto ao êxito da busca" ${ }^{94}$ : desde sempre um boato corre ou ainda melhor a ideia ocorre que existe uma saída. Aqueles que já não acreditam nela não estão a salvo de acreditar nela novamente [...]"95. A interação possível é o contato inescapável de corpos que roçam ou espremem suas peles ressequidas pela luz e pelas variações bruscas de temperatura, que passa de um extremo ao outro em segundos: 
O efeito desse clima sobre a alma não deve ser subestimado. Mas ela sofre com ele certamente menos do que a pele cujos sistemas de defesa desde o suor até o arrepio são a todo instante contrariados [...]. Esse ressecamento do invólucro tira da nudez uma boa parte de seu charme tornando-a cinza e transforma num roçar de urtigas a suculência natural de carne contra carne ${ }^{96}$.

Todos seguem normas estritas. As transgressões são punidas com violência. Os degraus faltantes das escadas, únicos objetos presentes no recinto, são usados para as retaliações: "os degraus que faltam estão nas mãos de uns poucos privilegiados e são usados para agressão e autodefesa. Tentativas solitárias de estourar o crânio com eles só levam a perda de consciência momentânea" ${ }^{97}$. Na verdade, o roçar das peles ou a violência são as vias habituais de "comunicação" entre as criaturas.

Embora o narrador pretenda descrever rigorosamente as ocorrências, junto às incertezas da fuga há algumas imprecisões infiltradas por todo o texto. Veja-se por exemplo estes trechos: "está portanto entendido que passado um certo prazo difícil de calcular mas que cada um sabe medir com uma diferença de segundos a escada volta a ficar livre" 98 ou "a infração não é voluntária mas se deve a uma desregulação temporária de sua ampulheta interior" ${ }^{\prime 99}$. Excertos como esses abalam o rigor e instilam vacilação e vagueza no relato.

Retomando os comentários sobre a instalação de Nauman, Floating Room [Recinto flutuante (1972)]. Tratava-se de um recinto retangular, aberto nas extremidades superior e inferior, suspenso a alguns centímetros do chão e iluminado por luzes fluorescentes brancas. A estrutura de madeira compensada prendia-se ao teto da galeria de Castelli por cabos de aço, a uma altura suficiente para que o centro do retângulo se localizasse 
acima do centro de um corpo que ali adentrasse pela porta aberta em uma das faces. Desse modo, simulava-se que o recinto não sofria a ação da força gravitacional, tal como se pudesse levitar ou equilibrar-se sobre a fatia de luz intensa projetada abaixo da estrutura. O texto que acompanhava a instalação é um exercício mental aos moldes dos demais concebidos pelo artista no mesmo período, e sucintamente propõe que se encontre o centro de um lugar. Nas palavras de Nauman, "Floating Room tratava de não ser capaz de controlar o espaço ao seu redor, o espaço dentro do recinto iluminado flutua para o exterior, onde está escuro" ${ }^{100}$.

Nesse conjunto de instalações e textos de meados da década de 1970, há dois trabalhos nos quais as relações entre o espaço arquitetônico e o corpo humano são ainda mais explícitas do que nos demais e se desdobram surpreendentemente em direção aos impalpáveis corpos celestes, seus movimentos e ritmos específicos. Tanto em Flayed Earth/ Flayed Self [Terra esfolada/Eu esfolado $\left(1973^{101}\right)$ ] quanto em Cones Cojones [Cones Cojones $\left(1974^{102}\right)$ ] as intervenções nos espaços expositivos são mínimas e ainda assim capazes de incitar as sutis distorções perceptivas pretendidas por Nauman: desenhos com fita adesiva nos chãos ou atravessando as paredes das galerias, procedimento semelhante de demarcação do espaço ao que o artista costumava empregar no ateliê. Nos recintos amplos e vazios, os desenhos extensos envolviam e continham o espaço como se pudessem movê-lo no mesmo compasso sugerido nos

100. No original, "The Floating Room was about not being able to control the space around you; the space inside the lit room floats to the outside, where it is dark". Cf. BRUGGEN, Coosje von. Op. cit., p. 194. 0 texto e a tradução podem ser consultados no Apêndice.

101. Há uma controvérsia não esclarecida na bibliografia disponível acerca da data deste texto. É provável que tenha sido escrito em 1973, juntamente com os desenhos do projeto da instalação, mas só tenha vindo a público no ano seguinte, na montagem da exposição homônima na galeria Nicholas Wilder, em Los Angeles. 0 texto foi integralmente impresso no fôlder distribuído por ocasião da mostra, mas a versão original é uma espécie de colagem a partir de recortes de trechos escritos à máquina. 0 texto completo e a tradução encontram-se no Apêndice. 102. O texto Cones Cojones é de 1974, mas a instalação só foi montada em 1975 na galeria de Leo Castelli, em Nova York. Consultem-se o texto e a tradução no Apêndice. 

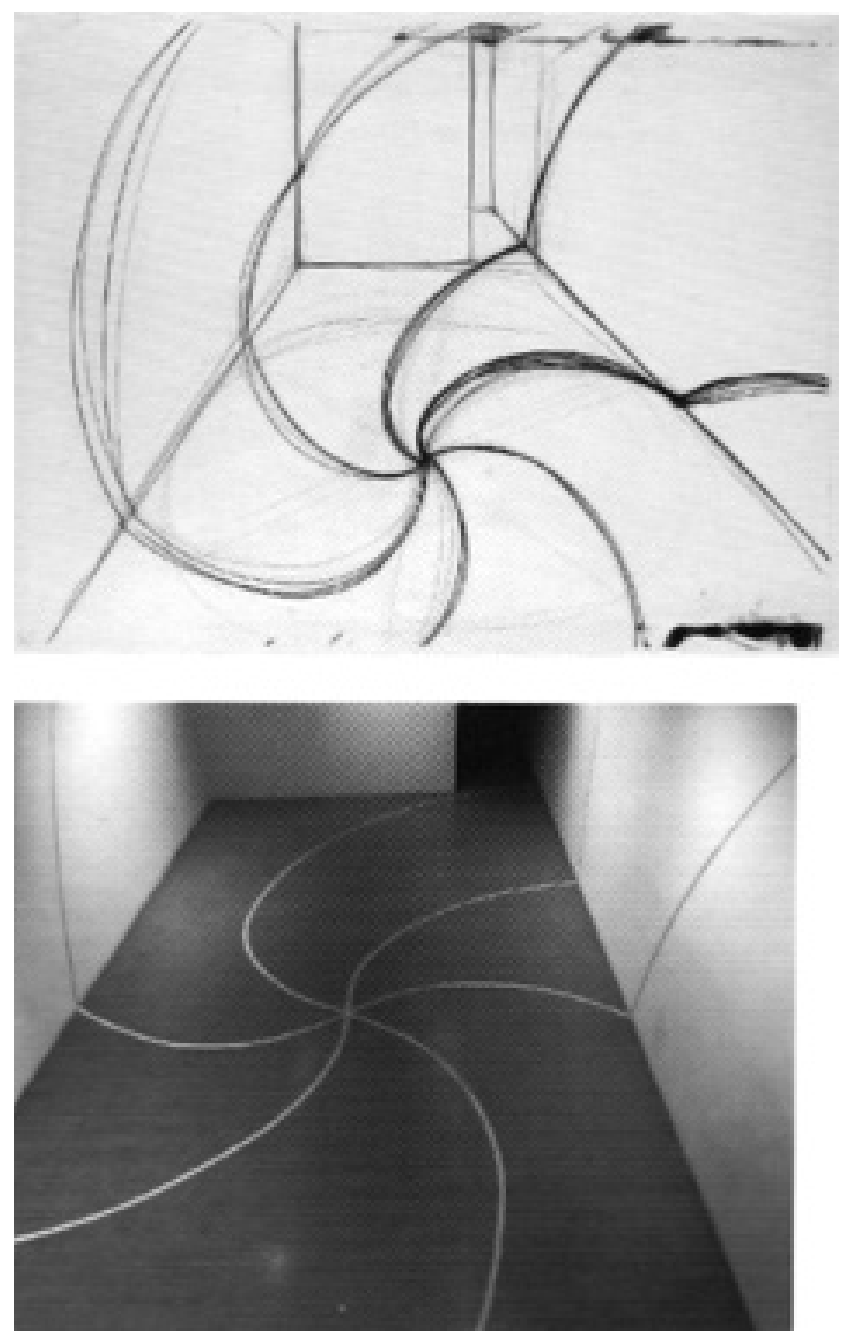

Estudo para Flayed Earth/Flayed Self: Skin/Sink, 1973-74, grafite, caneta e nanquim sobre papel, 56,5 x $102 \mathrm{~cm}$.

Flayed Earth/Flayed Self: Skin/Sink, 1973-74, instalação, dimensões variáveis.
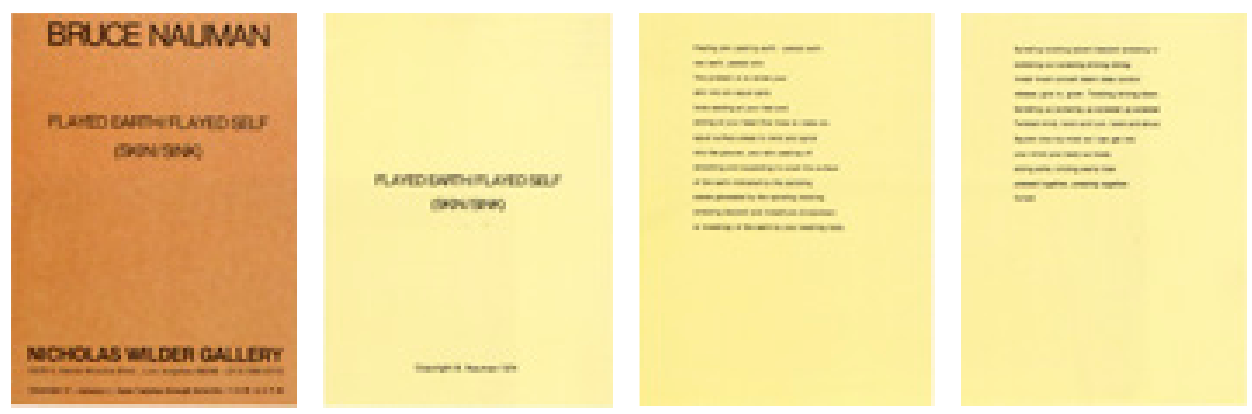


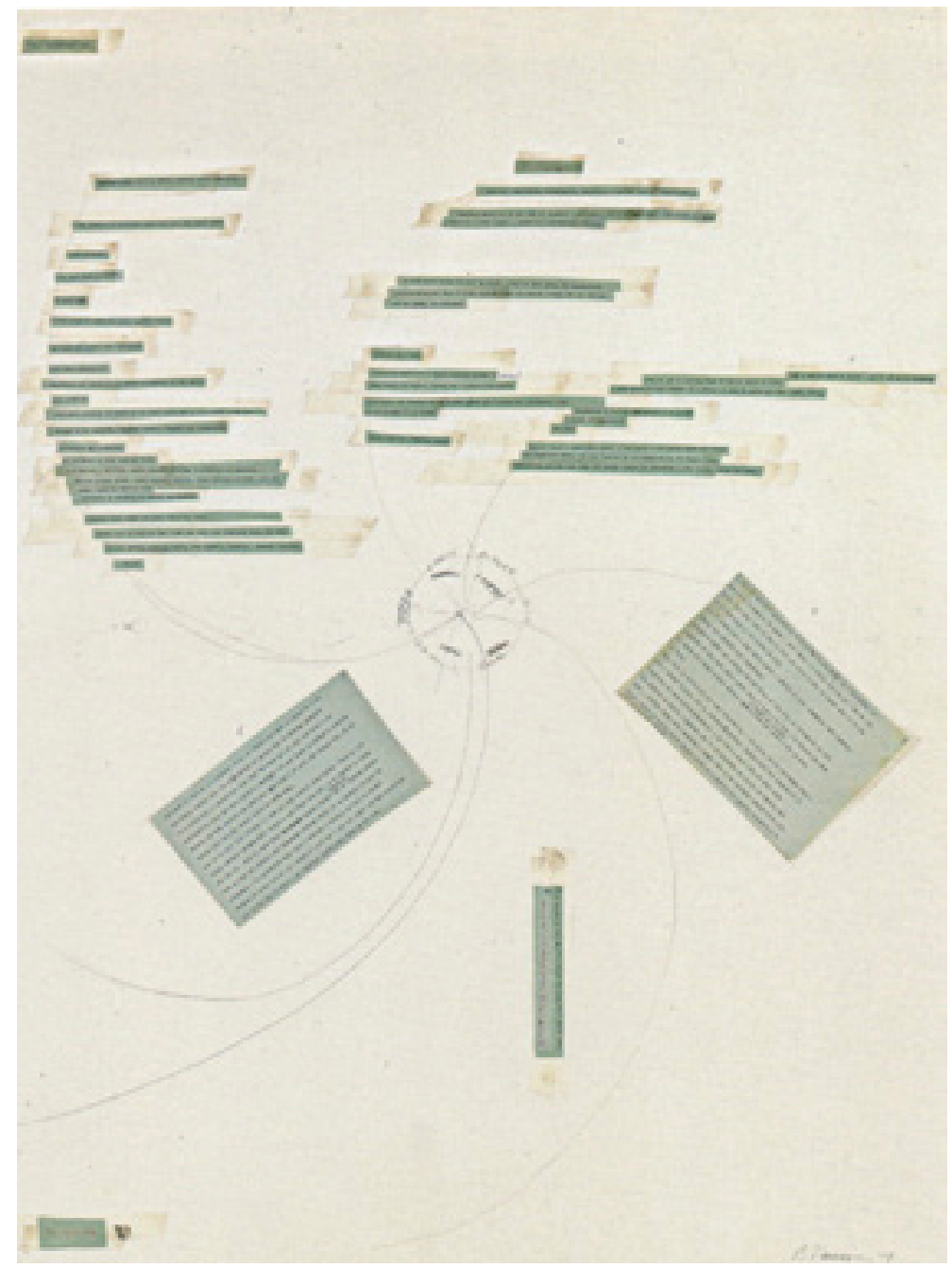

Estudo para Flayed Earth/Flayed Self: Skin/Sink, 1973-74, grafite e colagem com texto datilografado sobre papel, $102 \times 76,3 \mathrm{~cm}$.

Catálogo de Flayed Earth/Flayed Self: Skin/Sink, 1973-74.
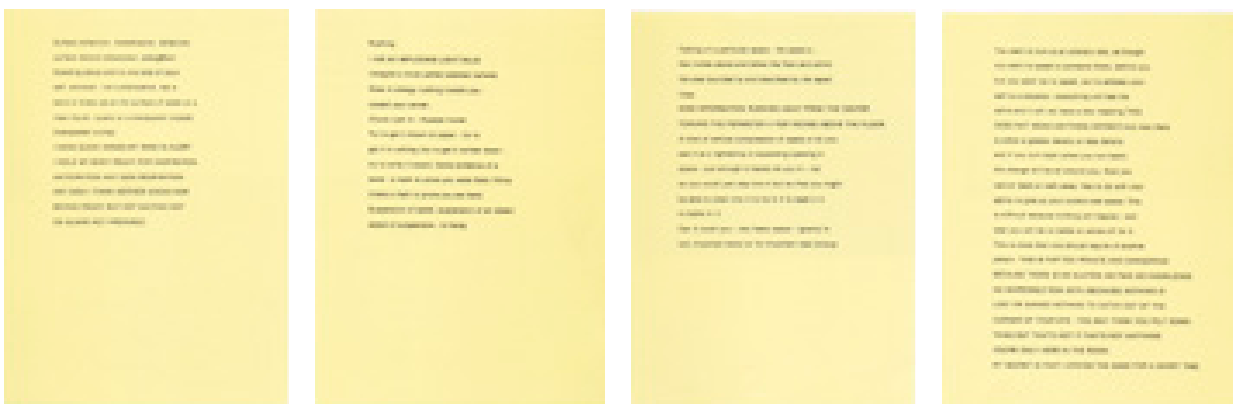
textos, ora expandindo ou comprimindo as bordas, ora propulsando uma rotação espiralada em torno de um eixo chão adentro, cada um dos desenhos acompanhando as imagens forjadas nos escritos.

A escolha do material para desenhar nas superfícies, a fita adesiva, adequa-se à própria sensação de impermanência ou de experiência fugidia assinalada nos textos, talvez relacionada à velocidade vertiginosa exigida do pensamento para equalizar grandezas tão diversas quanto as referidas aos buracos negros, à translação e à rotação do planeta, aos ritmos das marés - essencialmente, às características presentes nos ciclos geofísicos e para calibrá-las na escala do corpo e então transferi-las para a superfície do espaço e, mais do que isso, para a superfície do corpo, para a pele da qual se exige que descame, estique, expanda, retorça, ceda, relaxe, afunde, encolha, arrepie, inverta seu contorno, emerja, colapse. Repõem-se aqui, em alguma medida, as analogias que Nauman constrói entre os materiais que emprega: não o peso e a densidade que equiparam as palavras às pedras em The Consummate Mask of Rock, mas a adesão não duradoura dos desenhos às superfícies que os recebem, a própria impermanência que trai o material de que são feitos; a baixa aderência dos desenhos opera tal como um análogo preciso da falta de coesão, da vagueza e da urgência que caracterizam as escritas de Flayed Earth/Flayed Self e Cones Cojones.

Não bastassem as disparidades de escala e de temporalidades, os textos combinam um tom confessional oscilante com um linguajar pretensamente científico, que o artista tumultua e com imagens explicitamente sexuais ou com citações de clichés da cultura pop, como trechos de canções de Elvis Presley ou dos Beatles ${ }^{103}$. Comparados às

103. Há em Flayed Earth/ Flayed Self uma referência à canção Twist and Shout, escrita por Phil Medley e Bert Russell, mas eternizada pelos Beatles em 1964, como também uma menção a "fools rush in", conhecida expressão tornada célebre na voz de Elvis Presley cantando Can't
Help Falling in Love lescrita por Hugo Peretti, Luigi Creatore e George David Weiss) no filme Blue Hawaii, de 1961, "Wise men say /Only fools rush in /But I can't help /Falling in love with you ("Dizem os sábios /que somente os tolos se precipitam /Mas não consigo evitar /Cair de amores por 
torções agitadas da escrita e à profusão de estados que evocam, os desenhos adesivados no espaço parecem ainda mais austeros e diagramáticos, como se o contraste reiterasse a evidência de que se originaram de cálculos matematicamente precisos e não de um desenho gestual.

Fisionomicamente, as espirais de Flayed Earth/Flayed Self que atravessavam, de fora a fora, chão e paredes da galeria retangular, talvez até se passassem por um desenho gestual dada a desinibição com que ocupavam o espaço: a partir do centro da sala, as espirais dividiam o chão e as paredes em seis partes iguais, conferindo a sutil sensação de que torciam os planos em direção ao centro, como se pudessem afundá-los no solo a partir do ponto central, ou dando a impressão de que o movimento espiralado descascava - ou "esfolava" - as superfícies da mesma forma com que se descascam laranjas. E, de fato, essas são duas imagens sugeridas no texto: "pele descamando, terra descamando" ou ainda "o problema é dividir sua pele em seis partes iguais, linhas começando por seus pés, terminando em sua cabeça (cinco linhas para compor seis áreas de superfícies iguais) para torcer e espiralar chão adentro" 104 . Corpo e espaço físico são equivalentemente mensurados e suas superfícies se comutam, "sua pele descamando, esticando e expandindo para cobrir a superfície da terra" ${ }^{105}$.

Os movimentos sugeridos são velozes e explicitados pelo encadeamento ritmado de verbos, sem interposições ou só com pausas

você"). Desde então, a expressão é comumente empregada para se referir ao "tolo apaixonado" que entra de cabeça em um relacionamento lem particular, um que seja potencialmente destrutivo e malfadado); no texto, Nauman joga com a homofonia entre "rush in" e "russian".

104. "Raw earth, peeled skin"/"The problem is to divide your skin into six equal parts, lines starting at your feet and ending at your head (five lines to make six equal surface areas) to twist and spiral into the ground, your skin peeling off". Cf. Apêndice.
105. Nauman afirmou que sua ideia era “relacionar aquela descamação com a superfície da terra e com a superfície do corpo. Imagine ter de se expandir para preencher a terra, e a terra preencher você, depois, tendo se tornado equivalente à terra, ser esfolado ou descamado". No original, "to relate that peeling to the surface of the Earth and to the surface of the one's body. Imagine having to expand yourself to fill the Earth, and the Earth filling yourself, then, having become equivalent to the Earth, being flayed or peeled". Cf. BRUGGEN, Coosje van. Op. cit., p. 194. 
mínimas, "aparafusando desaparafusando penetrando conduzindo mergulhando invista inverta converta ceda relaxe controle libere, desista, rendido" ${ }^{106}$. Nesse trecho é possível notar que as referências sexuais permeiam o texto, sendo que os duplos sentidos empregados não são nada sutis, conforme se esclarece nas notas explicativas da tradução; o próprio verbo "aparafusar" tem, em inglês, inequívoca conotação sexual e seu uso é grosseiro, propositalmente vulgar.

$\mathrm{Na}$ fusão entre as imagens sugeridas no texto e o ambiente, Nauman constrói um grande entranhado de superfícies, uma espécie de "arquitetura corporal" e dela solicita um comportamento quase fisiológico, atribuindo-lhe uma capacidade de expansão e imiscuição multidirecional. Ao mesmo tempo, não cessa de restituir à prosa poética de Flayed Earth/ Flayed Self um estatuto de exercício mental, entrecortando a corporeidade e a ação material sugeridas pelas palavras quer com solicitações singelas à imaginação - "imagine uma esfera abstrata mais perfeita" ou "imagine um gás pesado caindo" - quer com intromissões mais invasivas, "contorçase para dentro de minha mente para que eu possa entrar na sua mente seu corpo nosso corpo" ${ }^{107}$. A propósito, todos os exercícios mentais da década de 1970 balizam-se pela ambiguidade, direcionam-se à imaginação justamente para instá-la a conceber imagens que aludem ao contato entre superfícies orgânicas e inorgânicas, como é o caso das instruções para afundar no chão, para permitir que o chão se eleve em torno do corpo ou para pressionar o corpo contra uma parede até removê-la mentalmente.

As alusões às ideias de impermanência e de velocidade perpassam Flayed Earth/Flayed Self assim como as formas espiraladas invadem a arquitetura, e há excertos que se referem à própria experiência fugidia ou

106. "[...] screwing in screwing out screwing driving diving spiraling twisting ascent descent invest invert convert relent relax control release, give in, given". Cf. Apêndice.
107. "[...] imagine a more perfect abstract sphere"|"Imagine a heavy gas sinking to the floor"/"Squirm into my mind so I can get into your mind your body our body". Cf. Apêndice. 
vacilante do processo da escrita e, logo, ao esforço do artista para plasmála de algum modo, "eu tenho mãos rápidas minha mente está alerta/eu mantenho meu corpo pronto para inspiração/antecipação e respiração de sinais/qualquer suspiro/acho eu nem à frente nem atrás/pronto mas não à espera/não em guarda/despreparado" ${ }^{108}$. Ou então o seguinte fragmento: "tente colocar no papel - tente escrever (...) algumas evidências de um estado - uma marca para provar que você estava lá: Kilroy (faça uma marca para provar que você está aqui)" ${ }^{109}$. A referência pop no trecho é a frase "Kilroy was here" ("Kilroy esteve aqui"), conhecida a partir da Segunda Guerra desde que passou a ser comumente pichada por soldados norteamericanos em combate no exterior para marcar de forma mais duradoura sua breve estadia no local; referência que ganha um sentido sinistro já que a Guerra do Vietnã ainda estava em curso (1955-1975). O texto se encerra justamente com a noção de impermanência, "meu segredo é que permaneci o mesmo por um curto período de tempo" ${ }^{110}$.

Em todos os textos da década de 1970, sobretudo naqueles que compõem as instalações, a escrita é deliberadamente fragmentária e orientada por procedimentos de desconexão, permutação e rearranjo de excertos, exigindo que se alterne de um pensamento disjuntivo a outro sem maiores esclarecimentos. São textos bastante diversos dos que Nauman produz a partir da década de 1980: acentuadamente repetitivos e muito adequados aos trabalhos sonoros, razão pela qual vêm comentados no próximo capítulo, dedicado ao emprego das vozes na obra do artista.

Também não são infrequentes, nos textos dos anos 1970, trechos concatenados cujos sentidos, todavia, são ligeiramente conflitantes ou de

108. "I have quick hands my mind is alert/I hold my body ready for inspiration/ anticipation and sign respiration any sigh/ I think neither ahead nor behind/ ready but not waiting/not on guard/ not prepared". Cf. Apêndice.

109. "Try to get it down on paper - try to get it in writing ltry to get it written down - try to write it down): Some evidences of a state - a mark to prove you were there: Kilroy Imake a mark to prove you are here)". Cf. Apêndice.

110. "My secret is that I stayed the same for a short time". Cf. Apêndice. 
todo contraditórios, impossibilitando quaisquer conclusões; um exemplo extraído de Cones Cojones: "não significa nada dizer que não existam espaços intermediários" seguido por "não há sentido em dizer que existam espaços intermediários" "111. Afastam-se, assim, leituras elucidativas ou que pudessem conduzir desfechos. A propósito, conforme se observa nas fotos de época, a própria feitura dos textos se dá por justaposição de fragmentos: Nauman recorta e organiza os trechos escritos à máquina e então os reúne numa espécie de colagem tosca, que por vezes é emoldurada e montada numa das paredes do espaço expositivo. Nauman chegou a declarar com bom-humor e despretensão que tais escritos se assemelham àquelas mensagens sucintas e incoerentes que vêm nos biscoitos da sorte chineses e que, se reunidas, talvez pudessem fazer algum sentido ${ }^{112}$.

Ainda que se recusem a explicar as instalações de que fazem parte, os textos trazem à tona as principais questões enfrentadas pelos trabalhos no período, além de circunscreverem desde sempre os termos e os "motivos" que constituem o repertório recorrente da obra. Dentre os muitos exemplos, podem-se destacar dois pequenos excertos de Cones Cojones que explicitam tópicos como controle e crueldade, tônicas mais pronunciadas em trabalhos das últimas décadas, a saber: "eu tenho intenções precisas, mas cruéis" e "vamos falar sobre controle/nós estávamos falando sobre controle/nós estamos falando sobre controle" ${ }^{113}$.

Para Cones Cojones, o chão da galeria de Leo Castelli recebeu oito círculos concêntricos desenhados com fita adesiva em progressão geométrica calculada de fora para dentro, de modo que os círculos diminuíam e se espaçavam mais um do outro conforme se aproximavam

111. "It doesn't mean anything to say there are no spaces in between. It is meaningless to say there are spaces between". Consulte-se o Apêndice para Cones Cojones e a respectiva tradução.

112. A declaração é de Coosje van Bruggen: "Nauman compared the text [Cones Cojones] to a bunch of fortune cookies lying on a dinner table'.
At first sight their messages might be incoherent, yet as a group they tell their own story". Cf. BRUGGEN, Coosje van. Op. cit., p. 195.

113. "I have precise but mean intentions"/ "1. Let's talk about control 2. We were talking about control 3. We are talking about control". Cf. Apêndice. 


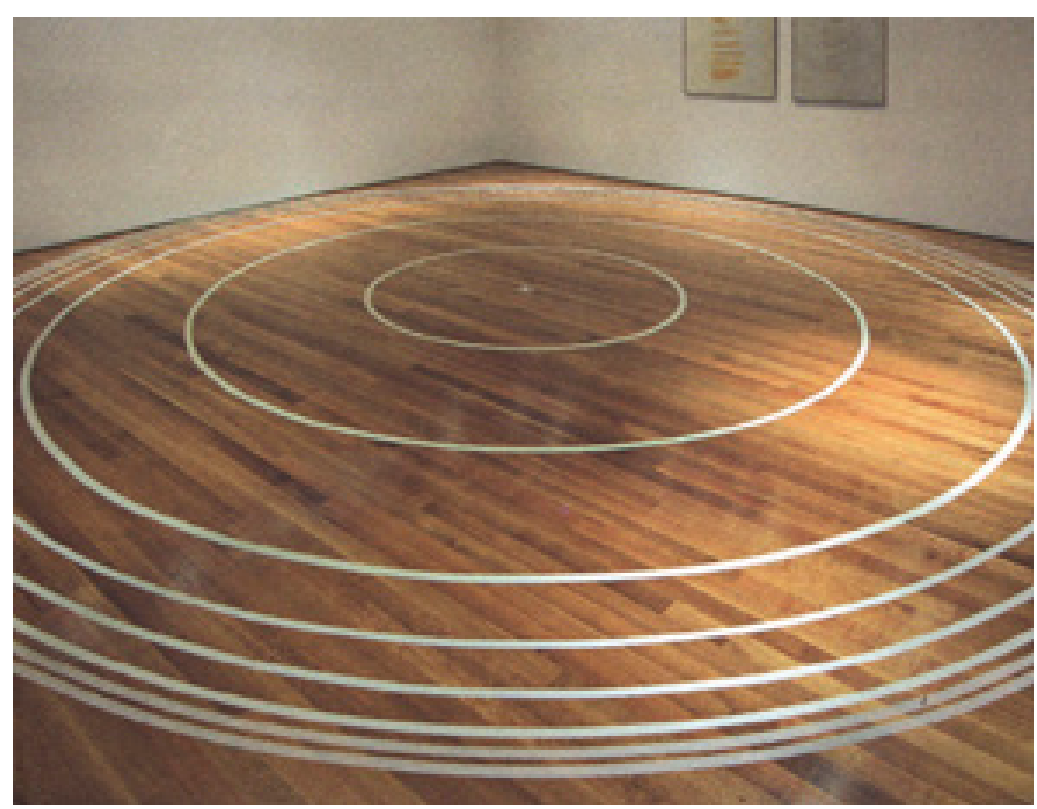

Cones Cojones, 1973-75, fita adesiva, $\emptyset 1219,2 \mathrm{~cm}$ (montagem de 2008).

do centro da sala. Nauman declarou que a instalação "é uma alegoria em duas dimensões, tudo que você realmente pode fazer é imaginá-la”114. A começar pelo título, "cones colhões", as relações entre corpo e geometria entretecem o escrito, e, assim como ocorre em Flayed Earth/ Flayed Self, a alternância de escala confirma as metáforas traçadas entre os movimentos de translação e rotação do planeta ("a Terra se move" - "Earth Moves" - é um dos subtítulos e nele as menções às marés e aos buracos negros são literais, embora demasiadamente genéricas), o movimento expansivo do desenho no espaço arquitetônico ("círculos concêntricos tornandose progressivamente mais próximos seja a partir do seu centro seja a partir da circunferência mais externa"115) e os movimentos do corpo,

114. Depoimento de Nauman para Coosje van Bruggen acerca de Cones Cojones: "It's a two dimensional allegory, all you really can do is to imagine it". Cf. BRUGGEN, Coosje van. Loc. cit.
115. "Concentric circles becoming progressively closer either from their center or measured from the outer circumference". Cf. Apêndice. 
especificamente da pele ("oh, minha pele que se encolhe, que se arrepia e a necessidade em mim de me alongar até um ponto" $\left.{ }^{116}\right)$.

Segundo depoimento de Nauman, a intenção da instalação era que se imaginasse que os círculos concêntricos desenhados no espaço representavam seções transversais incidentes sobre cones gigantescos em expansão rítmica a partir do ponto central indicado no chão da galeria que, por seu turno, coincidiria com o centro da Terra ${ }^{117}$. Mais do que isso, o texto efetua uma inversão súbita de pronomes pessoais ${ }^{118}$, o que sugere que o centro dos cones imaginados também devesse passar pelo centro do corpo, ou pelos "cojones" do título, testículos ali tomados como o centro do corpo masculino. As oscilações de grandezas e a solicitação de um desempenho “mental" perpassam o texto, e o leitor se depara com instruções como estas: "imagine descobrir acidentalmente uma linha e ajustar-se de modo que o centro de seu corpo se encontre nessa linha"; ou ainda, "ajuste-se em um espaço enorme onde muito, muito tempo está disponível uma vez que as distâncias em rápida e contínua expansão são enormes. Fique dentro do cone; evite as paredes; compacte a si mesmo; evite compressão"119.

116. “Oh, my shrinking, crawling skin and the need within me to stretch myself to a point". Cf. Apêndice.

117. Eis a explicação de Nauman, no original: "The idea is that you think of the tape line as cuts or planes that formed cones where large pieces of the universe are passing through. It's like a cone that is passing through the floor of the room - if you can imagine the floor as a transparent plane through which the circumference of this cone is passing". Cf. NAUMAN, Bruce. Drawings for Installations. Nova York: Sperone Westwater, 2008, p. 48.

118. No terceiro parágrafo de Cones Cojones, “Concentric circles becoming progressively closer either from their center or measured from the outer circumference, describing the intersection of the plane through your center parallel to the floor [...]", há uma súbita inclusão do pronome possessivo "your" em lugar de "its" ou "their" sugerindo que o trecho faz referência ao centro do corpo de um provável observador da obra, e não aos centros dos círculos e cones mencionados anteriormente. Cf. Apêndice.

119. “'Imagine accidentally coming upon a line and adjusting yourself so that the center of your body lies on that line"/ "fit into an enormous space where a great deal of time is available as the continually rapidly expanding distances are enormous. Stay inside the cone; avoid the walls; compact yourself; avoid compression". Cf. Apêndice. 


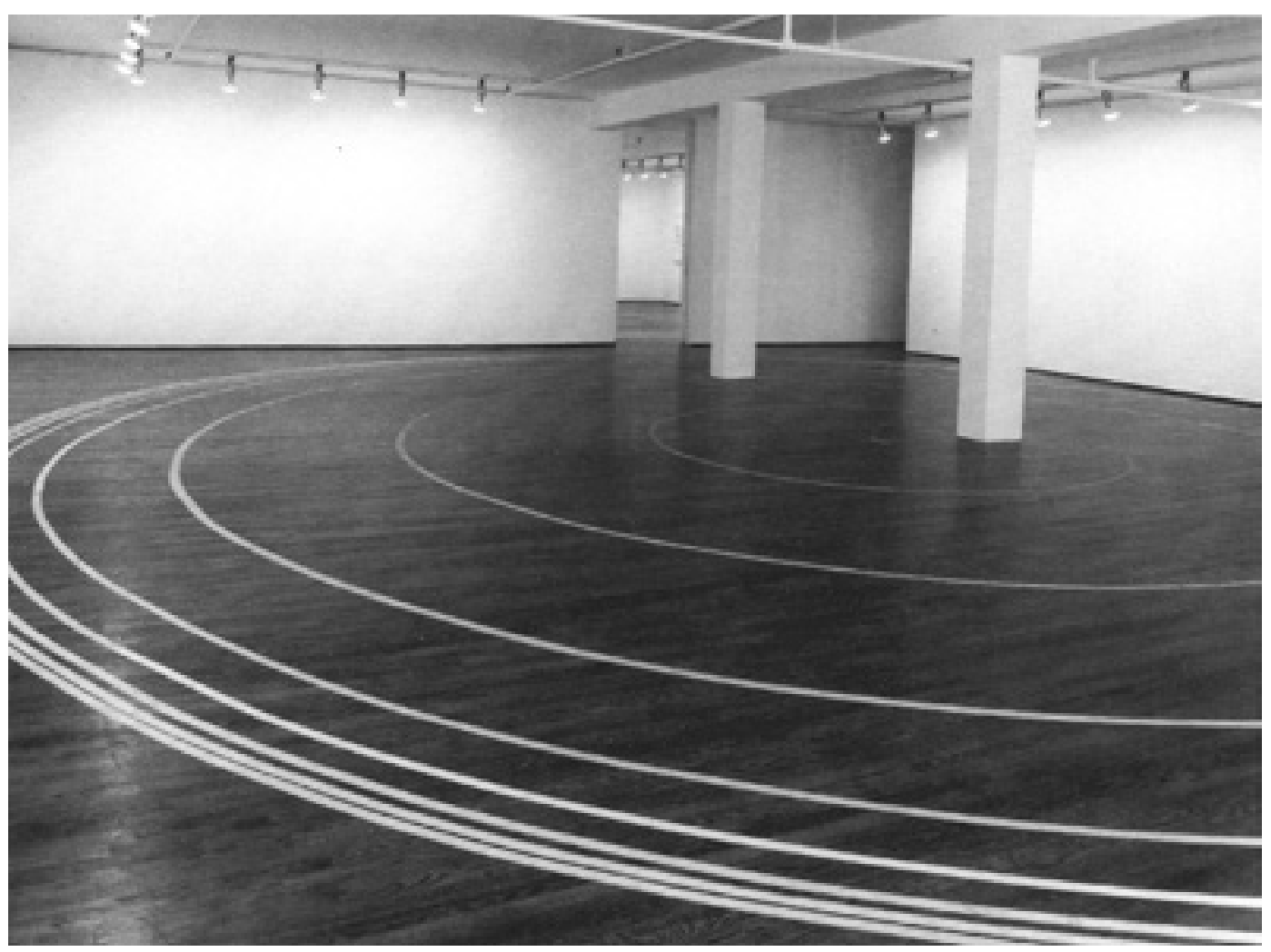

Cones Cojones, 1973-75, fita adesiva, $\emptyset 1219,2 \mathrm{~cm}$. 
Gapítulo 5

As vozes fundamentais ou um improviso de Coltrane 
Joan Simon: No que você pensa quando está trabalhando em uma obra?

Bruce Nauman: Penso muito sobre Lennie Tristano [1919-1978]. Você sabe quem era ele? Lennie Tristano foi um pianista cego, um dos primeiros - ou talvez da segunda geração - dos caras do bebop. Ele está em muitos dos melhores discos iniciais do bebop. Quando Lennie tocava bem, ele acertava você em cheio e continuava assim até terminar. Então ele simplesmente interrompia. Não havia introdução ou finalização - só intensidade máxima por 2 minutos ou 20 minutos ou algo assim. Seria como tirar o meio de John Coltrane [1926-1967] - apenas a parte mais dura, mais difícil dele. Isso era tudo o que se tinha.

Bruce Nauman, $1988^{1}$.

Uma pancada na nuca com um taco de basebol ou o trecho mais implacável de um improviso de John Coltrane são as imagens com as quais Nauman descreve sua busca por trabalhos que incitem experiências de intensidade máxima, inesperadas e inescapáveis. Dentre os exemplos que se poderiam citar dessa experiência no contexto de uma obra tão profícua e longeva, a retrospectiva "Raw Materials" [Matérias-primas], de 2004, é a mostra na qual tal intensidade atinge um ponto culminante por meio da reiteração exaustiva de poucos elementos. Convidado a ocupar o imenso corredor das turbinas, o Turbine Hall, na Tate Modern, em Londres, Nauman realizou uma única instalação sonora composta pela justaposição de diversos trabalhos: as "matérias-primas" referidas no título são os textos e, principalmente, as "falas" que comparecem na obra desde, pelo menos, Get Out Of My Mind, Get Out Of This Room [Saia da minha mente, saia desta sala (1968)].

1. No original: Joan Simon: What do you think about when you are working on a piece? Bruce Nauman: I think about Lennie Tristano a lot. Do you know who he was? Lennie Tristano was a blind pianist, one of the original - or maybe second generation - bebop guys. He's on a lot of the best early bebop records. When Lennie played well, he hit you hard and he kept going until he finished. Then he just quit. You didn't get any introduction, you didn't get any tail - you just got full intensity for 2 minutes or 20 minutes or whatever. It would be like taking the middle out of John Coltrane - just the hardest, toughest part of it. That was all you got. Cf. KRAYNAK, Janet (Ed.). Please Pay Attention Please: Bruce Nauman's Words. Op. cit., p. 320. 
Mais do que uma colagem de trabalhos antigos e de versões atualizadas, o resultado foi uma espécie de peça sonora² perfeitamente adequada às especificidades do espaço expositivo: um saguão comprido, alto e estreito, de cerca de 150 metros de comprimento, 35 metros de altura e 22 metros de largura. Enfrentar um espaço com tais dimensões foi um desafio considerável para uma obra marcada pela escala do corpo. A ideia de preencher o corredor apenas com sons foi inspirada em uma particularidade observada no próprio lugar, na primeira visita de Nauman:

\footnotetext{
O espaço é enorme. Quando se está lá, toma-se consciência do som dos motores de turbina do outro lado do prédio. Não havia pessoas no espaço quando eu o visitei pela primeira vez, talvez tenha sido após o expediente. Trata-se de uma espécie de zumbido constante, um tipo agradável de som. Na verdade, é quase um tipo de som meditativo, e se altera conforme você se move no espaço. Ressoa mais em alguns lugares do que em outros, e tem-se menos consciência dele quanto maior o número de pessoas no espaço. Deve-se ir a busca dele ou escutar atentamente. Então, essa pode ter sido a razão pela qual pensei em uma espécie de peça sonora. Comecei a procurar por altofalantes direcionais para que pudesse isolar o som $^{3}$.
}

O som é, a propósito, um material explorado desde o início da trajetória do artista, já nos primeiros filmes e vídeos. Em muitos trabalhos, os sons comparecem incidentalmente, como no caso dos neons, nos quais o zumbido

2. O CD anexo traz a reprodução dos sons de "Raw Materials". A cópia foi feita a partir do CD original posto à venda na época da mostra.

3. Em entrevista concedida a Joan Simon, após a abertura de "Raw Materials", Nauman descreveu a primeira visita ao local. No original: "The space is so enormous. When you are in there you become aware of the sound of the turbine engines on the other side of the building. There weren't people in the space when I first visited; maybe I was in there after hours. It's a constant kind of drone, a pleasant kind of sound. Actually, it's almost a meditative kind of sound, and it changes as you move around in the space. It resonates more in certain places than in others, and you become less aware of it as a larger number of people are in the space. You have to look for it or listen for it. So that may be the reason I thought of a kind of sound piece. Then I started looking for directional speakers so that I could isolate sound". Cf. SIMON, Joan. Hear Here: Interview with Bruce Nauman. Frieze Magazine n. 86, Londres, out. 2004. Disponível em: http:// www.frieze.com/issue/article/hear_here. Acesso em: 11 fev. 2010. 
contínuo dos transformadores tende a ser irritante aos ouvidos; "há um imediatismo e um aspecto invasivo no som que não podem ser evitados"4. Intrusão e desconforto potencial são, aliás, características do material "som" frequentemente manipuladas por Nauman. Os ruídos estridentes de Carousel [Carrossel (1988)], instalação já mencionada, também servem de exemplo: os moldes em alumínio, feitos a partir de carcaças taxidérmicas de animais, parcialmente suspensos por uma estrutura giratória, arrastavam-se no chão impelidos pelo mecanismo, e o atrito produzia sons tão azucrinantes que encurtavam a permanência no espaço expositivo, como a reiterar em novo registro a violência da peça escultórica.

A primeira instalação sonora de Nauman, Six Days Week: Six Sound Problems for Konrad Fischer [Seis dias da semana: seis problemas sonoros para Konrad Fischer], foi realizada em 1968, em sua primeira mostra individual na Europa, em Düsseldorf, na Alemanha. A galeria Konrad Fischer foi esvaziada, exceto por uma cadeira e um pequeno banco sobre o qual foi disposto um gravador que reproduzia, em looping, os ruídos de atividades realizadas previamente pelo artista naquele mesmo espaço, ao longo de dias. Nauman fez ali exercícios banais semelhantes àqueles que fazia no ateliê. Cada fita de áudio trazia uma sequência diversa dos sons resultantes, e deveriam ser ouvidos conforme um planejamento estrito: nas segundas-feiras, os ruídos do artista caminhado pela galeria; nas terças-feiras, o barulho de bolas de borracha sendo lançadas contra as paredes e o chão; nas quartas-feiras, o artista tocando algumas notas em um violino; nas quintas-feiras, caminhando e fazendo quicar bolas de borracha no espaço da galeria; nas sextas-feiras, caminhando e tocando algumas notas no violino; e, por fim, no sábado, tocando notas no violino e fazendo quicar as bolas de borracha ${ }^{5}$.

4. Acerca dos ruídos dos trabalhos, afirmou: "the neon pieces that have transformers, buzzing and clicking and what not; in some places I've installed them, people are disturbed by these sounds. They want them to be completely quiet. There is an immediacy and an intrusiveness about sound that you can 't avoid".
Cf. KRAYNAK, Janet (Ed.). Op. cit., p. 334.

5. Em uma anotação o artista descreveu o trabalho do seguinte modo: " 6 sound problems for Konrad Fischer - (6 day week) / 1.walk/ 2.balls/ 3.violin/ 4. violin w. walk/ 5. violin w. balls/6. balls w. walk/ must be short can be very short/ loop 1/ Monday/ 


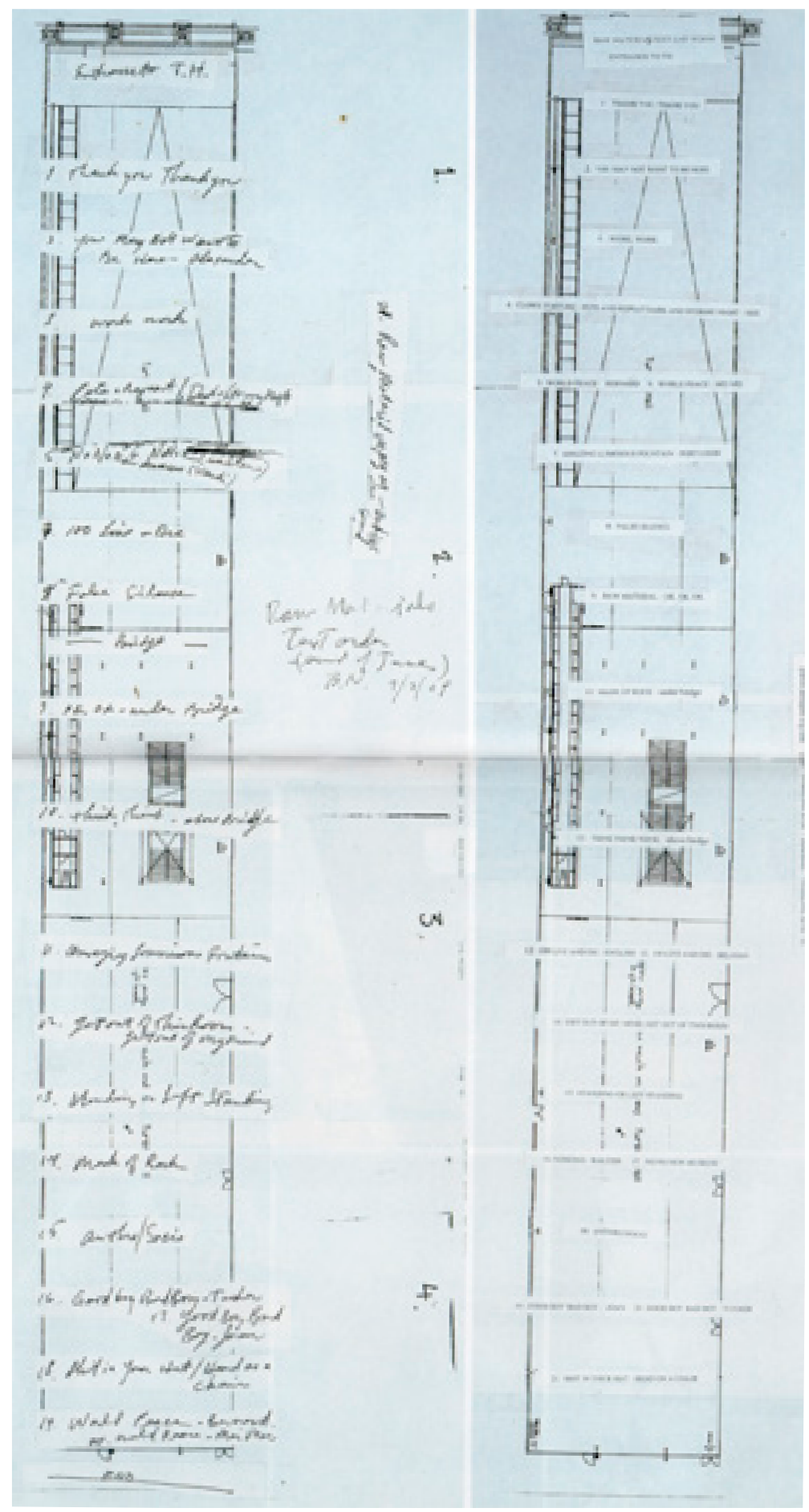

Estudo para "Raw Materials", 2004. 
No mesmo ano, foi realizada Get Out Of My Mind, Get Out Of This Room, uma instalação sonora com voz que pode ser tomada como protótipo de "Raw Materials". Em uma sala vazia, dois alto-falantes embutidos, completamente invisíveis, reproduziam uma voz de comando a entoar incessantemente e de modos variados a frase título "saia da minha mente, saia desta sala". Trata-se do primeiro trabalho em que a voz é tratada como um material bruto, uma matéria dotada de plasticidade da qual Nauman extrai um espectro amplo de possibilidades expressivas, com intensa reverberação emocional. É curioso atinar que a voz está no interior do corpo, dentro dele, e não deixa de ser o conteúdo do corpo/molde que Nauman traz à luz, tal como outras superfícies interiores são reviradas e expostas.

O artista não tardou a empregar as sutilezas alcançadas pelas diferentes possibilidades de inflexão da voz para incutir alterações pontuais em sistemas restritos, muitas vezes insinuando falsas rupturas em esquemas intrinsecamente circulares, recorrentes sobretudo nos trabalhos de meados da década de 1980 em diante. Desde os primeiros trabalhos com vozes, os fonemas, as palavras, as frases costumam ser repetidos e funcionar como refrãos, como no filme de 1969, Lip Sync [Sincronia labial], no qual a frase-título é entoada sem cessar por uma cabeça invertida, captada em close, com pequenas variações para a retomada do fôlego, de modo que, a certa altura, a sincronia é perdida, assim como o sentido das palavras, mas a cantilena segue indefinidamente.

Conforme havia se mencionado, em Get Out Of My Mind, Get Out Of This Room, a reiteração de uma única frase vocalizada de diferentes maneiras preenchia uma sala vazia simulando uma alucinação auditiva que,

2 Tuesday/ Wednesday 3/ Thursday 4/ Friday 5/ Saturday/loop 5/ loop 4/ loop 3/ on tape/ recorder/ loop 6/ loop 2/11 cm. 1968" [6 problemas sonoros para Konrad Fischer - 16 dias da semana)/ 1.caminhada/ 2.bolas/ 3.violino/ 4.violino e caminhada/ 5.violino com bolas/ deve ser curto pode ser muito curto/ loop 1/segunda-feira/ 2terça- feira/ quarta-feira 3/ quinta-feira 4/ sexta-feira/ sábado/loop 5/ loop 4/ loop 3/ na fita/ gravação/ loop 6/ loop 2/ $11 \mathrm{~cm}$ 1968]. Cf. LEWALLEN, Constance (Ed.). A Rose Has No Teeth: Bruce Nauman in the 1960s. Berkeley: University of California Press, 2007, p. 206 e BRUGGEN, Coosje van. Bruce Nauman. Nova York, 1988, p. 256. 
por sua vez, reforçava o paralelo que o artista frequentemente estabelece entre espaço físico e espaço mental. Inegável que essa situação foi reavivada muito tempo depois, no espaço da Tate, que se converteu em uma espécie de "manicômio do crânio", para usar a expressão de uma narrativa de Beckett ${ }^{6}$, saturado de vozes intrusivas que revezavam contenção e calmaria com extravasamento agressivo, de modo a enfatizar "a musicalidade e o conteúdo emocional mais do que o conteúdo intelectual" dos trabalhos?.

Não resta dúvida de que em "Raw Materials" são as qualidades expressivas das vozes que constroem a intensidade emocional pretendida. Os áudios não provocavam uma cacofonia de murmúrios ininteligíveis, mas uma experiência progressiva de exaustão e de saturação, conforme o ouvinte percorria o espaço e passava de uma área sonora para outra. $\mathrm{O}$ corpo era assediado por vozes inescapáveis e, desse modo, as dimensões monumentais do corredor calibravam-se em relação à escala humana, tal como ocorre na intervenção urbana realizada em Münster, já citadå

Em "Raw Materials" foram empregados 17 pares de alto-falantes planos para a emissão de sons direcionados, montados sobre as vigas ou rentes às paredes laterais do extenso corredor, com exceção da área junto

6. Expressão empregada pelo narrador de Mal visto mal dito. Cf. BECKETT, Samuel. 0 despovoador. Mal visto mal dito. Tradução de Eloísa Araújo Ribeiro. São Paulo: Martins Fontes, 2008, p. 45.

7. Em entrevista concedida a Robert Storr antes da montagem de "Raw Materials", enquanto testava os equipamentos sonoros em seu ateliê, Nauman declarou: "I think this installation is going to reinforce the musicality and the emotional content, rather than the intellectual content". Cf. STORR, Robert. Sound Waves: Bruce Nauman in Conversation with Robert Storr. Tate Etc, n. 2, Londres, set. 2004. Disponível em: http://www. tate.org.uk/context-comment/articles/soundwaves. Acesso em: 15 mar. 2011.
8. Em relação à mostra no hall das turbinas, Nauman ressaltou que ao desafio de enfrentar a imensidão do lugar somava-se o fato de ocupálo imediatamente após a exposição Weather Project, de Olafour Eliasson, que apresentou ali um espetacular sol amarelo despontando no escuro. Além de um "blockbuster", a mostra tornou-se o cartão de visitas do espaço. Nauman afirmou: "no trabalho de Eliasson, eles [o público] gravitavam em direção à imagem do sol na extremidade final, onde o piso é plano, reuniam-se lá e começavam a se entreter. Eu não posso fingir imitar aquele tipo de situação ["in the Eliasson piece, they gravitated towards the sun image at the far end where the floor is level, congregated there and started doing things. I can't pretend to imitate that kind of situation"] Cf. STORR, Robert. [Sound Waves]. Op. cit. 
à escadaria e à passarela na qual o som se projetava a partir de cima. Além disso, foram distribuídos no alto e ao redor de todo o espaço expositivo altofalantes de difusão mais geral, apropriados à transmissão de uma espécie de rumor constante provocado pela pronúncia do fonema "mmmmmm", um ruído que além de mimetizar o barulho dos motores de turbina existentes do outro lado do edifício - o zumbido discernível no Turbine Hall vazio que chamou a atenção de Nauman - servia para disfarçar os ecos.

A ideia de circularidade presente na elaboração de muitos dos textos e reforçada pelas falas repetidas em looping reiterava-se no próprio espaço, uma vez que a entrada e a saída da exposição ocorriam por um mesmo local, e a primeira fala ouvida era, portanto, também a última, "thank you, thank you, thank you". A proposta de caminhar em linha reta resultava forçosamente em um circuito, e os trechos de cada um dos textos eram ouvidos pelo menos duas vezes.

A construção de ciclos infindáveis dos quais não há escapatória ainda que dentro deles sejam instiladas variações que apontem para a possibilidade (malograda) de ruptura, procedimento característico da obra de Nauman, é potencializada nesse trabalho em virtude da ordem de emissão das falas, uma sequência de alternações entre textos curtos e longos e enunciações vigorosas e monótonas em vozes muito variadas. Os ritmos oscilam em cada trabalho e também no conjunto. As repetições intensas de palavras comprimidas em fonemas (no, work, think, ok, thank you) são intercaladas com textos cuja circularidade é um fator intrínseco (como Pete and Repeat e Dark and Stormy Night) ou decorrente de estruturação combinatória (100 Live and Die, Shit In Your Hat-Head On A Chair, World Peace e Good Boy Bad Boy). Outras vezes, são intercaladas com textos que parecem meros refrãos (Get Out Of $M y$ Mind, Get Out Of This Room, O verdadeiro artista é uma maravilhosa/ assombrosa fonte luminosa e Anthro/Socio) e por outros mais complexos como os já analisados Left or Standing, Standing or Left Standing, False Silence e The Consummate Mask of Rock? . 
As sequências rítmicas variadas evidenciavam a manipulação das qualidades expressivas da voz, acentuando tanto a musicalidade quanto a resposta emocional declaradamente pretendida. Trata-se, nesses termos, de uma expressividade decorrente da investigação minuciosa das propriedades do material e das possibilidades de sua organização no espaço. Nauman concebeu um tipo de sequenciamento não progressivo, mas modulado por zonas sonoras ritmicamente diversas, preenchendo o espaço sem deixar áreas silenciosas:

Isso era o que eu procurava: trabalhar horizontalmente era muito melhor do que ter os sons vindos de cima - é como quando se anda pelo espaço, segue-se através de ondas [sonoras] de diferentes textos. [...] Quando se anda por uma área de vários metros de comprimento, o texto é muito claro. Depois, torna-se impreciso, confuso, já que se mistura ao próximo, e, então, o próximo texto se torna claro. Há sempre algo acontecendo que atrai para o espaço [...]. Alguns dos meus textos são muito curtos e repetitivos, de modo que são entendidos rapidamente e pode-se seguir em frente. Outros são longos e bastante intensos, mas não espero necessariamente que as pessoas permaneçam e ouçam a coisa toda ${ }^{10}$.

Nauman constrói zonas sonoras que preenchem o vazio e estimulam o ouvinte a caminhar de uma área a outra. É curioso que nos esboços preparatórios de "Raw Materials", o longo corredor representado por

9. A sequência precisa dos trabalhos é a seguinte: 1)Thank You Thank You Thank You(1992); 2) You May Not Want To Be Here (1968); 3) Work Work Work (1994); 4) Pete and Repeat (1987) e Dark and Stormy Night (1987); 5) duas versões diferentes de NO NO NO NO (1987); 6)100 Live and Die (1985); 7) False Silence (1975); 8) OK OK OK (1990); 9) Think Think Think (1993); 10) 0 verdadeiro artista é uma maravilhosa/assombrosa fonte luminosa, uma versão de The True Artist is an Amazing Luminous Fountain (1968); 11) Get Out Of My Mind, Get Out Of This Room (1968); 12) Left or Standing/ Standing or Left Stanting (1971); 13) Consummate Mask of Rock (1975); 14) Anthro/Socio (1991); 15) Good Boy Bad Boy, vozes feminina e masculina (1985); 16) Shit In Your Hat - Head On A Chair (1990); 17) World
Peace, vozes feminina e masculina (1996). 0 som do trabalho MMMM (1990) envolvia todo o espaço.

10. No original: "That was what I was looking for: working horizontally was much better than having the sound come from above - it's as if when you walk through the space, you come through wave after wave of different texts. [...] When you walk into an area several meters wide the text is very clear. Then it becomes fuzzy as it merges with the next one, and then the next one becomes clear. There is always something going on to draw you into the space [...]. Some of my texts are very short and repetitive, so you get them pretty quickly and move on. Others are long and quite intense, but I don't necessarily expect people to stay and try to listen to the whole thing". Cf. STORR, Robert. [Sound Waves]. Op. cit. 
áreas sequenciadas guarde alguma semelhança com um singelo desenho de Beckett, no qual o purgatório de Dante é representado com capricho. A propósito, Dante (1265-1321) é um autor mencionado por Nauman de maneira surpreendente: no texto Notes and Projects [Notas e projetos (1970)], ele é citado em meio a termos chulos, em um trecho que poderia ser descrito como uma poesia obscena ${ }^{11}$. Há, ao menos, um ponto comum às três obras, a atenção dada ao "caminhar", o mais elementar dos movimentos humanos. Paul Auster, no mencionado ensaio em que analisa Mercier e Camier, cita um comentário sobre a obra de Dante para enfatizar que o ritmo da caminhada de Mercier e Camier pontua a narrativa, mesmo quando os personagens não estão propriamente caminhando: "o Inferno e especialmente o Purgatório glorificam o andar humano, a medida e o ritmo do caminhar, o pé e sua forma [...]. Em Dante, filosofia e poesia estão eternamente em movimento, eternamente sobre os pés. Mesmo ficar parado é uma variedade de movimento acumulado; abrir espaço para pessoas conversarem de pé dá tanto trabalho como escalar os Alpes"12. Em Nauman, o caminhar não é apenas o do próprio artista - que caminha extravagantemente pelos perímetros ou em corredores - mas também um convite dirigido à audiência, nas intervenções urbanas, nos corredores ou na instalação sonora em foco.

Iniciar e encerrar o ciclo com Thank You Thank You [Obrigado obrigado (1992)] deixava patente que o artista estava em busca da intensidade máxima, da pancada inesperada e certeira. A enunciação reiterada, rápida e ligeiramente nuançada provocava o inverso daquilo que usualmente se espera de um termo que exprime gratidão: a altura da voz, a rispidez e a agitação nervosa transmitidas revelavam irritação e agressividade e, por conseguinte, exasperavam o ouvinte. Pronunciada reiteradamente com violência, a expressão perdia o sentido original e,

11. Cf. Apêndice da tese.

12. MANDELSTAM, Ossip. Conversation on Dante apud AUSTER, Paul. AUSTER, Paul. De bolos a pedras. In: A arte da fome. Rio de Janeiro: José Olympio, 1996, p. 77. 
por breves instantes, tinha-se a sensação de ouvir "thank you" convertido em um palavrão bastante comum ("fuck you"), como se pode constatar no áudio anexo. Dentre os sons presentes na mostra, esses berros de Nauman agradecendo como quem xinga são exemplos inequívocos de que, na obra, a repetição é antes um mecanismo de saturação do que de esvaziamento dos sentidos: parte-se de um elemento mínimo como, no caso, duas palavras, e promove-se uma experiência de extenuação por acúmulo. $\mathrm{O}$ verso da moeda dos rituais banais de civilidade é trazido à tona pelo contraste entre o conteúdo daquilo que é dito e o modo de dizêlo. Esse trabalho remete a duas conhecidas litogravuras de 1973, uma com a sentença Please Pay Attention Please [Por favor preste $(m)$ atenção por favor] e a outra Pay Attention Motherfuckers [Prestem atenção, filhos da puta], sendo que no áudio a crescente violência da admoestação decorre de variações que, todavia, não atenuam o tom forte da voz.

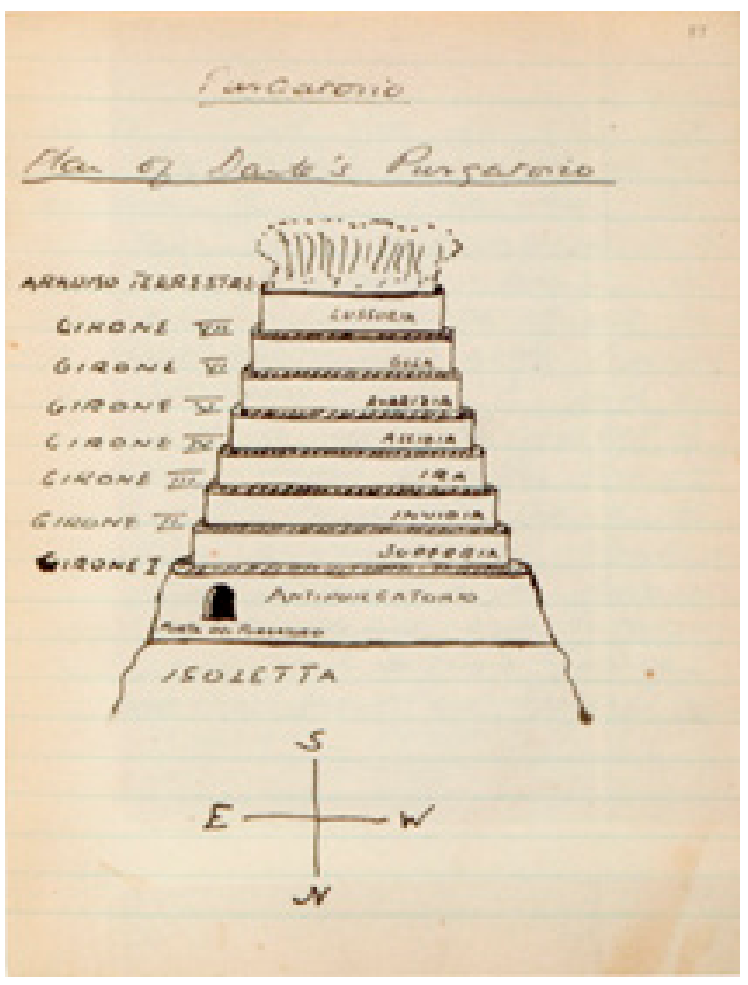



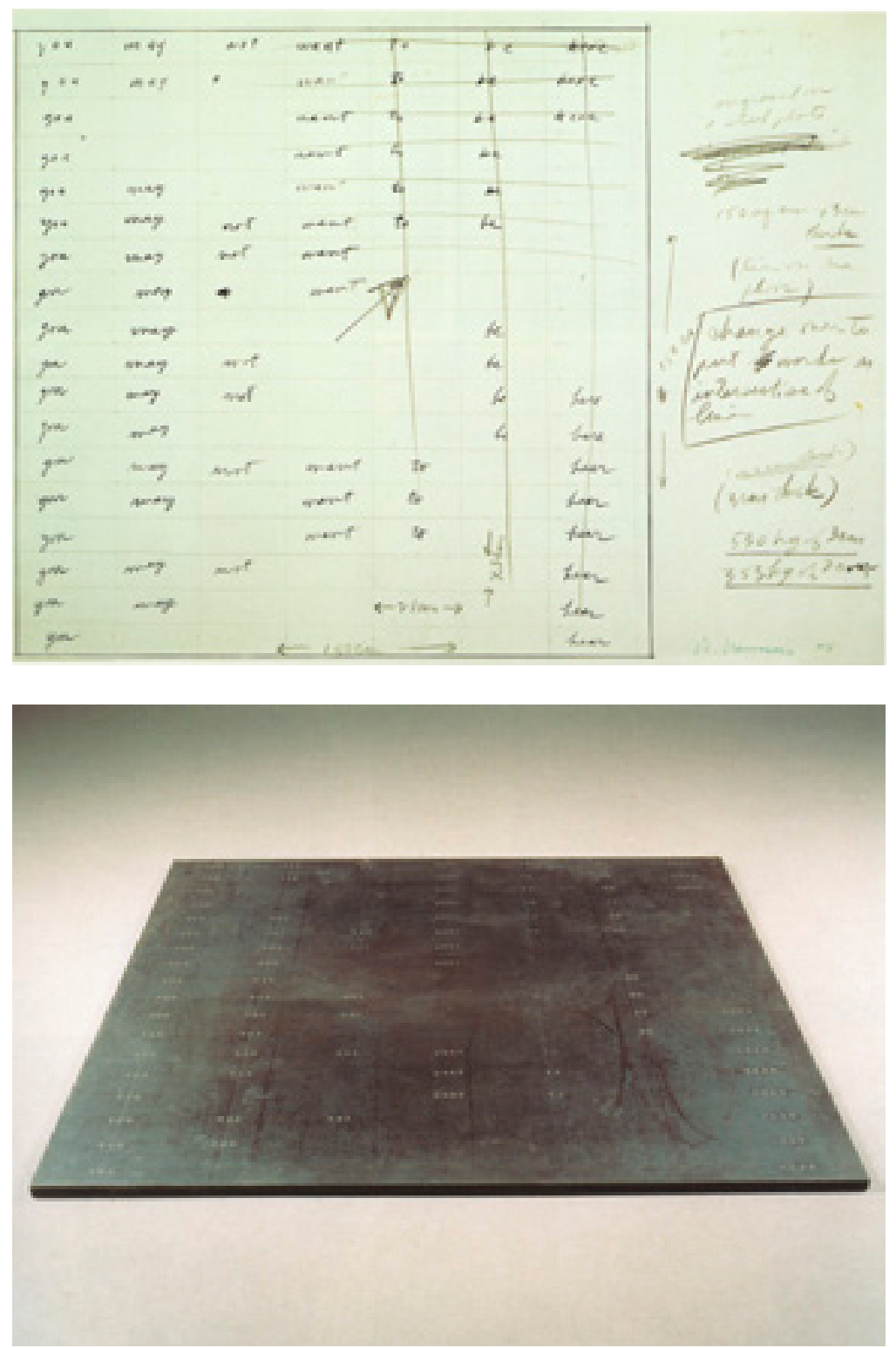

Estudo para First Poem Piece, 1968, grafite sobre papel, 36,7 x 51,1 cm. First Poem Piece, 1968, aço, 1,3 × 152,4 × 152,4 cm. 
Depois de quase expulsos pelos agradecimentos, os visitantes eram surpreendidos com uma voz infantil a recitar um poema composto por subtração e permutação dos termos de uma sentença matriz, "you may not want to be here" [você pode não querer estar aqui], extraída de um trabalho de 1968, First Poem Piece [Primeira Peça Poema], uma escultura feita a partir de uma placa quadrada de aço $(1,8$ x 152,4 x 152,4 cm), a ser disposta diretamente do chão. Em uma das superfícies, foi riscada uma grade formada por dezoito linhas horizontais e sete colunas, e sobre as intersecções das coordenadas foram gravadas as palavras do poema. No ano seguinte, Nauman realizou uma escultura semelhante, Second Poem Piece [Segunda Peça Poema], com material e dimensões idênticos e, a partir do mesmo método, gravou variações da frase "you may not want to screw here" ["você pode não querer 'aparafusar' aqui" - considerando que, conforme já se disse na análise do texto Flayed Earth/Flayed Self, o verbo "to screw" tem duplo sentido, podendo se referir também ao ato sexual].

A estruturação geométrica de First Poem Piece perde a exatidão quando pronunciada pela criança, um menino de quatro anos. Nauman afirmou que uma primeira versão foi feita com o auxílio de um programa de computador que reproduzia o poema com exatidão matemática mediante cálculos metronômicos que deixavam espaços silenciosos correspondentes às supressões sucessivas das palavras. Essa versão, no entanto, foi preterida pela voz do garoto e pela espontaneidade com a qual repetia o texto ${ }^{13}$. Ainda que não compreendesse os novos sentidos provocados por cada permutação e redução, a voz doce da criança mudava de cadência conforme o texto prosseguia, sendo possível flagrar berros ou resmungos de inquietude e irritação em meio à fala suave. Assim, os sentidos potenciais contidos na sentença "you may not want to be here" vinham à tona pela recombinação e pela omissão sistemática de algumas palavras, pelas inflexões da voz e pela exploração da homofonia entre "here" [aqui] e "hear" [ouvir], possibilidade exclusiva da versão sonora do texto ${ }^{14}$. 
Já o terceiro trabalho, bem como o quinto, o oitavo e o nono eram justamente os que implicavam a reiteração ininterrupta de fonemas de palavras monossilábicas, "work", "no", "ok" e "think" [trabalhe, não, ok e pense, respectivamente]. Esses sons relacionam-se diretamente à série intitulada Raw Material [Matéria-prima], três vídeos realizados em 1990 para serem exibidos em monitores de televisão dispostos em pares, um sobre o outro: $O K O K O K, M M M M$ e $B R R R$, cada qual nomeado segundo o fonema repetido exaustivamente por Nauman. Apenas a cabeça do artista foi captada nas imagens em close, tanto na posição normal ou invertida quanto na lateral. Em algumas versões, a cabeça gira e, em outras, oscila em movimentos verticais, sugerindo que, na gravação, o artista estivesse pulando em frente à câmera de vídeo. O modo de emissão da voz nos três casos é comparável a exercícios vocais e as variações surgidas decorrem, sobretudo, das pausas para a retomada do fôlego e das trepidações provocadas pelos movimentos corporais desempenhados ${ }^{15}$. Para a mostra da Tate, Nauman recorreu às gravações originais de $O K O K O K, M M M M$ e também utilizou os sons de dois outros trabalhos surgidos na mesma época e realizados segundo os mesmos princípios, Think Think Think (1993) e Work Work (1994). O áudio de MMMM foi transmitido nos alto-falantes difusos montados no teto a fim de reforçar a unidade da instalação e mimetizar o zumbido pré-existente no espaço. Os fonemas pronunciados em $O K O K$ OK, Think Think Think e Work Work - os dois últimos transmitidos por

15. Já se mencionou que Nauman apontou Meredith Monk como uma influência fundamental no início de sua trajetória, sobretudo no aprimoramento corporal exigido dos exercícios filmados no ateliê. No catálogo de "Raw Materials" há a sugestão de que os trabalhos com voz tenham sido influenciados pelos exercícios e coreografias vocais desenvolvidos por Monk [Cf. NAUMAN, Bruce. Raw materials. Londres: Tate Press, 2004, p. 141]. Monk é, de fato, uma das pioneiras da chamada técnica vocal expandida, com a qual criou um vocabulário vocal para exprimir séries de emoções que nem sempre encontram expressão exata nas palavras disponíveis, buscando trabalhar uma "voz dançante" - "eu trabalho entre as fendas, onde a voz começa a dançar, onde o corpo começa a cantar, onde o teatro se torna cinema" ["/ work in between the cracks, where the voice starts dancing, where the body starts singing, where theater becomes cinema"]. Para um aprofundamento do assunto, conferir algumas das performances de Monk no documentário dirigido por Peter Greenaway, no âmbito do projeto "Four American Composers", de 1983. 
$B R R R, 1990$,

videoinstalação,

dimensões variáveis.

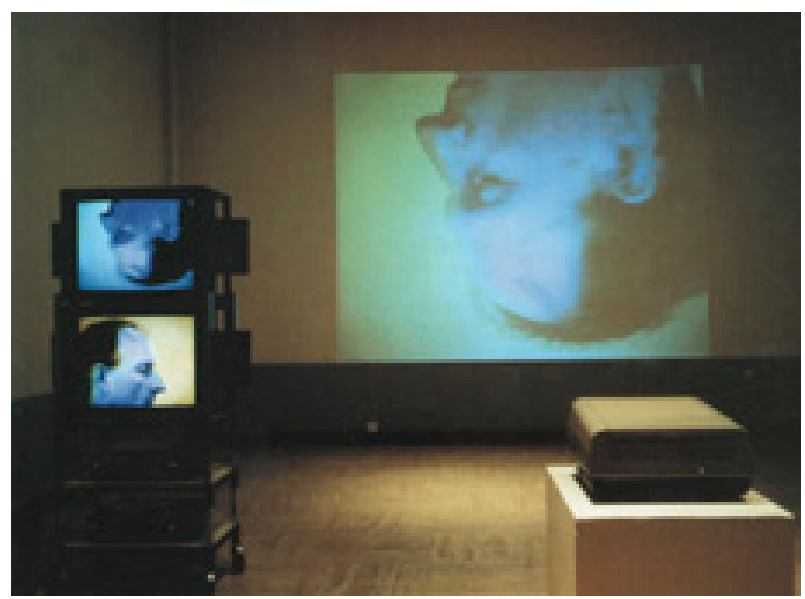

alto-falantes montados junto à passarela - eram acompanhados pelos ruídos captados nas gravações originais e que correspondiam aos sons produzidos pelo corpo saltitante de Nauman. Deslocados do contexto, os barulhos e a respiração ofegante somados à vocalização intensificada a cada repetição transformavam os comandos ditados no imperativo - pense e trabalhe - em sons ritmados com forte alusão sexual.

Já o fonema "no" foi reproduzido simultaneamente em duas versões, cada uma delas partindo de um dos alto-falantes do par. A voz feminina e a voz masculina correspondem a variações do trabalho NO NO NO NO, que compõe a série Clown Torture, já comentada: em uma, a mulher está vestida como um bobo da corte e, na outra, o homem representa um palhaço de cabelos vermelhos bastante semelhante ao Bozo. Enquanto pula freneticamente, a mulher emite os "no" de modo intenso e rápido como se estivesse a fazer birra, e, assim como acontecia em outros textos falados, ouvia-se na Tate o barulho provocado pelos movimentos junto com a voz, o que, nesse caso, acentuava a impressão de irritação transmitida pela atriz. Já o áudio da voz masculina traz repetições matizadas do fonema. Explorava-se ali a expressividade do material ao limite: da emissão rápida à exageradamente prolongada, dos grunhidos guturais à impostação, a palavra era pronunciada de modos tão diversos que remetiam a um amplo espectro de possibilidades, como sensações de dor, desespero, súplica, reclamação, ameaça, brincadeira etc. 
A reprodução simultânea de áudios diferentes pelo mesmo par de alto-falantes foi igualmente usada em Pete and Repeat [Pita e Repita (1987)] e Dark and Stormy Night [Noite escura e tempestuosa (1987)], trabalhos que também compõem a série dos palhaços torturados ${ }^{16}$. A estrutura dessas narrativas é circular, de modo que os palhaços veem-se impelidos a recomeçar os ciclos. Em ambos os casos, nota-se nas vozes a frustração e a fúria que parecem sentir a cada reinício. Valem-se de alguns expedientes para tentar libertar-se do ciclo: mudam as cadências, simulam sotaques, resmungam, gritam, capricham no tom assombroso, tornam-se ásperos, bufam e, ao fim, parecem desapontados com a inutilidade desses esforços. A circularidade inescapável é, afinal, o cerne das piadas.

Depois dos palhaços, ouvia-se um coro de vozes masculinas e femininas entoando em ritmo ligeiramente acelerado 100 Live and Die [100 Viva e Morra (1985)], texto no qual são elencados atributos e ações humanos em uma estrutura compositiva que se remete às equações matemáticas nas quais as unidades são fatoradas pelos valores binários, no caso, os verbos "to live" e "to die" ${ }^{17}$. Viver e morrer são tomados como meras ocorrências pontuadas por verbos. Nauman propõe um inventário da condição humana que iguala faculdades, aspirações, sentimentos e necessidades fisiológicas. Entre um extremo e outro, as ocorrências possíveis são equalizadas. A primeira versão do trabalho foi executada em neons coloridos e disposta na parede, um mecanismo luminoso cujo temporizador permitia ajustes minuciosos das frequências das piscadelas e da infinidade de combinações possíveis. Na cantiga das vozes, todavia, as permutações seguiam a ordem pré-estabelecida no texto e as palavras eram proferidas de modo idêntico, cuidando para que certas combinações não

16. Os dois textos já foram mencionados no Capítulo 3 e estão reunidos no Apêndice.

17. Cf. NAUMAN, Bruce. Raw Materials. Londres: Tate Press, 2004, p. 134-135. Nesse catálogo, o trabalho é comparado ainda às composições matemático-musicais do músico minimalista norte-americano Steve Reich (1936 - ), nas quais um refrão simples deforma-se a cada repetição, sem nunca perder a sua estrutura global. 
fossem enfatizadas em detrimento de outras. $\mathrm{O}$ formato de coro ou cantiga conferiu certa morbidez ao resultado que inexistia na versão em neon.

Nesse trabalho, o procedimento de contenção é marcante pois cada frase é composta por apenas três termos, geralmente um verbo, o conectivo "and" e, por último, "live" ou "die". Quarenta verbos são comutados com "live" e "die" (comer, dormir, ouvir, tentar, pensar, sorrir, conhecer, amar, gargalhar, odiar, foder, falar, mentir, tocar, chorar, cagar, mijar, beijar, pagar, enfurecer, temer, sentir, cortar, gritar, fracassar, correr, brincar, matar, cair, chupar, contar, cheirar, ir, vir, sentar, levantar, erguer, ficar, cuspir, cantar), além de oito adjetivos (doente, são, preto, branco, vermelho, amarelo, jovem e velho). No português, é possível traduzir o texto em dois modos verbais e ambos parecem adequados ao trabalho, uma vez que tanto o infinitivo quanto o imperativo são compatíveis com os procedimentos gerais da obra de Nauman: a indeterminação e universalidade fazem-se tão presentes quanto os comandos e a ideia de controle $^{18}$. Optar pelo imperativo, entretanto, enfatiza a ambiguidade da cantiga, potencializando a estranheza e o desconforto do trabalho.

Estranheza e desconforto descrevem igualmente bem os efeitos provocados pelo trabalho subsequente, False Silence (1975). O texto, abordado no capítulo anterior, era proferido na íntegra por uma voz feminina em um timbre muito parecidocom as "locuções de aeroporto", caracterizadas por transmitir informações e instruções através de vozes que são a um só tempo neutras e sensuais. No hall das turbinas, "a voz de aeroporto" proferia informações improváveis: "eu não transpiro/eu não tenho odor/eu inalo, não exalo/sem urina/eu não defeco: nenhuma excreção de qualquer tipo" ou "eu não tenho controle sobre os tipos e as qualidades dos pensamentos/

18. 0 Apêndice traz o texto em inglês e a tradução para o português nos dois modos verbais.

19. "I don't sweat/I have no odor/ I inhale, don't exhale/ no urine/l don't defecate: no excretions of any kind [...] I have no control over the kinds and qualities of thoughts [...] I can't react or act on sensation/no emotional response to situations/ [...] you can't reach me, you can't hurt me/l can suck you dry [...]". Para o texto na íntegra e a tradução, confira-se o Apêndice. 
[...]/eu não posso reagir ou agir com base em sensações/sem resposta emocional às situações/[...] você não pode me alcançar, você não pode me ferir/eu posso sugá-lo até a última gota” ${ }^{19}$. As contradições intrínsecas ao texto, o tipo de frieza vampirizante das imagens construídas por Nauman um "algo" sub-reptício que absorve tudo ao redor - decerto soavam irônicas quando proferidas por aquele tipo de voz.

O trabalho seguinte trazia uma tradução para o português da frase the true artist is an amazing luminous fountain, surgida em desenhos de 1966, antes, portanto, do conhecido neon The True Artist Helps the World by Revealing Mystic Truths, de 1968. Na Tate, Nauman reproduziu o áudio gravado em 1998, ano em que a Fundação de Serralves, no Porto, adquiriu o trabalho para seu acervo. Em português, o termo "amazing" recebeu duas traduções, "maravilhoso" e "assombroso". Uma voz feminina e outra masculina, cada qual saída de um alto-falante, repetiam com sotaque brasileiro "o verdadeiro artista é uma maravilhosa fonte luminosa/o verdadeiro artista é uma assombrosa fonte luminosa" ${ }^{20}$. Inicialmente, as vozes se alternavam e progressivamente iam se sobrepondo, travando uma discreta disputa fonética que podia ser notada pelos visitantes mesmo que não compreendessem o sentido das palavras em português. A escolha de uma versão do trabalho pelas características eufônicas de um idioma estrangeiro reforça a ideia de que Nauman preocupou-se antes com a musicalidade e com o teor emocional da instalação do que com a intelecção correta dos conteúdos.

A intensidade emocional das modulações de voz captadas na versão original de Get Out Of My Mind, Get Out Of This Room (1968) e transmitidas numa sala vazia provocava o mesmo efeito vigoroso e

20. A voz feminina é de Lilian Tone e a masculina é de Oswaldo Costa. Lilian Tone foi curadora, juntamente com Nessia Leonzini, da única exposição individual de Nauman ocorrida no Brasil, "Circuito Fechado: filmes e vídeos de Bruce Nauman 1967-2001", no Centro Cultural
Banco do Brasil, no Rio de Janeiro, em 2005. Em conversa com a curadora, durante o estágio de pesquisa no exterior, ela afirmou que Nauman acolheu prontamente as duas possibilidades de tradução em virtude das características melódicas de ambas as palavras. 


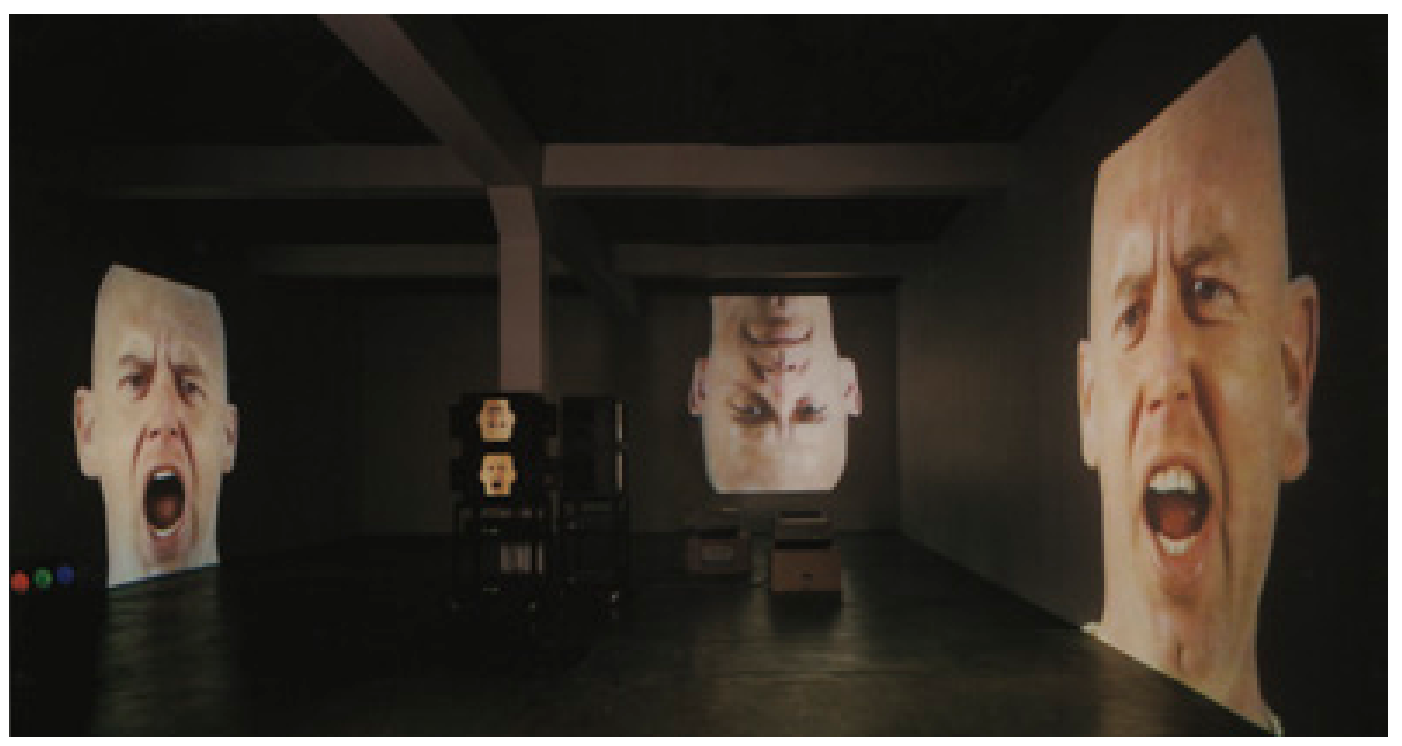

Anthro/Socio, 1991, videoinstalação, dimensões variáveis.

exasperante no imenso "manicômio do crânio" em que se converteu o corredor da Tate. As reiterações da fala áspera e gutural intercalada por sussurros, berros violentos, dicção entrecortada por respiração arfante reforçam a hostilidade da frase-comando que afugentava os visitantes ao passo que simulava um episódio paranoico. Conforme se adiantou, esse trabalho atesta que, desde o início, Nauman estava atento aos atributos expressivos inerentes à voz. Mas é em "Raw Materials" que a manipulação desse material atinge o ápice.

Para rebater a intensidade vocal que ordenava "saia da minha mente, saia desta sala", Nauman sequenciou dois textos longos e, desse modo, espaçou dois dos trabalhos mais fortes da mostra, Get Out Of My Mind, Get Out Of This Room e Anthro/Socio [Antro/Sócio (1991)]. A prosa de Left or Standing, Standing or Left Stanting [Deixado ou Em pé, Em pé ou Deixado em pé (1971)] e as reviravoltas de The Consummate Mask of Rock 
[A máscara consumada de pedra (1975)], textos analisados no capítulo anterior, foram ajustadas a vozes mais neutras e suaves do que as dos trabalhos que lhes faziam fronteira, e o próprio mecanismo de repetição era menos evidente em virtude da duração das leituras. Uma voz feminina encarregou-se de Left or Standing, Standing or Left Stanting, enfatizando ora um termo ora outro do poema sem, todavia, dramatizá-lo. De modo análogo, os dezessete itens listados na abertura de The Consummate Mask of Rock eram lidos por duas vozes combinadas: enquanto a feminina pronunciava a numeração, a voz masculina completava com o termo correspondente a cada número ("1. máscara/2. fidelidade/3. verdade/4. vida/5. cobertura/6. dor...” ${ }^{21}$ ). Dessa maneira, a carga emocional contida nos textos era relativamente encoberta pela imparcialidade das vozes, sendo necessário um tempo maior de permanência nessas áreas para que as nuances dos sentidos das palavras pudessem ser percebidas.

Já a intensidade indiscutível de Anthro/Socio constitui o próprio cerne do trabalho, explicitamente concebido para testar os limites da voz de Rinde Eckert (1951 - ), ator, músico e cantor norte-americano cuja ampla extensão vocal parece converter as falas "feed me, eat me, anthropology/ help me, hurt me, sociology" [alimente-me, coma-me, antropologia/ ajude-me, fira-me, sociologia] ora em canto operístico, ora em exercício de impostação vocal. A videoinstalação original trazia grandes projeções da imagem da cabeça giratória de Eckert pronunciando em altíssimo volume e em ritmos variados as frases que, conforme se mencionou, provêm de excertos de False Silence. A veemência expressiva do resultado é tamanha que Nauman comentou durante os testes de montagem de "Raw Materials": "gostaria de usar o canto de Rinde Eckert em Anthro/Socio de 1992, mas é um áudio tão intenso que devo tomar cuidado para que não se sobreponha à situação. Se não for controlado, não funcionará no contexto de todo o

21. "1. mask/2. fidelity/3. truth/4. life/5. cover/6. pain [...]". 0 texto na íntegra e a tradução constam no Apêndice. 


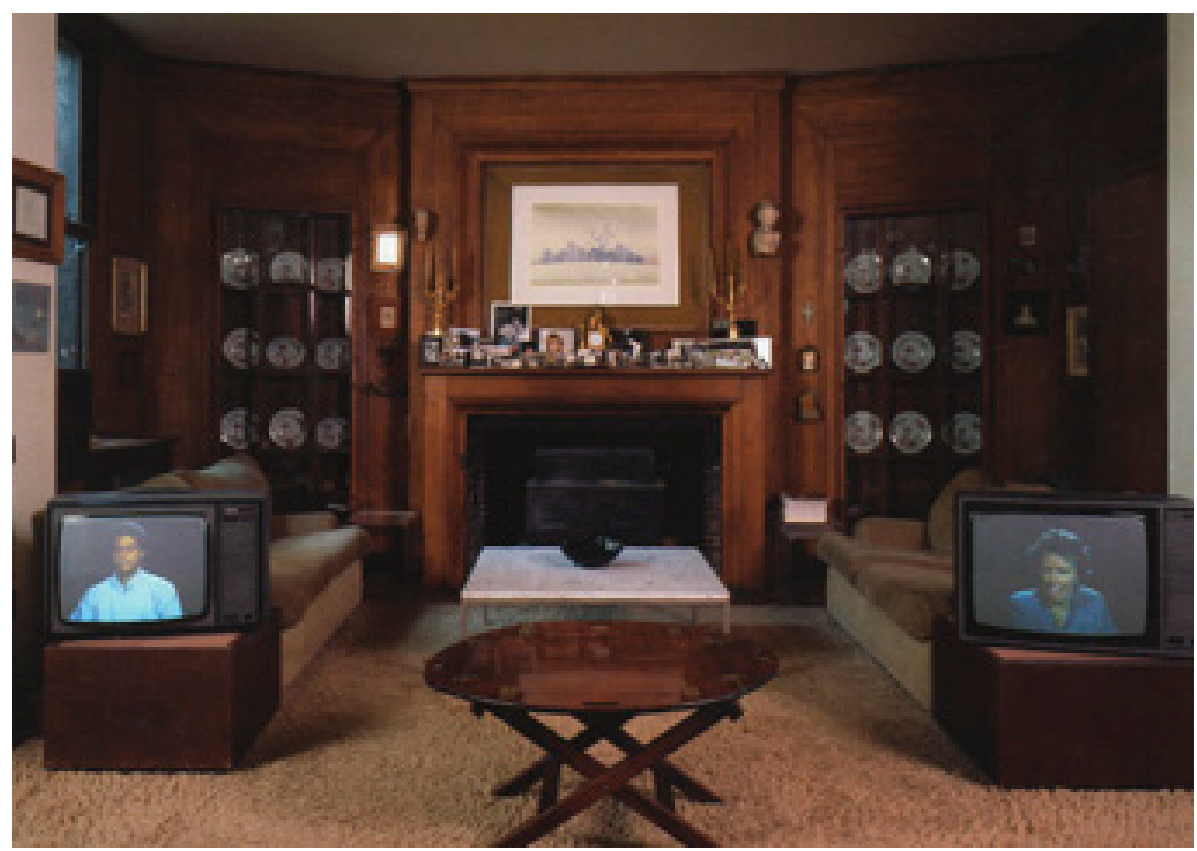

Good Boy Bad Boy, 1985, videoinstalação, dimensões variáveis.

espaço" 22. Por essa razão, intercalou o trabalho com textos mais longos e falados com suavidade. Essa calibragem minuciosa evitou que a voz dele sobrepujasse os demais sons do corredor, mas sem arrefecer a experiência de saturação auditiva causada pela potência dos exercícios vocais do cantor.

Inevitavelmente, em comparação com Rinde Eckert, as vozes feminina e masculina de Good Boy Bad Boy [Bom menino mau menino (1985)] soavam monótonas ao recitar as vinte e cinco estrofes de quatro linhas do texto, uma composição algoritmicamente estruturada que, em certa medida, simula o rigor das proposições lógicas. Na versão original, as cem frases foram escritas em neon e também pronunciadas em dois vídeos simultaneamente, cada qual projetado em um monitor de televisão. Um ator e uma atriz,

22. “I really want to use Rinde Eckert singing from Anthro/Socio 1992, but that's such an intense tape that I have to be careful it doesn't take over the situation. If it can't be controlled, it might not work in the context of the whole room". Cf. STORR, Robert.
Sound Waves: Bruce Nauman in Conversation with Robert Storr. Tate Etc, n. 2, Londres, set. 2004. Disponível em: http://www.tate.org.uk/ context-comment/articles/sound-waves. Acesso em: 15 mar. 2011. 
cabeças captadas em close, liam em entonações diversas a longa lista de cem itens. Suas vozes não conseguiam manter a sincronia e o descompasso era acentuado nos vídeos pelas expressões faciais que ambos realizavam no decorrer da leitura. No princípio, os neons piscavam em sintonia com as falas, mas logo perdiam a cadência. Na versão montada em "Raw Materials", cada uma das vozes era emitida por um alto-falante de modo que a dissintonia ficava evidente. A exemplo de 100 Live and Die, Good Boy Bad Boy também relaciona proposições derivadas de um conjunto não-hierárquico de ações e atributos humanos: "eu fui um bom menino/você foi um bom menino/ nós fomos bons meninos/isso foi bom" e, logo em seguida, "eu fui uma boa menina/você foi uma boa menina/nós fomos boas meninas/isso foi bom” ${ }^{23}$. As duas estrofes subsequentes contradizem as anteriores, substituindo "bom" e "boa" por "mau" e "má". Ao longo do texto, as estrofes vão se contradizendo mutuamente. Todas as combinações seguem a mesma lógica reiterativa ainda que temas tão distintos quanto virtude, maldade, trabalho, brincadeira, sexo, amor, ódio e necessidades fisiológicas estejam em questão. Apenas a última estrofe apresenta sentenças negativas "eu não quero morrer, você não quer morrer, nós não queremos morrer, isto é medo da morte" ${ }^{24}$.

As duas últimas áreas sonoras do corredor também correspondiam a trabalhos realizados a partir de textos de estrutura algorítmica, nos quais são permutados um número finito de termos para deles extrair sentidos diferentes. Shit In Your Hat - Head On A Chair [Cague em seu chapéu cabeça numa cadeira (1990)], já discutido, ganhou ainda mais intensidade na Tate justamente porque foi reduzido ao elemento essencial, a voz de comando. Sem a mediação do clown que compõe a videoinstalação original, as ordens cruéis emitidas pela voz impassível recaíam diretamente sobre os visitantes da mostra, provocando decerto risos ou incômodo.

23. "I was a good boy/you were a good boy/we were good boys/that was good/I was a good girl/you were a good girl/we were good girls/that was good". Conferir o texto integral no Apêndice desta tese.
24. "I don't want to die/you don't want to die/we don't want to die/ this is fear of death". Cf. Apêndice. 
Do mesmo modo, World Peace [Paz mundial (1996)] foi apresentado em "Raw Materials" em versão reduzida, contando com duas das cinco vozes do projeto original. Inicialmente, o trabalho previa duas formas de exibição, uma videoinstalação com as cinco versões projetados diretamente nas paredes do espaço expositivo (intitulado World Peace Projected) e uma outra com cinco televisores dispostos em semicírculo, contando com um banco ao centro, sugerindo que os vídeos fossem vistos por um espectador por vez (World Peace Received). Nos dois casos, o texto foi gravado por sete pessoas, sendo que duas delas interpretaram as palavras por meio da linguagem de sinais (um tradutor profissional da linguagem e uma atriz surda). As outras cinco (uma atriz, um dramaturgo, um pintor, uma poetisa e um pregador religioso) interpretaram o texto sem quaisquer sugestões ou instruções prévias. As vozes variadas produziram, obviamente, resultados diferentes, cada qual imprimindo sua personalidade vocal ao acentuar elementos específicos do texto.

Estudo para World Peace, 1996, grafite e colagem de polaroides sobre papel, $56,5 \times 76,5 \mathrm{~cm}$.

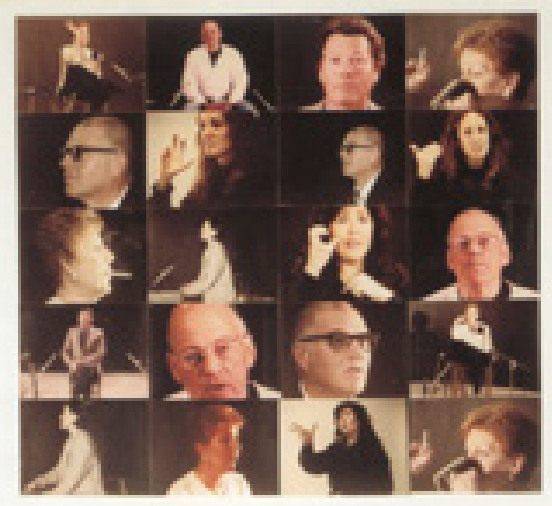


Já na versão transmitida pelos alto-falantes de "Raw Materials", uma voz feminina e outra masculina recitavam simultaneamente World Peace, texto cujo conteúdo sugere, a princípio, duas pessoas estabelecendo os parâmetros para um diálogo razoável, mas a reiteração de termos permutados em entonações crescentemente agressivas somada à perda da sincronia das falas parecia transformar a conversa em uma disputa por controle e poder; não à toa, portanto, a alusão às conferências internacionais presente no título. A complexidade do trabalho advém da manipulação dos recursos expressivos das vozes dos performers e não do teor do escrito, um texto simples e claro, semelhante a um mero exercício de conjugação de verbos.

Dividido em duas seções, o texto comuta dois verbos essenciais à comunicação "to talk" [falar] e "to listen" [escutar]. Na primeira parte, as permutações incidem sobre as conjugações simples dos verbos na primeira e na segunda pessoas do singular I e you [eu e você] e na primeira e na terceira do plural we e they [nós e eles], resultando em quatorze estrofes de "possibilidades comunicativas" combinadas por inversão dos termos; eis as oito primeiras delas: "eu falarei, você escutará/você falará, eu escutarei/eu falarei, eles escutarão/eles falarão, eu escutarei/você falará, eles escutarão/eles falarão, você escutará/nós falaremos, eles escutarão/eles falarão, nós escutaremos”" ${ }^{25}$. Constata-se que a sétima e a oitava estrofes são construídas pela inversão exata dos termos nas sentenças e, a partir desse ponto da primeira seção do texto, as estrofes começam a se repetir: a nona estrofe repete a quinta; a décima repete a sexta; a décima primeira repete a terceira; a décima segunda repete a quarta; a décima terceira repete a primeira e a décima quarta repete a segunda estrofe. A precisão matemático-musical da composição fica mais evidente na escrita organizada no papel, como se observa no Apêndice desta tese.

25. "I'll talk, you'll listen/ you'll talk, I'll listen/ I'll talk, they'll listen/ they'll talk, I'll listen/ you'll talk, they'll listen/ they'll talk, you'll listen/we'll talk, they'll listen/ they'll talk, we'll listen". A versão integral do texto e a tradução podem ser conferidas no Apêndice.

26. "You'll talk to me, I'll listen to you/I'll talk to you, you'll listen to me/ they'll talk to me, I'll listen to them [...]". Cf. Apêndice. 
Na segunda seção as combinatórias seguem exatamente o mesmo método: quatorze estrofes de duas linhas, sendo que a sétima e a oitava sinalizam a repetição espelhada das estrofes. A diferença das duas partes reside na adição de novos termos às combinações, os complementos "to me", "to you", "to them" que, no português, correspondem aos pronomes pessoais do caso oblíquo: "você falará comigo, eu escutarei você/eu falarei com você, você me escutará/eles falarão comigo, eu os escutarei..." ${ }^{26}$. Seguindo a lógica estabelecida, a última estrofe do texto é, portanto, igual à segunda estrofe da segunda seção, isto é, "eu falarei com você, você me escutará". Dessa forma, o texto se encerra de modo quase idêntico ao qual se inicia - "eu falarei, você escutará" - não fossem os complementos incorporados na segunda parte.

O processo de repetição em curso em World Peace é, de fato, estruturalmente mais complexo do que nos outros trabalhos, pois nele o mecanismo de circularidade se repete nas duas metades do texto. Considerado no conjunto, World Peace compõe-se de 28 estrofes de duas linhas e o ciclo se inicia com as permutações e inversões dos termos nas estrofes 1 e 2, depois na 3 e 4, 5 e 6, 7 e 8; então se segue o procedimento de repetição que resulta em estrofe $9=5,10=6,11=3,12=4,13=1$ e $14=2$; depois disso, o texto volta a ser pautado por processos de permutação e inversão de termos nas estrofes 15 e 16, 17 e 18, 19 e 20, 21 e 22; e, por fim, a repetição das estrofes retorna, $23=19,24=20,25=17,26=18,27=15,28=16$.

Embora essa tentativa de descrição matemática dos métodos compositivos não conste na bibliografia coligida sobre a obra e não haja um esboço disponível do trabalho, pode-se deduzir que Nauman tenha esquematizado previamente World Peace. Não há como não lembrar de Molloy e da busca obstinada pelo método mais adequado para chupar com perfeição as dezesseis pedrinhas guardadas em seus bolsos.

Os métodos empregados por Nauman na elaboração dos textos de World Peace, 100 Live and Die e Good Boy Bad Boy são frequentemente comparados às composições musicais que "exploram unidades modulares 
de melodia como as de Steve Reich ou Terry Riley" ${ }^{27}$. De fato, o artista declarou algumas vezes que, juntamente com as inovações propostas por John Cage (1912 - 1992), a convivência com as obras dos norte-americanos Steve Reich (1936 -), Terry Riley (1935 -), La Mont Young (1935-) e Philip Glass (1937 -), compositores usualmente associados ao "minimalismo" uma terminologia provavelmente tão genérica e insuficiente para designar a música surgida nas décadas de 1960 e 1970 quanto o é para explicar as artes visuais do período - foi importante para ampliar sua compreensão "dos sentidos de estrutura e tempo" 28 .

Sendo assim, parece legítimo e adequado comparar o rigor compositivo de certos textos de Nauman às partituras elaboradas por músicos afeitos a procedimentos reiterativos e especialmente atentos às variações mais ínfimas desencadeadas por quaisquer mudanças nos padrões de repetição. A ideia de estruturação temporal por meio de mecanismos de circularidade é um dos cernes da obra de Nauman e um ponto de convergência com a produção de Beckett, segundo se argumentou na análise da Caminhada angular lenta à luz dos caminhantes encapuzados de Beckett (Quad I + II).

Estabelecer sequências precisas e executá-las em conformidade com um método prévio é uma forma privilegiada de regular o tempo na obra de ambos. A contenção, o vagar, a celeridade ou o frenesi implicados nas rotinas, por mais extravagantes que sejam, dilatam ou comprimem as durações, desabituando a experiência. Muito natural, portanto, que o ajuste do timing dos trabalhos se assemelhe aos procedimentos matemático-

27. 0 próprio catálogo de "Raw Materials" aponta essas proximidades quando trata de World Peace: "this grammatical exploration of these two verbs is confined to a simple cellular structure seen in works like 100 Live and Die or Good Boy Bad Boy. As with those works, there are strong connections with the work of composers like Steve Reich or Terry Riley who explore modular units of melody". Cf. NAUMAN, Bruce. Raw Materials. Londres: Tate Press, 2004, p. 140.
28. Cf. KRAYNAK, Janet. Op. cit., p. 246. Nauman declarou: "fui capaz de usar as ideias sobre o tempo de modo muito favorável. Nunca houve nada que se pudesse tirar deles a não ser a postura frente ao tempo" ["I was able to use their idea about time as a really supportive idea. There was never anything you could really take from them, but their attitude about time"]. Cf. KRAYNAK, Janet. Op. cit., p. $174 ; 245-247 ; 306-307$. 
musicais, e que as duas obras componham métricas muito particulares a despeito das afinidades que possam compartilhar.

Já se argumentou aqui que a execução das "partituras" de Nauman prevê uma dose de improviso que não se costuma observar em Beckett. $\mathrm{O}$ único performer que não conta com uma margem mínima de improviso na obra de Nauman é ele mesmo: sempre que se lança em uma atividade, como na intrincada Caminhada Beckett, cumpre o planejamento à risca, e o faz com destreza física e concentração absoluta, cuidando para não demonstrar cansaço, para neutralizar suas idiossincrasias e afastar quaisquer exageros expressivos. $\mathrm{O}$ mesmo não ocorre quando as performances são executadas por outros, como se mencionou a respeito dos atores Tony e Elke que, ao desempenharem os exercícios mentais que preconizam o afundamento do corpo no chão ou a elevação deste em torno do corpo, imprimiram uma dramaticidade não prevista nas instruções: ambos interromperam os exercícios bruscamente alegando mal-estar provocado pela concentração extenuante exigida.

O "improviso consentido" é subjacente aos trabalhos com vozes, mesmo quando as partituras são restritas e aparentemente tão monótonas quanto a de Giorni/Days [Dias (2009)], instalação sonora aos moldes de "Raw Materials" que integrou a mostra "Topological Gardens", na $53^{\mathrm{a}}$ Bienal de Veneza. Sete pares de alto-falantes planos para a emissão de sons direcionados, montados em uma sala ampla e vazia, reproduziam vozes variadas entoando os sete dias da semana. Em um primeiro momento, o roteiro parecia seguir a sucessão natural dos dias, entretanto, tratava-se de uma ordenação minuciosa de permutações que subtraía alternadamente os termos das séries, de modo que as sequências cumpriam a lógica predeterminada pelo artista; após um "domingo", por exemplo, poderia vir uma "quartafeira". Durante as gravações, todas as vozes executaram o mesmo padrão, a mesma partitura, mas cada pessoa imprimiu um ritmo à fala e, juntas no espaço, as vozes tornavam-se vibrantes e não enfadonhas. Os textos são idênticos em inglês e em italiano, entretanto, na versão Days as vozes são 
indiscriminadamente repetidas em looping, sem que se possa distinguir o início ou o fim das séries, enquanto que em Giorni o sequenciamento se pauta pelas qualidades expressivas das vozes e a circularidade é substituída pela ideia de progressão, uma ocorrência pouco usual na obra. Segundo o depoimento do curador de "Topological Gardens":

Uma lógica diferente se desenrola em Giorni: uma voz abre a sequência, em seguida, uma segunda voz, depois o restante das vozes se junta; e, ao final, duas vozes e, depois, apenas uma voz é ouvida. A duração do ciclo resultante é ligeiramente mais longa do que o tempo requerido na leitura do texto. As primeiras vozes a serem ouvidas são as de duas jovens estudantes, e a última voz, a do homem mais velho do grupo. A sequência evoca claramente o passar do tempo, medido não apenas pelos dias mas também ao longo da vida. As vozes femininas que abrem a sequência vibram com expectativa e sensualidade; no final, um contraponto entre duas vozes masculinas sustenta um clima mais sombrio. Talvez pela primeira vez na longa carreira de Nauman, o fator determinante da duração do trabalho parece ser puramente subjetivo. Não surpreendentemente, essa estrutura torna o trabalho mais musical e mais emocional, como se a intenção do artista fosse levar o conteúdo expressivo das vozes individuais ainda mais longe ${ }^{29}$.

As instalações sonoras que permitem a Nauman explorar o potencial expressivo da matéria bruta "voz" são frequentemente associadas à música e

29. "A different logic plays out in Giorni: one voice opens the sequence, then a second, then the rest of the voices join in, and at the end, two and then finally just one voice is heard. The duration of the resulting cycle is slightly longer than the reading time required by the text. The first voices to be heard are those of two young female students, the last, that of the oldest man in the group. The sequency clearly evokes the passing time, measured not so much in days as in lives. The female voices that open the sequence vibrate with expectation and sensuality; toward the end, a counterpoint between two male voices declares a more somber mood. Perhaps the first time in Nauman's long career, the determining factor of the duration of the work seems to be purely subjective. Not surprisingly, this structure makes the work both more musical and more emotional, as if the artist's intentionality were carrying the expressive content of the individual voices even further". Cf. BASUALDO, Carlos. To Bear, to Endure. In: NAUMAN, Bruce. Topological Gardens. Filadélfia: Philadelphia Museum of Art, 2009, p. 161. 
à intensidade emocional que evocam. Organizar musicalmente o transcurso do tempo é uma constante na obra, e o próprio artista confirma que a "música desempenha um papel importante em muitos dos trabalhos, mesmo quando não há música” ${ }^{30}$. Já se comentou que a música - assim como a matemática - precedeu o interesse de Nauman pelas artes visuais, tendo se dedicado ao estudo de teoria musical na época da graduação em Wisconsin, período em que tocava baixo em pequenas formações de jazz ${ }^{31}$. Nada mais natural que a obra retivesse uma dose da precisão matemático-musical bem como a atenção às variações rítmicas e aos efeitos decorrentes, e que a metáfora da intensidade se remetesse à improvisação no jazz, uma prática sutil e complexa, que exige profundo conhecimento da técnica e da própria tradição musical, junto a uma capacidade de resposta aos desafios sonoros imediatos ${ }^{32}$. A escultura John Coltrane Piece [Peça John Coltrane], de 1968, uma placa quadrada de alumínio maciço com fundo espelhado invisível, recostado no chão, é uma espécie de cenotáfio realizado um pouco depois da morte do saxofonista admirado por Nauman:

30. "Music plays a role in a lot of my work, even when there is no music". Cf. AUPING, Michael. Sound Thinking: Michael Auping on Bruce Nauman at the Turbine Hall. Artforum, Nova York, jan. 2005, p. 161.

31. Eis o depoimento de Nauman sobre a época: “eu gosto de música. Eu me envolvi com ela mais tarde na graduação. Comecei a me meter no departamento de música. Mais uma vez, estava interessado em teoria musical e composição em vez de praticar. 0 que era interessante é que eu tinha o mesmo sentimento pela música que eu tinha para a matemática e, finalmente, de arte. Para mim, muito disso tinha a ver com o rearranjo das condições dentro de uma disciplina; ver se você podia encontrar a borda da estrutura” [“/ like music. I got involved with it later in high school. I started to slip into the music department. Again, I was interested in music theory and composition rather than having to practice. What was interesting was that I had the same feeling for music that I had for mathematics and eventually art. For me a lot of it had to do with the rearrangement of conditions within a discipline; seeing if you could find the edge of structure"]. Cf. AUPING, Michael. 30 Years: Interviews and Outtakes. Nova York: Prestel Publishing, p. 225. Além do jazz, Nauman interessou-se no período por compositores como Anton Webern (1883-1945), Alban Berg (1885-1935), Arnold Shoenberg (1874-1951). Cf. LEWALLEN, Constance M. (Org.). A Rose Has No Teeth: Bruce Nauman in the 1960s. Berkeley: University of California Press, 2007, p. 10.

32. Obviamente o assunto é vasto e complexo, e excede o objeto desta tese. Cf. DeVITO, Chris (Ed.). Coltrane on Coltrane. The John Coltrane Interviews. Chicago: Chicago Review Press, 2010; GIOIA, Ted. The History of Jazz. Nova York: Oxford University Press, 2011; GIDDINS, Gary. Visions of Jazz: The First Century. Nova York: Oxford University Press, 1998; KIRCHNER, Bill (Ed.). The Oxford Companion to Jazz: New York. . Nova York: Oxford University Press, 2000. 
Penso que escutei Coltrane tanto quanto qualquer outro e muita música era modal em vez de jazz mais tradicional. O que também tem aquele sentido de que não há progressão, somente continuidade que segue indefinidamente até que se decida parar. E eu realmente gostava da ideia de uma performance ou vídeo que fosse mais longo do que o filme ou um filme que passasse em loop e coisas assim nas quais pode-se entrar a qualquer momento ${ }^{33}$.

A exposição despertou grande atenção em jornais e revistas da época, que ressaltaram sobretudo os aspectos musicais e o impacto emocional da mostra. Os críticos que acompanham a obra de Nauman há tempos citaram, por exemplo, as características "sinfônicas" ${ }^{34}$ ou "melódico-linguísticas" ${ }^{35}$ da instalação:

[...] percorrer o Turbine Hall rapidamente, deixando que cada faixa de linguagem registre entonações breves é também é uma experiência musical. Não estou sugerindo que essas vozes cheguem até nós como uma sinfonia ou coro chegariam. É mais como um equivalente léxico do jazz, no qual um músico nos leva ao limite da melodia e depois nos devolve a um refrão. Imagine as vinte e uma faixas de som/linguagem atravessando a largura do espaço como um naipe de cordas ativado à medida que o espectador caminhe através delas ${ }^{36}$.

33. "I think Coltrane was the person I listened to as much as anybody and a lot of the music was modal rather than more traditional jazz. That also has that sense that there's no progression, it just goes on and on until you choose to stop. And so I really liked the idea of performance or videotape that went on longer than film, or film that went on in loops and things like that - you could walk in at any point". Cf. KRAYNAK, Janet (Ed.). Op. cit., p. 247.

34. Comentário de Joan Simon, no original: The arrangement of texts within the hall is, in a sense, symphonic. Cf. SIMON, Joan. Op. cit.

35. Comentário de Michael Auping, no original: "In fact, there are moments in Raw Materials when we don't seem to be experiencing language at all, but some hybrid form of melodic linguistic-sound attitude". Cf. AUPING, Michael. Sound Thinking: Michael Auping on Bruce Nauman at the Turbine Hall. Artforum, Nova York, jan. 2005, p. 160.

36." [...] walk through the Turbine Hall quickly, letting each band of language register brief intonations, is also a musical experience. I'm not suggesting that these voices come at us like a symphony or choir. It is more like a lexical equivalent of jazz, in which a musician take us to the very edge of melody, then brings us back to a refrain. Imagine the twenty-one bands of sound/ language crossing the width of the space as a set of strings activated as the viewer walks through them". Cf. Ibidem, p. 161. 
Ao que parece, em "Raw Materials" as qualidades expressivas da vozes construíram a intensidade pretendida por Nauman em sua obra. As vozes em disputa, assediando e convidando ao caminhar, preencheram o imenso saguão tal como uma peça musical de grande intensidade, talvez comparável a um improviso brutal de Coltrane ou, talvez, a uma mente torturada pelos sons fundamentais, à la Beckett, sofrendo de dores de cabeça e implorando pelas aspirinas.

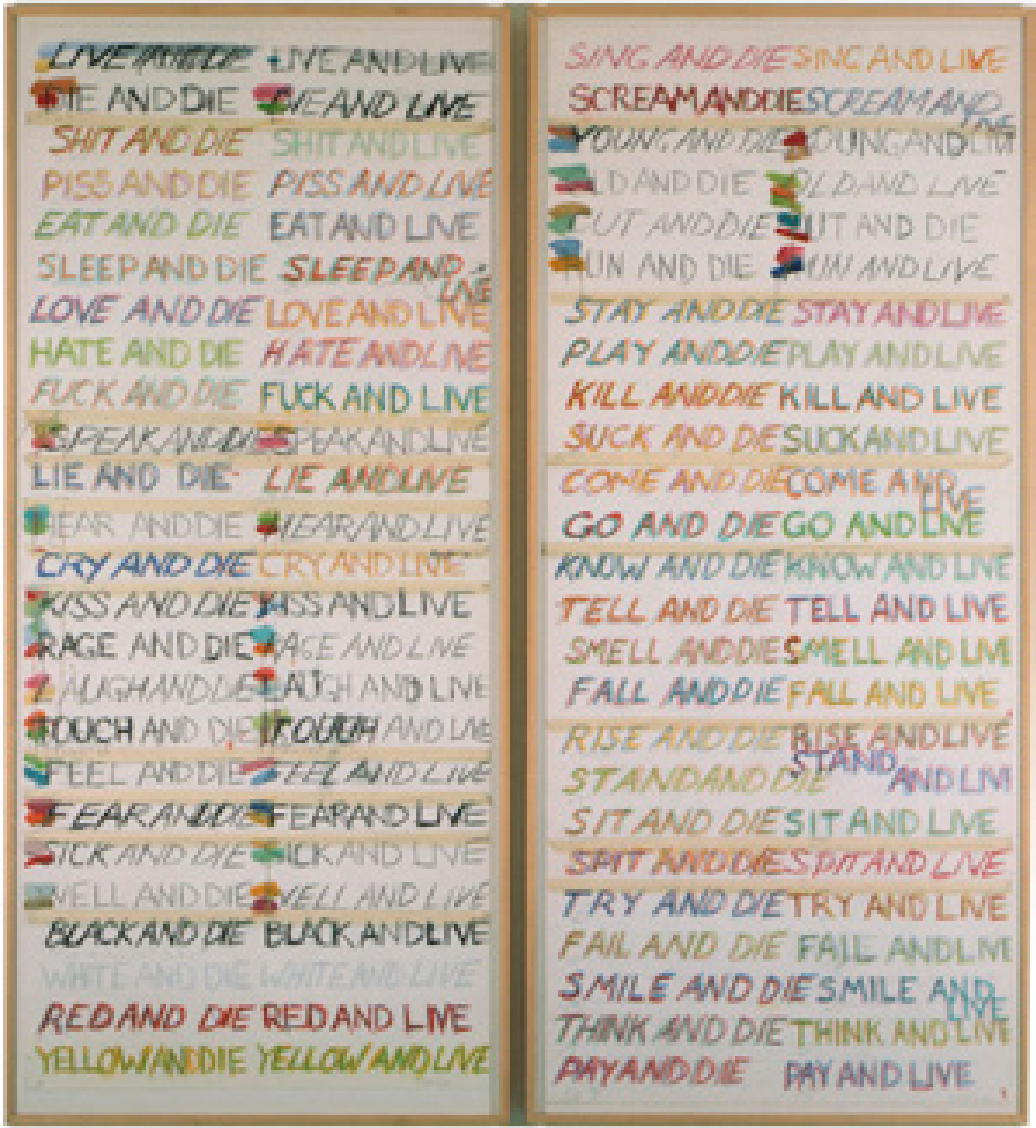

Estudo para 100 Live and Die, 1983, grafite, pastel, carvão e aquarela sobre papel, $285 \times 127 \mathrm{~cm}$. 


\title{
Considerações finais: verdades parciais...
}

\author{
"A afirmação abaixo é verdadeira. \\ A afirmação acima é falsa"”.
}

Diante da produção extensa e multifacetada de Bruce Nauman, esta tese apresentou um recorte que pretendeu circunscrever um conjunto de questões articulado em torno dos procedimentos mais recorrentes nas quatro décadas de projeção pública da obra. Não se buscou um viés historiográfico na abordagem do objeto mas, ao contrário disso, empreenderam-se sobrevoos pela produção e explicitou-se, aqui e acolá, o pano de fundo artístico no qual a obra se formou.

Propôs-se uma comparação pontual com a obra de Samuel Beckett, tendo em consideração certas analogias de procedimentos e convergências temáticas entre ambas as produções. Buscou-se discutir o uso de processos de simplificação, de contenção, de reiteração ininterrupta de padrões e de permutação de elementos restritos como formas de regular a percepção do transcurso do tempo e de promover experiências de saturação e de extenuação.

Discutiram-se também as implicações recíprocas entre trabalhos aparentemente diversos como as formas macias, as esculturas-corpo e os filmes $16 \mathrm{~mm}$ e vídeos captados no ateliê do artista. Com a análise de tais trabalhos pretendeu-se investigar a hipótese do aparecimento

\footnotetext{
1. Proposições frequentemente empregadas ao teorema de Gödel ou o preço da matemática como exemplo para explicar a noção de é o eterno matemático. In: Cadernos do IME/ paradoxo nos manuais de "ciências aplicadas". Cf. KUBRUSLY, Ricardo. Uma viagem informal UERJ, Rio de Janeiro, 1998.
} 
do corpo na obra do artista como uma culminação de procedimentos enraizados em uma tradição da escultura, por vezes tomada pela via negativa. Argumentou-se que, desde os primeiros trabalhos, Nauman trata indistintamente todos os materiais como matérias brutas, testandoos nas mais diversas circunstâncias. Pretendeu-se também demonstrar que a pergunta pela possibilidade de expressão se constitui como um movimento interno à obra do artista e não é suficientemente formulada nos termos de uma "expressividade corporal". A ideia de expressão nos trabalhos de Nauman vem de par com experiências de extenuação. A voz, dentre todos os materiais, é aquele cujas qualidades "expressivas" têm sido mais exploradas por Nauman nos últimos anos.

A tese pretendeu ainda apontar que, ao longo de toda a trajetória, a curiosidade e o espírito analítico de Nauman têm sustentado o caráter experimental da produção:

\footnotetext{
A arte é um meio que leva à aquisição de uma atividade investigativa. Não sei seé possível mudarmos as coisas em um sentido mais amplo. Você pode tornar-se cônscio das possibilidades; é importante fazer isso. Não sei, nesse sentido, se isso está relacionado à comunidade artística. Mas minha atitude vem de eu ser um artista em vez de um cientista, que é um modo de investigação bem diferente. Quando eu estava na escola, comecei como matemático. Eu acabei não me tornando um, mas acho que há um determinado processo de pensamento que é muito semelhante, e que acabei trazendo para a arte. Essa atividade investigativa é necessária. Acho que confiamos demasiadamente nas validações tradicionais que aceitamos ${ }^{2}$.
}

2. "Art is a means to acquiring an investigative activity. I don't know if you can necessarily change things in a broad sense. You can make yourself aware of the possibilities; it is important to do that. I don't know, in that sense, [if] it relates to the art community. But my attitude comes from being an artist and not a scientist, which is another way of investigating. When I was in school I started out as a mathematician. I didn't become one, but I think there was a certain thinking process which is very similar and which carried over into art. This investigative activity is necessary. I think that we trust too much in accepting traditional validations". Cf. KRAYNAK, Janet (Ed.). Please Pay Attention Please: Bruce Nauman's words: writings and interviews. Cambridge, Massachusetts: The MIT Press, 2005, p. 188. 
Da matemática, Nauman cita expressamente os problemas insolúveis, como a comentada quadratura do círculo ${ }^{3}$, e os teoremas da incompletude de Gödel, brevemente mencionados em Notes and Projects ${ }^{4}$ [Notas e Projetos (1970)]. Mesmo nas ciências exatas, Nauman busca pelos limites, pelas "bordas das estruturas" ${ }^{5}$. A desconfiança das validações tradicionais, a busca pelo reverso das regras ${ }^{6}$, a inversão das formas, o exame incessante dos materiais, o cultivo dos paradoxos são modos de pensar e de proceder que imprimem suas marcas na produção do artista. Trata-se, de fato, de uma obra que, metodicamente, testa as suas próprias premissas com meios e materiais variados.

Por fim, deve-se ressaltar que esta tese buscou as "verdades parciais" em lugar de uma conclusão - para tomar de empréstimo uma expressão reincidente na obra de Nauman, ora gravada em papel ora inscrita em placas austeras de granito preto.

3. Cf. Nota 13, Capítulo 3 desta tese.

4. Em termos gerais, os teoremas de Gödel postulam que é impossível definir um sistema de axiomas completo que seja simultaneamente consistente. Um sistema diz-se completo se, dentro dele, podemos provar qualquer afirmação ou a sua negação a partir dos axiomas los axiomas são os alicerces do sistema, são as afirmações iniciais que se consideram evidentes e sem necessidade de proval. Um sistema diz-se consistente se não podemos provar simultaneamente uma afirmação e a sua negação [Cf. KUBRUSLY, Ricardo. Op. cit.]. Em Notes and Projects, os teoremas são citados no seguinte trecho, no original: ["Goedel's Proof, 1931: 'On Formally Undecidable Propositions of Principia Mathematica and Related Systems. 1) If a system is consistent then it is incomplete. 2) (Goedel's incompleteness theorum[sic) theorem]l implies impossibility of construction of calculating machine equivalent to a human brain]. Cf. Apêndice.

5. Cf. Nota 31, Capítulo 5 desta tese.

6. Cf. Nota 3, Considerações iniciais desta tese. 

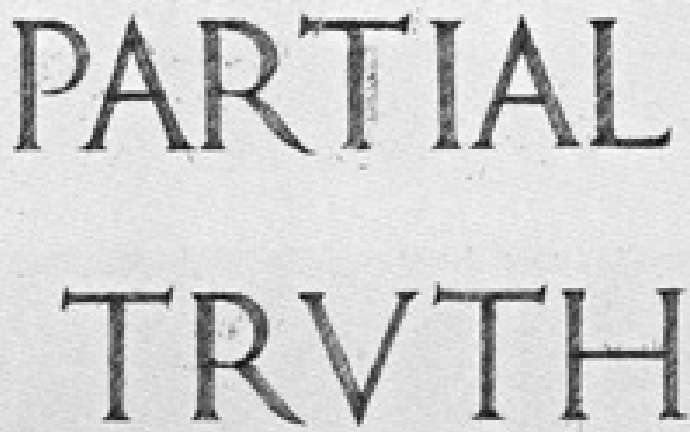
Referências bibliográficas 
Bibliografia sobre a obra de Bruce Nauman

\section{Escritos e Livros de artista}

NAUMAN, Bruce. Picture of Sculpture in a Room. San Francisco, 1965-1966 [editado por Bruce Nauman]

CLEA RSKY. Nova York: Leo Castelli Gallery, 1967.

. Burning Small Fires. San Francisco, 1968 [editado por Bruce Nauman]

. LAAir. Nova York: Multiples Inc., 1970.

Notes and Projects. Artforum 9, Nova York, n. 4, dez. 1970.

. Parkett: Collaborations and Editions since 1984, Zurique, 2001.

. A Thousand Words. Artforum 40, n. 7, Nova York, mar. 2002, p. 120-121.

Catálogos de Exposições

NAUMAN, Bruce. Bruce Nauman. Nova York: Leo Gastelli Gallery, 1968.

. Bruce Nauman: Works from 1965-1972. Los Angeles/Nova York/Dusseldorf:

Los Angeles County Museum of Art/Whitney Museum of American Art/

Stadtische Kunsthalle, 1972.

Prints 1970-1989: Catalogue Raisonné. Nova York/Chicago: Castelli Graphics/Donald Young Gallery, 1989.

. Bruce Nauman: 25 Years: Leo Castelli. Nova York: Leo Castelli, 1994.

\& SIMON, Joan. Bruce Nauman: Exhibition Catalogue and Catalogue

Raisonné. Minneapolis: Walker Center Art, 1994.

. Elliot's Stones. Chicago: Museum of Contemporary Art, 1995.

. Drawings, Prints, and Related Works: 1985-1996. Riggefield, Connecticut:

The Aldrich Museum of Contemporary Art, 1997.

. Selected Works. Nova York: Zwirner \& Wirth, 2001.

. Bruce Nauman: Neons, Sculptures, Drawings. Nova York: Van De Weghe

Fine Art, 2002.

. AC Bruce Nauman, Mapping the Studio I (Fat Chance John Cage). Colônia:

Verlag der Buchhandlung Walther Koning, 2003.

. Raw Materials. Londres: Tate Press, 2004.

. Audio-Video Underground Chamber. Nuremberg/Viena: Verlag fur modern

Kunst Nurnberg \& MUMOK, 2005.

Bruce Nauman: circuito fechado/filmes e vídeos de Bruce Nauman, 1967-

2001. Rio de Janeiro: CGBB, 2005.

Elusive Signs: Bruce Nauman Works with Light. Cambrigde, Massachusetts:

MIT Press, 2006. 
. Bruce Nauman: Make Me Think Me. Londres: Tate Publishing, 2006.

. Drawings for Installations. Nova York: Sperone Westwater, 2008.

Topological Gardens. Filadélfia: Philadelphia Museum of Art, 2009.

Topological Gardens: Installation Views. Venice Biennial. Filadélfia:

Philadelphia Museum of Art and Yale University Press, 2009.

Live or Die. Colônia: DuMont Buchverlag, 2010.

\section{Monografias e ensaios}

ADAMS, Parveen. Bruce Nauman and the Object of Anxiety. October Magazine 83, Cambrigde, Massachusetts, 1998.

AMMANN, Jean-Christophe. Wittgenstein and Nauman: Notes on the Works of Bruce Nauman. In: Bruce Nauman. Londres/Basel: Whitechapel/Kunsthalle, 1986, p. 21-29.

AUPING, Michael. Metacommunicator. In: NAUMAN, Bruce. Raw Materials.

Londres: Tate Press, 2004.

. Sound Thinking: Michael Auping on Bruce Nauman at the Turbine Hall.

Artforum, Nova York, jan. 2005, p. 158-161.

Projection and Displacement. In: NAUMAN, Bruce. Bruce Nauman:

Drawings for Installations. Nova York: Sperone Westwater, 2008, p. 7-12. 30 Years: Interviews and Outtakes. Nova York: Prestel Publishing, p. 225-235.

BAKER, Elizabeth \& RAFFAELE, Joseph. The Way-Out West: Interviews with Four San Francisco Artists. Artnews 66, n. 4, verão 1967, p. 39-41, 75-76.

BAKER, Kenneth. Nauman's Art Finds Richness in an Empty Room. San Francisco

Chronicle, San Francisco, abr. 2002, p. D1, D8.

BARNITZ, Jacqueline. In the Galleries: Bruce Nauman. Arts Magazine 42, n. 5, mar. 1968.

BASUALDO, Carlos. Bruce Nauman: Topological Gardens. In: NAUMAN, Bruce.

Topological Gardens. Filadélfia: Philadelphia Museum of Art, 2009, p. 15-44.

BATTLE, Erica F. Analogy as Art: The Infinite Trajectories of Bruce Nauman. In:

NAUMAN, Bruce. Topological Gardens. Filadélfia: Philadelphia Museum of Art, 2009, p. 85-109.

BENZERA, Neal. Raw Material. Art Press, n. 184, out. 1993, p. 10-20. . et al. Bruce Nauman. Madri: Museo Nacional Centro de Arte Reina Sofia, 1994. Surveying Nauman. In: MORGAN, Robert G. (Ed.). Bruce Nauman.

Baltimore: The Johns Hopkins University Press, 2002, p. 116-145. . Mind Over Matter. Artnews, Nova York, maio 1999, p. 143.

BIRNBAUM, Daniel. Samuel Beckett/ Bruce Nauman. ArtForum, Nova York, verão 2000.

BLUME, Eugen. Bruce Nauman: Live or Die - or: The Measuring of Being. In: NAUMAN, Bruce. Live or Die. Colônia: DuMont Buchverlag, 2010, p. 9-79. 
. \& KNAPSTEIN, Gabriele; NICHOLS, Catherine; CLASER, Sonja. Bruce Nauman: Ein Lesebuch. Berlim: Dumont, 2010.

BRUGGEN, Coosje van. Bruce Nauman: Entrance, Entrapment, Exit. Artforum 24, n. 10, Nova York, verão 1986, p. 88-97.

. Bruce Nauman. Nova York: Rizzoli International Publications, 1988.

BUTTERFIELD, Jan. Bruce Nauman: the Genter of Yourself. Arts Magazine, fev. 1975, p. 53-55.

CHIONG, Kathryn. Nauman's BeckettWalk. October 86, Cambrigde, Massachusetts, 1998, p. 63-81.

GROSS, Susan. Bruce Nauman: Theaters of Experience. Nova York: D.A.P., 2003.

DANIELI, Fidel A. The Art of Bruce Nauman. Artforum 6, n 4, Nova York, dez. 1967, p. 15-19.

DELAPORTE, Marie-Laure. Samuel Beckett/Bruce Nauman: Un noveau lieu de creation spatio-temporel. In: Samuel Beckett today aujourd'hui 23. Filiations \& Connexions/Filiations \& Connecting Lines. Mével, Yann, Dominique Rabaté and/et Sjef Houppermans (Eds.). Amsterdam/New York, NY, 2011.

DEXTER, Emma. Raw Materials. In: NAUMAN, Bruce. Raw Materials. Londres: Tate Publishing, 2004.

FOGLE, Douglas (Org.). The Last Picture Show: Artists Using Photography. Minneapolis: Walker Art Center, 2003.

GAYFORD, Martin. Sculpture for The Ears. The Daily Telegraph, Londres, 12 out. 2004. GRAW, Isabelle. Bruce Nauman: Being is Nothing. Flash Art, 169, mar./abr., 1993.

HAYES, Christa-Maria Lerm. Nauman... Beckett... Beckett... Nauman: the Necessity of Working in an Interdisciplinary Way. Circa 104, Dublin, verão 2003, p. 47-50. HOFFMANN, Christine \& GLASMEIER, Michael (Org.). Samuel Beckett/Bruce Nauman. Viena: Kunsthalle, 2000.

Bruce Nauman: Interviews 1967-1988. Amsterdam: Verl. Der Kunst, 1996.

KETNER II, Joseph D. Elusive Signs. In: NAUMAN, Bruce. Elusive Signs: Bruce Nauman Works with Light. Cambridge, Massachusetts: MIT Press, 2006, p. 15-40.

KÖLLE, Bigitte. Okey Dokey Konrad Fischer. Colônia: Verlag der Buchhandlung Walther König, 2002.

KRAYNAK, Janet (Ed.). Please Pay Attention Please: Bruce Nauman's Words: Writings and Interviews. Cambridge, Massachusetts: The MIT Press, 2005.

. Signs and Systems: On Nauman's Neon Templates and Other Works. In: NAUMAN, Bruce. Elusive Signs: Bruce Nauman Works with Light. Cambrigde, Massachusetts: MIT Press, 2006, p. 41-58.

LEWALlEN, Gonstance M. (Org.). A Rose Has No Teeth: Bruce Nauman in the 1960s. Berkeley: University of California Press, 2007.

LITZ, Christine. At Night All Cats Are Grey? Mysterious Elements in Bruce Nauman's 
Work. NAUMAN, Bruce. AC Bruce Nauman, Mapping the Studio I (Fat Chance John Cage). Colônia: Verlag der Buchhandlung Walther Koning, 2003, p. 21-27.

LUSK, Jennie. Bruce Nauman: 1/12 Scale Models for Underground Pieces. Albuquerque: Albuquerque Museum, 1981.

MICHELIS, Marco De. Spaces. In: NAUMAN, Bruce. Topological Gardens. Filadélfia: Philadelphia Museum of Art, 2009, p. 65-84.

MILLER, John. Three Statements on the Recent Reception of Bruce Nauman. October Magazine, Cambridge/ Massachusetts, n. 74, 1995.

MORGAN, Robert G. (Ed.). Bruce Nauman. Baltimore: The Johns Hopkins University Press, 2002.

MULLER, Gregoire (Ed.). The New Avant-Garde: Issues for the Art of the Seventies. Westport, Connecticut: Praeger Publishers, 1972.

NESBITT, Lois E. Lie Down, Roll Over. Artscribe, 82, Londres, 1990.

PINCUS-WITTEN, Robert. Bruce Nauman: Another Kind of Reasoning. Artforum 10, Nova York, n. 6, fev. 1972, p. 30-37.

PLAGENS, Peter. Cousin Bruce. Artforum 33, Nova York, n. 8, abr. 1995, p. 63.

RAMOS, Nuno. Violência silêncio: Bruce Nauman, Folha de S. Paulo, Jornal de Resenhas, São Paulo, 7 ago. 1995.

RELYEA, Lane. Cast Against Type. Artforum 33, Nova York, n. 8, abr. 1995, p. 63-69, 106.

RICHARDSON, Brenda. Bruce Nauman: Neons. Baltimore: Baltimore Museum of Art, 1982.

SGHAFFNER, Ingrid. Bruce Nauman through Samuel Beckett. In: MORGAN, Robert G. (Ed.). Bruce Nauman. Baltimore: The Johns Hopkins University Press, 2002, p. 163-173.

SIMON, Joan. Bruce Nauman: Theme and Meaning (and Sleight of Hand). New Yorker, v. 69, issue 50, Nova York, 14 fev. 1994, p. 36.

Bruce Nauman: The Matter in Hand. Londres, Tate, 1998.

Hear Here: Interview with Bruce Nauman. Frieze Magazine n. 86, Londres, out. 2004. Disponível em: http://www.frieze.com/issue/article/hear_here. Acesso em: 11 fev. 2010.

SLIFKIN, Robert. Now Man's Bound to Fail. October Magazine, Cambridge, Massachusetts, n. 135, 2011, p. 49-69.

. Bruce Nauman Going Solo. Portland, Oregon: Companion Editions, 2012.

SMITH, Robert. Comfortable? Easy? Not for Bruce Nauman. The New York Times, Nova York, 3 mar. 1995.

. Prospects of Bounding with a You, a Me, and a Them. The New York Times, Nova York, 14 nov. 1996.

SOLOMON, Andrew. Complex Cowboy: Bruce Nauman. The New York Times Magazine, Nova York, 5 mar. 1995. 
STORR, Robert. Beyond Words. In: NAUMAN, Bruce \& SIMON, Joan (Ed). Bruce

Nauman: Exhibition Catalogue and Catalogue Raisonné. Minneapolis: Walker

Center Art, 1994, p. 47-66. . Nowhere Man. Parkett n. 10, Zurique, set. 1986, p. 70-90.

. Flashing the Light in the Shadow of Doubt. In: MORGAN, Robert C. (Ed.).

Bruce Nauman. Baltimore: The Johns Hopkins University Press, 2002, p. 155-162 Partial Truths. In: NAUMAN, Bruce. Bruce Nauman: Neons, Sculptures,

Drawings. Nova York: Van De Weghe Fine Art, 2002.

. Disparities E Deformations: Our Grotesque. Santa Fe/Nova York: SITE Santa

Fe/DAP, 2004.

. Please Pay Attention, Please. In: LEWALLEN, Constance M. (Org.). A Rose

Has No Teeth: Bruce Nauman in the 1960s. Berkeley: University of California Press, 2007, p. 146-167.

Bruce Nauman: The Man Who Would Not Be King. Modern Painters

Magazine, Nova York, maio 2009, p. 42-47.

. Sound Waves: Bruce Nauman in Conversation with Robert Storr. Tate Etc, n.

2, Londres, set. 2004. Disponível em: http://www.tate.org.uk/context-comment/ articles/sound-waves. Acesso em: 15 mar. 2011.

TAYLOR, Michael R. Bruce Nauman: Mapping the Studio, Changing the Field. In: NAUMAN, Bruce. Topological Gardens. Filadélfia: Philadelphia Museum of Art, 2009, p. 45-64.

TONE, Lilian. Bruce Nauman: circuito fechado/filmes e vídeos de Bruce Nauman, 1967-2001. Rio de Janeiro: CCBB, 2005.

TUCKER, Marcia. PheNAUMANology. Artforum 9, Nova York, n. 4, dez. 1970, p. 38-44. . LIVINGSTON, Jane. Bruce Nauman: Forks from 1965 to 1962. Nova York: Praega Publishers and Los Angeles Country Museum of Art, 1972.

VOLK, Gregory. Miles of Stare: The Bruce Nauman Carnival. In: NAUMAN, Bruce. Elusive Signs: Bruce Nauman Works with Light. Cambridge, Massachusetts: MIT Press, 2006, p. 59-79.

WAGNER, Anne. Nauman's Body of Sculpture. In: LEWALLEN, Constance M. (Org.). A Rose Has No Teeth: Bruce Nauman in the 1960s. Berkeley: University of California Press, 2007.

WITHNEY, David. Bruce Nauman. Nova York: Leo Castelli Gallery, 1968.

YAU, John. Thirteen Ways to Skin a Nauman. In: NAUMAN, Bruce. Selected Works. Nova York: Zwirner \&Wirth, 2001. 
Vídeo

BRUCE NAUMAN: MAKE ME THINK. Diretor Heinz Peter Schwerfel.

Alemanha, 1997, cor, 70 min., em inglês.

Bibliografia sobre a obra de Samuel Beckett ${ }^{1}$

ACHESON, James; ARTHUR, Kateryna (Eds). Beckett's Later Fiction and Drama:

Texts for Company. Londres: McMillan, 1987.

ADORNO, Theodor W. Trying to Understand Endgame. New German Critique, n.

26 [Critical Theory and Modernity], 1982, p. 119-150.

Notes sur Beckett. Caen: Nous, 2008.

ALPHANT, Marianne \& LÉGER, Nathalie (Orgs.). Object Beckett. Paris: Centre Pompidou/Imec Éditeur, 2007.

ANDRADE, Fábio de Souza. Samuel Beckett: o silêncio possivel. São Paulo: Ateliê Editorial, 2001.

AUSTER, Paul. De bolos a pedras. In: A arte da fome. Rio de Janeiro: José Olympio, 1996, p. 75-81.

BECKETT, Samuel. The Selected Works of Samuel Beckett [Vol. I Novels; Vol. II

Novels; Vol. III Dramatic Works; Vol. IV Poems Short Fiction Criticism]. Nova York: Grove Press, 2010.

BEGKETT, Samuel. A Samuel Beckett Reader: I can't go on, I'll go on. Nova York: Grove Press, 1976.

Como é. Tradução de Ana Helena Souza. São Paulo: 2003.

. Dias Felizes. Tradução de Fábio de Souza Andrade. São Paulo: Cosac\&Naify, 2010.

Esperando Godot. Tradução de Fábio de Souza Andrade. São Paulo:

Cosac\&Naify, 2005.

Fim de partida. Tradução de Fábio de Souza Andrade. São Paulo:

Cosac\&Naify, 2002.

. Malone Morre. Tradução de Paulo Leminski. São Paulo: Codex, 2004.

Molloy. Tradução de Ana Helena Souza. São Paulo: Globo, 2007.

Murphy. Tradução de Maria Jorge Vilar de Figueiredo. Lisboa: Assírio \&

Alvim, 2003.

1. Não se trata de uma bibliografia exaustiva

algumas aproximações entre as produções de sobre a obra do autor, mas de uma compilação de títulos que foram essenciais para traçar 
. Nohow On: Company, Ill Seen Ill Said, Worstward ho. Nova York: Grove, 1996. . O despovoador. Mal visto mal dito. Tradução de Eloísa Araújo Ribeiro. São Paulo: Martins Fontes, 2008.

. O Expulso. O Calmante. O fim. Tradução de Eloisa Araújo Ribeiro. São

Paulo: Martins Fontes, 2006.

. O inominável. Tradução de Ana Helena Souza. São Paulo: Globo, 2009.

. Primeiro amor. Tradução de Célia Euvaldo. São Paulo: Cosac\&Naify, 2004.

. Proust. Tradução de Arthur Nestrovski. São Paulo: Cosac\&Naify, 2003.

. Watt. Tradução de Manuel Resende. Lisboa: Assírio \& Alvim, 2005.

BERRETTINI, Célia. Samuel Beckett: escritor plural. São Paulo: Perspectiva, 2004. . A linguagem de Samuel Beckett. São Paulo: Perspectiva, 1977.

BORGES, Gabriela. A poética televisual de Samuel Beckett. São Paulo: Annablume, 2009.

BRATER, Enoch. Beyond Minimalism: Beckett's Late Style in the Theater. Nova York, Oxford: Oxford University Press, 1987.

The Drama in the Text: Beckett's Later Fiction. Oxford: Oxford University Press, 1994.

DELEUZE, Gilles. O maior filme irlandês (Film de Beckett). In: Crítica e clínica. São Paulo: Editora 34, 1997, p. 33-35.

O esgotado. In: Sobre o teatro. Um manifesto de menos. O esgotado. Rio de Janeiro: Jorge Zahar Ed., 2010, p. 67-111.

GONTARSKI, S. E. On Beckett: Essays and Criticism. Nova York: Grove Press, 1986.

HANSEN, João Adolfo. Eu nos faltará sempre. In: BECKETT, Samuel. O inominável [prefácio]. Tradução de Ana Helena Souza. São Paulo: Globo, 2009.

HERREN, Graley. Samuel Beckett's Plays on Film and Television. Nova York: Palgrave Macmillian, 2007.

LEMKE, Inga. Fernsehtheater - Videoperformance. Samuel Beckett und die Videokunst. In: Peter Seibert (Ed). Samuel Beckett und die Medien. Neue Perspektiven auf einen Medienkünstler des 20 Jahrhunderts. Bielefeld: Transkript, 2008.

LOGATELLI, Carla. Unwording the World: Samuel Beckett's Prose Works After the Nobel Prize. Filadélfia: University of Pennsylvania Press, 1990.

McMULlAN, Anna. Theatre on Trial: Samuel Beckett's Later Drama. Londres, Nova York: Routledge, 1993.

RAMOS, Luiz Fernando. O parto de Godot e outras encenações imaginárias. São Paulo: Hucitec/ Fapesp, 1999.

SEGRÈ, Elisabeth Bregman. Style and Structure in Beckett's "Ping": "That Something Itself". Journal of Modern Literature, vol. 6, n. 1, Samuel Beckett Special Number, Indiana University Press, fev. 1977, p. 127-147.

SOUZA, Ana Helena. A tradução como um outro original. Rio de Janeiro: 7 Letras, 2006. 
TONNING, Erik. Samuel Beckett's Abstract Drama: Works for Stage and Screen/ 1962-1985. Berna: Peter Lang, 2007.

VASCONCELLOS, Cláudia Maria de. Teatro Inferno: Samuel Beckett. São Paulo: Terracota, 2012.

\section{Bibliografia geral}

ADORNO, Theodor W. Aesthetic Theory. Londres, Nova York: Continuum, 1997.

ALBERRO, Alexander; STIMSON, Blake (Ed.). Conceptual Art: a Critical Anthology. Cambridge, Massachusetts: The MIT Press, 2000.

ARTAUD, Antonin. O Teatro e seu Duplo. São Paulo: Martins Fontes, 1999.

Linguagem e Vida. São Paulo: Perspectiva, 2006.

BATTCOGK, Gregory (Org.). Minimal Art: a Critical Anthology. Nova York: E. P. Dutton\&Co, 1968.

(Ed.). La Idea como Arte: Documentos sobre el Arte Conceptual. Barcelona: Gustavo Gilli, 1977.

BELTING, Hans. O fim da história da arte : uma revisão dez anos depois. São Paulo : Cosac Naify, 2006.

BERNSTEIN, J.M. Against Voluptuous Bodies: Late Modernism and the Meaning of Painting. Stanford: Stanford University Press, 2006.

BOIS, Yve-Alain. Painting as Model. Cambridge, Massachusetts: TheMIT Press, 1990.

Pintura, a tarefa do luto. Ars, São Paulo, v. 3, 2004, p. 96-111.

Picasso Harlequin: 1917-1937. Milão: Skira, 2009. \& KRAUSS, Rosalind. Formless. Nova York: Zone Books, 1997.

\& BUCHLOH, Benjamin; FOSTER, Hal; KRAUSS, Rosalind. Art Since 1900: Modernism, Antimodernism, Postmodernism. London/ New York: Thames \& Hudson, 2004.

BUCHLOH, Benjamin. Neo-avantgarde and Culture Industry: Essays on European and American Art from 1955 to 1975. Cambridge, Massachusetts: The MIT Press, 2000.

El arte conceptual de 1962 a 1969: de la estética de la administración a la crítica de las instituciones. In: Formalismo e historicidad. Modelos y métodos en el arte del siglo XX. Madri: Ediciones Akal, 2004, pp. 167-199.

CLARK, T. J. Modernismos: ensaios sobre politica, história e teoria da arte. São Paulo: Cosac\&Naify, 2007.

CRAFT, Gatherine. Jasper Johns. Nova York: Parkstone, 2009.

CUNNINGHAM, Merce. Changes: Notes on Choreography. Nova York: Something Else Press, 1968

DANTO, Arthur G. A transfiguração do lugar-comum. São Paulo: Cosac\&Naify, 2006. 
DAVIES, Hugh M. \& ONORATO, Ronald J. Blurring the Boundaries: Installation Art 1969-1996. San Diego: Museum of Contemporary Art, 1997.

FERGUSON, Russell (Org.). Out of Action: Between Performance and the Object 1949-1979. Londres: Thames and Hudson, 1998.

FLAM, Jack (Ed.). Robert Smithson: the Collected Writings. Los Angeles: University of California Press, 1996.

FOSTER, Hal. (Ed.). The Anti-aesthetic: Essays on Postmodern Culture. Seattle: Bay Press, 1989.

The Return of the Real: the Avant-garde at the End of the Century. Cambridge, Massachusetts: The MIT Press, 1999.

FREUD, Sigmund. Recordar, repetir e elaborar. In: FREUD, Sigmund. Edição brasileira das obras psicológicas completas de Sigmund Freud. Volume XII. Rio de Janeiro: Imago, 1996.

FRIED, Michael. Art and Objecthood. Chicago: The University of Chicago Press, 1998. .Why Photography Matters as Art as Never Before. New Haven, Londres: Yale University Press, 2009.

GERSTEIN, Alexandra (Ed.). Display and Displacement: Sculpture and the Pedestal from Renaissance to Post-Modern. Londres: Paul Holberton Publishing, 2007.

GIEDON-WELCKER, Carola. Contemporary Sculpture. Londres: Faber\&Faber, 1961.

GREENBERG, Clement. A escultura moderna e seu passado pictórico. In: Arte e Cultura: ensaios críticos. São Paulo: Ática, 1996.

HARRISON, Charles. Essays on Art E Language. Oxford: Blackwell, 1991.

. Modernidade e modernismo reconsiderados. In: WOOD, Paul et al.

Modernismo em disputa. São Paulo: Cosac \& Naify, 1998. p. 170-259.

.WOOD, Paul (Eds.). Art in Theory 1900-2000: an Anthology of Changing Ideas. Oxford/Malden: Blackwell, 2002.

JUDD, Donald. Complete Writings: 1975-1986. Eindhovem: van Abbemuseum, 1987.

KAPROW, Allan \& KELLEY, Jeff (Eds.) Essays on the Blurring of Art and Life. Los Angeles: University of California Press, 1993.

KRAUSS, Rosalind. LeWitt in Progress. October Magazine, Cambridge/ Massachusetts, n. 06, 1978, p. 46-60. . A escultura no campo ampliado. Gávea, Rio de Janeiro, n 1, 1985.

. The Originality of the Avant-garde and Other Modernist Myths. Cambridge/

Londres: The MIT Press, 1996. Caminhos da escultura moderna. São Paulo: Martins Fontes, 1998.

. A Voyage on the North Sea/Art in the Age of the Post-Medium Condition. Nova York: Thames \& Houdson, 1999.

\& BOIS, Yve-Alain. A User's Guide to Entropy. October Magazine, Cambridge/ Massachusetts, n. 78, 1996, p. 38-88. 
LANGER, Susanne K. Filosofia em nova chave. São Paulo: Perspectiva, 2004.

LAPLANGHE, J. \& PONTALIS, J.-B. Vocabulário de psicanálise. São Paulo: Martins Fontes, 1983.

LIPPARD, Lucy. Six years: The Dematerialization of the Art Object from 1966 to 1972. Nova York: Studio Vista, 1973.

MARTIN, Jean-Hubert (Org.). Man Ray Photographs. Nova York: Thames and Hudson, 1991.

MAMMİ, Lorenzo. O que resta. São Paulo: Companhia das Letras, 2013.

MAUSS, Marcel. As técnicas do corpo. In: Sociologia e Antropologia. São Paulo: Cosac \& Naify, 2003.

McEVILLEY, Thomas. Sculpture in the Age of Doubt. Nova York: Allworth Press, 1999.

MEYER, James. Minimalism: Art and Polemics in the Sixties. New Haven: Yale University Press, 2001.

MORGAN, Robert G. Del arte a la idea. Ensayos sobre arte conceptual. Madrid: Akal, 2003.

MORRIS, Robert. Continuous Project Altered Daily: The Writings of Rober Morris. Cambridge: MIT Press, 1993.

The Mind/Body Problem. Nova York: Salomon R. Guggenheim Museum, 1994.

NAVES, Rodrigo. O Vento e o Moinho. São Paulo: Cia das Letras, 2007.

OITICICA, Hélio. Aspiro ao grande labirinto. Rio de Janeiro: Editora Rocco, 1986.

OSBORNE, Peter. Conceptual art. Londres: Phaidon, 2002.

RAMIREZ, Mari Carmen \& OLEA, Hector. Inverted Utopias: Avant-garde Art in Latin America. New Heaven: Yale University Press, 2004.

Tácticas para vivir de sentido: caracter precursor del conceptualismo en America Latina. In: Heterotopías: medio siglo sin-lugar, 1918-1968. Madri: Museo Nacional Centro de Arte Reina Sofía, 2000.

RAMOS, Nuno. Ensaio geral: projetos, roteiros, ensaios, memórias. São Paulo: Globo, 2007.

RORIMER, Anne. New Art in the 60s and 70s: Redefining Reality. Londres: Thames \& Hudson, 2001.

ROSENBERG, Harold. Objeto ansioso. São Paulo: Cosac\&Naify, 2004.

ROWELL, Margit (Org.). Qu'est-ce que la sculpture moderne? Paris: Éditions du Centre Pompidou, 1986.

SALZSTEIN, Sônia. A questão moderna/impasses e perspectivas na arte brasileira, 1910 a 1950. 2000. 233 f. Tese (Doutorado em Filosofia)-- Faculdade de Filosofia, Letras e Ciências Humanas da USP, São Paulo, 2000.

Arquitetura das passagens. In: Iole de Freitas. Rio de Janeiro: Centro Gultural Banco do Brasil, 2005. 
SERRA, Richard. Writings, Interviews. Chicago: The University of Chicago Press, 1994.

The Matter of Time. Bilbao: Steidl Publishers, 2005.

SMITHSON, Robert. The Writings of Robert Smithson. Nova York: Nova York University Press, 1979.

SONFIST, Alan (Ed.). Art in the Land: a Critical Anthology of Environmental Art. Nova York: E. P. Dutton\&Go, 1983.

STEINBERG, Leo. The Philosophical Brothel. October Magazine 44, Cambridge,

Massachusetts, 1988, p. 7-74.

. O fim de partida de Picasso. Ars n. 9, São Paulo, 2007, p. 24-35.

. Outros critérios: confronto com a arte do século XX. São Paulo: Cosac Naify, 2008.

SZONDI, Peter. Teoria do drama moderno (1880-1950). São Paulo: Cosac \& Naify, 2001.

SUDERBURG, Érika (Ed.). Space, Site, Intervention: Situating Installation Art. Minneapolis: University of Minnesota Press, EUA, 2000.

TUCKER, William. A linguagem da escultura. São Paulo: Cosac \& Naify, 1999.

WEISS, Jeffrey. Jasper Johns: an Allegory of Painting 1955-1965. New Haven, Londres: Yale University Press, 2007.

WITTGENSTEIN, Ludwig. Tratado Lógico-Filosófico. Investigações Filosóficas. Lisboa: Fundação Galouste Gulbenkian, 1995.

WOOD, Paul. Arte Conceitual. São Paulo: Cosac \& Naify, 2002. . \& PERRY, Gill. (Eds.). Themes in Contemporary Art. New Haven: Yale University Press/Londres: Open University, 2004. 

Apêndice 
Codification

You May Not Want To Be Here

Get Out of My Mind, Get Out of This Room

Untitled [1]

Untitled [2]

Untitled [3]

Untitled and Amplified Tree Piece

Notes and Projects

Microphone/Tree Piece

Left or Standing, Standing or Left Standing

Appendix

Floating Room

Double Doors - Projection and Displacement

Flayed Earth/ Flayed Self (Skin/Sink)

Instructions for a Mental Exercise

Cones Cojones

Body Pressure

The Consummate Mask of Rock

False Silence

100 Live and Die

Good Boy Bad Boy

Violent Incident

Pete and Repeat

Dark and Stormy Night

No no no no

Shit In Your Hat - Head On A Chair

OK OK OK

Anthro/ Socio

Thank You Thank You

Think Think Think

Work Work

World Peace

A Thousand Words: Bruce Nauman

Talks about Mapping the Studio 


\section{Codificação}

Você pode não querer estar aqui

Saia da minha mente, saia desta sala.

Sem título [1]

Sem título [2]

Sem título [3]

Sem título e Peça árvore amplificada

Notas e projetos

Peça Microfone/árvore

Deixado ou Em pé, Em pé ou Deixado em pé

Apêndice

Recinto flutuante

Portas duplas - Projeção e deslocamento

Terra esfolada/ Eu esfolado (Pele/ Afundar)

Instruções para um exercício mental

Cones Cojones

Pressão corporal

A máscara consumada de pedra

Silêncio Falso

100 Viva e Morra e 100 Viver e Morrer

Bom menino mau menino

Incidente violento

Pita e Repita

Noite escura e tempestuosa

Não não não não

Cague em seu chapéu - Cabeça numa cadeira

OK OK OK

Antro/ Sócio

Obrigado Obrigado

Pense Pense Pense

Trabalhe Trabalhe

Paz mundial

Mil palavras: Bruce Nauman

fala sobre Mapping the Studio 
Codification, $1966^{1}$

Codificação 
1. Personal appearance and skin

2. Gestures

3. Ordinary actions such as those concerned with eating and drinking

4. Traces of activity such as footprints and material objects

5. Simple sounds-spoken and written words

Metacommunication messages

Feedback

Analogic and digital codification 
1. Aparência pessoal e pele

2. Gestos

3. Ações comuns tais como aquelas relacionadas ao comer e ao beber

4. Vestígios de atividades tais como pegadas e objetos materiais

5. Sons simples-palavras faladas e escritas

Mensagens de metacomunicação

Retroalimentação

Codificação analógica e digital 
1. 0 original já não existe e as reproduções subsequentes deste texto se basearam na transcrição de Marcia Tucker para o ensaio do catálogo Bruce Nauman: Work from 1965 to 1972, publicado em 1972. Cf. KRAYNAK, Janet (Ed.). Please Pay Attention Please: Bruce Nauman's words: writings and interviews. Cambridge, Massachusetts: The MIT Press, 2005, p. 49. 
You May Not Want To Be Here, $1968^{2}$

Você pode não querer estar aqui 
You may not want to be here

You may not want to be

You want to be here

You want to be

You may want to be

You may not want to be

You may not want

You may want

You may be

You may not be

You may not be here

You may be here

You may not want to hear

You may want to hear

You want to hear

You may not hear

You may hear

You hear 
Você pode não querer estar aqui

Você pode não querer estar/ser

Você quer estar aqui

Você quer ser/estar

Você pode querer ser/estar

Você pode não querer ser/estar

Você pode não querer

Você pode querer

Você pode ser/estar

Você pode não ser/estar

Você pode não estar aqui

Você pode estar aqui

Você pode não querer ouvir

Você pode querer ouvir

Você quer ouvir

Você pode não ouvir

Você pode ouvir

Você ouve 
2.Este texto foi extraído de First Poem Piece [Peça Primeiro Poema (1968)], uma escultura de chão feita em metal, em cuja face superior o poema foi esquematicamente inscrito em dezoito linhas horizontais e sete colunas. Cf. NAUMAN, Bruce. Bruce Nauman: Raw Materials. Londres: Tate Press, 2004, p. 29. 
Get Out of My Mind, Get Out of This Room, $1968^{3}$

Saia da minha mente, saia desta sala 
Get out of my mind, get out of this room Get out of my mind, get out of this room Get out of my mind, get out of this room Get out of my mind, get out of this room Get out of my mind, get out of this room Get out of my mind, get out of this room Get out of my mind, get out of this room Get out of my mind, get out of this room Get out of my mind, get out of this room Get out of my mind, get out of this room Get out of my mind, get out of this room Get out of my mind, get out of this room Get out of my mind, get out of this room Get out of my mind, get out of this room Get out of my mind, get out of this room Get out of my mind, get out of this room Get out of my mind, get out of this room Get out of my mind, get out of this room Get out of my mind, get out of this room Get out of my mind, get out of this room Get out of my mind, get out of this room Get out of my mind, get out of this room Get out of my mind, get out of this room Get out of my mind, get out of this room Get out of my mind, get out of this room Get out of my mind, get out of this room Get out of my mind, get out of this room Get out of my mind, get out of this room Get out of my mind, get out of this room Get out of my mind, get out of this room Get out of my mind, get out of this room Get out of my mind, get out of this room Get out of my mind, get out of this room Get out of my mind, get out of this room Get out of my mind, get out of this room Get out of my mind, get out of this room Get out of my mind, get out of this room Get out of my mind, get out of this room Get out of my mind, get out of this room 
Saia da minha mente, saia desta sala Saia da minha mente, saia desta sala Saia da minha mente, saia desta sala Saia da minha mente, saia desta sala Saia da minha mente, saia desta sala Saia da minha mente, saia desta sala Saia da minha mente, saia desta sala Saia da minha mente, saia desta sala Saia da minha mente, saia desta sala Saia da minha mente, saia desta sala Saia da minha mente, saia desta sala Saia da minha mente, saia desta sala Saia da minha mente, saia desta sala Saia da minha mente, saia desta sala Saia da minha mente, saia desta sala Saia da minha mente, saia desta sala Saia da minha mente, saia desta sala Saia da minha mente, saia desta sala Saia da minha mente, saia desta sala Saia da minha mente, saia desta sala Saia da minha mente, saia desta sala Saia da minha mente, saia desta sala Saia da minha mente, saia desta sala Saia da minha mente, saia desta sala Saia da minha mente, saia desta sala Saia da minha mente, saia desta sala Saia da minha mente, saia desta sala Saia da minha mente, saia desta sala Saia da minha mente, saia desta sala Saia da minha mente, saia desta sala Saia da minha mente, saia desta sala Saia da minha mente, saia desta sala Saia da minha mente, saia desta sala Saia da minha mente, saia desta sala Saia da minha mente, saia desta sala Saia da minha mente, saia desta sala Saia da minha mente, saia desta sala Saia da minha mente, saia desta sala Saia da minha mente, saia desta sala 
3. Texto de instalação homônima realizada em 1968, um recinto vazio no qual dois alto-falantes embutidos nas paredes reproduziam incessantemente a frase-título em diferentes entonações. Cf. NAUMAN, Bruce. Bruce Nauman: Raw Materials. Londres: Tate Press, 2004, p. 45. 
Untitled, 19694

Sem título 
Leave the Land Alone. 
Deixem a terra em paz. 
4. Este pequeno texto foi enviado a uma mostra de Earth Art. A frase-título foi concebida para ser escrita no céu, com a fumaça de aviões de acrobacia. A proposta só foi realizada em 2009, no céu da cidade de Pasadena, na Califórnia. Cf. KRAYNAK, Janet (Ed.). Op. cit., p. 52. 
Untitled, $1969^{5}$

Sem título 
Hire a dancer and have him phone me from the museum. (Female dancer is satisfactory).

The dancer is to carry out or perfom the following instructions: the dancer should stand with his arms held straight like a T, with his legs crossed. He should hold the telephone between his legs. He should then jump up and down following the cadence I give him, for as long as he can until becoming tired.

For the exhibition, the tape is to be played back on a fairly large sreen monitor placed in about the same location as the conversation takes place.

(Probably an office or a phone booth.) 
Contrate um bailarino e faça com que ele me telefone do museu.

(Bailarina é satisfatório).

O bailarino deverá realizar ou desempenhar as seguintes instruções: o bailarino deverá ficar em pé e sustentar os braços esticados em forma de $\mathrm{T}$, com as pernas cruzadas. Ele deverá segurar o telefone entre suas pernas. Ele deverá, então, pular para cima e para baixo seguindo a cadência que eu lhe der, por quanto tempo puder até ficar cansado.

Para a exposição, a fita deve ser reproduzida em um monitor razoavelmente grande colocado no mesmo local, aproximadamente, em que a conversa acontece.

(Provavelmente um escritório ou uma cabine telefônica.) 
5. Proposta escrita para integrar a mostra "Art by Telephone", ocorrida no Museu de Arte Contemporânea de Chicago, entre $1^{\circ}$ de novembro e 14 de dezembro de 1969. As instruções foram gravadas em áudio e o catálogo da exposição consistiu em um LP contendo as descrições das performances de todos os artistas participantes. Cf. KRAYNAK, Janet (Ed.). Op. cit., p. 51. 
Untitled, $1969^{6}$

Sem título 
A person enters and lives in a room for a long time-a period of years or a lifetime.

One wall of the room mirrors the room but from the opposite side: that is, the image room has the same left-right orientation as the real room.

Standing facing the image, one sees oneself from the back in the room, standing facing a wall.

There should be no progression of images: that can be controlled by adjusting the kind of information the sensor would use and the kind the mirror wall would put out.

After a period of time, the time in the mirror room begins to fall behind the real time-until after a number of years, the person would no longer recognize his relationship to his mirrored image. (He would no longer relate to his mirrored image or a delay of his own time.) 
Uma pessoa entra e vive em um recinto por um longo período - por anos ou por toda uma vida.

Uma das paredes do recinto espelha o recinto, mas a partir do lado oposto: isto é, o recinto na imagem tem a mesma orientação espacial esquerda-direita que o recinto real.

Em pé e de frente para a imagem, alguém vê a si mesmo pelas costas no recinto, em pé e de frente para uma parede.

Não deve haver progressão de imagens: isso pode ser controlado ajustando-se o tipo de informação que o sensor utilizaria, e o tipo [de informação] produzido pela parede-espelho.

Depois de um período de tempo, o tempo no recinto no espelho começa a atrasar em relação ao tempo real - até que, depois de alguns anos, a pessoa não mais reconheceria sua relação com sua imagem espelhada. (Ele não mais se relacionaria com sua imagem espelhada ou com seu próprio tempo em atraso). 
6. Texto para uma performance impossível e que "está relacionada a um sonho que ele [Bruce Nauman] teve há muito tempo e que só poderia ser finalmente realizada com o auxílio de uma vasta rede de computadores", conforme informou Marcia Tucker no ensaio "PheNAUMANology", publicado na revista Artforum 9, em 1970. Cf. KRAYNAK, Janet (Ed.). Op. cit., p. 55. 
Untitled, 1969 and Amplified Tree Piece, 19707

Sem título e Peça árvore amplificada 
Sept. 69

Drill a hole about a mile into the earth and drop a microphone to within a few feet of the bottom. Mount the amplifier and speaker in a very large empty room and ajust the volume to make audible any sounds that may come from the cavity.

March 2, 70

Drill a hole into the heart of a large tree and insert a microphone. Seal the hole with cement.

Mount the amplifier and speaker in an empty room and adjust the volume to make audible any sounds that might come from the tree. 
Setembro de 1969

Faça um buraco de cerca de uma milha terra adentro e baixe um microfone até que esteja a poucos pés do fundo. Monte o amplificador e o alto-falante em um recinto vazio e muito grande e ajuste o volume para tornar audíveis quaisquer sons que possam vir da cavidade.

2 de Março de 1970

Faça um buraco no cerne de uma grande árvore e insira um microfone. Vede o buraco com cimento.

Monte o amplificador e o alto-falante em um recinto vazio e ajuste o volume para tornar audíveis quaisquer sons que possam vir da árvore. 
7. Os dois textos foram enviados para a mostra "Art in the Mind", realizada em 1970, que consistiu somente do catálogo com as propostas dos artistas convidados. Cf. KRAYNAK Janet (Ed.). Op. cit., p. 50. 
Notes and Projects, $1970^{8}$

Notas e projetos 
It has been shown that at least part of the information received by the optical nerves is routed through and affected by memory before it reaches the part of the brain that deals with visual impulses (input). Now René Dubos discusses the distortion of stimuli: we tend to symbolize stimuli and then react to the symbol rather than directly to the stimuli. Assume this to be true of other senses as well...

\section{FRENCH PIECE (August, 1968)}

1. Piece of steel plate or bar four inches by four inches by seven feet, to be gold plated, and stamped or engraved with the word "guilt" in a simple type face about one or two centimeters high. The weight will be about three hundred eighty pounds.

2. If the bar cannot be plated, the plain steel bar should be stamped or engraved "guilt bar", the letters running parallel to and close to a long edge.

3. Both pieces may be made.

lighted steel channel twice leen lech ${ }^{9}$ Dante's delight light leen snatches light leen lech Dante's delight leen snatches leen lech'l delight Dantes light leen snatch ${ }^{10}$ light leen snatch'l delight Dantes leen leech light leen leech'l delight Dantes leen snatch snatch leen leen leeche'l delight light Dante 
Foi demonstrado que ao menos uma parte das informações recebidas pelos nervos óticos passa pela memória e é por ela afetada antes de atingir a parte do cérebro que lida com impulsos visuais (entrada). Agora René Dubos discute a distorção de estímulos: tendemos a simbolizar estímulos e então reagir ao símbolo, em vez de [reagirmos] diretamente aos estímulos. Suponha que isto seja verdadeiro para outros sentidos também...

\section{PEÇA FRANCESA (Agosto,1968)}

1. Um pedaço de chapa ou barra de aço de quatro polegadas por quatro polegadas por sete pés, a ser banhado a ouro e carimbado ou gravado com a palavra "culpa" em tipografia simples de cerca de um ou dois centímetros de altura. $O$ peso será de cerca de 380 libras.

2. Se a barra não puder ser banhada, a barra de aço simples deverá ter "barra de culpa" carimbado ou gravado [em sua superfície], as letras posicionadas paralelamente a uma das bordas longas, próximas à mesma.

\section{Ambas as peças podem ser feitas.}

canal de aço iluminado duas vezes o deleite do magro e devasso Dante: rachas leves e magras o deleite do leve magro e devasso Dante: rachas magras magro depravado deleitará a racha leve e magra de Dante leve e magra racha deleitará a magra sanguessuga de Dante leve e magra sanguessuga irá deleitar a racha magra de Dante racha, magra magra sanguessuga, deleitará o leve Dante 
When I want to make a painting of something covered with dust or in fog should I paint the whole surface first with dust or fog and then pick out those parts of objects which can be seen or first paint in all the objects and then paint over them the dust or fog?

Hire a dancer or dancers or other performers of some presence to perform the following exercises for one hour a day for about ten days or two weeks. The minimum will require one dancer to work on one exercise for ten to fourteen days. If more money is available two dancers may perform, one dancer performing each exercise at the same time and for the same period as the other. The whole may be repeated on ten or fourteen day intervals as often as desired.

(A) Body as a Cylinder

Lie along the wall-floor junction of the room, face into the corner and hands at sides. Concentrate on straightening and lengthening the body along a line which passes through the center of the body parallel to the corner of the room in which you lie. At the same time attempt to draw the body in around the line. Then attempt to push that line into the corner of the room.

(B) Body as a Sphere

Curl your body into the corner of a room. Imagine a point at the center of your curled body and concentrate on pulling your body in around that point. Then attempt to press that point down into the corner of the room. It should be clear that these are not intended as static positions which are to be held for an hour a day, but mental and physical activities or processes to be carried out. At the start, the performer may need to repeat the exercise several times in order to fill the hour, but at the end of ten days or so, he should be able to extend the execution to a full hour. The number of days required for an uninterrupted hour performance of course depends on the receptivity and training of the performer. 
Quando eu quero fazer uma pintura de algo coberto com poeira ou na névoa, devo pintar primeiro toda a superfície com a poeira ou névoa e então escolher aquelas partes dos objetos que podem ser vistas, ou primeiro pintar todos os objetos e depois pintar sobre eles a poeira ou neblina?

Contrate um bailarino ou bailarinos ou outros performers com alguma presença para executar os seguintes exercícios por uma hora a cada dia por cerca de dez dias ou duas semanas. O mínimo exigirá que um bailarino dedique-se a um exercício por entre dez e quatorze dias. Se mais dinheiro estiver disponível dois bailarinos poderão desempenhar, um bailarino executando cada exercício simultaneamente ao outro, e pela mesma duração de tempo. O todo deve ser repetido em intervalos de dez ou quatorze dias tão frequentemente quanto se desejar.

\section{(A) Corpo como um cilindro}

Deite-se junto à junção da parede com o chão de um recinto, com o rosto para o canto e as mãos ao lado. Concentre-se no endireitamento e na expansão do corpo ao longo de uma linha que passa pelo centro do corpo paralelamente ao canto do recinto em que você se encontra. Ao mesmo tempo tente trazer o corpo em direção ao entorno dessa linha. Em seguida tente empurrar essa linha em direção ao canto do recinto.

(B) Corpo como uma esfera

Enrole seu corpo no canto de um recinto. Imagine um ponto no centro de seu corpo enrolado e concentre-se em tracionar seu corpo em torno desse ponto. Em seguida tente pressionar esse ponto para baixo no canto do recinto. Deve-se esclarecer que não se intenciona que essas sejam posições estáticas a serem mantidas por uma hora por dia, mas atividades ou processos mentais e físicos a serem realizados. No início, o performer pode precisar repetir o exercício várias vezes a fim de preencher a hora, mas ao fim de cerca de dez dias, ele deverá ser capaz de estender a execução a uma hora inteira. O número de dias necessários para uma performance ininterrupta de uma hora depende, naturalmente, da receptividade e da preparação do performer. 


\section{Goedel's Proof}

1931: “On Formally Undecidable Propositions of Principia Mathematica and Related Systems." 1) If a system is consistent then it is incomplete. 2) (Goedel's incompleteness theorum [sic/ theorem]) implies impossibility of construction of calculating machine equivalent to a human brain.

\section{Film Set A: Spinning Sphere}

A steel ball placed on a glass plate in a white cube of space. The ball is set to spinning and filmed so that the image reflected on the surface of the ball has one wall of the cube centered. The ball is center frame and fills most of the frame. The camera is hidden as much as possible so that its reflection will be negligible. Four prints are necessary. The prints are projected onto the walls of a room (front or rear projection; should cover the walls edge to edge.) The image reflected in the spinning sphere should not be that of the real room but of a more idealized room, of course empty, and not reflecting the image projected on the other room walls. There will be no scale references in the films.

\section{Film Set B: Rotating Glass Walls}

Film a piece of glass as follows: glass plate is pivoted on a horizontal center line and rotated slowly. Film is framed with the center line exactly at the top of the frame so that as the glass rotates one edge will go off the top of the frame as the other edge comes on the top edge of the frame. The sides of the glass will not be in the frame of the film. Want two prints of the glass rotating bottom coming toward the camera and two prints of bottom of plate going away from camera. The plate and pivot are set up in white cube as in Set A, camera hidden as well as possible to destroy any scale indications in the projected films. Projection: image is projected from edge to edge of all four walls of a room. If the image on one wall shows the bottom of the plate moving toward the camera, the opposite wall will show the image moving away from the camera. 


\section{Prova de Goedel}

1931: "Das Proposições Formalmente Indecidíveis dos Principia

Mathematica e Sistemas Relacionados." 1) Se um sistema for consistente, então será incompleto. 2) (O Teorema da Incompletude de Goedel) implica a impossibilidade de se construir uma máquina de calcular equivalente a um cérebro humano.

\section{Conjunto Cinematográfico A: Esfera giratória}

Uma bola de aço colocada sobre uma placa de vidro em um espaço cúbico branco. A bola é colocada em movimento giratório e filmada de forma que a imagem refletida na superfície da bola tenha uma das faces do cubo em seu centro. A bola está no centro do quadro, e preenche a maior parte dele. A câmara fica, na medida do possível, escondida, para que o seu reflexo seja insignificante. Serão necessárias quatro cópias. As cópias são projetadas nas paredes de um recinto (projeção frontal ou retroprojeção; deverão cobrir as paredes de uma ponta à outra). A imagem refletida na esfera giratória não deverá ser a do recinto real, mas a de um recinto mais idealizado, vazio, naturalmente, e sem refletir a imagem projetada nas outras parades do recinto. Não haverá referências de escala nos filmes.

\section{Conjunto Cinematográfico B: Paredes de vidro giratório}

Filme um pedaço de vidro como se segue: placa de vidro é articulada sobre um eixo horizontal e rotacionada lentamente. Filme é enquadrado com a linha central exatamente na parte superior do quadro de modo que à medida que o vidro roda uma borda sairá do topo do quadro enquanto a outra borda adentra o topo do quadro. Os lados do vidro não estarão enquadrados no filme. Quero duas cópias da borda inferior do vidro rotativo vindo em direção à câmera, e duas cópias da borda inferior da placa se afastando da câmera. A placa e o eixo estão dispostos no cubo branco como no Conjunto A, a câmera escondida tão bem quanto possível para destruir quaisquer indicações de escala nos filmes projetados. Projeção: a imagem é projetada de ponta a ponta nas quatro paredes de um recinto. Se a imagem projetada sobre uma parede mostrar a borda inferior da placa movendo-se em direção à câmera, a parede oposta irá mostrar a imagem se afastando da câmera. 


\section{DANCE PIECE}

You must hire a dancer to perform the following exercise each day of the exhibition for 20 minutes or 40 minutes at about the same time each day. The dancer, dressed in simple street or exercise clothes, will enter a large room of the gallery. The guards will clear the room, only allowing people to observe through the doors. Dancer, eyes front, avoiding audience contact, hands clasped behind his neck, elbows forward, walks about the room in a slight crouch, as though the celling were 6 inches or a foot lower than his normal height, placing one foot in front of the other, heel touching toe, very slowly and deliberately.

It is necessary to have a dancer or person of some professional anonymous presence.

At the end of the time period, the dancer leaves and the guards again allow people into the room.

If it is not possible to finance a dancer for the whole of the exhibition period a week will be satisfactory, but no less.

My five pages of the book will be publicity photographs of the dancer hired to do my piece, with his name affixed.

Manipulation of information that has to do with how we perceive rather than what.

Manipulation of functional (functioning) mechanism of an (organism) (system) person.

Lack of information input (sensory deprivation) = breakdown of responsive systems. Do you hallucinate under these circumstances? If so, is it an attempt to complete a drive (or instinct) (or mechanism)?

Pieces of information which are in "skew" rather than clearly contradictory, i.e., kinds of information which come from and go to unrelated response mechanism. Skew lines can be very close or far apart. (Skew lines never meet and are never parallel. How close seems of more interest than how far apart. How far apart = Surrealism? 


\section{PEÇA DE DANÇA}

Deve-se contratar um bailarino para executar o seguinte exercício a cada dia da exposição por 20 minutos ou 40 minutos, aproximadamente no mesmo horário todos os dias. O bailarino, vestido com roupas simples do dia a dia ou com roupas de ginástica, entrará em uma sala grande na galeria. Os guardas irão esvaziar a sala, permitindo apenas que as pessoas observem das portas. O bailarino, olhos à frente, evitando contato com o público, as mãos cruzadas atrás do pescoço, cotovelos para a frente, anda pela sala em um agachamento leve, como se o teto fosse 6 polegadas ou um pé mais baixo que sua altura normal, colocando um pé na frente do outro, o calcanhar [de um pé] tocando o dedão [do outro pé], lenta e deliberadamente.

É necessário ter um bailarino ou pessoa de alguma presença profissional anônima.

Ao fim do período de tempo, o bailarino sai e os guardas novamente permitem que as pessoas adentrem o recinto.

Se não for possível financiar um bailarino para a totalidade do período da exposição, uma semana será satisfatório, mas não menos.

Minhas cinco páginas do livro serão fotografias de publicidade do bailarino contratado para executar minha peça, com seu nome afixado.

Manipulação da informação que tenha a ver com como percebemos, e não com o que [percebemos].

Manipulação do mecanismo funcional (em funcionamento) de um (organismo) (sistema) pessoa.

Falta de entrada de informações (privação sensorial) = colapso de sistemas responsivos. Você alucina sob tais circunstâncias? Se assim for, é uma tentativa de tornar plena uma pulsão (ou instinto) (ou mecanismo)?

Informações que estejam "enviesadas uma em relação à outra", em vez de claramente contraditórias, isto é, tipos de informação que vêm de e vão para mecanismos de resposta não relacionados. Linhas enviesadas podem estar muito próximas ou separadas. (Linhas enviesadas nunca se encontram e não são nunca paralelas. O quão próximas [estão] parece [ser algo] de maior interesse do que o quão separadas [estão]. O quão separadas = Surrealismo? 
Withdrawal as an Art Form

activities

phenomena

Sensory Manipulation

amplification

deprivation

Sensory Overload (Fatigue)

Denial or confusion of a Gestalt invocation of physiological defense mechanism (voluntary or involuntary). Examination of physical and physiological response to simple or even over-simplified situations which can yield clearly experienceable phenomena (phenomena and experience are the same or undifferentiable).

Recording Phenomena

Presentation of recordings of phenomena as opposed to stimulation of phenomena.

Manipulation or observation of self in extreme or controlled situations.

- Observation of manipulations.

- Manipulations of observations.

- Information gathering.

- Information dispersal (or display). 
Privação como uma forma de arte

atividades

fenômenos

Manipulação sensorial

amplificação

privação

Sobrecarga sensorial (fadiga)

Negação ou confusão de uma invocação da Gestalt de mecanismo de defesa fisiológica (voluntária ou involuntária). Exame de resposta física e fisiológica a situações simples ou até sobre-simplificadas que podem produzir fenômenos claramente experenciáveis (fenômenos e experiência são o mesmo ou indiferenciáveis).

Registrando Fenômenos

Apresentação de gravações de fenômenos no lugar de estimular fenômenos.

Manipulação ou observação de si em situações extremas ou controladas.

- Observação de manipulações.

- Manipulações de observações.

- Coleta de informações.

- Dispersão (ou exibição) de informação. 
8. Este conjunto de notas, instruções e observações foi publicado na Artforum, vol. 9 , n. 4, em dezembro de 1970, p. 44-45. Cf. KRAYNAK, Janet (Ed.). Op. cit., p. 56-60.

9. “Leen” não é uma palavra dicionarizada no inglês, e é provável corruptela do termo homófono "lean" (magro, esguio). "Lech" é gíria empregada em sentido pejorativo que advém da palavra "lecher" (indivíduo promíscuo, depravado, devasso), isto é, alguém profunda e habitualmente envolvido com "lechery" (promiscuidade, devassidão).

10. Conforme esclarecimentos de Bruce Nauman, "Leen snatch" é um anagrama de "Steel channel" (Cf. KRAYNAK, Janet. Op. cit., p. 126). O verbo "to snatch" significa agarrar (algo) subitamente; substantivado, o termo "snatch" é gíria chula para o órgão sexual feminino. Assim, "Leen/lean snatch" foi aqui traduzido como "racha magra". 
Microphone/Tree Piece, $1971^{11}$

Peça Microfone/árvore 
Select a large solid tree away from loud noises.

Wrap the microphone in a layer of $1 / 4$ or $1 / 8$ inch foam rubber and seal it in a plastic sack.

Drill a hole of large enough diameter to accept the encased microphone to the center of the tree at a (convenient) height, and slip the microphone to within an inch of the end of the hole.

Plug the hole with cement or other waterproof sealant.

Extend the microphone wire inside to the pre-amp, amp, and speaker system. 
Selecione uma árvore grande e sólida distante de ruídos altos.

Envolva o microfone em uma camada de $1 / 4$ ou 1/8 de polegada de espuma de borracha e vede-o em um saco plástico.

Perfure um buraco de diâmetro suficientemente grande para conter o microfone revestido até o centro da árvore a uma altura (conveniente), e deslize o microfone até que esteja a uma polegada do fim do buraco.

Tape o buraco com cimento ou outro selante impermeável.

Estenda o fio do microfone que está ali dentro até o pré-amplificador, o amplificador e o sistema de alto-falantes. 
11. Este texto deriva de Amplified Tree Piece, de 1969. A proposta foi realizada em Los Angeles, na casa de colecionador particular. Cf. KRAYNAK, Janet (Ed.). Op. cit., p. 61. 
Left or Standing, Standing or Left Standing, $1971^{12}$

Deixado ou Em pé, Em pé ou Deixado em pé 


\section{Left or Standing}

His precision and accuracy

suggesting clean cuts, leaving

a vacancy, a slight physical

depression as though I had been

in a vaguely uncomfortable place

for a not long but undeterminable

period; not waiting. 


\section{Deixado ou Em pé}

Sua precisão e exatidão

sugerindo cortes limpos, deixando

uma vacância, uma leve depressão

física como se eu estivera

em um lugar vagamente desconfortável

por um período não muito longo mas

indeterminável; não esperando. 


\section{Standing or Left Standing}

His preciseness and acuity left small cuts on the tips of my fingers or across the backs of my hands without any need to sit or otherwise withdraw. 


\section{Em pé ou Deixado em pé}

Sua precisão e acuidade deixaram

pequenos cortes nas pontas dos meus

dedos ou sobre as costas das

minhas mãos, sem qualquer necessidade de

sentar-se, ou de retirar-se de qualquer outro modo. 
12. Texto originalmente publicado na forma de convite e de pôster destacável, acompanhava Installation with Yellow Lights, trabalho exibido na galeria de Leo Castelli, em Nova York, em 1971. Cf. KRAYNAK, Janet (Ed.). Op. cit., p. 62-63. Ver também BRUGGEN, Coosje van. Bruce Nauman. Nova York: Rizzoli International Publications, 1988, p. 198-199. 
Appendix, $1972^{13}$

Apêndice 
APPENDIX

LACK OF INFORMATION INPUT

(SENSORY DEPRIVATION) $\rightarrow$ BREAKDOWN

OF RESPONSIVE SYSTEMS.

PROVISION OF INFORMATION WHICH IS SKEW

RATHER THAN CLEARLY REINFORCED OR CON-

TRADICTORY $\rightarrow$

2 KINDS OF INFORMATION EACH OR WHICH TO

UNRELATED RESPONSE MECHANISM.

(SKEW LINES NEVER MEET AND ARE NOT

PARALLEL IN SPACE - BUT THEY CAN BE VERY

CLOSE TOGETHER OR VERY FAR APART).

WITHDRAWAL AS AN ART FORM?

SENSORY MANIPULATION

(AMPLIFICATION)

(DEPRIVATION)

SENSORY OVERLOAD (FATIGUE) DENIAL OR

CONFUSION OF GESTALT (VOLUNTARY - INVO-

LUNTARY)

INVOCATION OF PHYSIOLOGICAL

DEFENSE MECH.

EXAMINATION OF PHYSICAL AND PHYSIOLOGICAL RESPONSES TO SIMPLE OR EVEN OVERSIMPLIFIED

SITUATIONS WHICH CAN YIELD CLEARLY

EXPERIENCIABLE PHENOMENA.

$\rightarrow$ PHENOMENA + EXPERIENCE ARE

UNDIFFERENTIABILITY 


\section{APÊNDICE}

FALTA DE ENTRADA DE INFORMAÇÃO

(PRIVAÇÃO SENSORIAL) $\rightarrow$ COLAPSO

DE SISTEMAS RESPONSIVOS.

FORNECIMENTO DE INFORMAÇÃO QUE É ENVIESADA

EM VEZ DE CLARAMENTE REFORÇADA OU

CONTRADITÓRIA $\rightarrow$

2 TIPOS DE INFORMAÇÃO CADA OU QUAL A UM

MECANISMO DE RESPOSTA NÃO RELACIONADO.

(LINHAS ENVIESADAS NUNCA SE ENCONTRAM E NÃO SÃO

PARALELAS NO ESPAÇO - MAS PODEM ESTAR MUITO

PRÓXIMAS OU MUITO DISTANTES).

ABSTINÊNCIA COMO FORMA DE ARTE?

MANIPULAÇÃO SENSORIAL

(AMPLIFICAÇÃO)

(PRIVAÇÃO)

SOBRECARGA SENSORIAL (FADIGA) NEGAÇÃO OU

CONFUSÃO DE GESTALT (VOLUNTÁRIA - INVO-

LUNTÁRIA)

INVOCAÇÃO DE MECANISMO DE

DEFESA FISIOLÓGICO.

EXAME DE RESPOSTAS FÍSICAS E FISIOLÓGICAS

A SITUAÇÕES SIMPLES OU MESMO

SOBRE-SIMPLIFICADAS QUE PODEM PRODUZIR FENÔMENOS

CLARAMENTE EXPERIENCIÁVEIS.

$\rightarrow$ FENÔMENOS + EXPERIÊNCIA SÃO A

INDIFERENCIABILIDADE 
13. Este texto não foi escrito para acompanhar nenhuma instalação específica. Certas passagens são idênticas a trechos de Dance Piece e ao item Withdrawal as an Art Form, ambos reunidos nas notas e projetos (Notes and Projects) publicados em 1970, na revista Artforum (v. 9, n.4, dez. 1970, p. 44-45). Esta versão foi encontrada pela pesquisadora em meio à documentação do galerista Leo Castelli, consultada no Arquivo de Arte Americana do Instituto Smithsonian, em Washington (D.C.), entre os dias 28 de maio e 01 de junho de 2012 (atividade realizada no âmbito do estágio de pesquisa no exterior). Consta que esta versão foi publicada apenas uma vez em The New Avant-Garde: Issues for the Art of the Seventies (Westport, Connecticut: Praeger Publishers, 1972). 
Floating Room, $1972^{14}$

Recinto flutuante 


\section{Floating Room}

We are trying to get to the center of some place: that is, exactly halfway between each pair of parts.

We want to move our center (some measurable center) to coincide with such point.

We want to superimpose our center of gravity on this point.

Save enough energy and concentration to reverse.

(The center of most places is above eye level). 


\section{Recinto flutuante}

Estamos tentando alcançar o centro de algum lugar: ou seja, exatamente a meio caminho entre cada par de segmentos.

Queremos mover nosso centro (algum centro mensurável) para que coincida com esse ponto.

Queremos sobrepor nosso centro de gravidade a esse ponto.

Guarde energia e concentração suficientes para reverter [a ação].

(O centro da maior parte dos lugares se encontra acima do nível dos olhos). 
14. Este texto faz parte da instalação Floating Room: Lit from Inside, montada pela primeira vez em 1973, na galeria de Leo Castelli, em Nova York. Cf. KRAYNAK, Janet (Ed.). Op. cit., p. 65. 
Double Doors - Projection and Displacement, $1973^{15}$

Portas duplas - Projeção e deslocamento 
(Image Projection and Displacement) (No Promisses)

Stand in the wedge that will allow you to see through the doors and into the further room.

Become aware of the volume displaced by your body. Imagine it filled with water or some gas (helium).

Concentrate fully on this volume as other considerations dissipate (heat, cold, gravity).

It's not necessary to remain rigid or fixed in position. Form an image of yourself in the further room standing facing away.

Suppose you had just walked trough the doors into that room. Concentrate and try to feel the volume displaced by the image.

Walk through to the other and step into that volume - precisely that displaced image.

Pay attention to the placement of your extremities and those parts you cannot see: your fingers - the back of your neck - the small of your back.

Make your body fit your image. 
(Projeção de imagem e deslocamento) (Sem promessas)

Posicione-se na cunha que lhe permitirá ver através das portas e o interior do recinto seguinte.

Torne-se consciente do volume deslocado por seu corpo. Imagine-o repleto de água ou algum gás (hélio).

Concentre-se inteiramente nesse volume enquanto outras considerações se dissipam (calor, frio, gravidade).

Não é necessário permanecer rígido ou fixar uma postura. Forme uma imagem de si mesmo no recinto seguinte, em pé e de costas para você.

Suponha que você tenha acabado de atravessar as portas daquele recinto. Concentre-se e tente sentir o volume deslocado pela imagem.

Atravesse para o outro [recinto] e entre nesse volume - precisamente o da imagem deslocada.

Preste atenção ao posicionamento de suas extremidades e daquelas partes que você não vê: seus dedos - sua nuca - suas costas.

Faça com que seu corpo caiba na sua imagem. 
15. Cf. KRAYNAK, Janet (Ed.). Op. cit., p. 66. 
Flayed Earth/ Flayed Self (Skin/Sink), $1973^{16}$

Terra esfolada/ Eu esfolado (Pele/Afundar) 
Peeling skin peeling earth - peeled earth

raw earth, peeled skin

The problem is to divide your

skin into six equal parts

lines starting at your feet and

ending at your head (five lines to make six

equal surface areas) to twist and spiral

into the ground, your skin peeling off

stretching and expanding to cover the surface

of the earth indicated by the spiraling

waves generated by the spiraling twisting

screwing ${ }^{17}$ descent and investiture (investment

or investing) of the earth by your swelling body. 
Pele descamando terra descamando - terra descamada

terra nua, pele descamada

O problema é dividir sua

pele em seis partes iguais

linhas começando por seus pés

terminando em sua cabeça (cinco linhas para compor seis

áreas de superfícies iguais) para torcer e espiralar

chão adentro, sua pele descamando

esticando e expandindo para cobrir a superfície

da terra indicada pelas ondas

espiralantes geradas pela espiralante torcida

helicoide descida e investidura (investimento

ou investir) da terra por seu corpo a inchar. 
Spiraling twisting ascent descent screwing in screwing out screwing driving diving invest invert convert relent relax control release, give in, given. Twisting driving down. Spiraling up screwing up screwed up screwed ${ }^{18}$ Twisted mind, twist and turn, twist and shout. Squirm into my mind so I can get into your mind your body our body arcing ache, circling warily then pressed together, pressing together, forced. 
Espiralante e retorcida ascensão declínio aparafusando desaparafusando penetrando conduzindo mergulhando invista inverta converta ceda relaxe controle libere, desista, rendido. Retorcendo conduzindo para baixo.

Espiralando para cima errando errado ferrado Mente distorcida, torça e vire, contorça-se e grite.

Contorça-se para dentro de minha mente para que eu possa entrar na sua mente seu corpo nosso corpo dor em arco, circulando cautelosamente e então pressionados um contra o outro, pressionando juntos, forçados. 
Surface reflection, transmission, refraction-

surface tension absorption, adsorbtion

Standing above and to one side of your-

self - schizoid - not dislocation, but a

bend or brake (as at the surface of water or a

clear liquid - quartz or transparent crystal)

(transparent crying)

I HAVE QUICK HANDS MY MIND IS ALERT

I HOLD MY BODY READY FOR INSPIRATION

ANTICIPATION AND SIGN RESPIRATION

ANY SIGH I THINK NEITHER AHEAD NOR

BEHIND READY BUT NOT WAITING NOT

ON GUARD NOT PREPARED. 
Reflexo superficial, transmissão, refração-

tensão superficial absorção adsorção

Postado acima e lateralmente deslocado de

si mesmo - esquizóide - não um deslocamento, mas uma

curvatura ou interrupção (como na superfície da água ou algum

líquido translúcido - quartzo ou cristal transparente)

(choro transparente)

EU TENHO MÃOS RÁPIDAS MINHA MENTE ESTÁ ALERTA

EU MANTENHO MEU CORPO PRONTO PARA INSPIRAÇÃO

ANTECIPAÇÃO E RESPIRAÇÃO DE SINAIS

QUALQUER SUSPIRO ACHO EU NEM À FRENTE NEM

ATRÁS PRONTO MAS NÃO À ESPERA NÃO

EM GUARDA DESPREPARADO. 
Rushing:

I AM AN IMPLODING LIGHT BULB

(imagine a more perfect abstract sphere)

Draw in energy rushing toward you -

toward your center.

(Fools rush in - Russian fools)

Try to get it down on paper - try to

get it in writing (try to get it written down -

try to write it down): Some evidences of a

state - a mark to prove you were there: Kilroy

(make a mark to prove you are here)

Suspension of belief, suspension of an object

object of suspension - to hang. 
Às pressas:

EU SOU UMA LÂMPADA IMPLODINDO

(imagine uma esfera abstrata mais perfeita)

Atraia a energia que se move rapidamente em sua direção em direção ao seu centro.

(Os tolos se precipitam ${ }^{19}$ - tolos russos)

Tente colocar no papel - tente

escrever (tente obtê-lo por escrito -

tente escrevê-lo): Algumas evidências de um

estado - uma marca para provar que você estava lá: Kilroy ${ }^{20}$

(faça uma marca para provar que você está aqui)

Suspensão da crença, suspensão de um objeto

objeto de suspensão - a ser suspenso. 
Talking of a particular space - the space a

few inches above and below the floor and within

the area bounded by and described by the tapedlines.

NOW INFORMATION RUSHING AWAY FROM THE CENTER

TOWARD THE PERIMETER A FEW INCHES ABOVE THE FLOOR.

A kind of vertical compression of space or do you

see it as a lightening or expanding opening in

space - just enough to barely let you in - not

so you could just step into it but so that you might

be able to crawl into it to lie in it to bask in it

to bathe in it.

Can it crush you - very heavy space - (gravity is

very important here) (or for important read strong) 
Falando de um determinado espaço - o espaço que fica algumas polegadas acima e abaixo do piso e no interior da área delimitada pelas linhas de fita adesiva, e por elas descrita.

AGORA INFORMAÇÃO MOVENDO-SE RAPIDAMENTE PARA LONGE DO CENTRO

EM DIREÇÃO AO PERÍMETRO UMAS POUCAS POLEGADAS ACIMA DO CHÃO.

Uma espécie de compressão vertical do espaço ou você

o vê como uma abertura a iluminar-se ou expandir-se no

espaço - apenas o suficiente para mal deixá-lo entrar - não

de forma que você possa simplesmente adentrá-la mas de forma que você possa

rastejar para dentro dela para deitar-se no interior dela e refestelar-se banhar-se nela.

Ela pode esmagar você - espaço muito pesado - (gravidade é muito importante aqui) (ou por "importante" leia "forte") 
Imagine a heavy gas sinking to the floor: If you

walk or otherwise disturb it, it will disperse

so you must use a great deal of care - go slow

(as though you were to enter water making neither

waves nor sounds. It's not so easy)

Be thin. 
Imagine um gás pesado caindo em direção ao chão: Se você

caminhar ou de qualquer modo perturbá-lo, ele se dispersará

então você deve tomar muito cuidado - vá devagar

(como se você fosse entrar na água sem fazer

ondas ou sons. Não é tão fácil)

Seja esguio. 
Now this is difficult and very frightening -

the space is not spherical here - not a closed

figure, but an unbounded parabola or hyperbola

(hyperbolae) and suppose it is expanding or

contracting (shrinking) in time - fixed only at

this apex.

The problem is how do you enter? Can it be

something so simple as turning around, rolling

over, entering a room, going around the corner?

Each is an enormous change - facing north to facing

south - things lined up a certain way rapidly

reversed or left behind (put behind) 
Agora isto é difícil e muito assustador -

o espaço aqui não é esférico - não é uma figura

fechada, mas uma parábola ou hipérbole (hyperbolae)

sem limites, e suponha-no em expansão ou

contração (encolhendo) no tempo - fixado apenas

neste ápice.

O problema é como você entra? Pode ser algo

tão simples como voltar-se para trás, virar-se

de bruços, entrar em um recinto, virar uma esquina?

Cada um é uma mudança enorme - de encarar o norte para encarar

o sul - coisas alinhadas de um certo modo rapidamente

revertidas ou deixadas para trás (postas para trás) 
You want to turn at an ordinary rate, as though you want to speak to someone there, behind you but you want not to speak, but you address yourself to a situation. (everything will feel the same and it will not have a new meaning THIS DOES NOT MEAN ANYTHING ANYWAY) but now there is either a greater density or less density and if you turn back (when you turn back) the change will be around you. Now you cannot leave or walk away. Has to do with your ability to give up your control over space. This is difficult because nothing will happen - and later you will be no better or worse off for it. This is more than one should require of another person. THIS IS FAR TOO PRIVATE AND DANGEROUS BECAUSE THERE IS NO ELATION NO PAIN NO KNOWLEDGE AN INCREDIBLE RISK WITH (BECAUSE) NOTHING IS LOST OR GAINED NOTHING TO CATCH OUT OF THE CORNER OF YOUR EYE - YOU MAY THINK YOU FELT SOMETHING BUT THAT'S NOT IT THAT'S NOT ANYTHING YOU'RE ONLY HERE IN THE ROOM: MY SECRET IS THAT I STAYED THE SAME FOR A SHORT TIME. 
O ideal é voltar-se em ritmo usual, como se

você quisesse falar com alguém ali, atrás de você

mas você quer permanecer calado, mas você se dirige

à situação. (tudo parecerá

igual e não terá um novo sentido ISTO

NÃO SIGNIFICA NADA DE TODO MODO) mas agora

há ou uma maior densidade ou menor densidade

e se você olhar para trás (quando você olhar para trás)

a mudança estará ao seu redor. Agora você

não pode sair ou ir embora. Tem a ver com a sua

habilidade de abrir mão de seu controle sobre o espaço. Isto

é difícil porque nada irá acontecer - e

depois você não estará nem melhor nem pior por isso.

Isso é mais do que uma pessoa deveria exigir de outra

pessoa. ISSO É DE LONGE PRIVADO E PERIGOSO DEMAIS

POROUE NÃO HÁ NENHUMA ELAÇÃO NENHUMA DOR NENHUM

CONHECIMENTO

UM RISCO INCRÍVEL COM (POROUE) NADA É

PERDIDO OU GANHO NADA PARA VISLUMBRAR COM O

CANTO DO SEU OLHO - VOCÊ PODE PENSAR OUE SENTIU ALGUMA

COISA MAS NÃO ISSO NÃO É NADA

VOCÊ SÓ ESTÁ AOUI NO RECINTO:

MEU SEGREDO É QUE PERMANECI O MESMO POR UM PERÍODO CURTO DE TEMPO. 
16. Este escrito faz parte da instalação homônima, montada na galeria Nicholas Wilder, em 1973 e 1974. Cf. KRAYNAK, Janet (Ed.). Op. cit., p. 67-75.

17. O verbo "to screw" - "aparafusar", “atarraxar com parafuso" - também possui sentido sexual, sendo termo chulo para descrever a relação sexual.

18. Conforme a nota anterior, "to screw" é eufemismo frequentemente empregado para substituir a expressão "to fuck"; mais precisa e detalhadamente, dada a multiplicidade de sentidos empregados a um só tempo no trecho, to screw (someone or something): verbo transitivo direto: parafusar; copular com (alguém), comer (sex., chulo); to screw (with someone): verbo transitivo indireto: brincar com alguém, "zoar"; to screw up: phrasal verb: cometer um erro, fazer bobagem, fracassar; screwed: adjetivo: ferrado, lascado, enrascado, fodido.

19. A expressão é tradicional, e aparece na canção "Can't Help Falling in Love" lescrita por Hugo Peretti, Luigi Creatore e George David Weiss), tornada célebre por Elvis Presley em 1961, no filme Blue Hawaii: Wise men say / Only fools rush in / But I can't help / Falling in love with you l"Dizem os sábios / que somente os tolos se precipitam / Mas não consigo evitar / Cair de amores por você"). Desde então, a expressão é comumente empregada para se referir ao "tolo apaixonado". No texto, o jogo é com a homofonia entre "rush in" e "Russian".

20. "Kilroy was here" ("Kilroy esteve aqui") é uma pichação comum desde a Segunda Guerra, perpetrada por soldados americanos em solo internacional para marcar de forma mais duradoura sua breve estadia no local. 
Instructions for a Mental Exercise, $1974^{21}$ Instruções para um exercício mental 
I N S T R U C T I O N S

\section{A. LEE DOWN ON THE FLOOR NEAR THE CENTER OF THE SPACE, FACE DOWN, AND SLOWLY ALLOW YOURSELF TO SINK DOWN INTO THE FLOOR. EYES OPEN.}

\section{B. LE ON YOUR BACK ON THE FLOOR NEAR THE CENTER OF THE SPACE AND SLOWLY ALLOW THE FLOOR TO RISE UP AROUND YOU. EYES OPEN.}

This is a mental exercise.

Practice each day for one hour

$1 / 2$ hour for $A$, then a sufficient break to clear

the mind and body, then 1/2 hour practice B.

At first, as concentration and continuity are broken or allowed to stray every few seconds or minutes, simply start over and continue to repeat the exercise until the $1 / 2$ hour is used.

The problem is to try to make the exercise continuous and uninterrupted for the full $1 / 2$ hour. That is, to take the full 1/2 hour to A. Sink under the floor, or B. to allow the floor to rise completely over you.

In exercise $\mathrm{A}$ it helps to become aware of peripheral vision use it to emphasise the space at the edges of the room and begin to sink below the edges and finally under the floor.

In $\mathrm{B}$ begin to deemphasize peripheral vision - become aware of tunneling of vision - so that the edges of the space begin to fall away and the center rises up around you.

In each case use caution in releasing yourself at the end of the period of exercise. 
I N S T R U Ç Õ E S

\section{A. DEITE-SE NO CHÃO, PRÓXIMO DO CENTRO DO ESPAÇO, DE BRUÇOS, E LENTAMENTE PERMITA-SE AFUNDAR NO CHÃO. OLHOS ABERTOS.}

\section{B. DEITE-SE DE COSTAS NO CHÃO, PRÓXIMO DO CENTRO DO ESPAÇO, E LENTAMENTE PERMITA OUE O CHÃO ELEVE-SE AO SEU REDOR. OLHOS ABERTOS.}

Este é um exercício mental.

Pratique todos os dias por uma hora

$1 / 2$ hora para $A$, em seguida, um intervalo suficiente para arejar a mente e o corpo, em seguida $1 / 2$ hora de prática $B$.

No início, como a concentração e a continuidade são interrompidas ou é permitido que se desviem a cada poucos segundos ou minutos, simplesmente recomece e continue a repetir o exercício até que 1/2 hora seja usada.

O problema é tentar fazer o exercício de forma contínua e ininterrupta por 1/2 hora completa. Isto é, usar toda $1 / 2$ hora para A. Afunde no piso, ou B. para permitir que o chão se eleve completamente sobre você.

No exercício A tornar-se ciente da visão periférica ajuda use-a para enfatizar o espaço nas extremidades do recinto e começar a afundar para baixo das extremidades e, finalmente, para debaixo do chão.

Em B comece deixando de enfatizar a visão periférica - torne-se ciente do estreitamento da visão - para que as extremidades do espaço desapareçam e o centro eleve-se em torno de você.

Em cada caso tenha cautela ao libertar-se ao fim do período de exercício. 
21. Publicado em 1974 na revista alemã Interfunktionen (n. 11, 1974, p. 122-124). A primeira versão deste texto foi escrita em 1969 e serviu de base para as performances documentadas nos vídeos Elke Allowing the Floor to Rise Up Over Her, Face Up (1973) e Tony Sinking into the Floor, Face Up and Face Down (1973). Cf. KRAYNAK, Janet (Ed.). Op. cit., p. 76-77. 
Cones Cojones, $1974^{22}$

Cones Cojones 


\section{Cones}

Floater: Rising time/count-up sequence.

A finite number of concentric circles not equally spaced: starting at the outside and measuring inward, the distance between circumferences is a geometric progression (expanding or constructing).

Concentric circles becoming progressively closer either from their center or measured from the outer circumference, describing the intersection of the plane through your center parallel to the floor and a very large but finite series of concentric cones whose common center is located through the center of the earth at a distant place in the universe.

The point of the universe which is the apex of a countable number of concentric cones whose intersection with the plane parallel to the floor passing through your center describing an equal number of concentric circles, appear to radiate, inward or not, that point, moving with the universe, expanding, and so changing, the shape, of the cones, and circles, at this rate.

\section{Earth Moves}

The massive center moves about tides.

Black hole functions: contraction, concentration, compression, collapse, contour inversion, contour immersion, inverse/diverse/divest.

Thinking feeling.

Sinking, feeling ${ }^{23}$. 


\section{Cones}

Flutuador: Tempo de subida/sequência de contagem.

Um número finito de círculos concêntricos espaçados de forma desigual: medidos de fora para dentro, a distância entre as circunferências é uma progressão geométrica (em expansão ou construção).

Círculos concêntricos tornando-se progressivamente mais próximos seja a partir do seu centro seja medidos a partir da circunferência mais externa, descrevendo a intersecção do plano através do seu ${ }^{24}$ centro paralelo ao chão, e uma série muito grande mas finita de cones concêntricos, cujo centro comum está localizado através do centro da terra em um lugar distante no universo.

O ponto do universo que é o ápice de um número contável de cones concêntricos cuja intersecção com o plano paralelo ao chão passando através de seu centro descrevendo um mesmo número de círculos concêntricos parecem irradiar, para o interior ou não, aquele ponto, movendo-se com o universo, expandindo, e assim mudando, a forma, dos cones, e círculos, neste ritmo.

\section{A Terra Se Move}

O centro colossal ${ }^{25}$ se move sobre marés.

Funções de buracos negros: contração, concentração, compressão, colapso, inversão de contorno, imersão de contorno, inverso/diverso /despir.

Pensando sentindo.

Afundando, sentindo. 
Expansion Ethics

Release the gas and the container is contained.

Free thinking free thinker; free thinker thinking free.

Floater flauting flauter ${ }^{26}$ floating.

Fit into an enormous space where a great deal of time is available as the continually rapidly expanding distances are enormous. Stay inside the cone; avoid the walls; compact yourself; avoid compression. Now time is short.

(You can't get there from here but you can get here from there if you don't mind the $t$ left over.)

What I mean is everything is finite, everything is closed, nothing touches.

It doesn't mean anything to say there are no spaces in between.

It is meaningless to say there are spaces between.

As though the water had recently been removed.

As though water had emptied. 
Ética da expansão

Libere o gás e o continente está contido.

Livre pensar pensador livre; livre pensador pensando livre.

Flutuador escarnecendo com pompa, escarnecedor pomposamente flutuando.

Ajuste-se em um espaço enorme onde muito, muito tempo está disponível uma vez que as distâncias em rápida e contínua expansão são enormes. Fique dentro do cone; evite as paredes; compacte a si mesmo; evite compressão. Agora o tempo é curto.

(Você não pode chegar lá a partir daqui, mas você pode chegar aqui a partir de lá, desde que você não se importe com o " $t$ " sobrando ${ }^{27}$ )

O que quero dizer é que tudo é finito, tudo está fechado, nada toca.

Não significa nada dizer que não existam espaços intermediários.

Não há sentido em dizer que existam espaços intermediários.

Como se a água tivesse sido removida recentemente.

Como se a água tivesse esvaziado. 


\section{Cojones}

I want to get the whole. I'm trying to get everything, accurate.

I want to get the whole,

Here is every.

Here is the whole, everything accurate, precise:

Imagine accidentally coming upon a line and adjusting yourself so that the center of your body lies on that line. When you accomplish this there is no next step.

Take my meaning not my intentions.

You will just have to do something else.

Here is every.

Here is my precision.

Here is everything.

Apparently this is my hole.

Apparently this is my meaning.

(I have precise but mean intentions.)

Ere he is very. 


\section{Cojones}

Eu quero obter o todo. Estou tentando obter tudo, exato.

Eu quero obter o todo,

Aqui está cada.

Aqui está o todo, tudo exato, preciso:

Imagine descobrir acidentalmente uma linha e ajustar-se de modo que o centro de seu corpo se encontre nessa linha. Quando você consegue isso não há próximo passo.

Entenda o que quero dizer, não minhas intenções.

Você simplesmente terá que fazer alguma outra coisa.

Aqui está cada

Aqui está a minha precisão.

Aqui está tudo.

Aparentemente isto é meu buraco.

Aparentemente é isto que quero dizer.

(Eu tenho intenções precisas, mas cruéis)

Antes que ele esteja muito. 
1. Let's talk about control.

2. We were talking about control.

3. We are talking about control.

There is no preparation for this occurrence.

There is no excuse for this occurrence, there is no reason, no need, no urgency, no...

Apparently this is what I mean, although it's not what I intend.

This accuracy is not my intention.

Oh, my shrinking, crawling skin.

and the need within me to stretch myself to a point.

This accuracy is my intention. Placate my art. 
1. Vamos falar sobre controle.

2. Nós estávamos falando sobre controle.

3. Nós estamos falando sobre controle.

Não há preparação para esta ocorrência.

Não há desculpa para esta ocorrência, não há razão, não há necessidade, não há urgência, não ...

Aparentemente é isto o que eu quero dizer, embora não seja o que intenciono.

Esta precisão não é a minha intenção

Oh, minha pele que encolhe, que se arrepia ${ }^{28}$.

e a necessidade em mim de me alongar até um ponto.

Esta exatidão é a minha intenção. Aplaque minha arte. 
22. Este texto é parte da instalação Cones Cojones e foi apresentado de dois modos na mostra homônima ocorrida na galeria de Leo Castelli, em Nova York, em 1975: a versão orginal foi emoldurada e disposta na parede da galeria e a versão impressa assumiu o formato de pôsteres destacáveis deixados na entrada da galeria, a fim de ser levados pelos visitantes. Cf. KRAYNAK, Janet (Ed.). Op. cit., p. 78-82. Ver também BRUGGEN, Coosje van. Op. cit., p. 208-213.

23. Provável jogo de palavras com a expressão “sinking feeling”, sem tradução imediata para o português, e que se refere ao sentimento desencadedo ao nos darmos conta, retroativamente, de que um evento passado acarretará consequências mais nefastas do que suspeitáramos; a sensação resultante poderia ser descrita, imageticamente, como um naufrágio do coração em direção às entranhas.

24. 0 emprego de "your" e não "its" ou "their" sugere que este trecho do texto refere-se ao centro [do corpo] de um provável observador da obra, e não aos centros dos círculos e cones mencionados.

25. Aqui, a tradução empregada para "massive" segue o sentido físico literal do termo - "colossal", "imenso", "descomunal"; vale lembrar, entretanto, que massive também é palavra comumente utilizada para qualificar buracos-negros de massa considerável e, uma vez que estes figuram no texto, pode-se presumir intencional duplo-sentido. No âmbito das publicações acerca de física contemporânea em português, o anglicismo "massivo" já foi, inclusive, incorporado ao léxico para se referir aos buracos-negros supermassivos, isto é, àquela espécie de buraco negro que se encontra no centro da maior parte das galáxias (ou mesmo, infere-se, de todas elas).

26. "Flaut" é termo que não existe em língua inglesa. É possível que se trate de corrupção intencionalmente executada a fim de produzir palavra-valise capaz de evocar, a um só tempo, o conteúdo semântico dos verbos "(to) flaunt" lostentar, exibir de forma impudente ou exagerada) e "(to) flout" (desprezar, tratar com escárnio), leitura da qual advém a tradução proposta.

27. Obviamente, o jogo de palavras construído nesta frase funciona apenas no inglês: você pode alcançar o aqui (here) a partir do lá (there), desde que não se importe de remover o " $t$ ".

28. "My skin/flesh is crawling" é expressão que denota sensação de formigamento descomunal provocada por situações excessivamente aflitivas ou repulsivas vivenciadas por um indivíduo; quando empregada para a descrição de sensações relacionadas a circunstâncias francamente patológicas indica, no mais das vezes, que o indivíduo afetado sente que a própria pele the foge às carnes, ameaçando romper-se. 
Body Pressure, $1974^{29}$

\section{Pressão corporal}


Body Pressure

Press as much of the front surface of your body (palms in or out, left or right cheek) against the wall as possible.

Press very hard and concentrate.

Form an image of yourself (suppose you had just stepped forward) on the opposite side of the wall pressing back against the wall very hard. 
Pressão corporal

Pressione tanto da superfície frontal de

seu corpo (palmas para a frente ou para trás, bochecha

esquerda ou direita)

contra a parede quanto for possível.

Pressione com muita força e se concentre.

Forme uma imagem de si mesmo (suponha que

você tivesse acabado de dar um passo à frente) no

outro lado da parede empurrando

contra a parede com as costas com muita força. 
Press very hard and concentrate on the image pressing very hard.

(the image pressing very hard)

Press your front surface and back surface toward each other and begin to ignore or block the thickness of the wall. (remove the wall)

Think how various parts of your body press against the wall; which parts touch and which do not.

Consider the parts of your back which press against the wall; press hard and feel how the front and back of your body press together. 
Pressione com muita força e se concentre na imagem pressionando arduamente.

(a imagem pressionando com muita força)

Pressione sua superfície frontal e sua superfície posterior uma em direção à outra e comece a ignorar ou bloquear a espessura da parede. (remova a parede)

Pense na forma como várias partes de seu corpo pressionam a parede; quais partes a tocam e quais não o fazem.

Considere as partes de suas costas pressionadas contra a parede; pressione com força e sinta como a frente e as costas do seu corpo pressionam uma contra a outra. 
Concentrate on tension in the muscles,

pain where bones meet, fleshy deformations

that occur under pressure; consider

body hair, perspiration, odors (smells).

This may become a very erotic exercise. 
Concentre-se na tensão nos músculos,

na dor onde os ossos se encontram, deformações da carne

que ocorrem sob pressão; considere

os pelos do corpo, suores, odores (cheiros).

Isto pode tornar-se um exercício muito erótico. 
29. Estas instruções integraram a mostra "Yellow Body", ocorrida na galeria de Konrad Fischer, em Düsseldorf, Alemanha, em 1974. Atualmente, o texto pertence ao acervo da Dia Art Foundation, em Beacon, Estados Unidos, e fica disponível para o público. Cf. KRAYNAK, Janet (Ed.). Op. cit., p. 83-85; NAUMAN, Bruce. Live or Die. Colônia: DuMont Buchverlag, 2010, p. 200-201. 
The Consummate Mask of Rock, $1975^{30}$ A máscara consumada de pedra 


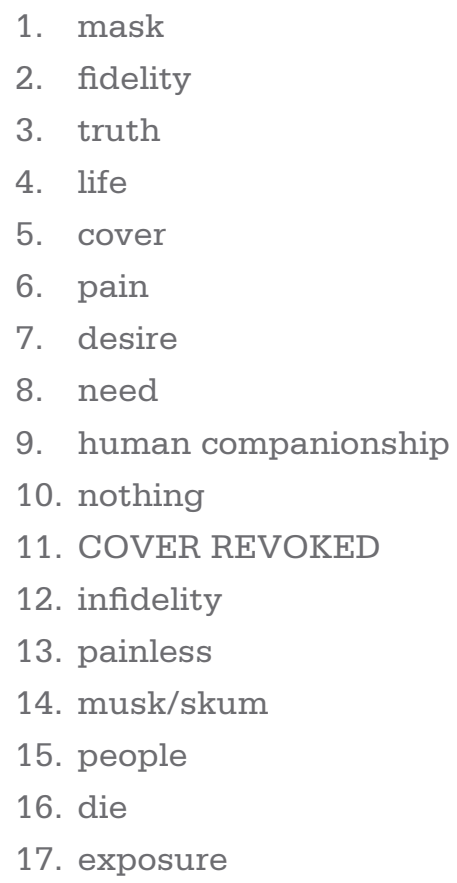




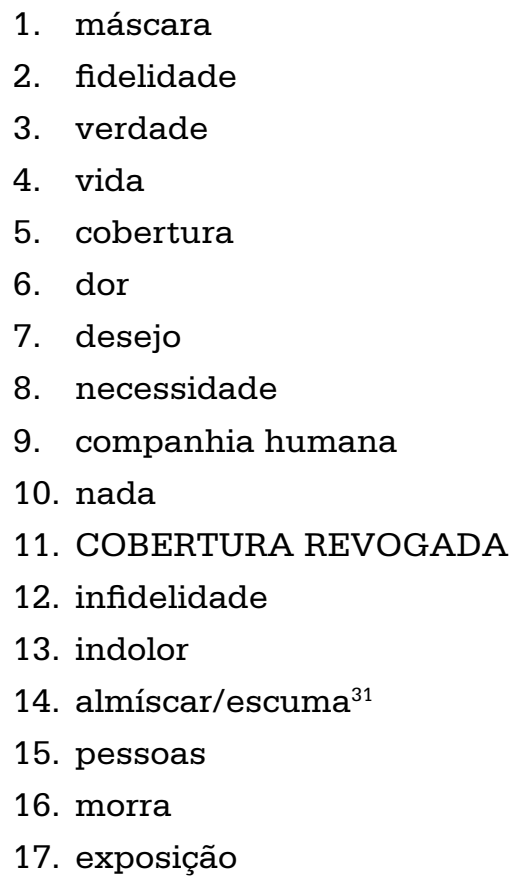


1. This is my mask of fidelity to truth and life.

2. This is to cover the mask of pain and desire.

3. This is to mask the cover of need for human companionship.

4. This is to mask the cover.

5. This is to cover the mask.

6. This is the need for cover.

7. This is the need of the mask.

8. This is the mask of cover of need. Nothing and no

9. No thing and no mask can cover the lacks, alas.

10. Lack after nothing before cover revoked.

11. Lack before cover paper covers rock rock breaks mask alas, alack

12. Nothing to cover.

13. This is the mask to cover my infidelity to truth. (This is my cover.)

14. This is the need for pain that contorts my mask conveying the message of truth and fidelity to life.

15. This is the truth that distorts my need for human companionship.

16. This is the distortion of truth masked by my painful need.

17. This is the mask of my painful need distressed by truth and human companionship.

18. This is my painless mask that fails to touch my face but floats before the surface of my skin my eyes my teeth my tongue.

19. Desire is my mask.

(Musk of desire)

20. Rescind desire

cover revoked

desire revoked

cover rescinded.

21. PEOPLE DIE OF EXPOSURE. 
1. Esta é a minha máscara de fidelidade à verdade e à vida.

2. Isto é para cobrir a máscara de dor e desejo.

3. Isto é para mascarar a cobertura da necessidade de companhia humana.

4. Isto é para mascarar a cobertura.

5. Isto é para cobrir a máscara.

6. Esta é a necessidade de cobertura.

7. Esta é a necessidade da máscara.

8. Esta é a máscara de cobertura de necessidade. Nada e não

9. Coisa alguma, máscara alguma pode cobrir as faltas, lamentavelmente ${ }^{32}$.

10. Falta de nada perante cobertura revogada.

11. Falta perante cobertura papel cobre pedra pedra quebra máscara lamentavelmente, infelizmente

12. Nada para cobrir.

13. Esta é a máscara para cobrir minha infidelidade à verdade. (Esta é a minha cobertura).

14. Esta é a necessidade de dor que deforma minha máscara transmitindo a mensagem da verdade e da fidelidade à vida.

15. Esta é a verdade que distorce minha necessidade de companhia humana.

16. Esta é a distorção da verdade mascarada por minha necessidade dolorosa.

17. Esta é a máscara da minha necessidade dolorosa torturada pela verdade e pela companhia humana.

18. Esta é minha máscara indolor que fracassa em tocar minha face mas flutua diante da superfície da minha pele meus olhos meus dentes minha língua.

19. Desejo é minha máscara.

(Almíscar de desejo)

20. Rescinda desejo cobertura revogada desejo revogado cobertura rescindida

21. PESSOAS MORREM DE EXPOSIÇÃO. 


\title{
CONSUMMATION/CONSUMNATION/TASK ${ }^{33}$
}

\author{
(passive) \\ paper covers rock \\ (active-threatening) \\ scissors cuts paper \\ (active-violent) \\ rock breaks scissors
1. mask
4. desire
2. cover
5. need for human companionship
3. diminish
6. lack

desire covers mask

need for human companionship masks desire

mask diminishes need for human companionship

need for human companionship diminishes cover

desire consumes human companionship

cover lacks desire 
CONSUMAÇÃO/ CONSUNAÇÃO ${ }^{33} /$ TAREFA

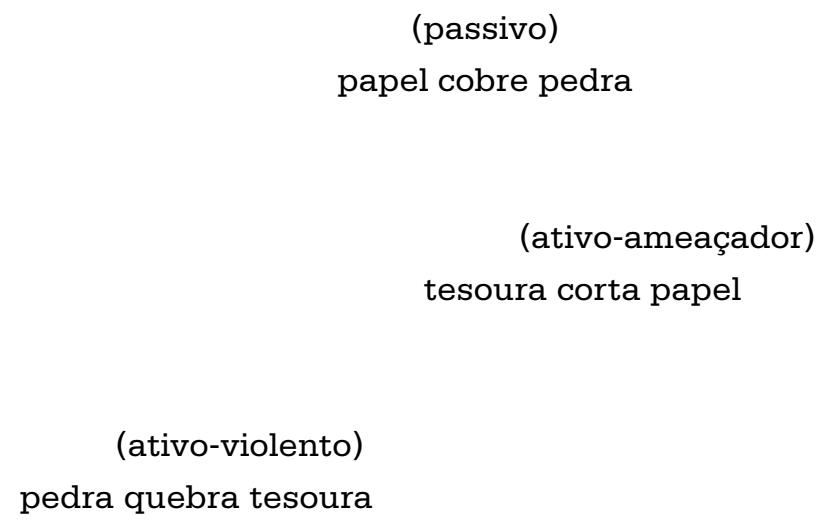

1. máscara

4. desejo

2. cobertura

5. necessidade de companhia humana

3. diminuir

6. falta

desejo cobre máscara

necessidade de companhia humana mascara desejo

máscara diminui necessidade de companhia humana

necessidade de companhia humana diminui cobertura

desejo consome companhia humana

cobertura carece de desejo 
THIS IS THE COVER THAT DESIRES THE MASK OF LACK THAT CONSUMES THE NEED FOR HUMAN COMPANIONSHIP. THIS IS THE COVER THAT DESPISES THE TASK OF THE NEED OF HUMAN COMP.

THIS IS THE TASK OF CONSUMING HUMAN COMP

5

1. some kind of fact

2. some kind of fiction

3. the way we behaved in the past

4. what we believe to be the case now

5. the consuming task of human companionship

6. the consummate mask of rock

(1.) Fiction erodes fact.

(2.) Fact becomes the way we have behaved in the past.

(3.) The way we have behaved in the past congeals into the consummate mask of rock.

(4.) The way we have behaved in the past contributes to the consuming task of human companionship.

(5.) The consuming task of human comp. erodes the consummate mask of rock. However (2.) Fact becomes the way we have behaved in the past may be substituted into (3.) and (4.) so that

(6.) Fact congeals into the consummate mask of rock. But (5.) the consuming task of human comp. erodes the consummate mask of rock or the consuming task of human comp. erodes fact, then from (1.) it follows that THE CONSUMMING TASK OF HUMAN COMPANIONSHIP IS FALSE. 
ESTA É A COBERTURA QUE DESEJA A MÁSCARA DE FALTA QUE CONSOME A NECESSIDADE DE COMPANHIA HUMANA. ESTA É A COBERTURA OUE DESPREZA A TAREFA DA NECESSIDADE DE COMP.

HUMANA ESTA É A TAREFA DE CONSUMIR A COMP. HUMANA.

1. algum tipo de fato

2. algum tipo de ficção

3. o modo como nos comportávamos no passado

4. o que acreditamos ser o caso agora

5. a tarefa extenuante da companhia humana

6. a máscara consumada de pedra

(1.) Ficção corrói fato.

(2.) Fato torna-se o modo como nos comportamos no passado.

(3.) O modo como nos comportamos no passado gelifica-se na máscara consumada de pedra.

(4.) O modo como nos comportamos no passado contribui para a tarefa extenuante da companhia humana.

(5.) A tarefa extenuante da comp. humana corrói a máscara consumada de pedra.

Entretanto (2.) Fato torna-se o modo como nós nos comportamos no passado pode ser substituído por (3.) e (4.) de modo que

(6.) Fato gelifica-se na máscara consumada de pedra.

Mas (5.) a tarefa extenuante da comp. humana corrói a máscara consumada de pedra ou a tarefa extenuante da comp. humana corrói o fato, do que (1.) se segue que A TAREFA EXTENUANTE DA COMPANHIA HUMANA É FALSA. 
THE CONSUMMATE MASK OF ROCK HAVING DRIVEN THE WEDGE OF DESIRE THAT DISTINGUISHED

TRUTH AND FALSITY LIES COVERED BY PAPER

7

1. (This young man, taken to task so often, now finds it his only sexual relief.)

2. (This young man, so often taken to task, now finds it his only sexual fulfillment.)

3. (This man, so often taken to task as a child...)

4. (This man, so often taken to task, now finds it satisfies his sexual desires.)

arouses needs

5. This man, so often taken as a child, now wears the consummate mask of rock and uses it to drive his wedge of desire into the ever squeezing gap between his truth, his falsity.

6. This man, so often taken as a child, now uses his consummate mask of his rock

to drive his wedge of his desire into his ever squeezing (his) gap between his truth, his falsity.

7. (This) man, (so often) taken as (a) child, finding his consummate mask of rock covered by paper, he finding his wedge being squeezed (from) between his desired truth (truth desired) and his desireless falsity (falsity desireless), he unable to arouse his satisfaction, he unable to desire his needs, he proceeds into the gap of his fulfillment his relief lacking the task of human companionship.

Moral

Paper cut from rock, releases rock to crush scissors. Rock freed from restrictions of paper/scissors/rock, lacking context proceeds. 


\author{
A MÁSCARA CONSUMADA DE PEDRA, TENDO FORÇADO A \\ CUNHA DE DESEJO QUE DISTINGUIU \\ VERDADE E FALSIDADE, JAZ COBERTA PELO PAPEL
}

1. (Este jovem homem, tão frequentemente repreendido, agora se dá conta de que esse é seu único alívio sexual). 2. (Este jovem homem, tão frequentemente repreendido, agora se dá conta de que disso depende sua satisfação sexual).

3. (Este homem, tão frequentemente repreendido quando criança...)

4. (Este homem, tão frequentemente repreendido, agora se dá conta de que isso satisfaz seus desejos sexuais).

desperta necessidades

5. Este homem, tão frequentemente conduzido quando criança, agora veste a máscara consumada de pedra e a usa para forçar sua cunha de desejo para dentro do sempre premente vão entre sua verdade, sua falsidade.

6. Este homem, tão frequentemente conduzido quando criança, agora usa a sua máscara consumada de pedra para forçar sua cunha de seu desejo para dentro de seu sempre premente (seu) vão entre sua verdade, sua falsidade.

7. (Este) homem, (tão frequentemente) conduzido quando (uma) criança, ao encontrar sua máscara consumada de pedra coberta por papel, ele percebendo sua cunha sendo premida (para fora de) entre sua verdade desejada (desejada verdade) e sua falsidade sem desejo (sem desejo falsidade), ele incapaz de despertar sua satisfação, ele incapaz de desejar suas necessidades, ele procede para dentro do vão de sua satisfação seu alívio carecendo da tarefa de companhia humana.

Moral

Papel cortado da pedra, libera a pedra para esmagar a tesoura. Pedra liberta das restrições de papel/tesoura/pedra, carente de contexto, prossegue. 
30. Este texto é parte da instalação homônima primeiramente montada na galeria AlbrightKnox, Buffalo, Nova York, 1975. O texto original foi emoldurado e pendurado no espaço expositivo e também foram feitas impressões no formato de brochura. Cf. KRAYNAK, Janet (Ed.). Op. cit., p. 86-91; BRUGGEN, Coosje van. Op. cit., p. 214-221. Rock foi traduzido por "pedra" e não "rocha", dada a referência à brincadeira/jogo infantil conhecido por "pedra, papel, tesoura", ou Joquempô.

31. A palavra "skum" não existe no inglês. É possível que seja amálgama de "scum" l"escuma", "escória", tanto no sentido físico de "material que se remove da superfície de um líquido em ebulição" quanto no sentido figurativo de "indivíduo mal-ajustado e/ou danoso à sociedade"), "skim" ("escoimar", "remover da superfície") e, pela presença do termo almíscar, "skin" (pele). Adicionalmente, a palavra "skunk" (gambá) pode ter alguma relevância, dado o campo semântico relativo a "pele animal/odor animal" em jogo no trecho.

32. "Alas" e "alack" são interjeições intraduzíveis que expressam profundo pesar. Há instâncias em que recebem a tradução questionável de "ai de mim"; para o presente texto, no entanto, "infelizmente" e "lamentavelmente" parecem ser opções mais razoáveis. A interjeição "alack" faz um trocadilho com "a lack", "uma falta", "uma deficiência". É interessante notar que Nauman emprega as duas formas em sequência: ele aproxima "alas" de "lack" diversas vezes - tal pesar, poder-se-ia dizer, advém de uma falta.

33. "CONSUMNATION" é decerto palavra-valise (Consummation = Consume + Nation). 
FALSE SILENCE, $1975^{34}$

SILÊNCIO FALSO 
I DON'T SWEAT

I HAVE NO ODOR

I INHALE, DON'T EXHALE

NO URINE

I DON'T DEFECATE: NO EXCRETIONS OF ANY KIND

I CONSUME ONLY

OXYGEN, ALL FOODS, ANY FORM

I SEE, HEAR

I DON'T SPEAK, MAKE NO OTHER SOUNDS, YOU CAN'T HEAR MY

HEART, MY FOOTSTEPS

NO EXPRESSION, NO COMMUNICATION OF ANY KIND

AN OBSERVER, A CONSUMER, A USER ONLY

MY BODY ABSORBS ALL COMMUNICATIONS, EMOTIONS, SUCKS UP

HEAT AND COLD

SUPER REPTILIAN SOAKING UP ALL KNOWLEDGE, COMPACTOR OF

ALL INFORMATION

NOT GROWING

I FEEL DON'T TOUCH

I HAVE NO CONTROL OVER THE KINDS AND QUALITIES OF THOUGHTS I COLLECT, I CAN'T PROCESS

I CAN'T REACT OR ACT ON SENSATION

NO EMOTIONAL RESPONSE TO SITUATIONS

THERE IS NO REACTION OF INSTINCT TO PHYSICAL OR MENTAL THREATS

YOU CAN'T REACH ME, YOU CAN'T HURT ME

I CAN SUCK YOU DRY

YOU CAN'T HURT ME

YOU CAN'T HELP ME

SHUFFLE THE PAGES

FIND ME A LINE

ARAPAHOE, ARAPAHOE ${ }^{35}$

WHERE DID YOU GO

I BLINK MY EYES

TO KEEP THE TIME 
EU NÃO TRANSPIRO

EU NÃO TENHO ODOR

EU INALO, NÃO EXALO

SEM URINA

EU NÃO DEFECO: NENHUMA EXCREÇÃO DE OUALQUER TIPO

EU SÓ CONSUMO

OXIGÊNIO, TODAS AS COMIDAS, QUALOUER FORMA

EU VEJO, OUÇO

EU NÃO FALO, NÃO PRODUZO OUTROS SONS, VOCÊ NÃO PODE

OUVIR MEU CORAÇÃO, MEUS PASSOS

NENHUMA EXPRESSÃO, NENHUMA COMUNICAÇÃO DE QUALOUER TIPO

UM OBSERVADOR, UM CONSUMIDOR, UM USUÁRIO APENAS

MEU CORPO ABSORVE TODAS AS COMUNICAÇÕES, EMOÇÕES,

ABSORVE CALOR E FRIO

SUPER REPTILIANO ABSORVENDO TODO CONHECIMENTO,

COMPACTADOR DE TODA INFORMAÇÃO

SEM CRESCER

EU SINTO NÃO TOOUE

EU NÃO TENHO CONTROLE SOBRE OS TIPOS E AS QUALIDADES

DOS PENSAMENTOS

EU COLECIONO, EU NÃO CONSIGO PROCESSAR

EU NÃO POSSO REAGIR OU AGIR COM BASE EM SENSAÇÕES

SEM RESPOSTA EMOCIONAL ÀS SITUAÇÕES

NÃO HÁ REAÇÃO INSTINTIVA A AMEAÇAS FÍSICAS OU MENTAIS

VOCÊ NÃO PODE ME ALCANÇAR, VOCÊ NÃO PODE ME FERIR

EU POSSO SUGÁ-LO ATÉ A ÚLTIMA GOTA

VOCÊ NÃO PODE ME FERIR

VOCÊ NÃO PODE ME AJUDAR

EMBARALHE AS PÁGINAS

ENCONTRE PARA MIM UMA LINHA

ARAPAHOE, ARAPAHOE

ONDE VOCÊ FOI

EU PISCO MEUS OLHOS

PARA MARCAR O TEMPO 
34. Este texto foi publicado na revista Vision (n.1, set., 1975) e também gravado em áudio pelo artista. Foi regravado em áudio - com voz feminina - para a exposição "Samuel Beckett/ Bruce Nauman", realizada em Viena, em 2000.

35. Os Arapahoe são um povo indígena natural dos estados do Colorado e Wyoming (EUA), e seu nome provavelmente deriva do termo alappahó, "gente com muitas tatuagens", pelo costume que tinham de gravar círculos cerimoniais no rosto. 
100 Live and Die, $1984^{36}$

100 Viva e Morra

[imperativo]

100 Viver e Morrer

[infinitivo] 


$\begin{array}{llll}\text { Live and Die } & \text { Love and Live } & \text { Know and Die } & \text { Sit and Live } \\ \text { Live and Live } & \text { Stay and Die } & \text { Know and Live } & \text { Sick and Die } \\ \text { Sing and Die } & \text { Stay and Live } & \text { Kiss and Die } & \text { Sick and Live } \\ \text { Sing and Live } & \text { Hate and Die } & \text { Kiss and Live } & \text { Spit and Die } \\ \text { Die and Die } & \text { Hate and Live } & \text { Tell and Die } & \text { Spit and Live } \\ \text { Die and Live } & \text { Play and Die } & \text { Tell and Live } & \text { Well and Die } \\ \text { Scream and Die } & \text { Play and Live } & \text { Rage and Die } & \text { Well and Live } \\ \text { Scream and Live } & \text { Fuck and Die } & \text { Rage and Live } & \text { Try and Die } \\ \text { Shit and Die } & \text { Fuck and Live } & \text { Smell and Die } & \text { Try and Live } \\ \text { Shit and Live } & \text { Kill and Die } & \text { Smell and Live } & \text { Black and Die } \\ \text { Young and Die } & \text { Kill and Live } & \text { Laugh and Die } & \text { Black and Live } \\ \text { Young and Live } & \text { Speak and Die } & \text { Laugh and Live } & \text { Fail and Die } \\ \text { Piss and Die } & \text { Speak and Live } & \text { Fall and Die } & \text { Fail and Live } \\ \text { Piss and Live } & \text { Suck and Die } & \text { Fall and Live } & \text { White and Die } \\ \text { Old and Die } & \text { Suck and Live } & \text { Touch and Die } & \text { White and Live } \\ \text { Old and Live } & \text { Lie and Die } & \text { Touch and Live } & \text { Smile and Die } \\ \text { Eat and Die } & \text { Lie and Live } & \text { Rise and Die } & \text { Smile and Live } \\ \text { Eat and Live } & \text { Come and Die } & \text { Rise and Live } & \text { Red and Die } \\ \text { Cut and Die } & \text { Come and Live } & \text { Feel and Die } & \text { Red and Live } \\ \text { Cut and Live } & \text { Hear and Die } & \text { Feel and Live } & \text { Think and Die } \\ \text { Sleep and Die } & \text { Hear and Live } & \text { Stand and Die } & \text { Think and Live } \\ \text { Sleep and Live } & \text { Go and Die } & \text { Stand and Live } & \text { Yellow and Die } \\ \text { Run and Die } & \text { Go and Live } & \text { Fear and Die } & \text { Yellow and Live } \\ \text { Run and Live } & \text { Cry and Die } & \text { Fear and Live } & \text { Pay and Die } \\ \text { Love and Die } & \text { Cry and Live } & \text { Sit and Die } & \text { Pay and Live }\end{array}$




$\begin{array}{llll}\text { Viva e Morra } & \text { Ame e Viva } & \text { Conheça e Morra } & \text { Sente e Viva } \\ \text { Viva e Viva } & \text { Fique e Morra } & \text { Conheça e Viva } & \text { Doente e Morra } \\ \text { Cante e Morra } & \text { Fique e Viva } & \text { Beije e Morra } & \text { Doente e Viva } \\ \text { Cante e Viva } & \text { Odeie e Morra } & \text { Beije e Viva } & \text { Cuspa e Morra } \\ \text { Morra e Morra } & \text { Odeie e Viva } & \text { Conte e Morra } & \text { Cuspa e Viva } \\ \text { Morra e Viva } & \text { Brinque e Morra } & \text { Conte e Viva } & \text { São e Morra } \\ \text { Grite e Morra } & \text { Brinque e Viva } & \text { Enfureça e Morra } & \text { São e Viva } \\ \text { Grite e Viva } & \text { Foda e Morra } & \text { Enfureça e Viva } & \text { Tente e Morra } \\ \text { Cague e Morra } & \text { Foda e Viva } & \text { Cheire e Morra } & \text { Tente e Viva } \\ \text { Cague e Viva } & \text { Mate e Morra } & \text { Cheire e Viva } & \text { Preto e Morra } \\ \text { Jovem e Morra } & \text { Mate e Viva } & \text { Ria e Morra } & \text { Preto e Viva } \\ \text { Jovem e Viva } & \text { Fale e Morra } & \text { Ria e Viva } & \text { Fracasse e Morra } \\ \text { Mije e Morra } & \text { Fale e Viva } & \text { Caia e Morra } & \text { Fracasse e Viva } \\ \text { Mije e Viva } & \text { Chupe e Morra } & \text { Caia e Viva } & \text { Branco e Morra } \\ \text { Velho e Morra } & \text { Chupe e Viva } & \text { Toque e Morra } & \text { Branco e Viva } \\ \text { Velho e Viva } & \text { Minta e Morra } & \text { Toque e Viva } & \text { Sorria e Morra } \\ \text { Coma e Morra } & \text { Minta e Viva } & \text { Erga e Morra } & \text { Sorria e Viva } \\ \text { Coma e Viva } & \text { Venha e Morra } & \text { Erga e Viva } & \text { Vermelho e Morra } \\ \text { Corte e Morra } & \text { Venha e Viva } & \text { Sinta e Morra } & \text { Vermelho e Viva } \\ \text { Corte e Viva } & \text { Ouça e Morra } & \text { Sinta e Viva } & \text { Pense e Morra } \\ \text { Durma e Morra } & \text { Ouça e Viva } & \text { Levante e Morra } & \text { Pense e Viva } \\ \text { Durma e Viva } & \text { Vá e Morra } & \text { Levante e Viva } & \text { Amarelo e Morra } \\ \text { Corra e Morra } & \text { Vá e Viva } & \text { Tema e Morra } & \text { Amarelo e Viva } \\ \text { Corra e Viva } & \text { Chore e Morra } & \text { Tema e Viva } & \text { Pague e Morra } \\ \text { Ame e Morra } & \text { Chore e Viva } & \text { Sente e Morra } & \text { Pague e Viva }\end{array}$




$\begin{array}{llll}\text { Live and Die } & \text { Love and Live } & \text { Know and Die } & \text { Sit and Live } \\ \text { Live and Live } & \text { Stay and Die } & \text { Know and Live } & \text { Sick and Die } \\ \text { Sing and Die } & \text { Stay and Live } & \text { Kiss and Die } & \text { Sick and Live } \\ \text { Sing and Live } & \text { Hate and Die } & \text { Kiss and Live } & \text { Spit and Die } \\ \text { Die and Die } & \text { Hate and Live } & \text { Tell and Die } & \text { Spit and Live } \\ \text { Die and Live } & \text { Play and Die } & \text { Tell and Live } & \text { Well and Die } \\ \text { Scream and Die } & \text { Play and Live } & \text { Rage and Die } & \text { Well and Live } \\ \text { Scream and Live } & \text { Fuck and Die } & \text { Rage and Live } & \text { Try and Die } \\ \text { Shit and Die } & \text { Fuck and Live } & \text { Smell and Die } & \text { Try and Live } \\ \text { Shit and Live } & \text { Kill and Die } & \text { Smell and Live } & \text { Black and Die } \\ \text { Young and Die } & \text { Kill and Live } & \text { Laugh and Die } & \text { Black and Live } \\ \text { Young and Live } & \text { Speak and Die } & \text { Laugh and Live } & \text { Fail and Die } \\ \text { Piss and Die } & \text { Speak and Live } & \text { Fall and Die } & \text { Fail and Live } \\ \text { Piss and Live } & \text { Suck and Die } & \text { Fall and Live } & \text { White and Die } \\ \text { Old and Die } & \text { Suck and Live } & \text { Touch and Die } & \text { White and Live } \\ \text { Old and Live } & \text { Lie and Die } & \text { Touch and Live } & \text { Smile and Die } \\ \text { Eat and Die } & \text { Lie and Live } & \text { Rise and Die } & \text { Smile and Live } \\ \text { Eat and Live } & \text { Come and Die } & \text { Rise and Live } & \text { Red and Die } \\ \text { Cut and Die } & \text { Come and Live } & \text { Feel and Die } & \text { Red and Live } \\ \text { Cut and Live } & \text { Hear and Die } & \text { Feel and Live } & \text { Think and Die } \\ \text { Sleep and Die } & \text { Hear and Live } & \text { Stand and Die } & \text { Think and Live } \\ \text { Sleep and Live } & \text { Go and Die } & \text { Stand and Live } & \text { Yellow and Die } \\ \text { Run and Die } & \text { Go and Live } & \text { Fear and Die } & \text { Yellow and Live } \\ \text { Run and Live } & \text { Cry and Die } & \text { Fear and Live } & \text { Pay and Die } \\ \text { Love and Die } & \text { Cry and Live } & \text { Sit and Die } & \text { Pay and Live }\end{array}$




\begin{tabular}{|c|c|c|c|}
\hline Viver e Morrer & Amar e Viver & Conhecer e Morrer & Sentar e Viver \\
\hline Viver e Viver & Ficar e Morrer & Conhecer e Viver & Doente e Morrer \\
\hline Cantar e Morrer & Ficar e Viver & Beijar e Morrer & Doente e Viver \\
\hline Cantar e Viver & Odiar e Morrer & Beijar e Viver & Cuspir e Morrer \\
\hline Morrer e Morrer & Odiar e Viver & Contar e Morrer & Cuspir e Viver \\
\hline Morrer e Viver & Brincar e Morrer & Contar e Viver & São e Morrer \\
\hline Gritar e Morrer & Brincar e Viver & Enfurecer e Morrer & São e Viver \\
\hline Gritar e Viver & Foder e Morrer & Enfurecer e Viver & Tentar e Morrer \\
\hline Cagar e Morrer & Foder e Viver & Cheirar e Morrer & Tentar e Viver \\
\hline Cagar e Viver & Matar e Morrer & Cheirar e Viver & Preto e Morrer \\
\hline Jovem e Morrer & Matar e Viver & Rir e Morrer & Preto e Viver \\
\hline Jovem e Viver & Falar e Morrer & Rir e Viver & Fracassar e Morrer \\
\hline Mijar e Morrer & Falar e Viver & Cair e Morrer & Fracassar e Viver \\
\hline Mijar e Viver & Chupar e Morrer & Cair e Viver & Branco e Morrer \\
\hline Velho e Morrer & Chupar e Viver & Tocar e Morrer & Branco e Viver \\
\hline Velho e Viver & Mentir e Morrer & Tocar e Viver & Sorrir e Morrer \\
\hline Comer e Morrer & Mentir e Viver & Erguer e Morrer & Sorrir e Viver \\
\hline Comer e Viver & Vir e Morrer & Erguer e Viver & Vermelho e Morrer \\
\hline Cortar e Morrer & Vir e Viver & Sentir e Morrer & Vermelho e Viver \\
\hline Cortar e Viver & Ouvir e Morrer & Sentir e Viver & Pensar e Morrer \\
\hline Dormir e Morrer & Ouvir e Viver & Levantar e Morrer & Pensar e Viver \\
\hline Dormir e Viver & Ir e Morrer & Levantar e Viver & Amarelo e Morrer \\
\hline Correr e Morrer & Ir e Viver & Temer e Morrer & Amarelo e Viver \\
\hline Correr e Viver & Chorar e Morrer & Temer e Viver & Pagar e Morrer \\
\hline Amar e Morrer & Chorar e Viver & Sentar e Morrer & Pagar e Viver \\
\hline
\end{tabular}


36. Este texto conta com versões em neon e em áudio, além de certos trechos aparecerem em litogravuras, pontas-secas e desenhos. Cf. NAUMAN, Bruce. Bruce Nauman: Raw Materials. Londres: Tate Press, 2004, p. 36-37. 
Good Boy Bad Boy, $1985^{37}$

Bom menino mau menino 


I was a good boy
You were a good boy
We were good boys
That was good
I was a good girl
You were a good girl
We were good girls
That was good
I was a bad boy
You were a bad boy
We were bad boys
That was bad
I was a bad girl
You were a bad girl
We were bad girls
That was bad
I am a virtuous man
You are a virtuous man
We are virtuous men
This is virtue
I am a virtuous woman
You are a virtuous woman
We are virtuous women
This is virtue
I am an evil man
You are an evil man
We are evil men
This is evil
I am an evil woman
You are an evil woman
We are evil women
This is evil
I'm alive
You're alive
We're alive
This is our life
I live the good life
You live the good life
We live the good life
This is the good life
I have work
You have work
We have work
This is work
W play
This
You
The


Eu fui um bom menino

Você foi um bom menino

Nós fomos bons meninos

Isso foi bom

Eu fui uma boa menina

Você foi uma boa menina

Nós fomos boas meninas

Isso foi bom

Eu fui um mau menino

Você foi um mau menino

Nós fomos maus meninos

Isso foi mau

Eu fui uma má menina

Você foi uma má menina

Nós fomos más meninas

Isso foi mau

Eu sou um homem virtuoso

Você é um homem virtuoso

Nós somos homens virtuosos

Isto é virtude

Eu sou uma mulher virtuosa

Você é uma mulher virtuosa

Nós somos mulheres virtuosas

Isto é virtude

Eu sou um homem malvado

Você é um homem malvado

Nós somos homens malvados

Isto é maldade

Eu sou uma mulher malvada

Você é uma mulher malvada

Nós somos mulheres malvadas

Isto é maldade

Eu estou vivo

Você está vivo

Nós estamos vivos

Isto é a nossa vida

Eu vivo uma vida boa

Você vive uma vida boa

Nós vivemos uma vida boa

Isto é uma vida boa

Eu tenho trabalho

Você tem trabalho

Nós temos trabalho

Isto é trabalho

Eu brinco/jogo

Você brinca/joga

Nós brincamos/jogamos

Isto é brincar/ jogar

Eu estou me divertindo

Você está se divertindo 
51 We're having fun

52 This is fun

53 I'm bored

54 You're bored

55 We're bored

56 Life is boring

$57 \quad$ I'm boring

58 You're boring

59 We're boring

60 This is boring

61 I have sex

62 You have sex

63 We have sex

64 This is sex

65 I love

66 You love

67 We love

68 This is our love

69 I hate

70 You hate

71 We hate

72 This is hating

73 I like to eat

74 You like to eat

75 We like to eat

76 This is eating

77 I like to drink

78 You like to drink

79 We like to drink

80 This is drinking

81 I (like to) shit

82 You (like to) shit

83 We (like to) shit

84 This is shit(ing)

85 I piss

86 You piss

87 We piss

88 This is piss

89 I like to sleep

90 You like to sleep

91 We like to sleep

92 Sleep well

93 I pay

94 You pay

95 We pay

96 This is payment

97 I don't' want to die

98 You don't want to die

99 We don't want to die

100 This is fear of death 


\begin{tabular}{|c|c|}
\hline 51 & Nós estamos nos divertindo \\
\hline 52 & Isto é diversão \\
\hline 53 & Eu estou entediado \\
\hline 54 & Você está entediado \\
\hline 55 & Nós estamos entediados \\
\hline 56 & Vida é entediante \\
\hline 57 & Eu sou entediante \\
\hline 58 & Você é entediante \\
\hline 59 & Nós somos entediantes \\
\hline 60 & Isto é entediante \\
\hline 61 & Eu faço sexo \\
\hline 62 & Você faz sexo \\
\hline 63 & Nós fazemos sexo \\
\hline 64 & Isto é sexo \\
\hline 65 & Eu amo \\
\hline 66 & Você ama \\
\hline 67 & Nós amamos \\
\hline 68 & Isto é nosso amor \\
\hline 69 & Eu odeio \\
\hline 70 & Você odeia \\
\hline 71 & Nós odiamos \\
\hline 72 & Isto é odiar \\
\hline 73 & Eu gosto de comer \\
\hline 74 & Você gosta de comer \\
\hline 75 & Nós gostamos de comer \\
\hline 76 & Isto é comer \\
\hline 77 & Eu gosto de beber \\
\hline 78 & Você gosta de beber \\
\hline 79 & Nós gostamos de beber \\
\hline 80 & Isto é beber \\
\hline 81 & Eu (gosto de) cagar \\
\hline 82 & Você (gosta de) cagar \\
\hline 83 & Nós (gostamos de) cagar \\
\hline 84 & Isto é merda (cagar) \\
\hline 85 & Eu mijo \\
\hline 86 & Você mija \\
\hline 87 & Nós mijamos \\
\hline 88 & Isto é mijo \\
\hline 89 & Eu gosto de dormir \\
\hline 90 & Você gosta de dormir \\
\hline 91 & Nós gostamos de dormir \\
\hline 92 & Durma bem \\
\hline 93 & Eu pago \\
\hline 94 & Você paga \\
\hline 95 & Nós pagamos \\
\hline 96 & Isto é pagamento \\
\hline 97 & Eu não quero morrer \\
\hline 98 & Você não quer morrer \\
\hline 99 & Nós não queremos morrer \\
\hline 100 & Isto é medo da morte \\
\hline
\end{tabular}


37. Este texto foi elaborado para a videoinstalação homônima, composta de dois televisores: em um deles, as cem frases são recitadas por um ator, e, no outro, por uma atriz. 0 texto conta ainda com uma versão em neon. Foi integralmente publicado na revista Parkett (n. 10, set., 1986, p. 58-59). Cf. NAUMAN, Bruce. Bruce Nauman: Raw Materials. Londres: Tate Press, 2004, p. 56-57. 
Violent Incident, $1986^{38}$

Incidente violento 
The scene includes a table set for two with chairs in place and cocktails on the side.

The scene is shot in one take starting with a tightly framed low angle shot that will spiral up and away and clockwise until the finish of the action with the camera at a fairly high angle (looking down on the scene from above head-level) and having made one revolution of the scene.

Both part one and part two are shot with the same directions. I would see the action taking place on the left side of the table. Shot in accurate color.

1. The man holds a chair for the woman as she starts to sit down. The man pulls the chair out from under her and she falls to the floor. Man is amused but woman is angry.

2. Man turns and bends over to retrieve the chair and she gets up she gooses him.

3. Man stands up and turns and faces her now very angry also and calls her a name (shit- asshole-bitch-slutwhatever).

4. The woman reaches back to the table and takes a cocktail and throws it in the man's face.

5. Man slaps woman in the face.

6. Woman knees or kicks man in the groin.

7. Man is hurt and bends over, takes a knife from table, they struggle and she stabs.

8. He is stabbed. 
A cena inclui uma mesa preparada para dois com cadeiras no lugar e coquetéis ao lado.

A cena é filmada em uma única tomada que começa em ângulo baixo e enquadramento apertado e que irá mover-se em espiral em sentido horário até o fim da ação com a câmera posicionada em um ângulo razoavelmente elevado (olhando a cena de cima do nível da cabeça) e tendo feito uma volta completa na cena.

Tanto a parte um quanto a parte dois são filmadas segundo as mesmas instruções. Eu gostaria de ver a ação ocorrendo no lado esquerdo da mesa. Filmada em cores exatas.

1. O homem segura uma cadeira para a mulher que começa a sentar-se. O homem puxa a cadeira de debaixo da mulher e ela cai no chão. O homem se diverte, mas a mulher está furiosa.

2. Homem se vira e se curva para pegar a cadeira e ela se levanta e lhe cutuca o cu.

3. Homem se levanta e se vira e a encara agora também com muita raiva e a xinga (bosta-cu-cadela-vadia-o que for).

4. A mulher estica o braço em direção à mesa e pega um coquetel e o joga na cara do homem.

5. O homem estapeia a cara da mulher.

6. A mulher dá uma joelhada ou um chute no saco do homem

7. O homem está ferido e se debruça, pega uma faca da mesa, eles lutam e ela esfaqueia.

8. Ele é esfaqueado. 
All instructions are the same except the roles are reversed. Woman holds chair for man, pulls it away, man falls, gooses woman; she calls him a name, he throws a drink, she slaps, he kicks, she stabs and he stabs her. 
Todas as instruções são as mesmas, mas os papéis são invertidos. A mulher segura a cadeira para o homem, a remove, o homem cai, cutuca a mulher; ela o xinga, ele joga uma bebida, ela dá um tapa, ele chuta, ela esfaqueia e ele a esfaqueia. 
38. Roteiro para videoinstalação homônima composta de 12 monitores que reproduzem as ações descritas em cenas ligeiramente diferentes e de modo não sincronizado. Cf. KRAYNAK, Janet (Ed.). Op. cit., p. 96-97. 
Pete and Repeat, $1987^{39}$

Pita e Repita 
Pete and Repeat were sitting on a fence. Pete fell off. Who was left? Repeat. Pete and Repeat were sitting on a fence. Pete fell off. Who was left? Repeat. Pete and Repeat were sitting on a fence. Pete fell off. Who was left? Repeat. Pete and Repeat were sitting on a fence. Pete fell off. Who was left? Repeat. Pete and Repeat were sitting on a fence. Pete fell off. Who was left? Repeat. Pete and Repeat were sitting on a fence. Pete fell off. Who was left? Repeat. Pete and Repeat were sitting on a fence. Pete fell off. Who was left? Repeat. Pete and Repeat were sitting on a fence. Pete fell off. Who was left? Repeat. Pete and Repeat were sitting on a fence. Pete fell off. Who was left? Repeat. Pete and Repeat were sitting on a fence. Pete fell off. Who was left? Repeat. Pete and Repeat were sitting on a fence. Pete fell off. Who was left? Repeat. Pete and Repeat were sitting on a fence. Pete fell off. Who was left? Repeat. Pete and Repeat were sitting on a fence. Pete fell off. Who was left? Repeat. Pete and Repeat were sitting on a fence. Pete fell off. Who was left? Repeat. Pete and Repeat were sitting on a fence. Pete fell off. Who was left? Repeat. Pete and Repeat were sitting on a fence. Pete fell off. Who was left? Repeat. Pete and Repeat were sitting on a fence. Pete fell off. Who was left? Repeat. Pete and Repeat were sitting on a fence. Pete fell off. Who was left? Repeat. Pete and Repeat were sitting on a fence. Pete fell off. Who was left? Repeat. Pete and Repeat were sitting on a fence. Pete fell off. Who was left? Repeat. Pete and Repeat were sitting on a fence. Pete fell off. Who was left? Repeat. Pete and Repeat were sitting on a fence. Pete fell off. Who was left? Repeat. Pete and Repeat were sitting on a fence. Pete fell off. Who was left? Repeat. Pete and Repeat were sitting on a fence. Pete fell off. Who was left? Repeat. Pete and Repeat were sitting on a fence. Pete fell off. Who was left? Repeat. Pete and Repeat were sitting on a fence. Pete fell off. Who was left? Repeat. Pete and Repeat were sitting on a fence. Pete fell off. Who was left? Repeat. Pete and Repeat were sitting on a fence. Pete fell off. Who was left? Repeat. Pete and Repeat were sitting on a fence. Pete fell off. Who was left? Repeat. Pete and Repeat were sitting on a fence. Pete fell off. Who was left? Repeat. Pete and Repeat were sitting on a fence. Pete fell off. Who was left? Repeat. Pete and Repeat were sitting on a fence. Pete fell off. Who was left? Repeat. Pete and Repeat were sitting on a fence. Pete fell off. Who was left? Repeat. Pete and Repeat were sitting on a fence. Pete fell off. Who was left? Repeat. Pete and Repeat were sitting on a fence. Pete fell off. Who was left? Repeat. Pete and Repeat were sitting on a fence. Pete fell off. Who was left? Repeat. 
Pita e Repita estavam sentados numa cerca. Pita caiu. Quem ficou? Repita. Pita e Repita estavam sentados numa cerca. Pita caiu. Quem ficou? Repita. Pita e Repita estavam sentados numa cerca. Pita caiu. Quem ficou? Repita. Pita e Repita estavam sentados numa cerca. Pita caiu. Quem ficou? Repita. Pita e Repita estavam sentados numa cerca. Pita caiu. Quem ficou? Repita. Pita e Repita estavam sentados numa cerca. Pita caiu. Quem ficou? Repita. Pita e Repita estavam sentados numa cerca. Pita caiu. Quem ficou? Repita. Pita e Repita estavam sentados numa cerca. Pita caiu. Quem ficou? Repita. Pita e Repita estavam sentados numa cerca. Pita caiu. Quem ficou? Repita. Pita e Repita estavam sentados numa cerca. Pita caiu. Quem ficou? Repita. Pita e Repita estavam sentados numa cerca. Pita caiu. Quem ficou? Repita. Pita e Repita estavam sentados numa cerca. Pita caiu. Quem ficou? Repita. Pita e Repita estavam sentados numa cerca. Pita caiu. Quem ficou? Repita. Pita e Repita estavam sentados numa cerca. Pita caiu. Quem ficou? Repita. Pita e Repita estavam sentados numa cerca. Pita caiu. Quem ficou? Repita. Pita e Repita estavam sentados numa cerca. Pita caiu. Quem ficou? Repita. Pita e Repita estavam sentados numa cerca. Pita caiu. Quem ficou? Repita. Pita e Repita estavam sentados numa cerca. Pita caiu. Quem ficou? Repita. Pita e Repita estavam sentados numa cerca. Pita caiu. Quem ficou? Repita. Pita e Repita estavam sentados numa cerca. Pita caiu. Quem ficou? Repita. Pita e Repita estavam sentados numa cerca. Pita caiu. Quem ficou? Repita. Pita e Repita estavam sentados numa cerca. Pita caiu. Quem ficou? Repita. Pita e Repita estavam sentados numa cerca. Pita caiu. Quem ficou? Repita. Pita e Repita estavam sentados numa cerca. Pita caiu. Quem ficou? Repita. Pita e Repita estavam sentados numa cerca. Pita caiu. Quem ficou? Repita. Pita e Repita estavam sentados numa cerca. Pita caiu. Quem ficou? Repita. Pita e Repita estavam sentados numa cerca. Pita caiu. Quem ficou? Repita. Pita e Repita estavam sentados numa cerca. Pita caiu. Quem ficou? Repita. Pita e Repita estavam sentados numa cerca. Pita caiu. Quem ficou? Repita. Pita e Repita estavam sentados numa cerca. Pita caiu. Quem ficou? Repita. Pita e Repita estavam sentados numa cerca. Pita caiu. Quem ficou? Repita. Pita e Repita estavam sentados numa cerca. Pita caiu. Quem ficou? Repita. Pita e Repita estavam sentados numa cerca. Pita caiu. Quem ficou? Repita. Pita e Repita estavam sentados numa cerca. Pita caiu. Quem ficou? Repita.Repita estavam sentados numa cerca. Pita e Repita estavam sentados numa cerca. Pita caiu. Quem ficou? Repita. Pita e Repita 
39. Texto da série Clown Torture [Tortura do palhaço (1987)]. Cf. NAUMAN, Bruce. Bruce Nauman: Raw Materials. Londres: Tate Press, 2004, p. 32. 
Dark and Stormy Night, $1987^{40}$

Noite escura e tempestuosa 
It was a dark and stormy night. Three men were sitting around a campfire. One of the men said, "Tell us a story, Jack". And Jack said, "It was a dark and stormy night. Three men were sitting around a campfire. One of the men said, 'Tell us a story, Jack'. And Jack said, 'It was a dark and stormy night. Three men were sitting around a campfire. One of the men said, 'Tell us a story, Jack'. And Jack said, 'It was a dark and stormy night. Three men were sitting around a campfire. One of the men said, 'Tell us a story, Jack'. And Jack said, 'It was a dark and stormy night. Three men were sitting around a campfire. One of the men said, 'Tell us a story, Jack'. And Jack said, 'It was a dark and stormy night. Three men were sitting around a campfire. One of the men said, 'Tell us a story, Jack'. And Jack said, 'It was a dark and stormy night. Three men were sitting around a campfire. One of the men said, 'Tell us a story, Jack'. And Jack said, 'It was a dark and stormy night. Three men were sitting around a campfire. One of the men said, 'Tell us a story, Jack'. And Jack said, 'It was a dark and stormy night. Three men were sitting around a campfire. One of the men said, 'Tell us a story, Jack'. And Jack said, 'It was a dark and stormy night. Three men were sitting around a campfire. One of the men said, 'Tell us a story, Jack'. And Jack said, 'It was a dark and stormy night. Three men were sitting around a campfire. One of the men said, 'Tell us a story, Jack'. And Jack said, 'It was a dark and stormy night. Three men were sitting around a campfire. One of the men said, 'Tell us a story, Jack'. And Jack said, 'It was a dark and stormy night. Three men were sitting around a campfire. One of the men said, 'Tell us a story, Jack'. And Jack said, 'It was a dark and stormy night. Three men were sitting around a campfire. One of the men said, 'Tell us a story, Jack'. And Jack said, 'It was a dark and stormy night. Three men were sitting around a campfire. One of the men said, 'Tell us a story, Jack'. And Jack said, 'It was a dark and stormy night. Three men were sitting around a campfire. One of the men said, 'Tell us a story, Jack'. And Jack said, 'It was a dark and stormy night. Three men were sitting around a campfire. One of the men said, 'Tell us a story, Jack'. And Jack said, 'It was a dark and stormy night. Three men were sitting around a campfire. One of the men said, 'Tell us a story, Jack'. And Jack said, 'It was a dark and stormy night. Three men were sitting around a campfire. One of the men said, 'Tell us a story, Jack'. And Jack said, 'It was a dark and stormy night. Three men were sitting around a campfire. One of the men said, 'Tell us a story, Jack'. And Jack said, 'It was a dark and stormy night. Three men were sitting around a campfire. One of the men said, 'Tell us 
Era uma noite escura e tempestuosa. Três homens estavam sentados em volta de uma fogueira. Um dos homens disse, "Conte-nos uma história, Jack". E Jack disse, "Era uma noite escura e tempestuosa. Três homens estavam sentados em volta de uma fogueira. Um dos homens disse, 'Conte-nos uma história, Jack'. E Jack disse, 'Era uma noite escura e tempestuosa. Três homens estavam sentados em volta de uma fogueira. Um dos homens disse, 'Conte-nos uma história, Jack'. E Jack disse, "Era uma noite escura e tempestuosa. Três homens estavam sentados em volta de uma fogueira. Um dos homens disse, 'Conte-nos uma história, Jack'. E Jack disse, "Era uma noite escura e tempestuosa. Três homens estavam sentados em volta de uma fogueira. Um dos homens disse, 'Conte-nos uma história, Jack'. E Jack disse, "Era uma noite escura e tempestuosa. Três homens estavam sentados em volta de uma fogueira. Um dos homens disse, 'Conte-nos uma história, Jack'. E Jack disse, "Era uma noite escura e tempestuosa. Três homens estavam sentados em volta de uma fogueira. Um dos homens disse, 'Conte-nos uma história, Jack'. E Jack disse, "Era uma noite escura e tempestuosa. Três homens estavam sentados em volta de uma fogueira. Um dos homens disse, 'Conte-nos uma história, Jack'. E Jack disse, "Era uma noite escura e tempestuosa. Três homens estavam sentados em volta de uma fogueira. Um dos homens disse, 'Conte-nos uma história, Jack'. E Jack disse, "Era uma noite escura e tempestuosa. Três homens estavam sentados em volta de uma fogueira. Um dos homens disse, 'Conte-nos uma história, Jack'. E Jack disse, "Era uma noite escura e tempestuosa. Três homens estavam sentados em volta de uma fogueira. Um dos homens disse, 'Conte-nos uma história, Jack'. E Jack disse, "Era uma noite escura e tempestuosa. Três homens estavam sentados em volta de uma fogueira. Um dos homens disse, 'Conte-nos uma história, Jack'. E Jack disse, "Era uma noite escura e tempestuosa. Três homens estavam sentados em volta de uma fogueira. Um dos homens disse, 'Conte-nos uma história, Jack'. E Jack disse, "Era uma noite escura e tempestuosa. Três homens estavam sentados em volta de uma fogueira. Um dos homens disse, 'Conte-nos uma história, Jack'. E Jack disse, "Era uma noite escura e tempestuosa. Três homens estavam sentados em volta de uma fogueira. Um dos homens disse, 'Conte-nos uma história, Jack'. E Jack disse, "Era uma noite escura e tempestuosa. Três homens estavam sentados em volta de uma fogueira. Um dos homens disse, 'Conte-nos uma história, Jack'. E Jack disse, "Era uma noite escura e tempestuosa. Três homens estavam sentados em volta de uma fogueira. Um dos homens disse, 'Conte-nos uma história, Jack'. 
40. Texto da série Clown Torture [Tortura do palhaço (1987)]. Cf. NAUMAN, Bruce. Bruce Nauman: Raw Materials. Londres: Tate Press, 2004, p. 33. 
No no no no, $1987^{41}$

Não não não não 
No no no no no no no no no no no no no no no no no no no no no no no no no no no no no no no no no no no no no no no no no no no no no no no no no no no no no no no no no no no no no no no no no no no no no no no no no no no no no no no no no no no no no no no no no no no no no no no no no no no no no no no no no no no no no no no no no no no no no no no no no no no no no no no no no no no no no no no no no no no no no no no no no no no no no no no no no no no no no no no no no no no no no no no no no no no no no no no no no no no no no no no no no no no no no no no no no no no no no no no no no no no no no no no no no no no no no no no no no no no no no no no no no no no no no no no no no no no no no no no no no no no no no no no no no no no no no no no no no no no no no no no no no no no no no no no no no no no no no no no no no no no no no no no no no no no no no no no no no no no no no no no no no no no no no no no no no no no no no no no no no no no no no no no no no no no no no no no no no no no no no no no no no no no no no no no no no no no no no no no no no no no no no no no no no no no no no no no no no no no no no no no no no no no no no no no no no no no no no no no no no no no no no no no no no no no no no no no no no no no no no no no no no no no no no no no no no no no no no no no no no no no no no no no no no no no no no no no no no no no no no no no no no no no no no no no no no no no no no no no no no no no no no no no no no no no no no no no no no no no no no no no no no no no no no no no no no no no no no no no no no no no no no no no no no no no no no no no no no no no no no no no no no no no no no no no no no no no no no no no no no no no no no no no no no no no no no no no no no no no no no no no no no no no no no no no no no no no no no no no no no no no no no no no no no no no no no no no no no no no no no no no no no no no no no no no no no no no no no no no no no no no no no no no no no no no no no no no no no no no no no no no no no no no no no no no no no no no no no no no no no no no no no no no no no no no no no no no no no no no no no no no no no no no no no no no no no no no no no no no no no no no no no no no no no no no no no no no no no no no no no no no no no no no no no no no no no no no no no no no no no no no no no no no no no no no no no no no no no no no no no no no no no no no no no no no no no no no no no no no no no no no no no no no no no no no no no no no no no no no no no no no no no no no no no no no no no no no no no no no no no no no no no no no no no no no no no no no no no no no no no no no no no no no no no no no no no no no no no no no no no no no no no no no no no no no no no no no no no 
Não não não não não não não não não não não não não não não não não não não não não não não não não não não não não não não não não não não não não não não não não não não não não não não não não não não não não não não não não não não não não não não não não não não não não não não não não não não não não não não não não não não não não não não não não não não não não não não não não não não não não não não não não não não não não não não não não não não não não não não não não não não não não não não não não não não não não não não não não não não não não não não não não não não não não não não não não não não não não não não não não não não não não não não não não não não não não não não não não não não não não não não não não não não não não não não não não não não não não não não não não não não não não não não não não não não não não não não não não não não não não não não não não não não não não não não não não não não não não não não não não não não não não não não não não não não não não não não não não não não não não não não não não não não não não não não não não não não não não não não não não não não não não não não não não não não não não não não não não não não não não não não não não não não não não não não não não não não não não não não não não não não não não não não não não não não não não não não não não não não não não não não não não não não não não não não não não não não não não não não não não não não não não não não não não não não não não não não não não não não não não não não não não não não não não não não não não não não não não não não não não não não não não não não não não não não não não não não não não não não não não não não não não não não não não não não não não não não não não não não não não não não não não não não não não não não não não não não não não não não não não não não não não não não não não não não não não não não não não não não não não não não não não não não não não não não não não não não não não não não não não não não não não não não não não não não não não não não não não não não não não não não não não não não não não não não não não não não não não não não não não não não não não não não não não não não não não não não não não não não não não não não não não não não não não não não não não não não não não não não não não não não não não não não não não não não não não não não não não não não não não não não não não não não não não não não não não não não não não não não não não não não não não não não não não não não não não não não não não não não não não não não não não não não não não não não não não não não não não não não não não não não 
41. Texto da série Clown Torture [Tortura do palhaço (1987)]. Cf. NAUMAN, Bruce. Bruce Nauman: Raw Materials. Londres: Tate Press, 2004, p. 34-35. 
Shit In Your Hat - Head On A Chair, $1990^{42}$ Cague em seu chapéu - Cabeça numa cadeira 
Put your hat on the table. Put your head on your hat. Put your hand on your head with your head on your hat. Put your hat in your lap. Put your hand on your hat, your hat in your lap. Drop your hat. Put your hand in your lap. Put your head on your hand, your hand in your lap. Put your hand in your lap. Put your hat in your hand in your lap. Put your head on your lap, your hand in your lap. Put your hat on your face. Put your hand in your lap, your hat on your face. Put your hands on your face, your hat on your head. Put your hands in your lap, your hat on your head. Sit on your hat, your hands on your head. Shit in your hat. Show me your hat. Put your hat on your head. Put your head on the table. Put your hand on the table... 
Ponha o seu chapéu sobre a mesa. Ponha sua cabeça em seu chapéu. Ponha sua mão em sua cabeça com sua cabeça em seu chapéu. Ponha o seu chapéu no seu colo. Ponha sua mão em seu chapéu, seu chapéu no seu colo. Largue o seu chapéu. Ponha sua mão no seu colo. Ponha sua cabeça em sua mão, a sua mão no seu colo. Ponha sua mão no seu colo. Ponha o seu chapéu na sua mão no seu colo. Ponha sua cabeça em seu colo, sua mão no seu colo. Ponha o seu chapéu em seu rosto. Ponha sua mão no seu colo, seu chapéu em seu rosto. Ponha suas mãos em seu rosto, seu chapéu em sua cabeça. Ponha suas mãos no seu colo, seu chapéu em sua cabeça. Sente-se em seu chapéu, suas mãos em sua cabeça. Cague no seu chapéu. Mostre-me o seu chapéu. Ponha o seu chapéu em sua cabeça. Ponha a cabeça sobre a mesa. Ponha sua mão sobre a mesa... 
42. Este texto refere-se à vídeoinstalação homônima de 1990. Cf. NAUMAN, Bruce. Live or Die. Colônia: DuMont Buchverlag, 2010, p. 188-189. 
OK OK OK, $1990^{43}$

OK OK OK 
OK OK OK OK OK OK OK OK OK OK OK OK OK OK OK OK OK OK OK OK OK OK OK OK OK OK OK OK OK OK OK OK OK OK OK OK OK OK OK OK OK OK OK OK OK OK OK OK OK OK OK OK OK OK OK OK OK OK OK OK OK OK OK OK OK OK OK OK OK OK OK OK OK OK OK OK OK OK OK OK OK OK OK OK OK OK OK OK OK OK OK OK OK OK OK OK OK OK OK OK OK OK OK OK OK OK OK OK OK OK OK OK OK OK OK OK OK OK OK OK OK OK OK OK OK OK OK OK OK OK OK OK OK OK OK OK OK OK OK OK OK OK OK OK OK OK OK OK OK OK OK OK OK OK OK OK OK OK OK OK OK OK OK OK OK OK OK OK OK OK OK OK OK OK OK OK OK OK OK OK OK OK OK OK OK OK OK OK OK OK OK OK OK OK OK OK OK OK OK OK OK OK OK OK OK OK OK OK OK OK OK OK OK OK OK OK OK OK OK OK OK OK OK OK OK OK OK OK OK OK OK OK OK OK OK OK OK OK OK OK OK OK OK OK OK OK OK OK OK OK OK OK OK OK OK OK OK OK OK OK OK OK OK OK OK OK OK OK OK OK OK OK OK OK OK OK OK OK OK OK OK OK OK OK OK OK OK OK OK OK OK OK OK OK OK OK OK OK OK OK OK OK OK OK OK OK OK OK OK OK OK OK OK OK OK OK OK OK OK OK OK OK OK OK OK OK OK OK OK OK OK OK OK OK OK OK OK OK OK OK OK OK OK OK OK OK OK OK OK OK OK OK OK OK OK OK OK OK OK OK OK OK OK OK OK OK OK OK OK OK OK OK OK OK OK OK OK OK OK OK OK OK OK OK OK OK OK OK OK OK OK OK OK OK OK OK OK OK OK OK OK OK OK OK OK OK OK OK OK OK OK OK OK OK OK OK OK OK OK OK OK OK OK OK OK OK OK OK OK OK OK OK OK OK OK OK OK OK OK OK OK OK OK OK OK OK OK OK OK OK OK OK OK OK OK OK OK OK OK OK OK OK OK OK OK OK OK OK OK OK OK OK OK OK OK OK OK OK OK OK OK OK OK OK OK OK OK OK OK OK OK OK OK OK OK OK OK OK OK OK OK OK OK OK OK OK OK OK OK OK OK OK OK OK OK OK OK OK OK OK OK OK OK OK OK OK OK OK OK OK OK OK OK OK OK OK OK OK OK OK OK OK OK OK OK OK OK OK OK OK OK OK OK OK OK OK OK OK OK OK OK OK OK OK OK OK OK OK OK OK OK OK OK OK OK OK OK OK OK OK OK OK OK OK OK OK OK OK OK OK OK OK OK OK OK OK OK OK OK OK OK OK OK OK OK OK OK OK OK OK OK OK OK OK OK OK OK OK OK OK OK OK OK OK OK OK OK OK OK OK OK OK OK OK OK OK OK OK OK OK OK OK OK OK OK OK OK OK OK OK OK OK OK OK OK OK OK OK OK OK OK OK OK OK OK OK OK OK OK OK OK OK OK OK OK OK OK OK OK OK OK OK OK OK OK OK OK OK OK OK OK OK OK OK OK OK OK OK OK OK OK OK OK OK OK OK OK OK OK OK OK OK OK OK OK OK OK OK OK OK OK OK OK OK OK OK OK OK OK OK OK OK OK OK OK OK OK OK OK OK OK 
OK OK OK OK OK OK OK OK OK OK OK OK OK OK OK OK OK OK OK OK OK OK OK OK OK OK OK OK OK OK OK OK OK OK OK OK OK OK OK OK OK OK OK OK OK OK OK OK OK OK OK OK OK OK OK OK OK OK OK OK OK OK OK OK OK OK OK OK OK OK OK OK OK OK OK OK OK OK OK OK OK OK OK OK OK OK OK OK OK OK OK OK OK OK OK OK OK OK OK OK OK OK OK OK OK OK OK OK OK OK OK OK OK OK OK OK OK OK OK OK OK OK OK OK OK OK OK OK OK OK OK OK OK OK OK OK OK OK OK OK OK OK OK OK OK OK OK OK OK OK OK OK OK OK OK OK OK OK OK OK OK OK OK OK OK OK OK OK OK OK OK OK OK OK OK OK OK OK OK OK OK OK OK OK OK OK OK OK OK OK OK OK OK OK OK OK OK OK OK OK OK OK OK OK OK OK OK OK OK OK OK OK OK OK OK OK OK OK OK OK OK OK OK OK OK OK OK OK OK OK OK OK OK OK OK OK OK OK OK OK OK OK OK OK OK OK OK OK OK OK OK OK OK OK OK OK OK OK OK OK OK OK OK OK OK OK OK OK OK OK OK OK OK OK OK OK OK OK OK OK OK OK OK OK OK OK OK OK OK OK OK OK OK OK OK OK OK OK OK OK OK OK OK OK OK OK OK OK OK OK OK OK OK OK OK OK OK OK OK OK OK OK OK OK OK OK OK OK OK OK OK OK OK OK OK OK OK OK OK OK OK OK OK OK OK OK OK OK OK OK OK OK OK OK OK OK OK OK OK OK OK OK OK OK OK OK OK OK OK OK OK OK OK OK OK OK OK OK OK OK OK OK OK OK OK OK OK OK OK OK OK OK OK OK OK OK OK OK OK OK OK OK OK OK OK OK OK OK OK OK OK OK OK OK OK OK OK OK OK OK OK OK OK OK OK OK OK OK OK OK OK OK OK OK OK OK OK OK OK OK OK OK OK OK OK OK OK OK OK OK OK OK OK OK OK OK OK OK OK OK OK OK OK OK OK OK OK OK OK OK OK OK OK OK OK OK OK OK OK OK OK OK OK OK OK OK OK OK OK OK OK OK OK OK OK OK OK OK OK OK OK OK OK OK OK OK OK OK OK OK OK OK OK OK OK OK OK OK OK OK OK OK OK OK OK OK OK OK OK OK OK OK OK OK OK OK OK OK OK OK OK OK OK OK OK OK OK OK OK OK OK OK OK OK OK OK OK OK OK OK OK OK OK OK OK OK OK OK OK OK OK OK OK OK OK OK OK OK OK OK OK OK OK OK OK OK OK OK OK OK OK OK OK OK OK OK OK OK OK OK OK OK OK OK OK OK OK OK OK OK OK OK OK OK OK OK OK OK OK OK OK OK OK OK OK OK OK OK OK OK OK OK OK OK OK OK OK OK OK OK OK OK OK OK OK OK OK OK OK OK OK OK OK OK OK OK OK OK OK OK OK OK OK OK OK OK OK OK OK OK OK OK OK OK OK OK OK OK OK OK OK OK OK OK OK OK OK OK OK OK OK OK OK OK OK OK OK OK OK OK OK OK OK OK OK OK OK OK OK OK OK OK OK OK OK OK OK OK OK OK OK OK OK OK OK OK OK OK OK OK OK OK OK OK OK OK OK OK OK OK OK 
43. Texto para vídeo homônimo da série "Raw Material”, realizada em 1990. Cf. NAUMAN, Bruce. Bruce Nauman: Raw Materials. Londres: Tate Press, 2004, p. 40. 
Anthro/ Socio, $1991^{44}$

Antro/ Sócio 
Feed $\mathrm{Me}$

Eat $\mathrm{Me}$

Anthropology

Help Me

Hurt Me

Sociology 
Alimente-me

Coma-me

Antropologia

Ajude-me

Fira-me

Sociologia 
44. Texto da videoinstalação homônima. Cf. NAUMAN, Bruce. Bruce Nauman: Raw Materials. Londres: Tate Press, 2004, p. 106-109. 
Thank You Thank You, 1992 ${ }^{45}$

Obrigado Obrigado 
Thank you thank you thank you thank you thank you thank you thank you thank you thank you thank you thank you thank you thank you thank you thank you thank you thank you thank you thank you thank you thank you thank you thank you thank you thank you thank you thank you thank you thank you thank you thank you thank you thank you thank you thank you thank you thank you thank you thank you thank you thank you thank you thank you thank you thank you thank you thank you thank you thank you thank you thank you thank you thank you thank you thank you thank you thank you thank you thank you thank you thank you thank you thank you thank you thank you thank you thank you thank you thank you thank you thank you thank you thank you thank you thank you thank you thank you thank you thank you thank you thank you thank you thank you thank you thank you thank you thank you thank you thank you thank you thank you thank you thank you thank you thank you thank you thank you thank you thank you thank you thank you thank you thank you thank you thank you thank you thank you thank you thank you thank you thank you thank you thank you thank you thank you thank you thank you thank you thank you thank you thank you thank you thank you thank you thank you thank you thank you thank you thank you thank you thank you thank you thank you thank you thank you thank you thank you thank you thank you thank you thank you thank you thank you thank you thank you thank you thank you thank you thank you thank you thank you thank you thank you thank you thank you thank you thank you thank you thank you thank you thank you thank you thank you thank you thank you thank you thank you thank you thank you thank you thank you thank you thank you thank you thank you thank you thank you thank you thank you thank you thank you thank you thank you thank you thank you thank you thank you thank you thank you thank you thank you thank you thank you thank you thank you thank you thank you thank you thank you thank you thank you thank you thank you thank you thank you thank you thank you thank you thank you thank you thank you thank you thank you thank you thank you thank you thank you thank you thank you thank you thank you thank you thank you thank you thank you thank you thank you thank you thank you thank you thank you thank you thank you thank you thank you thank you thank you thank you thank you thank you thank you thank you thank you thank you thank you thank you thank you thank you thank you thank you thank you thank you thank you thank you thank you thank you thank you thank you thank you thank you thank you thank you thank you thank you thank you thank you thank you thank you thank you thank you thank you thank you thank you 


\begin{tabular}{|c|c|c|c|c|c|c|}
\hline 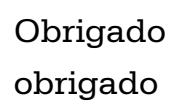 & & & & & & \\
\hline & & & & & & \\
\hline & & & & & & \\
\hline & & & & & & \\
\hline & & & & & & \\
\hline & o & & & & & \\
\hline & obric & do & obri & & & \\
\hline & & & & & & \\
\hline do & obri & & & & & \\
\hline & & & & & & \\
\hline & obri & & & & & \\
\hline & & & & & & \\
\hline & & & & & & \\
\hline & & & & & & \\
\hline & & & & & & \\
\hline do & obr & & & & & \\
\hline & & & & & & \\
\hline & obl & & & & & \\
\hline & & & & & & \\
\hline & & & & & & \\
\hline & & & & & & \\
\hline & & & & & & \\
\hline & & & & & & \\
\hline & & & & & & \\
\hline & & & & & & \\
\hline & o & & & & & \\
\hline & & & & & & \\
\hline & o & & & & & \\
\hline & & & & & & \\
\hline & obr & & & & & \\
\hline & & & & & & \\
\hline & & & & & & \\
\hline & & & & & & \\
\hline & & & & & & \\
\hline & obric & & & & & \\
\hline & & & & & & \\
\hline & 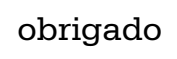 & 10 & & & & \\
\hline & oric & obrigado & obrigado & obrigado & obr & 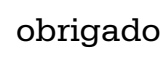 \\
\hline
\end{tabular}


45. Texto da série Clown Torture [Tortura do palhaço (1987)] . Cf. NAUMAN, Bruce. Bruce Nauman: Raw Materials. Londres: Tate Press, 2004, p. 27. 
Think Think Think, $1993^{46}$

Pense Pense Pense 
Think think think think think think think think think think think think think think think think think think think think think think think think think think think think think think think think think think think think think think think think think think think think think think think think think think think think think think think think think think think think think think think think think think think think think think think think think think think think think think think think think think think think think think think think think think think think think think think think think think think think think think think think think think think think think think think think think think think think think think think think think think think think think think think think think think think think think think think think think think think think think think think think think think think think think think think think think think think think think think think think think think think think think think think think think think think think think think think think think think think think think think think think think think think think think think think think think think think think think think think think think think think think think think think think think think think think think think think think think think think think think think think think think think think think think think think think think think think think think think think think think think think think think think think think think think think think think think think think think think think think think think think think think think think think think think think think think think think think think think think think think think think think think think think think think think think think think think think think think think think think think think think think think think think think think think think think think think think think think think think think think think think think think think think think think think think think think think think think think think think think think think think think think think think think think think think think think think think think think think think think think think think think think think think think think think think think think think think think think think think think think think think think think think think think think think think think think think think think think think think think think think think think think think think think think think think think think think think think think think think think think think think think think think think think think think think think think think think think think think think think think think think think think think think think think think think think think think think think think think think think think think think think think think think think 
Pense pense pense pense pense pense pense pense pense pense pense pense pense pense pense pense pense pense pense pense pense pense pense pense pense pense pense pense pense pense pense pense pense pense pense pense pense pense pense pense pense pense pense pense pense pense pense pense pense pense pense pense pense pense pense pense pense pense pense pense pense pense pense pense pense pense pense pense pense pense pense pense pense pense pense pense pense pense pense pense pense pense pense pense pense pense pense pense pense pense pense pense pense pense pense pense pense pense pense pense pense pense pense pense pense pense pense pense pense pense pense pense pense pense pense pense pense pense pense pense pense pense pense pense pense pense pense pense pense pense pense pense pense pense pense pense pense pense pense pense pense pense pense pense pense pense pense pense pense pense pense pense pense pense pense pense pense pense pense pense pense pense pense pense pense pense pense pense pense pense pense pense pense pense pense pense pense pense pense pense pense pense pense pense pense pense pense pense pense pense pense pense pense pense pense pense pense pense pense pense pense pense pense pense pense pense pense pense pense pense pense pense pense pense pense pense pense pense pense pense pense pense pense pense pense pense pense pense pense pense pense pense pense pense pense pense pense pense pense pense pense pense pense pense pense pense pense pense pense pense pense pense pense pense pense pense pense pense pense pense pense pense pense pense pense pense pense pense pense pense pense pense pense pense pense pense pense pense pense pense pense pense pense pense pense pense pense pense pense pense pense pense pense pense pense pense pense pense pense pense pense pense pense pense pense pense pense pense pense pense pense pense pense pense pense pense pense pense pense pense pense pense pense pense pense pense pense pense pense pense pense pense pense pense pense pense pense pense pense pense pense pense pense pense pense pense pense pense pense pense pense pense pense pense pense pense pense pense pense pense pense pense pense pense pense pense pense pense pense pense pense pense pense pense pense pense pense pense pense pense pense pense pense pense pense pense pense pense pense pense pense pense pense pense pense pense pense pense pense pense pense pense pense pense pense pense pense pense pense pense pense pense pense pense pense pense pense pense pense pense pense pense pense pense pense pense pense pense pense 
Work Work, $1993^{47}$

Trabalhe Trabalhe 
Work work work work work work work work work work work work work work work work work work work work work work work work work work work work work work work work work work work work work work work work work work work work work work work work work work work work work work work work work work work work work work work work work work work work work work work work work work work work work work work work work work work work work work work work work work work work work work work work work work work work work work work work work work work work work work work work work work work work work work work work work work work work work work work work work work work work work work work work work work work work work work work work work work work work work work work work work work work work work work work work work work work work work work work work work work work work work work work work work work work work work work work work work work work work work work work work work work work work work work work work work work work work work work work work work work work work work work work work work work work work work work work work work work work work work work work work work work work work work work work work work work work work work work work work work work work work work work work work work work work work work work work work work work work work work work work work work work work work work work work work work work work work work work work work work work work work work work work work work work work work work work work work work work work work work work work work work work work work work work work work work work work work work work work work work work work work work work work work work work work work work work work work work work work work work work work work work work work work work work work work work work work work work work work work work work work work work work work work work work work work work work work work work work work work work work work work work work work work work work work work work work work work work work work work work work work work work work work work work work work work work work work work work work work work work work work work work work work work work work work work work work work work work work work work work work work work work work work work work work work work work work work work work work work work 
Trabalhe trabalhe trabalhe trabalhe trabalhe trabalhe trabalhe trabalhe trabalhe trabalhe trabalhe trabalhe trabalhe trabalhe trabalhe trabalhe trabalhe trabalhe trabalhe trabalhe trabalhe trabalhe trabalhe trabalhe trabalhe trabalhe trabalhe trabalhe trabalhe trabalhe trabalhe trabalhe trabalhe trabalhe trabalhe trabalhe trabalhe trabalhe trabalhe trabalhe trabalhe trabalhe trabalhe trabalhe trabalhe trabalhe trabalhe trabalhe trabalhe trabalhe trabalhe trabalhe trabalhe trabalhe trabalhe trabalhe trabalhe trabalhe trabalhe trabalhe trabalhe trabalhe trabalhe trabalhe trabalhe trabalhe trabalhe trabalhe trabalhe trabalhe trabalhe trabalhe trabalhe trabalhe trabalhe trabalhe trabalhe trabalhe trabalhe trabalhe trabalhe trabalhe trabalhe trabalhe trabalhe trabalhe trabalhe trabalhe trabalhe trabalhe trabalhe trabalhe trabalhe trabalhe trabalhe trabalhe trabalhe trabalhe trabalhe trabalhe trabalhe trabalhe trabalhe trabalhe trabalhe trabalhe trabalhe trabalhe trabalhe trabalhe trabalhe trabalhe trabalhe trabalhe trabalhe trabalhe trabalhe trabalhe trabalhe trabalhe trabalhe trabalhe trabalhe trabalhe trabalhe trabalhe trabalhe trabalhe trabalhe trabalhe trabalhe trabalhe trabalhe trabalhe trabalhe trabalhe trabalhe trabalhe trabalhe trabalhe trabalhe trabalhe trabalhe trabalhe trabalhe trabalhe trabalhe trabalhe trabalhe trabalhe trabalhe trabalhe trabalhe trabalhe trabalhe trabalhe trabalhe trabalhe trabalhe trabalhe trabalhe trabalhe trabalhe trabalhe trabalhe trabalhe trabalhe trabalhe trabalhe trabalhe trabalhe trabalhe trabalhe trabalhe trabalhe trabalhe trabalhe trabalhe trabalhe trabalhe trabalhe trabalhe trabalhe trabalhe trabalhe trabalhe trabalhe trabalhe trabalhe trabalhe trabalhe trabalhe trabalhe trabalhe trabalhe trabalhe trabalhe trabalhe trabalhe trabalhe trabalhe trabalhe trabalhe trabalhe trabalhe trabalhe trabalhe trabalhe trabalhe trabalhe trabalhe trabalhe trabalhe trabalhe trabalhe trabalhe trabalhe trabalhe trabalhe trabalhe trabalhe trabalhe trabalhe trabalhe trabalhe trabalhe trabalhe trabalhe trabalhe trabalhe trabalhe trabalhe trabalhe trabalhe trabalhe trabalhe trabalhe trabalhe trabalhe trabalhe trabalhe trabalhe trabalhe trabalhe trabalhe trabalhe trabalhe trabalhe trabalhe trabalhe trabalhe trabalhe trabalhe trabalhe trabalhe trabalhe trabalhe trabalhe trabalhe trabalhe trabalhe trabalhe trabalhe trabalhe trabalhe trabalhe trabalhe trabalhe trabalhe trabalhe trabalhe trabalhe trabalhe trabalhe trabalhe trabalhe trabalhe trabalhe trabalhe trabalhe trabalhe trabalhe trabalhe trabalhe trabalhe trabalhe trabalhe trabalhe trabalhe trabalhe trabalhe trabalhe trabalhe trabalhe trabalhe trabalhe trabalhe trabalhe trabalhe trabalhe trabalhe trabalhe trabalhe trabalhe trabalhe trabalhe trabalhe trabalhe trabalhe trabalhe trabalhe trabalhe 
47. Texto da videoinstalação homônima. Cf. NAUMAN, Bruce. Bruce Nauman: Raw Materials Londres: Tate Press, 2004, p. 31. 
World Peace, $1996^{48}$

Paz mundial 
I'll talk

You'll listen

You'll talk

I'll listen

I'll talk

They'll listen

They'll talk

I'll listen

You'll talk

They'll listen

They'll talk

You'll listen

We'll talk

They'll listen

They'll talk

We'll listen

You'll talk

They'll listen

They'll talk

You'll listen

I'll talk

They'll listen

They'll talk

I'll listen

I'll talk

You'll listen

You'll talk

I'll listen 
Eu falarei

Você escutará

Você falará

Eu escutarei

Eu falarei

Eles escutarão

Eles falarão

Eu escutarei

Você falará

Eles escutarão

Eles falarão

Você escutará

Nós falaremos

Eles escutarão

Eles falarão

Nós escutaremos

Você falará

Eles escutarão

Eles falarão

Você escutará

Eu falarei

Eles escutarão

Eles falarão

Eu escutarei

Eu falarei

Você escutará

Você falará

Eu escutarei 
You'll talk to me

I'll listen to you

I'll talk to you

You'll listen to me

They'll talk to me

I'll listen to them

I'll talk to them

They'll listen to me

They'll talk to you

You'll listen to them

You'll talk to them

They'll listen to you

They'll talk to us

We'll listen to them

We'll talk to them

They'll listen to us

They'll talk to you

You'll listen to them

You'll talk to them

They'll listen to you

They'll talk to me

I'll listen to them

I'll talk to them

They'll listen to me

You'll talk to me

I'll listen to you

I'll talk to you

You'll listen to me 
Você falará comigo

Eu escutarei você

Eu falarei com você

Você me escutará

Eles falarão comigo

Eu os escutarei

Eu falarei com eles

Eles me escutarão

Eles falarão contigo

Você os escutará

Você falará com eles

Eles escutarão você

Eles falarão conosco

Nós os escutaremos

Nós falaremos com eles

Eles nos escutarão

Eles falarão contigo

Você os escutará

Você falará com eles

Eles escutarão você

Eles falarão comigo

Eu os escutarei

$\mathrm{Eu}$ falarei com eles

Eles me escutarão

Você falará comigo

Eu escutarei você

Eu falarei com você

Você me escutará 
48. Este texto faz parte da videoinstalação homônima e também conta com uma versão em áudio. Cf. NAUMAN, Bruce. Bruce Nauman: Raw Materials. Londres: Tate Press, 2004, p. 60-61. 
A Thousand Words:

Bruce Nauman Talks about Mapping the Studio, $2001^{49}$

Mil palavras:

Bruce Nauman fala sobre Mapping the Studio 
What triggered this piece were the mice. We had a big influx of field mice that summer, in the house and in the studio. They were so plentiful even the cat was getting bored with them. I was sitting around the studio being frustrated because I didn't have any new ideas, and I decided that you just have to work with what you've got. What I had was this cat and the mice, and I happened to have a video camera in the studio that had infrared capability. So I set it up and turned it on at night and let it run when I wasn't there, just to see what I'd get.

I have all this stuff lying around the studio, leftovers from different projects and unfinished projects and notes. And I thought to myself, Why not make a map of the studio and its leftovers? Then I thought it might be interesting to let the animals, the cat and the mice, make the map of the studio. So I set the camera up in different locations around the studio where the mice tended to travel just to see what they would do among the remnants of the work. The camera was eventually set up in a sequence of seven positions that I felt pretty much mapped the space.

I only had one camera, and I could only shoot one hour per night. So it's a compilation. There's forty-two hours altogether, made over forty-two nights of shooting in the course of four months. Before I went to bed I'd turn the camera on, and then in the morning I'd go out and see what had happened. The piece ended up being about six hours. (That is, each of the seven simultaneous video projections--representing each of the camera positions-runs six hours.) It just felt like it needed to be long so that you wouldn't necessarily sit down and watch the whole thing but could come and go, as with some of those Warhol films. I wanted that feeling that the piece was just there, almost like an object, just there, ongoing, being itself. I wanted the piece to have a real-time quality. I like the idea of knowing it is going on whether you are there or not.

"Fat chance," which I think is just an interesting saying, refers to a response for an invitation to be involved in an exhibition. Some time ago Anthony d'Offay was going to do a show of John Cage's scores, which are often very beautiful. He also wanted to show work by artists who were interested in or influenced by Cage. So he asked if I would send him something that related. Cage was an important influence for me, especially his writings. So I sent d'Offay a fax that said FAT CHANCE JOHN CAGE. D'Offay thought it was a refusal to participate. I thought it was the work. 
O que desencadeou este trabalho foram os camundongos. Nós tivemos uma grande invasão de camundongos silvestres naquele verão, na casa e no ateliê. Eles eram tão numerosos que até mesmo o gato estava ficando entediado. Estava sentado no ateliê me sentindo frustrado por não ter nenhuma nova ideia, e decidi que você precisa simplesmente trabalhar com o que tem. O que eu tinha eram este gato e os camundongos, e aconteceu de eu ter uma câmera de vídeo de infravermelho no ateliê. Assim, eu a posicionei e a liguei à noite e deixei que ela funcionasse quando eu não estava lá, só para ver o que eu conseguiria.

Eu tenho um monte de coisas por toda parte no meu ateliê, sobras de diferentes projetos, projetos inacabados e notas. Pensei comigo mesmo. Por que não fazer um mapa do ateliê e suas sobras? Então pensei que poderia ser interessante deixar que os animais, o gato e os camundongos, fizessem o mapa do ateliê. Então posicionei a câmera no ateliê em diferentes lugares pelos quais os camundongos tendiam a passar, só para ver o que eles fariam entre os restos dos trabalhos. A câmera foi, por fim, posicionada em uma sequência de sete posições que pareciam mapear bastante bem o espaço.

Eu só tinha uma câmera e só podia filmar uma hora por noite. Então é uma compilação. Tem quarenta e duas horas no total, feitas em quarenta e duas noites de filmagem no decorrer de quatro meses. Antes de ir para a cama, eu ligava a câmera, e então pela manhã saía e via o que havia acontecido. O trabalho acabou ficando com seis horas. (Isto é, cada uma das sete projeções de vídeo simultâneas - representando cada uma das posições da câmera - tem seis horas de duração). Parecia ter que ser longo, para que você não necessariamente se sentasse e assistisse a coisa toda, mas pudesse ir e vir, como com alguns filmes de Warhol. Eu queria aquela sensação de que o trabalho estivesse simplesmente lá, quase como um objeto, simplesmente lá, acontecendo, sendo ele mesmo. Eu queria que o trabalho tivesse uma qualidade de tempo real. Eu gosto da ideia de saber que ele está acontecendo quer você esteja lá ou não.

"Sem chance", que eu acho que é simplesmente uma expressão interessante, refere-se a uma resposta a um convite para que eu participasse de uma mostra. Algum tempo atrás, Anthony d'Offay pretendia fazer uma mostra com as partituras de John Cage, que são frequentemente muito belas. Ele também queria exibir trabalhos de artistas que tivessem interesse em John Cage ou tivessem sido 
I was interested in the relationship between the cat and the mice, but more in a psychological way. Their relationship exists somewhere between a joke and reality. They've been cartoon characters for so long that we think of them as lighthearted performers, but there is this obvious predator-prey tension between them. I wanted to create a situation that was slightly unclear as to how you should react. The overall effect is... ambiguous, maybe a little anxious. Then you can hear the dogs barking once in a while and the coyotes howling now and again. So there is also an element of what's going on inside and what's going on outside, which I like.

What I've felt in watching it is almost a meditation. Because the projection image is fairly large, if you try and concentrate on or pay attention to a particular spot in the image, you'll miss something. So you really have to not concentrate and allow your peripheral vision to work. You tend to get more if you just scan without seeking. You have to become passive, I think.

Because I wasn't shooting every night, every hour the camera moves a tiny bit. The image changes a little bit every hour regardless of any action that's taking place. I was working in the studio during the day all that time, and I would unconsciously move things around. Maybe organize a few things--what you do in a studio when you're supposedly not making art. So the areas that I was shooting tended to get cleaner or have fewer objects in them over the six hours. I thought that was kind of interesting.

It ends pretty much how it starts. It begins with a title and a few credits, and then basically it just starts, and then it ends. The image goes blank. No crescendo, no fade, no "The End." It just stops, like a long slice of time, just time in the studio. 
influenciados por ele. Por isso, ele perguntou se eu enviaria a ele alguma coisa relacionada. Cage foi uma importante influência para mim, especialmente seus escritos. Assim, enviei a d'Offay um fax que dizia SEM CHANCE JOHN CAGE. D'Offay achou que era uma recusa em participar. Eu achei que fosse o trabalho.

Eu estava interessado na relação entre gatos e camundongos, mas de um modo mais psicológico. Sua relação existe em algum lugar entre uma piada e a realidade. Eles foram desenhos animados por tanto tempo que pensamos neles como se fossem personagens despretensiosos, mas existe esta óbvia tensão predador-presa entre eles. Eu queria criar uma situação que fosse levemente difusa quanto a como você deveria reagir. $O$ efeito total é... ambíguo, talvez um pouco ansioso. Então, você pode ouvir os cães latindo de vez em quando, e os coiotes uivando vez ou outra. Portanto há também um elemento relacionado ao que está ocorrendo dentro e ao que está ocorrendo fora, de que eu gosto.

O que eu senti ao assisti-lo é quase uma meditação. Porque a imagem projetada é razoavelmente grande, se você tentar se concentrar em um ponto particular da imagem ou prestar atenção a ele, você irá perder alguma coisa. Então você realmente tem que não se concentrar, e permitir que sua visão periférica trabalhe. Você tende a obter mais se simplesmente vislumbrar sem buscar. Você tem que se tornar passivo, eu acho.

Porque eu não estava filmando todas as noites, a cada hora a câmera se move um pouquinho. A imagem muda um pouquinho a cada hora, a despeito de qualquer ação que esteja ocorrendo. Eu estava trabalhando no ateliê durante o dia todo o tempo, e mudava a posição das coisas inconscientemente. Talvez organizasse algumas coisas - aquilo que você faz num ateliê quando supostamente não está fazendo arte. Então as áreas que eu estava filmando tendiam a ficar mais limpas ou a possuir menos objetos no decorrer das seis horas. Achei isso interessante.

Ele termina basicamente como começa. Ele começa com um título e alguns créditos, e então, basicamente, ele simplesmente começa, e então ele termina. A imagem fica vazia. Sem crescendo, sem fade, sem "Fim". Simplesmente para, como uma longa fatia de tempo, simplesmente tempo passado no ateliê. 
49. Trata-se da edição de trechos das respostas de Nauman em entrevista concedida para Michael Auping. Foi publicado como sendo um escrito de Nauman em 2002, na Artforum 40 [n. 7, Nova York, mar. 2002, p. 120-121] e posteriormente em um catálogo de exposição [NAUMAN, Bruce. AC Bruce Nauman, Mapping the Studio I (Fat Chance John Cage). Colônia: Verlag der Buchhandlung Walther Koning, 2003]. 

Esta conversa ocorreu em 9 de julho de 2012, na escola de arte de Yale, em New Haven. Optou-se, aqui, por uma edição que preservasse ao máximo a oralidade da língua.

Robert Storr é artista, crítico de arte, curador, professor de história da arte e, atualmente, Diretor da Escola de Arte da Universidade Yale. Ocupou, entre 1990 e 2002, o posto de curador das áreas de pintura e escultura do Museu de Arte Moderna de Nova York (MoMA) e, em 2007, foi o primeiro norte-americano nomeado curador geral da Bienal de Veneza. Storr escreveu ensaios importantes sobre a obra de Bruce Nauman (coligidos na bibliografia desta tese) e foi curador de algumas mostras do artista, como a individual realizada no MoMA, em 1995; a coletiva "Dislocations", também no MoMA, em 1992, para a qual Nauman concebeu a videoinstalação Anthro/Socio; e a participação de Nauman na 24a. Bienal de São Paulo, em 1998, dentre outras. Além disso, Storr escreveu livros, ensaios e organizou mostras sobre diversos artistas contemporâneos (Gerhard Richter, Louise Bourgeois, Chuck Close, Philip Guston, Robert Ryman, Tony Smith, entre eles). 
Entrevista com Robert Storr 
L.B.: I would like to use this opportunity to ask about your opinion on certain topics that are tangent to the research I have been doing on the work of Bruce Nauman, which encompasses certain common points between his production and Samuel Beckett's, in particular the films and videos created by Nauman between 1967 and 1969 and Beckett's later works, such as the prose piece The Lost Ones and the TV play Quad I + II. I would specifically like you to comment on some of the remarks you have made in the essay Beyond Words (1994), where brief comparisons between Nauman and Beckett are drawn. At the time, you wrote that Nauman had "a keen ear for plain American English, and no matter how ambiguous his meaning, the pace and accents of his writing are sharply defined. Even on the page you hear him." Could you talk a bit more about this idea?

R.S.: I don't think Bruce's work has much to do with pronunciation, or anything like a regional accent or anything like that at all, it has more to do with very simple sentence construction, and very plain uses of nouns and verbs and adjectives and so on, and his is a kind of anti-literary style, at least a non-literary style - I mean, Bruce is not a poetry reader, he's not somebody who reads literature a great deal, although he's very knowledgeable; he reads a lot of things, but not for their obvious literary style, and I think what he likes in Beckett is the way that Beckett's mind works, the turn of mind that he has, and also that Beckett strips language down about as far as you can, at least in his best things.

L.B.: Yes, it seems to me that Beckett eviscerates language in search for an element that, while minimal, is still capable of communication... in that same essay, you also discuss Wittgenstein's thought, and point out some commonalities between his procedures and Nauman's. Could you comment on that?

R.S.:Wittgenstein's argument is not just about the sparseness of language, but also about just what language is, and his argument essentially - he changes his argument later on - is that only those statements which can be verified can be meaningful, and other language philosophers essentially developed this argument further to say that it may be the case that you don't know if something is true or not, but it's a different case when you 
L.B.: Gostaria de aproveitar a oportunidade desta conversa para saber a sua opinião sobre alguns assuntos que tangenciam a pesquisa que venho desenvolvendo sobre a obra de Bruce Nauman e que abrange aproximações pontuais com a produção de Samuel Beckett, especialmente entre os filmes e vídeos realizados por Nauman entre 1967 e 1969 e a obra tardia de Beckett, como a prosa The Lost Ones e a peça para veiculação na TV Quad I + II. Gostaria que você comentasse algumas das suas afirmações no ensaio Beyond Words (1994), no qual são traçadas breves comparações entre Nauman e Beckett. Na ocasião você escreveu que Nauman tem "um ouvido aguçado para o inglês americano simples, e independentemente do quão ambíguo seja o sentido que almeja estabelecer, as cadências de sua escrita são precisamente definidas. Mesmo no papel você consegue ouvilo". Você poderia falar mais sobre essa ideia?

R.S.: Não acho que a obra de Bruce tenha muita relação com questões de pronúncia ou qualquer coisa como um sotaque regionalista ou coisas dessa espécie, em absoluto, mas tem mais a ver com a construção de sentenças simples e empregos bem usuais de verbos e adjetivos e assim por diante, e o estilo dele é um tipo de estilo antiliterário ou, ao menos, um estilo nãoliterário - quer dizer, Bruce não é um leitor de poesia, ele não é alguém que leia muita literatura, embora ele tenha bastante conhecimento; ele lê muitas coisas, mas não por seu estilo literário óbvio, e eu acho que aquilo de que ele gosta em Beckett é o modo como a mente de Beckett funciona, o viés mental que ele possui, e também o fato de que Beckett despe a linguagem tanto quanto possível, ao menos em seus melhores trabalhos.

L.B.: Sim, parece-me que Beckett eviscera a linguagem em busca de um elemento que, embora mínimo, seja capaz de comunicar algo... No mesmo ensaio, você também aborda o pensamento de Wittgenstein e o aproxima de algumas operações de Nauman. Você poderia comentar sobre isso?

R.S.: $\mathrm{O}$ argumento de Wittgenstein não é somente sobre a simplicidade da linguagem, mas também sobre em que exatamente a linguagem consiste, e seu argumento, essencialmente - ele muda o argumento mais tarde - é que apenas aquelas proposições que puderem ser verificadas poderão ser dotadas de sentido, e outros filósofos da linguagem essencialmente desenvolveram 
cannot know if it's true or not, if there's no basis for saying "yes" or "no". And that is the crux of what Wittgenstein was talking about, language is only meaningful if one can say where the proof is, but he understood that that's not the sum of human experience, or aspiration either, and therefore we use approximations in language and other kinds of things. I think Bruce is very much of the same turn of mind, he is a kind of empiricist of matters for which there's no empirical proof.

L.B.: What about Beckett? Are there any possible analogies in that regard?

R.S.: I think Beckett is somebody who has a keen understanding of the sort of inevitable frustration of any attempts to find metaphysical meaning and, for that matter, any kind of meaning; one does things out of a certain drive or conviction, but one cannot rationalize or explain that conviction or drive, and Godot is not gonna show up and tell you you're right after all. Godot is kind of like Pascal's God, he's the God you can talk to, but he won't talk back.

L.B.: I insisted on bringing up Beckett because you've made a very insightful remark in one of the footnotes to the essay, but did not pursue the matter further. You wrote: "Beckett wrote in English and French to achieve verbal estrangement (...) Nauman's use of different visual idioms might be thought of as the rough equivalent of Beckett's bilingualism - that is, as a means of getting away from a certain inherent fluency in order to get closer to a sense of the inevitable artificiality and ambiguity of communication".

R.S.: And also, different languages are equipped to do different things, and there's not a mot juste, there's a nom juste.

L.B.: I would like to change the focus of our conversation to a piece I believe to be fundamental to Nauman's body of work, but which I personally did not have the opportunity to see and, therefore, would very much like to hear your impressions about; I am referring to "Raw 
esse argumento mais a fundo, de forma a afirmar que pode ser o caso que você não saiba se algo é verdade ou não, mas é uma situação muito diferente quando você não pode determinar se algo é ou não verdade, se não houver justificativa para que se diga "sim" ou "não". E esse é o cerne daquilo de que falava Wittgenstein, a linguagem somente será dotada de sentido se pudermos dizer onde está a prova, mas ele entendeu que aquela não era a totalidade da experiência humana, ou mesmo das aspirações humanas, e portanto nós nos valemos de aproximações na linguagem e em outros tipos de coisas. Eu acho que a mente de Bruce possui o mesmo viés, ele é uma espécie de empirista de questões para as quais não há prova empírica.

L.B.: E a respeito de Beckett? Há alguma aproximação possível nesse ponto? R.S.: Eu acho que Beckett é alguém que tem um entendimento agudo do tipo de frustração inevitável envolvido em quaisquer tentativas de encontrar sentido metafísico, ou mesmo sentido de qualquer outra espécie; fazemos as coisas com base em um determinado ímpeto ou convicção, mas não podemos racionalizar ou explicar tal convicção ou ímpeto, e Godot não irá aparecer e dizer a você que você estava certa no fim das contas. Godot é meio que como o Deus de Pascal, ele é o deus com quem você pode conversar, mas ele não responde.

L.B.: Insisti em mencionar Beckett porque você fez um comentário bastante pertinente em uma das notas de rodapé do ensaio, mas o assunto não foi enfatizado depois. Você escreveu: "Beckett escrevia em inglês e francês para alcançar um estranhamento verbal... [e] o uso que Nauman faz de diferentes linguagens visuais pode ser compreendido, grosso modo, como equivalente ao bilinguismo de Beckett - isto é, como um modo de escapar a certa fluência inerente, de forma a recuperar uma percepção da artificialidade e ambiguidade inevitáveis à comunicação".

R.S.: E também, linguagens diferentes estão equipadas para fazer coisas diferentes, e não há um mot juste, há apenas um nom juste. 
Materials", the large sound installation held at Tate Modern's Turbine Hall, in 2004. You interviewed Nauman at the time...

R.S.: Well, I was in the studio when Bruce was working on that piece so, what he did was to set speakers in the studio that would do what would happen in the Tate. I was unable to actually get to the Tate and hear it myself, so I only know from other people's descriptions how it actually was realized.

L.B.: Wow, what a pity. I thought you'd tell me in great detail your impressions of that space, filled with nothing but voices...

R.S.: I know what the principle involved was, I've seen the film, an audiofilm of somebody moving in the space, and I know how it was run around the studio, but I can't say "I was there."

L.B.: In the interview you conducted with Nauman before the opening of that show at Tate, you drew a comparison between the organization of sound in space and something you'd witnessed at a recent Bob Dylan concert: he would play old songs at a much faster pace, and it all sounded very much like a Jazz improvisation, since he used the material as a modular pattern that would be repeated with variations in rhythm and tempo... which is an interesting comparison, especially once one considers what a significant part of Nauman's life Jazz has been, at least at the time he played bass with small formations. Being here, and having had the opportunity to attend concerts with the way they used up the space provided, the multiple voices in Nauman's installation, and the emotional intensity they evoked, could be similar to hearing John Coltrane's material arranged for a Big Band... In this trip, I finally had the opportunity to listen to the live improvisations of musicians such as Cecil Taylor, McCoy Tyner, Joshua Redman, Ron Carter, and realize how different-sized line-ups and their distribution in space influence the way they improvise and, consequently, the way "sound masses" travel through the performance space, how they circle from side to side. And, of course, added to the technical dexterity of such virtuoso performers, these sounds provoke all kinds of emotional reactions in their transitions through space. Well, I imagine you've mentioned Bob Dylan's "improvisation" mostly due to the way he handled language, but I believe these things make a certain sense, don't they? 
L.B.: Gostaria de mudar o foco de nossa conversa para um trabalho que creio ser fundamental na obra de Nauman, mas que eu mesma não tive a oportunidade de ver ao vivo e, portanto, gostaria de seu depoimento e suas impressões a respeito; refiro-me a "Raw Materials", a grande instalação sonora montada no Turbine Hall da Tate Modern, em 2004. Você entrevistou Nauman na ocasião...

R.S.: Bem, eu estava no ateliê quando Bruce estava trabalhando naquela obra, o que ele fez foi montar alto-falantes no ateliê que fizessem o que deveria ocorrer na Tate. Não foi possível para mim ir até a Tate e ouvi-la pessoalmente, então eu conheço somente pela descrição de outras pessoas a maneira como foi de fato realizada.

L.B.: Puxa, que pena. Achei que você iria relatar com detalhes suas impressões daquele espaço, ocupado somente por vozes...

R.S.: Eu sei qual era o princípio envolvido, eu vi o filme, um audiofilme de alguém se movendo pelo espaço, e eu sei como foi realizado no espaço do ateliê, mas eu não posso dizer "eu estive lá".

L.B.: Na entrevista que você fez com Nauman antes da abertura dessa mostra na Tate, você esboçou uma comparação entre a organização do material sonoro no espaço e algo que você havia presenciado em um show recente de Bob Dylan: ele tocava músicas antigas do repertório, mas num ritmo muito mais rápido, e tudo soava a improvisações de Jazz, pois ele usava o material como um padrão modular e o repetia com andamentos e ritmos diversos... o que é uma comparação interessante, sobretudo se pensarmos o quanto o Jazz fez parte da vida de Nauman, ao menos na época em que ele tocava baixo em pequenas formações. Estando aqui e tendo a oportunidade de assistir a concertos com as mais diversas configurações eu posso entender melhor a sua comparação: talvez, no espaço, os arranjos de vozes na instalação de Nauman e a intensidade emocional que provocavam pudessem se assemelhar a ouvir John Coltrane tocado por uma Big Band... Nessa viagem, eu pude, enfim, ouvir as improvisações de músicos como Cecil Taylor, McCoy Tyner, Joshua Redman, Ron Carter e perceber como as diversas formações dos músicos no espaço influenciam o modo como 
R.S.: Yes, we're probably talking about the same thing. And, I don't remember the name of the piece, but the one that was in the show in Venice, and he showed it here in New York, it's the one with the slide guitar [End of the World]... and, he has, you know, a guy who just, all you see is the hands making the motion and turning it into music, and in one way that particular piece begins elsewhere, it doesn't begin with the sound, it doesn't even begin with the music per se, it's connected to the coffee cup pieces and to the whole idea that we train our hands, we train our bodies to do things that don't come naturally. The coffee cup pieces are about repeating the same mistake over and over again and not learning from experience, and not creating a second-nature, and the musical pieces are about creating a second-nature, and it's about creating a kind of articulateness and dexterity that is the positive version of learned behavior... but learned helplessness is the more likely outcome.

L.B.: I just recalled that Nauman once mentioned how much he liked Lennie Tristano and Coltrane.

R.S.: Lennie Tristano, by the way, was a musician who was very important to Bob Ryman, the painter Robert Ryman.

L.B.: Well, I thought of Tristano not only because of the intensity of his improvisations, or the fact that his interpretations stopped abruptly, with no previous indication of an approaching end, important characteristics for Nauman. I thought of him mostly because of the recurring appearance of hands in Nauman's work, and the image of Tristano's hands looking for the keys in a very particular way, as can be seen on videos currently available on the Internet...

R.S.: Have you seen the most recent big piece? You must've seen it in New York, the, the... what's it called... it's based on Bartók, For Children... The one with the fingers? 
improvisam e, consequentemente, o modo como as "massas sonoras" transitam no espaço, como circulam de um lado a outro. E, claro, junto com a manipulação da técnica que esses virtuoses alcançam, provocam reações emocionais completamente diversas nessas transições de sons no espaço. Bem, imagino que você tenha mencionado o "improviso" de Bob Dylan mais pelo modo como ele lidou com a linguagem, mas creio que todas essas coisas façam algum sentido, não?

R.S.: Sim, provavelmente estamos falando da mesma coisa. E, eu não me lembro do nome da obra, mas aquela que estava na mostra de Veneza, e que ele exibiu aqui em Nova York, é aquela com a slide guitar [End of the World]... e ele coloca um cara que só, tudo o que você vê são as mãos realizando o movimento e o transformando em música e, de certa forma, essa obra em particular começa em outro lugar, ela não começa com o som, ela nem mesmo começa com a música em si, ela está conectada às obras com xícaras de café e com toda aquela ideia de que nós adestramos nossas mãos, nós adestramos nossos corpos para fazer coisas que não nos vêm naturalmente. As obras com xícaras de café tratam da repetição do mesmo erro de novo e de novo, e do não-aprendizado a partir da experiência, e da não-criação de uma segunda natureza, e as obras musicais tratam da criação de uma segunda natureza, e da criação de uma espécie de capacidade de articulação e destreza que é a versão positiva de um comportamento aprendido... mas desamparo aprendido é o resultado mais provável.

L.B.: Lembrei-me agora de que Nauman certa vez afirmou gostar muito de Lennie Tristano e de Coltrane.

R.S.: Lennie Tristano, incidentalmente, foi um músico que teve grande importância para Bob Ryman, o pintor Robert Ryman.

L.B.: Bem, pensei em Tristano não apenas pela intensidade de seus improvisos ou pelo fato de que suas interpretações se encerrassem de rompante, sem dar indícios de que a finalização se aproximava, algo importante para Nauman. Pensei nele mais por causa da reincidência de mãos na obra de Nauman e nas imagem das mãos de Tristano buscando as 
L.B.: Yes, well, I know about it, but I haven't seen it in person, as the exhibition was over by the time I got to New York... Another topic I cannot avoid mentioning is the comparison you have made between the works of Nauman and the works of Paul McCarthy, connected to an exhibition held in Santa Fe, curated by you, the central theme of which was the grotesque in art. It seemed to me a bit uncalled for... well, I wasn't convinced...

R.S.: I mean, the connection is Paul knows Bruce's work, not that Bruce knows Paul's work, I mean, they actually know each other's work, kinda, now, but Bruce is the generation before Paul, not by much but by some, and the early performance pieces, and body-painting pieces, and all the things where he used himself as a protagonist, but also did it in a way where there's a kind of abjectness to the way he does it. The word "abject”, I'm not crazy about it, it's been overused, but I actually think it's the right word here, there's a kind of abjectness in the way that he does it I think probably had a profound influence on Paul, and other people as well, and, you know, I also don't mind telling you, all that performance dimension, all those people knew Bruce's work, and knew it well. In terms of object-making, Paul's cartoon casts of sculptures are not that far away from Bruce's casts of animal sculptures. So, materially speaking, if you say they have certain formal similarities, then the interesting thing is how they are different, or to what degree they are different. But they are, they are together in the same world, they involve many of the same material operations, cutting, reassembling, misassembling, for example. They locate their work in a kind of adolescent state, right? A kind of primal state. Bruce's work is not there very much, except for a few of his clown pieces; his work is really... "adult", let's call it that. And it's adult in a particular skeptical-but-I-wish-I-could-believe kind of way. McCarthy works with the tragic, Paul makes pieces about helpless physicalities...

L.B.: In my opinion, they use very different procedures, even opposite procedures: the works of Nauman all have to do with subtraction, reduction, contention. He will sometimes turn the pieces inside-out or upside-down in order to reveal what's inside, to put emptiness forward. 
teclas de um jeito muito particular, conforme se pode ver hoje em dia nos filmes disponíveis na internet...

R.S.: Você viu o mais recente trabalho grande? Você deve tê-lo visto em Nova York... baseado em Bartók, For Children [Para crianças]... Aquele com os dedos?

L.B.: Sim, bem, eu sei qualé, mas nãoo vi pessoalmente, pois a mostrajá havia se encerrado quando cheguei a Nova York... Outro assunto que não posso deixar de abordar é a comparação que você fez entre as obras de Nauman e as de Paul McCarthy, associada a uma exposição realizada em Santa Fe, com a sua curadoria, e cujo tema central era o grotesco na arte. Parece-me uma comparação um tanto despropositada... Bem, não me convenceu...

R.S.: Bem, a conexão é que Paul conhece o trabalho de Bruce, e não que Bruce conheça o trabalho de Paul; quer dizer, eles de fato conhecem o trabalho um do outro, mais ou menos, hoje em dia, mas Bruce é da geração anterior à de Paul, não por muito, mas um pouco, e as performances iniciais e trabalhos de pintura corporal e todas as coisas nas quais ele usa a si mesmo como protagonista, mas também o fez de uma forma na qual há uma espécie de abjeção na maneira como ele o faz. O termo "abjeto" não é um pelo qual eu tenha predileção, ele foi usado em excesso, mas eu acho que é de fato a palavra correta aqui. Há um tipo de abjeção na forma como ele o faz que eu acho que teve uma influência profunda sobre Paul e sobre outras pessoas também. Eu também não me importo de dizer a você que toda aquela dimensão performática, todas aquelas pessoas conheciam o trabalho de Bruce e o conheciam bem. Em termos de feitura de objetos, os moldes de personagens de desenho animado de Paul não são tão diferentes assim dos moldes de animais de Bruce. Portanto, falando em termos de materiais, se você disser que eles têm certas semelhanças formais, então o interessante é o quão diferentes eles são ou em que grau são diferentes. Mas eles estão juntos em um mesmo mundo, eles envolvem muitas das mesmas operações materiais, corte, "reassemblagem", misassembling, por exemplo. Os seus trabalhos se localizam em um estado de adolescência, 
McCarthy, on the other hand, creates pieces that imply a constant adding of elements, an excess of information, an unrestrained "expressiveness"...

R.S.: That is true, but also McCarthy does lots of reversals and things like that, so I'm not saying that you're wrong, I think there are big differences, and I think the differences are significant and they're interesting, but there, it's a case of where a comparison between the two of them doesn't exist in order to establish a lineage, or to create a movement or whatever, it's because what's different about them is also based on points of contact which are influencing how one reads them, you know. At least they influence how I read them. But, I mean, I'm a fan of both of them, number one. And I think they're very different, too. For example, I mean, Paul, Mike [Kelley] and Raymond Pettibon are all Catholic, and their Catholicism and their way of dealing with that is very much a part of what they do. Bruce is absolutely, absolutely not Catholic, and he's not Jewish either. I think he - without turning it into a matter of family heritage he comes from a very, very different cultural milieu, it's Midwestern, Protestant... reserved. Mike came from Catholic, Midwestern, and rebelled - hugely, right? Bruce never rebelled in quite the same way. Paul came from Catholic, also Midwestern, I think, and, again, rebellion, you know, violation of taboo was the point of the piece. For Bruce, violation of taboo has been done, but is not the reason for doing it.

L.B.: Since we have begun making comparisons, I'd like to ask you about any possible relations between the work of Nauman and Jasper Johns', an artist of a generation preceding Nauman's.

R.S.: Well, it's complex; first of all, Bruce respects Jasper a great deal. Jasper owns works by Bruce. There's been a kind of dialogue; they were in the same gallery for many, many, many years... I think their connection to Wittgenstein is part of it. I wouldn't say this with any certainty, but I think it would probably be the case that Bruce's discovery of Wittgenstein has somewhat to do with Johns' interest in Wittgenstein. 
certo? Um tipo de estado primário. A obra de Bruce não é assim com tanta frequência, com exceção de alguns dos trabalhos com palhaços; o trabalho dele é realmente... adulto, podemos dizer. E é adulto de uma forma muito particular, de um jeito meio que "cético-mas-gostaria-de-poderacreditar". McCarthy trabalha com o "trágico", Paul faz trabalhos sobre fisicalidades desamparadas...

L.B.: Na minha opinião, eles utilizam procedimentos diversos, mesmo procedimentos opostos: as obras de Nauman tratam de apagamento, redução, contenção. Às vezes, ele vira as peças do avesso ou de pontacabeça para mostrar o que está por dentro, para apresentar o vazio. Já McCarthy faz trabalhos que implicam constante adição de elementos, excesso de informações, "expressividade" incontida...

R.S.: Isso é verdade, mas McCarthy também produz grande quantidade de reversões e coisas do tipo, então não estou dizendo que você esteja errada, acho que existem diferenças grandes, e eu acho que as diferenças são significativas e são interessantes, mas o caso é que uma comparação entre os dois não existe com o intuito de estabelecer uma linhagem, ou criar um movimento ou qualquer coisa do tipo, porque o que é diferente entre eles também se baseia em pontos de contato que influenciam a leitura que se faz deles. Ao menos, eles influenciam como eu os leio. Mas eu sou um fã de ambos, em primeiro lugar. E eu também acho que eles são muito diferentes. Por exemplo, Paul, Mike [Kelley] e Raymond Pettibon são todos católicos, e o seu catolicismo e sua forma de lidar com isso é uma parte significativa do que eles fazem. Bruce não é católico em absoluto, e nem judeu. Eu acho que ele - sem querer transformar a questão em uma relativa à herança familiar - vem de um milieu cultural muito diferente, do meio-oeste, protestante, reservado. O Mike veio de um meio católico no meio-oeste, e se rebelou enormemente, certo? Bruce nunca se rebelou da mesma maneira, exatamente. Paul também veio de um meio católico, também no meio-oeste, eu acho, e uma vez mais, a rebeldia, sabe, a violação do tabu era a razão de ser da obra. Na obra de Bruce há violação de tabu, mas isso não é o motivo de realizá-la. 
I mean, a number of people were reading Wittgenstein at the time that this all happened, but I think Johns is one of the people who began that, early on. Jasper plays word games, as does Bruce, but he plays word games that create screens that you can never get through, you know, and so his deferral of meaning goes on for, it just feels like forever. In the case of Bruce, the ambiguities are not... It's a game of language played not within language, but within the experience of life, where language's ability to match human uncertainty is really the issue. In Jasper's case, there are indeed aspects of the same thing, but he's turned the game more formal, in a way - in linguistic terms, more formal. And he is actually talking about things that matter to him personally, but he doesn't tell you much about them in his work. But anyway I think there's a lot of resonance between the two of them.

L.B.: I also must ask you about the relation between Nauman's work and Duchamp's, even though at this point a question about Duchamp sounds entirely cliché...

R.S.: And what about Duchamp... Oddly enough, Bruce is not so interested in Duchamp... Which doesn't mean he wasn't really interested in him, that that's not where he got the stuff. And I think that also is one of the reasons that Bruce is not, for example, discussed as much as he should be in most of the American, sort of $60 \mathrm{~s}$ and $70 \mathrm{~s}$ and even into the 80 s general art histories, because the shift in this country was from the Picasso model to Duchamp. And the Rosalind Krauss version of it basically is you are on one team or you are on the other, or you were on one team and then you go onto the other. If you're not on the Duchamp team, you know, then you're on no team. And so she'll, she'll take people who were not really duchampians and turn them into duchampians, but she'll also ignore people who are insufficiently duchampian, even though she might have converted them. You know, Bruce plays a very small role in her writing about sculpture, very small, and a very small role in all of her 
L.B.: Uma vez que começamos a fazer comparações, eu gostaria de lhe perguntar sobre relações possíveis entre a obra de Nauman e a de Jasper Johns, um artista de uma geração que precede a de Nauman.

R.S.: Bem, é complexo; em primeiro lugar, Bruce respeita muito Jasper. Jasper possui obras de Bruce. Houve algum diálogo; eles estiveram na mesma galeria por muitos, muitos e muitos anos... Eu acho que a conexão deles com Wittgenstein é uma parte disso. Eu não diria isto com qualquer certeza, mas eu acho que deve provavelmente ser o caso que a descoberta de Bruce de Wittgenstein tenha algo a ver com o interesse de Johns por Wittgenstein. Quer dizer, um grande número de pessoas estava lendo Wittgenstein na época em que isso tudo aconteceu, mas eu acho que Johns é uma das pessoas que começaram com isso, bem cedo. Jasper faz jogos de linguagem, como Bruce, mas ele faz jogos que criam barreiras que não podem ser jamais atravessadas e, assim, esse decesso de sentido continua indefinidamente. No caso de Bruce, as ambiguidades não são... É um jogo de linguagem que não é jogado no interior da linguagem, mas no interior da experiência da vida, onde a habilidade da linguagem de se ajustar à incerteza humana é de fato a questão. No caso de Jasper, há realmente aspectos da mesma coisa, mas ele tornou o jogo mais formal, de certa forma - em termos linguísticos, mais formal. E ele está realmente falando sobre coisas que têm grande importância pessoal para ele, mas ele não nos diz muito a respeito delas em sua obra. Mas eu acho, de qualquer modo, que há muita ressonância entre os dois.

L.B.: Também preciso lhe perguntar sobre a relação entre os trabalhos de Nauman e os de Duchamp, ainda que, a esta altura, uma pergunta sobre Duchamp soe como cliché...

R.S.: E sobre Duchamp... Estranhamente, Bruce não tem tanto interesse assim por Duchamp... O que não quer dizer queele nãotenha sido realmente interessado nele, que não seja dali que ele obteve aquilo que faz. E eu acho que essa é também uma das razões pelas quais Bruce não é, por exemplo, discutido tanto quanto deveria ser na maior parte das histórias gerais da arte 
writing, especially when you consider how important he really was; and why also, because Bob Morris was the person who occupied this role for her. Bob Morris is the source of an awful lot of her ideas but, you know, there was a time when Bob and Bruce and numbers of artists were working on very similar ideas, and she chose to make a hero out of one of them, which meant that she had to downplay the existence of the other one. And Morris also had a strong relation with Johns, and still does.

L.B.: Could you comment, then, on the reception of Nauman's work in the United States? Well, a criticism I cannot overlook is the one offered by Arthur Danto. While he agrees that Nauman deals with the deepest issues of human condition, he complains about the unpleasant loudness of some of his sound installations, such as one held at MoMA in 1995 which, coincidentally, you had curated...

R.S: I like Arthur Danto personally, but he doesn't make any sense at all when it comes to Nauman; he is interested in philosophy, it should make him interested in the things that Bruce is doing, he's interested in a lot of issues that should bring him to Bruce, but ultimately he has a very bourgeois sense of what art is, and it just annoys him that this man makes so much noise, that this man is so difficult and so aggressive and so often so, you know? I've discussed this with him, I mean, I told him I think that this doesn't make any sense, but, you know, I can't change his mind. But the reception in this country of Nauman is very interesting. Bruce was picked up very early on by Leo Castelli, and was supported by Leo until Leo's death... He had a retrospective at the Los Angeles County Museum of Art, and here at the Whitney, in 1972, so about four years after he was picked up he was getting a retrospective or a survey. It's the kind of career that should've been like Johns' career, just continues to rise, right? Well, it stopped cold. And he was supported partly because Leo kept giving him the stipend regardless of sales, partly because he had critical and curatorial support - although not all that much attention, he had steady, solid attention from some peoplebut mostly because of the European market, and Konrad Fischer and others 
americana dos anos 1960, 1970 e mesmo 1980, porque a mudança neste país foi do modelo estabelecido por Picasso para o de Duchamp. E a versão de Rosalind Krauss disso é basicamente que ou você está em um time ou você está no outro, ou você estava em um time e então passou para o outro. Se você não estiver no time do Duchamp, então você não está em time algum. E então ela pega indivíduos que não eram duchampianos de fato, e os torna duchampianos, mas também ignora outros que considera insuficientemente duchampianos, mesmo que ela mesma os tenha convertido. Sabe, Bruce tem um papel muito pequeno nos escritos dela sobre escultura, muito pequeno, e um papel muito pequeno na obra dela como um todo, especialmente em se considerando o quão importante ele realmente foi; e também porque Bob Morris foi a pessoa que, para ela, realizou esse papel. Bob Morris é a fonte de uma porção das ideias dela, mas, sabe, houve um tempo em que Bob e Bruce e muitos outros artistas estavam trabalhando com ideias bastante semelhantes, e ela decidiu fazer de um deles um herói, o que significa ter de minimizar a existência do outro. E, também, Morris tinha uma relação bastante estreita com Johns, e ainda tem.

L.B.: Você poderia comentar então sobre a recepção da obra de Nauman nos Estados Unidos? Bem, uma crítica que não posso deixar passar é a de Arthur Danto. Ao mesmo tempo em que afirma que Nauman lida com as questões mais profundas da condição humana, ele reclama do barulho desconfortável de algumas de suas instalações sonoras, como a de uma exposição no MoMA, em 1995, cuja curadoria era justamente sua...

R.S.: Eu gosto de Arthur Danto enquanto pessoa, mas ele não faz sentido algum quando se trata de Nauman; ele se interessa por filosofia, o que deveria fazer com que ele tivesse interesse pelas coisas que Bruce está fazendo, ele tem interesse por uma série de questões que deveriam trazê-lo a Bruce, mas, em última instância, a percepção dele do que é arte é bastante burguesa, e ele simplesmente se sente incomodado que esse homem faça tanto barulho, que esse homem seja tão difícil e agressivo, e que o seja com tanta frequência, sabe? Eu discuti isso com ele, quer dizer, eu disse a ele que isso não faz sentido algum, mas, você sabe, eu não tenho como mudar a opinião dele. Mas a 
kept his career alive. But basically between 1972-3 and 1982-3 his career in this country was flat, or worse: he was off the map. And, in the early $80 \mathrm{~s}$ a number of writers sort of brought attention back to him and, you know, that was the beginning of his rise again, but, under present circumstances, for example, Bruce doesn't make that many editions, Bruce doesn't make collectibles very much, in general, and Bruce absolutely does not show up to cultivate curators and collectors, and so on and so forth. He has good relations with people, in my case we're actually just friends, but, you know, he doesn't do the circuit, he's not there always, the present art world is not made for him at all. I mean, Jeff Koons will show up for the opening of an envelope, and he does, and he's always there, and he's always gracious, and that's the way careers are made and maintained now, and Bruce doesn't do that. He doesn't live in New York, he's never lived in New York, and even when he was in the East Coast he was out in Long Island.

L.B.: Changing the subject, I've also read an interesting remark where you talked about Nauman as a cowboy figure, emphasizing not the mythical side that is a part of the imaginary American landscape, but pointing out that the discipline, the rigor Nauman devoted to many of his artistic works is precisely the same as that with which he takes care of his horses. You've also mentioned his activities as a horse trainer, and how that is related to a sense of helplessness that appears throughout his entire body of work. From that I got the impression that Nauman's entire ranch is his artistic workplace, like his old studio in San Francisco, the place where he made his first films... of course he has a studio in Galisteo, but for me the entire ranch appears as a kind of studio. You talk about the way he does his everyday activities, and the image that occurs to me is that the New Mexico ranch is comparable to the Studio we see in the films and videos of the 1960s, where he does predetermined exercises repeatedly, to the point of exhaustion. The ranch's space is obviously immense, but there is the same discipline in his execution of day-to-day activities... I had, of course, no opportunity to go to Galisteo and talk to him directly, but I knew that from the outset, that it would be quite impossible to talk to him... 
recepção de Nauman neste país é muito interessante. Bruce foi adotado por Leo Castelli logo de cara, e recebeu o apoio de Leo até o dia em que Leo morreu... Ele teve uma retrospectiva no Los Angeles County Museum of Art, e aqui, no Whitney, em 1972, ou seja, cerca de quatro anos depois de começar ele já tinha uma retrospectiva ou uma mostra extensiva. É o tipo de carreira que deveria ter sido como a de Johns, continuamente em ascensão, certo? Bem, ela estagnou completamente. E ele foi sustentado em parte pelo fato de que Leo continuou a dar o pagamento dele independentemente das vendas, em parte porque ele tinha o apoio de críticos e curadores - embora não recebesse muita atenção, ele recebia atenção sólida e contínua de algumas pessoas - mas principalmente por conta do mercado europeu, e Konrad Fischer e outros mantiveram viva sua carreira. Mas, basicamente, entre 19723 e 1982-3, a carreira dele neste país estava estagnada, ou pior: ele estava fora do mapa. E, no começo dos anos 80 , certos escritores trouxeram atenção de volta a ele e, você sabe, esse foi o princípio de sua segunda ascensão, mas, nas circunstâncias atuais Bruce, por exemplo, não produz muitas edições, Bruce em termos gerais não produz muitos objetos colecionáveis, e Bruce absolutamente não aparece para cultivar curadores e colecionadores, e assim por diante. Ele tem boas relações com as pessoas, no meu caso nós na verdade somos simplesmente amigos, mas ele não percorre o circuito, ele não está lá o tempo todo, o mundo da arte como é atualmente não foi feito para ele em absoluto. Quer dizer, Jeff Koons está disposto a comparecer à abertura de um envelope que seja, e ele o faz, e está sempre por ali, e é sempre gracioso, e é desse modo que carreiras são construídas e mantidas atualmente, e Bruce não faz isso. Ele não mora em Nova York, nunca morou em Nova York, e mesmo quando residiu na Costa Leste ele ficava em Long Island.

L.B.: Mudando de assunto, li também um comentário interessante no qual você discute a figura de Nauman como um cowboy, enfatizando não o lado mítico que compõe o imaginário do cowboy americano, mas apontando que a disciplina, o rigor que Nauman emprega em muitos de seus trabalhos é precisamente o mesmo que ele emprega ao cuidar de seus cavalos. Você 
R.S.: And Setting a Good Corner, have you seen that too? I mean that's sort of the example of what you're saying.

L.B.: Yes, that seems to me to be the artist's role for Nauman, something more existential... I mean, "existential" is not such a good word...

R.S.: Doing work, it's about doing work. If you look at [Gerhard] Richter, I mean, Richter talks about the daily practice of painting, although Bruce, he does many, many different things, and there are also many days where he doesn't do any work at all, he's a different kind of artist, he mulls things over, he thinks slowly.

L.B.: I'm curious about a slightly unrelated characteristic... What are Nauman's speech patterns like? Did he pick up a Western accent? Does he speak with a slow drawl, or...?

R.S.: He's thoughtful, he doesn't have a western accent particularly, he's just kind of middle-American, he uses some expressions that are regional, but not that many. He's from Indiana, he's not from the West, but of course, then, a lot of the original cowboys weren't from the West either, they came from wherever, they came from Poland...

L.B.: Yes, a cowboy by choice.

R.S.: ...so, he's slow-speaking, basically, and not excessively so, but he takes his time to say when he wants to think.

L.B.: The first impression I had in the beginning of my research work, about two years ago, was that there was this incredible sculptural intelligence in Nauman's work, in the relations it establishes between the body and space, the way he uses the body as a raw material... I mean, everything for him seems to be potentially a raw material, but I was 
também comentou acerca das atividades dele como domador de cavalos e como isso tem relação com a ideia de desamparo que perpassa a obra de Nauman como um todo. Disso, eu obtive a impressão de que o rancho de Nauman é, em sua totalidade, um local de trabalho artístico, como seu antigo ateliêem São Francisco, o lugar em que ele produziu seus primeiros filmes... é claro que ele tem um estúdio em Galisteo, mas, para mim, o rancho como um todo parece ser um tipo de ateliê. Você fala sobre o modo como ele conduz suas atividades cotidianas, e a imagem que me ocorre é a de que rancho no Novo México é comparável ao ateliê que vemos nos filmes e vídeos da década de 1960, onde ele executa exercícios pré-determinados, repetidamente, à exaustão. No rancho o espaço é obviamente imenso, mas há a mesma disciplina na execução das tarefas do dia a dia... eu não tive, é claro, a oportunidade de ir a Galisteo e falar diretamente com ele, mas eu sabia disso desde o princípio, que seria impossível entrar em contato com ele...

R.S.: E Setting a Good Corner, você viu essa também? Quero dizer, ela é meio que o exemplo disso que você está dizendo.

L.B.: Sim, esse me parece o papel do artista para Nauman, algo mais existencial... Quer dizer, "existencial” não é uma boa palavra...

R.S.: Produzir, é sobre produzir. Se você pensar em [Gerhard] Richter, quer dizer, Richter fala da pintura como prática diária, embora Bruce, ele faz muitas, muitas coisas diferentes, e há também muitos dias em que ele não trabalha em absoluto, ele é um tipo diferente de artista, ele rumina as coisas, ele pensa vagarosamente.

L.B.: Estou curiosa acerca de uma característica um tanto lateral... Como são os padrões de fala de Nauman? Ele adquiriu um sotaque do oeste? Fala devagar, ou...?

R.S.: Ele é contemplativo, ele não tem um sotaque particularmente do oeste, ele é meio que das regiões centrais dos Estados Unidos, ele emprega algumas expressões regionais, mas não muitas. Ele é de Indiana, não do oeste, mas, é claro, muitos dos cowboys originais também não eram originariamente do oeste, eles vinham de toda a parte, vinham da Polônia... 
thinking about Anne Wagner's essays... What we can see in Nauman's first videos, and also his first sculptures, the ones with body shapes... and, of course, that installation in Germany, in Münster I believe, that massive square referred to as Depression Square...

R.S.: Oh yeah, that's Münster; that was a project that he planned years ago, and then finally did, yeah. Four, five years ago he did it.

L.B.: Yeah, and once again he seems to be removing something, subtracting something, in an attempt to show us internal space; this is an enormous structure, of course, but it is curious how the scale remains proportional to the human body, it's still a human scale...

R.S.: Scale is a very important thing to him; if you think that sculptural values are material, weight, scale, disposition, things like that, I mean, that's what his work is about. Some of his things are very, very strong images, others are more abstract and almost neutral kinds of images, but no matter whether it's an image or not an image, he never does anything where those other factors - disposition, weight, scale, materiality, and so on and so forth - [do not] count, and to be honest with you, if you look at Jeff Koons, does any of that matter? Size makes the difference, but not scale. He likes it big, but big not in terms that really relate to a sort of fundamental apprehension, and Jeff is an image sculptor; as an image sculptor, I should say he is sometimes pretty good, but he's not really a sculptor.

L.B.: So do you agree with me that Nauman has a very strong sculptural intelligence?

R.S.: Very, very, very. The other person who was like that was Louise Bourgeois.

L.B.: Oh, yes... yes, of course it's possible to connect them...

R.S.: Sure, look, Bruce and Louise were both, along with Eva Hesse in 
L.B.: Sim, um cowboy por escolha própria.

R.S.: ...então, ele fala de forma vagarosa, basicamente, e não excessivamente, mas, quando quer, ele toma cuidado ao dizer o que está pensando.

L.B.: A primeira impressão que tive no começo de meu trabalho de pesquisa, há cerca de dois anos, foi de que há uma inteligência escultórica incrível na obra de Nauman, nas relações que estabelece entre o corpo e o espaço, na forma como ele usa o corpo como matéria prima... Quer dizer, para ele tudo parece ser potencialmente matéria-prima, mas eu estava pensando nos ensaios de AnneWagner... E o que vemos nos primeiros vídeos de Nauman, e também em suas primeiras esculturas, dotadas de formas corpóreas... e, é claro, naquela instalação na Alemanha, creio que em Münster, aquele quadrado imenso que recebe o nome de "Depression Square"...

R.S.: Oh sim, fica em Münster; foi um projeto que ele planejou anos atrás, e então finalmente realizou, isso mesmo. Ele o realizou uns quatro ou cinco anos atrás.

L.B.: Sim, e uma vez mais ele parece estar removendo algo, subtraindo algo, na tentativa de revelar uma interioridade; a estrutura é enorme, é claro, mas é curioso como a escala permanece proporcional ao corpo humano, ainda é uma escala humana...

R.S.: Escala é algo muito importante para ele; se você pensar que os valores escultóricos são material, peso, escala, disposição, coisas do tipo, bem, é disso que se trata a obra dele. Algumas das coisas que ele produz são imagens muito, muito fortes, outras são imagens de um tipo mais abstrato e quase neutro, mas quer se trate de uma imagem ou de algo que não é uma imagem, ele nunca produz nada onde esses outros fatores-disposição, peso, escala, materialidade, e assim por diante - [não] contem e, para ser honesto, se você olhar o trabalho de Jeff Koons, será que qualquer um desses elementos importa? O tamanho faz a diferença, mas não a escala. Ele gosta de que seja grande, mas não grande em termos que realmente se relacionem a qualquer espécie de apreensão fundamental, e Jeff é um escultor imagético; como escultor de imagens, eu diria que às vezes ele é bastante bom, mas não é realmente um escultor. 
Lucy Lippard's Eccentric Abstractions show, in 1966, and that was one of the first shows that Bruce got a lot of attention in, and it was one of the first times that Louise had gotten attention in years. I put them together in a show at the Modern, and Louise's sculpture was already [set-up] when Bruce came to look at his room, and he looked at me and he said "you gotta look out for that one", because he really understood how strong she was; he was really acknowledging the fact that here they were again after all these years. I don't think in some ways he liked her work all that much, but I think he took it seriously, and understood what she was after, gave her a lot of credit. And I'm sure that she was aware of his.

L.B.: In your essay Bruce Nauman: The man who would not be king you've mentioned a "horse-whisperer" with whom Nauman worked; could you tell me a little bit more about your firsthand experience with the methods employed by this professional, and their connection to the works of Nauman?

R.S.: His name is Ray Hunt, Bruce and I went up to see him do one of his clinics once, it was fascinating, he was an extraordinary guy, really an extraordinary guy. What he said is, rather than exert your will over an animal who has a will of its own, analyze what it is that the animal likes and does not like, and how the animal relates to you as a person, rather than simply trying to impose yourself. One of his observations was that because horses have their eyes here, they're very, very uncomfortable with things going on behind them, so don't approach an animal from an angle where the animal can't see you, because that will frighten him. And if you're standing next to an animal and you have to move into a position where the animal cannot see you, establish contact with the animal and then keep your hand on his back as you move around, so the animal will know that what's going on back there is you, and that your hand is an indication that you are no more a threat behind than you were when you were up front. Things like that. And, you know, he came from a rough cowboy tradition where breaking horses really meant breaking them, and he understood that behavioral psychology, without any help from Mr. Skinner, worked. So if you have the musicians training themselves to make 
L.B.: Então você concorda quando digo que Nauman tem uma inteligência escultórica muito forte?

R.S.: Muito, muito, muito. Outra pessoa que também era assim era Louise Bourgeois.

L.B.: Oh, sim... sim, é claro que é possível conectá-los...

R.S.: Claro, veja, Bruce e Louise estavam, junto com Eva Hesse, na mostra de Lucy Lippard, Eccentric Abstractions, de 1966, e aquela foi uma das primeiras mostras em que Bruce recebeu bastante atenção, e foi uma das primeiras vezes em que Louise recebera atenção em anos. Eu os coloquei juntos em uma mostra na Modern, e a escultura de Louise já estava [montada] quando Bruce veio olhar sua sala, e ele me olhou e disse "cuidado com essa aí", por ter realmente compreendido o quão forte ela era; ele estava realmente reconhecendo o fato de que aqui estavam eles uma vez mais, depois de todos esses anos. De certo modo, eu não creio que ele gostasse muito do trabalho dela, mas acho que ele o levava a sério, e compreendia o que é que ela estava buscando, dava a ela muito crédito. E eu tenho certeza de que ela estava ciente da obra dele.

L.B.: Em seu ensaio Bruce Nauman: The man who would not be king [Bruce Nauman: O homem que não queria ser rei] você menciona um "encantador de cavalos" com quem Nauman trabalhou; você poderia me falar um pouco mais acerca da experiência pessoal dele com os métodos empregados por esse profissional, e a relação dos mesmos com a obra de Nauman?

R.S.: O nome dele é Ray Hunt; certa vez, Bruce e eu fomos vê-lo conduzir uma de suas clínicas, e foi fascinante, ele era um cara extraordinário, realmente um cara extraordinário. O que ele disse foi, em vez de exercer sua vontade sobre um animal dotado de vontade própria, analise do que é que o animal gosta ou não gosta, e como o animal se relaciona com você como pessoa, no lugar de simplesmente tentar se impor. Uma de suas observações era que, porque os cavalos têm olhos aqui, eles se sentem muito, muito desconfortáveis com coisas que ocorram atrás deles, então 
sounds with very elaborate fine motor-control motions, and then you have Ray teaching animals to do things that they're not naturally inclined to do, there are circumstances where you can, in fact, bring to a body a consciousness it would not otherwise have. But you have to bring it, and you have to figure out what the resistance points are, and you have to do it in a way that's sympathetic with the way the organism wants to be.

L.B.: That reminds me of a very interesting text by Gilles Deleuze I am not a big fan of Deleuze, but this is truly a great piece - called L'Epuisé/The Exhausted, in which those last plays Beckett wrote for television are discussed; they are, of course, visual plays, in the sense that they are only visual, they have no sound... you probably know Quad, for instance, where four characters pace inside a square. Deleuze, through Beckett, reminds us that there is an exhaustion that exists beyond tiredness, when things are simply no longer possible and then, paradoxically, extraordinary things can happen. This seems uncannily related to the procedures employed by Nauman in his studio exercises; do you believe Nauman's attempts at obtaining body consciousness are related to this, or...

R.S.: Well, that's certainly one place where he tried to do things that his body was not prepared to do; he deliberately did what an amateur could do in relation to a professional activity. So, playing the violin, you play a very simple set of notes, but then you do it for so long that you test the limits of your endurance as well as your ability to master a particular technical exercise... which is, again, what he is doing with the recent figure exercises.

L.B.: It's very interesting because, while it's a simple exercise, it's taken to its absolute limit; he seems so focused on it, you can almost feel how exhausting it must be. On the other hand, there are the two videos he used actors for, Tony and Elke, I believe, where one is sinking and the other is allowing the floor to rise up around her. I read that Nauman is really fond of that piece, but it seems very odd to me, they were overacting, everything was so contrived... The exercises are very powerful, of course, to do something like that takes great effort and concentration; it's just 
não se aproxime de um animal por um ângulo no qual o animal não consiga ver você, pois isso irá assustá-lo. E, se você estiver de pé próximo a um animal e tiver de mover-se para uma posição na qual o animal não possa vê-lo, estabeleça contato com o animal e então mantenha sua mão sobre o dorso do mesmo enquanto dá a volta, a fim de que o animal saiba que o que está ocorrendo ali atrás é você, e que sua mão é uma indicação de que você não representa uma ameaça maior agora que está atrás do que representava quando estava na frente. Coisas assim. E, sabe, ele veio de uma tradição cowboy rude na qual domar cavalos significava realmente quebrá-los, e ele compreendeu que a psicologia comportamental realmente funcionava, mesmo sem a ajuda do Sr. Skinner. Então, se você tem músicos treinando para produzir sons com movimentos muitíssimo elaborados de controle motor, e então tem Ray adestrando animais a fazerem coisas que não são naturalmente inclinados a fazer, há circunstâncias nas quais você pode, de fato, trazer a um corpo uma consciência que ele não possuiria de outra forma. Mas você tem que trazê-la, e você tem que descobrir quais são os pontos de resistência, e você tem que fazê-lo de uma maneira que esteja em harmonia com a maneira como o organismo quer ser.

L.B.: Isso me lembra de um texto interessantíssimo de Gilles Deleuze - eu não sou uma grande fã de Deleuze, mas esseé realmente um ensaio excelentechamado L'Epuisé/O esgotado, no qual aquelas peças tardias de Beckett para a televisão são discutidas; elas são, é claro, peças visuais, querendo dizer somente visuais, não têm som... você provavelmente conhece Quad, por exemplo, onde quatro personagens caminham no interior de um quadrado. Deleuze, por meio de Beckett, nos lembra de que há uma exaustão que existe para além do cansaço, quando as coisas se tornam simplesmente impossíveis e então, paradoxalmente, coisas extraordinárias passam a poder acontecer. Isso parece ter relação surpreendente com os procedimentos empregados por Nauman nos exercícios em seu ateliê; você acredita que os esforços de Nauman por obter uma consciência corporal têm relação com isso, ou...

R.S.: Bem, essa é certamente uma área na qual ele tentou fazer coisas que seu corpo não estava preparado para fazer; ele deliberadamente fez tudo 
that, when Nauman does it himself, he seems so concerned, he's so in the exercise, that it feels stronger, and more real...

R.S.: He's a great performer.

L.B.: Yeah... incredible, right?

R.S.: But it's kind of a spiritual exercise for him, you know? I mean, I use that word with care, I don't mean something religious, but it's an exercise, it's a challenge. 
o que um amador poderia fazer no âmbito de uma atividade profissional. Então, ao tocar o violino, você toca um conjunto bem simples de notas, mas então você o faz por tanto tempo que testa os limites de sua resistência, assim como sua habilidade para dominar um determinado exercício técnico... o que, uma vez mais, é o que ele está fazendo com seus exercícios figurativos mais recentes.

L.B.: É muito interessante porque, embora o exercício seja simples, o mesmo é levado completamente ao limite; ele parece tão focado no exercício que você quase sente o quão exaustivo ele deve ser. Por outro lado, há os dois vídeos nos quais ele usou atores, Tony e Elke, se não me engano, nos quais um está submergindo e o outro está permitindo que o chão se eleve ao seu redor. Eu li que Nauman gosta bastante dessa obra, mas a mesma me parece um tanto estranha, eles pareciam estar atuando, tudo era tão forçado... Os exercícios são muito fortes, é claro, fazer algo assim requer muito esforço e concentração; o problema é que, quando o próprio Nauman os realiza, ele parece tão preocupado, ele está tão investido no exercício, que o mesmo parece mais forte, e mais real...

R.S.: Ele é um excelente performer.

L.B.: É... incrível, não é?

R.S.: Mas é um tipo de exercício espiritual para ele, sabe? Quer dizer, eu uso essa palavra com cautela, eu não me refiro a nada religioso, mas é um exercício, é um desafio. 


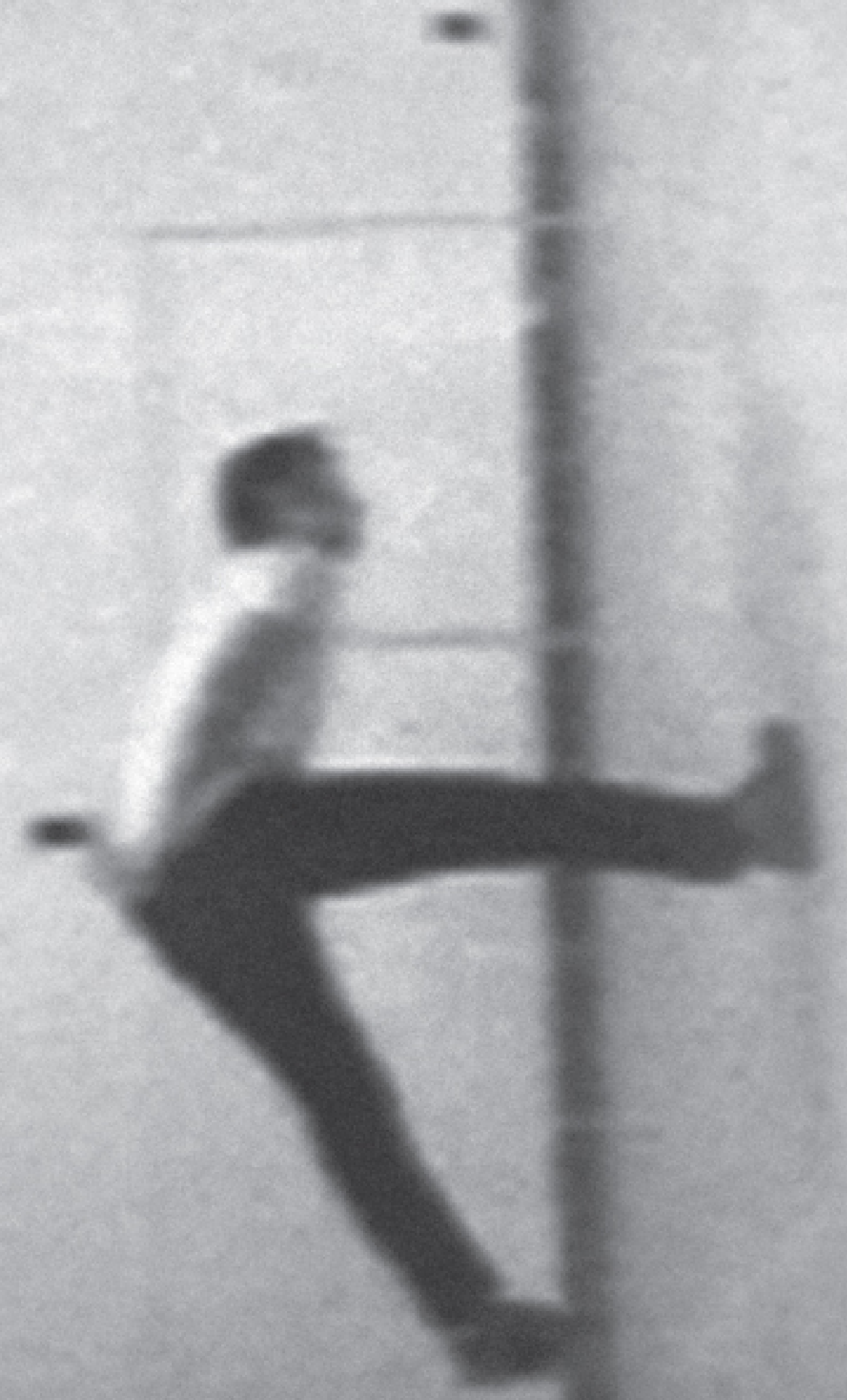